Tellus 


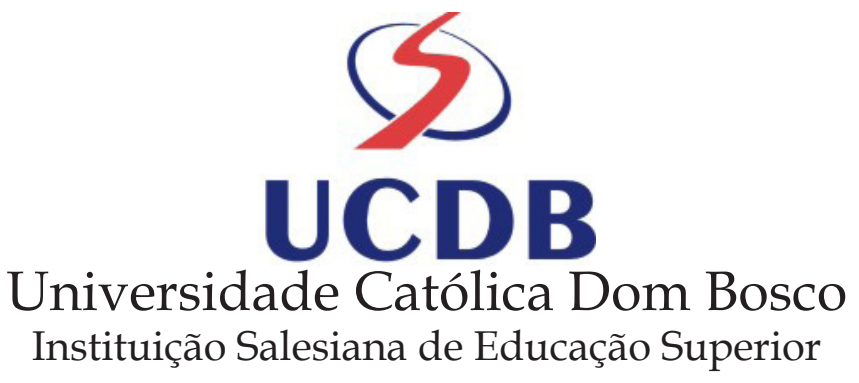

Chanceler

Pe. Gildásio Mendes dos Santos

Reitor

Pe. Ricardo Carlos

Pró-Reitor de Pesquisa e Pós-Graduação

Prof. Cristiano Marcelo Espinola Carvalho

Tellus / Universidade Católica Dom Bosco. Pró-Retoria de Pesquisa e Pós-Graduação.-- Campo Grande, MS : UCDB, 2001 -

ISSN Impresso 1519-9452

ISSN Eletrônico 2359-1943

1. Índios da América do Sul - Brasil - Periódicos. 2. Antropologia Periódico I. Universidade Católica Dom Bosco - Pró-Reitoria de Ensino e Pesquisa. II. Título.

CDD: Ed. 20 -- 980.41

Dados Internacionais de Catalogação na Publicação (CIP)

Bibliotecária Mourâmise de Moura Viana- CRB-1 3360

Publicação do Núcleo de Estudos e Pesquisas das Populações Indígenas (NEPPI) da Universidade Católica Dom Bosco

www.tellus.ucdb.br

Indexada em:

Sumarios.org, Sumários de Revistas Brasileiras (www.sumarios.org)

Latindex, Directorio de publicaciones cientificas seriadas de America Latina, El Caribe, España y Portugal (www.latindex.org)

IUPERJ, Banco de Dados Bibliográficos do Instituto Universitário de Pesquisas do Rio de Janeiro (http://dataindice.iuperj.br/)

Clase, Citas Latinoamericanas en Ciencias Sociales y Humanidades, Universidad Nacional Autônoma de México (http://132.248.9.1:8991/F/-/?func=find-b-0\&local_base=CLA01)

IBSS, International Bibliography of the Social Sciences, The London School of Economics and Political Science (http://www.Ise.ac.uk/collections/IBSS/)

HAPI, Hispanic American Periodicals Index, International Institute - University of California (http://hapi.ucla.edu/web/?token=69daf7174e1a601cf82fdb20d8dc15ac) 


\section{Tellus}

ano 20

ก. 42

maio/ago. 2020

p. 1-367

Núcleo de Estudos e Pesquisas das Populações Indígenas - NEPPI

Universidade Católica Dom Bosco - UCDB

Campo Grande, MS, Brasil www.ucdb.br/neppi neppi@ucdb.br 
Direitos desta edição reservados à Editora UCDB

Membro da Associação Brasileira das Editoras Universitárias (ABEU)

Editoração Eletrônica: Glauciene da Silva Lima; Nichole Beatriz Munaro da Silva

Gerente Editorial (Portal): Nichole Beatriz Munaro da Silva

Revisão: Dáfini Lisboa

Capa: Terena na Dança do Bate Pau, na aldeia Buriti, MS.

Foto e capa: José Francisco Sarmento Nogueira

\section{Editora Responsável}

Adir Casaro Nascimento - PPGE/UCDB

\section{Comissão Editorial}

Eva Maria Luiz Ferreira - NEPPI/UCDB

José Francisco Sarmento - NEPPI/UCDB

Leandro Skowronski - NEPPI/UCDB

Lenir Gomes Ximenes - UCDB

Conselho Editorial

Ángel Espina Barrio - USAL/Espanha

Antonella Tassinari - UFSC

Antonio Carlos de Souza Lima - MN-UFRJ

Antonio Hilário Aguilera Urquiza - UFMS

Beatriz Landa - UEMS

Daniel Mato - UNTREF/Argentina

Deise Lucy Montardo - UFAM

Dominique Tilkin Gallois - USP

Esther Jean Langdon - UFSC

Flávio Braune Wiik - UEL

Graciela Chamorro - UFGD

Inge Sichra - UMSS/Bolívia

Josè Zanardini - UCA/Paraguay

Levi Marques Pereira - UFGD

Marcelo Marinho - UNILA

Márcio Ferreira da Silva - USP
Maria Augusta de Castilho - UCDB

Manuel Ferreira Lima Filho - UFG

Marta Azevedo - UNICAMP

Miguel Alberto Bartolomé - INAH/Mexico

Mônica Thereza Soares Pechincha - UFG

Nádia Heusi Silveira

Neimar Machado de Sousa - UFGD

Pedro Ignácio Schmitz - UNISINOS

Rodrigo de Azeredo Grünewald - UFCG

Roque de Barros Laraia - UnB

Rosa Sebatiana Colman

Ruth Montserrat - UFRJ

Wilmar D'Angelis - UNICAMP

\section{Pareceristas Ad Hoc}

Osvaldo Ribeiro da Silva - UCDB

Yan Leite Chaparro - UCDB / UFGD

lara Quelho Castro - UFMS

Anita Guazzelli Bernardes - UCDB

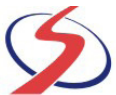

Editora UCDB

Av. Tamandaré, 6.000 - Jardim Seminário

79117-900 - Campo Grande, MS 


\section{Sumário}

\section{Artigos}

As representações sociais dos indígenas no jornal O Progresso, no estado brasileiro de Mato Grosso do Sul

Social representations of indigenous people in the newspaper O Progresso, in the Brazilian state of Mato Grosso do Sul

Henrique Duarte

Esmael Alves de Oliveira

Orientaciones teóricas sobre procesos identitarios y trayectorias de maestros/as indígenas en la región chaqueña (Argentina)

Diretrizes teóricas sobre processos e trajetórias identitárias de professores indígenas na região do Chaco (Argentina)

Soledad Aliata

De Caminha a Zé Carioca: invisibilidade, apagamento e silenciamento da identidade cultural indígena 59

From Caminha to Zé Carioca: invisibility, erasure, and silencing of indigenous cultural identity ... 59

Cidiclei Alcione Biavatti

Leni Barbosa Feitosa

Idemar Vizolli

André Luis Campanha Demarchi

Percepções indígenas Paiter Suruí sobre o ensino superior: busca de sentido a partir de narrativas de estudantes de graduação 81

Indigenous perceptions Paiter Suruí about higher education: searching for meaning from narratives of graduation students.

Alceu Zoia

Maria Gabriela de Assis Souza

Direitos constitucionais e povos indígenas: apontamentos sobre a disputa pela efetivação do direito fundamental às suas terras tradicionais 109 Constitutional rights and indigenous peoples: remarks on the dispute of effecting the basic law to their traditional lands....

Antônio Hilário Aguilera Urquiza

Anderson Santos

Os Kambeba, a escola e seus significados

The Kambeba, the school and their meanings ....

Kácia Neto de Oliveira Fonseca

Jaspe Valle Neto

Valeria Augusta Cerqueira de Medeiros Weigel 
Etnomatemática e educação escolar indígena: ensino por meio de uma atividade piscatória.... 153

Ethnomathematics and indigenous school education: teaching through a fishing activity

José Roberto Linhares de Mattos

Sandra Maria Nascimento de Mattos

Gamalonô Surui

Localização, orientação e representação espacial como expressão de territorialidades indígenas..181

Positioning, orientation and spatial representation as expression of indigenous territorialities.. 181

Ozirlei Teresa Marcilino

Vanessa Sena Tomaz

A caça e os caçadores Tapirapé da Aldeia Tapi'itãwa

The Tapirapé Hunt and hunters of the Village Tapi'itãwa

Edivaldo Soares Silva

Flávio Bezerra Barros

Para além das demarcações territoriais: a inserção e permanência da/o estudante Kaingang na Universidade Federal do Pampa

Beyond territorial demarcations: the insertion and permanence of the student Kaingang at the Federal University of Pampa

Tatiane Motta da Costa e Silva

Suzana Cavalheiro de Jesus

Renata Colbeich da Silva

Substancialidade A'uwê no espelho Waradzu: escutar o corpo indígena Xavante em contexto de trânsito espacial e cultural

A'uwê substanciality on Waradzu mirror: listening to indigenous Xavante's body within a spatial and cultural exchange context.

Maria Clara Campos

José Francisco Miguel Henriques Bairrão

\section{Entrevista}

Pedagogia da contextualização e interculturalidade na formação de professores indígenas

Entrevista - Profa. Dra. Maria do Socorro Pimentel da Silva 306

Lilian Abram dos Santos

\section{Escritos Indígenas}

Uma breve história de retomada: a comunidade Lago da Praia e conflitos territoriais 324

A brief history of retaking: the Lago da Praia community and territorial conflicts

Eriki Aleixo de Melo

A diversidade sexual entre povos indígenas do Brasil

Sexual diversity among Brazil's indigenous people

Eriki Paiva 


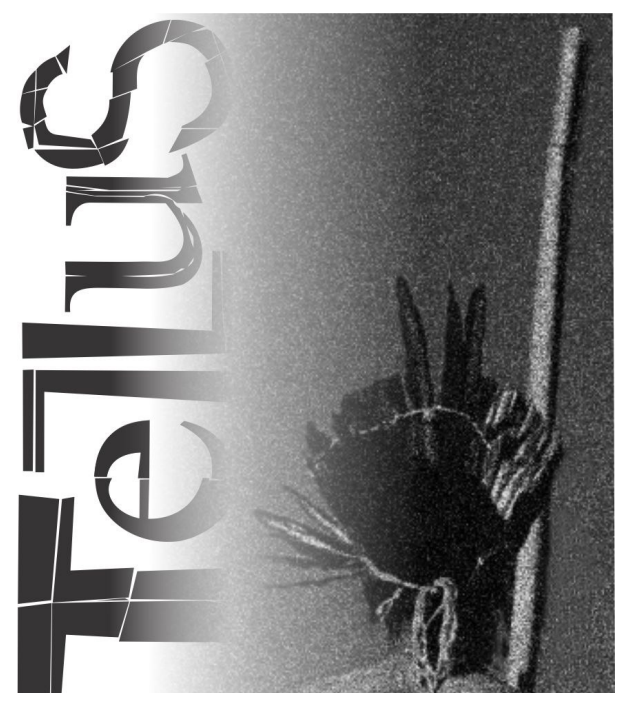

Artigos 



\section{Editorial}

Prezados leitores,

Temos o prazer de apresentar o número 42 da revista TELLUS. Mantendo o objetivo e o compromisso de ser um espaço multidisciplinar e de visibilidade às questões indígenas, a TELLUS, nesta edição, contempla-nos com trabalhos em níveis regional, nacional e internacional, abrangendo diversos temas que perpassam pelas reflexões no campo da educação, da diferença identitária e dos direitos territoriais, entre outros, que contemplam o ser e estar dos povos indígenas. Traz, também, a entrevista com a professora Maria Socorro Pimentel sobre a sua rica experiência e produção de conhecimento no contexto de formação de professores indígenas. Ainda, nesta edição, cumprindo com o propósito de ouvir as vozes originárias, apresentamos duas significativas contribuições de autores indígenas que nos brindam com textos produzidos desde seus lugares de fala e de vivências, o que muito a enriquece.

Desejamos que tenham uma boa leitura!

Profa. Dra. Adir Casaro Nascimento Editora da Revista TELLUS 



\title{
As representações sociais dos indígenas no jornal $O$ Progresso, no estado brasileiro de Mato Grosso do Sul
} Social representations of indigenous people in the newspaper
O Progresso, in the Brazilian state of Mato Grosso do Sul

Henrique Duarte ${ }^{1}$

Esmael Alves de Oliveira²

DOI: http://dx.doi.org/10.20435/tellus.v20i41.656

\begin{abstract}
Resumo: O presente artigo visa refletir sobre o modo como os indígenas são descritos e narrados pela imprensa na cidade de Dourados, Mato Grosso do Sul, MS. Em específico no jornal O Progresso, que tem relevante circulação e divulgação na região. $O$ estado de exceção retrata os discursos que matam ligado ao sentido de extermínio, formulado por Agamben no termo "estado de exceção". Como podemos entender a categorização do indígena para e na sociedade a partir da mídia? É com esta indagação que os artigos jornalísticos publicados nos cadernos policiais das edições foram analisados. Partindo da produção dos discursos expressos pelo jornal em questão, a partir do conceito de representações sociais, buscamos evidenciar as teias de significados presentes na narrativa jornalística e que têm servido para construir e naturalizar violências e subalternidades em relação às populações indígenas do estado. Assim, a partir de pesquisa documental, em diálogo com o campo das Ciências Sociais, em especial com a Sociologia, buscou-se compreender os papéis que esses discursos noticiosos apresentam, constroem e reiteram.
\end{abstract}

Palavras-chave: indígenas; representações sociais; jornal; estado de exceção.

Abstract: The purpose of this paper is to reflect on the way indigenous people are described and narrated by the press in the city of Dourados, Mato Grosso do Sul, MS. Specifically in the newspaper O Progresso (The Progress), which has important circulation and dissemination in the area. The state of exception portraits the discourses that kill associated with the meaning of extermination, as expressed by Agamben in the term "state of exception". How can we understand the category of indigenous people for and in society according to the media? This is the question with which I have analyzed the news stories published in the crime section. Starting with the production of the discourses

1 Secretaria de Estado de Educação (SEDUC), Cuiabá, Mato Grosso, Brasil.

2 Universidade Federal da Grande Dourados (UFGD), Dourados, Mato Grosso do Sul, Brasil. 
expressed by the newspaper in question, based on the concept of social representations, I have attempted to highlight the webs of meanings found in the journalistic narrative and which has served to construct and naturalize acts of violence and inferiority in relation to the indigenous populations in the state. Thus, supported by documental research, in dialogue with the field of Social Sciences, especially with Sociology, I have sought to comprehend the roles that these news discourses present, construct, and reiterate.

Keywords: indigenous people; social representations; newspaper; state of exception.

\section{INTRODUÇÃO}

Ao longo deste trabalho, foram pesquisadas e analisadas algumas notícias que retratavam os indígenas nas páginas policiais do jornal $O$ Progresso ${ }^{3}$. Todas as edições (com exceção de uma) datam do ano de 2013 e a pesquisa foi feita por meio da leitura dos artigos encontrados na seção de casos que retratam situações de violência que diretamente envolvem a população indígena Kaiowá ${ }^{4}$ presente no município de Dourados, Mato Grosso do Sul, MS. O veículo de informação foi acessado na sua versão impressa e digital, cuja tiragem circula diariamente no estado, principalmente na região circundante a Dourados. Esses artigos, por sua vez, quando noticiam casos de violência envolvendo indígenas, são produzidos de forma genérica e estigmatizante, utilizando um discurso recorrentemente preconceituoso e que reflete o imaginário racista da sociedade douradense (BECKER; OLIVEIRA, CAMPOS, 2016).

3 Para Silva (2007), é considerado o jornal mais antigo de MS, fundado ainda na época da não divisão entre MT e MS. Sua fundação histórica data do ano de 1920 na cidade de Ponta Porã, tendo José dos Passos Rangel Torres como fundador do periódico, que teve suas atividades encerradas em 1943. Em 1951, há a retomada da publicação de O Progresso por Weimar Gonçalves Torres no município de Dourados, ainda pertencente ao estado de Mato Grosso.

4 Conforme Urquiza e Prado (2015), a partir de dados apontados pelo IBGE, a estimativa da população Kaiowá e Guarani da região sul do estado de Mato Grosso do Sul gira em torno 52.000 pessoas. Ainda segundo os autores, deste total, aproximadamente 2.700 vivem em situação de acampamentos à beira de estradas ou em pequenas áreas dentro dos seus antigos territórios, cerca de 38.700 estão em reservas indígenas criadas pelo SPI nas décadas de 1910 e 1920, e 11.000, em terras indígenas demarcadas após os anos 1980. 
Tomando-se esse fato como objeto de reflexão, buscou-se pensar sobre o modo como a questão indígena é narrada pelo referido jornal ${ }^{5}$. O público assíduo consumidor das notícias desse periódico são os comerciantes locais, fazendeiros e jornalistas que trabalham em outras mídias, como as rádios locais e redes de televisão ${ }^{6}$. A abordagem desse periódico não difere de outras mídias de massa locais, em relação ao que é narrado cotidianamente sobre os indígenas. O Progresso tem uma grande representatividade de mercado publicitário na cidade de Dourados, caracterizando-se como um dos principais periódicos locais. Tomando-se a obra de Rita de Cássia Pacheco Limberti (2012), em que trata da imagem do índio nos discursos e nas narrativas do mesmo periódico, a pesquisadora compõe um percurso histórico da narrativa que esse veículo traçou sobre os indígenas. Ao separar esse estudo em décadas, tomando como marco a década de 1990, Limberti (2012) aponta que, apesar da transição cronológica, pouca mudança ocorreu com relação ao imaginário construído pelo noticiário em torno das populações indígenas. Tais constatações nos motivam a percorrer este artigo buscando perceber quais discursos são produzidos e que imaginários são reiterados.

Perlato (2015), ao tratar da mídia brasileira, apresenta que essa produz a esfera pública, ou seja, aborda o modo como os atores sociais narrados nos textos jornalísticos são tomados em sua representação. Há dois contextos de esfera pública, a "seletiva" e a "subalterna". Na história do Brasil, percebemos

5 Cabe ressaltar que diferentes autores têm chamado a atenção para a especificidade e complexidade sociopolítica e cultural das populações indígenas existentes em MS (VIETTA, 2001; PEREIRA, 2006; URQUIZA; PRADO, 2015). Com relação específica ao Kaiowá e Guarani, presentes na região sul do estado, não há como ignorar o fato de que o processo de contato interétnico ocasionado principalmente pelas políticas de ocupação e expansão econômica resultou na expulsão dessas populações do território tradicionalmente ocupado (tekoha). Tal fato não apenas foi responsável por ocasionar uma série de problemas de ordem social, política e cultural para os indígenas como também por criar um imaginário social que tende a encarar o indígena como um empecilho ao desenvolvimento do estado/região. Assim, diante desse quadro complexo, em que interagem diferentes atores, instituições e interesses, recorrentemente essa população tem sido alvo de discursos e de práticas que apontam tanto para a existência de um racismo de Estado (FOUCAULT, 2005) quanto para um estado/condição de exceção (AGAMBEN, 2000). E, nesse campo em disputas, a mídia não tem permanecido "imparcial".

6 Mesmo considerando que os jornais impressos detêm um público reduzido diante das plataformas midiáticas de informação atuais via internet, O Progresso também possui sua versão on-line das notícias. Porém esse mesmo conteúdo divulgado de modo impresso pelo jornal efetiva a interpretação e reprodução da notícia nos outros meios de comunicação social local, como as emissoras de rádio e televisão. 
uma construção excludente quando os códigos de legitimidade são exercidos por interlocutores seletos. Há um percurso de mídia da esfera pública subalterna quando buscamos identificar o indígena nesse processo. Porém nosso objetivo é identificar os dispositivos que enredam as narrativas protagonizadas pela seletividade das informações.

Sobre o campo de pesquisa documental e as implicações éticas, Laraia (1994) ressalta e aconselha que o antropólogo deve proteger a confidencialidade dos dados obtidos quando acessados e tratados pelo pesquisador. Para tanto, não é permitido realizar acareações ou indevidamente utilizar as informações que foram fornecidas quando essas não possuem uma prévia autorização. Ao refletir sobre essas posturas éticas, podemos afirmar que o conteúdo analisado neste artigo não é objeto confidencial, justamente por se tratar de um material já publicado. O acervo material de notícias impressas se encontra digitalizado e arquivado no Centro de Documentação Regional (CDR) da Universidade Federal da Grande Dourados (UFGD) e também disponibilizado na página online do referido jornal?.

Algumas indagações são propostas neste artigo, como: qual é a imagem do indígena construída pelo jornal O Progresso? Quais as principais ideias/representações associadas ao indígena na cidade de Dourados, MS? O que essas imagens discursivas revelam? Essas três perguntas serão norteadoras das reflexões que apresentamos no presente artigo.

Para Limberti (2012), o jornal é um lugar construído a partir do discurso e, assim, torna-se porta-voz de uma sociedade. Consequentemente, ele divulga ideias, saberes e representações por meio de publicações, fazendo com que o registro dinâmico das informações cristalize os sentidos daquilo que é passado ao público, por conta dos critérios de sua construção. Assim, temos por referência que uma reflexão sobre as representações sociais pode evidenciar os processos sociais de estigmatização e exclusão social, aqui, no caso específico, a estigmatização da população indígena Guarani e Kaiowá residentes nas reservas de Dourados e região.

Nas páginas policiais onde encontramos as notícias, o objeto de análise são os artigos jornalísticos que apresentam classificações de maneira padronizada.

7 Disponível em: https://www.progresso.com.br/edicao-impressa/ 
Entendemos que o meio de comunicação constrói um dispositivo de significação responsável pela criação de estereótipos e generalizações. Assim, as representações ${ }^{8}$ envolvendo os indígenas são compreendidas não somente pelo número alarmante dos índices de violência apresentados nas notícias, mas também pelas diversas representações feitas quando se descreve o indígena no discurso e nas imagens publicadas (e que revelam o caráter seletivo e tendencioso das notícias produzidas).

Cabe pontuar que a supressão das terras e o aldeamento ${ }^{9}$ foram responsáveis pela violação de direitos dos povos indígenas presentes no estado bem como por sua vulnerabilidade social. Desse modo, é possível observar recorrentemente nos jornais locais notícias que tratam da violência envolvendo a histórica disputa pela terra no estado de Mato Grosso do Sul. Ali os indígenas pertencentes às etnias Guarani, Kaiowá e Terena são apresentados de maneira genérica. Portanto, a pesquisa das notícias demonstrará de que modo essa narrativa reitera a imagem de um índio genérico, "selvagem", "bárbaro" e, consequentemente, tem servido para justificar seu lugar de exclusão e morte.

Destarte, podemos afirmar que há a construção de uma representação pública a partir da formação da opinião pública midiática: “A opinião pública elevada à condição de poder, já se torna uma esfera pública, pois há uma opinião já formada que define uma ação política, por isso há a necessidade de manipulação para construir esta esfera" (DUARTE, 2016, p. 43).

8 Aqui trabalhamos com a concepção de representações sociais, em um processo de concepção iniciada em Durkheim como representação coletiva. Tomamos a concepção cunhada por Porto (2009), Moscovici (1988) e Goffman (1985), que ultrapassam essa norma funcionalista do processo de representação dos sujeitos, e compreendemos como os atores sociais são apropriados e demarcados de símbolos e significados quando observamos as representações sociais como método de análise do conteúdo dos documentos noticiosos.

9 A partir de 1910, começou um processo de mudança em relação à ocupação do território. Esses indígenas encontraram dificuldades para se assentarem e viver de forma autônoma. O Estado instituiu um órgão tutor para lidar com as questões relativas aos indígenas e os trabalhadores. Esse organismo foi o Serviço de Proteção aos Índios (SPI) e Localização dos Trabalhadores Nacionais (LTN), o qual, no atual Cone Sul do estado de Mato Grosso do Sul, entre 1915 e 1928, efetivou estrategicamente a delimitação de oito minúsculos espaços de terra, denominados "Aldeia Indígena" e/ou "Posto Indígena" (BENITES, 2009, p. 27). Em Brand (1997), o aldeamento dos Guarani e Kaiowá é paradigma de confinamento que se deu após a Guerra do Paraguai. No sentido de uma etnologia indígena e história do indigenismo em MS, tal confinamento não se deu apenas na forma territorial, mas também na cultural. 
Para além de compreender a violência em sua dimensão física, há de se considerar, sobretudo, seu caráter simbólico. Afinal, a violência simbólica, não menos problemática que a violência física, acaba por constituir um aparato sutil e perverso de negação da alteridade que extrapola a dimensão física e que se enraíza em formas de ver e de pensar numa intrincada teia de aspectos objetivos e subjetivos. "A violência simbólica é uma violência que se exerce com a cumplicidade tácita daqueles que a sofrem e também, frequentemente, daqueles que a exercem na medida em que uns e outros são inconscientes de exercê-la ou a sofrer" (BOURDIEU, 1997, p. 22).

As diversas formas de discurso do jornal tornam essa construção da violência simbólica por meio de uma representação pública estigmatizante e/ou estereotipada. Rocha (2008) afirma que há uma fabricação da notícia e que a mídia nessa sociedade democrática detecta e apresenta uma realidade a partir da configuração que pretende para a cultura e a formação social. Ou seja, considerando a violência simbólica midiática, podemos dizer que ela produz não apenas um produto para o consumo (as notícias), mas também (e principalmente) uma determinada forma dos indivíduos se compreenderem, compreenderem o(s) outro(s) e o(s) contexto(s) onde estão inserido(s) (SOUZA, 2018). Imagem essa marcada por processos de estigmatização e exclusão. Nesse sentido, problematizando as notícias do jornal O Progresso a partir do conceito de estado de exceção ${ }^{10}$, não há como ignorar o fato de que "o campo jornalístico detém um monopólio real sobre os instrumentos de produção e de difusão em grande escala da informação" (BOURDIEU, 1997, p. 65).

\footnotetext{
${ }^{10}$ Este conceito é cunhado por Agamben (2000), quando, no advento de guerras e práticas governamentais ditas democráticas, elas se apresentaram efetivamente como absolutistas, havendo o contraste entre uma representação de práticas que eximem uma parcela da população. O Estado se beneficia de dispositivos legais para suprimir os limites da sua atuação, a própria legalidade e os direitos dos cidadãos. Para Agamben, "o estado de exceção apresenta-se como a forma legal daquilo que não pode ter forma legal" (AGAMBEN, 2000, p. 12). Há uma relação próxima entre as áreas do direito, da democracia e da comunicação quando servem para legitimar a violência, a arbitrariedade e a suspensão de direitos em um discurso de segurança e promoção do poder.
} 


\section{OS SENTIDOS DE EXCEÇÃO NOS DISCURSOS JORNALÍSTICOS: CULTURA DE MASSA E EXCLUSÃO}

Agamben (2000) sustenta que a exceção é o dispositivo por excelente da produção da morte no interior do dispositivo jurídico. Nesse sentido, haveria estreita relação entre o direito e a vida. Para o autor, na exceção, com efeito, um determinado caso é excluído do ordenamento jurídico, mas está excluído apenas na medida em que segue uma relação com a norma jurídica (a norma aplica-se desaplicando-se). De acordo com Agamben, a vida nua seria o paradigma por excelência de um estado de exceção. Ou seja, uma vida deixada à própria sorte. Para nós, a mídia (neste caso, o jornal) tem se constituído, por meio das imagens e dos discursos que veicula, como um importante dispositivo na produção e reiteração de uma vida nua. Portanto, por meio de sua análise, é possível ter acesso ao modo como a sociedade estabelece processos de estigmatização, violência e morte.

Cabe à época moderna, então, o triste privilégio de ter transformado a óbvia constatação do poder sugestivo da palavra no projeto consciente de introduzir a violência na própria linguagem. A manipulação das consciências através da violência linguística organizada se tornou uma experiência tão comum que uma exposição das relações entre violência e linguagem é hoje parte integrante de uma teoria da violência. (AGAMBEN, 1970, p. 157).

Deste modo, tratamos como "sentidos de exceção" todas as formas linguísticas e imagéticas com que as narrativas jornalísticas retratam determinadas sociedades, comunidades, etnias. Como não pensar, portanto, a figura do "índio violento", "sujo", "bugre", "estuprador", que tem sito reiteradamente veiculada pela mídia local (e quiçá regional), como a produção de uma contínua condição/ estado de exceção? Tal exceção é desvelada quando os conteúdos elencados pelo jornal, tornam-se massivamente consumidos, internalizados e dialeticamente reproduzidos no âmbito social. Como exemplo, podemos tomar a notícia veiculada na edição de 28 de junho de 2013 com o título "Violência entre indígenas aumenta 237\%, aponta relatório"11.

Em certo trecho do jornal, deparamo-nos com o seguinte discurso: "O relatório aponta também que, no caso de violência relacionada à omissão do

11 "Violência entre indígenas aumenta 237\%, aponta relatório" (O PROGRESSO, 28 de junho de 2013, n. 11.822). 
poder público, houve crescimento na falta de assistência à educação escolar (18,8 mil vítimas), à saúde (80,4 mil vítimas) e disseminação de bebidas alcoólicas (254 vítimas)". No corpo da notícia, observamos as representações da violência sendo elencadas como problemas políticos e sociais, porém antes de ser uma análise trazida pelo próprio o jornal, trata-se de um relatório que é do Conselho Indigenista Missionário (CIMI).

Apesar da pesquisa apresentada (o que garantiria o caráter de "fundamentação" da notícia), o jornal deliberadamente parece ir na contramão da fonte utilizada. Ou seja, é possível ler no interior na notícia que uma atenção muito maior é dada ao aumento da violência do que as possíveis causas sociais que a produzem.

Em outra da notícia, publicada na edição n. 11.725, de 1ㅇ de março de 2013, é emblemático: "O Ministério Público e a Funai batem muito em cima dessa questão mas a verdade é que aqui a cultura está praticamente morta e ninguém toma providência". O sentido de extinção dos indígenas é posto em evidência, em que sua "identidade" estaria deteriorada ou em vias de extinção. Assim, a linguagem utilizada em "a cultura está praticamente morta" denota um sentido de exceção. Não é nosso objetivo discutir os conceitos inerentes à cultura e identidade indígena neste artigo (algo que escaparia da presente proposta), mas vale ressaltar que estudos antropológicos apontam que tanto a cultura quanto a identidade são processos dinâmicos e abertos à ressignificação. Portanto falar em perda ou morte, seja da cultura ou da identidade étnica, é um equívoco (PACHECO DE OLIVEIRA, 1998; CARNEIRO DA CUNHA, 1994).

Ainda na esteira da criação de estereótipos, a notícia "Polícia prende índio acusado de estupro", presente na edição n. 11.723, de 27 de fevereiro de 2013, de forma aparentemente "objetiva", realiza um julgamento prévio, ou seja, ainda que o caso legalmente tivesse que passar por um processo de investigação, o jornal antecipando-se a qualquer procedimento técnico, julga por si mesmo: "estupro". Destacamos ainda o seguinte fragmento que inicia a descrição da notícia: "Um indígena de 19 anos foi preso no final da tarde dessa segunda feira (25) sob acusação de assaltar e estuprar uma estudante de 18 anos, em Amambai". Quando nos voltamos para a referida notícia numa perspectiva interseccional, considerando que raça/etnia, classe, gênero (dentre outros) funcionam como marcadores sociais de diferença no mundo social, é que nos damos conta da importância que é atribuída pelo jornal da ligação entre "delito" (o pretenso estupro) e pertencimento 
étnico do acusado. Em cena, a produção de uma violência simbólica que opera por meio de um duplo enquadramento: é indígena e "estuprador".

Como destacamos anteriormente, a mensagem produzida pela esfera pública é seletiva. Carey (1973) explana que a comunicação é um processo de mensagens que são transmitidas e distribuídas no espaço para controle das distâncias e das pessoas, portanto comunicação é o processo simbólico por meio do qual há uma construção da realidade produzida, mantida, reparada e transformada.

Na mesma edição do dia 27 de fevereiro de 2013, encontramos o seguinte fragmento da notícia "Advogada de fazendeiro diz que há exagero".

A advogada Sueli Lima, que defende o fazendeiro Orlandino Barbosa (61), acusado de ter provocado a morte de um adolescente indígena de 15 anos, a tiros de espingarda, convocou a imprensa para expor a versão da defesa. Ela afirmou que "existe um exagero sobre o caso" e que seu cliente está sendo prejudicado mais pela repercussão que o caso ganhou do que pelos próprios fatos. (O PROGRESSO, 27 de fevereiro de 2013, n. 11.723).

Ou seja, se na notícia anterior há um julgamento prévio do jovem indigena, aqui há espaço para a produção da dúvida: "acusado". Portanto, se na notícia anterior há a constatação ("estuprador"), aqui parece prevalecer a incerteza (ou de acordo com o jargão jurídico, o princípio da dúvida), ou nos próprios termos do noticiário, um "exagero". Dois pesos e duas medidas? O que sim é que na primeira notícia temos um indígena (o que num estado ruralista e latifundiário é um problema), na segunda um fazendeiro. Como apontam Becker, Oliveira e Martins,

Em solo sul mato-grossense esse é um dos indicadores da intolerância e do ódio que verte seu sangue, tal como se marca a ferro e a fogo o gado, mas, é claro sem que esses objetos corporificados e generificados no feminino, como travestis, gays, transexuais, mulheres tenham o valor que o gado assume por aqui. (BECKER, OLIVEIRA; MARTINS, 2016, online).

Ainda para pensar a relação entre mídia e estereótipo, o trabalho de Limberti (2012) é uma das referências. Em seu trabalho sobre a imagem do índio na produção jornalística no MS, a autora constata que a produção jornalística relativa ao indígena é dada de forma diferenciada. No exame da imagem do índio produzida pelo jornal O Progresso, a autora percebe um discurso típico acerca da história de Dourados. Por exemplo, o jornal seleciona, transforma e propaga preceitos ideológicos, legitimados como memória, separando essas imagens em fases. 
Como exemplo dessas imagens, tem-se na edição de O Progresso, n. 11.765, de 19 de abril de 2013, a notícia: "Polícia está com medo de ir às aldeias". Nela se apresenta uma situação bastante característica desse discurso típico quando o jornal coloca em sua narrativa a perspectiva do comando policial sobre as condições das aldeias. No trecho "Policiais Civis e Militares temem pela própria segurança ao adentrar às aldeias Jaguapiru e Bororó em Dourados", percebemos como é caracterizada a aldeia como espaço de violência. Em outro ponto da notícia, há a afirmação da pretensa periculosidade: "Para adentrar às aldeias é necessário uma série de equipamentos especiais, como armas não letais, e nós não temos", ou seja, o espaço em que o indígena reside é "perigoso" e necessita de certos cuidados como forma de precaução e "segurança". Não é à toa que a notícia está localizada em uma sessão que retrata casos policiais e, a partir disso, apresenta a "justificativa" da segurança pública para uma "intervenção" diante da situação de "perigo". "O alerta dos policiais se dá em razão da série de conflitos que vêm acontecendo entre fazendeiros e indígenas, sobretudo problemas sociais que ocorrem dentro da própria aldeia" (O PROGRESSO, 19 de abril de 2013, n. 11.675). O conflito entre fazendeiros e indígenas é citado nessa notícia como um mero acaso, o mais importante é destacar que já existem "problemas sociais que ocorrem dentro da própria aldeia". Assim, deliberadamente se minimiza ou desconsidera os dilemas historicamente produzidos pelo processo de expulsão dos indígenas de seus territórios tradicionais. Como golpe final, ao desconsiderar a dimensão social da realidade vivida pelos indígenas, está a construção de um indígena que é naturalmente atrelado a uma terra violenta, porque "naturalmente" violento.

Silva (2007) demonstra em sua pesquisa o retrato de negação da presença indígena no jornal quando os discursos provocam a noção de expansão desenvolvimentista e econômica voltada ao trabalho a partir das representações negativas feitas dos Guarani.

Comandulli (2012, p. 23), por sua vez, aponta que, nos países em que os povos Guarani estão presentes, é semelhante o desrespeito dos estados para com as populações originárias, como a ausência de respeito aos territórios, a depreciação da cultura dos Guarani e em diversos momentos a exclusão desse povo da sociedade nacional. Cita também que uma das prioridades fomentadas pelos próprios indígenas, nos diversos congressos e reuniões sobre a causa indígena, 
versa sobre o "reconhecimento político de nossa Nação por parte dos países assentados sobre o espaço territorial ancestral guarani e de sua livre determinação" (COMANDULLI, 2012, p. 28). O que sim é que, apesar da reivindicação dos indígenas por um processo de autodeterminação, a mídia produz justamente o contrário: um contínuo desapropriar. Isso se dá pela via da desvalorização e desqualificação do estilo de vida Guarani e Kaiowá.

Conforme Bourdieu (1997, p. 25), "Os jornalistas têm óculos especiais a partir dos quais veem certas coisas e não outras, e veem de certa maneira as coisas que veem. Eles operam uma seleção e construção do que é selecionado".

Dessa forma, os sentidos de exceção estão impressos na representatividade e interpretação feita pelo jornalista, bem como na forma como é estruturada e conduzida a narrativa no periódico.

O caráter de desenvolvimento empregado tanto no nome do jornal como na sua capa inicial está em perfeita consonância como os projetos federais de ocupação e desenvolvimento da região, bem como dos ideais que sustentam a formação da identidade sul-mato-grossense. (SILVA, 2007, p. 25).

O jornal O Progresso representa apenas um discurso diante de tantos outros veículos de comunicação que circulam pela região sul do estado de MS e que reiteram uma condição de pauperização e desumanização dos indígenas. Traçando essa identidade sul-mato-grossense e toda a relação de discurso, observamos a constituição de um ethos (jeito de ser) de jornalismo anti-indígena. Essa depreciação da imagem do indígena no processo de construção do jornalismo em MS é um percurso identificado pelas pesquisas de Silva (2007), Limberti (2012) e Benites (2014 ), quando retratam a imagem do índio bom ou índio mau.

Na notícia "Índia mata marido com duas facadas", percebemos logo no título da edição n. 11.800, de 3 de junho de 2013, a relação entre índio e crime, índio e violência. Como vimos anteriormente, o estado de exceção se dá não apenas por meio da linguagem de violência, mas pelo processo de banalização da mesma. Dessa forma, parece não haver nenhum problema em descrever o ocorrido por meio da descrição dos detalhes. A vítima foi assassinada com dois golpes de faca, um no pescoço e outro nas costas". Aqui é como se estabelecesse uma banalização do mal, como se o mal estar dos outros pudesse ser descortinado sem nenhum pudor, sem nenhuma culpa (SONTAG, 2003). 
Assim, a opinião pública é fabricada por uma imprensa que se compromete a forjar um consenso a todo custo - ainda que precise apelar para o falseamento das informações ou mesmo para um espetáculo ardiloso e sádico.

\section{COMO SÃO REPRESENTADOS OS INDÍGENAS?}

O que são as representações sociais? Goffman (1985), Moscovici (1988), Machado e Porto (2015) atribuem a Durkheim a primeira noção de representação social. Segundo os autores, Durkheim percebe os valores comuns da sociedade como uma representação coletiva. Superando essa noção de representação coletiva, Goffman (1985) define as representações sociais como um processo de padronização intencional ou inconsciente da ação do indivíduo durante manifestações públicas - o que ele chama de "fachada".

Retomando a noção durkheiminiana de fato social, Goffman (1985) vai chamá-la de "fachada" por conta da institucionalização e estereotipação das representações coletivas, passando a ser concebida como idealização, como percepção teórica das representações sociais. "Pensar os saberes a partir da análise de representações sociais é produzir conhecimento quando se interroga a realidade através do que se pensa sobre ela" (MACHADO; PORTO, 2015, p. 298).

Como explica Moscovici (1988, p. 214), "as representações sociais que modelam nossas relações com a sociedade, e ao mesmo tempo, um componente de organização social", por sua vez, compõem um imaginário que estabelece relações de poder na forma de representações sociais. Essa ênfase se dá em Moscovici (1988), na medida em que as relações e interações sociais chegam a manter ou transformar determinadas condutas que podem até motivar políticas públicas.

[...] independentemente de sua condição de falsa ou verdadeira, o que importa ressaltar é que, por força de repetição, tais afirmações passam a fazer parte do imaginário popular. Uma vez constituídas como "verdade", informam condutas e comportamentos de atores sociais. (PORTO, 2009, p. 215).

Assim, a violência enquanto um conceito pode ser compreendida pela via das representações sociais. Porto (2010) enfatiza que esse conceito tem sido apropriado pelo senso comum, pela política, pela mídia e por outros âmbitos em que se valida a discussão sobre as representações sociais da violência. O consenso da notícia produzida e o papel da mídia na confecção das notícias sobre violência 
auxiliam no entendimento dessas representações sociais. Ainda segundo Porto (2009), a mídia é geradora da violência, justamente por seu discurso tornar um comportamento, uma prática ou uma identidade genéricos.

A partir da noção de violência simbólica, busca-se compreender como é representado o sentido de violência e os processos que favorecem desdobramentos múltiplos e complexos da imagem do indígena. Afinal, "A violência sempre foi empregada, no Brasil e no mundo, para forçar o consenso, defender a ordem social" (ZALUAR, 1999, p. 11).

De acordo com Saraiva e Coutinho (2012, p. 56), "a violência é um fenômeno que precisa ser descaracterizado como um ato natural”. Ou seja, o que ocorre é que a sociedade produz uma naturalização da violência, formando pareceres e hábitos como condutas sociais e leis de convivência. Assim, dando tom de normalidade na vida da sociedade, é preciso forjar força ideológica para descaracterizar tal poder.

Os estereótipos criados produzem uma mensagem de convencimento para o consumidor/leitor. Muitas das notícias, ao contrário de apenas "relatar" eventos envolvendo indígenas, acabam, por meio de juízos de valor, atribuindo-lhes uma identidade deteriorada. O que podemos compreender desta mídia local é que a noção de formação da sociedade não inclui o indígena em seu discurso ou, quando o faz, é apenas para reiterar o lugar de subalternidade socialmente imposto.

Para Bourdieu (1989), a dominação cultural exercida por uma classe sobre outra, a partir de vários capitais (por exemplo: econômico, cultural etc.), desenvolve a violência simbólica. Ou seja, o sistema simbólico dos estereótipos é proposto por uma construção cultural que pode ser exercida pela mídia, assim permitindo que tal discurso conceitue e determine os diversos significados, entre eles, a violência.

Os estereótipos podem ser encontrados na quantidade de notícias que reforçam as representações da violência narrada. Por exemplo, as notícias relacionadas a furto e assalto: "A Polícia Civil faz um alerta para uma onda de furtos praticados por indígenas, que vem ocorrendo em regiões consideradas nobres da cidade, em Amambai"12. A questão dos assaltos está atrelada aos indígenas

12 "Indígenas são suspeitos de assaltos em Amambai" (O PROGRESSO, 14 de janeiro de 2013, n. 11.688). 
como agentes dos furtos. O discurso caracteriza e estigmatiza um coletivo a partir da mensagem de periculosidade, assim como nas notícias que seguem: "Taxista diz que foi vítima de três indígenas"13, "Índio esquartejador já teria matado mais três"14 e "Índios são apreendidos por furto e estupro"15.

Referente à notícia veiculada sobre a aldeia indígena Bororó, podemos destacar o seguinte trecho: "Durante ronda nas proximidades do Residencial Santa Fé, a polícia deu ordem de parada a um homem de motocicleta. Como ele empreendeu fuga, iniciou-se a perseguição. Ao ser pego, o homem, morador na Aldeia Bororó, na Reserva Indígena de Dourados...". Tal fragmento demonstra em específico como aldeia e cidade são espaços narrados a partir de uma separação simbólica incontornável. É como se não fosse possível pensar a cidade de Dourados sem essa divisão simbólico-geográfica que separa indígenas de não indígenas, quem mora abaixo ou acima da avenida Marcelino Pires, quem tem e quem não tem caminhonete (MILAN, 2019).

Outras representações envolvem a acoplagem entre violência e consumo de bebidas alcoólicas. É o que se pode verificar nas seguintes notícias: "O indígena teria passado a noite fora de casa consumindo bebida alcoólica e ao retornar, na manhã de terça-feira, teria cometido o suicídio"16"; "Após consumir bebida alcoólica, um adolescente indígena de 14 anos cometeu suicídio na noite de domingo passado, na Aldeia Amambai"17; "Índio bêbado fere criança de dois anos com golpes de facão" ${ }^{18}$. Mais uma vez em nenhum momento se considera o contexto de precarização em que vivem os Guarani e Kaiowá no contexto de confinamento de suas reservas ou nos inúmeros acampamentos ao redor da BR 163 (CRESPE, 2015).

Em outra notícia, há relação entre indígenas e homicídio. Com o título "Pesquisa mostra que índio mata índio no MS", por meio de uma linguagem aparentemente "descritiva", constitui-se um dispositivo produtor de um juízo de

\footnotetext{
13 "Taxista diz que foi vítima de três indígenas" (O PROGRESSO, 16 de janeiro de 2013, n. 11.690). 14 "Índio esquartejador já teria matado mais três" (O PROGRESSO, 2 de fevereiro de 2012, n. 11.415). 15 "Índios são apreendidos por furto e estupro" (O PROGRESSO, 25 de abril de 2013, n. 11.769). 16 "Índio comete suicídio usando fio de rádio" (O PROGRESSO, 24 de janeiro de 2013, n. 11.697). 17 "Mais um adolescente indígena comete suicídio" (O PROGRESSO, 5 de março de 2013, n. 11.728). 18 "Índio bêbado fere criança de dois anos com golpes de facão" (O PROGRESSO, 28 de janeiro de 2013, n. 11.700).
} 
valor discriminatório, como se qualquer indígena de Mato Grosso do Sul, por ser indígena, fosse um homicida em potencial. Temos como consequência (o que parece não ser mero acaso) a desresponsabilização do não indígena diante de um possível homicídio de indígenas, haja vista que é "índio que mata índio no MS". Neste editorial de 20 de junho de 2013, n. 11.815, temos o seguinte destaque: "92\% dos homicídios contra indígenas são cometidos por outros indígenas". A questão da disputa territorial e principalmente a forma como são justificados os crimes são demonstradas no texto jornalístico por interesses seletivos: "Foi elaborado a pedido da Federação da Agricultura e Pecuária de MS (Sistema Famasul) com a finalidade de esclarecer informações sobre os homicídios". Vale ressaltar que a FAMASUL é justamente o órgão responsável pelos interesses dos latifundiários no Mato Grosso do Sul. A notícia se apropria da informação como uma pesquisa e representa autoridade e formação de consenso, se observarmos a continuidade da notícia: "Para o presidente da Famasul, Eduardo Riedel, as informações disponibilizadas pelo governo estadual evidenciam que o consumo de álcool é o principal motivo dos crimes nas aldeias". Ou seja, seria o consumo de bebida alcoólica e a pretensa índole homicida e/ou violenta dos indígenas que justificaria suas precárias condições de vida. A notícia, ao privilegiar a situação "degradante" em que vivem os indígenas, acaba por desviar o "olhar" do conflito de terras e do papel nefasto do agronegócio em terras sulmatogrossenses, desconsiderando, portanto, deliberadamente os impactos dos conflitos de terras nas condições de vida dos povos indígenas da região e a (i)responsabilidade do estado e de suas instituições.

\section{OS DISCURSOS QUE MATAM!}

Sobre as demarcações de terras indígenas, os discursos apresentados nos noticiários analisados retratam o indígena como inimigo do "Progresso". Mas que "progresso" é esse? "Progresso" segundo quem e para quem? (MILAN, 2019). Vale ressaltar que um dos grandes dilemas em torno do reconhecimento dos direitos dos povos indígenas no estado está justamente atrelado a ideia que representariam um empecilho ao desenvolvimento. Não por acaso um discurso comum no MS nas pautas envolvendo a demarcação de terras indígenas ou a desapropriação de fazendas improdutivas seja o de: para que tanta terra para pouco índio? 
Nesse cabo de guerra desigual (e desumano), o discurso midiático tem um papel proeminente. Por meio dele criam-se espaços de controle e estigmatização dos indígenas como inimigos do progresso, do desenvolvimento. Esse outro "inimigo" passa ocupar todos os atributos essencializantes que atestam seu grau de animalidade e barbarismo. Enquanto um outro degradado, assujeitado, sem dignidade, só resta ou a mendicância ${ }^{19}$ ou as páginas policiais.

Retomando a notícia do dia 20 de junho de 2013, temos a seguinte expressão: "Remeter os homicídios ao conflito fundiário é manipular a informação e camuflar o problema social". E, no dia 27 de fevereiro de 2013, esta declaração: "[...] 'existe um exagero sobre o caso' e que seu cliente está sendo prejudicado mais pela repercussão que o caso ganhou". Em nenhum momento é possível ter acesso a um contra-discurso. Falam os jornalistas, falam os latifundiários e seus advogados, mas e os indígenas? E as lideranças indígenas? Nesse "manipular e informação" ou "camuflar" ou mesmo "exagerar", está explícito que se há algum problema isso de deve ou à natureza "selvagem" desse outro perigoso ou a questões que não nos dizem respeito.

Outro exemplo dessa desresponsabilização social é encontrada na edição n. 11.725 , de $1^{\circ}$ de março de 2013, cujo título da notícia é: "Deprimido, jovem da etnia guarani comete suicídio". Há a descrição de um evento sem preocupação com o contexto, ou seja, em nenhum momento se consideram os impactos político-sociais na organização social dos Kaiowá em decorrência do conflito fundiário no estado (PEREIRA, 2015, CRESPE, 2015). E, mesmo quando considerado, o que impera é a desmoralização do coletivo, como é possível observar pelo título da matéria seguinte presente na mesma edição20: "Criadores de área próxima a aldeias denunciam furtos". Em cena, a acoplagem entre indígenas, suicídio e delinquência - questões amplamente exploradas pela mídia sul-mato-grossense, de modo geral, e douradense, de modo particular, que servem para "justificar" as inúmeras injustiças sociais sofridas pelos povos indígenas do estado e cujos Guarani e Kaiowá são exemplos dramáticos.

\footnotetext{
${ }^{19}$ Vale mencionar a prática dos indígenas Kaiowá percorrem determinados bairros considerados de classe média em Dourados batendo de porta em porta a procura de "pão".
}

${ }^{20}$ O Progresso em $1^{\circ}$ de março de 2013, n. 11.725 
Com o histórico dos conflitos de terras ocorridos no Estado do Mato Grosso do Sul, observa-se uma severa violação dos direitos dos indígenas. A falta de política de terras e a situação de confinamento étnico tornam as etnias indígenas vítimas de marginalização na tensão entre aldeia e cidade, justamente pelo aldeamento existente. A mídia faz sua escolha pela causa dos grandes proprietários de terra e pela produção agrícola em massa, o plantio extensivo de grãos. (DUARTE, 2016, p. 18)

Já a notícia a seguir, apresentada no dia 23 de outubro de 2013, ilustra explicitamente esse discurso que mata:

Figura 1 - Destaque do noticiário

\section{Criança índia cai de bicicleta embaixo de pneu de ônibus}

\section{Ela seguia com o pai e a máe, que estavam alcoolizados}

De Dourados

Sidnei Bronka

Uma menina de seis anos morreu depois de ser atropelada por um ônibus, no final da tarde desta segunda-feira, por volta das $18 \mathrm{~h}$, depois de cair na bicicleta onde seguia em companhia do pai e da mãe. Segundo a polícia, os país da menina estavam alcoolizados.

De acordo com o boletim de ocorrência, a família seguia em uma bicicleta por uma estrada vicinal da Re- serva Indígena de Dourados, quando passou por eles um ônibus de uma empresa conduzido por uma motorista de 27 anos, moradora no Parque das Naçōes 11.

\section{Caiu}

A condutora contou que desviou deles, mas o casal deixou a menina cair da bicicleta, parando embaixo da roda traseira esquerda do coletivo. Uma equipe do corpo de bombeiro chegou a ser acionada, mas a vitima já estava morta.

Na delegacia, a mãe e o pai, ainda embriagados, foram ouvidos pela delegada Andreia Alves Pereira. A Polícia Civil abriu inquérito para apurar o caso.

Fonte: Jornal O Progresso. 
Figura 2 - Destaque do noticiário

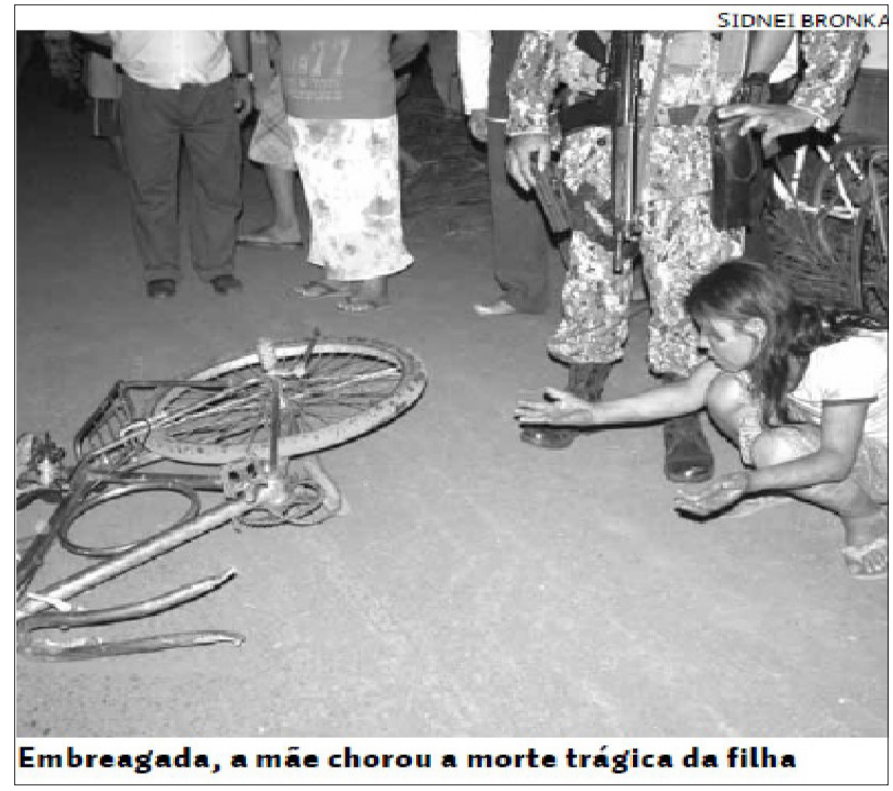

Fonte: Jornal O Progresso.

Algumas expressões presentes nos seguintes trechos: "Criança índia cai de bicicleta embaixo de pneu de ônibus. [...] morreu depois de ser atropelada por um ônibus [...]. Segundo a polícia, os pais da menina estavam alcoolizados. [...] Na delegacia, a mãe e o pai, ainda embriagados", recorrem à ligação do atropelamento com a questão da embriaguez e novamente reaparecem como justificativa, isto é, há a desqualificação do homicídio em decorrência da suposta embriaguez dos genitores da vítima. Ou seja, o crime fica em segundo plano pelo simples fato da identidade estigmatizante atribuída aos indígenas. A questão que entendemos como estigmatização dos indígenas no discurso se dá pela relativização que é feita da morte da vítima em nome da necessidade de desqualificação das condições em que se encontram seus pais (que, conforme o noticiário, se encontravam na cena do acidente).

Porém os discursos que matam também são representados nas imagens veiculadas no jornal quando identificam dois fatos violentos com exposições fotográficas sem a menor preocupação com a exposição do sujeito indígena. A edição n. 11.830, de 8 de julho de 2013, é ilustrativa disso: 
Figura 3 - Destaque para a violência contida nas imagens

\section{Dois índios guaranis são mortos a golpes de faca}

Um deles, da aldeia de Caarapó, levou $\mathbf{3 7}$ facadas no abdômen, já o outro, de Dourados, foi morto com vários golpes no pescoço
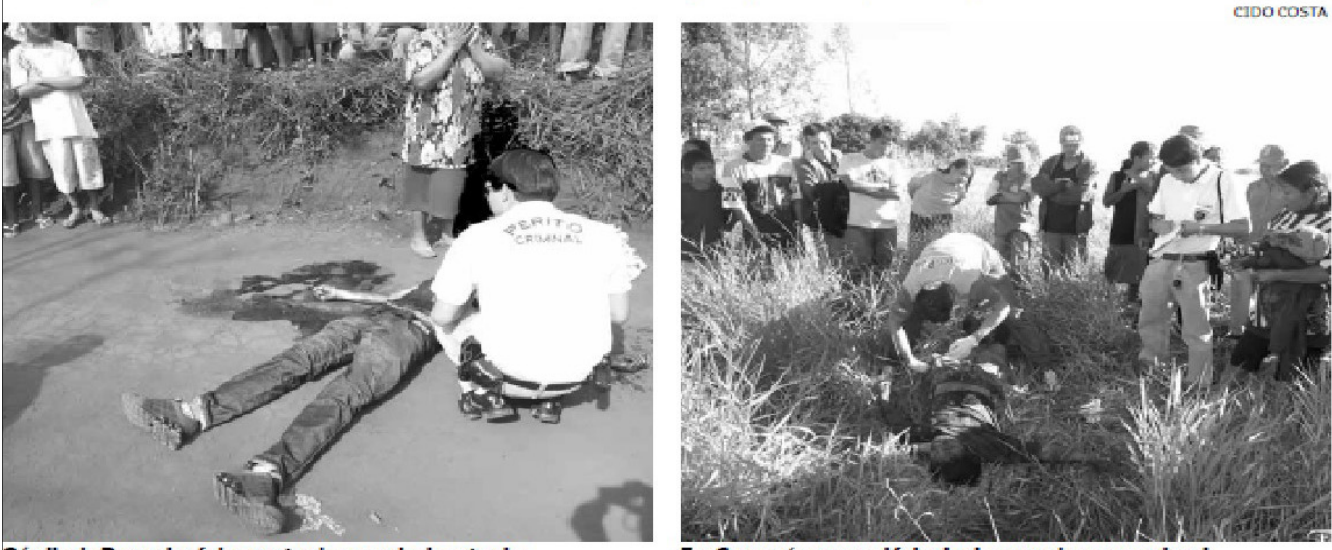

O índio de Dourades foi eneontrado no moio da *etrada

Em Carapó o ruarani foi wehado om moio a um eapinzal

Fonte: Jornal O Progresso.

Nas imagens, os corpos jogados (seja na estrada seja no matagal) se constituem como ícones de uma violência simbólica midiática que não tem pudor em expor sem vergonha a desumanização do outro animalizado pela lente de uma câmera cujo único compromisso é com a banalização da dor do outro (SONTAG, 2003; OLIVEIRA, ARAUJO, 2020). Trata-se de um corpo racial e etnicamente perscrutado cuja a morte desumana e sua exposição "reificadora" (ALMEIDA, 2000), revelam

[...] o papel jogado pelas representações do corpo (através da fotografia de grande circulação e da notícia jornalística que a acompanha) na reprodução da visão hegemónica sobre os grandes níveis de identidade social propiciadores de desigualdades: a classe, a "raça", o género e a sexualidade e, também, a idade. (ALMEIDA, 2000, p. 147). 


\section{CONSIDERAÇÕES FINAIS}

Ao buscarmos compreender os diversos discursos linguísticos e imagéticos produzidos pelo jornal O Progresso, pudemos identificar a ação de um poder simbólico que, por meio de um discurso de barbárie e violência, justifica as condições socialmente produzidas de degradação da diferença. Assim, ao intitularmos este artigo como os discursos plurais que matam, referimo-nos às repetidas mensagens veiculadas no referido jornal e que reiteram exatamente a mensagem de extermínio social dos indígenas no contexto do estado de Mato Grosso do Sul, seja por uma suposta "natureza" degradante que os constituiria, seja por uma "condição degradada" cujos únicos responsáveis seriam eles mesmos.

Se, conforme Agamben (2000), o estado de exceção corresponde a um "momento" em que, no interior das normas jurídicas, se abre espaço (numa aparência de extraordinariedade) para que determinadas vidas sejam matáveis, isso nos permite pensar a mídia enquanto um dos dispositivos por excelência de naturalização desse estado de exceção. Por meio de um discurso dissimulado de "descrição da realidade" ou de "relato dos fatos", é responsável pela naturalização de violências, discriminações e justificação de desigualdades socialmente produzidas. Ao mesmo tempo, ao mostrar em suas páginas determinados corpos, sujeitos e coletivos, ao inscrevê-los em determinadas sessões, ou mesmo ao escondê-los (quem está estampado nas páginas policiais? Quem aparece nas páginas de coluna social?), revela o caráter seletivo e racista de sua violência simbólica (OLIVEIRA, ARAUJO, 2020).

Portanto, ao analisar tais notícias, foi possível deslindar a máquina da violência simbólica produzida pela mídia sul-mato-grossense em relação aos indígenas. Assim, em nosso entender, não se trata de mero acaso que o jornal O Progresso venha a caracterizar, de modo geral, os indígenas como personagens atrelados ontologicamente à violência. Tais discursos, intencionalmente produzidos e orientados, (re)produzem reiteradamente um estado de exceção cuja consequência principal é a marginalização e exclusão dos povos indígenas existentes no estado. Seu principal mecanismo de sustentação é operado por meio de um discurso de "objetividade" e "imparcialidade" como forma de autojustificação e legitimação. Contudo, ao contrário, compreendemos que essas imagens-discursos deliberadamente orientam uma visão local negativa sobre os indígenas e que, nesse sentido, não são desvinculadas de interesses e intencionalidades ideológica e 
economicamente orientados. Não por acaso, ao mesmo tempo que o espaço concedido ao indígena é o da marginalidade, o espaço voltado para o agronegócio e as elites locais é o da exaltação e do reconhecimento.

Foi a partir desse processo de desnaturalização do discurso jornalístico que pudemos descortinar os mecanismos ideologicamente comprometidos com a (re)produção e reiteração de uma perversa violência simbólica. Esperamos ter demonstrado que a constituição do indígena enquanto "perigoso", "violento", "homicida", "estuprador", "ladrão", "bêbado", "desordeiro" e/ou "desajustado", longe de significar uma ontologia, trata, antes, de imagens e sentidos que só podem ser devidamente compreendidos numa perspectiva que contemple discursos e imagens como política e ideologicamente produzidos numa disputa complexa e assimétrica de práticas e representações sociais. Esse campo em disputas aponta para as instabilidades e precariedades dos mecanismos de opressão, ao mesmo tempo em que não nos permite ignorar as possibilidades para seu questionamento e subversão. É o que o modo de viver Teko Porã (bem viver) dos Guarani e Kaiowá tem dado mostras de longa data.

\section{REFERÊNCIAS}

ADORNO, Theodor. Indústria cultural e sociedade. São Paulo: Paz e Terra, 2002.

AGAMBEN, Giorgio. Estado de exceção. São Paulo: Boitempo, 2000.

AGAMBEN, Giorgio. Sobre os limites da violência. Nuovi Argomenti. n. 17, p. 154-74, 1970. Disponível em: http://www.culturaebarbarie.org/sopro/outros/violencia.html\#. WKO2-X9TLYY. Acesso em: 2 fev. 2017.

ALMEIDA, Miguel Vale de. Corpos marginais: notas etnográficas sobre páginas "de polícia" e páginas "de sociedade". Cadernos Pagu (14) 2000, p. 129-147.

BECKER, Simone; OLIVEIRA, Esmael Alves; CAMPOS, Marcelo Siqueira. Guarani-Kaiowá: 'onde fala a bala, cala a fala'. Revista IHU, 23 jun. 2016. Disponível em: http://www.ihu. unisinos.br/78-noticias/556749-guarani-kaiowa-onde-fala-a-bala-cala-a-fala. Acesso em: 2 fev. 2017.

BECKER, Simone; OLIVEIRA, Esmael A. de; MARTINS, Catia P. "Onde fala a bala, cala a fala". Rede Humaniza SUS, 19 jun., 2016. Disponível em: http://redehumanizasus.net/94812onde-fala-a-balacala-a-fala. Acesso em: 16 abr. 2020. 
BENITES, Tonico. A escola na ótica dos Avá Kaiowá: impactos e interpretações indígenas. Dissertação (Mestrado em Antropologia Social) - Universidade Federal do Rio de Janeiro, Rio de Janeiro, RJ, 2009.

BENITES, Tonico. Rojerokyhina ha roikejevytekohape (Rezando e lutando): o movimento histórico dos AtyGuasu dos Ava Kaiowa e dos Ava Guarani pela recuperação de seus tekoha. Tese (Doutorado em Antropologia Social)- Universidade Federal do Rio de Janeiro, Rio de Janeiro, RJ, 2014.

BOURDIEU, Pierre. Sobre a televisão. Seguido de a influência do jornalismo e os jogos olímpicos. Tradução de Lúcia Machado. Rio de Janeiro: Jorge Zahar, 1997.

BOURDIEU, Pierre. O poder simbólico. Rio de Janeiro: Bertrand, 1989.

BRAND, Antonio. O impacto da perda da terra sobre a tradição Kaiowá/Guarani: os difíceis caminhos da palavra. Tese (Doutorado em História)- Pontifícia Universidade Católica/RS, Porto alegre, RS, 1997.

CAREY, James. A cultural approach in communication. Urbana-Champaign, Institute of Communications Research, University of Illinois, 1973. [mimeo].

CARNEIRO DA CUNHA, Manuela. O futuro da questão indígena. Estud. av., v. 8, n. 20, São Paulo, jan./abr. 1994.

CHOMSKY, Noam. Fabricando el consenso: el control de los medios masivos de comunicación. Buenos Aires, 2004. Disponível em: https://sociologedu.files.wordpress. com/2012/03/chomsky-fabricando-el-consenso.pdf. Acesso em: 10 maio 2015.

CRESPE, Aline Castilho. Mobilidade e Temporalidade kaiowá: do tekohá à reserva, do tekoharã ao tekoha. 2015. Tese (Doutorado em História)- Universidade Federal da Grande Dourados.

COMANDULLI, Carolina Schneider. Mobilidade, identidade e acesso a direitos: os povos Guarani e as fronteiras. Revista Ñanduty, Dourados, ano 1, n. 1, p. 22-31, jul./dez. 2012. Disponível em: http://www.periodicos.ufgd.edu.br/index.php/nanduty. Acesso em: 20 maio 2016.

COMPARATO, Fábio Konder. A democratização dos meios de comunicação de massa. Revista USP, São Paulo, n. 48, p. 6-17, dez./fev. 2001.

DA MATTA, Roberto. Carnavais, malandros e heróis: para uma sociologia do dilema brasileiro. Rio de janeiro: Zahar Editores, 1979. 
DUARTE, Henrique. As representações sociais da violência envolvendo "as juventudes indígenas" na imprensa de Dourados (MS). 2016. Dissertação (Mestrado em Sociologia) - Universidade Federal da Grande Dourados (UFGD), Dourados, MS, 2016.

FOUCAULT, Michel. Aula de 17 de março de 1976. In: FOUCAULT, Michel. Em defesa da sociedade. Martins Fontes: São Paulo, 2005.

GOFFMAN, Erwing. As representações do eu na vida cotidiana. Petrópolis: Vozes, 1985.

HABERMAS, Jurgen. Mudança estrutural da Esfera Pública: investigações quanto a uma categoria da sociedade burguesa. Rio de Janeiro: Tempo Brasileiro, 1984.

LARAIA, Roque de Barros. Ética e Antropologia: algumas questões. Florianópolis: ABASUL, 1994 (Série Antropologia, n. 157).

LIMBERTI, Rita de Cássia Pacheco. A imagem do índio: discursos e representações. Dourados: UFGD, 2012.

MACHADO, Bruno Amaral; PORTO, Maria Stela Grossi. Homicídio na área metropolitana de Brasília: representações sociais dos delegados de polícia, promotores de justiça e magistrados. Revista Sociologias, Porto Alegre, ano 17, n. 40, p. 294-325, set./dez. 2015.

MILAN, Ezequias Freire. Dos "professores de verdade" às "crianças laudadas" do condomínio que ninguém entra: Etnografia em espaços reprodutores de práticas necropolíticas e de (re)existência em Dourados/MS. 2019. Dissertação (Mestrado em ANTROPOLOGIA)- Universidade Federal da Grande Dourados.

MOSCOVICl, Serge. Notes towards a description of social representations. European Journal of Social Psychology, n. 18, p. 211-50, 1988.

OLIVEIRA, Esmael Alves de; ARAUJO, Joalisson Oliveira. Marcas necropolíticas sobre corpos dissidentes em Mato Grosso do Sul (MS). Perspectivas em diálogo: revista de educação e sociedade, v. 7, p. 295-306, 2020.

PACHECO DE OLIVEIRA, João. Uma etnologia dos "índios misturados"? Situação colonial, territorialização e fluxos culturais. Mana, Rio de Janeiro, v. 4, n. 1, p. 47-77, 1998.

PEREIRA, Levi Marques. Assentamentos e formas organizacionais dos Kaiowá atuais: o caso dos "índios de corredor". Tellus, ano 6, n. 10, p. 69-81, abr. 2006.

PERLATTO, Fernando. Seletividade da esfera pública e esferas públicas subalternas: disputas e possibilidades na modernização brasileira. Revista Brasileira de Sociologia, v. 23, n. 53, p. 121-45, mar. 2015. 
PEREIRA, Levi Marques. A Reserva Indígena de Dourados: a atuação do Estado brasileiro e o surgimento de figurações indígenas multiétnicas. In: Graciela Chamorro; Isabelle Combès. (Org.). Povos indígenas em Mato Grosso do Sul: História, cultura e transformações sociais. Dourados: UFGD, 2015, v. 1, p. 781-794.

PORTO, Maria Stela Grossi. Sociologia da violência: do conceito às representações sociais. Brasília: Verbana Editora, 2010.

PORTO, Maria Stela Grossi. Mídia, segurança pública e representações sociais. São Paulo: Tempo Social, Revista de Sociologia da USP, v. 21, n. 2, nov. 2009.

ROCHA, Heitor Costa Lima. Habermas e a teoria do jornalismo: a manipulação ideológica do jornalismo como distorção sistemática da comunicação. Estudos em comunicação, Recife, n. 4, p. 41-57, 2008.

SARAIVA, Evelyn R. Albuquerque; COUTINHO, Maria da Penha de Lima. Meios de comunicação impressos, representações sociais e violência contra idosos. Psicologia em Estudo, Maringá, n. 2, p. 205-14, 2012.

SILVA, Andreia Fernandes. Os meios de comunicação social enquanto elementos de regulação cultural - breve apontamento. 2012. Disponível em: http://www.bocc.ubi.pt/ pag/silva-andreia-regulacao-cultural.pdf. Acesso em: 10 maio 2015.

SILVA, Lélio Loureiro. As representações dos Kaiowa-Ñandeva no jornal O Progresso na década de 1980. 2007. Dissertação (Mestrado em História) - Universidade Federal da Grande Dourados (UFGD), Dourados, MS, 2007.

SONTAG, Susan. Diante da dor dos outros. São Paulo: Companhia das Letras, 2003.

SOUZA, Jessé. A ralé brasileira. 3ạ. ed. São Paulo: Editora Contracorrente, 2018.

TRAVANCAS, Isabel; NOGUEIRA, Silva G. Antropologia da comunicação de massa. Campina Grande: Eduepb, 2016.

URQUIZA, Antonio Hilario Aguilera; PRADO, José Henrique. O impacto do processo de territorialização dos Kaiowá e Guarani no sul de Mato Grosso do Sul. Tellus, Campo Grande, ano 15, n. 29, p. 49-71, jul./dez. 2015.

VIETTA, Katya. Tekoha e te'y guasu: algumas considerações sobre articulações políticas Kaiowá e Guarani a partir das noções de parentesco e ocupação espacial. Tellus, Campo Grande, ano 1, n. 1, p. 89-102, out. 2001. 
ZALUAR, Alba. Um debate disperso: violência e crime no Brasil da redemocratização. Revista São Paulo em Perspectiva, n. 13, 1999. Disponível em: http://www.scielo.br/pdf/ spp/v13n3/v13n3a01.pdf. Acesso em: 22 fev. 2016.

\section{Sobre os autores:}

Henrique Duarte: Mestre em Sociologia pela Universidade Federal da Grande Dourados (UFGD). Especialista em Antropologia e História dos Povos Indígenas pela Universidade Federal de Mato Grosso do Sul (UFMS). Licenciado em Ciências Sociais pela UFGD. Bacharel em Teologia pela Pontifícia Universidade Católica do Paraná (PUCPR). Leciona Sociologia como professor efetivo na Secretaria de Estado de Educação (Seduc-MT). Redator das Diretrizes Referenciais Curriculares da Base Nacional Comum Curricular no Ensino Médio do Estado de Mato Grosso (DRCEM/ MT - BNCC) na área de Ciências Humanas e Sociais Aplicadas (CHSA). E-mail: poetadosjardins@gmail.com, Orcid: http://orcid.org/0000-0002-6832-7048

Esmael Alves de Oliveira: Pós-doutorado em Antropologia Social pela Universidade Federal do Rio Grande do Sul (UFRGS), junto ao Núcleo de Pesquisa em Antropologia do Corpo e da Saúde (Nupacs). Doutorado em Antropologia Social pela Universidade Federal de Santa Catarina (UFSC), com estágio doutoral na Universidade Eduardo Mondlane (UEM, Moçambique). Mestrado em Antropologia Social, especialização em Antropologia e graduação em Filosofia pela Universidade Federal do Amazonas (UFAM). Professor adjunto, em regime de dedicação exclusiva, do curso de Ciências Sociais e do Programa de Pós-Graduação em Antropologia (PPGAnt) da Faculdade de Ciências Humanas da Universidade Federal da Grande Dourados (FCH/UFGD) e do Programa de Pós-Graduação em Antropologia Social da Universidade Federal de Mato Grosso do Sul (PPGAS/UFMS). Pesquisador vinculado ao Impróprias - Grupo de Pesquisa em Gênero, Sexualidade e Diferenças. E-mail: esmael_oliveira@live.com, Orcid:http://orcid.org/0000-0002-9235-5938

Recebido em 28 de outubro de 2019.

Aprovado para publicação em 2 de março de 2020. 



\title{
Orientaciones teóricas sobre procesos identitarios y trayectorias de maestros/as indígenas en la región chaqueña (Argentina)
}

\author{
Diretrizes teóricas sobre processos e trajetórias identitárias \\ de professores indígenas na região do Chaco (Argentina)
}

Soledad Aliata ${ }^{1}$

DOI: http://dx.doi.org/10.20435/tellus.v0i42.694

Resumen: Este artículo es parte del trabajo de tesis doctoral en Antropología Social, centrada en documentar la diversidad y complejidad en las trayectorias socioeducativas de un grupo de maestros/as indígenas de la provincia del Chaco, Argentina. El presente escrito apunta a indagar en los principales ejes teóricos que atañen a nuestro problema de investigación vinculados con la figura de los/ as maestros/as indígenas y los estudios sobre la noción de identidad. Creemos que la pertinencia teórica de esta investigación para los estudios centrados en la educación en contextos interculturales reside en poner en diálogo categorías que, si bien son frecuentes en las ciencias sociales, albergan significados y usos analíticos contradictorios y, en algunos casos, conflictivos. De este modo, la obra busca cuestionar las perspectivas esencialistas y cosificantes. A su vez, se espera reflexionar sobre la articulación entre la idea de trayectorias y procesos de identificación étnica que permiten evidenciar la heterogeneidad que existe en las interacciones sociales, y al mismo tiempo el carácter paradójico y espiralado que encarna la vida de los sujetos. Advertimos que la sistematización de los debates que presentaremos no agota la multiplicidad de enfoques sobre la temática. Se trata simplemente de un recorte teórico que efectuamos a los fines de mostrar los antecedentes que consideramos pertinentes para nuestra investigación.

Palavras-chave: procesos identitarios; trayectorias socioeducativas; desigualdad; diversidad; maestros/as indígenas.

Resumo: Este artigo é parte da tese de doutorado em Antropologia Social, cujo objetivo é documentar a diversidade e a complexidade das trajetórias socioeducativas de um grupo de professores indígenas da província do Chaco, Argentina. Este escrito tem como objetivo investigar os principais

${ }^{1}$ Universidad de Buenos Aires, Buenos Aires, Argentina. 
eixos teóricos que concernem ao nosso problema de pesquisa relacionado à figura do professor indígena e aos estudos sobre a noção de identidade. Acreditamos que a relevância teórica desta pesquisa para estudos voltados para a educação em contextos interculturais reside em colocar em diálogo categorias que, embora frequentes nas ciências sociais, abrigam significados e usos analíticos contraditórios e, em alguns casos, conflitantes. Dessa forma, o trabalho busca questionar perspectivas essencialistas e reificadoras. Por sua vez, espera-se refletir sobre a articulação entre a ideia de trajetórias e processos de identificação étnica que permitem evidenciar a heterogeneidade existente nas interações sociais e, ao mesmo tempo, o caráter paradoxal e espiralado que a vida dos sujeitos encarna. Alertamos que a sistematização dos debates que apresentaremos não esgota a multiplicidade de abordagens sobre o assunto. É simplesmente um recorte teórico que fizemos para mostrar o pano de fundo que consideramos relevante para a nossa investigação.

Keywords: processos de identidade; trajetórias socioeducativas; desigualdade; diversidade; professores indígenas.

\section{INTRODUCCIÓN}

El artículo se enmarca en la Tesis doctoral en Antropología Social, centrada en documentar la diversidad y complejidad en las trayectorias socioeducativas de un grupo de maestros/as indígenas de la provincia del Chaco, Argentina. Específicamente en este trabajo, presentaremos los ejes teóricos principales que atañen a nuestro problema de investigación. Por un lado, desarrollamos algunos antecedentes teóricos en torno a los maestros/as que se encuentran en contextos interculturales, que nos permiten repensar acerca de los saberes, las representaciones y las identificaciones en contextos de diversidad y desigualdad socioeducativa. Por otro lado, describiremos los estudios sobre la noción de identidad desde una perspectiva crítica, indagando en los modos en que son identificados los sujetos y en las formas en que los sujetos se identifican como tales. Finalmente, delinearemos algunas reflexiones.

Para comprender desde dónde estamos pensando las categorías, nos parece relevante anticipar algunos aspectos de una de las ideas teóricas que atraviesa la investigación: la noción de "trayectorias". Desde varias disciplinas como las ciencias de la educación, este término ha sido abordado principalmente desde la noción de "trayectorias escolares", para diagnosticar las situaciones que atraviesan los estudiantes durante su escolaridad. Algunas autoras como Terigi (2007) 
describen los desafíos que acarrea el término de "trayectorias". Como bien señala la autora, las trayectorias denominadas "escolares" se han convertido en centro de análisis en los estudios sobre la niñez y la juventud, en las políticas sociales y educativas y en las iniciativas de las escuelas. En muchos casos, dichas trayectorias evidencian recorridos no esperados por el sistema educativo. Para comprender la idea de trayectorias, la autora distingue entre "trayectorias teóricas" que son aquellas que define el sistema educativo, es decir, itinerarios en el sistema que siguen una progresión lineal estándar determinada por éste, y "trayectorias reales" que son las realizadas efectivamente por los sujetos. Estos enfoques acerca de las "trayectorias escolares" se esfuerzan mayormente en analizar los grados de "eficiencia" de los establecimientos educativos. Si bien consideramos pertinente estos aportes y retomamos datos del acceso, permanencia y/o abandono de los/ as estudiantes en el sistema educativo, nos interesa aclarar que nuestro marco teórico se focaliza en la articulación entre las discusiones sobre trayectorias socioeducativas, y los procesos de identificación étnica. En ese sentido, lo nodal del enfoque antropológico en el cual nos posicionamos, es que éste permite pensar lo escolar en relación con otros espacios, o sea, da cuenta de que no es posible indagar en lo escolar de manera aislada, sino en su complejidad de relaciones con otros ámbitos (doméstico, barrial etc.). Como bien señala Santillán refiriéndose al trabajo con niños y niñas, no se trata del análisis en "términos estrictos de la escuela y la experiencia escolar. Sino que busca atender a dimensiones más amplias y diversificadas de las experiencias formativas de los niños, que incluyen y a la vez rebasan los espacios escolares" (SANTILLÁN, 2011, p. 27).

Antes de terminar esta introducción, recuperamos algunas reflexiones relevantes para comprender las trayectorias, en relación con las vinculaciones que experimentan los agentes sociales entre sus decisiones personales, los condicionamientos estructurales de su entorno (sociales, económicos, familiares etc.) y el impacto de los diseños de políticas educativas específicas para indígenas (desde los modelos monolingües hasta los bilingües interculturales) (HECHT, 2014, 2015b). Si bien los recorridos que realizan los sujetos se encuentran insertos en espacios y tiempos determinados, es interesante pensarlos como heterogéneos y contradictorios en relación con los contextos en los cuales se enmarcar (DE CERTAU, 1996). Desde la perspectiva crítica en la cual nos posicionamos, nos parece muy sugerente considerar que las trayectorias no responden a una lógica 
lineal, ni aparentemente coherente con el marco espacio-temporal en el cual se desarrollan. Sino que se encuentran en constante transformación y movimiento. De esta manera, destacamos que lejos de pensar las trayectorias de maestros/ as indígenas como historias cristalizadas y condicionadas de forma homogénea, proponemos un enfoque que invite a pensar los procesos sociales e individuales que atraviesan los sujetos, en términos paradójicos e incoherentes.

\section{MAESTROS/AS EN CONTEXTOS INTERCULTURALES}

La figura del/a maestro/a ha convocado el estudio de diversas disciplinas. Desde las ciencias de la educación, algunas investigaciones se han centrado en analizar, por ejemplo, los procesos de conformación del sistema educativo, las características que adoptaban los establecimientos de formación docente, los modos de ejercer la profesión docente respondiendo a los intereses y políticas educativas de la época (PUIGGROS, 2003; ALLIAUD, 2007; DIKER; SERRA, 2008). Otros trabajos, como Leite (2011) en España, han abordado las historias de vida de maestros/as y los procesos identitarios. Estudios interesantes desde la perspectiva antropológica han analizado las trayectorias, las identidades laborales y las transformaciones docentes, la cotidianeidad escolar y las nuevas prácticas de los educadores, mayormente de maestros/as no indígenas (BATALLÁN, 1998, 2004; ROCKWELL, 2013; PETRELLI 2014, entre otros). Estos antecedentes nos parecen relevantes para pensar desde dónde se viene analizando a la figura del/a educador/a, los contextos sociales y políticos en los cuales se forman y ejercen su trabajo, así también como los procesos personales y domésticos que los atraviesan. Por otra parte, algunas de estas investigaciones nos permiten problematizar ciertas prácticas y discursos en torno a temáticas que atraviesan el sentido común y los medios de comunicación hegemónicos, como las problemáticas educativas vinculadas con la tarea del docente y los debates sobre la capacitación y formación de los mismos.

Si nos adentramos en los antecedentes en torno a maestros/as en contextos interculturales, muchos estudios se han centrado en los/as maestros/ as indígenas, sus prácticas y las políticas educativas que los regulan. Así, vemos numerosas investigaciones realizadas en Latinoamérica. Es importante tener en cuenta que, en la actualidad, la educación destinada a contextos interculturales 
abarca países como México, Guatemala, Honduras, Nicaragua, Costa Rica, Panamá, Colombia, Venezuela, Guyana Francesa, Surinam, Brasil, Ecuador, Perú, Bolivia, Chile, Paraguay y Argentina. En algunos como México y Ecuador, en términos generales la EIB se trata de un subsistema que funciona paralelamente al sistema tradicional destinado a la mayoritaria de la población hispano hablante. Las grandes contribuciones que ha dejado la EIB invitan a repensar los destinatarios de estas políticas, y postular formas más amplias que puedan aplicarse a la sociedad en general (LÓPEZ; KÜPER, 2000).

Ahora bien, volviendo a nuestro tópico en relación con los estudios acerca de los/as maestros/as indígenas, éstos han indagado en su mayoría sobre cómo debería ser ese rol, reflexionan sobre las funciones específicas del/a maestro/a y la participación de los pueblos en el diseño y planificación de los programas de EIB. Para mencionar solo algunos, podemos citar a trabajos de Colombia, Bolivia y México. En el caso colombiano, por ejemplo, postulan qué requisitos debe tener un/a maestro/a indígena, como por ejemplo "ser un abridor de mundos", o qué capacidades y saberes deben alcanzar para dicho rol (SERRANO RUIZ, 1998). Para el caso boliviano, educadores como Ipiña (1997), analizan estudios similares en los cuales presentan los perfiles que deberían tener los docentes que trabajan en contextos interculturales, como por ejemplo estar comprometidos con las causas de la comunidad, entre otras. Asimismo, Remedios y Tafoya Vargas (2001) para el caso mexicano, analizan el papel que desempeña los maestros/as en la escuela y la comunidad, indagando en la idea de los/as maestros/as indígenas como agentes de revitalización cultural. A partir de un panorama general sobre los avances que se han dado en los proyectos de educación estatal respecto a las comunidades indígenas, los autores se preguntan qué tan importante es el papel del/a maestro/a para la revitalización cultural y qué actividades realiza para orientar ese fin. El trabajo de campo evidencia, por un lado, el interés de algunos/as maestros/as en enseñar lo que consideren conveniente según la necesidad de la comunidad; y por otro, docentes que no tienen en consideración los proyectos de educación estatal para comunidades indígenas y ejercen su rol del mismo modo que si se encontraran en escuelas de educación tradicional. Según las conclusiones arribadas por los autores, estas formas antagónicas tienen que ver con la complejidad de los contextos y las diversas maneras que tienen los/as docentes de estructurar su propia noción de lo que es su identidad (REMEDIOS; TAFOYA VARGAS, 2001). Lo 
relevante de estos trabajos es que nos brindan un panorama general de ciertas miradas que se construyen en torno a cómo los/as educadores/as responden o no a las demandas de las diversas comunidades indígenas en Latinoamérica. Más allá de las particularidades de cada región, pueden evidenciarse como común denominador en estos trabajos ciertas tendencias sobre qué se espera del rol de un/a maestro/a indígena a diferencia de lo que sucede con el resto de los docentes, como por ejemplo la idea de compromiso con la comunidad, el rol como revitalizador de la lengua indígena etc.

Otras líneas de estudios interesantes, son aquellos que analizan las perspectivas de los propios sujetos considerando el recurso de los relatos autobiográficos, como es el caso de Guzman y Garzon (2008) que trabajan con la población del Cauca, Colombia, enfatizando en la idea de "identidades pedagógicas". Éstas son entendidas como "los rasgos particulares que se expresan tanto en sus relatos autobiográficos, como en sus repertorios docentes, [...] los cuales están directamente relacionados con las diversas manifestaciones del control cultural o estatal sobre sus prácticas pedagógicas" (GUZMAN; GARZON; 2008, 82-3). Las autoras señalan la relevancia para el análisis de considerar tanto las percepciones y prácticas de los/as docentes en su cotidianeidad escolar, como las formas de narrar su tránsito por la familia, la escuela primaria y secundaria, la universidad, el barrio etc. El análisis de los sentidos construidos por los/as maestros/as indígenas cobra relevancia en la medida que reconocemos a dichos sujetos como productores de un saber que implica un aporte intelectual en la investigación de sus prácticas. Este saber está relacionado con conceptos, prácticas y representaciones dadas tanto en espacios escolarizados como no escolarizados (GUZMÁN; GARZÓN, 2008).

Creemos que las investigaciones mencionadas, muchas de ellas del campo de las ciencias de la educación, la psicología y la lingüística han sido un aporte fundamental para repensar las complejidades del sistema escolar, articulando las instituciones educativas, la agencia de los sujetos inmersos en los procesos socio-históricos, los entramados de poder y las condiciones de profunda desigualdad socioeducativa que afecta a las distintas regiones. Si bien consideramos valiosos dichos trabajos, creemos necesario complementar y complejizar el enfoque en torno a las prácticas y percepciones de los/as propios maestros/as desde el aporte de la antropología. O sea, a partir del enfoque etnográfico, buscamos indagar en procesos a través de los cuales los/as maestros/as se conforman como tales, y en 
los debates en torno a la diversidad de formas de identificarse y la multiplicidad de intereses, desafíos y metas que están en juego.

De esta manera, retomamos trabajos antropológicos como el de Achilli $(1986,2008)$ que abordan la formación docente en contextos interculturales y la multiplicidad de saberes de los/as maestros/as. En el caso del trabajo en talleres con docentes en Santa Fe, es interesante cómo la autora trabaja desde la construcción de conocimiento basado en el diálogo y reflexión junto con los propios docentes, acerca de las representaciones y saberes que circulan en esos espacios (ACHILLI, 1986). En esa misma línea, el libro compilado por Hecht y Schmidt (2016) sobre la situación general de los/as maestros/as indígenas de Argentina reúne varios relatos de experiencias de casos que son un importante antecedente. Algunos de los aportes reflejados en ese material que consideramos más importantes, trabajan en torno a la diversidad lingüística y sociocultural, los procesos identitarios y la formación docente. Así, el trabajo de Rodríguez y Alaniz (2016) analiza los desafíos que atraviesan los/as maestros/as indígenas en la provincia de Santa Cruz, en donde se ha negado durante décadas la presencia indígena como varias provincias de nuestro país. Las autoras explican que si bien se han elaborado políticas atentas a las necesidades de los grupos indígenas y los/as maestros/as en particular, éstas han sido escasas y en muchos casos funcionales a los procesos de negación de dichas identidades.

Otras investigaciones, estudian cómo ha sido el proceso de formación de docentes indígenas y analizan distintas propuestas en contextos de EIB en Argentina, como el caso de la capacitación para la docencia en comunidades guaraníes del norte salteño (HIRSCH, 2003), y las trayectorias de docentes wichí y guaraní en la misma provincia (HIRSCH; SERRUDO, 2016). Asimismo, algunos autores indagan en las dificultades materiales y simbólicas de dicho proceso. En ese sentido, investigadoras como Villarreal y Martínez (2016) estudian el quehacer de los docentes indígenas de la provincia de Santa Fe y las problemáticas que atraviesan muchos/as jóvenes que deciden ser docentes ya que "no cuentan con condiciones materiales algunas, ni con un reconocimiento en términos de sueldo como tampoco de certificación ni hacia quienes se responsabilizan por los procesos de enseñanza ni hacia quienes asumen el compromiso del aprendizaje" (VILLARREAL; MARTíNEZ, 2016, p. 101). Por su parte, el trabajo de Schmidt y Hecht (2016), expone los resultados de una experiencia de investigación-acción colectiva 
elaborada durante más de diez años en la provincia de Salta, que visibiliza distintas problemáticas que afectan a los/as docentes indígenas en torno a la capacitación y asesoramiento pedagógico, y las acciones de intervención llevadas a cabo a partir de las demandas realizadas por los/as auxiliares indígenas.

Por último, señalaremos algunos antecedentes sobre los/as maestros/as en contextos de EIB en la provincia del Chaco, región en la cual realicé mi trabajo de investigación. El Chaco por ser una de las provincias pioneras en EIB cuenta con su propia tradición de estudios que tiene a esa provincia como su referente empírico. Así, destacamos las sistematizaciones realizadas en torno a la educación superior indígena en la región, como el trabajo de Valenzuela (2009), quien analiza el inicio, el desarrollo y la continuidad del instituto de formación de docentes indígenas, CIFMA. El estudio del contexto histórico y social, los logros y las dificultades que atravesó el establecimiento, así como las distintas etapas por las cuales fueron pasando los/as estudiantes, nos brinda un panorama interesante para indagar en la figura del/a maestro/a indígena en esta provincia (ZIDARICH, 2010; SERRUDO, 2010). Se trata de trabajos que permiten comprender cómo se fue consolidando la EIB en el Chaco y las distintas instancias en las cuales los/as docentes indígenas se fueron incorporando a dicha modalidad. Estos estudios son de suma importancia para nuestra investigación ya que permiten historizar la figura del/a docente indígena y divisar la complejidad y las tensiones que implicó (e implica) el proceso de formación de los primeros docentes.

Otros aportes relevantes, son los estudios de Artieda, Liva y Almirón (2012) que analizan la participación de docentes y organizaciones indígenas en las discusiones acerca de la implementación de escuelas públicas de gestión social indígena en la región chaqueña, a partir de un corpus de notas y actas de docentes y dirigentes indígenas, y de trabajo de campo en la realización algunos de los debates. En relación con las reivindicaciones de los grupos indígenas en el campo educativo, autoras como Zidarich (2016) indagan sobre los procesos a través de los cuales los/as docentes indígenas del norte chaqueño se incorporan en el sistema educativo para ejercer su profesión, y las disputas que se suscitaron en torno a dichos procesos. Asimismo, son interesantes las reflexiones que presenta Medina (2016) acerca de las representaciones construidas entre los/as docentes indígenas en establecimientos de modalidad de EIB en la capital de la provincia. A partir del análisis, la autora explica cómo la tarea que realizan termina siendo 
"monumental ya que deben articular el proyecto etnoeducativo con las exigencias de la educación pública y las acciones de revitalización de las lenguas indígenas en las aulas" (MEDINA, 2016, p. 175). También son medulares los aportes de las investigaciones de Hecht $(2015 a, 2017)$ sobre trayectorias de escolarización de maestros/as indígenas chaqueños, que indagan en las experiencias extraescolares en su formación, las estrategias de enseñanza y los desafíos de la práctica como docentes en contextos sociolingüísticos complejos en los cuales sus funciones se van interpelando y modificando.

Muchos de estos trabajos muestran avances respecto a la EIB en general, pero al mismo tiempo evidencian ciertas falencias respecto a la formación de los/as docentes en dichos contextos. Asimismo, dan cuenta de los múltiples sentidos que se construyen en torno a la figura del/a docente, las disímiles tareas y responsabilidades que se desarrollan en los establecimientos, y cómo estas condiciones, en muchos casos, generan fuertes rivalidades. Creemos que aún queda un camino importante para indagar en la articulación entre los modos de identificar y las percepciones sobre las propias identificaciones como maestros/ as indígenas en contextos de acentuada diversidad y desigualdad socioeducativa. Ya que este enfoque implica dar voz a los propios sujetos, investigar y reflexionar acerca de sus propias miradas y subjetividades.

\section{ACERCA DE LOS PROCESOS DE IDENTIFICACIÓN}

Los enfoques que se han interesado en el estudio de los procesos identitarios han sido disímiles. Algunos de ellos, como lo explica Restrepo, se han basado en perspectivas esencialistas, como aquellas que se presentan como posiciones ontológicas que conciben que "un ser-esencial-compartido condicionante de una serie de rasgos característicos -somáticos, culturales, lingüísticos e históricosconstituiría la etnicidad y la conciencia de la identidad étnica" (RESTREPO, 2004, p. 29). Otros autores, se han fundado en posturas "que suponen una necesaria correspondencia entre dos o más aspectos o planos de la vida social", por ejemplo, que determinadas condiciones sociales, económicas etc. se correspondan con ciertas representaciones o identificaciones (HALL, 1996 y GROSSBERG, 1997 en RESTREPO, 2004, p. 29). Asimismo, otros posicionamientos teóricos esencialistas se han perfilado al reduccionismo, el cual supone que "las diferencias en las 
prácticas culturales son expresiones de una especificidad del grupo social que lo antecede y son garantes de la identidad étnica" (RESTREPO, 2004, p. 30).

Sin embargo, otros trabajos cuestionan dichas miradas esencialistas y proponen, por ejemplo, poder pensar las identidades como identificaciones. Como desarrollaremos más adelante, Brubaker y Cooper (2001) explican cómo la categoría "identidad" suele designar una condición más que un proceso. Por lo cual, al pensarlas como identificaciones, es posible dar cuenta de la complejidad y ambivalencia que implica dicha categoría. En ese sentido, proponen diferenciar los lenguajes analíticos que empleamos para trabajar temas como "raza", "religión", etnia" etc., evitando de este modo, englobar todas esas autocomprensiones, "dentro del gran conteiner conceptual que es la identidad" (BRUBAKER; COOPER, 2001, p. 26). Incluso, los autores advierten las limitaciones de las posturas más constructivistas, que tienden a considerar a las identidades como algo que los grupos y las personas "tienen", aun siendo "tenencias" que son fluidas. Es decir, muchas posturas que intentan correrse de la mirada esencialista, tienden a "objetizar" la idea de "identidad", a tratarla como una "cosa", aunque maleable, que la gente "tiene", "forja", y "construye". Esta tendencia nos priva de fuerza analítica. Hace más difícil la "grupalidad" y la "limitación" como propiedades emergentes de escenarios estructurales o coyunturales particulares en lugar de tomarlos como si siempre hubieran estado alli" (BRUBAKER; COOPER, 2001, p. 35).

Para clarificar estas ideas, autores como Briones (2002) explican que cuando ciertos términos son usados como verdades ontológicas, que parten de diferencias naturales, se terminan cosificando las características de los grupos sociales. De esta manera, se desplaza del ámbito sociológico cualquier diferencia y se la ubica en el campo de lo biológico y concreto. Así, se terminan caracterizando las diferencias socioculturales de los colectivos, impidiendo la comprensión dinámica de las identificaciones. Estos enfoques están relacionados con una percepción reduccionista y estática de los fenómenos sociales que, desde nuestro punto de vista, obstaculizan el análisis ya que limitan nuestra visión de la realidad social y la complejidad que ella implica. En ese sentido, una idea nodal para nuestro trabajo es la de los procesos de negación identitaria, o sea, aquellos procesos sociohistóricos que han silenciado/arrinconado/discriminado el lugar de las poblaciones indígenas en nuestro país (FRANCIA; TOLA, 2011). Bajo esta idea subyacen las 
miradas estáticas acerca de lo cultural e identitario mencionadas, que buscamos cuestionar y de las cuales nos distanciamos.

Dadas estas discusiones, muchos debates en torno a las identidades se han suscitado con la intención de desvincularlos de las posturas esencialistas. Como ya mencionamos, si bien las perspectivas constructivistas de fines del siglo XIX fueron ganando terrero, al mismo tiempo desde miradas histórico-sociológicas, dichas teorías fueron cuestionadas sosteniendo que se pasó de categorías estáticas a otras imprecisas o frágiles. Autores como Brubaker y Cooper, afirman que: "el intento de "suavizar" el término para liberarlo de la carga de "esencialismo" mediante la estipulación de que las identidades son construidas, fluidas y múltiplesnos deja sin argumento para hablar sobre identidades [...], el término pierde su valor analítico. Si la identidad está en todas partes entonces no está en ninguna" (BRUBAKER; COOPER, 2001, p. 1). De esta manera, conceptualmente a la noción de identidad se le atribuyeron calificativos como "construido", "múltiple" etc. que se han naturalizado en el ámbito académico sin una reflexión profunda de los significados. Si bien muchas investigaciones abordaron esta temática, en ciertos casos se teorizó de manera imprecisa. Bajo esta perspectiva, Brubaker y Cooper (2001) reflexionan sobre otras alternativas de análisis que puedan reemplazar el término de "identidad", introduciendo la noción de "identificaciones". En palabras de los autores, ese término "nos invita a especificar los agentes que llevan a cabo la acción de identificar. Y no presupone que tal acción de identificar deberá necesariamente resultar en la igualdad interna" (BRUBAKER; COOPER, 2001, p. 18).

Hacia esa misma dirección, la idea de identificaciones entendidas como mecanismos refleja un sentido de la identidad en proceso. Recuperando estas posturas, sostenemos que el término es fundamental para poder comprender la dinámica de las identidades y cómo son asumidas por los sujetos y los grupos según los distintos contextos (CARDOSO DE OLIVEIRA, 2007). Asimismo, otros trabajos explican que, para no confundirnos con los aspectos más psicológicos del término, es importante distinguir que las identidades comprenden dos dimensiones; una individual y otra social (CARDOSO DE OLIVEIRA, 2007). Si bien ambos están relacionados y se complementan, el aspecto individual es profundizado mayormente por la psicología y el social, por la antropología.

Otros aspectos para tener en cuenta, que provienen de estudios antro- 
pológicos, sociológicos y desde las ciencias de la educación, sostienen que las identidades responden a las condiciones del contexto socio-histórico (DUBAR, 2002 apud LEITE, 2011). Añadiendo a esta idea, Rivas Flores et al. (2010), afirma que lejos de plantear las teorías sobre la identidad como una conquista personal, como algo eterno, las entiende como construcciones en el marco de entornos socio-culturales, tratándose de este modo de un proceso político. Así, "la identidad es diferencia, pero también es pertenencia común [...] De este modo, no es posible establecer identidades generalizadas ni uniformes, sino más bien un repertorio de posibilidades, de carácter identitario para todos los participantes" (RIVAS FLORES et al., 2010, p. 192).

Asimismo, un aspecto relevante es el lugar de los sujetos en los procesos de identificación. No necesariamente son acciones conscientes y elegidas, sino que puede darse acciones que operan dentro de los límites que dan acceso diferencial a las experiencias y saberes. Se trata de "maquinarias territorializadoras que definen dispares movilidades estructuradas que indican por qué lugares cada cual puede o no moverse, a cuáles cada cual puede o no acceder" (BRIONES, 2007, p. 68). Es decir, los procesos de identificación no pueden escindirse de los procesos socio-históricos. En palabras de Briones, "los sujetos se articulan como tales a partir de un trabajo de identificación que opera suturando identidades personales y colectivas (para sí y para otros)" (BRIONES, 2007, p. 71). De esta manera, esas acciones no las realizan a partir del propio discernimiento, sino que son producto en muchos casos de situaciones que no han elegido.

Para complementar estos estudios sobre las identidades, retomamos a Brubaker y Cooper (2001) que proponen la noción de "identificaciones externas". Como ya señalamos, el término abarca diversas aristas y complejidades. Una de ellas es considerar que la identificación puede ser del "yo" o del "otro", pero en ambos casos son indispensables los contextos en los que están inmersos. Como bien explican estos autores, "la manera en la que uno se identifica - y la manera en que uno es identificado por otros - puede variar mucho de un contexto a otro; la identificación del yo y la identificación del otro son fundamentalmente situacionales y contextuales" (BRUBAKER; COOPER, 2001, p. 19). Estas identificaciones van variando y van interactuando entre ellas. O sea, en la medida que nos relacionamos como seres sociales, identificamos a los demás, lo categorizamos, y al mismo tiempo nos identificamos a nosotros mismos. Asimismo, otro aporte 
interesante es reconocer que existe otro modo de identificar indispensable para comprender los procesos sociales que abordamos. Se trata de una "identificación externa que no tiene un correlato en la auto identificación: los sistemas de categorización formalizados, codificados y objetivados desarrollados por instituciones poderosas y autoritarias" (BRUBAKER; COOPER, 2001, p. 19). Estas identificaciones externas se van modificando históricamente, respondiendo a intereses y posturas hegemónicas relacionadas, en el caso de los/las maestros/as indígenas, con la formación de los Estados nacionales, los procesos de castellanización y las políticas educativas neoliberales, entre otras.

Otro aspecto interesante para pensar las identidades son los estudios sobre las identidades étnicas. Éstos surgen con más relevancia entre las décadas de 1970 y 1980 , en un contexto en el cual las ciencias sociales depositan gran centralidad en el lugar de los sujetos. Algunos autores como Bartolomé (2006), plantean la necesidad de diferenciar las identidades y la etnicidad a fin de alcanzar cierta precisión conceptual. Siguiendo esta idea, la identidad étnica se presenta como representaciones sociales colectivas, que permiten identificarnos al interior de un grupo, mientras que la etnicidad refiere a la identidad en su aspecto de acción política, es decir, refiere al comportamiento y al aspecto político de la identidad (BARTOLOMÉ, 2006). En ese sentido, cobran un rol relevante los movimientos etnopolíticos que se desencadenaron históricamente, para la comprensión y el análisis de las identidades en acción, ya que representan los momentos en los cuales "la identidad étnica se manifiesta como etnicidad, como una adscripción totalizadora que orienta las conductas sociales y políticas y que puede llevar a confrontaciones radicales" (BARTOLOMÉ, 2006, p. 29).

Si nos adentramos en la idea de identidades étnicas, algunos autores hablan de que se trata de "un acto discursivo consciente, de comparación, selección y significación de determinadas prácticas o representaciones culturales [...]" (DIETZ, 2012, p. 125). De este modo, vemos que la etnicidad se concibe como producto de una relación de diferenciación y semejanza con los otros, que se externaliza en el vínculo con los otros y se internaliza en la auto-identificación personal (BERGER; LUCKMAN, 1995). Así, las identificaciones étnicas no han sido etiquetamientos externos, sino que se trata de procesos que atraviesan las comunidades indígenas, que involucran la distribución geográfica de una población con la conformación de unidades domésticas y un territorio determinado, y una compleja red de 
relaciones de residencia, de parentesco, de asociaciones productivas, grupos de edad, espacios cosmovisionales etc. Es decir, pensar en identificaciones étnicas es también pensar en el concepto de comunidades indígenas como núcleo de interacción y transacción (RADOVICH, 2014).

Otro aspecto interesante es que, considerando que tanto las fronteras étnicas como las fronteras estatales son permeables y dinámicas (BARTOLOMÉ, 2006), se generan posibilidades de circulación de aspectos culturales materiales y simbólicos que están condicionadas por la distribución de poder. "Es por ello que el análisis de los procesos de identificación étnica tiene que incluir la estructura de las desigualdades económicas, así como el tipo de estratificación social vigente" (DIETZ, 2012, p. 109). Cabe aclarar que, la desigualdad la entendemos como un proceso que involucra tanto lo económico, lo político y lo ideológico, o sea, "partimos de asociar la desigualdad al acceso diferencial a la propiedad y al control de bienes materiales y simbólicos que tienen importancia social, [...], proceso histórico que incluye distintas dimensiones y debe entenderse en termino de relaciones de desigualdad" (MANZANO et al., 2010, p. 210).

Para comprender estos contextos, creemos fundamental entenderlos como procesos históricos y en articulación con la noción de la diferencia. Interesantes discusiones se han suscitado en torno a esta temática. Es importante aclarar que existen entre los seres humanos diferencias en cuanto a los rasgos fenotípicos, costumbres, idiomas etc. Estas diferencias no determinan, sin embargo, formas de desigualdad en las estructuras sociales, "el problema es la forma en que se valoran y jerarquizan esas diferencias y la relación entre estas valoraciones y la justificación de situaciones de desigualdad" (MANZANO et al., 2010, p. 211). Es decir, en donde se debe poner atención es en los mecanismos evaluativos que se generan en torno a las diferencias, estableciendo de manera generalizada grupos sociales superiores respecto a otros inferiores. De esta manera, se naturalizan y justifican formas de desigualdad bajo el ala de las diferencias biológicas, culturales, psicológicas etc. Así, lo medular de esta relación diferencia-desigualdad es considerarlas desde una mirada más abarcadora que no se limite a lo económico, sino que involucre multiplicidad de dimensiones sociales como lo ideológico, lo político, el parentesco, entro otras (NEUFELD, 2010). Desde ciertas disciplinas como la antropología, parecen ser debates ya superados. Sin embargo, es central la vigencia que aún tienen los discursos y las prácticas discriminatorias en las experiencias cotidianas de los sujetos. 
Otro aspecto a tener en cuenta para abordar la temática de las identidades es considerar que el entramado social está atravesado de intereses y constituido por relaciones de poder en constante redefinición. Siguiendo a Villarreal (1985), “el poder es mucho más difuso, general y complejo que una forma de gobierno, que sus protagonistas y sus leyes" (VILLARREAL, 1985, p. 214). La perspectiva del poder tiene que ver con una red de relaciones de fuerza que va más allá de la oposición entre gobernados y gobernantes. El poder deja sus efectos en las dinámicas sociales. Se trata de la coexistencia de múltiples relaciones de poder en distintos niveles, que puede abarcar instituciones, temas ideológicos, familiares etc. (VILLARREAL, 1985). Creemos que esta perspectiva habilita a complejizar los debates y comprender más en profundidad las problemáticas. En palabras de Gledhill (2000, p. 46), "solo el análisis concreto y contextualizado de las situaciones particulares nos permitirá comprender qué está ocurriendo y por qué está ocurriendo".

En síntesis, para el abordaje de los procesos identitarios acordamos con las discusiones teóricas que buscan cuestionar las interpretaciones esencialistas sobre los cambios socioculturales, ya que utilizan parámetros ahistóricos de autenticidad cultural y abordan las transformaciones como "pérdidas" que "padecen" ciertos grupos indígenas (HECHT, 2010). En cuanto al espíritu de nuestro trabajo, coincidimos con Boccara en sostener que

[...] mientras muchos "expertos en culturas amerindias" se preguntan quiénes son los "indígenas auténticos", algunos antropólogos críticos (y comprometidos) aspiran a dar cuenta de esas nuevas luchas por la sobrevivencia, el respeto, la dignidad, el reconocimiento de la subjetividad propia y el derecho a tener derechos. (BOCCARA, 2013, p. 263).

\section{REFLEXIONES FINALES}

Este trabajo forma parte de una investigación más amplia enfocada en analizar las trayectorias socioeducativas y los procesos identitarios de un grupo de maestros/as indígenas de la provincia del Chaco en Argentina. En este escrito, se buscó presentar los principales ejes teóricos vinculados con la figura de los/as maestros/as y los estudios sobre las nociones de identidad.

Como ya señalamos, nos distanciamos de pensar dichas categorías como ideas cerradas y homogéneas. Proponemos un enfoque que invite a pensar los 
procesos sociales e individuales que atraviesan los sujetos, de modo amplio y en constante transformación. De esta manera, nos parece interesante hablar de "trayectorias socioeducativas" ya que entendemos que este término intenta no circunscribir la categoría a espacios escolares concretos o como diagnóstico del proceso escolar, sino como categoría analítica que permita evidenciar a lo largo de la vida de una persona, sus experiencias sociales y educativas de modo más complejo y abarcador. Como bien anticipamos, estamos pensando no sólo en los espacios escolares transitados por los sujetos (los proyectos educativos de los establecimientos, el vínculo con los docentes y los modos de experimentar dichos espacios etc.), sino también en los espacios formativos que se dan por fuera del sistema formal de aprendizaje (como los domésticos y/o barriales, entre otros.). Desde esta perspectiva, es posible comprender cómo los sujetos han sido identificados en distintas etapas de la vida (niñez, juventud, adultez), por múltiples actores e instituciones (escuela, iglesia, familia etc.). Así también, indagar qué procesos de autoidentificación atravesaron en los distintos momentos y lugares. De este modo, se descentralizan las responsabilidades atribuidas, en muchos casos, a las elecciones personales que realizan los propios sujetos respecto a dónde estudiar para formarse como maestros/as, o a los agentes educativos de los establecimientos con o sin modalidad de EIB en sus distintos niveles. A diferencia de las miradas parciales y reduccionistas, creemos que se trata de procesos colectivos en los cuales intervienen variados factores, y ni los establecimientos educativos en su totalidad, ni ciertas relaciones domésticas o comunitarias en particular pueden determinar el sinfín de recorridos socioeducativos que han transitado los/as maestros/as.

Si bien estas reflexiones teóricas en torno a los estudios centrados en la educación en contextos interculturales no agotan la multiplicidad de enfoques sobre la temática, permiten poner en diálogo categorías que albergan significados y usos analíticos contradictorios. En ese sentido, las discusiones presentadas intentan desnaturalizar ciertas perspectivas esencialistas y cosificantes. A mismo tiempo, habilita a pensar sobre la articulación entre la idea de trayectorias y procesos de identificación étnica que permiten evidenciar la heterogeneidad y complejidad de vida de los sujetos en situaciones de diversidad y desigualdad social. 
Orientaciones teóricas sobre procesos identitarios y trayectorias de maestros/as indígenas en la región chaqueña (Argentina)

\section{REFERENCIAS}

ACHILLI, E. Formación docente e interculturalidad. Diálogos Pedagógicos, [S.I.], año VI, n. 12, p. 121-38, oct. 2008.

ACHILLI, E. La práctica docente: una interpretación desde los saberes del maestro. Cuadernos de Formación Docente, Universidad Nacional de Rosario, 1986. Disponible en: https://www.academia.edu/22365406/LA_PR\%C3\%81CTICA_DOCENTE_UNA_ INTERPRETACI\%C3\%93N_DESDE_LOS_SABERES_DEL_MAESTRO. Acceso en: 30 jul. 2020.

ALLIAUD, A. Los maestros y su historia. Orígenes del magisterio argentino. Buenos Aires: Granica, 2007.

ARTIEDA, T.; LIVA, Y.; ALMIRÓN, S. La participación de docentes y organizaciones indígenas en los procesos de definición de las escuelas públicas de gestión social indígena en la provincia del Chaco, Argentina. In: CONGRESO INTERNACIONAL DE LA RED ESTRADO, 9., 2012, Santiago de Chile. Resúmenes [...]. Santiago de Chile: Universidad Nacional de Chile, 2012. p. 3-6.

BARTOLOMÉ, M. A. Los laberintos de la identidad: procesos identitarios en las poblaciones indígenas. Revista Avá, Misiones, Argentina, n. 9, p. 28-48, ago. 2006.

BATALLÁN, G. El poder y la construcción de la identidad laboral de los docentes de infancia. Limitaciones de la teoría para pensar la transformación escolar. Cuadernos de Antropología Social, Buenos Aires, n. 19, p. 63-81, jul. 2004.

BATALLÁN, G. ¿Puede la docencia ser una profesión? Contradicciones en el marco de la escuela democrática. Revista de la Academia, Santiago del Chile, n. 3, p. 123-134, 1998.

BERGER, P.; LUCKMAN, T. La construcción social de la realidad. Buenos Aires: Amorrortu Editores, 1995.

BOCCARA, G. Prefacio (Tercera Parte: En la intersección. Reflexiones en torno a la alteridad): Cultura, identidad y poder en la(s) historia(s). In: TOLA, F.; MEDRANO, C.; CARDIN, L. (Ed.). Gran Chaco. Ontologías, poder, afectividad. Buenos Aires: Asociación Civil Rumbo Sur, 2013. p. 257-67.

BRIONES, C. Teorías performativas de la identidad y performatividad de las teorías. Tabula Rasa, Bogotá, Colombia, n. 6, p. 55-83, 2007.

BRIONES, C. Mestizaje y blanqueam111iento como coordenadas de aboriginalidad y nación argentina. RUNA, Archivo Para Las Ciencias Del Hombre, Buenos Aires, v. 23, n. 1, p. 61-88, 2002. 
BRUBAKER, R.; COOPER, F. Más allá de "identidad". Apuntes de Investigación del CECYP, n. 7,, 2001 https://www.comisionporlamemoria.org/archivos/jovenesymemoria/ bibliografia_web/ejes/Brubaker-Cooper\%5Bdefinitivo\%5D.pdf

CARDOSO DE OLIVEIRA, R. Etnicidad y estructura social. México D. F. Centro de Investigaciones y Estudios Superiores en Antropología Social Universidad Iberoamericana, A.C. Universidad Autónoma Metropolitana, 2007.

DE CERTEAU, M. La invención de lo cotidiano. I. Artes de hacer. México, D.F.: Universidad Iberoamericana, 1995.

DIKER, G.; SERRA, J. C. La cuestión docente Argentina: las políticas de capacitación docente. Buenos Aires; FLAPE, 2008.

DIETZ, G. Multiculturalismo, interculturalidad y diversidad en educación. Una aproximación antropológica. México: Fondo de Cultura Económica, 2012.

FRANCIA, T.; TOLA, F. Reflexiones dislocadas. Pensamientos políticos y filosóficos qom. Buenos Aires: Rumbo Sur/Universidad de Buenos Aires, 2011.

GLEDHILL, J. El poder y sus disfraces. Barcelona: Bellaterra, 2000.

GUZMÁN, E. C.; GARZÓN, L. T. Historias y trayectorias de maestras y maestros indígenas en el Cauca: ¿la etnoeducación, posibilidad para otras educaciones? Revista Educación y Pedagogía, [S. I.], v. XX, n. 50, p. 81-97, ene./abr. 2008.

HECHT, A. C. Maestros/as indígenas en contextos de desplazamiento lingüístico: desafíos y dilemas contemporáneos. Cuadernos del Instituto Nacional de Antropología y Pensamiento Latinoamericano, Buenos Aires, v. 26, n. 2, p. 87-100, 2017.

HECHT, A. C. Trayectorias escolares de maestros Toba/qom del chaco. Cuadernos del Instituto Nacional de Antropología y Pensamiento Latinoamericano, Buenos Aires, v. 24, n. 2, p. 1-12, 2015a.

HECHT, A. C. Educación Intercultural bilingüe en Argentina: el caso del Chaco entre 1987 y 2014. Revista Latinoamericana de Educación Inclusiva, Santiago de Chile, v. 9, n. 2, p. 129-144, nov. 2015b.

HECHT, A. C. Demandas pendientes y logros educativos. Un balance de la ElB en el Chaco entre 1987 y 2014. In: CONGRESO ARGENTINO DE ANTROPOLOGÍA SOCIAL, 11. Actas [...]. Rosario, Argentina: Universidad Nacional de Rosario, 2014. 
HECHT, A. C. "Todavía no se hallaron hablar en idioma". Procesos de socialización lingüística de los niños en el barrio toba de Derqui, Argentina. In: LINCOM Studies in Sociolinguistics. München, Alemanha: LINCOM EUROPA, Academic Publications, 2010. Cap. IX.

HECHT, A. C.; SCHMIDT, M. (Ed.). Maestros de la Educación Intercultural Bilingüe. Regulaciones, experiencias y desafíos. Buenos Aires: Centro de Publicaciones Educativas y Material Didáctico, 2016

HIRSCH, S. Aportes a la Formación Docente en Educación Bilingüe Intercultural: la capacitación para la docencia en comunidades guaraníes del norte salteño. Trabajo presentado en ENCUENTRO NACIONAL DE EDUCACIÓN E IDENTIDADES. LOS Pueblos Originarios y la Escuela, 26 y 27 de septiembre. Buenos Aires: Universidad Nacional de Luján, 2003.

HIRSCH, S.; SERRUDO, A. Trayectorias de la docencia en contextos interétnicos: la labor de los docentes wichí y guaraní en Salta. In: HECHT, A. C.; SCHMIDT, M. (Ed.). Maestros de la Educación Intercultural Bilingüe. Regulaciones, experiencias y desafíos. Buenos Aires: Centro de Publicaciones Educativas y Material Didáctico, 2016. p. 179-200.

IPIÑA, E. Condiciones y perfil del docente de educación intercultural bilingüe. Revista Iberoamericana de Educación: Educación Bilingüe Intercultural, [S. I.], n. 13, ene./abr. 1997. Disponible en: https://rieoei.org/historico/oeivirt/rie13a04.htm. Acceso el: 30 jul. 2020.

LEITE, A. E. Historias de vida de maestros y maestras. La interminable construcción de las identidades: vida personal, trabajo y desarrollo profesional. 2011. Tesis (Doctorado en Educación) - Universidad de Málaga, España, 2011.

LÓPEZ, L.; KÜPER, W. La educación intercultural bilingüe en América Latina: balance y perspectivas. Documento de Trabajo. Cooperación Técnica Alemana (GTZ). 2000. Disponible en: http://www.schwartzman.org.br/simon/delphi/pdf/lopes comp1.pdf. Acceso el: 30 jul, 2020.

MANZANO, V.; NOVARO, G.; SANTILLÁN, L.; WOODS, M. Introducción a la problemática de la desigualdad. Hacia un abordaje antropológico. In: NEUFELD, M. R. (Comp.). Introducción a la antropología social y política: relaciones sociales. Desigualdad y poder. Buenos Aires: Editorial de la Facultad de Filosofía y Letras, Universida de Buenos Aires, 2010. p. 209-41. (Libros de Catedra).

MEDINA, M. Representaciones sobre las funciones de los docentes indígenas en la modalidad EIB de Resistencia. In: HECHT, A. C.; SCHMIDT, M. (Ed.). Maestros de la Educación Intercultural Bilingüe. Regulaciones, experiencias y desafíos. Buenos Aires: Centro de Publicaciones Educativas y Material Didáctico, 2016. p. 183-204. 
NEUFELD, M. R. (Comp.). Introducción a la antropología social y política: relaciones sociales. Desigualdad y poder. Buenos Aires: Editorial de la Facultad de Filosofía y Letras, Universida de Buenos Aires, 2010. (Libros de Catedra).

PETRELLI, L. Formación docente, Estado y apropiación: notas sobre la implementación de un nuevo plan de estudio en la carrera docente. Propuesta Educativa, Buenos Aires, año 23, n. 42, p. 65-76, nov. 2014.

PUIGGROS, A. Qué pasó en la educación argentina. Desde la conquista hasta el menemismo. Buenos Aires: Kapelusz, 2003. [Publicado originalmente em 1996].

RADOVICH, J. C. Identidad y conflicto en el Waj Mapu (territorio mapuche) en Norpatagonia, Argentina. El Calafate, Conferencia; PRE ALAS; Calafate, Santa Cruz. Universidad Nacional de la Patagonia, 2014.

REMEDIOS, A. J.; TAFOYA VARGAS, C. Maestros de educación indígena y revitalización cultural. 2001. Trabajo Terminal (Graduación en Antropología Social) - Universidad Autónoma Metropolitana, México, D.F., 2001

RESTREPO, E. Teorías contemporáneas de la etnicidad: Stuart Hall y Michel Foucault. Popayán, Colombia: Editorial Universidad del Cauca, 2004. 129 p

RIVAS FLORES, J.; MÉNDEZ, A. E. L.; GONZÁLEZ, P. C.; GARCÍA, M. J. M.; ARCOS, D. P. La configuración de identidades en la experiencia escolar. Escenarios, sujetos y regulaciones. Revista de Educación, Málaga, España, n. 353, p. 187-209, dec. 2010.

ROCKWELL, E. El trabajo docente hoy: nuevas huellas, bardas y veredas. In: CONGRESO NACIONAL DE INVESTIGACIÓN EDUCATIVA, 11. Conferencias Magistrales [...]. México: Consejo Mexicano de Investigación Educativa, 2013. p. 437-73.

RODRIGUEZ, M. E.; ALANIZ, M. Desafíos de la EIB en contextos de invisibilización: el caso de Santa Cruz. In: HECHT, A. C.; SCHMIDT, M. (Ed.). Maestros de la Educación Intercultural Bilingüe. Regulaciones, experiencias y desafíos. Buenos Aires: Centro de Publicaciones Educativas y Material Didáctico, 2016. p. 27-46.

SANTILLÁN, L. ¿Quiénes educan a los chicos? Infancia, trayectorias educativas y desigualdad. Buenos Aires: Biblos, 2011.

SCHMIDT, M.; HECHT, A. C. La importancia del rol docente en las políticas interculturales en educación. In: HECHT, A. C.; SCHMIDT, M. (Ed.). Maestros de la Educación Intercultural Bilingüe. Regulaciones, experiencias y desafíos. Buenos Aires: Centro de Publicaciones Educativas y Material Didáctico, 2016. p. 9-25. 
SERRANO RUIZ, J. El papel del maestro en la Educación Intercultural Bilingüe. Revista Iberoamericana de Educación: Educación, Lenguas, Culturas, [S. I.], n. 17, p. 91-102, mayo/ago. 1998.

SERRUDO, A. Indígenas en la escuela: representaciones y tensiones acerca de los docentes indígenas bilingües en Argentina. In: HIRSCH, S.; SERRUDO, A. (Ed.). La Educación Intercultural Bilingüe en Argentina. Identidades, lenguas y protagonistas. Buenos Aires: Novaduc, 2010.

TERIGI, F. Los desafíos que plantean las trayectorias escolares. Ponencia presentada en el III Foro Latinoamericano de Educación jóvenes y docentes. La escuela secundaria en el mundo hoy. Buenos Aires: Fundación Santillana, mayo 2007.

VALENZUELA, E. Educación Superior Indígena en el Centro de Investigación y Formación para la Modalidad Aborigen (CIFMA): génesis, desarrollo y continuidad. In: MATO, D. (Coord.). Instituciones Interculturales de Educación Superior en América Latina. Procesos de construcción, logros, innovaciones y desafíos. Caracas: Instituto Internacional de la UNESCO para la Educación Superior en América Latina y el Caribe (UNESCO-IESALC), 2009. p. 79-102.

VILLARREAL, J. Los hilos sociales del poder, en crisis de la dictadura argentina. Buenos Aires: Siglo XXI, 1985.

VILLARREAL, M. C.; MARTínEZ, M. E. Maestros indígenas en la provincia de Santa Fe. In: HECHT, A. C.; SCHMIDT, M. (Ed.). Maestros de la Educación Intercultural Bilingüe. Regulaciones, experiencias y desafíos. Buenos Aires: Centro de Publicaciones Educativas y Material Didáctico, 2016. p. 89-104.

ZIDARICH, M. Pareja vulnerable, si las hay: docente originario y docente no originario. In: HIRSCH, S.; SERRUDO, A. (Comp.). La Educación Intercultural Bilingüe en Argentina: análisis antropológicos de experiencias en comunidades indígenas. Buenos Aires: Novedades Educativas, 2010. p. 223-54.

ZIDARICH, M. Maestros indígenas wichí de la provincia del Chaco. En: HECHT, A. C.; SCHMIDT, M. (Ed.). Maestros de la Educación Intercultural Bilingüe. Regulaciones, experiencias y desafíos. Buenos Aires: Centro de Publicaciones Educativas y Material Didáctico, 2016. p. 161-183 


\section{Sobre la autora:}

Soledad Aliata: Becaria Posdoctoral CONOCET-IL. E-mail: soledadaliata@gmail.com, Orcid: https://orcid.org/0000-0001-8998-2693

Recibido el 25 de abril de 2020.

Aprobado para su publicación el 18 de mayo de 2020. 


\title{
De Caminha a Zé Carioca: invisibilidade, apagamento e silenciamento da identidade cultural indígena From Caminha to Zé Carioca: invisibility, erasure, and silencing of indigenous cultural identity
}

\author{
Cidiclei Alcione Biavatti ${ }^{1}$ \\ André Luis Campanha Demarchi ${ }^{1}$ \\ Leni Barbosa Feitosa ${ }^{1}$ \\ Idemar Vizolli ${ }^{1}$
}

DOI: http://dx.doi.org/10.20435/tellus.v0i42.678

Resumo: Este artigo objetiva compreender, por meio de um estudo comparativo, como a identidade cultural indígena é representada nas narrativas apresentadas na Carta de Pero Vaz de Caminha e na revista em quadrinhos Especial Brasil 500 Anos - Zé Carioca, à luz de estudos antropológicos sobre identidade e processos culturais. Compreende-se que a revista é quase que uma ilustração contemporânea da carta de Caminha, uma vez que ambos retratam as diferenças culturais que há entre os povos indígenas e portugueses, representando a imagem do colonizador com fortes princípios morais, religiosos e de dominação, em oposição à imagem do nativo atrasado, sem cultura e ambição, estagnado no tempo à espera de quem explorasse seus recursos e potencialidades. As narrativas, textual e imagética, criam estereótipos que contribuem para a situação de invisibilidade, apagamento e silenciamento da identidade cultural indígena, sobretudo ao depreciá-la diante da cultura eurocêntrica do colonizador.

Palavras-chave: Carta de Pero Vaz de Caminha; revista em quadrinhos Especial Brasil 500 anos - Zé Carioca; apagamento e silenciamento da identidade cultural indígena.

Abstract: This article aims to understand, through a comparative study, how indigenous cultural identity is represented in the narratives presented in Pero Vaz de Caminha's letter and the comic book Especial Brasil 500 Anos - Zé Carioca, in the light of anthropological studies on identity and cultural processes. It is understandable that the magazine is almost a contemporary illustration of the letter of Caminha, since both portray the cultural differences

$\overline{1}$ Universidade Federal do Tocantins (UFT), Palmas, Tocantins, Brasil. 
that exist between the Indigenous and Portuguese people, representing the image of the colonizer with strong moral principles, religious and domination, as opposed to the image of the archaic native, without culture and ambition, stagnant in time waiting for those who explore their resources and potentiality. The narratives, textual and imagetic, create stereotypes that contribute to the situation of invisibility, erasure, and silencing of indigenous cultural identity, especially by depreciating it in the face of the Eurocentric culture of the colonizer.

Keywords: Letter from Pero Vaz de Caminha; comic book Especial Brasil 500 anos -Zé Carioca; erasing and silencing the indigenous cultural identity.

\section{INTRODUÇÃO}

Pretensioso seria dar luz à formação da identidade de uma nação como o Brasil, miscigenado étnica e culturalmente, a partir do estudo comparativo entre uma revista em quadrinhos e a Carta de Pero Vaz de Caminha². Entretanto almejamos com este artigo a compreensão, por meio de um estudo comparativo, de como a identidade cultural indígena é representada nas narrativas apresentadas na Carta de Pero Vaz Caminha, primeiro registro oficial sobre a chegada dos portugueses por essas paragens, e na revista em quadrinhos Especial Brasil 500 Anos - Zé Carioca, por ocasião do quingentésimo aniversário do descobrimento do Brasil, à luz de estudos antropológicos sobre identidade e processos culturais.

A carta escrita por Pero Vaz de Caminha ao então rei de Portugal, Dom Manuel, descrevia brevemente a jornada realizada por Cabral e sua esquadra até chegar ao novo território. Entretanto, após a ancoragem, o escrivão oficial passou a relatar de maneira detalhada os acontecimentos ocorridos nos dez dias em que a esquadra aqui permaneceu. Sua narrativa tem uma capacidade de projeção imagética interessante, como destaca Limberti (2012, p. 28), já que cria relação "de espaço (um lugar, o Brasil), de seus atores (seus habitantes, os índios), num determinado tempo (início do século XVI)", ilustrando a percepção do europeu colonizador, criada a partir de seus referenciais contemporâneos.

Aspectos culturais, a aparência física dos habitantes nativos e a religiosidade são alguns dos pontos que Caminha destaca em sua correspondência à corte portuguesa. O registro do primeiro contato entre dois povos completamente

2 Designado pelo rei para registrar a viagem de Pedro Álvares Cabral, que culminou com a chegada ao Brasil. 
desconhecidos um ao outro é feito, em alguns momentos, com certa dose de espanto, que aos poucos vai se modificando com as estratégias adotadas pelos portugueses para aproximar-se dos indígenas. Wittmann (2015, p. 154) analisa esse primeiro movimento de aproximação "como um flerte, quando se age, apesar da insegurança do desconhecido". Esse, diz a autora na sequência de seu raciocínio, "é um momento de dar-se a conhecer", mesmo se sabendo que essas impressões construídas sobre o outro, via de regra, tendem a não corresponder fielmente com a realidade.

Já o conteúdo da revista em quadrinhos é composto por relatos históricos dos eventos oficiais sobre a chegada dos descobridores, ao mesmo tempo em que desenvolve uma trama centrada em José Manoel dos Calotes, ou simplesmente Zé Lusitano - personagem que descreveremos mais adiante -, um antepassado do personagem Zé Carioca, este último criado pelos estúdios de Walt Disney ${ }^{3}$ no ano de 1942 e, de acordo com Cavalcanti (1977, p. 241), "personificando um brasileiro na figura de um papagaio".

No ano de 1941, o mundo vivia sob os horrores da Segunda Guerra Mundial, que somente seria encerrada em 1945. Nesse contexto, surge Zé Carioca, a partir de traços identificadores de um comportamento social e cultural e, segundo Guazzelli Filho (2009), fruto de uma sucedida ação de relações públicas do governo norte-americano em promover uma política de boa vizinhança comercial e cultural com países da América Latina. Disney foi um dos convidados a participar do desenvolvimento dessa política, visitando o Brasil em 1941. Segundo Cappellari (2005), essa viagem originou uma animação chamada Alô Amigos, na qual Pateta ${ }^{4}$ e Donald ${ }^{5}$ fazem novas amizades pelo Brasil, Chile e Argentina, e marcou o nascimento oficial de Zé Carioca.

Em princípio, o que fica evidente sobre a personalidade atribuída ao personagem remete ao que aponta Sergio Buarque de Holanda (1995, p. 146), em seu livro Raízes do Brasil, para quem "a contribuição brasileira para a civilização será de cordialidade - daremos ao mundo o 'homem cordial'". Corroborando essa

3 Walt Disney foi um produtor de cinema e televisão e showman americano, famoso como pioneiro dos filmes de desenho animado e como criador da Disneylândia (tradução livre) (BIOGRAHY, 2017).

4 Criado pelos Estúdios Disney (GUIA DOS QUADRINHOS, 2017a).

5 Personagem criado pelos Estúdios Disney (GUIA DOS QUADRINHOS, 2017b). 
impressão, Santos (2002) chama atenção para outro filme de animação produzido na época, Você já foi à Bahia? (1944), em que Zé Carioca convida Donald para visitar a Bahia. Nele, conforme descreve o autor, o papagaio brasileiro é mostrado como um tipo falastrão, afetuoso, simpático e hospitaleiro.

Contrapondo, mas não criando antítese, e sim um acréscimo ao que se definiu acima como personalidade para o papagaio Zé Carioca, alguns traços, como a preguiça, a malandragem, a facilidade para desvencilhar-se de determinadas situações, são perceptíveis, sem, no entanto, configurar sua figura como mau caráter. DaMatta (1997, p. 269), em sua concepção de "malandro", observa que esse tipo social cobre um espaço social complexo, em que, segundo o autor, "encontramos desde o pequeno gesto de sagacidade, que pode ser realizado por qualquer pessoa", até o profissional dos pequenos golpes.

No enredo desenvolvido na trama descrita na revista, objeto deste estudo, José Manoel dos Calotes, o Zé Lusitano, é um antepassado de Zé Carioca e teria sido o primeiro europeu a pisar em terras brasileiras. Lusitano era muito conhecido em terras portuguesas principalmente pela a plicação de pequenos golpes. Em uma dessas armações, para fugir da perseguição de soldados que o perseguiam para capturá-lo a mando da rainha, acaba parando na esquadra comandada por Dom Peru Álvares Cabral", que partia em direção à Índia, mas acabou "descobrindo" o Brasil. Os traços de personalidade citados na breve biografia de Zé Carioca são utilizados como se fossem intrínsecos, primeiro ao parente lusitano e, depois, pelo descendente brasileiro, como uma herança genética que se configura como a baliza identitária de um Zé "Brasileiro".

\section{IDENTIDADE CULTURAL INDÍGENA: INTERLOCUÇÃO DE CAMINHA E ZÉ CARIOCA}

Contudo, o melhor fruto que dela se pode tirar parece-me que será salvar esta gente. E esta deve ser a principal semente que Vossa Alteza em ela deve lançar. [...] Quanto mais, disposição para se nela cumprir e fazer o que Vossa Alteza tanto deseja, a saber, acrescentamento da nossa fé! (Pero Vaz de Caminha, 1500).

$\overline{6}$ Personagem que faz as vezes de Pedro Álvares Cabral na história em quadrinhos. 
No dia 22 de abril de 1500, de acordo com o que conta a história oficial, aportou em terra desconhecida a esquadra portuguesa, que, supostamente, teria se desviado acidentalmente de sua rota original até as Índias. Em sua carta enviada a Dom Manuel, então rei de Portugal, Caminha (1963, p. 2) faz uma breve descrição do "gentio" que aqui habitava. O escrivão da frota os descreve como pardos e um tanto avermelhados, bem-feitos e com bons rostos e narizes. Não usam vestimenta, e isso, em absoluto, parece incomodá-los; nas palavras de Caminha, "nem fazem mais caso de encobrir ou deixar de encobrir suas vergonhas do que de mostrar a cara". Essa definição superficial de Caminha longe está de ser tomada como um traçado da identidade étnica e cultural dos povos que aqui habitavam à época desse contato.

Hall (2003) observa que identidade cultural é presumivelmente absorvida desde o nascimento, como parte constituinte de nossa personalidade. Para Carneiro (2013), a questão da identidade e os elementos que distinguem os grupos sociais partem justamente das diferenças. O autor alerta, porém, que as sociedades e suas particularidades são constituídas por meio de processos de influência mútuas, por intermédio de suas relações com outras culturas. A partir dessa premissa, podemos supor que a identidade está sempre em construção.

A premissa anterior encontra eco em Funari e Piñon (2016, p. 20), quando os autores descrevem o pensamento anteriormente vigente de que identidade seria algo "único, evidente e imutável". Transportando essa abordagem à perspectiva da trajetória e das transformações do "ser índio", este deveria ser estático em sua cultura, em suas interações sociais, sob pena de deixá-lo de ser.

Fiorin (2010, p. 115) apresenta as condições para a caracterização da identidade nacional, construída "a partir de uma autodescrição da cultura", sendo que a projeção da identidade do brasileiro é "criada pelo princípio da participação, da mistura", sublinhando a reflexão de Holanda (1995), exposta anteriormente, sobre o brasileiro e sua capacidade de ser cordial, acolhedor e agradável.

Ribeiro (1995, p. 19) define a formação social brasileira como emergida do encontro, dos desencontros e da miscigenação do "invasor português com índios silvícolas e campineiros e com negros africanos", criando, segundo palavras do autor, um "povo novo", por se ver e ser visto como "gente nova", mas ao mesmo tempo "velho", por manter em sua estrutura a essência do "proletariado externo", utilizado para gerar lucro à sua matriz, pelo seu papel de colônia. 
Partindo de uma leitura direta e relacionada com a revista que este trabalho traz para o centro do seu estudo, buscaremos agora entender os meandros do primeiro contato entre Pedro Álvares Cabral e indígenas. Nesse episódio, Cabral oferece espelhos, colares e até uma joia de ouro como presente, tentando conquistar a confiança dos indígenas, que, entretanto, não aceitam. Aqui temos a história contrariando a história.

No relato de Caminha (1963, p. 1), os indígenas não só aceitam como também retribuem as ofertas portuguesas. Segundo o escrivão da esquadra, o responsável pelo encontro foi Nicolau Coelho ${ }^{7}$. Esse, conforme descrito na carta, "arremessou-lhe um barrete vermelho e uma carapuça de linho que levava na cabeça, e um sombreiro preto". Em retribuição, os indígenas Ihe deram "um sombreiro de penas de ave, compridas, com uma copazinha de penas vermelhas e pardas, como de papagaio ${ }^{8 \prime}$. Mas o que mais chamou atenção de Caminha foi uma peça feita de contas, as quais pareciam pequenas pérolas, e que por aparentar ter valor deveria ser enviada ao rei.

Mostra-se oportuno buscar em Mauss (2003, p. 188), que trata da troca voluntária entre sociedades, elementos para refletir sobre o exposto acima. Para o autor, as trocas se constituem, quase como regra, em ofertas feitas de maneira generosa, "mesmo quando, nesse gesto que acompanha a transação, há somente ficção, formalismo e mentira social". Entre sociedades arcaicas estudadas por Mauss, esse rito transcenderia para além de um modelo econômico, configuraria, sim, a confraternização entre povos que mantinham uma rotina de convivência.

7 Navegador português (http://cvc.instituto-camoes.pt/navegaport/g17.html).

${ }^{8}$ Souza (2001, p. 67) narra sobre a formação do nome do Brasil, que, "após 1501, quando chegou do Oriente a armada de Cabral, a terra foi referida como Terra dos Papagaios". Por ironia, Disney representou o brasileiro utilizando a figura de um papagaio para dar vida a Zé Carioca. 
Figura 1 - Os presentes: Cabral oferece regalos aos indígenas

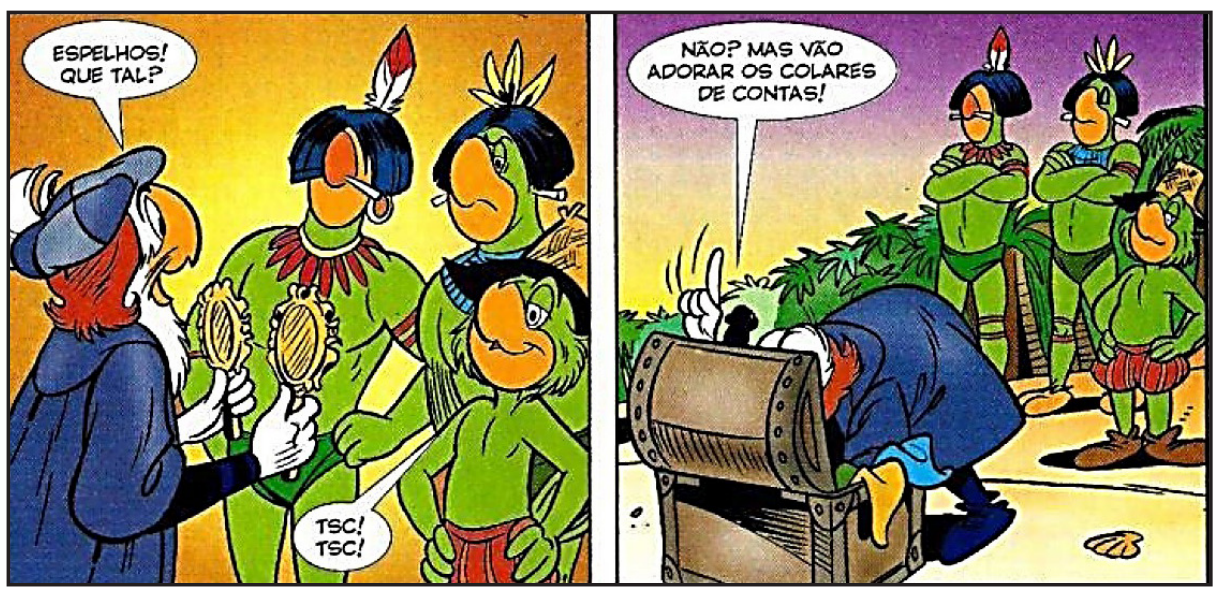

Fonte: Especial Brasil 500 Anos - Zé Carioca (2000).

Observando o exercício da "dádiva", na relação de troca entre "descobridores" e "descobertos" em 1500, por ocasião do ancorar dos primeiros aqui, o entendimento de Mauss (2003, p. 188) sobre "interesse econômico" explicita a descrição de Caminha (1963, p. 2), quando esse narra o folguedo de um indígena com um rosário e a suposta intenção dos portugueses em trocar a peça por ouro. A afirmação "isto tomávamos nós nesse sentido, por assim o desejarmos!", denota a intenção projetada pelo escrivão.

Mas, na história em quadrinhos, que presente foi aceito pelos indígenas como prova das boas intenções portuguesas? Nesse ponto, Zé Lusitano mostra a Cabral que o que despertou sobremaneira o interesse dos nativos foi o futebol, embora esse tenha sido oficialmente inventado na Inglaterra, no século XIX9, chegando ao Brasil no mesmo período e, seguindo o raciocínio de DaMatta (1982, p. 15), tornou-se, "em menos de meio século, um autêntico esporte de massas", tal foi sua assimilação pela sociedade brasileira.

\footnotetext{
9 A origem do futebol moderno, tal como o conhecemos hoje, é a Inglaterra do século XIX. Mas jogos cowm bola, praticado com os pés ou com as mãos, têm registros muito anteriores, em diversas partes do mundo (LIMA, 2002).
} 
Figura 2 - O futebol: Zé Lusitano insere o futebol na cultura indígena

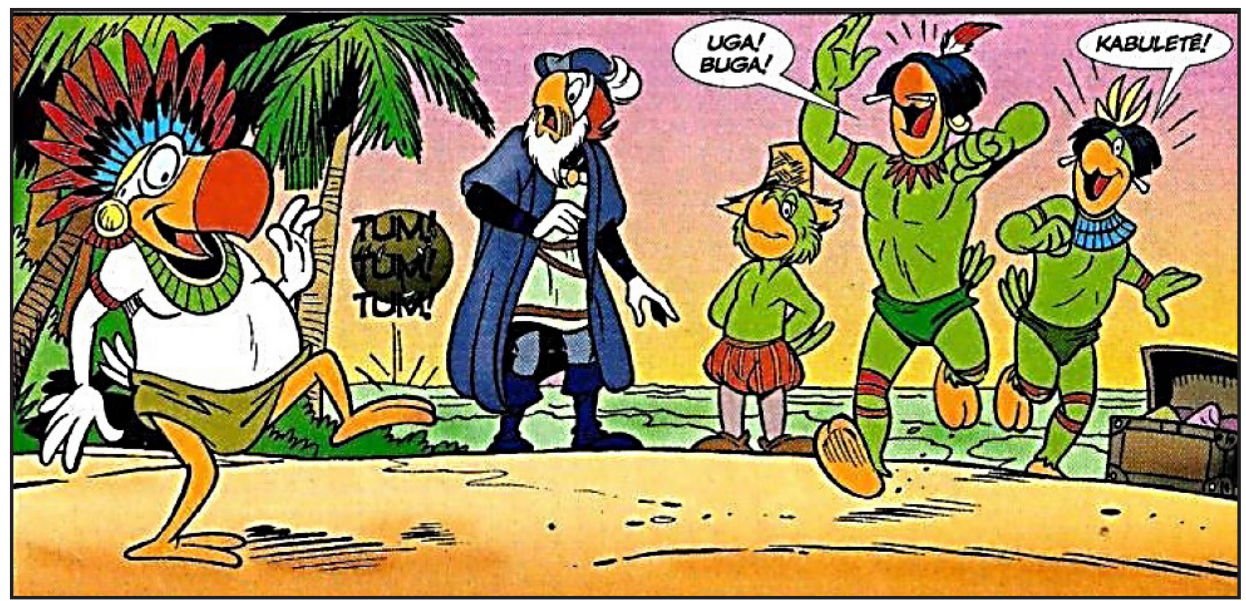

Fonte: Especial Brasil 500 Anos - Zé Carioca (2000).

Demarchi (2014, p. 63), que realizou um estudo etnográfico junto aos Mẽbêngôkre, mais conhecidos como Kayapó, no sul do estado do Pará, alude que o futebol faz parte da rotina nas aldeias, sendo visível nos jogos "uma interessante capacidade nativa de mimetizar as formas culturais e rituais dos brancos", fato reforçado pelo autor ao descrever também a grande quantidade de camisetas de clubes futebolísticos usadas pelos indígenas.

O desfecho do episódio sobre o futebol na revista do Zé Carioca não poderia ser mais simbólico. Como descrito anteriormente, Zé Lusitano havia se antecipado a Cabral e tomado posse do recém-descoberto território, ignorando completamente a presença de habitantes. Cabral, percebendo o interesse dos nativos pelo esporte apresentado por Lusitano, decide desafiá-los para uma partida de futebol. O prêmio para o vencedor é o direito sobre a terra que esses habitavam. 
Figura 3 - O futebol: a primeira partida de futebol entre Portugal e Brasil

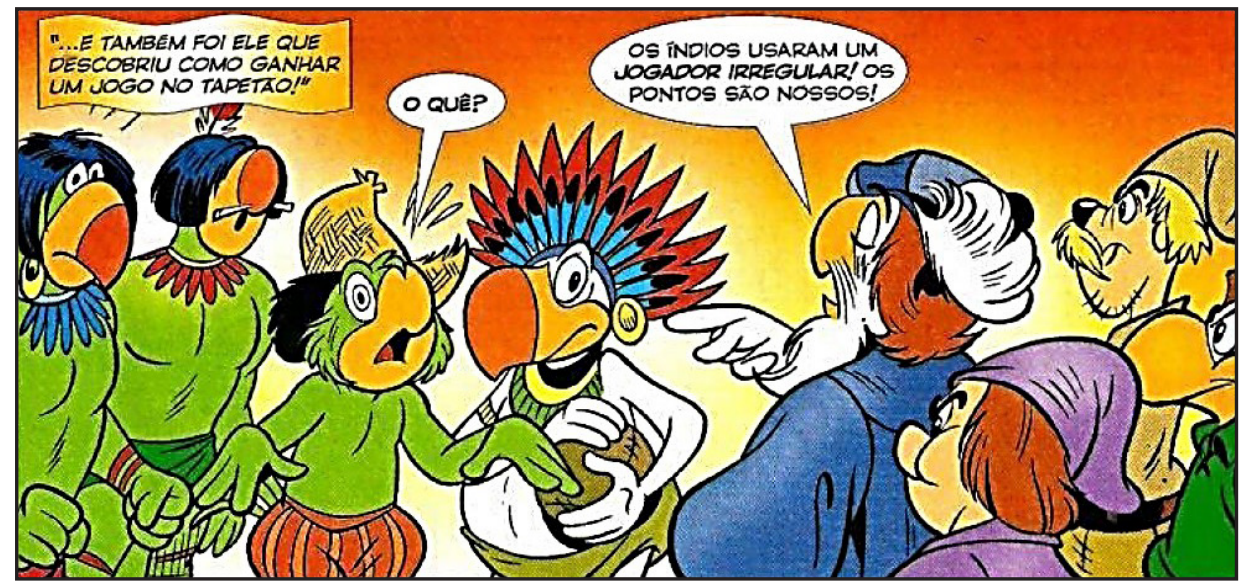

Fonte: Especial Brasil 500 Anos - Zé Carioca (2000).

O resultado não poderia ser outro. Mesmo vencendo em campo, os indígenas foram derrotados, usurpados por um conjunto de regras criadas para beneficiar apenas um lado da disputa. De acordo com DaMatta (1982, p. 30-31), as regras dramatizam o jogo, e este cria uma separação densa e tensa entre "as regras do jogo e as vontades individuais" dos participantes. O autor acrescenta ainda que o resultado, vitória ou derrota, constitui-se em "metáfora para o jogo como destino e biografia, tema básico da própria sociedade". Esse desenrolar instiga à reflexão sobre os presentes e o futebol, entre a troca social ocorrida entre descobridores e descobertos, em que os primeiros tomaram posse da maior dádiva que os últimos possuíam, a sua terra e as representações simbólicas e sagradas que essa encerra.

Os portugueses, ao chegarem ao Brasil, traziam suas próprias representações em seu extrato cultural, por meio de costumes e crenças, amparados por uma hierarquização social bem definida, com a nobreza e clero sobrepondo-se, naturalmente, à plebe. Holanda (1995, p. 35), ao descrever a formação dessas sociedades, observa que "toda hierarquia funda-se necessariamente em privilégios". Aqui, necessário se faz destacar o papel da igreja na formação da nação lusitana, que, segundo define Menck (2011, p. 44), foi fundeada no espírito das Cruzadas, ao findar da Idade Média, quando "a fé se serviu largamente das espadas para se estender e propagar a cristandade" e, como registra Limberti (2012, p. 37), a igreja assumiu em contrapartida "o papel de legitimar o caráter altruísta da expedição", incluindo aí a empreitada que resultou no descobrimento do Brasil. 
O registro de simulacros religiosos foi uma constante na história contada pelos portugueses sobre sua chegada ao novo mundo. O primeiro se relaciona com a festa de Páscoa, relatado na carta de Caminha (1963, p. 1) quando esse descreve o famoso grito dos marinheiros: terra à vista!, ao avistar um "morro redondo" que se destacava na paisagem e ao qual "o capitão pôs o nome de O Monte Pascoal", provavelmente batizado pela proximidade com a celebração da páscoa pelos católicos.

A narrativa da celebração pascoal feita na revista do Zé Carioca diz que Cabral solicitou a sua tripulação que houvesse uma celebração especial pela passagem do dia sagrado. Na sequência, revela-se que o ritual representado não agrada nem um pouco o capitão-mor. Marinheiros vestidos de coelhinhos dançam e cantam em torno de um ovo gigante. Essa representação não conforma a celebração da Páscoa para os portugueses, que tinham nessa festa o simbolismo religioso como principal elemento.

Figura 4 - Páscoa: a celebração pelos portugueses em solo brasileiro

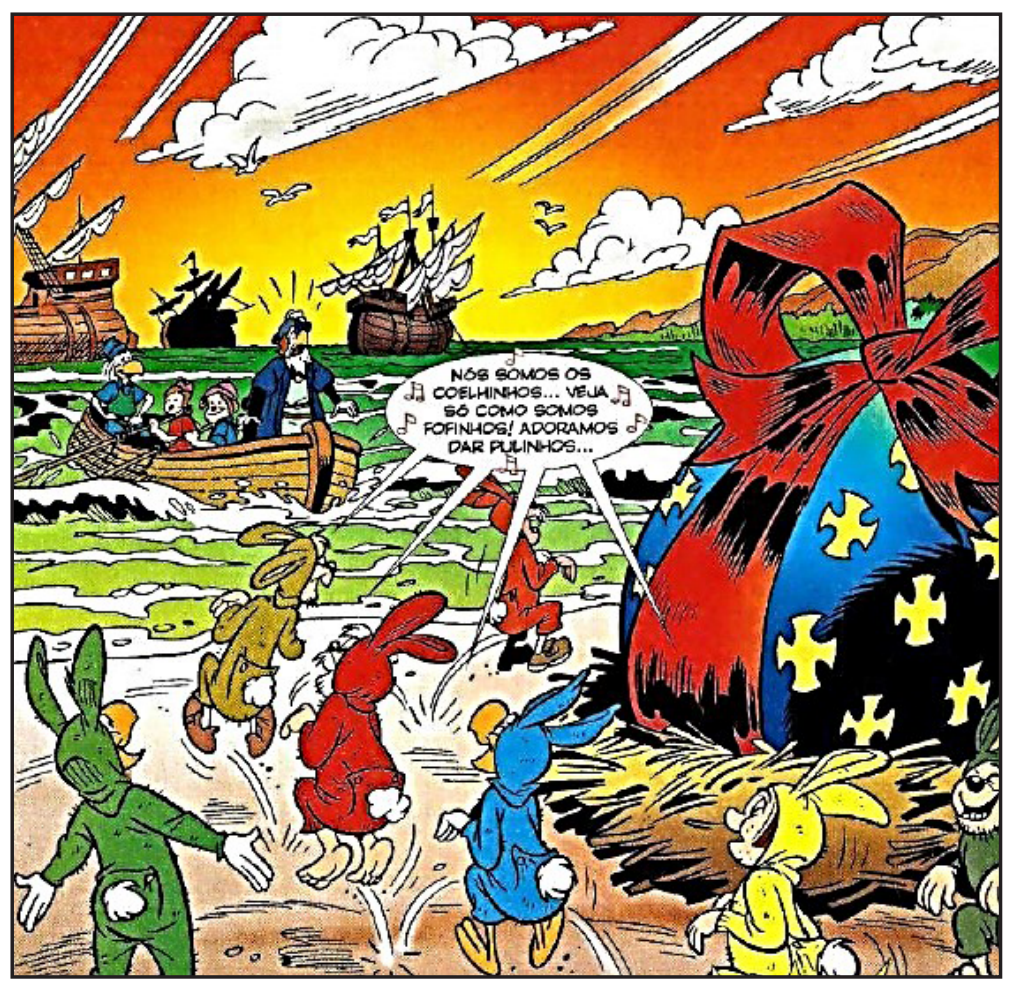

Fonte: Especial Brasil 500 Anos - Zé Carioca (2000). 
Geertz (1989, p. 66-67) traz uma reflexão precisa de como as representações simbólicas ligadas à religiosidade conseguem "sintetizar o ethos de um povo", quando destacamos, por ocasião do contato cultural entre portugueses e índios, como os primeiros priorizaram impor "[...] seu estilo e disposições morais e estéticos e sua visão de mundo". Caminha (1963, p. 3) narra que a celebração da primeira missa pelos portugueses no novo território descoberto foi justamente no domingo de "Pascoela", quando, "pela manhã, determinou o Capitão ir ouvir missa e sermão naquele ilhéu", acrescentando ainda a notada devoção demonstrada pelos participantes.

Por outro lado, descontente com festa de Páscoa preparada pelos marujos, o Cabral da revista ordena que seja erguido um altar e celebrada uma missa. Essa é a forma encontrada para agradecer ao Deus católico pela descoberta e glorificar a passagem da Páscoa. A narrativa da revista retrata os símbolos religiosos do catolicismo, inseridos e integrados ao novo ambiente. Em primeiro plano, os nativos assistem com curiosidade ao evento, enquanto ao fundo destacam-se a cruz, o monte pascoal, frei Henrique, responsável pela celebração, e os portugueses ajoelhados, em sinal de submissão a seu Deus.

Figura 5 - A missa: primeira celebração religiosa em solo brasileiro

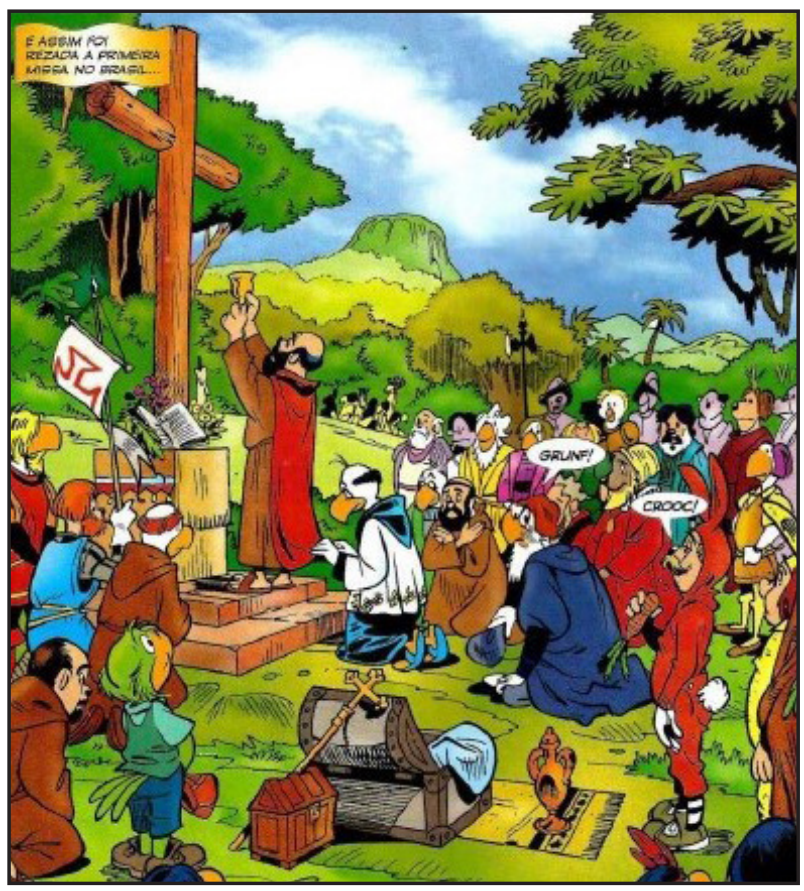

Fonte: Especial Brasil 500 Anos - Zé Carioca (2000). 
A celebração dupla - a primeira missa e comemoração da Páscoa - expôs o espírito de devoção e, mais que isso, apresentou a uma civilização considerada atrasada moral e culturalmente, à figura central do cristianismo católico, Jesus Cristo. No juízo do conquistador, como observa Cunha (2009, p. 313), os povos que viviam nas áreas periféricas "não haviam conhecido a verdadeira religião ou a haviam perdido". Aos colonizadores, com aval e participação da Igreja, cabia o encargo de tirá-los das "trevas".

Essa percepção é corroborada por Morin (2010, p. 27), quando assevera que o mundo europeu, e "mais largamente o ocidental", conceituava que sua civilização detinha toda a "razão e sabedoria", enquanto os demais povos e nações carregavam em si apenas o pensamento amparado pela mitologia e superstição.

\section{ESTEREÓTIPO, INVISIBILIDADE E SILENCIAMENTO DA IDENTIDADE CULTURAL INDÍGENA}

A construção de estereótipos culturais e étnicos nas duas fontes de narrativas estudadas também merece ser destacada. Na revista, especificamente, a condução da trama, que transita entre época presente e os acontecimentos do passado, traz à tona o tratamento dispensado e, de certa forma, a maneira como a sociedade reage e condiciona seu pensamento a esses fatos. Nela podemos perceber a idealização da beleza feminina e a construção de uma figura passiva e, por que não, pacata do indígena. No dicionário on-line Michaelis (2017), estereótipo é definido como imagem, ideia que categoriza alguém ou algo com base apenas em falsas generalizações, expectativas e hábitos de julgamento. Para Amossy e Pierrot (2010), são representações cristalizadas, amparadas por esquemas culturais já existentes, por meio dos quais cada indivíduo cria sua visão da realidade, de acordo com o ambiente que o cerca.

Quando começamos a ler a revista do Zé Carioca, logo em sua quarta página da sequência de ilustrações, há um quadro com a narrativa que envolve um diálogo entre Zé Lusitano e Vasco da Gama ${ }^{10}$. A conversa gira em torno de um mapa que Lusitano vendeu ao famoso navegador. Tal carta geográfica seria um caminho para as Índias ${ }^{11}$, contudo Vasco da Gama aportou em outro lugar, que

${ }^{10}$ Navegador português (1460-1524).

${ }^{11}$ A primeira viagem de Vasco da Gamaà Índia se deu entre 1497-1499 (www.mosteirojeronimos.gov.pt). 
não a Índia, sem, no entanto, chatear-se com o acontecido. O navegador mostra-se feliz por ter descoberto o caminho das índias, ilustrado por quatro garotas indígenas, utilizando vestimentas com motivos que remetem aos povos nativos norte-americanos. O ponto que queremos destacar é a representação imagética da mulher indígena, ingênua, mas com elementos que caracterizam sensualidade.

Figura 6 - As Índias: representação da mulher indígena

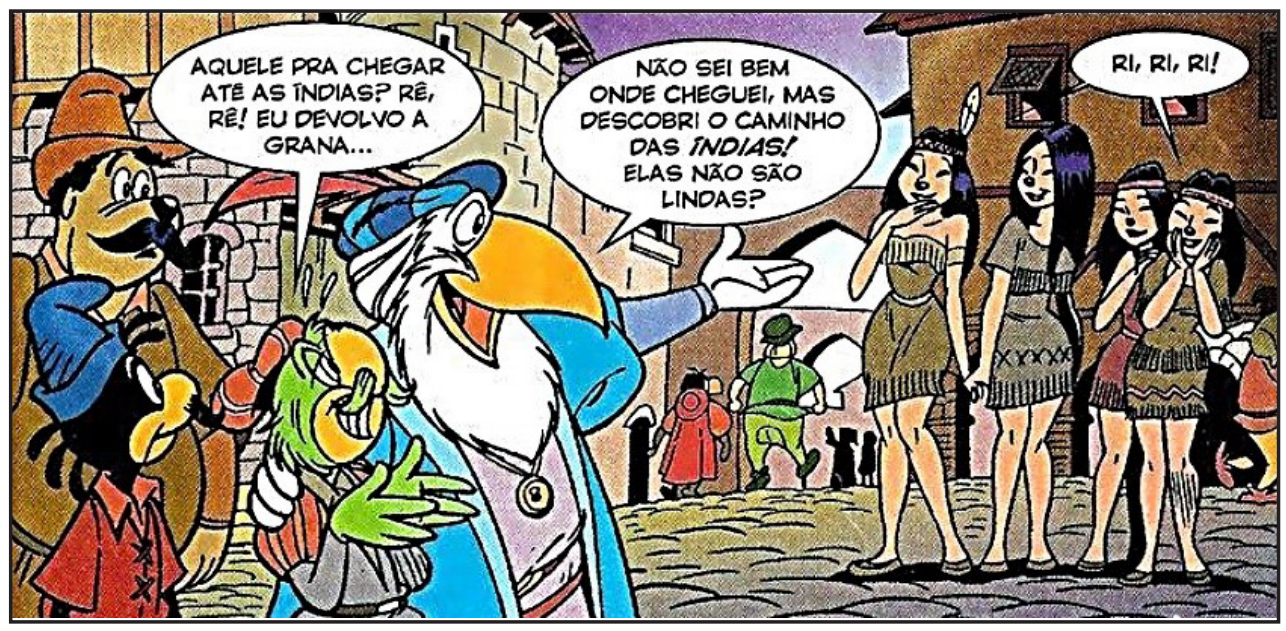

Fonte: Especial Brasil 500 Anos - Zé Carioca (2000).

Na visão do colonizador português descrita na carta, Caminha (1963, p. 3) delineia o primeiro contato com a mulher indígena. O escrivão conta que eram "três ou quatro moças bem novinhas e gentis". Ainda segundo o relato, tinham "cabelos muito pretos e compridos pelas costas", andavam nuas com "suas vergonhas tão limpas das cabeleiras" e não se envergonhavam por andarem assim e serem observadas.

É de se imaginar o impacto que esse evento causou nos portugueses, que tiveram de lidar com seus conceitos embutidos em sua carga cultural e religiosa, como explica Miranda (2003, p. 4), para quem "olhar masculino, europeu" é centrado no "controle e ocultamento do corpo", em particular o feminino, considerado estimulador do pecado. Continua seu relato Caminha, descrevendo a visita de uma mulher "a qual esteve sempre à missa" e para quem Ihe foi dado um "pano com que se cobrisse". A tentativa mostrou-se inútil, já que a mulher não lembrava, por não ter costume, de estender o pano para se cobrir. 
Caminha, nas vezes em que descreveu as mulheres indígenas, buscou parecer confortável pelo fato de elas se encontrarem nuas, não se furtando, no entanto, de destacar que uma delas tinha "sua vergonha tão graciosa que a muitas mulheres de nossa terra, vendo-lhe tais feições envergonhara, por não terem as suas como ela". Nesse sentido, Tambke (2013, p. 141) discorre sobre "o estereótipo da mulher brasileira exótica e gostosa", observando que essa projeção da mulher se apresenta "como um desdobramento dos tempos coloniais", o que nitidamente nas duas fontes deste trabalho ficou destacado.

Vamos agora fazer um exercício na busca de deslindar como o português viu de fato o habitante das terras que havia descoberto em 1500. Em primeiro lugar, vamos ver como a revista do Zé Carioca tratou esse momento do encontro. Como descrito anteriormente, Zé Lusitano, utilizando-se da malandragem, conseguiu deixar a nau de Cabral sem ser percebido e rumou em um bote na direção daquela terra desconhecida. Refletindo novamente sob a conjectura de DaMatta (1997) sobre o mito de Pedro Malasartes, vemos em Zé Lusitano a mesma perspicácia de quem sabe extrair vantagem de momentos completamente adversos.

Figura 7 - A posse: Lusitano se adianta a Cabral e toma posse da terra

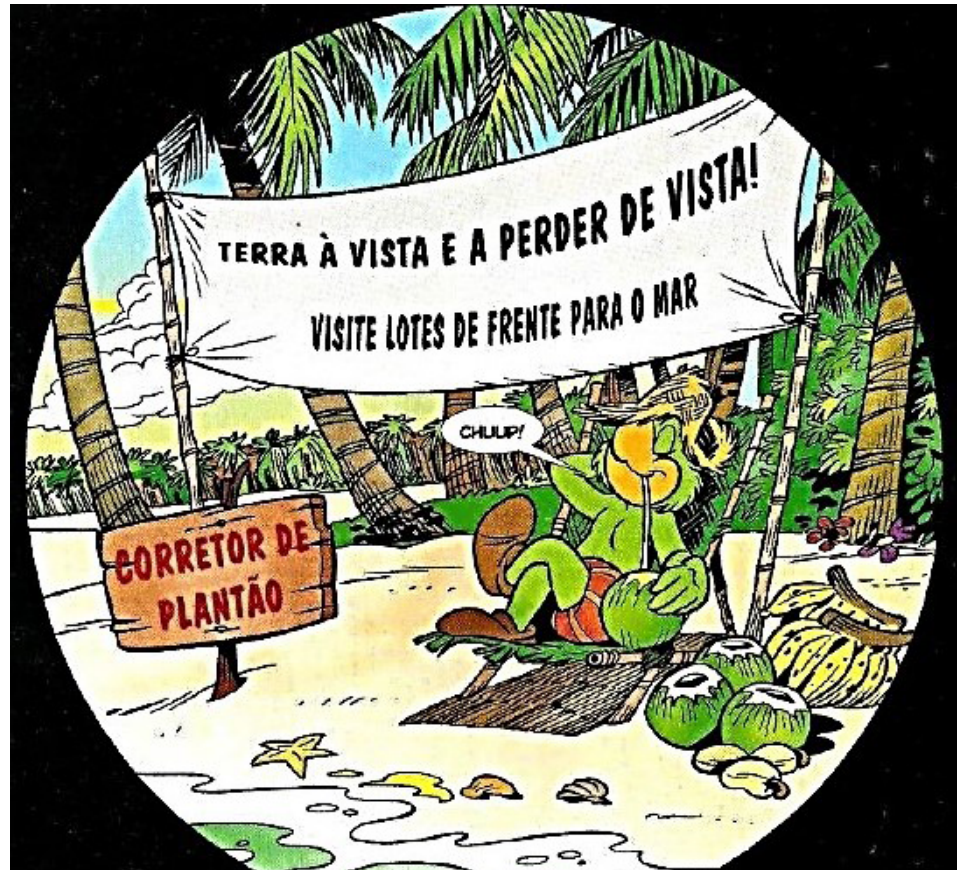

Fonte: Especial Brasil 500 Anos - Zé Carioca (2000). 
Na sequência da história em quadrinhos, ao perceber que fora enganado, Cabral vai até a terra avistada a fim de tirar satisfações com Lusitano e tomar posse do território para a coroa portuguesa. Chegando, depara-se com os habitantes nativos e sua primeira reação é denominá-los de selvagens, em um misto de espanto e medo. Lusitano então esclarece que o capitão não precisa se preocupar, já que "é tudo gente boa!".

Figura 8 - O indígena: a invisibilidade cultural

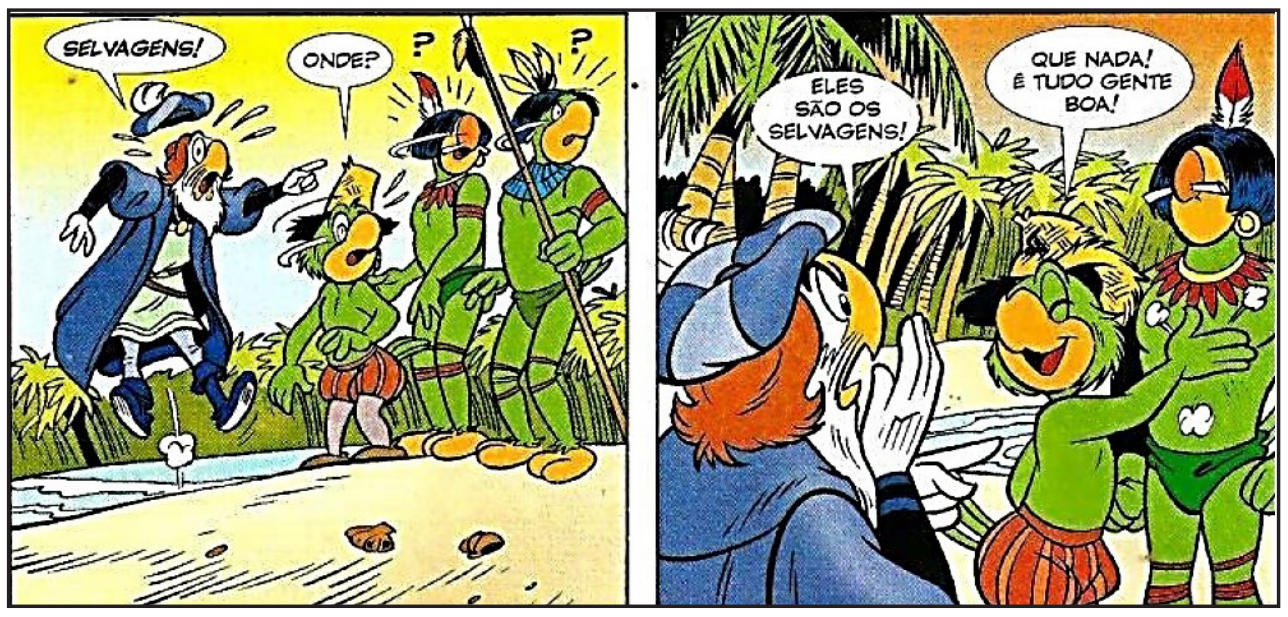

Fonte: Especial Brasil 500 Anos - Zé Carioca (2000).

Esmiuçando um pouco mais a versão oficial do descobrimento, no primeiro parágrafo de sua carta ao rei, Caminha $(1963$, p. 1) relatou como certa a posse do novo território por parte de Portugal, "posto que o Capitão-mor desta Vossa frota, e assim os outros capitães escrevam a Vossa Alteza a notícia do achamento desta Vossa terra nova".

O desenvolvimento tecnológico das técnicas de navegação durante o século XIV abriu caminho para as viagens colonizadoras. Em uma sanha incontrolável, lançaram-se ao mar as principais nações do velho continente, tendo como intenção, como ressalva Ribeiro (1995, p. 39), estruturar o mundo em um só, comandado pela Europa. O autor observa também que "tudo isso com o fim de carrear para lá toda a riqueza saqueável", explorando ainda toda a 
capacidade produtiva dos povos dominados ${ }^{12}$.

Olhando para a colonização do Brasil, é perceptível a invisibilidade do índio durante o processo. A começar pela gênese do descobrimento, quando a posse do território foi concretizada mesmo em face da presença de habitantes aqui radicados anteriormente. E o desenrolar da história do Brasil não mudou esse quadro. No livro A temática indígena na escola, Funari e Piñon (2016, p. 110) creditam à "associação do índio com a floresta", distante do convívio com a sociedade, o desconhecimento e a desvalorização da cultura ancestral desses povos e, por conseguinte, a sua condição de invisível perante a sociedade.

Foi por meio das descrições da carta que se vinculou a imagem do indígena com a imagem do território. Limberti (2012, p. 104) atribui a Caminha essa associação imagética, "a partir de um conjunto de significados produzidos" seguindo as representações simbólicas construídas em sua experiência do contato. A descrição de um povo que não arava a terra, tampouco criava animais, mas sim vivia em comunhão com a natureza, alimentando-se do que a terra os fornecia por espontaneidade, que se viu inserido em uma realidade complemente oposta a partir da convivência com o novo brasileiro.

Vainfas (2007, p. 37) descreve a história indígena no seio da colonização como "história de despovoamento", marcada por "enganos e incompreensões", começando pelo termo que identifica os povos que já aqui habitavam, cunhado erroneamente por Colombo ao chegar à América, julgando estar nas Índias.

Seguindo o mesmo entendimento, Terena ${ }^{13}$ (MORIN, 2010) aponta que, quando da chegada de Cabral, quase 1.000 povos habitavam o território depois nomeado de Brasil. Agora, restam 200, e essa informação é desconhecida da maioria da população brasileira, que constrói uma imagem completamente deturpada do indígena, como define Terena (MORIN, 2010, p. 47), "uma imagem totalmente caricaturada", alguém que, ainda na concepção de Terena, foi o grande mudo no decorrer dos 500 anos de Brasil.

12 Ribeiro utiliza o termo conscrito para definir os povos contatados e recrutados pelos colonizadores, mas acreditamos que isso serviu apenas para tornar mais branda a prática exploratória dos colonizadores europeus.

${ }^{13}$ Líder indígena Xané. 
Para Gomes (1988, p. 18), por mais que se relegue o indígena a uma condição de indiferença, a questão que evolve esses povos continuará existindo enquanto viver o último dos indivíduos que os represente. A questão indígena, segundo o autor, diz respeito à sua relação com esse "mundo que se criou a sua volta e à revelia" de sua vontade, transformando-o em um estranho em sua própria terra.

\section{CONSIDERAÇÕES FINAIS}

Ao andarilhar pela representação textual e imagética reverberada na carta de Caminha e na Revista Zé Carioca acerca da identidade cultural indígena, compreendemos que a revista é quase que uma ilustração contemporânea da carta de Caminha, uma vez que ambos retratam as diferenças culturais que há entre os povos indígenas e portugueses, representando a imagem do colonizador com fortes princípios morais, religiosos e de dominação, em oposição à imagem do nativo atrasado, sem cultura e ambição, estagnado no tempo à espera de quem explorasse seus recursos e potencialidade.

As narrativas, textual e imagética, criam estereótipos que contribuem para a situação de invisibilidade, apagamento e silenciamento da identidade cultural indígena, sobretudo ao depreciá-la diante da cultura eurocêntrica do colonizador, evidenciando sua existência exclusivamente ao interesse da coroa portuguesa, que passa a dominar os indígenas, decidindo sobre seu futuro e deveres no novo território brasileiro.

\section{REFERÊNCIAS}

AMOSSY, Ruth; PIERROT, Anne Herschberg. Estereotipos y clichés. Buenos Aires: Eudeba, 2010. (Colección Enciclopedia Semiológica).

BIOGRAPHY. Walt Disney. A\&E Television Networks, 2017. Disponível em: https://www. biography.com/people/walt-disney-9275533. Acesso em: 20 maio 2017.

CAMINHA, Pero Vaz. Carta a El Rei D. Manuel. Dominus: São Paulo, 1963.

CAPPELLARI, Márcia Schmitt Veronezi. Zé Carioca, um brasileiro: reflexos da modernidade e da pós-modernidade na trajetória do personagem. In: Encontro dos Núcleos de Pesquisa da Intercom, 5., História em Quadrinhos. 5 a 9 de setembro de 2005, Rio de Janeiro. Anais [...]. Rio de Janeiro: UERJ, 2005. Disponível em: www.intercom.org.br/papers/ nacionais/2005/resumos/R0670-1.pdf. Acesso em: 28 jun. 2017. 
CARNEIRO, Neri P. Identidade e diferenças: para uma antropologia do eu e do outro. Revista Brasileira de Ciências da Amazônia, v. 2, n. 1, p. 112-26, 2013. Disponível em: http://www. periodicos.unir.br/index.php/rolimdemoura/article/view/806/. Acesso em: 27 jun. 2017.

CAVALCANTI, lonaldo de Andrade. Mundo dos Quadrinhos. São Paulo: Ed. Símbolo, 1977.

CUNHA, Manuela Carneiro. "Cultura" e cultura: conhecimentos tradicionais e direitos intelectuais. In: CUNHA, Manuela Carneiro (Org.). Cultura com Aspas e outros ensaios. São Paulo: Cosac Naify, 2009. p. 311-75.

DAMATTA, Roberto. Carnavais, malandros e heróis: para uma sociologia do dilema brasileiro. Rio de Janeiro: Rocco, 1997.

DAMATTA, Roberto; FLORES, Luis Roberto Baêta Neves; GUEDES, Simone Lahud; VOGEL, Arno. Universo do futebol: esporte e sociedade brasileira. Rio de Janeiro: Pinakotheke, 1982.

DEMARCHI, André Luis Campanha. Kukràdjà Nhipêjx: fazendo cultura - beleza, ritual e políticas da visualidade entre os Mẽbêngôkre Kayapó. 2014. Tese (Doutorado em Antropologia Cultural) - Instituto de Filosofia e Ciências Sociais, Universidade Federal do Rio de Janeiro. Rio de Janeiro, RJ, 2014. Disponível em: https://www.academia. edu/27658203/Tese_de_doutorado_Kukradja_Nhipejx-Fazendo_cultura.pdf. Acesso em: 25 jul. 2017.

FIORIN, José Luiz. A construção da identidade nacional brasileira. Bakhtiniana - Revista de Estudos do Discurso, São Paulo, n. 1, jun. 2010. Disponível em: https://revistas.pucsp. br/index.php/bakhtiniana/article/view/3002. Acesso em: 20 jun. 2017.

FUNARI, Pedro Paulo; PIÑON, Ana. A temática indígena na escola: subsídios para os professores. São Paulo: Contexto, 2016.

GEERTZ, Clifford. A interpretação das culturas. Rio de Janeiro: LTC, 1989.

GOMES, Mércio Pereira. Os índios e o Brasil: ensaio sobre um holocausto e uma nova possibilidade de convivência. Petrópolis: Vozes, 1988.

GUAZZELLI FILHO, Eloar. Canini e o anti-herói brasileiro: do Zé Candango ao Zé - realmente - Carioca. 2009. 190 f. Dissertação (Mestrado em Ciências da Comunicação) - Escola de Comunicação e Artes da Universidade de São Paulo, São Paulo, SP, 2009. Disponível em: www.teses.usp.br/teses/disponiveis/27/27154/tde-16092009-205951/en.php. Acesso em: 25 jul. 2017. 
GUIA DOS QUADRINHOS. Pateta. 2017a. Disponível em: http://www.guiadosquadrinhos. com/personagem/pateta-(goofy-)/2374. Acesso em: 21 maio 2017.

GUIA DOS QUADRINHOS. Pato Donald. 2017b. Disponível em: http://www. guiadosquadrinhos.com/personagem/pato-donald-(donald-duck)/583. Acesso em: 21 maio 2017.

HALL, Stuart. Da diáspora: identidades e mediações culturais. Belo Horizonte: UFMG; Brasília, DF: Representação da Unesco no Brasil, 2003.

HOLANDA, Sérgio Buarque. Raízes do Brasil. 26. ed. São Paulo: Companhia das Letras, 1995.

LIMA, Marco Antunes. As origens do futebol na Inglaterra e no Brasil. 2002. Disponível em http://www.klepsidra.net/klepsidra14/futebol.html. Acesso em: 22 jun. 2017.

LIMBERTI, Rita de Cássia Pacheco. A imagem do índio: discursos e representações. Dourados: UFGD, 2012.

MAUSS, Marcel. Ensaio sobre a dádiva - forma e razão da troca nas sociedades arcaicas. São Paulo: Cosac Naify, 2003.

MENCK, José Theodoro Mascarenhas. A primeira missa no Brasil: a origem das relações Igreja Estado no sistema jurídico institucional brasileiro até o século XIX. Cadernos Aslegis, Brasília-DF, n. 44, p. 65-91, set./dez. 2011.

MICHAELIS. Moderno Dicionário da Língua Portuguesa. São Paulo: Melhoramentos, 2017. Disponível em: http://michaelis.uol.com.br/moderno/portugues/index.php. Acesso em: 1o jun. 2017.

MIRANDA, Janira Sodré. Mulheres indígenas, igreja e escravidão na América Portuguesa. Em Tempo de Histórias, Brasília-DF, n. 7, p. 1-16, 2003. Disponível em: https://periodicos. unb.br/index.php/emtempos/article/view/20135. Acesso em: 20 jul. 2017.

MORIN, Edgar. Participação de Marcos Terena. Saberes globais e saberes locais: o olhar transdisciplinar. Rio de Janeiro: Garamond, 2010.

RIBEIRO, Darcy. O Povo Brasileiro: a formação e o sentido do Brasil. 2. ed. São Paulo: Companhia das Letras, 1995.

SANTOS, Roberto Elisio. Zé Carioca e a Cultura Brasileira. In: CONGRESSO BRASILEIRO DE CIÊNCIAS DA COMUNICAÇÃO, 25., 1o a 5 set. 2002, Salvador, BA. Anais [...]. Salvador, 2002. 
Disponível em: http://www.intercom.org.br/papers/nacionais/2002/Congresso2002_ Anais/2002_NP16SANTOS.pdf. Acesso em: 15 jun. 2017.

SOUZA, Laura de Mello. O nome do Brasil. Revista de História, São Paulo, n. 145, p. 6186, dez. 2001. ISSN 2316-9141. Disponível em: http://www.revistas.usp.br/revhistoria/ article/view/18919. Acesso em: 2 ago. 2017.

TAMBKE, Erika. Mulheres Brasil $40^{\circ}$ : os estereótipos das mulheres brasileiras em Londres. Espaço e Cultura, Rio de Janeiro, n. 34, p. 123-50, jul./dez. 2013. Disponível em http:// www.e-publicacoes.uerj.br/index.php/espacoecultura/. Acesso em: 28 jul. 2017.

VAINFAS, Ronaldo. História indígena: 500 anos de despovoamento. In: Brasil: 500 anos de povoamento. Rio de Janeiro: IBGE, 2007.

WITTMANN, Luisa Tombini. Ressonâncias de Caminha: revisitando uma fonte célebre. Revista Fronteiras \& Debates, Macapá, v. 2, n. 1, p. 149-63, jan./jun. 2015. ISSN 2446-8215. Disponível em: https://periodicos.unifap.br/index.php/fronteiras/article/view/2520/ luisav2n1.pdf. Acesso em: 30 jul. 2017.

ZÉ CARIOCA. Especial Brasil 500 anos. São Paulo: Abril, edição especial, ano 1, n. 1, 2000. $84 \mathrm{p}$.

\section{Sobre os autores:}

Cidiclei Alcione Biavatti: Mestre em Comunicação e Sociedade e graduado em Comunicação Social - Jornalismo pela Universidade Federal do Tocantins (UFT). Membro do Grupo de Estudos e Pesquisa Social (Gepes) - linha de pesquisa: Educação Indígena na Amazônia Paraense, na Universidade do Estado do Pará (Uepa). Atua, principalmente, nas seguintes temáticas: Comunicação e Imagem, Narrativas Gráficas, Charges, Quadrinhos, Comunicação e Pinturas Rupestres, História da Linguagem e da Comunicação, Imagem e Imaginário Indígena. E-mail: cidbiavatti@gmail.com, Orcid: http://orcid.org/0000-0003-0122-1799

André Luis Campanha Demarchi: Doutor em Antropologia Cultural e mestre em Sociologia e Antropologia pela Universidade Federal do Rio de Janeiro (UFRJ). Graduado em Ciências Sociais pela Universidade Federal do Espírito Santo (Ufes). Antropólogo e professor adjunto na Universidade Federal do Tocantins (UFT), no curso de Ciências Sociais. Membro fundador e coordenador do Centro de Referências em Cidadania e Direitos Humanos (CDH-TOC), na UFT, campus Tocantinópolis. Coordenador do Pibid Apinajé e do Projeto Kukràdjà Nhipêjx (Projeto de Documentação da Cultura Kayapó), realizado no Museu do Índio (Funai), com financiamento da Unesco. Desenvolve pesquisa 
com os Mebengôkre-Kayapó. Atua nas áreas: etnologia indígena da Amazônia; arte indígena; antropologia da arte e dos rituais; antropologia urbana; educação interétnica; e teoria antropológica. E-mail: andredemarchi@uft.edu.br, Orcid: https://orcid.org/0000-0002-9134-441X

Leni Barbosa Feitosa: Doutoranda em Educação - Programa de Pós-Graduação em Educação na Amazônia (Educanorte), Universidade Federal do Tocantins (UFT). Mestra em Educação pela UFT. Membro efetivo da agremiação de escritores e escritoras da Academia Redencense de Letras (ARL); membro do Grupo de Estudos e Pesquisa Social (Gepes) - linha de pesquisa: Educação Indígena na Amazônia Paraense, da Universidade do Estado do Pará (Uepa); Grupo de Estudos e Pesquisas em Educação Matemática na Formação de Professores (Gepemfor) - linha de pesquisa: Educação, Diversidade e Interculturalidade, da UFT; e Grupo de Estudos e Pesquisas Territórios Indígenas e Etno-Envolvimento (GPTIE) - linha de pesquisa: Educação Escolar Indígena, do Instituto Federal de Educação, Ciência e Tecnologia do Pará (Ifto). E-mail: lenifeitosa@hotmail.com, Orcid: http://orcid.org/0000-0001-7333-5264

Idemar Vizolli: Doutor em Educação pela Universidade Federal do Paraná (UFPR). Mestre em Educação pela Universidade Federal de Santa Catarina (UFSC). Graduado em Ciências Naturais pela Universidade Regional do Noroeste do Estado do Rio Grande do Sul (Unijuí), e em Matemática pela Universidade do Contestado (UnC). Professor adjunto da Universidade Federal do Tocantins (UFT), professor e orientador no Programa de Mestrado Acadêmico e Profissional em Educação na UFT e no Programa de Pós-Graduação em Educação em Ciências e Matemática (Ppgecem), na Rede Amazônica de Educação em Ciências e Matemática (Reamec). Coordenador estadual da Reamec. E-mail: idemar@mail.uft.edu.br, Orcid: http://orcid.org/0000-0002-7341-7099

Recebido em 27 de janeiro de 2020.

Aprovado para publicação em 6 de maio de 2020. 



\title{
Percepções indígenas Paiter Suruí sobre o ensino superior: busca de sentido a partir de narrativas de estudantes de graduação
}

\author{
Indigenous perceptions Paiter Suruí about higher \\ education: searching for meaning from narratives of \\ graduation students
}

\author{
Alceu Zoia ${ }^{1}$ \\ Maria Gabriela de Assis Souza²
}

DOI: http://dx.doi.org/10.20435/tellus.v0i42.683

\begin{abstract}
Resumo: Este artigo tem como base parte dos resultados de pesquisa realizada no Programa de Pós-Graduação em Educação da Universidade do Estado de Mato Grosso (Unemat), campus de Cáceres, MT. Destacamos como principais interlocutores os estudantes pertencentes ao povo indígena da etnia Paiter Suruí, matriculados em cursos de graduação na cidade de Cacoal, RO, localidade mais próxima da Terra Indígena Sete de Setembro com oferta de educação de nível superior. Pela necessidade de delimitação, focamos o presente estudo na abordagem das perspectivas dos estudantes sobre a educação superior. Os instrumentos utilizados para a coleta de dados foram: pesquisa documental e de campo, por meio de entrevista semiestruturada. Entre os resultados obtidos, foi possível constatar que todos os estudantes indígenas da etnia Paiter Suruí que colaboraram com a pesquisa expressaram a perspectiva de utilizar os conhecimentos adquiridos na universidade em benefício da comunidade indígena, vislumbrando a possibilidade de ajudar a família e o seu povo, para manter vivas suas origens culturais, ainda que, para isso, tenham de reivindicar seu espaço e continuar lutando por seus direitos perante a sociedade não indígena.
\end{abstract}

Palavras-chave: educação indígena; ensino superior indígena; povo Paiter Suruí.

Abstract: This article is based on part of the results of research carried out in the Postgraduate Program in Education at the State University of Mato Grosso (Unemat), campus of Cáceres, MT. We highlight as main interlocutors the students belonging to the indigenous people of the Paiter Suruí ethnic group, enrolled in undergraduate courses in the city of Cacoal, RO, closest to the Sete

1 Universidade do Estado de Mato Grosso (Unemat), Sinop, Mato Grosso, Brasil.

2 Instituição de Ensino Superior de Cacoal (Fanorte), Cacoal, Rondônia, Brasil. 
de Setembro Indigenous Land with a higher education offer. Due to the need for delimitation, we focus the present study on the approach of students' perspectives on higher education. The instruments used for data collection were: documentary and field research, through semi-structured interviews. Among the results obtained, it was found that all Paiter Suruí indigenous students who collaborated with the research expressed the perspective of using the knowledge acquired at the university for the benefit of the indigenous community, envisioning the possibility of helping their families and their people, to keep their cultural origins alive, even if they have to claim their space and continue to fight for their rights before non-indigenous society.

Keywords: indigenous education; indigenous higher education; Paiter Suruí folk.

\section{INTRODUÇÃO}

A cultura é a herança deixada por cada sociedade aos seus descendentes, pelos processos educativos próprios e pela convivência social que repercute na formação da pessoa aquilo que se espera para o futuro de todo o seu povo.

No processo de transmissão da cultura, há, inevitavelmente, as transformações das formas de ver o mundo pelos integrantes das novas gerações, que recebem as culturas materiais e não materiais de seus antecessores e as utilizam da forma apreendida, podendo, ainda, reinventá-las, transformá-las ao longo do tempo.

Brandão (2002) trata da educação como cultura, reforçando a lição de Leontiev (2004) de que o movimento da história só é possível com a transmissão, às novas gerações, da cultura humana adquirida pelas gerações precedentes.

As concepções de Leontiev (2004) e Brandão (2002) se coadunam no sentido de que o ser humano, diferentemente das demais espécies animais, é um ser obrigado a aprender e que invariavelmente precisa criar e recriar o mundo, transformando o ambiente natural e a ele próprio por meio da cultura adquirida, aprendida e absorvida pela vivência social, que deve ser transmitida para que exista.

O rompimento dos laços culturais dos antepassados com os descendentes acarreta a perda da cultura pela impossibilidade de se conhecer o que existia antes e continuar a transmissão das memórias e saberes de um povo.

A transmissão dessa cultura ocorre de diversas formas, sendo a educação tradicional, originária, o mecanismo social mais importante nesse processo de 
Percepções indígenas Paiter Suruí sobre o ensino superior: busca de sentido a partir de narrativas de estudantes de graduação

busca, manutenção e aperfeiçoamento humano constante, que só sobrevive com a passagem e a aprendizagem dos conhecimentos de geração em geração.

Há um movimento dinâmico na transmissão e transformação da cultura, por influências internas do processo evolucionário, biológico e cultural, ou por influências externas, como o encontro de culturas.

Com efeito, não se pode pretender que identidade cultural expresse apenas o resguardo do passado, em sentido estático. Esta condição é impossível, biológica e culturalmente. No plano biológico, o processo evolucionário não deixa nada intocado, de forma que o tempo impõe-se como algo implacável, tanto como movimento da dinâmica interna, quanto como movimento advindo de fora. No plano cultural, mais ainda, em particular pela capacidade de aprender e conhecer, mas também sob o impacto do encontro/desencontro de culturas. (DEMO, 2009, p. 193).

As consequências desse encontro de culturas podem propiciar uma integração importante para o crescimento humano, o conhecimento de algo novo e a forma como se devem relacionar os integrantes das diferentes culturas, respeitando um ao outro e o modo de cada um ver o mundo.

No entanto a história nos mostra que outras e terríveis consequências podem haver desse encontro, a exemplo do processo de colonização e escravização, em que os integrantes de uma determinada cultura se veem superiores a outra, sentindo-se no direito de eliminar a cultura do outro, implantando forçadamente o seu modo de vida sobre os povos supostamente inferiores.

Esse processo de invasão, "colonização", inferiorização e apagamento de culturas marcou boa parte da história do Brasil, não apenas pela tentativa de eliminação das culturas indígenas, mas também pela repulsa às culturas africanas, embora estas estivessem muito presentes na formação do povo brasileiro, de forma biológica e cultural. Se não fosse dessa maneira, não existiria o Brasil com suas características próprias, proporcionadas pela mistura das raças e culturas (ORTIZ, 2003).

Constata-se que essas concepções vêm se transformando, ainda que lentamente, e rompendo, de certa forma e em alguns pontos, com o absurdo ideário discriminatório e de extermínio impregnado na sociedade como consequência da "colonização", especialmente na América Latina, berço de diversos povos nativos que foram invadidos, acuados e, em grande parte, dizimados. 
Num processo de decolonização, a resistência desses povos vem transformando as relações sociais, conquistando, a duras penas, direitos civis e políticos que deveriam ser garantidos a todos, desde sempre e independentemente de origem ou raça.

São essas lutas que direcionam o futuro para um sentido mais humano, embora os traços de colonialidade do poder ainda estejam operantes em certo nível na sociedade, conforme nos adverte Quijano (2005).

As influências mútuas dos contatos entre culturas diferentes são inevitáveis ante a dinamicidade com que a sociedade caminha e à medida que um grupo toca o universo e a realidade do outro, num processo que possibilita, em alguma proporção, a absorção recíproca de conteúdos culturais.

Cada povo e cada geração contribui para as modificações, alterações e adaptações do que apreendeu, fazendo a sua parte na história do grupo e imprimindo as particularidades do seu tempo na construção do futuro.

Os povos indígenas, além de terem seus direitos negados por muito tempo, tiveram suas culturas exterminadas no todo ou em parte, para serem obrigados a se submeter à cultura dominante.

As etnias sobreviventes buscam nos dias atuais uma forma de reconstruir os costumes de seu povo, na medida do possível e a partir das experiências presentes, uma vez que reconhecem a impossibilidade de retorno integral ao modo de vida tradicional. Seguem reafirmando seu pertencimento étnico e se impondo enquanto sujeitos de direitos, em especial, o direito a estar na sociedade não indígena e participar, sempre que possível, de um processo intercultural em ambientes como a escola e a universidade.

Essa interculturalidade pressupõe o conhecimento e o respeito aos costumes do outro, não a sua prática, muito menos a substituição de uma cultura pela outra. Portanto estar num grupo, aprendendo com ele, não significa esquecer de seus costumes, mas de interagir com o outro de forma respeitosa e acolhedora.

A exemplo do movimento inverso ou decolonial, podemos mencionar a garantia insculpida nos artigos 78 e 79 da Lei de Diretrizes e Bases da Educação Nacional (Lei 9.394/96), que passou a prever inclusão e reconhecimento identitário às populações indígenas, determinando, na educação fundamental, o respeito 
Percepções indígenas Paiter Suruí sobre o ensino superior: busca de sentido a partir de narrativas de estudantes de graduação

aos seus costumes e a preservação da língua materna, além da possibilidade de se adequar currículo e materiais didáticos às realidades culturais desses povos.

Também, mediante mecanismos de combate ao racismo e de reivindicações sociais, houve um passo importante no sentido do reconhecimento do valor e da contribuição dos negros africanos e dos indígenas para a formação do país e das manifestações culturais, por meio da Lei 11.645/2008, que alterou a redação do artigo 26-A da LDB, tornando obrigatório o ensino sobre História e Cultura Afro-Brasileira e Indígena nos estabelecimentos de ensino fundamental e médio, oficiais e particulares.

A escola é um dos instrumentos sociais mais importantes e profundos para a formação das identidades culturais, no entanto uma outra questão vem à tona com a ideia de identidade, que é o respeito pelas diferenças e a criação de políticas que realmente atendam e valorizem essa diversidade.

É exatamente nesse contexto que se encontra o povo indígena Paiter Suruí, colaborador deste trabalho. Eles demonstram um protagonismo peculiar pela organização interna que estruturaram e pela definição específica de seus objetivos dentro e fora de sua comunidade.

Por essa razão, encontram-se plenamente conscientes de sua posição e, pela impossibilidade de reversão das consequências advindas do contato, reivindicam o direito de serem ouvidos e o dever de se fazerem presentes na sociedade não indígena, mas não para deixarem de ser quem são e abandonarem sua cultura, e sim para a afirmarem ainda mais, mostrando que ela está viva, reivindicando a proteção ao que existe de suas raízes tradicionais, retomando os costumes da forma mais ampla que puderem.

E assim o fazem, dando relevância à educação em todos os níveis, em especial à educação superior.

A proposta deste trabalho é apresentar as perspectivas dos estudantes indígenas da etnia Paiter Suruí em relação ao ensino superior, especialmente em relação ao curso de graduação que estão estudando.

Veremos que, apesar de já terem superado muitas dificuldades desde o ensino fundamental, continuam acreditando em seus sonhos e na efetivação de seus direitos, principalmente o direito à educação de qualidade e formação acadêmica de nível superior, sem a perda de sua identidade cultural e com um sentimento de coletividade muito presente. 


\section{OS PAITER SURUÍ}

Juntamente de outros povos indígenas da região de Mato Grosso e Rondônia, como os Cinta-Larga, Zoró e Gavião, os Paiter Suruí falam a língua do tronco Tupi, da família Mondé. Eram, originalmente, um povo nômade. No entanto o contato com os não indígenas provocou conflitos e reduziu o território que habitavam, em decorrência da devastação das matas para criação de áreas de pastagens e lavouras (SURUÍ, 2013).

Com isso, o território indígena que habitavam antes foi gradativamente reduzido, uma vez que, mediante a fuga, as moradias indígenas eram abandonadas e passavam a ser invadidas pelos não indígenas, cuja intenção era a exploração das riquezas naturais (KEMPER, 2006).

Por fim, assentaram-se oficialmente na Terra Indígena denominada Sete de Setembro, homologada ao povo Paiter Suruí, localizada em parte no Estado de Rondônia e parte no Estado de Mato Grosso (SURUÍ, 2013).

Cardozo (2012) registra que a denominação da Terra Indígena Sete de Setembro foi dada pela Fundação Nacional do Índio (Funai), por ser a data do contato oficial (7 de setembro de 1969), mas que o povo Paiter denomina a terra de Paiterey Karah, que significa Terra dos Paiterey, o plural de Paiter. A autora ressalta ainda que foram as políticas governamentais para a colonização do Estado de Rondônia que atraíram migrantes de várias regiões do país para povoarem o local.

A política federal era de atração populacional para Rondônia que se iniciou na década de 1920, com a construção da Ferrovia Madeira-Mamoré, as linhas telegráficas de Rondon e um segundo impulso na economia da borracha. Seguramente, o período mais acentuado foi a partir da década de 1960 e 1970 com a construção da BR 364 que liga Cuiabá a Porto Velho. (CARDOZO, 2012, p. 22).

Além da perda do território e da introdução de um modo de vida diferente, que ameaçou os costumes tradicionais indígenas, o contato levou aos Paiter Suruí diversas doenças e epidemias, que provocaram a morte de parte significativa de sua população.

No ano de 1971, meu povo foi vitimado pela primeira epidemia de sarampo, mais da metade de nossa população cruzou os caminhos do Maraimepeter (o caminho pelo qual cruzam os espíritos dos mortos na cosmologia Paiter Suruí). Sem saber como enfrentar essa situação, meu povo se aproxima 
Percepções indígenas Paiter Suruí sobre o ensino superior: busca de sentido a partir de narrativas de estudantes de graduação

definitivamente do acampamento da expedição de contato em busca de socorro para os que ainda se encontravam vivos. Isso aconteceu quase três anos depois do início do contato com a expedição de contato da FUNAl. Epidemias de sarampo, gripe e tuberculose seguiram-se ao contato. As epidemias não só mataram muitas pessoas entre nós, mas abalaram profundamente a organização social do meu povo, que tornou-se, assim, muito dependente dos serviços da FUNAI. (SURUí, 2013, p. 25).

Diante de tais acontecimentos, o contato com os não indígenas tornou os Paiter Suruí dependentes de serviços de saúde, medicamentos, artefatos e outras condições que não eram seus costumes, introduzindo na realidade do povo a necessidade de meios de assistência nas cidades e de formas de produção antes não praticadas, bem como materiais e objetos que precisam ser comprados com dinheiro (ZOIA; MENDES, 2017).

Em decorrência disso, muitas tradições do povo, como rituais, alimentação, moradias e meios de cultivo da terra, perderam-se ou se modificaram, e as pessoas da aldeia tiveram o desejo de viver como os não indígenas. Alguns membros da comunidade, inclusive, viram-se obrigados a aderir ao trabalho de exploração da floresta em favor dos não indígenas, em troca de benefícios.

Em recente pesquisa sobre o povo Paiter Suruí, Mendes (2017) constata, ainda nos dias atuais, a existência de exploração das terras indígenas por membros da própria comunidade e atribui essa prática a uma dependência econômica de costumes não indígenas e desejo pelos artefatos tecnológicos.

Os conflitos pelas riquezas naturais e por territórios ainda persistem, principalmente entre o povo pesquisado e os grandes latifundiários, madeireiros, garimpeiros, usineiros, tornando esse povo vulnerável frente aos desmandos do capitalismo opressor. Presenciei, por algumas vezes, caminhões carregados de toras nas estradas que dão acesso a Terra Paiterey Karah. Não acredito que os povos indígenas vendem suas florestas porque assim o querem, mas por falta de opção de sobrevivência mediante a necessidade de subsistência, principalmente, dos mais jovens que desejam utilizar os objetos tecnológicos e o assédio do invasor. (MENDES, 2017, p. 22).

As informações históricas obtidas na pesquisa relativa à origem e ao caminho percorrido pelo povo Paiter Suruí mostram a realidade vivenciada por esse povo ao longo dos anos e a interferência da cultura não indígena no modo com que passaram a enxergar o mundo a sua volta. 
Embora muitos traços culturais tenham sido alterados, adaptados, substituídos ou até perdidos, os Paiter Suruí têm buscado a retomada e revitalização de seus costumes, na medida do possível, reafirmando sua pertença étnica e a continuidade das práticas culturais.

Dessa forma, a organização do povo se transforma a cada dia, seja pelas mudanças de pensamentos, seja pela interferência dos não indígenas, presença e contato com as tecnologias e acesso rápido às informações ou, por último, pela busca por conhecimento como forma de alcançar objetivos maiores e que estão além da Terra Indígena.

O que se vê, nesse contexto, é a tentativa de manter viva a cultura Paiter Suruí da forma mais ampla possível, embora a retomada total aos costumes praticados antes do contato seja impossível. Busca-se, então, conciliar as culturas, compreender o outro, estar inserido no meio da sociedade não indígena. Trilhar esse caminho pode ser uma forma que os Paiter Suruí encontraram de serem respeitados e de continuar lutando para manutenção da vida e da cultura do seu povo (SURUÍ; SURUÍ, 2017).

Os Paiter Suruí pensam a educação indígena e a educação escolar indígena como conceitos diferentes, mas não antagônicos. Propõem, assim, que a educação indígena (conhecimentos do seu povo) seja observada e transmitida às crianças desde o nascimento, e que a educação escolar indígena (ofertada pelo Estado) seja inserida na comunidade respeitando o contexto de sua cultura, seu tempo, seus rituais e crenças.

Sobre o ensino superior, o qual este estudo focaliza, foi possível perceber que, para o povo Paiter Suruí, alcançar uma graduação e obter formação profissional é uma questão de sobrevivência e manutenção da própria cultura, mesmo que isso represente, neste momento de curso, o aprendizado de outra cultura, a obrigação de falar português e submeter-se às regras nacionais do ensino superior que não foram criadas nem pensadas por e para os indígenas.

\section{A EDUCAÇÃO ESCOLAR INDÍGENA E O ENSINO SUPERIOR PARA OS PAITER SURUÍ}

Assumindo a posição de protagonistas dos seus direitos e demonstrando a reafirmação étnica com consciência de seu papel na luta que ainda são obrigados 
Percepções indígenas Paiter Suruí sobre o ensino superior: busca de sentido a partir de narrativas de estudantes de graduação

a enfrentar no caminho do reconhecimento efetivo, os Paiter Suruí não se calam e propõem as mudanças que, do seu ponto de vista, devem ser discutidas a fim de que a educação escolar indígena aconteça.

É fato que a luta continua e, apesar dos avanços obtidos com a existência de normas garantidoras dos direitos, há a necessidade de enfrentar e buscar a aplicação na prática de meios de efetivação desses direitos.

Considerando tais pressupostos, Suruí e Suruí (2017) propõem sugestões para concretização do respeito e da interculturalidade na Educação Escolar Indígena.

Propomos que a educação infantil indígena das escolas da Terra Indígena Sete de Setembro seja inserida na educação escolar indígena oferecido pelo Estado, desde que se respeite o princípio da educação diferenciada e bilíngue. A criança Paiter Suruí deve ser ensinada na língua materna a partir dos valores culturais, humanos e sócio-político do seu povo. Esse ensinamento leva a entender que o princípio da vida Paiter é respeito ao próximo, que compõe a base fundamental da existência de uma pessoa. Inclusive para os que não tem idade própria para estudar na escola, mas que já sabem falar na língua materna, entre os três a quatro anos de idade. Os professores indígenas precisam ser capacitados, para que possam colaborar com a educação inicial das crianças, porém, partindo da responsabilidade maior da família. [...] Da educação básica indígena até a graduação deve haver o diálogo entre os conhecimentos indígenas e 'não indígenas'. Por isso, na grade curricular da educação escolar indígena deveria haver mais matérias, essas novas matérias seriam especificamente os conhecimentos indígenas.

A disciplina da língua materna viria com o conteúdo, o alfabeto, a escrita, a história do povo, os nomes, substantivos e adjetivos; Etnomatemática, conteúdo, construção de uma maloca, contagem e quilometragem. Educação etnoambiental, uso e manejo florestal tradicional do povo Paiter Suruí, todos estudados em língua Tupi Mondé.

Então, a educação que queremos deveria partir do princípio da junção de ambos entendimentos de educação, do Paiter Suruí e do Estado-Nação, pois não é possível o povo indígena manter sua identidade cultural apenas se adequando uma parte do conhecimento. (SURUÍ; SURUÍ, 2017, p. 52-53, grifo nosso).

A busca por alternativas que atendam às necessidades do povo Paiter Suruí e proporcione educação escolar indígena de qualidade e com respeito a sua cultura também foi relatada por Mendes (2017), confirmando que o enfrentamento das 
dificuldades e a luta pela efetivação do direito à educação têm sido a esperança que move esse povo, tanto para a integração e interculturalidade quanto para a melhoria de suas condições de vida.

As escolas indígenas dos Paiter Suruí vêm se reinventando na busca de fortalecer os conhecimentos ancestrais dentro da comunidade e ao mesmo tempo contribuir com novas técnicas de aprendizagem que possam melhorar a qualidade de vida desse povo, apesar das dificuldades impostas pelo mundo capitalista, é preciso ter esperança e sonhar com um mundo melhor. (MENDES, 2017, p. 84).

A organização do povo Paiter Suruí, apesar da longa história de imposição, exclusão e práticas etnocidas, comprova que sua cultura e seu sentimento de pertencimento étnico não se desfizeram totalmente, uma vez que continuam lutando para que a educação seja um instrumento de reafirmação e manutenção de seus costumes.

No que diz respeito à educação de nível superior, os Paiter Suruí também apresentam suas propostas, reafirmando o que vem sendo discutido neste trabalho no que se refere à busca pela educação em todos os níveis e da forma mais ampla possível. Suruí e Suruí (2017) afiançam a perspectiva do seu povo com os cursos de graduação e também apresentam suas propostas nesse sentido.

Assim, entendemos que seja importante destacar aqui, de forma especial, tais proposições, pois consideramos relevante a pauta central pretendida com este trabalho:

No caso da graduação, deve haver também mudanças na grade curricular dos cursos de acordo com os conhecimentos e necessidades indígenas. Porém, é difícil adaptar essa mudança no ensino superior, primeiro, porque é preciso que essa iniciativa venha dos próprios indígenas, o que envolve diferentes etnias; segundo, porque os cursos de graduação interculturais e diferenciados abrigam tanto indígenas quanto não-indígenas. No entanto, a necessidade de mudar a grade curricular dos cursos continua sendo válida. A partir dessa inciativa, acredito que os não-indígenas comecem a reconhecer a importância dos conhecimentos e culturas dos povos indígenas. A atividade como caça, pesca, roça, construção de malocas faz parte da educação tradicional e deve fazer parte do currículo escolar, pois essas especificidades se inserem no calendário tradicional.

As universidades que oferecem cursos de licenciatura indígena poderiam além deste, pensar na possibilidade de abertura de outros cursos de gradu- 
Percepções indígenas Paiter Suruí sobre o ensino superior: busca de sentido a partir de narrativas de estudantes de graduação

ação para os jovens indígenas, a partir das necessidades dos povos, como enfermagem, medicina, engenharia florestal e outros, pois o desenvolvimento e sustentabilidade de um povo e de seu território se firmam atendendo todas as áreas de formação e atuação. (SURUÍ; SURUÍ, 2017, p. 54-55).

O primeiro ponto que merece destaque nas considerações acima é a afirmação de que há uma dificuldade em adequar a matriz curricular de graduação aos conhecimentos e necessidades indígenas, o que os autores atribuem a dois motivos: a necessidade de iniciativa dos próprios indígenas de diversas etnias e o abrigo de indígenas e não indígenas nas graduações interculturais.

De fato, a construção das regulamentações educacionais genéricas para aplicação em território nacional é pensada e realizada pelos órgãos estatais sem a participação dos povos indígenas nessa elaboração. Isso acontece também com a educação escolar indígena, resultando na ineficácia de educação intercultural e diferenciada garantida pela Lei de Diretrizes e Bases da Educação Nacional.

Em virtude de tais fatos, afirmamos que a elaboração de ações, políticas e mecanismos institucionais relacionados à efetivação dos direitos indígenas deve, necessariamente, observar a participação desses povos no processo de discussão e de tomada de decisões.

Nesse sentido, cabe destacar uma relevante observação sobre o debate acadêmico acerca da educação indígena:

Neste momento, o debate acadêmico sobre a educação indígena situa-se na autonomia e na participação dos próprios povos indígenas no planejamento e na gestão de suas escolas. São os próprios povos que precisam estar discutindo, propondo e planejando a realização dos seus modelos ideais de escola, partindo dos seus interesses e de suas necessidades. Desta forma, será possível pensar uma educação do índio e não uma educação para o índio. (ZOIA, 2010, p. 85).

Ora, não há como pensar normas que valorizem e respeitem a interculturalidade sem o conhecimento das culturas envolvidas, pois continuaremos tendo políticas indígenas criadas por não indígenas e que, por conseguinte, não serão verdadeiramente implementadas.

Sobre a necessidade de educação escolar indígena feita para indígenas e que se caracterize pela valorização dos conhecimentos específicos, Mattos e Ferreira Neto (2019) advertem que, apesar de tantos discursos mais recentes no 
sentido de promover a formação de professores indígenas e respeitar a língua e os costumes desses povos no ambiente escolar, visualizam uma via de mão única, em que os conhecimentos não indígenas continuam a prevalecer nos espaços educacionais:

Há pouco mais de vinte anos começaram a surgir no Brasil, cursos de formação de professores indígenas. Sabemos da importância de se formar professores indígenas, pois o indígena conhece e respeita seu povo. O sistema de ensino indígena é monoculturista, valorizando apenas as práticas culturais da sociedade envolvente. Por isso, mesmo a educação escolar indígena, deve ser diferenciada. [...] Percebemos que há por parte dos professores indígenas a valorização dos conhecimentos próprios nos métodos de ensino e aprendizagem de seu povo. É importante salientar que os indígenas reconhecem que os conhecimentos dos não indígenas são necessários e vitais para a sua comunidade. Não se trata de valorizar apenas os conhecimentos culturais próprios. Estudar em profundidade Matemática, Ciências, Português e outros conteúdos curriculares da cultura não indígena é importante e isso é feito pelos professores indígenas nas aldeias com muito esforço. [...] Fala-se muito em uma escola indígena bilíngue e diferenciada, mas não podemos nos esquecer do conceito de específica. A questão intercultural também é às vezes esquecida e o que percebemos é uma via de mão única, onde o índio tem que aprender o nosso conhecimento. E o conhecimento deles é praticamente desprezado por nós. (MATTOS; FERREIRA NETO, 2019, p. 54-55).

Essa via de mão única é evidente também no contexto universitário. As políticas de acesso e permanência de indígenas em qualquer dos níveis da educação são necessárias e demandam a interculturalidade de forma adequada e eficiente. Não se trata de formar essas pessoas com os mesmos critérios e conteúdos destinados à formação não indígena, indistintamente, mas alinhar as ações pedagógicas aos objetivos de preservação, liberdade e valorização das culturas.

Outro ponto que cabe destaque na citação acima consiste na proposta dos Paiter Suruí da criação de cursos de graduação em várias áreas de conhecimento, e não apenas cursos de licenciatura intercultural para formação de professores. Em sua fala, Suruí e Suruí (2017) registram que o seu povo tem necessidade de profissionais de outras áreas, como Enfermagem, Medicina, Engenharia Florestal e outras, porque a vida atual da comunidade reclama a presença de diversos conhecimentos para o desenvolvimento e a sustentabilidade do seu povo. 
Percepções indígenas Paiter Suruí sobre o ensino superior: busca de sentido a partir de narrativas de estudantes de graduação

Lançamos os questionamentos supramencionados a fim de difundir a reflexão, sobretudo a ideia de participação ativa dos indígenas nesses espaços de tomada de decisões, para que estas possam ser de fato concretizadas.

Reafirmando esse sentimento de pertença e de busca por diversas áreas de conhecimento que visam benefícios para as suas comunidades, destacamos uma importante manifestação do líder Paiter Suruí quanto às perspectivas do seu povo, em especial, com a educação superior.

Em entrevista publicada em 2011 na Revista Brasileiros de Raiz, Almir Narayamoga Suruí, atual líder do povo Paiter Suruí, já relatava que a busca pela educação superior era um desejo do seu povo, como forma de consolidação e disseminação de sua cultura, assim como forma de aprendizado para atender às necessidades do povo. Na oportunidade, relatou:

Mas também temos avanços conquistados pelos indígenas como o acesso a faculdade. [...] Os Paiter Suruí tem o sonho de criar a Universidade Indígena, onde os professores indígenas possam repassar os conhecimentos e formar mestres e doutores que lutem pela defesa de seus direitos. [...] Temos vários desafios. O mais importante é o de implementar o Plano de Gestão de 50 anos, onde tem a proteção do território, o acesso à educação e a criação da universidade indígena [...] Estamos repassando nossa cultura e colocando jovens para fazer a faculdade, em cursos diferentes, incentivando a fazerem mestrado, doutorado, enfim estudando para poder aplicar o que aprenderam junto aos Paiter Suruí e outros povos. Estamos preparando nossos jovens para aprender a viver nos dois mundos: - o Suruí e o do não índio. (FURTADO FILHO, 2011, p. 45).

A necessidade de valorizar o ensino superior e adequá-lo aos costumes indígenas a fim de preservar sua identidade é ainda uma latente preocupação dos Paiter Suruí. Justamente por isso que reafirmamos que o enfrentamento e a busca pelo verdadeiro reconhecimento e promoção da interculturalidade e do respeito aos povos indígenas continuam sendo um desafio extremamente complexo. No entanto os Suruí estão dispostos a enfrentar tais percalços, como já foi possível constatarmos por meio das relevantes contribuições dos autores da etnia citados neste texto.

É pertinente salientarmos que, nas respostas do líder Suruí às perguntas, ele trata do ensino superior de seu povo como mecanismo necessário de conhecimento a ser buscado pelos jovens, revelando o sonho de criar uma universidade indígena e a concepção de que a educação é o caminho para a liberdade. 
A reivindicação é legítima, embora possa ser difícil pela variedade de etnias e culturas diferentes em todas as regiões do país. Ainda assim, não é impossível e poderá ser alcançada com a descentralização dos estudos envolvendo as adequações das práticas educacionais em instituições ou cursos interculturais. Acreditamos que um fato que propiciaria o sucesso nessa missão seria atribuir tal tarefa a comissões específicas formadas por representantes das etnias de cada estado.

\section{AS PERSPECTIVAS DOS ESTUDANTES PAITER SURUÍ COM O ENSINO SUPERIOR}

Como vimos, os indígenas da etnia Paiter Suruí estão buscando mecanismos para adequar as propostas de educação superior às necessidades do seu povo, colocando-se na posição de protagonistas, para que, dessa forma, não ocorra o apagamento integral e definitivo das suas tradições e costumes, ao passo que sejam efetivadas as garantias legais de educação intercultural diferenciada.

Eles desejam nada mais do que respeito ao seu modo de vida, pleiteando a construção dos currículos e das metodologias de ensino de forma a levar em consideração a existência de culturas diferentes. Pleiteiam isso com o intuito não de substituir os saberes indígenas pela formação técnica, mas para juntá-los, conciliando-os para criação de um novo modelo que privilegie o respeito às diferenças e à diversidade. Isso significa que a única coisa que eles querem é a efetivação dos direitos que já foram, na teoria, assegurados.

Esperançoso, o povo Paiter Suruí está elaborando novas perspectivas de enxergar o mundo a sua volta, construindo suas estruturas de sobrevivência e de busca pela realização de seus objetivos, pela manutenção de sua cultura, mas conhecendo e respeitando as outras. O apelo é para que todas as culturas existam e se integrem com respeito, sem que ocorra o apagamento de nenhuma delas.

Por essa razão, os jovens têm buscado a educação de nível superior, predominantemente, na cidade de Cacoal, RO, por ser a localidade mais próxima da Terra Indígena Sete de Setembro com oferta de educação superior.

Situada no centro-sul do Estado e às margens da BR-364, a cidade de Cacoal se desenvolveu como um centro urbano de referência e atualmente é uma das maiores cidades de Rondônia. Distante, aproximadamente, 480 quilômetros da 
Percepções indígenas Paiter Suruí sobre o ensino superior: busca de sentido a partir de narrativas de estudantes de graduação

capital (Porto Velho), é a quarta maior cidade do Estado, que possui o total de 52 municípios.

Para possibilitar a constatação das perspectivas dos estudantes Paiter Suruí, foi realizada uma pesquisa de campo nas instituições de ensino superior da cidade de Cacoal, RO.

Inicialmente, contatamos as instituições de ensino superior por meio de um dirigente institucional, a fim de apresentar a pesquisa e seus objetivos e obter autorização para a coleta de dados institucionais, bem como para um levantamento da existência de estudantes da etnia Paiter Suruí matriculados no corpo discente de graduação.

Para coleta das informações, foi elaborado um roteiro de entrevista semiestruturado para os graduandos indígenas, sendo entrevistados 15 estudantes da etnia Paiter Suruí, que, após os esclarecimentos necessários, concordaram em contribuir para a pesquisa, mediante assinatura de Termo de Consentimento Livre e Esclarecido².

Observamos que, sob uma ótica mais ampla, as perspectivas dos estudantes entrevistados estão relacionadas ao sentimento de coletividade, no sentido de conhecer outro mundo (não indígena), com infinitas e diferentes possibilidades de conhecimento e de formação profissional para, assim, poder proporcionar melhores condições de vida a si mesmos, as suas famílias e também as suas comunidades.

A escolha do curso, muitas vezes, está ligada às condições dos estudantes em se manterem em determinado curso e à necessidade vivenciada pelo povo quanto à ausência ou escassez de profissionais, naquela determinada área, que trabalhem com as comunidades indígenas.

Por ser oportuno e enriquecedor, destacamos algumas falas dos estudantes, ao expressarem suas perspectivas com a formação acadêmica.

Um graduando em Direito reporta que:

Pra mim é uma realização, né, e pra minha família também, porque nós somos em oito irmãos e eu sou o primeiro a tá cursando um ensino superior.

\footnotetext{
${ }^{3}$ O projeto de pesquisa, roteiros de entrevistas, Termo de Consentimento Livre e Esclarecido e demais documentos pertinentes foram submetidos ao Comitê de Ética em Pesquisa da Universidade do Estado de Mato Grosso (Unemat), CAAE n. 05554918.0.0000.5166, sendo aprovado em 19/03/2019 pelo Parecer n. 3.233.292.
} 
Então eu imagino que é um incentivo até para os outros, né. (Entrevista no dia 30/05/2019).

Outro graduando do mesmo curso disse:

Eu acho que pra mim seria muito importante o término desse curso pra ter alguma voz indígena que luta pelos nossos direitos nessa parte. (Entrevista no dia 30/05/2019).

Já aqui, uma graduanda em Direito relata:

Pela questão assim, de sentir vontade, né, de fazer Direito, e eu acho que é uma forma de colaborar mais com o meu povo também. Eu comecei fazer uma licenciatura de educação básica intercultural que é ofertada em JiParaná, aí depois de dois anos, ai eu desisti e optei por fazer Direito. [...] Eu penso em trabalhar no órgão, assim, tipo a Funai, ou tipo, fazer um concurso para trabalhar nesses lugares, os órgãos, assim que envolvam indígenas. [...] É muito importante, né, por saber assim que tem um indígena que estudou, vamos dizer assim, que venceu, né, porque pra passar por tudo isso é muito difícil, então se você chegar no fim com um diploma já é uma conquista. (Entrevista no dia 28/05/2019).

Graduanda em Ciências Contábeis disse:

Meu objetivo é permanecer na minha área, que eu faço, e fazer mestrado e doutorado pra me qualificar mais na área de Contábeis e ter, tipo, ajudar a Associação Indígena com a minha formação. Também pra ter um emprego também. (Entrevista no dia 23/04/2019).

Outra graduanda do curso supramencionado explica que:

Esse curso, porque assim, tipo, meu sonho, sempre quis fazer faculdade, né, mas que eu queria fazer mesmo a faculdade era Turismo, que eu gosto, mas só pra fazer mesmo eu tô fazendo esse daí, pra não perder a faculdade que eu tô querendo fazer, meu sonho, né, mas eu consegui esse daí eu tô fazendo. [...] Trabalhar na Associação, ajudar minha família. (Entrevista no dia 23/04/2019).

Graduanda do mesmo curso afirma:

Eu pretendo trabalhar, né, mas não sei se tem vaga, tipo, vaga na área, que eu não sei se tem como voltar na aldeia pra trabalhar na área, que depende, né, disso. Se tiver eu volto, se não tiver, aí eu tenho que procurar aqui na cidade mesmo, né. Aí depois me especializar mais, né, pretendo fazer mestrado, essas coisas. [...] É importante [a conclusão do curso], porque meu 
Percepções indígenas Paiter Suruí sobre o ensino superior: busca de sentido a partir de narrativas de estudantes de graduação

sonho é ter uma graduação e ter emprego, né, aí vai ser melhor pra mim. [...] Eu acho que vai ser um orgulho pra eles [comunidade], né, porque é bem, não é, raro as mulher indígena estudar, né, e fazer graduação e sair da aldeia, né, ai eles vão ter orgulho, né... ahhh, ela estudou, ela se esforçou e ela merece, né. (Entrevista no dia 22/04/2019).

Graduando em Direito relatou:

Ahh, bom, pela minha familia, mais diretamente pelo meu pai, ele diz que é o sonho dele, ele quer que eu ajude meu povo, nessa parte eu também reconheço, mas eu também penso na minha parte, sabe, quero fazer minha família feliz e também quero ser feliz. (Entrevista no dia 06/05/2019).

Graduanda em Psicologia explica o motivo de ter escolhido o curso:

[...] porque tem, assim, é [...] nós indígenas tem uma equipe de saúde que trabalha só pra indígena, né, aí cada mês eles vão pra aldeia, é médica, enfermeira, dentista, nutricionista, psicólogo, mas só tem um psicólogo que atende na área de Suruí, aqui, e acho que ela, talvez pra ela é muito cansativo só um psicólogo que trabalha, né. É por isso quero fazer esse curso, pra entrar na área também pra trabalhar com meu povo. (Entrevista no dia 06/05/2019).

Graduanda em Enfermagem informou:

No começo, quem me incentivou a fazer o curso de Enfermagem foi meu pai, porque ele sempre gostou, tipo, dessa área, da área da saúde. [Pretendo] Isso, ajudar meu povo. (Entrevista no dia 14/06/2019).

Graduando em Enfermagem revelou:

Na verdade, eu acho que essa profissão, eu acho muito ausente na área indígena, acho que por essa dificuldade eu acho que eu escolhi. [...] A conclusão, pra mim, mais assim, é como se fosse o final da batalha pra mim, né, se eu concluir, né, porque muitas pessoas começam o curso e depois param, né. (Entrevista no dia 14/06/2019).

Graduanda em Engenharia Civil esclareceu:

Eu tenho curso de graduação já, em Pedagogia. Como eu comecei dando aula na escola indígena, então eu já fiz pra melhorar como professora dentro da escola indígena. Mas daíminha vontade mesmo é fazer Engenharia né, então, é um sonho de fazer Engenharia, desde infância [...] Bem, assim, eu penso... tem alguns estudantes Suruí, por exemplo, na área de... ele faz... esqueci o nome do curso... Engenharia e tem... Arquitetura! Então, né, assim, eu até já estive conversando com ele pra gente fazer algum projeto voltado para 
cultura mesmo, tradicional, e incrementar com a engenharia e arquitetura, e a gente, assim, vem pensando num modelo de casas, porque a gente vive hoje lá, nas casas assim, pela mudança... antes a gente morava em palhas, né, casas de palhas, mais fresco, né, e hoje está todo mundo naquelas casinhas muito malfeitas, de madeira, assim, sem nenhum conforto assim, então a gente pensa em criar um modelo, né, que possa ficar, porque assim, a casa de palha, ela se destrói facilmente, assim com o tempo, com 2 anos já num... porque assim, como a gente mudava de lugar, então aquilo ali a gente deixava aquela lá, hoje não, hoje a gente precisa manter num local, né, na aldeia tem que se manter ali, então a gente quer fazer uma intercalação do ambiente, mas assim, fresco, utilizar palha, mas aí modelando pra uma residência mais confortável. (Entrevista no dia 13/08/2019).

Graduando em Zootecnia falou sobre o motivo de ter escolhido o curso e relatou suas perspectivas com a formação:

Mais por influência da minha família, né. Quando eu terminei o ensino médio, eu não quis fazer nenhum curso, ai eles me indicaram, insistiram pra mim fazer, me identifiquei com o curso e continuei [...] Então, o curso é mais destinado à área rural e mexe bastante na parte de nutrição e bem-estar animal, então, por eu ser indígena, eu gostaria de voltar e de alguma forma beneficiar a comunidade. (Entrevista no dia 13/08/2019).

\section{Outro graduando em Zootecnia disse:}

Eu fui incentivado pelo meu irmão, né, é meu irmão e meu pai, porque meu pai também é professor, de... biólogo, a minha mãe também é professora de Geografia, ai outro meu irmão também é professor de Química, aí ele tá fazendo Educação Física, ai ele falou assim, você vai estudar ou não? Falei, tô querendo. Só se você estudar não, se vai trabalhar o resto da vida e não vai ter nada. [...] aí eu quis esse curso que eu tô fazendo [...] Quando eu concluir o meu curso, quero fazer... ajudar o meus povo, como que é?[...] fazer uma coisa... tipo um projeto, né, que eu queria fazer, aí já tô fazendo um, até já fiz uma montagem de projeto pra mim hoje, tava fazendo... manejo de... da pastagem, tava fazendo, tipo, documento, né, e isso que eu queria fazer quando concluir o curso, né, ajudar meus povo [...] ensinar também, como que eu aprendi [...] Quando eu concluir meu curso, assim, vai ser muito importante, porque a minha família também é muito, é... também são, como que fala? É, já completaram o curso dele, né, a única pessoa que tá faltando é eu e dois meus irmãos e... fazer o melhor por fazer o estudo, ter profissão, pra ter uma coisa de vida melhor assim [...] quando eu concluir o meu curso, ai tem que compartilhar o meu ensinamento com a minha comunidade, pra ter mais orgulho pra mim. (Entrevista no dia 13/08/2019). 
Percepções indígenas Paiter Suruí sobre o ensino superior: busca de sentido a partir de narrativas de estudantes de graduação

Graduanda em Matemática também relata a necessidade da aldeia e suas perspectivas:

Na verdade eu tô na minha segunda graduação, eu sou formada em Pedagogia, né, desde o ano de 2012, então nesse caso, né, é em 2016 que eu comecei essa segunda graduação em Matemática, assim, pelo fato de se inserir mesmo em educação, né, que pelo jeito de eu ser indígena é bem escasso, tá precisando realmente de professores. [...] O curso de Matemática, né, porque na verdade hoje tem bastante concursos, né, que precisam realmente nas áreas das exatas, principalmente Física, Química e Matemática [...] [Meu objetivo] primeiro é ser concursada, tanto é que pra esse ano eu tô estudando para eu ver se consigo me encaixar nesse processo seletivo que me inscrevi também... e são poucos indígenas que têm formação também, de graduação. (Entrevista no dia 13/08/2019).

Graduando em Arquitetura e Urbanismo explicou:

Antes eu queria ser engenheiro florestal, mas como nos era bom de desenho e gostava um pouco mais de cálculo, essas coisas assim, e como minha mãe também gostava de serviço de arquiteto, desde criança eu ouvia ela falando desse negócio, eu peguei uma paixão por isso [...] eu escolhi porque era o que eu via e gostei [...] eu quero avançar mais, fazer mestrado, doutorado, eu quero ser mais evoluído, eu tenho projeto na aldeia, pra comunidade indígena, tipo ser... de crescer mais e mais, trazer um pouco mais voltado para a cultura indígena. (Entrevista no dia 13/08/2019).

Os discursos desses estudantes quanto às suas motivações e perspectivas revelam a preocupação principal com a família e o povo indígena a que pertencem, buscando de alguma forma reverter em favor de seu povo a formação profissional adquirida ou refletir nos membros de sua comunidade a importância dos conhecimentos acadêmicos e o incentivo à busca pela educação de nível superior.

Esses estudantes acreditam em algo além de uma conquista pessoal, acreditam na conclusão da educação de nível superior e na possibilidade de trabalhar numa área específica que servirá para proporcionar melhores condições de vida ao seu povo, algo que, em linhas gerais, consideram necessário diante da escassez de profissionais nas áreas escolhidas.

Nas falas acima expostas, constatamos que os estudantes almejam colocar a sua formação acadêmica a serviço do próprio povo, trabalhando dentro das aldeias, prestando serviço para as Associações Indígenas ou mesmo em algum cargo em órgãos governamentais que exerçam atividades com indígenas. 
Para tanto, submetem-se a toda gama de obstáculos para aquisição desse conhecimento, com objetivo muito bem definido e uma visão mais adiante, sem se aterem tanto ao meio, mas tendo o final (a conclusão do curso) como maior incentivo para continuar.

Ao tratar da experiência dos Guarani nesse movimento de aquisição de conhecimento no mundo universitário, Melo (2016) nos afirma que:

Esses acadêmicos têm o objetivo de obtenção deste conhecimento outro, que envolve dificuldades, desgastes físicos, afastamento dos núcleos familiares e ingestão de alimentos "perigosos". É, nesse contexto, que tanto o xamanismo quanto o ensino superior, são tomados como possibilidades de comunicação, aquisição de conhecimentos e trânsito entre mundos distintos. Compreende-se que, na atualidade, esse esforço é vislumbrando como uma possibilidade de trânsito entre mundos: o "mundo Guarani" e todas as especificidades culturais e conhecimentos que o compõem; e o não indígena, buscando os conhecimentos dos brancos que lhes são postos na educação escolar e ensino superior.

Todavia, esse trânsito entre mundos tem suas regras próprias e suas interdições. Alguns acadêmicos Guarani ressaltam que há um limite nesse processo, explicam que caminham em direção à aquisição de conhecimentos dos brancos, e voltam para suas aldeias para conviver com seus modos de transmissão e aquisição de conhecimentos próprios de seus grupos - com a participação na opy (casa de rezas Guarani). (MELO, 2016, p. 53).

O "trânsito entre mundos" de que trata o autor também é referenciado pelo líder Suruí, como lembramos, quando afirma que estão preparando os seus jovens para "aprender a viver nos dois mundos: o Suruí e o do não índio".

Reiteramos essa definição, pois notamos um sentimento parecido entre os Suruí e os Guarani, que parece representar os estudantes indígenas de todas as etnias quanto às perspectivas com a educação superior e com o mundo não indígena como um todo. O que chama atenção e merece nosso registro é o limite imposto pelos indígenas na interligação entre esses mundos, ou seja, querem aprender a cultura não indígena até certo ponto, até onde esse aprendizado não interfira de modo a prejudicar ainda mais a sua cultura.

No mesmo sentido da existência de dois universos em que se inserem os indígenas quando estão na universidade, foi feita a análise de Barreto (2016), quando trata da experiência própria enquanto estudante indígena Tukano, adver- 
Percepções indígenas Paiter Suruí sobre o ensino superior: busca de sentido a partir de narrativas de estudantes de graduação

tindo sobre a necessidade de diálogo dos indígenas com as culturas envolvidas, mas estando atentos para que não se submetam à exclusão da própria cultura:

É importante sempre construir um diálogo entre o conhecimento indígena e o que vem da universidade. Mais do que isso, é necessário uma abertura entre os dois universos, indígena e universidade. Isso porque nós mesmos, indígenas, muitas vezes estamos subordinados ao sistema de "ostracismo cultural". (BARRETO, 2016, p. 41).

É indispensável que tenham essa consciência e que saibam os limites do encontro de culturas, a fim de absorver aprendizados que sejam úteis e ao mesmo tempo resguardem a preservação dos costumes e das tradições de seu povo.

Identificamos, portanto, que, entre as perspectivas dos estudantes Paiter Suruí com a educação superior, está a perspectiva de trilhar o caminho do retorno.

E esses que buscam a educação de nível superior com a certeza de que com tal formação poderão utilizar os conhecimentos em benefício dos seus, impondo limites nessa troca de experiência e conscientes de que isso não deve retirar, atrapalhar ou substituir seus costumes, estão reafirmando sua pertença, dando vida a sua cultura. Com essa atitude, estão provando desde agora que serão profissionais dedicados nas áreas de formação escolhidas.

Não se trata apenas de um desejo individual de cada estudante em se formar e seguir a carreira profissional escolhida em busca de sucesso perante a sociedade e dinheiro para satisfação material. Esses estudantes desejam ajudar o seu povo.

A educação superior tem sido vista pelos Paiter Suruí como meio de continuar a convivência tradicional, agregando a essa convivência os conhecimentos profissionais que possam, de alguma forma, aperfeiçoar a vida das pessoas de sua etnia, sem, contudo, desprezar os costumes próprios da cultura.

Podemos visualizar a educação superior desses estudantes como um momento de trilhar o caminho de retorno às suas origens, uma vez que nesse período de estudos modificam suas formas de vida, passando por várias dificuldades e privações, muitas vezes vindo para a cidade e deixando a convivência familiar por um tempo, mas pensando sempre no retorno. A partir do momento que essa fase de aprendizado em "outro mundo" for concluída, eles poderão fazer a viagem de volta para a sua realidade, com conhecimentos agregados que possibilitarão fazer algo a mais e melhor pela sua gente. 
Apesar de conviver, respeitar e estudar nos moldes impostos pelos não indígenas, eles não querem ser como os não indígenas. Eles enxergam e analisam nosso modo de agir no ambiente acadêmico, mas não veem nisso a obrigação de fazerem o mesmo, de imitar.

Melo (2016) também relata o que observou da experiência com os Guarani quanto ao limite da ligação cultural proporcionada pela educação superior:

Além de aquisição de conhecimentos que residem na alteridade, esses estudantes analisam o modo como nós pensamos. Os djuruá - não indígenas - são vistos como "abelhas" na universidade, pois estão sempre "reunidos falando junto", ao contrário de um grupo de Guarani, em que um fala os outros escutam atentamente: "nossos ouvidos ainda não estão treinados para tanto barulho e informação!". Esta é uma comparação de um entre muitos aspectos salientados por um professor indígena e acadêmico do curso, sobre a vivência entre brancos e índios. Segundo ele, refletem sobre a nossa forma de adquirir conhecimento, de pensar e ver o mundo, filtrando os conhecimentos advindos da universidade, para sua entrada nas aldeias indígenas. Apontam nossa cultura como "rápida" e "pesada", e enfatizam em seu discurso a necessidade atual de registrar e praticar a cultura indígena, para que esta não fique apenas na memória e se perca em meio ao movimento e às mudanças. (MELO, 2016, p. 53).

Nessa mesma perspectiva tem sido a experiência dos Paiter Suruí, comparando a vida universitária e os costumes dos não indígenas não para se tornarem iguais, mas apenas para filtrar o conhecimento que necessitam e visando praticar os costumes tradicionais de seu povo para que não se percam.

Deve ocorrer a efetivação da interculturalidade. Isso significa que, por parte dos indígenas, há o entendimento desse aprendizado entre culturas, do conhecimento e do respeito, sem impor ao outro o seu modo de ver e fazer as coisas, a sua visão de mundo. O contrário, infelizmente, não ocorre.

O importante para nós foi poder constatar que a universidade pode proporcionar aos estudantes indígenas e não indígenas uma experiência bastante rica de interculturalidade, embora esta tenha sido mais bem aproveitada pelos indígenas que aprendem do outro, respeitam o que não é igual ao seu costume, mas filtram o que realmente Ihes agrega e o que realmente importa para alcançar os seus objetivos, que é a formação a serviço de seu povo.

Ficamos satisfeitos que isso esteja ocorrendo. Esperamos que essa constatação seja concretizada quando esses estudantes concluírem os cursos, para que 
Percepções indígenas Paiter Suruí sobre o ensino superior: busca de sentido a partir de narrativas de estudantes de graduação

assim tenhamos o início de uma verdadeira coexistência pacífica de culturas, a comprovação de que a história de inferiorização e eliminação tenha de fato e de direito ficado para trás, superada pelo respeito e pelo amor.

\section{CONSIDERAÇÕES FINAIS}

Os Paiter Suruí reivindicam oportunidades e condições de acesso aos artefatos tecnológicos existentes, bem como conhecimentos em diversas áreas, e fazem isso com o intuito de utilizar os métodos e saberes adquiridos como meio de manter, ampliar e valorizar os objetivos do seu povo, o que visa, dentro do possível, ao modo de vida tradicional de sua gente.

Foi relatado que os estudantes desejam trabalhar em funções que os mantenham ligados ao seu povo, como forma de ajudar em suas necessidades, a exemplo da graduanda em Ciências Contábeis, que pretende trabalhar na Associação Indígena, e da graduanda em Psicologia, que acredita ser necessário mais profissionais dessa área nas aldeias. Houve também a fala da graduanda em Engenharia Civil, que, juntamente do estudante de Arquitetura, está pensando em criar um projeto de moradia indígena que seja confortável e utilize a palha como matéria-prima, seguindo a tradição.

O desejo do povo, ao incentivar os jovens a buscar uma graduação, mesmo que seja em instituições não indígenas, não é abandonar suas raízes culturais e adotar a cultura não indígena, pelo contrário, pretendem se fazer presentes na sociedade nacional, com representação jurídica e em busca de reconhecimento da sua cultura.

Quanto às perspectivas dos estudantes com a educação superior, constatamos que todos alimentam o desejo de poder dar a seu povo um pouco mais de qualidade de vida, de visibilidade, de respeito, para preservar sua história e cultura por meio de uma formação acadêmica que possa ser revertida em favor do povo Paiter Suruí, seja diretamente na aldeia com atuação profissional na área de formação, seja por meio de entidades governamentais ou não que trabalhem com a questão indígena e a proteção a seus direitos.

Entre as falas dos estudantes, podemos identificar a força do pertencimento étnico dos Paiter Suruí e o desejo de dar a sua comunidade um retorno de melhorias que o conhecimento adquirido e o trabalho após a formação possam fornecer. 
A entrevista do líder do povo não deixa dúvidas quanto à intenção de incentivar os seus jovens a cursar graduação em áreas diferentes, a buscarem o aprofundamento acadêmico por meio de mestrado e doutorado, com objetivo de que apliquem seus conhecimentos junto aos Paiter Suruí e outros povos.

Quando o líder afirma que "Estamos preparando nossos jovens para aprender a viver nos dois mundos: - o Suruí e o do não índio", observamos que a finalidade dessa busca não é apenas terem uma profissão para viver "melhor" fora da aldeia, adotando a cultura não indígena, individualista e capitalista, para abandonar o seu povo e os seus costumes, mas, diferente disso, fazer com que compreendam que não é mais possível retornar ao modo de vida originário.

Dessa forma, o ideal é que conciliem as duas culturas (dos dois mundos), aplicando os benefícios e conhecimentos adquiridos com a educação não indígena de nível superior para revitalizar a sua cultura e promover o seu fortalecimento por meio da reafirmação da pertença e do orgulho de fazer parte dela.

O que deve direcionar a busca pela educação superior indígena é o objetivo de que os conhecimentos tradicionais desses povos sejam, além de preservados, difundidos, para que possam continuar a valorizar e praticar a sua cultura de forma autônoma, livre e reconhecida pelas demais sociedades como dignas de respeito e de compartilhamento.

Apesar de tudo, são as perspectivas desses estudantes que movimentam e dão sentido a discussões como estas, visando chamar atenção para condutas que podem e devem ser tomadas para efetivação do direito à educação em todos os níveis.

Eles não veem as pedras que estão no caminho do acesso e da permanência no ensino superior como barreiras instransponíveis. Estão muito focados na luz que os espera ao final da jornada, nutridos pela gigantesca esperança de que ultrapassar os obstáculos os leva ao caminho certo, à conclusão do curso superior, ao alcance de sua visibilidade e ao progresso do seu povo.

Esses estudantes se submetem aos esforços diários pensando na coletividade que representam, e não no seu "eu" individual. E esta é uma importante lição que deveríamos aprender com a cultura indígena. 
Percepções indígenas Paiter Suruí sobre o ensino superior: busca de sentido a partir de narrativas de estudantes de graduação

\section{REFERÊNCIAS}

BARRETO, João Rivelino Rezende. Veiculação de propriedade intelectual indígena na universidade: um desafio para todos. In: OLIVEIRA, Lucia Alberta Andrade (Org.). A questão indígena na educação superior. Rio de Janeiro: Flacso; GEA; Uerj; LPP. (Cadernos do GEA, Rio de Janeiro, n. 10, jul./dez. 2016, p. 38-42). Disponível em: http://flacso.org. br/files/2017/12/Caderno-GEA-10-digital.pdf. Acesso em: 6 jul. 2019.

BRANDÃO, Carlos Rodrigues. A educação como cultura. Ed. rev. e ampl. Campinas, SP: Mercado das Letras, 2002.

BRASIL. Lei n. 9.394, de 20 de dezembro de 1996. Estabelece as diretrizes e bases da educação nacional. Diário Oficial da União, Poder Executivo, Brasília, 23 dez. 1996. Disponível em: http://www.planalto.gov.br/ccivil_03/leis/I9394.htm. Acesso em: 7 jul. 2018.

CARDOZO, Ivaneide Bandeira. Iway e Metare: a marca do território Paiter Surui. 115 f. 2012. Dissertação (Mestrado em Geografia) - Universidade Federal de Rondônia, Porto Velho, RO, 2012.

DEMO, Pedro. Introdução à sociologia: complexidade, interdisciplinaridade e desigualdade social. 1. ed. São Paulo: Atlas, 2009.

FURTADO FILHO, Cid. Tecnologia e desenvolvimento Paiter Suruí. Revista Brasileiros de Raiz, Brasília, v. 1, n. 3, p. 44-6, ago./set. 2011. Disponível em: https://pt.calameo.com/ read/00132727704476d3fafof. Acesso em: 7 ago. 2019.

KEMPER, Lourdes. Cacoal, sua história sua gente. 2. ed. Goiânia: Grafopel, 2006.

LEONTIEV, Alexis. O Desenvolvimento do psiquismo. Tradução de Rubens Eduardo Frias. 2. ed. São Paulo: Centauro, 2004.

MATTOS, José Roberto Linhares; FERREIRA NETO, Antônio. Etnomatemática e educação escolar indígena Paiter Suruí. São Paulo: Editora Livraria da Física, 2019.

MELO, Clarissa Rocha. A experiência na Licenciatura Intercultural Indígena do Sul da Mata Atlântica da UFSC. In: OLIVEIRA, Lucia Alberta Andrade de (Org.). A questão indígena na educação superior. Rio de Janeiro: Flacso; GEA; Uerj; LPP. (Cadernos do GEA, Rio de Janeiro, n. 10, p. 52-57, jul./dez. 2016). Disponível em: http://flacso.org.br/files/2017/12/ Caderno-GEA-10-digital.pdf. Acesso em: 6 jul. 2019.

MENDES, Matilde. Educação escolar indígena Paiter Suruí e sua relação com os etnoconhecimentos. 2017. 142 f. Dissertação (Mestrado em Educação) - Universidade 
do Estado de Mato Grosso, Cáceres, MT, 2017. Disponível em: http://portal.unemat.br/ media/files/PPGEdu/Dissertacoes/Defendidas_2017/Matilde_Mendes.pdf. Acesso em: 31 jul. 2019.

ORTIZ, Renato. Cultura brasileira e identidade nacional. 2. ed., São Paulo: Brasiliense, 2003, p. 13-44.

QUIJANO, Aníbal. Colonialidade do poder, eurocentrismo e América Latina. In: CONSEJO LATINOAMERICANO DE CIENCIAS SOCIALES (CLACSO). A colonialidade do saber: eurocentrismo e ciências sociais. Perspectivas latino-americanas. Buenos Aires: Clacso, 2005. p. 117-42. Disponível em: http://bibliotecavirtual.clacso.org.ar/clacso/sursur/20100624103322/12_Quijano.pdf. Acesso em: 25 set. 2019.

SURUÍ, Chicoepab. Reflorestamento da Terra Indígena Sete de Setembro: uma mudança da percepção e da conduta do povo Paiter Suruí de Rondônia. 2013. 63 f. Dissertação (Mestrado Profissional em Desenvolvimento Sustentável) - Universidade de Brasília, Brasília, DF, 2013. Disponível em: https://repositorio.unb.br/handle/10482/14338. Acesso em: 3 ago. 2019.

SURUÍ, Chicoepab; SURUÍ, Nauama Dias. Educação Escolar Indígena: um novo modelo de educação para o Povo Paiter Suruí. In: JESUS, Sérgio Nunes; NEGREIROS, Davys Sleman; BARBOSA, Ingrid Letícia Menezes; SILVA, Reginaldo Conceição (Org.). Povos e comunidades tradicionais: perspectivas além da epistemologia. Curitiba: CRV, 2017. p. 47-56.

ZOIA, Alceu. A questão da educação indígena na legislação brasileira e a escola indígena. In: GRANDO, Beleni; PASSOS, Luiz Augusto (Org.). O eu e o outro na escola: contribuições para incluir a história e a cultura dos povos indígenas na escola. Cuiabá: EdUFMT, 2010. p. 69-86. Disponível em: http://www2.esporte.gov.br/arquivos/snelis/esporteLazer/cedes/ euOutro.pdf. Acesso em: 18 jun. 2018.

ZOIA, Alceu; MENDES, Matilde. Protagonismo PaiterSuruí: práticas político-pedagógicas e suas relações com os etnoconhecimentos. Revista de Educação Pública, Cuiabá, 2017. Disponível em: http://periodicoscientificos.ufmt.br/ojs/index.php/educacaopublica/ article/view/5002. Acesso em: 18 jun. 2018.

\section{Sobre os autores:}

Alceu Zoia: Doutor em Educação. Professor da Faculdade de Educação e Linguagem, na área da Filosofia, e professor do programa de Pós-Graduação em Educação na linha de pesquisa Educação e Diversidade na Universidade do Estado de Mato Grosso (UEMT). E-mail: alceuzoia@hotmail.com, Orcid: http://orcid.org/0000-0002-0512-9511 
Percepções indígenas Paiter Suruí sobre o ensino superior: busca de sentido a partir de narrativas de estudantes de graduação

Maria Gabriela de Assis Souza: Mestre em Educação pela Universidade do Estado de Mato Grosso. Advogada e professora no Instituto de Ensino Superior de Cacoal (Fanorte). E-mail: mariagabriela.adv@hotmail.com, Orcid: http://orcid.org/0000-0002-9191-7898

Recebido em 5 de março de 2020.

Aprovado para publicação em 2 de junho de 2020. 



\title{
Direitos constitucionais e povos indígenas: apontamentos sobre a disputa pela efetivação do direito fundamental às suas terras tradicionais
}

\author{
Constitutional rights and indigenous peoples: remarks on \\ the dispute of effecting the basic law to their traditional \\ lands
}

\author{
Antônio Hilário Aguilera Urquiza ${ }^{1}$ \\ Anderson Santos ${ }^{2}$
}

DOI: http://dx.doi.org/10.20435/tellus.v0i42.680

\begin{abstract}
Resumo: O presente trabalho tem por objetivo analisar os direitos fundamentais dos povos indígenas conquistados com a promulgação da Constituição Federal de 1988, seguindo a ordem internacional de proteção de Direitos Humanos e o rompimento de paradigmas inaugurados pela Convenção 169 da Organização Internacional do Trabalho (OIT). Com efeito, as efetivações dos direitos indígenas perpassam várias nuances, não sendo possível aqui abordálas por completo. Assim, este trabalho se restringirá a analisar as disputas políticas que envolvem a organização do Estado brasileiro, protagonizadas por interesses de setores anti-indígenas, conforme consta no relatório do Conselho Indigenista Missionário (Cimi) de 2018, que visam, especificamente, em relação aos arts. 231 e 232 da Constituição Federal de 1988, à extinção e/ ou modificação de direitos no texto constitucional. Trata-se de pesquisa com enfoque sociojurídico, com método indutivo, com base na análise de dados, pesquisa bibliográfica, sítios da rede mundial de computadores, relatórios de organizações e produções científicas.
\end{abstract}

Palavras-chave: direitos humanos; constitucionalismo; direito indígena; demarcação.

\begin{abstract}
This paper aims to analyze the fundamental rights of indigenous peoples conquered with the promulgation of the Federal Constitution of 1988, following the international order of protection of Human Rights and the breaking of paradigms inaugurated by Convention 169 of the International Labor Organization (ILO). Indeed, the realization of indigenous rights permeates
\end{abstract}

1 Universidade Católica Dom Bosco (UCDB), Campo Grande, Mato Grosso do Sul, Brasil.

2 Universidade Federal de Mato Grosso do Sul (UFMS), Campo Grande, Mato Grosso do Sul, Brasil. 
various nuances, and it is not possible here to address them completely. Thus, this paper will be restricted to analyzing the political disputes involving the organization of the Brazilian State, carried out by interests of anti-indigenous sectors, as stated in the report of the Indigenous Missionary Council (Cimi) of 2018, which aimed, specifically, in relation to arts. 231 and 232 of the Federal Constitution of 1988, at the extinction and/or modification of rights in the constitutional text. This is a research with a socio-legal focus, with the inductive method, based on data analysis, bibliographic research, sites of World Wide Web, organization reports, and scientific productions.

Keywords: human rights; constitutionalism; indigenous law; demarcation.

\section{INTRODUÇÃO}

A presente pesquisa, de caráter empírico, realizada a partir do acúmulo de experiência junto à advocacia popular, surgiu após provocações feitas por participantes de uma oficina ministrada na cidade de Alta Floresta, MT, em fevereiro de 2019, pois foi considerado um tema atual e de suma importância para as comunidades indígenas. Dessa forma, os esforços foram a fim de reunir todas as informações pertinentes ao tema em um artigo científico para utilização como instrumento de formação de jovens e anciões, lideranças dos povos indígenas em âmbito nacional, resultando neste trabalho. Assim, a pesquisa tem esse cunho de importância, busca levar o diálogo acadêmico-científico entre as aldeias e os espaços de discussão acerca dos direitos indígenas no país.

Feitas essas considerações, busca-se traçar uma linha histórica, a fim de abordar o período pré-constituinte e a promulgação da Constituição Federal de 1988, fazendo uma análise entre os direitos indígenas antes e após o ano de 1988, à luz de sua efetivação e desafios de ordem política, econômica, ideológica e social.

Antes da promulgação da Constituição Federal, em 5 de outubro de 1988, os povos indígenas tinham aparatos jurídicos que garantiam, apenas, a ocupação permanente ${ }^{3}$ de seus territórios tradicionais. Podemos notar que essas constituições

3 Constituição Federal de 1934: "Art. 129. Será respeitada a posse de terras de silvícolas que nelas se achem permanentemente localizados, sendo-lhes, no entanto, vedado aliená-las"; Constituição Federal de 1937: "Art. 154. Será respeitada aos silvícolas a posse das terras em que achem localizados em caráter permanente, sendo-lhes, porém, vedada sua alienação das mesmas"; Constituição Federal de 1946: "Art. 216. Será respeitada aos silvícolas a posse das terras onde se achem permanentemente localizados, com a condição de não a transferirem"; Constituição Federal de 1967 - Emenda Constitucional n. 1 de 1969: "Art. 198- As terras habi- 
não priorizavam a reprodução sociocultural dos povos indígenas, muito menos a possibilidade de demarcação dos territórios reivindicados por essas comunidades.

Vale destacar o primordial empenho e articulação do movimento indígena nacional a fim de reivindicar na pré-constituinte (1986-87) a promulgação dos artigos constitucionais referentes aos direitos indígenas. Apoiado por ONGs, movimentos sociais e sociedade civil, redigiu e buscou a aprovação dos arts. 231 e 232 da Carta Magna, o que se dá maior ênfase.

Após a aprovação do texto constitucional, incorporando o capítulo "Dos Índios", inaugurou-se um novo cenário da política de Estado, seguindo uma tendência internacional de proteção dos Direitos Humanos e reconhecendo a existência de uma sociedade heterogênea (DUPRAT, 2014), voltada aos povos tradicionais de nosso país.

\section{CONSTITUIÇÃO FEDERAL DE 1988}

Seguindo a tendência de reconhecimento de grupos distintos dentro do Estado, a Lei Maior deixou de somente reconhecer o direito indígena ao território, mas também trouxe em seu texto uma inovação quanto às garantias de outros direitos dos indígenas, nos artigos 231 e 232, que compõem o Capítulo VIII da Constituição, veja:

Art. 231. São reconhecidos aos índios sua organização social, costumes, línguas, crenças e tradições, e os direitos originários sobre as terras que tradicionalmente ocupam, competindo à União demarcá-las, proteger e fazer respeitar todos os seus bens.

$\S 1$ 으o ão terras tradicionalmente ocupadas pelos índios as por eles habitadas em caráter permanente, as utilizadas para suas atividades produtivas, as imprescindíveis à preservação dos recursos ambientais necessários a seu bem-estar e as necessárias a sua reprodução física e cultural, segundo seus usos, costumes e tradições.

$\S 20$ As terras tradicionalmente ocupadas pelos índios destinam-se a sua posse permanente, cabendo-lhes o usufruto exclusivo das riquezas do solo, dos rios e dos lagos nelas existentes.

tadas pelos silvícolas são inalienáveis nos termos que a lei federal determinar, a eles cabendo a sua posse permanente e ficando reconhecido o seu direito ao usufruto exclusivo das riquezas naturais e de todas as utilizadas nelas existentes. 1ㅇ- Ficam declaradas a nulidade e a extinção dos efeitos jurídicos de qualquer natureza que tenham por objeto o domínio, a posse ou a ocupação de terras habitadas pelos silvícolas". 
$\S 3$ O O aproveitamento dos recursos hídricos, incluídos os potenciais energéticos, a pesquisa e a lavra das riquezas minerais em terras indígenas só podem ser efetivados com autorização do Congresso Nacional, ouvidas as comunidades afetadas, ficando-lhes assegurada participação nos resultados da lavra, na forma da lei.

$\S 4$ ㅇ As terras de que trata este artigo são inalienáveis e indisponíveis, e os direitos sobre elas, imprescritíveis.

$\S 5$ ํ É vedada a remoção dos grupos indígenas de suas terras, salvo, "ad referendum" do Congresso Nacional, em caso de catástrofe ou epidemia que ponha em risco sua população, ou no interesse da soberania do País, após deliberação do Congresso Nacional, garantido, em qualquer hipótese, o retorno imediato logo que cesse o risco.

$\S 60$ São nulos e extintos, não produzindo efeitos jurídicos, os atos que tenham por objeto a ocupação, o domínio e a posse das terras a que se refere este artigo, ou a exploração das riquezas naturais do solo, dos rios e dos lagos nelas existentes, ressalvado relevante interesse público da União, segundo o que dispuser lei complementar, não gerando a nulidade e a extinção direito a indenização ou a ações contra a União, salvo, na forma da lei, quanto às benfeitorias derivadas da ocupação de boa-fé.

$\S 7$ ㅇ Não se aplica às terras indígenas o disposto no art. 174, § 3 o e $\S 4 ㅇ$.

Art. 232. Os índios, suas comunidades e organizações são partes legítimas para ingressar em juízo em defesa de seus direitos e interesses, intervindo o Ministério Público em todos os atos do processo. (BRASIL, 1988).

O capítulo VIII da Constituição Federal de 1988 se assemelha a uma constituição dos direitos indígenas, reconhecendo "sua organização social, costumes, línguas, crenças e tradições", além dos "direitos originários sobre as terras que tradicionalmente ocupam", formando-se como uma norma superior aplicada a todas as comunidades indígenas existentes no Brasil, mesmo com traços culturais, tradições e costumes totalmente diferenciados.

O Supremo Tribunal Federal, quando do julgamento do caso Raposa Serra do Sol, levanta aspectos de importante relevância quanto aos direitos indígenas presentes na Carta Maior, promulgada em 1988.

O Supremo Tribunal Federal, por ocasião do julgamento da Pet. 3388, caso Raposa Serra do Sol, acentuou que: EMENTA4: AÇÃO POPULAR.

\footnotetext{
${ }^{4}$ (Pet. 3388. fls. 230, 231 e 234/STF).
} 
DEMARCAÇÃO DA TERRA INDÍGENA RAPOSA SERRA DO SOL. INEXISTÊNCIA DE VÍCIOS NO PROCESSO ADMINISTRATIVO-DEMARCATÓRIO. OBSERVÂNCIA DOS ARTS. 231 E 232 DA CONSTITUIÇÃO FEDERAL, BEM COMO DA LEI N. 6.001/73 E SEUS DECRETOS REGULAMENTARES.

CONSTITUCIONALIDADE E LEGALIDADE DA PORTARIA N. 534/2005, DO MINISTRO DA JUSTIÇA, ASSIM COMO DO DECRETO PRESIDENCIAL HOMOLOGATÓRIO. RECONHECENDO DA CONDIÇÃO INDÍGENA DA ÁREA DEMARCADA, EM SUA TOTALIDADE. MODELO CONTÍNUO DE DEMARCAÇÃO. CONSTITUCIONALIDADE. REVELAÇÃO DO REGIME CONSTITUCIONAL DE DEMARCAÇÃO DAS TERRAS INDÍGENAS. A CONSTITUIÇÃO FEDERAL COMO ESTATUTO JURÍDICO DA CAUSA INDÍGENA. A DEMARCAÇÃO DAS TERRAS INDÍGENAS COMO CAPÍTULO AVANÇADO DO CONSTITUCIONALISMO FRATERNAL. INCLUSÃO COMUNITÁRIA PELA VIA DA IDENTIDADE ÉTNICA. VOTO DO RELATOR QUE FAZ AGREGAR AOS RESPECTIVOS FUNDAMENTOS SALVAGUARDAS INSTITUCIONAIS DITADAS PELA SUPERLATIVA IMPORTÂNCIA HISTÓRICO-CULTURAL DA CAUSA. SALVAGUARDAS AMPLIADAS A PARTIR DE VOTO-VISTA DO MINISTRO MENEZES DIREITO E DESLOCADAS PARA A PARTE DISPOSITIVA DA DECISÃO.

\section{$[\ldots]$}

9. A demarcação de terras indígenas como capítulo avançado do constitucionalismo fraternal. Os arts. 231 e 232 da Constituição Federal são de finalidade nitidamente fraternal ou solidária, própria de uma quadra constitucional que se volta para efetivação de um novo tipo de igualdade: a igualdade civil-moral de minorias, tendo em vista o proto-valor da integração comunitária. Era constitucional compensatória de desvantagens historicamente acumuladas, a se viabilizar por mecanismos oficiais de ações afirmativas. No caso, os índios a desfrutar de um espaço fundiário que Ihes assegure meios dignos de subsistência econômica para mais eficazmente poderem preservar sua identidade somática, linguística e cultural. Processo de uma aculturação que não se dilui no convívio com os não-índios, pois a aculturação de que trata a Constituição não é a perda de identidade étnica, mas somatório de mundividências. Uma soma, e não uma subtração. Ganho, e não perda. Relações interétnicas de mútuo proveito, a caracterizar ganhos culturais incessantemente cumulativos. Concretização constitucional do valor de inclusão comunitária pela via de identidade étnica.

Todas as organizações sociais, culturas, costumes, tradições, línguas e crenças foram reconhecidos no texto constitucional, não de forma declaratória, mas sim recepcionados, cabendo ao Estado brasileiro fazer respeitar essas 
diferenças socioculturais, que ainda têm embasamento jurídico no preâmbulo ${ }^{5}$ da Constituição, quando esta traz que a sociedade brasileira é pluralista, e no art. 4ํㅡ, III, que afirma a autodeterminação dos povos.

Com efeito, os povos indígenas possuem uma diversidade de direito, tanto cultural, organizacional, quanto às terras tradicionais, podendo exercê-los conforme seus costumes e tradições.

O Supremo Tribunal Federal trata os direitos dos povos indígenas, na Constituição Federal, como um estatuto jurídico da causa indígena ${ }^{7}$, isto é, ao nosso modo de ver, uma constituição do direito indígena ancorada na Carta Magna, sendo, de fato, um avanço dentro do constitucionalismo brasileiro.

A terra tradicionalmente ${ }^{8}$ ocupada pelos povos indígenas é devidamente compreendida como o complexo capaz de garantir, primeiramente, o espaço habitado em caráter permanente, áreas de coleta, pesca e caça, com a devida preservação dos recursos ambientais necessários ao bem-estar da comunidade ao longo dos tempos, e capaz de garantir a reprodução física e cultural dessas populações, geração após geração, de acordo com sua organização social, costumes, tradições e crenças.

Nossa Constituição ainda traz importantes aspectos em relação ao uso da terra pelos povos originários, o qual se diferencia da posse da terra pelo não

\footnotetext{
5 "Nós, representantes do povo brasileiro, reunidos em Assembleia Nacional Constituinte para instituir um Estado Democrático, destinado a assegurar o exercício dos direitos sociais e individuais, a liberdade, a segurança, o bem-estar, o desenvolvimento, a igualdade e a justiça como valores supremos de uma sociedade fraterna, pluralista e sem preconceitos, fundada na harmonia social e comprometida, na ordem interna e internacional, com a solução pacífica das controvérsias, promulgamos, sob a proteção de Deus, a seguinte CONSTITUIÇÃO DA REPÚBLICA FEDERATIVA DO BRASIL."

6 "Art. 40 A República Federativa do Brasil rege-se nas suas relações internacionais pelos seguintes princípios: [...] III - autodeterminação dos povos;"

7 Pet. 3388/STF.

8 O tradicionalmente refere-se não a uma circunstância temporal, mas ao modo tradicional de os índios ocuparem e utilizarem as terras e ao modo tradicional de produção, enfim, ao modo tradicional de como eles se relacionam com a terra, já que há comunidades mais estáveis, e as que têm espaços mais amplos pelo qual se deslocam etc. Daí dizer- se que tudo se realiza, segundo seus usos, costumes e tradições (SILVA, 2005, p. 836).
} 
índio, advinda do direito de propriedade civilista ${ }^{9}$, que é o indigenato ${ }^{10}$. 0 texto constitucional não deu a propriedade da terra às comunidades indígenas, mas somente a posse e o usufruto exclusivo das riquezas do solo, dos rios e dos lagos nelas existentes, o que está previsto no parágrafo 20 do art. 231, significando que a Constituição salvaguarda o direito comunitário dos índios diante do modelo individualista da sociedade não índia.

Para Eloy Amado (2014, p. 73), a “[...] posse indígena não pode ser tratada da mesma forma que a posse regulada pelo direito civil brasileiro, isso porque sua previsão decorre de comando constitucional", então, podemos verificar aqui uma distinção jurídica entre a posse meramente civilista e a posse constitucional indígena, sendo que a primeira é baseada no direito de propriedade, individualista e exploratória, e a segunda, baseada em um direito coletivo, de uma comunidade, para sua subsistência e a exploração dos recursos existentes calcada em costumes, crenças e tradições com respeito ao meio ambiente, para garantia da reprodução física e cultural, isto é, foge à lógica capitalista de exploração da terra e dos recursos nela existentes. Pode-se afirmar que a posse indígena, advinda do comando constitucional, é superior à posse civilista.

O texto constitucional traz disposições sobre o aproveitamento de "hídricos, incluídos os potenciais energéticos, a pesquisa e a lavra das riquezas minerais em terras indígenas" ( $§ 30$ do art. 231), além de tratar da indisponibilidade, inalienação e imprescritibilidade das terras indígenas em seu § 4으, vedar a remoção de povos, salvo "ad referendum" do Congresso Nacional, finalizando com a nulidade e extinção de títulos que tenham "por objeto a ocupação, o domínio e a posse das terras a que se refere este artigo, ou a exploração das riquezas naturais do solo, dos rios e dos lagos nelas existentes", no $\S 60$.

Temos então o art. 232, que rompe com o regime tutelar imposto aos povos indígenas ao garantir que "os índios, suas comunidades e organizações são partes legítimas para ingressar em juízo em defesa de seus direitos e interesses"; em

9 Art. 1.196, CC - "Considera-se possuidor todo aquele que tem de fato o exercício, pleno ou não, de algum dos poderes inerentes à propriedade".

"Art. 1.228. O proprietário tem a faculdade de usar, gozar e dispor da coisa, e o direito de reavê-la do poder de quem quer que injustamente a possua ou detenha".

${ }^{10}$ Por conseguinte, o indigenato não é um fato dependente de legitimação, ao passo que a ocupação, como fato posterior, depende de requisitos que a legitimem (MENDES JÚNIOR, 1912, p. 58). 
interpretação lato sensu, se os índios têm legitimidade para ingressar em juízo, podem eles gerir os atos da vida civil, estando então equiparados à capacidade regulada na lei adstrita ao não índio.

Em 1996, o então presidente da República, Fernando Henrique Cardoso, editou o Decreto n. 1.775/96 (BRASIL, 1996), que passaria a disciplinar administrativamente a demarcação de terras indígenas. Cuidaremos de compreendê-lo no tópico seguinte.

\section{DECRETO 1.775, DE 8 DE JANEIRO DE 1996}

O Decreto 1.775/96 foi criado para dar corpo a um procedimento administrativo de demarcação de terras indígenas no país, ainda não existente, provocado pela formulação da tese de que as demarcação de terras indígenas não obedecia ao princípio do contraditório e da ampla defesa, conforme acreditavam os representantes dos setores que se contrapunham ao método adotado pela Constituição Federal para a efetivação do direito ao território indígena; para isso, o decreto incorporou nove fases procedimentais, por nós compreendidas da seguinte forma:

1. Reivindicação pela comunidade indígena da demarcação de sua terra tradicional11;

2. Publicação de Portaria de Constituição de Grupo Técnico (GT) - Cabe ao presidente da Fundação Nacional do Índio (Funai) publicar, no Diário Oficial da União, portaria constituindo grupo técnico, coordenado por antropólogo com qualificação reconhecida em relação ao povo e à terra indígena (TI) a ser demarcada, podendo contar com outros profissionais para "realizar estudos complementares de natureza etno-histórica, sociológica, jurídica, cartográfica, ambiental e o levantamento fundiário necessários à delimitação"12;

3. Envio do Relatório Circunstanciado de Identificação e Delimitação ao Presidente

\footnotetext{
${ }^{11}$ Pontua que essa fase não se encontra no texto do decreto, todavia, como a Funai não opera ex officio, ou seja, não havendo a provocação da comunidade, não se inicia o procedimento administrativo, então essa se configura como uma fase extrínseca ao decreto.

12 Art. 2, "§ 1 ㅇ O órgão federal de assistência ao índio designará grupo técnico especializado, composto preferencialmente por servidores do próprio quadro funcional, coordenado por antropólogo, com a finalidade de realizar estudos complementares de natureza etno-histórica, sociológica, jurídica, cartográfica, ambiental e o levantamento fundiário necessários à delimitação".
} 
Direitos constitucionais e povos indígenas: apontamentos sobre a disputa pela efetivação do direito fundamental às suas terras tradicionais

da Funai - Feito o estudo de identificação e delimitação, o grupo técnico apresentará Relatório Circunstanciado de Identificação e Delimitação (Recid) ao presidente do órgão federal de assistência ao índio, "caracterizando a terra indígena a ser demarcada", conforme o § 6ํ13 do Dec. 1.775/96;

4. Publicação do Relatório Circunstanciado de Identificação e Delimitação - De porte do Recid, caberá ao presidente do órgão de assistência ao índio publicar o relatório no Diário Oficial da União, onde se localiza a área de objeto de demarcação, "acompanhado de memorial descritivo e mapa da área, devendo a publicação ser afixada na sede da Prefeitura Municipal da situação do imóvel", no prazo de 15 dias;

5. Contestação e levantamento de benfeitorias - O início da contestação ao processo administrativo promovido pelo órgão indigenista oficial se dá desde a publicação da portaria de constituição do grupo técnico, até 90 (noventa) dias após a publicação do Relatório Circunstanciado de Demarcação e Delimitação (Recid), conforme preconiza o art. $2, \S 8^{0^{14}}$ do decreto. Cabe destaque de que, nesta fase, também se dá o levantamento de benfeitorias de boa-fé as quais o ocupante não indígena tem direito de indenização;

6. Envio do procedimento ao ministro de Estado da Justiça - Feito isso, nos 60 (sessenta) dias para o encerramento do prazo de contestação, cabe ao órgão indigenista oficial encaminhar ao ministro da Justiça o procedimento com "pareceres relativos às razões e provas apresentadas", como trata o parágrafo 9o15;

13 “§ 60 Concluídos os trabalhos de identificação e delimitação, o grupo técnico apresentará relatório circunstanciado ao órgão federal de assistência ao índio, caracterizando a terra indígena a ser demarcada."

14 "§ 70 Aprovado o relatório pelo titular do órgão federal de assistência ao índio, este fará publicar, no prazo de quinze dias contados da data que o receber, resumo do mesmo no Diário Oficial da União e no Diário Oficial da unidade federada onde se localizar a área sob demarcação, acompanhado de memorial descritivo e mapa da área, devendo a publicação ser afixada na sede da Prefeitura Municipal da situação do imóvel."

"§ 8ㅇ Desde o início do procedimento demarcatório até noventa dias após a publicação de que trata o parágrafo anterior, poderão os Estados e municípios em que se localize a área sob demarcação e demais interessados manifestar-se, apresentando ao órgão federal de assistência ao índio razões instruídas com todas as provas pertinentes, tais como títulos dominiais, laudos periciais, pareceres, declarações de testemunhas, fotografias e mapas, para o fim de pleitear indenização ou para demonstrar vícios, totais ou parciais, do relatório de que trata o parágrafo anterior."

15 “§ 9o Nos sessenta dias subsequentes ao encerramento do prazo de que trata o parágrafo ante- 
7. Declaração dos limites e determinação de demarcação física - De porte do procedimento, cabe ao ministro da Justiça: declarar os limites da terra indígena e determinar a sua demarcação; devolver os autos à Funai, prescrevendo diligências que julgue necessárias a fim de complementar o estudo de identificação e delimitação, que deveria ser realizado pelo órgão indigenista no prazo de noventa dias; ou, mediante decisão fundamentada, desaprovar a identificação e a devolver ao órgão de assistência ao índio para arquivamento; tais decisões deverão se dar em até trinta dias, reza o parágrafo $10^{\circ}{ }^{16}$ do art. 2ㅇ․ Cabe destaque nesse ponto à declaração dos limites que, consequentemente, levará aos atos procedimentais seguintes.

8. Homologação da Terra Indígena - Transcorridos esses atos disciplinados pelo ato normativo mencionado, a terra indígena demarcada será homologada por decreto do presidente da República, em acordo com o art. 517;

9. Registros - Finalmente, será necessário ainda, em até trinta dias após o ato anterior, promover "o respectivo registro em cartório imobiliário da comarca correspondente e na Secretaria do Patrimônio da União do Ministério da Fazenda", sendo de competência do órgão de assistência ao índio, nos dizeres do art. 6.

A Constituição Federal de 1988 determinou o prazo de 5 anos $^{18}$ para demarcação dos territórios indígenas, que expirou em 1993, sem que fossem concluídos todos os processos de demarcação devido ao acirramento da disputa entre interesses antagônicos envolvidos na questão.

rior, o órgão federal de assistência ao índio encaminhará o respectivo procedimento ao ministro de Estado da Justiça, juntamente de pareceres relativos às razões e provas apresentadas."

16 "§ 10 o Em até trinta dias após o recebimento do procedimento, o Ministro de Estado da Justiça decidirá:

I- declarando, mediante portaria, os limites da terra indígena e determinando a sua demarcação; II- prescrevendo todas as diligências que julgue necessárias, as quais deverão ser cumpridas no prazo de noventa dias;

III- desaprovando a identificação e retornando os autos ao órgão federal de assistência ao índio, mediante decisão fundamentada, circunscrita ao não atendimento do disposto no $§ 1$ 잉 do art. 231 da Constituição e demais disposições pertinentes."

17 "Art. $5^{\circ}$ A demarcação das terras indígenas, obedecido o procedimento administrativo deste Decreto, será homologada mediante decreto."

${ }^{18}$ Art. 67, ADCT, CF88. 
Tal fato é constatado pela simples análise das áreas em demarcação em Mato Grosso do Sul em relação à região norte do país. Naquelas existem terras até hoje sem criação de Grupo de Trabalho para identificação e delimitação, a exemplo da TI Nioaque, localizada no município de Nioaque; TI Kinikinau, localizada no município de Miranda; e diversos Tekoha ${ }^{19}$ Guarani e Kaiowá ao sul do Estado. Por outro lado, as terras indígenas demandadas na região norte do país foram, em quase sua integralidade, efetivamente demarcadas.

Em Mato Grosso do Sul, sul da Bahia e Região Sul, o hoje chamado "agronegócio" foi o setor que mais combateu e investiu em mecanismos para impossibilitar a efetivação do direito do índio ao seu território. Isso fez com que o então presidente editasse o Decreto n. 1.775/96, que inicialmente foi combatido pelo movimento indígena e seus aliados, mas atualmente passou a ser defendido.

Para poder compreender os trâmites que um procedimento administrativo de demarcação de terras precisa seguir até sua homologação, faz-se necessário compreender como o Estado brasileiro está organizado em suas esferas de poder e atribuições, refletindo como esses poderes podem influenciar positiva ou negativamente na efetivação do direito indígena, aqui tratado, especificamente, o direito à terra tradicional.

\section{ORGANIZAÇÃO DO ESTADO BRASILEIRO}

Após a análise dos direitos dos índios com enfoque na demarcação de suas terras tradicionais, o principal elemento deste trabalho será apontar os principais entraves para a efetivação dos direitos fundamentais de solidariedade "[...] porque têm, ao mesmo tempo, uma dimensão 'individual' e uma dimensão 'coletiva', uma vez que concernem à pessoa humana: o índio como tal, assim como as coletividades humanas: as comunidades indígenas" (SILVA, 2016, p. 5), para a efetivação do índio à demarcação de sua terra tradicionalmente ocupada.

\footnotetext{
${ }_{19}$ Pela tradução livre, significa "lugar onde se é". Trata-se de um termo de ampla significação para os Guarani (Kaiowá e Ñandeva), é muito utilizado pelo grupo como aquele lugar onde se pode viver bem, ou onde o teko porã (o bom modo de viver) é possível. Refere-se à dimensão territorial, sendo o lugar (território) onde se desenrolam as relações sociais, políticas, culturais e simbólicas. Sobre este termo é possível obter mais informações consultando a tese de doutorado do antropólogo Levi Pereira (2004).
} 
O Estado brasileiro tem sua organização político-administrativa de forma descentralizada, e a União Federal ${ }^{20}$ é a junção dos poderes Legislativo, Executivo e Judiciário - a eles cabe trabalhar de forma independente e harmônica entre si. Sendo assim, o Estado brasileiro é formado pela União, estados, municípios, territórios e o Distrito Federal, todos com diversas competências e estruturas independentes de organização, disciplinados pela Constituição Federal.

Em relação aos Estados Federados, o professor José Afonso da Silva assevera que:

A União ficou ainda bem aquinhoada na partilha das competências federativas. Dispõe de competência material exclusiva conforme ampla enumeração de assuntos no art. 21, de competência legislativa privativa consoante discriminação constante do art. 22, de competência comum com Estados, Distrito Federal e Municípios arrolada no art. 23 e, ainda de competência legislativa concorrente com Estados sobre temas específicos no art. 24. (SILVA, 2005, p. 496).

Nesta separação de competência, vale destacar que compete à União demarcar as terras indígenas, sendo assim, não é uma mera competência, mas se trata de um direito fundamental (SILVA, 2005), impondo-se como dever da União.

Cabe, neste trabalho, trazer algumas acepções político-administrativas da União Federal, analisando-se sua organização e competência em relação aos direitos indígenas. Serão abordadas as competências ${ }^{21}$ desses poderes e o seu papel político passível de influir na temática aqui discutida.

No que tange à demarcação dos territórios indígenas, segundo o art. 231, caput, compete à União demarcá-las. Cabe ainda dizer que o art. 20 da Constituição Federal dispõe que são bens da União, entre outros, "as terras tradicionalmente ocupadas pelos índios", conforme prevê o inciso XI. Sendo assim, também compete à União "proteger e fazer respeitar todos os seus bens" - trecho insculpido no caput do art. 231 do texto constitucional.

\footnotetext{
20 "A União é a entidade federal formada pela reunião das partes componentes, constituindo pessoa jurídica de Direito Público interno, autônoma em relação às unidades federadas (ela é unidade federativa, mas não é unidade federada) e a que cabe exercer as prerrogativas da soberania do Estado brasileiro" (SILVA, 2005, p. 493).

${ }^{21}$ Competências são, assim, as diversas modalidades de poder de que se servem os órgãos ou entidades estatais para realizar suas funções (SILVA, 2005, p. 496).
} 
Dessa forma, abordaremos a seguir a divisão dos poderes do Estado brasileiro, trazendo apontamentos acerca dos instrumentos utilizados por eles para inviabilizar, modificar ou extinguir direitos.

\subsection{Poder Executivo}

O Poder Executivo é responsável pela gestão político-administrativa da União e "Pode dizer-se, de modo geral, que se trata de órgão constitucional (supremo) que tem função a prática de atos de chefia de estado, de governo e de administração" (SILVA, 2005, p. 542).

O chefe da administração pública é o presidente da República, que deve ser brasileiro nato e ter 35 (trinta e cinco) anos de idade ${ }^{22}$, eleito por voto popular e com mandato de quatro anos, podendo ser reeleito por uma vez. Cabe a ele sancionar, promulgar, publicar leis, expedir decretos e regulamentos, vetar projetos de lei etc. e tem como auxiliares os ministros de Estado. Para abarcar todas as demandas constitucionais garantidoras do bem-estar social, a administração pública federal é desconcentrada entre os ministérios e, ao caso analisado, basta mencionar o Ministério da Justiça, que descentraliza a função administrativa de demarcação de terras indígenas à Funai, sendo depois responsável pela Declaração dos Limites da Terra, objeto do estudo, e por determinar a demarcação, que, quando concluída, será enviada ao presidente da República para homologação via decreto, conforme já vimos detalhadamente em tópico anterior.

Assim, percebe-se a competência que é atribuída pela Constituição ao Poder Executivo para demarcar os territórios indígenas.

No âmbito do Poder Executivo, cabe apontar que houve, nos últimos anos, mesmo sendo um governo favorável a defender os interesses das populações indígenas, algumas iniciativas que vieram para inviabilizar e paralisar os procedimentos de demarcação. Impulsionada por meio da pressão das bancadas de congressistas contrários à causa indígena, com ênfase à bancada ruralista, foi publicada a Portaria 303/2012 (BRASIL, 2012) da Advocacia-Geral da União (AGU), que orientava os advogados da União a não operarem contra a tese do marco temporal e as 19 condicionantes da Raposa Serra do Sol - PET 3.388/STF. Essa portaria foi suspensa

\footnotetext{
${ }^{22}$ Art. 14, § 2ㅇ, VI, “a”, CF88.
} 
logo em seguida de sua publicação, todavia serviu para o governo de Dilma Rousseff paralisar todos os processos de demarcação de terras indígenas no Brasil.

Por meio do "impeachment" da presidente Dilma Rousseff, seu sucessor, Michel Temer, em seu primeiro ato enquanto presidente, editou o Parecer 001/2017 da Presidência da República (PR. 2017), que também trouxe as condicionantes do Caso Raposa Terra do Sol e a tese do marco temporal, vinculando todos os advogados da União, mas também toda a administração pública federal23, a observar as diretrizes do parecer.

O caso se agrava quando há advogados da União com responsabilidade de defender judicialmente os interesses das comunidades indígenas, por meio da Procuradoria Federal Especializada (PFE), e ficam eles proibidos de fazer, se contrário ao Parecer 001/2017. Assim, o parecer, além de aplicar teses ainda não fixadas pelo STF, também retira da comunidade indígena a autonomia do seu advogado, a PFE.

Para melhor compreensão dos efeitos desse parecer, pode-se expor dois exemplos. Primeiro, o povo Kinikinau em MS, que está reivindicando a criação de Grupo Técnico de Estudo de Identificação e Delimitação de sua terra indígena; para isso, protocolizaram ofício junto à Funai em Brasília, requerendo a publicação da portaria de criação de um Grupo de Trabalho. A Funai, em resposta, enviou ordem para que servidor lotado na Coordenação Regional de Campo Grande produzisse "qualificação" quanto ao pedido do povo. Esse servidor teve o papel de visitar o povo Kinikinau, conhecer um pouco de sua história e realizar levantamentos prévios. Tais apontamentos mostram que os Kinikinau foram expulsos da região conhecida como "Agachi", localizada no município de Miranda, MS, ainda no início do século XX; dessa forma, sendo a Funai obrigada a confrontar a trajetória do povo com o Parecer 001/2017, indeferiu administrativamente o pedido da comunidade. Segundo, no ano de 2010, vários sindicatos rurais e municípios de MS ingressaram com ações judiciais contra a Funai e União visando à aplicação do marco temporal para imunizar as fazendas abrangidas por todo o município do litigante, seja o próprio município, seja o sindicato rural, além de ações propostas por sindicatos de nível estadual; grande parte dessas ações já foram julgadas improcedentes por ilegitimidade ativa, no entanto, em alguns casos, e coincidentemente ou não, o juiz decidiu citar a comunidade para responder ao processo, momento em que a comunidade indígena

${ }^{23}$ Portaria 839, de 18 de junho de 2010/AGU (BRASIL, 2010). 
procurou a Procuradoria Federal Especializada (PFE) ${ }^{24}$ atuando junto à Funai para defesa das comunidades indígenas, para que as representasse judicialmente como é rotineiro. Para a demanda apresentada, as comunidades receberam resposta de que os "procuradores estariam impedidos de advogar em favor das comunidades e se contrapondo às 19 condicionantes e ao marco temporal" 25. Isto é, caso essas comunidades não possuíssem condições de contratar advogado particular ou ter acesso de forma pro bono, correriam o risco de ter tais processos julgados à revelia.

Destaca-se, com isso, que o Parecer 001/2017 está em vigor até este momento. Já o governo atual viola a Constituição, retirando da Funai a competência de realizar o procedimento administrativo de demarcação de terras indígenas e transferindo-a para o Ministério da Agricultura, por meio da reedição da Medida Provisória 870/2019 (BRASIL, 2019a), pela Medida Provisória 886/2019 (BRASIL, 2019b). A iniciativa presidencial foi frustrada pela rejeição da proposta pelo Congresso Nacional e, posteriormente, pela Suprema Corte no julgamento da ADI 6062. Estamos diante de um contrassenso, repudiado pelas organizações indígenas.

Figura 1 - Intenções do atual governo para a não demarcação de terras indígenas

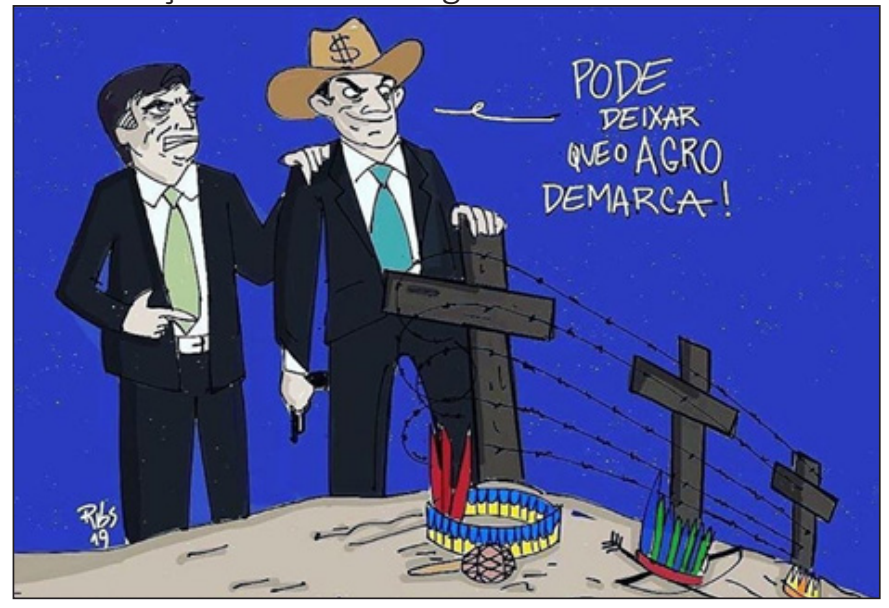

Fonte: Conselho Terena (MS), 2019.

\footnotetext{
${ }^{24}$ Regulamentado pela Portaria 839/2010/AGU (BRASIL, 2010).

${ }^{25}$ Relato feito pelo cacique Erpídio Pires, da Aldeia Potrero Guasu, em Paranhos, MS, em reunião realizada para organizar a defesa das comunidades de Arroyo Korá, Ipo'y, Potrero Guassu, Pirajuí e Sete Cerros nos autos processuais de n. 0000158-14.2010.4.03.6005, que tramitam na Justiça Federal de Ponta Porã, MS.
} 
A imagem acima é uma publicação de Conselho Terena de Mato Grosso do Sul, organização de base da Articulação dos Povos Indígenas do Brasil (Apib), após notícia da nova medida provisória que transfere a demarcação de terras indígenas para o Ministério da Agricultura ${ }^{26}$.

\subsection{Poder Legislativo}

O Poder Legislativo é composto pela união da Câmara Federal e do Senado Federal: o Congresso Nacional, que exerce suas atividades por legislaturas ${ }^{27}$, sessões legislativas ordinárias ${ }^{28}$ ou extraordinárias e reuniões ordinárias ${ }^{29}$ ou extraordinárias. Sua atribuição é legislar (art. 48), deliberar (art. 49), fiscalizar e controlar o Poder Executivo (art. 50), além de julgar crimes de responsabilidade (arts. 51, 52 e 86); por fim, tem atribuições constituintes (art. 60).

A Câmara dos Deputados é composta por representantes do povo, eleitos nos estados, nos territórios e no Distrito Federal, pautada no sistema proporcional, onde cada estado tem um número total de representantes, não podendo ser menor que oito nem maior que setenta (art. 45, § 1ㅇ).

O Senado Federal é regido pelo sistema majoritário, ao contrário da Câmara Federal, é representativo dos Estados Federados, tendo 3 (três) eleitos, com dois suplentes cada um, nos estados e no Distrito Federal. O mandato do senador é de oito anos, tendo eleições de quatro em quatro anos, quando se renovará alternadamente a composição da Casa, por um ou dois terços, conforme dispõe o art. 46.

O Conselho Indigenista Missionário, em levantamento recente, aponta que o Poder Legislativo tem várias bancadas ${ }^{30}$ formadas em razão de interesses comuns, cabendo destaque à bancada ruralista, como é popularmente conhecida, formada com 207 parlamentares e cerca de 20 senadores ligados à Frente Parlamentar

\footnotetext{
${ }^{26}$ Disponível em: https://www.instagram.com/?hl=pt-br. Acesso em: 20 jun. 2019.

${ }^{27}$ A legislatura tem duração de quatro anos e corresponde ao período que vai do início do mandato dos membros da Câmara dos Deputados até o seu término (art. 44, parágrafo único).

28 É o período anual em que deve estar reunido o Congresso para os trabalhos legislativos (SILVA, 2005, p. 517).

${ }^{29}$ Os trabalhos legislativos realizam-se efetivamente nas reuniões diárias dos congressistas, chamadas sessões ordinárias, que se processam nos dias úteis (SILVA, 2005, p. 517).

30 Termo popularmente referenciado aos grupos com interesses políticos unificados.
} 
Agropecuária; bancada da mineração, que conta com 23 deputados; bancada da bala, com 35 deputados; bancada evangélica, com 197 deputados; e a bancada das empreiteiras e construtoras, com 226 deputados (CIMI, 2018a).

Com a formação dessas bancadas, financiadas por empresários e/ou pessoas de vasto poder econômico, iniciou-se então na última década um sistemático ataque aos direitos indígenas, pois o que se entende é que, para eliminar de vez a demarcação das terras, deveria ser modificada a Constituição Federal, configurada num arcabouço jurídico altamente avançado, garantidor dos direitos dos povos tradicionais.

Merece apontamento o fenômeno de resistência indígena ${ }^{31}$, ou seja, a "retomada" de territórios que de lá foram expropriados. Esse fator incomoda, e muito, esses setores organizados contra os direitos dos povos indígenas, pois poucos são os casos que, após retomarem o território tradicional, de lá são retirados se aplicada a legislação vigente.

A Justiça brasileira, de modo especial, por meio do Supremo Tribunal Federal, tem deferido liminares requeridas ora pela Funai, ora pelo Ministério Público Federal ${ }^{32}$, a fim de evitar tragédias a exemplo do assassinato do índio Terena, em 2013, chamado de Oziel Gabriel ${ }^{33}$, morto durante operação de reintegração de posse comandada pela Polícia Federal e apoiada pelo batalhão de Polícia Militar Estadual.

Os mais fortes sindicatos rurais de Mato Grosso do Sul, campeão na violência contra as comunidades tradicionais, contabilizaram o total de $140^{34}$ (cento e quarenta) fazendas retomadas pelos indígenas no Estado. Este é o fator que causa maior impacto, protagonizado pelos povos na busca da efetivação de seus direitos.

Esse fenômeno da resistência indígena materializada na retomada de territórios dos quais foram expulsos fez gerar, nos últimos anos, vários projetos de lei que visam modificar e/ou extinguirem direitos constantes no art. 231 da Carta Republicana.

31 "....] a resistência compreende todo comportamento de ruptura contra a ordem constituída, que ponha em crise o sistema pelo simples fato de produzir-se, como ocorre num tumulto, num motim, numa rebelião, numa insurreição, até o caso limite da revolução [...]" (BOBBIO, 2004, p. 61).

${ }^{32}$ Art. 129 da Constituição Federal: "São funções institucionais do Ministério Público: [...] V- defender judicialmente os direitos e interesses das populações indígenas".

${ }_{33}$ Disponível em: https://www.campograndenews.com.br/cidades/interior/morre-indio-ferido-em-confronto-com-a-policia-outros-tres-ficaram-feridos. Acesso em: 19 jun. 2019.

${ }^{34}$ Disponível em: https://www.midiamax.com.br/politica/2019/famasul-aponta-que-ms-tem-140-propriedades-em-conflitos-indigenas/. Acesso em: 19 jun. 2019. 
Primeiramente, tais atores apresentaram diversas proposições legislativas nas últimas décadas, e a 55a legislatura (2015-2019) é tida como a mais conservadora desde $1964^{35}$. Segundo levantamento do Conselho Indigenista Missionário:

[...] há, hoje, 33 proposições anti-indígenas em tramitação no Congresso e no Senado. Somadas às propostas apensadas por tratarem de temas semeIhantes, elas ultrapassam uma centena. Das 33 proposições anti-indígena apuradas, 17 buscam a alteração nos processos de demarcação de Terras Indígenas (TI) - oito sustam portarias declaratórias; seis transferem ao Congresso Nacional a competência de aprovar e gerir as demarcações das terras; as outras três correspondem a autorizar arrendamento em TI, impedir a desapropriação para demarcações de TI e estabelecer indenizações para invasores que ocupam TI após 2013. (CIMI, 2018a, p. 13).

O Conselho Indigenista Missionário indica ainda que, em 2017, foram identificadas 848 tramitações de projetos de lei desfavoráveis aos indígenas. Um levantamento da Agência Pública, com base nos dados do Cimi:

[...] identificou que os parlamentares ruralistas trabalham incansavelmente para fazer que as 33 propostas contra indígenas avancem. Isso fez com que as violências ruralistas sobre os direitos constitucionais das populações tradicionais atingissem 1.930 procedimentos legislativos em 2 anos - de 2015 a 2017. Esse número é maior que o de 20 anos, que chegou em 1.926 de 1995 até 2014 (CIMI, 2018b, p. 13-14).

Confirma-se o ambiente desfavorável aos indígenas, também denominado de tomada do Poder Legislativo, a partir de $1995^{36}$, um ano antes da entrada em vigor do Dec. 1.775/96, configurando o período da formação de bancadas contra os direitos indígenas para modificar a Constituição Federal, principalmente o art. 231.

A seguir, o montante financeiro empenhado nesses parlamentares, especificando aqui os atores de maior repercussão na causa indígena, iniciando pela atual ministra da Agricultura, Tereza Cristina (PSB/MS), cuja família37, inclusive, possui fazenda em terra indígena e a qual recebeu do agronegócio $\mathrm{R} \$ 2.689 .800,00$ (dois milhões e seiscentos e oitenta e nove mil e oitocentos reais); Luis Carlos Heinze

\footnotetext{
${ }^{35}$ Ver mais em Cimi, 2018a.

${ }^{36}$ Informação extraída com base em levantamento de proposições legislativas do Conselho Indigenista Missionário (CIMI, 2018a).

37 Encontrado em: https://www.campograndenews.com.br/politica/familia-da-ministra-tereza-cristina-tem-conflito-historico-com-indios-em-ms. Acesso em: 19 abr. 2019.
} 
(PP/RS), que recebeu $\mathrm{R} \$ 1.668 .200,00$ (um milhão e seiscentos e sessenta e oito mil e duzentos reais); Jerônimo Goergen (PP/RS), que recebeu $\mathrm{R} \$ 1.575 .800,00$ (um milhão e quinhentos e setenta e cinco mil e oitocentos reais). No Senado, temos Antonio Anastasia (PSDB/MG), recebendo R\$ 4.483.292,84 (quatro milhões e quatrocentos e oitenta e três mil e duzentos e noventa e dois reais e oitenta e quatro centavos); Simone Tebet (PMDB/MS), que recebeu $\mathrm{R} \$ 2.840 .000,00$ (dois milhões e oitocentos e quarenta mil reais); e, por fim, Katia Abreu (PDT/TO), que recebeu $\mathrm{R} \$ 2.485 .000,00$ (dois milhões e quatrocentos e oitenta e cinco mil reais). Isso na última campanha eleitoral (CIMI, 2018, p. 36).

Dentro do Poder Legislativo, houve a identificação de alguns instrumentos como sendo as principais pautas dos setores desfavoráveis aos indígenas, a fim de brecar a demarcação de Terras Indígenas e, com ela, todos os direitos indígenas arduamente conquistados, entre eles: PEC 215 38 : visa transferir ao Congresso Nacional a competência para homologar as demarcações das terras tradicionalmente ocupadas por comunidades indígenas, além de ratificar demarcações já homologadas; PLP 227/2012 39 : visa regulamentar o § 60 do art. 231, da CF de 1988, definindo os bens de relevante interesse da União para fins de demarcação de $\mathrm{TI}$, tornando qualquer medida desenvolvimentista de relevante interesse da União; e o PLP 227/2012, o qual foi pensado ao PLP 260/9040, que dispõe sobre a exploração das riquezas materiais do solo, dos rios e dos lagos em Terra Indígena.

\subsection{Poder Judiciário}

O Poder Judiciário é disciplinado em nossa Constituição do art. 92 ao 126, tendo como função compor conflitos de interesse em cada caso concreto; dessa

38 PEC 215/00 teve a maior impulsão nos últimos tempos, sendo somente barrada pelo movimento indígena no fim de 2015, nos últimos minutos do encerramento da legislatura, na Comissão de Constituição e Justiça, fazendo com que ela ficasse para segundo plano. Encontrado em: https://www.camara.leg.br/proposicoesWeb/fichadetramitacao?idProposicao=14562 Acesso em: 19 abr. 2019.

39 Disponível em: https://www.camara.leg.br/proposicoesWeb/fichadetramitacao?idProposic ao=584494. Acesso em: 19 abr. 2019.

${ }^{40}$ Disponível em: https://www2.camara.leg.br/camaranoticias/noticias/MEIO-AMBIENTE/97323PROPOSTA-REGULAMENTA-A-OCUPACAO-DE-TERRAS-INDIGENAS.html. Acesso em: 21 jun. 2019. 
forma, é exercida a jurisdição, vindo a se realizar por meio do processo judicial (SILVA, 2005, p. 555).

A jurisdição é exercida pelo Supremo Tribunal Federal; Superior Tribunal de Justiça; os tribunais regionais federais e juízes federais; os tribunais e juízes do Trabalho; os tribunais e juízes eleitorais; os tribunais e juízes militares; os tribunais e juízes dos estados, do Distrito Federal e dos territórios.

Sob a ótica da demarcação de terras indígenas, conforme exposto no art. 109, XI, cabe aos juízes federais, originalmente, processar e julgar conflitos relativos à disputa sobre direitos indígenas; dessa forma, matérias em que se discutem direitos indígenas de forma coletiva, a exemplo de ações declaratórias de domínio, ações possessórias, anulatórias de domínio etc., que incidam sobre terra indígena demarcada, reivindicada ou em processo de demarcação, devem ser processadas pela Justiça Federal e, consequentemente, pelo Tribunal Regional Federal, conforme sua jurisdição. E, por fim, pelo Supremo Tribunal Federal, cabendo ao Superior Tribunal de Justiça tão somente averiguar irregularidades procedimentais, não adentrando ao mérito do processo, que cabe ao Supremo Tribunal Federal.

As matérias de competência do STF, que constam no art. 102, são classificadas por José Afonso da Silva em três grupos:

(1) As que lhe cabe processar e julgar originariamente, ou seja, como Juízo único e definitivo, e são as questões relacionadas no inc. I; (2) as que the incumbe julgar, em recurso ordinário, e são as indicadas no inc. II; (3) e, finalmente, as que lhe toca julgar, em recurso extraordinário, e são as causas decididas em única ou última instância, quando a decisão recorrida envolve umas das questões constitucionais referidas nas alíneas do inc. III. (SILVA, 2005, p. 559).

Cabe, por fim, quanto à Suprema Corte, em relação aos julgamentos de direitos indígenas, analisar a denominada "súmula vinculante" ${ }^{41}$, que são de competência do Supremo Tribunal Federal, conforme disposto no art. 103-A, veja:

Art. 103-A, CF88. O Supremo Tribunal Federal poderá, de ofício ou por provocação, mediante decisão de dois terços dos seus membros, após reiteradas decisões sobre matéria constitucional, aprovar súmula que, a partir de sua

\footnotetext{
${ }^{41}$ Para Nelson Nery Junior, a súmula é o conjunto das teses jurídicas reveladoras da jurisprudência dominante no tribunal e vem traduzida em forma de verbetes sintéticos numerados e editados (NERES JUNIOR, 2000, p. 86).
} 
publicação na imprensa oficial, terá efeito vinculante em relação aos demais órgãos do Poder Judiciário e à administração pública direta e indireta, nas esferas federal, estadual e municipal, bem como proceder à sua revisão ou cancelamento, na forma estabelecida em lei.

§ 1ㅇ A súmula terá por objetivo a validade, a interpretação e a eficácia de normas determinadas, acerca das quais haja controvérsia atual entre órgãos judiciários ou entre esses e a administração pública que acarrete grave insegurança jurídica e relevante multiplicação de processos sobre questão idêntica.

$\S 2$ 2 Sem prejuízo do que vier a ser estabelecido em lei, a aprovação, revisão ou cancelamento de súmula poderá ser provocada por aqueles que podem propor a ação direta de inconstitucionalidade.

§ 3으o ato administrativo ou decisão judicial que contrariar a súmula aplicável ou que indevidamente a aplicar, caberá reclamação ao Supremo Tribunal Federal que, julgando-a procedente, anulará o ato administrativo ou cassará a decisão judicial reclamada, e determinará que outra seja proferida com ou sem a aplicação da súmula, conforme o caso.

Portanto a Suprema Corte pode contribuir com aspectos interpretativos da Constituição Federal, tanto para garantir quanto para negar ou modular direitos.

Em 2009, quando do julgamento do caso Raposa Serra do Sol, criaram-se 19 condicionantes para finalizar a demarcação daquela terra e, entre elas, surgiu a interpretação restritiva dos direitos indígenas na Constituição Federal de 1988, o marco temporal. O marco temporal visa estabelecer um divisor dos direitos territoriais dos povos indígenas antes e após a Constituição de 1988.

Para o ministro relator da PET. 3.388, Ayres Britto,

a Constituição Federal trabalhou com data certa - a data da promulgação dela própria (5 de outubro de 1988) - como insubstituível referencial para o dado da ocupação de um determinado espaço geográfico por essa ou aquela etnia aborígene; ou seja, para o reconhecimento, aos índios, dos direitos originários sobre as terras que tradicionalmente ocupam. (STF, 2010, p. 235).

Esse tema foi fixado no próprio julgamento como não sendo extensivo a outros casos, ou seja, não se vinculando a processos de matérias semelhantes; ainda assim, por ser de agrado dos setores, está sendo matéria de fundamentação de direito em quaisquer processos judiciais após seu surgimento, mesmo naqueles em que o julgamento de primeira instância ou em segunda ocorreu antes do seu surgimento, 
como no caso da Terra Indígena Buriti/MS (RE 997325, STF), que teve sua demarcação anulada com fundamento no marco temporal de ocupação pelo Tribunal Regional Federal da Terceira Região (TRF3), neste momento aguardando definição no STF.

O STF, considerado guardião da Constituição, afirmou, na Ementa do Acórdão, que julgou os embargos de declaração das aldeias indígenas e do Ministério Público Federal na Pet. 3.388, de forma que a decisão proferida não tem efeito vinculante e seus efeitos não se estendem, de forma automática, a outros processos em que se discutam matérias similares.

EMENTA: EMBARGOS DE DECLARAÇÃO. AÇÃO POPULAR. DEMARCAÇÃO DA TERRA INDÍGENA RAPOSA SERRA DO SOL. 1. Embargos de declaração opostos pelo autor, por assistentes, pelo Ministério Público, pelas comunidades indígenas, pelo Estado de Roraima e por terceiros. Recursos inadmitidos, desprovidos, ou parcialmente providos para fins de mero esclarecimento, sem efeitos modificativos. 2. Com o trânsito em julgado do acórdão embargado, todos os processos relacionados à Terra Indígena Raposa Serra do Sol deverão adotar as seguintes premissas como necessárias: (i) são válidos a Portaria/MJ no 534/2005 e o Decreto Presidencial de 15.04.2005, observadas as condições previstas no acórdão; e (ii) a caracterização da área como terra indígena, para os fins dos arts. 20, XI, e 231, da Constituição torna insubsistentes eventuais pretensões possessórias ou dominiais de particulares, salvo no tocante à indenização por benfeitorias derivadas da ocupação de boa-fé (CF/88, art. 231, § 60). 3. As chamadas condições ou condicionantes foram consideradas pressupostos para o reconhecimento da validade da demarcação efetuada. Não apenas por decorrerem, em essência, da própria Constituição, mas também pela necessidade de se explicitarem as diretrizes básicas para o exercício do usufruto indígena, de modo a solucionar de forma efetiva as graves controvérsias existentes na região. Nesse sentido, as condições integram o objeto do que foi decidido e fazem coisa julgada material. Isso significa que a sua incidência na Reserva da Raposa Serra do Sol não poderá ser objeto de questionamento em eventuais novos processos. 4. A decisão proferida em ação popular é desprovida de força vinculante, em sentido técnico. Nesses termos, os fundamentos adotados pela Corte não se estendem, de forma automática, a outros processos em que se discuta matéria similar. Sem prejuízo disso, o acórdão embargado ostenta a força moral e persuasiva de uma decisão da mais alta Corte do País, do que decorre um elevado ônus argumentativo nos casos em se cogite da superação de suas razões. (BRASIL, 2014).

Mesmo assim, vimos que a tese do marco temporal está sendo utilizada em todas as instâncias do Poder Judiciário; no Legislativo, por meio de projetos de leis como 
o Projeto de Lei n. 490/2007, que altera artigos da Lei n. 6.001/73; e no Executivo, por meio da Portaria 303/AGU/2012, seguida pelo Parecer Presidencial 001/2017.

\section{CONCLUSÃO}

Os direitos indígenas no Brasil não integram a agenda da maioria dos governantes, pois se contrapõem ao sistema econômico dominante, são tidos por eles, publicamente, como entraves ao desenvolvimento do país.

Com efeito, os índios sempre tiveram seus direitos violados, passando por um processo de genocídio histórico, marcado pelo desinteresse político para a efetivação dos direitos indígenas, entre eles, a demarcação de suas terras, pauta prioritária do movimento indígena em todas as regiões.

O Relatório de Violência do Conselho Indigenista Missionário (2018) mostra que 767 terras indígenas pendem de regularização, o que provoca uma acentuação na violência relacionada aos povos indígenas. E os números são alarmantes: nos anos de 2003 a 2017, foram 1.119 indígenas assassinados; deste total, 41,19\% são em Mato Grosso do Sul, estado conhecido internacionalmente pelo intenso conflito entre indígenas e fazendeiros. Dados do ano de 2017 indicam 68 indígenas assassinados.

Segundo dados do IBGE 2010, o Brasil tinha uma população de 3 milhões de indígenas no ano de 1500, restando apenas 70 mil em 1957; e, após a década de 1980, esse contingente populacional voltou a crescer, registrando-se, em 2010, uma população de 817,962 habitantes indígenas ${ }^{42}$.

Vários foram os períodos de expulsão e/ou remoção de comunidades indígenas de seus territórios, dando espaço à expansão da agricultura e pecuária no país, e Mato Grosso do Sul foi um dos estados que mais foi impactado por essa expansão desordenada, afetando os territórios indígenas por completo e contribuindo com disputas territoriais até a atualidade.

Várias são as consequências ocasionadas pela correlação de força política e econômica nas últimas décadas, que pressiona a garantia e efetivação dos direitos dos povos indígenas, especificamente, em relação às suas terras tradicionais.

${ }^{42}$ Disponível em: http://www.funai.gov.br/index.php/indios-no-brasil/quem-sao. Acesso em: 19 abr. 2019. 
Como já exposto neste trabalho, antes da Constituição Federal de 1988, o Estado somente garantia aos povos o espaço de ocupação permanente, não tendo respeitadas as demais garantias trazidas pelo caput do art. 231 da atual Constituição.

Por conta das mortes de diversos indígenas, há décadas sofridas pelos povos indígenas no Brasil, eles protagonizaram um forte processo de luta; entre as práticas, ressalta-se a retomada dos territórios de onde foram expulsos e a realização de grandes assembleias indígenas para reivindicação de direitos.

No período constituinte, os povos indígenas foram protagonistas de forte movimento que garantiu a promulgação do "Capítulo VIII dos Índios" na Constituição, de forma que foi alterada a política de Estado, rompendo com o paradigma da tutela indígena e da política integracionista, bem como dando lugar ao protagonismo e à autonomia das comunidades indígenas e ao direito às terras tradicionalmente ocupadas por eles, sua língua, seus costumes, crenças e tradições.

Assim, a questão indígena no país fica dividida em três períodos, a saber. O primeiro período de quase extinção que perpassa o momento da invasão portuguesa até a década de 1980, surgindo, assim, os primeiros movimentos indígenas pela mudança de paradigmas e defesa de direitos, alcançando-os com a promulgação da Constituição Federal de 1988; o segundo, da promulgação da Constituição Federal de 1988, regrando um verdadeiro estatuto jurídico da causa indígena, inovador constitucional protagonizado pelos povos indígenas que possibilitou uma série considerável de garantias e de efetivação de direitos aos povos, perdurando até a baixa do Dec. $1.775 / 96$, criado por pressão de setores que questionavam a legalidade das demarcações, estabelecendo um procedimento administrativo de demarcação de terras indígenas, antes não existente. Terceiro e contemporâneo, desde 1996, iniciou-se uma nova fase em relação aos direitos indígenas, que chamamos de "fase do declínio". Essa nova fase é caracterizada pelo protagonismo do Poder Legislativo (bancadas anti-indígenas), numa atuação forte e concentrada na busca incansável de mudança da legislação indigenista a fim de extinguir, modificar ou flexibilizar dispositivos constitucionais. Esses agentes vêm criando há décadas projetos de leis letais aos direitos indígenas, dando prioridade à mudança do texto constitucional sobre os direitos dos índios.

Pode-se conjecturar as estratégias desses setores no período do governo Lula e Dilma. Inicialmente, lotaram a pauta do Congresso com projetos de leis 
e emendas que, como já dito, visam modificar, flexibilizar ou extinguir direitos, que só não avançaram por força do movimento indígena. Após, com o Executivo, ocorre a paralisação nos processos de demarcação de terras indígenas em troca de colocar em pauta medidas prioritárias do governo e forçam, para isso, reduzir o orçamento da Funai, não haver abertura de concurso público para preenchimento de quadros, abandono político do órgão, entre outros fatores.

No entanto o Poder Legislativo não foi capaz de mudar o texto constitucional, e sua última tentativa foi frustrada com a não votação da PEC 215/00 em dezembro de 2015.

Só que, mesmo não cumprindo esse objetivo, a força dessas bancadas implantou dentro do Poder Executivo os instrumentos anti-indígenas, como a Portaria 303/2012, o Parecer 001/2017 e a MP 870/2019 reeditada pela MP $886 / 2019$, que, na prática, analisando a finalidade das propostas, dificultaram qualquer possibilidade de avanço em relação à efetivação de direitos indígenas a partir da demarcação de seus territórios.

Mesmo não sendo efetivado esse direito por dever do Estado em promover a demarcação, as comunidades indígenas, especificamente em Mato Grosso do Sul, estão na posse de várias propriedades rurais, continuando a exercer seu direito de resistência e, em processos autônomos, continuando a retomar seus territórios, parcial ou integralmente, obtidos por meio de suspensões de despejos de retomadas realizadas pelos índios.

Nesse ponto, já tendo visto que o Poder Legislativo e o Poder Executivo se encontram com pautas contrárias à efetivação dos direitos indígenas, resta então o Poder Judiciário, que vem concedendo, mesmo que de forma provisória, a manutenção da posse indígena.

Todavia está para ser julgado pela Suprema Corte o Recurso Extraordinário no 1017365, que discute o âmago da posse civilista (marco temporal) e da posse indígena (indigenato). Tal julgamento é interpretado pelo movimento indígena e aliados como a possibilidade de pôr fim à tese do marco temporal ou enterrar de vez a possibilidade de cumprimento da Carta Maior, com a vinculação da multicitada interpretação aplicada ao art. 231.

Com efeito, presencia-se um sistemático e voraz ataque do poder econômico e político às comunidades indígenas do país, em que todos os poderes do Estado estão 
influenciados tomados por medidas anti-indígena, e pode-se afirmar que qualquer iniciativa em prol da resolução do conflito passa a ser alvo imediato de algum projeto de lei ou emenda à Constituição Federal, a fim de embaraçar a sua efetivação.

\section{REFERÊNCIAS}

BOBBIO, Norberto. 1909 - A era dos direitos. Tradução de Carlos Nelson Coutinho. Rio de Janeiro: Elsevier, 2004.

BRASIL. Medida Provisória n. 870, de 10 de janeiro de 2019. Estabelece a organização básica dos órgãos da Presidência da República e dos Ministérios. Brasília-DF, 2019a. Disponível em: http://www.planalto.gov.br/ccivil_03/_ato2019-2022/2019/Mpv/mpv870. htm. Acesso em: 6 out. 2020.

BRASIL. Medida Provisória n. 886, de 2019. Altera a Lei n. 13.844, de 18 junho de 2019, a Lei n. 8.171, de 17 de janeiro de 1991, a Lei n. 12.897, de 18 de dezembro de 2013, a Lei n. 9.613, de 3 de março de 1998, e a Lei n. 13.334, de 13 de setembro de 2016, para dispor sobre a organização básica dos órgãos da Presidência da República e dos Ministérios. Brasília-DF, 2019b. Disponível em: https://www.congressonacional.leg.br/ materias/medidas-provisorias/-/mpv/137363; Acesso em: 6 out. 2020.

BRASIL. Supremo Tribunal Federal. Pet n. 3.388. Embargos de declaração. Ação popular. Demarcação da terra indígena Raposa Serra do Sol. Relator: Min. Roberto Barroso. Brasília-DF, 2014. Disponível em: http://redir.stf.jus.br/paginadorpub/paginador. jsp?docTP=TP\&doclD=5214423. Acesso em: 6 out. 2020.

BRASIL. Advocacia-Geral da União. Portaria n. 303, de 16 de julho de 2012. Dispõe sobre as salvaguardas institucionais às terras indígenas conforme entendimento fixado pelo Supremo Tribunal Federal na Petição 3.388 RR. Brasília-DF: 2012. Disponível em: http:// www4.planalto.gov.br/consea/comunicacao/artigos/2012/portaria-agu-303-advocaciae-ilegalidade-anti-indio. Acesso em: 6 out. 2020.

BRASIL. Advocacia-Geral da União. Portaria n. 839, de 18 de junho de 2010. Disciplina e estabelece critérios para a atuação dos órgãos da Procuradoria-Geral Federal na defesa de direitos indígenas. Brasília-DF, 2010. Disponível em: https://www.legisweb.com.br/ legislacao/?id=227561. Acesso em: 6 out. 2020.

BRASIL. Decreto n. 1.775, de 8 de janeiro de 1996. Dispõe sobre o procedimento administrativo de demarcação das terras indígenas e dá outras providências. Brasília-DF, 1996. Disponível em: http://www.planalto.gov.br/ccivil_03/decreto/d1775.htm. Acesso em: 6 out. 2020. 
Direitos constitucionais e povos indígenas: apontamentos sobre a disputa pela efetivação do direito fundamental às suas terras tradicionais

BRASIL. Constituição Federal de 1988. Brasília-DF, 1988. Disponível em http://www. planalto.gov.br/ccivil_03/constituicao/constituicao.htm. Acesso em: 13 nov. 2019.

CONSELHO INDIGENISTA MISSIONÁRIO. Congresso Anti-Indígena: os parlamentares que mais atuaram contra os direitos dos povos indígenas. Organização de Guilherme Cavalli. Brasília, DF: Cimi, 2018a.

CONSELHO INDIGENISTA MISSIONÁRIO. Relatório: Violência contra os Povos Indígenas no Brasil - dados de 2017. Organização de Lúcia Helena Rangel. Brasília, DF: Cimi, 2018b.

DUPRAT, Débora. A Convenção 169 da OIT e o direito à consulta prévia, livre e informada. Culturas Jurídicas, Niterói, v. 1, n. 1, p. 51-72, 2014.

ELOY AMADO, Luiz Henrique. Pokéexa ûti o território indígena como direito fundamental para o etnodesenvolvimento local. 2014. 125 f. Dissertação (Mestrado em Desenvolvimento Local) - Universidade Católica Dom Bosco, Campo Grande, MS, 2014.

MENDES JÚNIOR, João. Os indígenas do Brasil, seus direitos individuais e políticos. São Paulo: Typ. Hennies Irmãos, 1912.

NERY JUNIOR, Nelson. Princípios fundamentais: teoria geral dos recursos. 5. ed. São Paulo: Revista dos Tribunais, 2000.

PEREIRA, Levi M. Imagens Kaiowá do sistema social e seu entorno. Tese (Doutorado em Antropologia) - Universidade de São Paulo, São Paulo, SP, 2004.

SILVA, José Afonso. Parecer sobre Marco Temporal e Renitente Esbulho. São Paulo, 2016. Disponível em: http://www.mpf.mp.br/atuacao-tematica/ccr6/documentos-epublicacoes/artigos/docs_artigos/jose-afonso-da-silva-parecer-maio-2016-1.pdf. Acesso em: 17 jun. 2019.

SILVA, José Afonso. Curso de Direito Constitucional Positivo. 25. ed. revisada e atualizada nos termos da Reforma Constitucional, emenda constitucional n. 48, de 10/08/2005. São Paulo: Malheiros Editores, 2005.

SUPREMO TRIBUNAL FEDERAL. Ação Popular, PET. 3388. Brasília, DF, 2010.

\section{Sobre os autores:}

Antônio Hilário Aguilera Urquiza: Doutor em Antropologia. Professor adjunto da Universidade Federal de Mato Grosso do Sul (UFMS). Professor do Programa de Pós-Graduação em Antropologia da Universidade Federal da Grande Dourados (UFGD) 
e da Pós-Graduação em Educação da Universidade Católica Dom Bosco (UCDB). E-mail: hilarioaguilera@gmail.com, Orcid: http://orcid.org/0000-0002-3375-8630 Anderson Santos: Mestrando em Direito (área de concentração: Direitos Humanos) no Programa de Pós-Graduação em Direito da Universidade Federal de Mato Grosso do Sul (UFMS). Advogado do Conselho Indigenista Missionário (Cimi). E-mail: adv.andersonsantos@gmail.com, Orcid: http://orcid.org/0000-0003-1649-3797

Recebido em 30 de janeiro de 2020.

Aprovado para publicação em 10 de junho de 2020. 


\title{
Os Kambeba, a escola e seus significados The Kambeba, the school and their meanings
}

\author{
Kácia Neto de Oliveira Fonseca ${ }^{1}$ \\ Jaspe Valle Neto ${ }^{1}$ \\ Valeria Augusta Cerqueira de Medeiros Weige ${ }^{1}$
}

DOI: http://dx.doi.org/10.20435/tellus.v0i42.698

Resumo: A Educação Escolar Indígena se constitui em um processo de enfrentamento dos grupos étnicos em vivenciar, dentro das aldeias, um modelo de escola diferenciada dos padrões não indígenas. Essa luta se torna possível com a promulgação da Constituição Federal de 1988, que destina um artigo para Ihes possibilitar a apropriação dessa reivindicação. A escola entre os Kambeba da Terra Indígena da Barreira da Missão, Comunidade Betel Tefé (AM), foi incorporada e vivenciada pela comunidade a partir desse período. Diante disso, esse texto traz como objetivo central analisar como os Kambeba da Comunidade Betel Tefé (AM) percebem a função da Escola Municipal Rural Indígena Padre Augusto Cabrolié no fortalecimento cultural e identitário do grupo étnico. O caminhar metodológico utilizou o método hermenêutico-dialético, pela possibilidade de discutir os dados, percebendo os enfrentamentos e tensões intrínsecos desse processo. Os resultados nos mostraram que esse grupo de Kambeba percebe a escola como elo que fortalece a comunidade, sendo o lugar onde o resgate das crenças, das tradições e dos costumes está sendo desenvolvido pelos professores nas salas de aula, e o aluno Kambeba tem se apropriado de elementos singulares da cultura e construído novos significados que são necessários para o fortalecimento identitário. As conclusões evidenciam que a escola que um dia foi palco para homogeneização e negação das diferenças étnicas é, atualmente, o lugar de novaspossibilidades, pois procura atender às expectativas e aos anseios do grupo, culminando para o fortalecimento da cultura do povo Kambeba.

Palavras-chave: Kambeba; escola indígena; identidade.

Abstract: The Indigenous School Education constitutes itself in a process of confronting ethnic groups in experiencing, within the villages, a school model differentiated from non-indigenous patterns. This struggle becomes possible with the promulgation of the Federal Constitution of 1988, which aims an article to enable them to appropriate this claim. The school among

1 Universidade Federal do Amazonas (Ufam), Manaus, Amazonas, Brasil. 
the Kambeba of the Indigenous Territory of Barreira da Missão, Community Betel Tefé (AM), was incorporated and experienced by the community from that period on. Therefore, this text has as its central objective to analyze how the Kambeba of the Betel Tefé Community (AM) perceive the function of the Municipal Rural Indigenous School Padre Augusto Cabrolié in the cultural and identity strengthening of the ethnic group. The methodological journey used the hermeneutic-dialectic method, for the possibility of discussing the data, perceiving the intrinsic confrontations and tensions of this process. The results showed us that this Kambeba group perceives the school as a link that strengthens the community, being the place where the rescue of beliefs, traditions, and customs is being developed by the teachers in the classrooms, and the Kambeba student has appropriated unique elements of culture and built new meanings that are necessary for identity strengthening. The conclusions show that the school that once was the stage for homogenization and denial of ethnic differences is currently the place of new possibilities, as it seeks to meet the expectations and aspirations of the group, culminating in the strengthening of the culture of the Kambeba people.

Keywords: Kambeba;indigenous school; identity.

\section{INTRODUÇÃO}

O auge do protagonismo indígena foi nos anos de 1970 e 1980. Esses anos foram marcados pelos movimentos sociais, assim como pela luta por uma escola diferenciada para os grupos étnicos. Isso foi consequência da ação dos movimentos indígenas que lutavam pelo reconhecimento das especificidades e características próprias dos povos, bem como pela autonomia na organização de uma escola que priorizasse os conhecimentos tradicionais e, consequentemente, valorizasse as identidades étnicas.

Em 1988, podemos encontrar as primeiras realizações em termos legais quanto às reivindicações feitas pelos movimentos indígenas, referentes à apropriação da escola pelos indígenas. O tema foi contemplado no escopo da Constituição Federal (CF) de 1988, no seu artigo 210. Nele, descreveu-se algo que indicava o caminho para se pensar a escola indígena diferenciada, priorizando o desenvolvimento das atividades concebidas em torno da cultura e na língua materna, algo que, até então, era considerado desnecessário dentro da concepção não indígena de escola para os índios.

A escola indígena, concebida como supramencionada, construiu-se a partir da CF de 1988. Partindo daí, observou-se que, na Lei de Diretrizes e Bases da 
Educação (LDB 9.394/96), o tema passou a ser sistematizado com mais detalhes. Outro documento que consolidou vários pontos com a finalidade de encurtar distâncias entre a teoria e a prática foi o Referencial Curricular para Educação Escolar Indígena (Rcnei), de 1998, o qual fez inúmeros apontamentos e esclareceu situações pertinentes da organização pedagógica dessa escola diferenciada.

As demais resoluções e documentos jurídicos que foram incorporadas nessa discussão corroboram para a construção de uma política de autoafirmação das identidades étnicas, tendo na escola diferenciada um instrumento para esse fim. O documento final da I Conferência Nacional de Educação Escolar Indígena (1998; 2014) e as resoluções n. 5, de 22 de junho de 2012, e n. 1, de 7 de janeiro de 2015, discorrem sobre isso, sendo específicos nas tratativas que discutem a adequação da escola indígena que visa ao fortalecimento das identidades culturais.

É dentro desse contexto, de construção de significados, de autoafirmação da identidade indígena, de tomada de território, que este estudo é apresentado. Trata-se de uma explanação teórica e epistemológica, que busca analisar como os Kambeba da Comunidade Betel Tefé, AM, percebem a função da Escola Municipal Rural Indígena Padre Augusto Cabrolié no fortalecimento cultural e identitário de seu povo, a fim de contribuir com a discussão que apresenta a escola indígena como um dos espaços de produção de conhecimentos científicos e tradicionais, conferindo empoderamento e autonomia ao grupo.

Faz-se necessário esclarecer que, nas terras indígenas da Barreira da Missão², residem povos das etnias Kambeba, Tikuna e Kokama, considerando que esta pesquisa optou por representar o ponto de vista dos Kambeba, pois se percebeu, em contato anterior com esse grupo, que a equipe da escola era a principal idealizadora dos eventos culturais e que as reuniões com os comunitários partiam das demandas da escola, apresentando o desafio de manter os costumes ativos, garantindo que os alunos aumentassem o vocabulário na língua materna, com o intuito de mantê-la em uso, visando à continuidade dos aspectos culturais do grupo. Isso, de certa forma, constitui-se num grande desafio, tendo em vista que a comunidade fica nas proximidades de Tefé, AM, contexto em que o trânsito entre índios e não índios é livre.

2 Área indígena localizada no município de Tefé, Amazonas. 
Quanto ao marco metodológico, o estudo traz uma abordagem qualitativa, orientado pelo método hermenêutico-dialético, tendo em vista que pesquisas fundamentadas nesse método levam em consideração os aspectos socioculturais, econômicos, os movimentos históricos e suas contradições (MINAYO,2004). Basicamente, o texto está estruturado em quatro tópicos: a introdução, os marcos legais de efetivação da educação escolar Kambeba, o espaço de aprendizagem dos Kambeba e as considerações finais.

No primeiro tópico, abordam-se os amparos legais em que os Kambeba fundamentam o trabalho pedagógico na escola, seguidos das percepções do grupo em relação à instituição, ficando claro que eles a têm como instrumento para apropriação de conhecimentos tradicionais e científicos, num diálogo intercultural que gera autonomia ao grupo e fortalece os elementos culturais que são propulsores para identificação do coletivo.

\section{MARCOS LEGAIS E EFETIVAÇÃO DA EDUCAÇÃO ESCOLAR KAMBEBA}

Apresentar a organização da educação escolar do povo Kambeba da Barreira da Missão - Comunidade Betel - Tefé, AM,com ênfase nos seus sentidos/significados e valores, remete ao conhecimento de como ela está sendo constituída, quais processos educacionais estão sendo efetivados e quais princípios fundamentam essa construção.

De acordo com o gestor da escola, A. L. M., o ensino em desenvolvimento está fundamentado à luz das leis brasileiras que garantem aos povos indígenas o direito à educação escolar indígena específica e diferenciada. Nessa perspectiva, ele indicou que a Escola Municipal Rural Indígena Padre Augusto Cabrolié procura seguir o que rege a Constituição Federal de 1988 e a Lei de Diretrizes e Bases da Educação Nacional (BRASIL-LDBEN, 1996), quando garantem aos índios processos próprios de ensino e aprendizagem. Nosso informante também observou que a equipe pedagógica da escola adota parâmetros legais de algumas resoluções específicas que dão diretrizes para a construção da escola indígena. Segundo ele: "É com base nesses princípios que nossa escola se encontra fundamentada".

Assim sendo, a escola entre os Kambeba é organizada com base nos preceitos estabelecidos, em primeiro lugar, na Constituição Federal de 1988 (BRASIL, 1988), artigo 210, que determina: “§ 2 ㅇ O ensino fundamental regular será ministrado 
em língua portuguesa, assegurada às comunidades indígenas também a utilização de suas línguas maternas e processos próprios de aprendizagem".

Nessa ótica, Almeida e Silva (2003) observam que, no presente momento, a atual legislação que trata sobre a educação escolar indígena brasileira não se fundamenta mais na distinção que, anteriormente, visava integrar e assimilar os povos indígenas aos ideais hegemônicos de origem ocidental, mas sim na incumbência de "[...] proteger, respeitar valorizar os saberes, as línguas, crenças, tradições e as formas de organização dos povos indígenas" Almeida e Silva (2003, p. 20).

Seguindo tal princípio constitucional, é assegurado ao povo Kambeba e a todos os indígenas brasileiros o direito de:

[...] permanecerem índios, isto é, de permanecerem eles mesmos com suas línguas, culturas e tradições. Ao reconhecer que os índios poderiam utilizar as suas línguas maternas e os seus processos de aprendizagem na educação escolar, instituiu-se a possibilidade de a escola indígena contribuir para o processo de afirmação étnica e cultural desses povos e ser um dos principais veículos de assimilação e integração. (GRUPIONI, 2002, p. 130).

Essa garantia enunciada na atual Legislação Magna brasileira é marco e ápice das conquistas indígenas no país, em especial na área da educação, haja vista que houve uma mudança qualitativamente significativa, uma vez que os povos indígenas deixaram de ser obrigados a integrarem-se aos processos sociais da ideologia ocidental, rompendo com ações constituídas e legalizadas anteriormente que os tratavam como seres estigmatizados, estereotipados e em via de extinção.

Nesse viés, as práticas de ensino da Escola Municipal Rural Indígena Padre Augusto Cabrolié seguem parâmetros estabelecidos pela legislação brasileira que garantem o direito à "[...] Educação Escolar Indígena, socialmente diferenciada, requerida pelos povos indígenas e almejada para impor o respeito e a preservação das diferenças étnicas, linguísticas e culturais dos povos indígenas" (SOUSA; CARVALHO, 2017, p. 47).

Com a atual Constituição Federal (BRASIL, 1988), os indígenas passaram a ser reconhecidos como povos/pessoas com culturas próprias e modos de organização de vida peculiares. Essa análise é tecida por Grupioni (2002, p. 131) ao destacar que a maior conquista vinculada à atual Constituição refere-se ao abandono da postura assimilacionista, que sempre buscou "[...] incorporar os 
índios à 'comunidade nacional', vendo-os como uma categoria étnica e social transitória fadada ao desaparecimento". O autor acrescenta que a aprovação do novo texto constitucional favoreceu aos povos indígenas a obtenção do direito "[...] à diferença cultural, isto é, o direito de serem índios e de permanecerem como tal" (GRUPIONI, 2002, p. 131).

Visando à efetivação dos direitos garantidos na Constituição de 1988, os Kambeba, desde o início da década de 90 do século XX, iniciaram a participação em movimentos indígenas brasileiros, como nos Encontros da Comissão de Professores Indígenas dos Estados do Amazonas, Roraima e Acre (Copiar), que buscavam discutir e elaborar projetos que tinham por objetivo fortalecer os processos da educação escolar na ótica da implementação da escola específica e diferenciada, como afirma o gestor A. L. M. da Escola Municipal Rural Indígena Padre Augusto Cabrolié:

Eu participo do movimento desde muito tempo, buscando a Educação escolar Indígena desde 1994, a partir do momento que foi os primeiros princípios a que vinha nortear a Educação Escolar Indígena em nível do Norte do Brasil, a Declaração de Princípios foi o primeiro documento que a gente viu nascer, e hoje dentro do contexto de educação eu vejo que está acontecendo; a Educação Escolar Indígena, ela vem fluindo, já colhemos os frutos de uma luta que os povos sempre queriam, apesar das distâncias de alguns, mas já temos conseguido hoje estabelecer esse conhecimento.(fonte oral).

A Declaração de Princípio, mencionada no depoimento do gestor, consiste no documento elaborado pelo "Movimento de Professores Indígenas do Amazonas, Roraima e Acre durante o IV Encontro Anual" - realizado na cidade de Manaus, em 1991 -, o qual trata dos projetos para efetivação da escola indígena (documento do Conselho Indigenista Missionário [CIMI] NORTE I, de Tefé, AM, 1990). No documento, consta ainda "que os currículos das escolas indígenas devem ser elaborados com as comunidades, organizações e lideranças indígenas que poderão contar com a ajuda de entidades públicas ou não governamentais, a critério dos índios".

Os movimentos indígenas, com atuação dos professores, lutavam pela escola com necessidade do currículo diferenciado da maneira de ensinar do "branco" ocidental. Esse currículo diferenciado tornou-se pauta dos diversos encontros realizados pelos professores e os enfrentamentos empreendidos pelos grupos contribuíram significativamente para aquisição do espaço de aprendizagem, atendendo a certo padrão. 
Analisando essa dinâmica, é possível registrar que o movimento indígena fortalece os grupos para a apropriação do espaço escolar. Sabe-se que os processos educacionais estão acontecendo e que são inúmeros os avanços na efetivação desse ambiente. Contudo as reivindicações são de que esta escola não fosse apenas mais um espaço físico nas aldeias, pois "não basta o poder público construir escolas nas aldeias, se não reconhecer a necessidade de uma educação diferenciada, sob a coordenação dos índios" (GERSEN BANIWA, 1998, p. 59).

Nesse sentido, o povo Kambeba da Betel empenha-se em construir um espaço de aprendizagem que interage com a comunidade, buscando unir conhecimentos, relacionando o tradicional com o científico, pois eles compreendem que é necessário viver os processos de interculturalidade dentro da escola diferenciada. A partir disso, percebe-se que

[...] os povos indígenas estão conscientes de que a escola pode ser, dentro da dinâmica de reestruturação social e cultural em que está inserida, um instrumento de fortalecimento do que lhes é próprio, além de ser um veículos de conhecimentos universais. Em terras indígenas, a escola deixou de ser uma imposição para se tornar uma reivindicação dos povos indígenas. (BRASIL, 2002, p. 23).

É consensual entre os Kambeba que a Escola Municipal Rural Indígena Padre Augusto Cabrolié é fruto dos movimentos indígenas. Assim, o povo busca efetivar processos educativos que primam pela autonomia do coletivo e levam aprendizagem aos alunos, contando com a participação de professores indígenas, sendo um dos avanços que fazem parte da construção desse espaço educativo.

\section{O ESPAÇO DE APRENDIZAGEM DOS KAMBEBA DA BETEL}

A Escola Indígena é definida administrativamente "como o estabelecimento de ensino localizado no interior das terras indígenas voltado para o atendimento das necessidades escolares expressas pelas comunidades indígenas" ${ }^{\prime 3}$. A Escola Municipal Rural Indígena Padre Augusto Cabrolié foi construída na aldeia dos Kambeba nessa perspectiva e visava ao atendimento de reivindicações do grupo étnico.

\footnotetext{
3 Parecer n. 14/99, encaminhado ao Conselho Nacional de Educação - Câmara de Educação, aprovado em 14/09/1999 a respeito das Diretrizes Curriculares Nacionais da Educação Escolar Indígena.
} 
O modelo implantado trouxe, contudo, o formato das escolas para não indígenas: sua estrutura é bastante precária e trata-se de um ambiente que, a princípio, foi adaptado a fim de oferecer aos alunos indígenas a Educação institucionalizada. Em 2016, foram construídas outras salas de aula para Escola Municipal Rural Indígena Padre Augusto Cabrolié, possibilitando a ampliação e democratizando o acesso à educação formal para o grupo, de forma a gerar avanços significativos para autonomia dos Kambeba. Sabe-se que há um grande descompasso entre o que se prevê nos ordenamentos jurídicos para as escolas indígenas e as realidades reconhecidas na implementação desses espaços.

Todavia esses percalços não se apresentam como impedimentos para a escola que os Kambeba estão construindo. A Augusto Cabrolié, segundo o gestor A. L. M., está contribuindo para o fortalecimento da identidade cultural do grupo. Contudo, no início da sua implantação, esse pensamento foi confrontado, pois, ao mesmo tempo em que parte do grupo percebia a necessidade de avançar para a educação escolar, os mais antigos das aldeias refutavam a intencionalidade dessa escola.

Sobre essa questão, o professor $01^{4}$ informa que:

[...] foi depois de muito tempo que os indígenas foram aceitando a escola na aldeia, principalmente os mais antigos, como minha avó. Ela dizia que os brancos iam ensinar mais coisa que eram diferentes das nossas, mas só que temos que aprender, mesmo, os conhecimentos dos brancos. (fonte oral).

Houve, portanto, certa resistência dos anciãos em aceitar a escola como um espaço que poderia ser aliado aos interesses do coletivo. Autores como Albuquerque e Grando (2012, p. 8) partem do ponto de vista no qual "a escola pode ser um espaço de fortalecimento de identidades coletivas, de fortalecimento de lutas, de apropriação da história vivida individual e coletiva".

Alguns comunitários não compartilhavam desse ideal, o que era previsível, dada a história de contato dos indígenas que sofreram em princípio. O relato do professor 02 reforça a resistência inicial dos anciãos Kambeba em permitir a chegada da escola para o grupo:

Desde que me entendi como pessoa e conhecendo nossa história, os mais velhos, eles prezavam para que os filhos não estudassem; até meu pai, ele

\footnotetext{
${ }^{4}$ Entrevista concedida na Comunidade Betel, em 2018.
} 
disse que não aprendeu na escola, ele aprendeu sozinho, porque meu avó dizia que aprendia em casa, então a escola na comunidade foi no começo um conflito, eles não queriam que os filhos saíssem para estudar. Hoje está diferente, abriram mão, tem a escola, tanto podem estudar aqui na Betel como ir para outros lugares, ou seja, eles aceitam com bons olhos o trabalho feito aqui na escola. (fonte oral).

Associando ao depoimento do participante, recupera-se a fala de Santos (2008, p. 292) na qual afirma que "os camponeses, os povos indígenas e os imigrantes estrangeiros foram os grupos sociais mais diretamente atingidos pela homogeneização cultural, descaracterizadora das suas diferenças". Em vias gerais, foram essas as conjunturas políticas de implantação do ambiente escolar e, por isso, os indígenas mais antigos resistiram, de certa forma, à chegada da escola, percebendo que haveria mudanças nos hábitos do grupo.

Sobre isso, Sacristán (2011, p. 32) afirma que, "em suas origens, a escola cumpria uma missão de domesticação e adestramento moral, quando os aparelhos ideológicos dos Estados modernos não tinham força moral nem meios apropriados para impor uma ideia de cidadãos que se comportasse adequadamente". A escola, de forma geral, teve uma construção histórica com críticas acentuadas, principalmente ao que se refere aos grupos étnicos, dada a política e os processos homogeneizadores a que os indígenas eram submetidos, inibindo as diferenças, o que demonstrava formas de violências às especificidades do índio quanto a sua forma de aprender. Desse modo, as formas de expressão cultural estavam em jogo nesses confrontos, o que atingia diretamente a representação dos sujeitos e suas respectivas identidades.

A consciência da sobreposição de valores e imposições vivenciadas pelos povos anteriormente faz parte do discurso dos Kambeba, principalmente quanto à maneira como a instituição escolar atuou, com uma educação com viés que buscava homogeneizar ou assimilar os elementos culturais próprios da cultura indígena. Nesse sentido, posicionando-se sobre isso, temos o depoimento do gestor A. L. M., em que ele afirma que:

A escola foi um meio utilizado para perda de muitas identidades étnicas do nosso país, nós estamos fazendo o contrário, nós estamos querendo que a escola seja uma das protagonistas em trazer de volta as nossas histórias, refazendo o caminho de volta para a comunidade; então é essa situação que 
a gente está vendo hoje, e relacionar os dois conhecimentos, tradicional e científico, pra ser trabalhado pelo professor dentro da escola.(fonte oral).

O depoimento expressa a existência da consciência das dificuldades a que os indígenas foram submetidos, mas que eles buscam com seriedade transformar o histórico das formas intolerantes que os antepassados vivenciaram dentro da escola, indicando outro caminho, que demonstra superação das práticas nesse ambiente. Nesse sentido, Silva afirma que:

[...] ao aceitar a escola, e mesmo reivindicá-la, os índios a têm "ressignificado", conferindo-lhe um novo valor: a possibilidade de decifrar o mundo "de fora", "dos brancos". Em síntese, decifrar a nova realidade advinda do contato. Longe de ser uma "adesão" a nosso modelo, é, nesse sentido, uma estratégia de resistência. (SILVA, 1999, p.65).

Dessa forma, observa-se que é possível que a escola funcione, concordando com a perspectiva dos Kambeba da Betel, de maneira que envolva a comunidade num ambiente que compactua para os projetos societários do grupo, tendo nela um lugar em que práticas possam ser ressignificadas. Corroborando tal pensamento, Silva (1999) demonstra que os indígenas têm trabalhado não só a fim de reivindicar o espaço escolar, mas, principalmente, de ressignificá-lo.

De acordo com a professora 03, do $1^{\circ}$ ano do Ensino Fundamental, o planejamento escolar é diferenciado, incluindo temas que sejam pertinentes ao grupo e favoreçam os aspectos culturais Kambeba. As crianças aprendem as pinturas com grafismo e seus significados, palavras do dia a dia e músicas na língua materna. Em seu depoimento, ela diz: "[...] trabalhar com o barro, pedrinhas, pintura com urucum mostra para as crianças nossas raízes, esse modo de desenvolver as atividades fortalece a nossa cultura indigena" (fonte oral).

Constata-se na fala da professora que a escola avança, no sentido de proporcionar aos alunos indígenas a vivência de suas culturas dentro da sala de aula. Acredita-se que um ponto favorável para esse fim refere-se ao fato de a professora ser indígena e lutar pela mesma causa. Sabe-se que o papel da escola indígena é justamente esse, porém, em realidades como as do contexto amazônico, isso muitas vezes não acontece, de forma que "alunos indígenas recebem do poder público o mesmo tratamento destinado às escolas ribeirinhas" (WEIGEL, 1995).

Segundo Libâneo (1985, p. 15), "a escola existe, pois, para propiciar a aquisição dos instrumentos que possibilitam o acesso ao saber elaborado (ciência), 
bem como o próprio acesso aos rudimentos desse saber", os conhecimentos são sistematizados e transmitidos às gerações dentro do ambiente escolar.

Para o professor 04, a Augusto Cabrolié tem uma função específica para o coletivo. No seu depoimento, ele afirma que:

Temos uma compreensão bem clara sobre a função da escola, nós optamos por trabalhar a Educação Escolar Indígena e a escola tem essa função, porque querendo ou não nós temos três professores bilíngues e a gente, quando vai fazer um evento, buscamos integrar tanto a comunidade quanto a escola, ela está fazendo o papel de socialização com a comunidade em geral, trabalhando para que esta escola seja um meio de trazer de volta muito da nossa cultura que esteve adormecida.(fonte oral).

No depoimento do professor 04, constata-se que a escola é processo de luta e mantê-la na comunidade requer posicionamento do grupo. Sobre tal questão, Albuquerque e Grando (2012, p.8) argumentam que:

Essa escola, que é evidenciada por alguns educadores como espaço que fez diferença na sua formação, é também pauta de reivindicação dos povos indígenas. [...] Como parte da autonomia das comunidades indígenas, a educação aparece como um dos principais elementos de construção dessa autonomia e possibilidade de intervenção dos indígenas no mundo "dos brancos".

Nas palavras do professor 05, a escola é imbuída do papel de ensinar. Ele compartilha do pensamento dos demais participantes, afirmando que

[...] a escola tem a função de ensinar o científico, mas também trabalhar a cultura do povo, tendo o dever de sensibilizar o povo e dizer que eles são pertencentes àquele grupo étnico, e é isso que estamos fazendo na sala de aula, fortalecendo a nossa identidade.(fonte oral).

O depoimento evidencia que a escola está na comunidade com um papel que lhe é específico: o desenvolvimento de processos educativos que reflitam uma educação intercultural, sendo favorável à luta do movimento indígena.

Outros depoimentos expressam ser

Bom ter a escola na nossa comunidade, ela fortalece a identidade, pois os professores ensinam o conhecimento científico e o tradicional, as atividades que passam na sala de aula estão relacionadas ao que fazemos aqui, o professor bilíngue dar aula no contraturno, ensinando toda comunidade como falar nossa língua para manter nossa cultura viva. (fonte oral). 
A partir dos depoimentos, é possível entender o quanto a escola não é um local neutro, mas um lugar em que relações de poder estão sendo definidas e é preciso ter bem claro que essas relações definem modelos com padrões preestabelecidos. Ter professores indígenas ministrando aulas nesses espaços é, portanto, fundamental para que o grupo continue avançando na escola que valoriza os costumes, as crenças, as raízes étnicas, ou seja, os elementos da cultura indígena.

Por outro lado, a escola, mesmo estando localizada na aldeia, não está imune às práticas que não priorizam a cultura indígena, dados alguns fatores que podem influenciar para o insucesso dessa escola. Considera-se, nesse sentido, a efetivação do quadro de profissionais da educação que sejam também indígenas. A Escola Municipal Rural Indígena conta com 18 professores indígenas que trabalham com afinco no desenvolvimento de projetos pedagógicos com foco na identidade do coletivo.

Todavia, na escola indígena da Betel, a equipe pedagógica ainda conta com professores não indígenas. Essa é uma realidade recorrente em comunidades longínquas, constituindo-se em fator que não colabora com a perspectiva da educação escolar indígena. Isso acontece devido à carência de profissionais indígenas com a qualificação profissional para exercer o magistério. O coordenador indígena J. U. N.confirma essa realidade em sua fala: "[...] temos uma boa quantidade de professores indígenas, mas ainda contamos com professores não indígenas que dão aula para o nosso povo" (fonte oral). De certa forma, essa atuação de professores não indígenas dentro das escolas indígenas colabora para o processo intercultural acontecer de forma unilateral.

A partir da análise das entrevistas e da observação da dinâmica escolar, à luz das teorias e legislação educacional, constatou-se que a escola para os povos indígenas ainda está em processo de consolidação, necessitando de políticas efetivas não apenas no nível nacional, pois as escolas indígenas em que as Secretarias Estaduais de Educação estão como principais responsáveis apresentam, majoritariamente, uma estrutura diferente, sendo mais bem assistidas em comparação com aquelas escolas cuja manutenção está a cargo das Secretarias Municipais de Educação. Por isso as reivindicações seriam para políticas efetivas para toda a rede de escolas dos indígenas do contexto nacional.

Pode-se dizer, ainda, que um conjunto de fatores leva ao sucesso da construção da escola indígena. Nesse caso, os Kambeba precisam de que o quadro de 
professores seja formado por indígenas, assim como melhorar a estrutura física da escola, colocando-a nos padrões almejados por eles, tornando-se possível viabilizar a escola que atua no desenvolvimento e na autoafirmação da identidade indígena.

\section{ALGUMAS CONSIDERAÇÕES}

As reflexões feitas neste estudo buscaram atender aos objetivos propostos, realizando análise de como os Kambeba percebiam o papel da Escola Municipal Rural Indígena Padre Augusto Cabrolié para o fortalecimento da identidade do povo Kambeba. Nesse sentido, buscou-se conhecer essa realidade e os modos de desenvolvimento dos trabalhos pedagógicos que culminavam para a obtenção dos anseios aqui expostos.

Nesse sentido, ficou constatado que a equipe escolar indígena da Betel tinha a escola como um instrumento para revitalização da língua materna, sendo ela agenciadora dos eventos e atividades que envolviam a coletividade. Então, a escola que um dia havia sido palco para homogeneização e negação das diferenças étnicas é, atualmente, considerada como o lugar onde acontece o resgate das crenças, das tradições e dos costumes indígenas. Constatou-se também que os temas trabalhados pedagogicamente na escola dialogam estreitamente com as práticas culturais do povo Kambeba, sendo articulados com os demais conteúdos dos diversos componentes curriculares oferecidos aos alunos.

Assim, fica clara a dedicação dos professores indígenas da Escola Municipal Rural Indígena Padre Augusto Cabrolié em oferecer aos alunos atividades que priorizam a historicidade do grupo. Isso se constitui em instrumento que valoriza a identidade coletiva, portanto fortalece o grupo para um contexto de educação escolar ainda mais amplo, pois a escola torna-se referência de educação diferenciada, que respeita as diferenças, tornando-se mais um espaço de autoafirmação identitária.

Nesse sentido, é imprescindível que as comunidades indígenas recebam do poder público o devido apoio financeiro para financiar processos de formação específicos indígenas e, a partir dessa ação, consigam fortalecer seus processos pedagógicos, desenvolvendo pesquisas e tendo a oportunidade de divulgar sua produção cultural e seus materiais didático-pedagógicos, como estratégia de valorizar o conhecimento tradicional e fortalecer a identidade étnica. 


\section{REFERÊNCIAS}

ALBUQUERQUE, Marcos Alexandre dos Santos; GRANDO, Beleni Salete. Introdução: sobre noções nativas e antropológicas em educação indígena. In: TASSINARI, Antonella Maria Imperatriz; GRANDO, Beleni Saléte; ALBUQUERQUE, Marcos Alexandre dos Santos. Educação indígena: reflexões sobre noções nativas de infância, aprendizagem e escolarização. Florianópolis: UFSC, 2012. p. 7-14.

ALMEIDA, Eliene Amorine; SILVA, Rosa Helena Dias. A política de educação escolar indígena na década de 90. Amazônida: Revista do Programa de Pós-Graduação em Educação da Ufam, ano 8, n. 1,jan./jun.2003.

BRASIL. Constituição da República Federativa do Brasil de 1988. Brasília, 5 de outubro de 1988. Disponível em:www.planalto.gov.br/legislação. Acesso em: 1으 mar. 2019.

BRASIL. Lei n. 9.394, de 20 de dezembro de 1996.Lei de Diretrizes e Bases da Educação Nacional. Brasília-DF, 1988. Disponível em:www.planalto.gov.br/legislação. Acesso em: 10 mar. 2019.

BRASIL. Ministério da Educação e do Desporto. Secretaria de Educação Fundamental. Referencial. Referencial Curricular Nacional para Educação Indígena. Brasília: MEC/SEF, 1998.

BRASIL. Ministério da Educação. Secretaria de Educação Fundamental - Coordenação Geral de Apoio às Escolas Indígenas. Referenciais para a formação de professores indígenas. Brasília-DF, 2002.

BRASIL. Ministério da Educação. Secretaria de Educação Continuada, Alfabetização, Diversidade e Inclusão. Documento Final da I Conferência Nacional de Educação Escolar Indígena. Brasília: Secadi, 2014.

BRASIL. Ministério da Educação. Conselho Nacional de Educação. Conselho Pleno. Resolução n. 5, de 22 de junho de 2012. Brasília-DF: MEC,2012.

CONSELHO INDÍGENA MISSIONÁRIO (CIMI). Regional Norte I. Encontro dos professores do Amazonas e Roraima. Manaus, 1990.

GERSEN BANIWA. Índios defendem identidade étnica. In: SEMINÁRIO DE EDUCAÇÃO ESCOLAR INDÍGENA DO ESTADO DO AMAZONAS, 1., Educação Escolar Indígena do Estado do Amazonas Projeto Pira-Yawara. 1998, Manaus. Relatório [...]. Manaus: Instituto de Educação Rural do Amazonas, 1998. 
GRUPIONI, Luís Donisete B. (Org.). As leis e a educação indígena: Programa Parâmetros em Ação de Educação Escolar Indígena. Brasília: Ministério da Educação,Secretaria de Educação Fundamental, 2002.

LIBÂNEO, José Carlos. Democratização da escola pública: a pedagogia crítico-social dos conteúdos. São Paulo: Loyola, 1985.

MINAYO, Maria Cecília de Souza. O desafio do conhecimento: pesquisa qualitativa em saúde. 8.ed. São Paulo: Hucitec, 2004.

SACRISTÁN, José Gimeno. A educação obrigatória: seu sentido educativo e social. Tradução de Jussara Rodrigues. Porto Alegre: Artmed, 2011.

SOUSA, Maria Lucimar Jacinto; CARVALHO, Maria de Lurdes Dias. Educação escolar indígena: legislação, currículo e organização. Pará de Minas, MG: VirtualBooks Editora, 2017.

SANTOS, Boaventura de Sousa. A gramática do tempo: para uma nova cultura política. 2. ed. São Paulo: Cortez, 2008.

SILVA, Rosa Helena Dias. A autonomia como valor e articulação de possibilidades: o movimento dos professores indígenas do Amazonas, de Roraima e do Acre e a construção de uma política de educação escolar indígena. Cadernos Cedes, ano XIX, n. 49, dez. 1999.

WEIGEL, Valéria. Educação, cultura e globalização: um debate sobre a identidade étnica e a escola. Contexto \& Educação, Ijuí, ano 9, n. 38, p. 40-5, 1995.

\section{Sobre os autores:}

Kácia Neto de Oliveira Fonseca: Mestre em Educação pela Universidade Federal do Amazonas (UFA), com pesquisa em andamento na Educação Escolar Indígena. Especialista em Gestão de Currículo pela Universidade do Estado do Amazonas (UEA). Graduada em Pedagogia pela UFA. Professora na Secretaria de Estado de Educação e Qualidade do Ensino. Experiência na área de Educação, com ênfase em Educação. E-mail: kacia_neto@hotmail.com, Orcid: https://orcid.org/0000-0003-4506-676X

Jaspe Valle Neto: Doutorando em Educação na Faculdade de Educação da Universidade Federal do Amazonas (Ufam). Mestre em Educação pela Ufam. Graduado em Pedagogia pela Universidade Paulista. Servidor público exercendo a função de assessor pedagógico, junto ao Núcleo Pedagógico do Centro de Mídias de Educação do Amazonas (Cemeam-Seduc/AM). Experiência na área de 
docência em Educação junto aos alunos de graduação e pós-graduação (lato sensu) em Ciências Humanas, com ênfase em Educação e Multiculturalismo, Educação Escolar Indígena, Orientação de Estágio Supervisionado, Metodologia da Pesquisa e da Produção Científica, Projeto de Pesquisa, Filosofia da Educação, Psicologia da Educação, Gestão Educacional, Sociologia da Educação, História da Educação, Educação Infantil, Orientação de Trabalhos de Conclusão de Curso,entre outros.

E-mail: jaspe@seduc.net, Orcid: https://orcid.org/0000-0002-5917-2013

Valeria Augusta Cerqueira de Medeiros Weigel: Doutora em Ciências Sociais (Antropologia) pela Pontifícia Universidade Católica de São Paulo. Mestre em Educação pela Universidade de São Paulo. Graduada em Letras e Artes pela Universidade Federal do Pará.Professora associada IV da Universidade Federal do Amazonas. Tem experiência na área de Educação, com ênfase em Antropologia Educacional, atuando principalmente nos seguintes temas: educação indígena, educação amazônica, educação e cultura, educação e meio ambiente e identidade étnica. E-mail:valeriaweigel@hotmail.com, Orcid: https://orcid.org/0000-0002-1247-5674

Recebido em 8 de maio de 2020.

Aprovado para publicação em 30 de maio de 2020. 


\title{
Etnomatemática e educação escolar indígena: ensino por meio de uma atividade piscatória
}

\author{
Ethnomathematics and indigenous school education: \\ teaching through a fishing activity
}

\author{
José Roberto Linhares de Mattos ${ }^{1}$ \\ Sandra Maria Nascimento de Mattos² \\ Gamalonô Surui ${ }^{3}$
}

DOI: http://dx.doi.org/10.20435/tellus.v0i42.691

\begin{abstract}
Resumo: Este trabalho envolve a cultura da etnia Paiter Suruí e o ensino na escola indígena. Utilizamos como metodologia de pesquisa a observação participante, com características etnográficas, em uma prática piscatória tradicional, rodas de conversa e entrevistas com professores indígenas. $\mathrm{O}$ objetivo foi mostrar conexões de conteúdos curriculares da educação escolar indígena com essa prática cultural da etnia. Baseando-nos no Programa Etnomatemática, identificamos diferentes atividades que são realizadas para os conteúdos escolares, com os conhecimentos cotidianos, que empoderam o professor e seus alunos cultural, social, política e afetivamente. Constatamos, por meio de relatos de professores indígenas, que a prática cultural observada é utilizada no ensino das disciplinas Matemática, Língua Materna e Cultura Indígena.
\end{abstract}

Palavras-chave: práticas; piscatória; Etnomatemática; indígena.

Abstract: This work involves the culture of the Paiter Suruí ethnic group and the teaching in the indigenous school. As a research methodology, we used participant observation, with ethnographic characteristics, in a traditional fishing practice, conversation circles and interviews with indigenous teachers. The goal was to show connections of curricular contents in indigenous school education with this cultural practice of the ethnicity. Based in Ethnomathematics Program, we identified different activities carried out for school content, with this traditional knowledge, which empower the teacher and his students culturally, socially, politically and affectively. We have found, through reports

\footnotetext{
1 Universidade Federal Fluminense (UFF), Niterói, Rio de Janeiro, Brasil.

2 Universidade Federal Rural do Rio de Janeiro (UFRRJ), Seropédica, Rio de Janeiro, Brasil.

3 Secretaria de Educação do Estado de Rondônia, Cacoal, Rondônia, Brasil.
} 
of indigenous teachers, that the observed cultural practice is used in teach of Mathematics, Native Language and Indigenous Culture.

Keywords: practices; fishing; Ethnomathematics; indigenous.

\section{INTRODUÇÃO}

Os povos indígenas preservam tanto a fauna quanto a flora, por meio da cultura passada pelos anciãos ou sabedores, como eles os chamam, aos jovens indígenas da etnia. Seus saberes e fazeres garantem que as tradições do povo sejam resguardadas e transmitidas de geração a geração. Entre essas tradições, temos uma prática piscatória denominada "bater timbó", que é utilizada desde antes do contato com os não indígenas.

Os saberes e fazeres das etnias indígenas são protegidos por leis nacionais e internacionais, entre essas, temos como principais a Declaração das Nações Unidas sobre os Direitos dos Povos Indígenas (Drips) (ONU, 2008), que garante a revitalização da cultura e o direito à educação de acordo com seus métodos culturais; e a Constituição Federal Brasileira (BRASIL, 1988), que reconhece os indígenas, em suas diferentes etnias, como organização social com costumes, crenças e tradições próprias.

Com mesmo grau de importância, temos, no que diz respeito à educação escolar indígena propriamente dita, a Lei de Diretrizes e Bases da Educação Nacional (Ldben), n. 9.394/96 (BRASIL, 1996), que afirma que a educação escolar indígena deve ser intercultural, bilíngue e diferenciada, preservando assim a identidade, os costumes e as tradições de cada etnia. O Referencial Curricular Nacional para as Escolas Indígenas (Rcnei) (BRASIL, 1998) e as Diretrizes Curriculares Nacionais para a Educação Escolar Indígena da Educação Básica (Dcneei) (BRASIL, 2013) asseguram, além de um currículo prescrito, um viés local, priorizando anseios, necessidades e interesses das comunidades indígenas.

Baseados nessas leis, em autores como D’Ambrosio (2011, 2008), Domite (2009), Vergani (2007), Scandiuzzi (2009), Grupione (1994), Gallois (2006), Sampaio (2006), Mattos (2020), Mattos e Ferreira Neto (2019, 2016), Mattos e Mattos (2019, 2018), Mattos (2018), Mindlin (1985, 2006) e nas próprias experiências da etnia Paiter Suruí sobre as práticas piscatórias, em especial o bater 
timbó, realizamos uma pesquisa de campo com características etnográficas, com observação participante e conversas com membros da etnia. O objetivo foi identificar conteúdos escolares, em especial de matemática, explorados pelo professor indígena em sala de aula, relacionados com a tradicional pescaria de bater timbó. Nessa perspectiva, antes de buscar as atividades matemáticas inerentes à pescaria, fomos entender como essa prática era desenvolvida de acordo com a tradição dos Paiter Suruí. Para isso, participamos da pescaria tradicional de bater timbó que foi realizada em dois dias em um rio na Floresta Amazônica.

De acordo com o que observamos, foi possível identificar algumas atividades relacionadas à matemática, bem como a outras diferentes disciplinas que o professor indígena trabalha em sala de aula. O saber notório impregnado na prática piscatória de bater timbó dos Paiter Suruí, desde o dia anterior até a finalização desta, no dia seguinte ao início da pesca, deixa-nos antever conexões com o ensino e a aprendizagem tomando por base o Programa Etnomatemática. Dá um novo olhar para uma prática desenvolvida com naturalidade desde os primórdios da etnia. Ao realizá-la, os Paiter Suruí conseguem preservar a cultura, retiram o alimento que é distribuído para os membros participantes, asseguram a língua materna e resguardam as histórias, os cantos e os mitos que envolvem tal prática.

Verificamos a preocupação com a sustentabilidade e a preservação da floresta, da fauna e da flora, já que é tradição do povo assegurar que as futuras gerações tenham acesso à mesma biodiversidade encontrada atualmente. Observamos que essa pescaria é realizada coletivamente e envolve tanto homens como mulheres, cada qual com seus afazeres. Assim, tomamos como justificativa a necessidade de adequar a matemática acadêmica à vivência da etnia para possibilitar uma ressignificação da matemática escolar. Em suma, pudemos constatar que os saberes e fazeres da etnia são repletos de uma matemática própria que pode ser levada para a sala de aula, pelo professor indígena, para ressignificar a matemática escolar. Dessa forma, a aprendizagem dos alunos torna-se mais atraente, envolvente e significativa, por estar contextualizada na cultura da etnia.

\section{OS PAITER SURUÍ E A EDUCAÇÃO (ESCOLAR) INDÍGENA}

Paiter Suruí de Rondônia é um povo indígena que ocupa a Terra Indígena (TI) Sete de Setembro, demarcada, nos estados de Rondônia e Mato Grosso, com 
uma extensão aproximada de $2.478 \mathrm{~km}^{2}$, tendo aldeias nos dois estados. Fala um idioma da família linguística Mondé, do tronco linguístico Tupi. Conforme o cacique da aldeia Paiter Linha 09, a palavra Paiter, que os não indígenas consideram significar "gente de verdade" (MINDLIN, 1985, p. 13), na realidade, significa "gente". Segundo ele, "Paiter Iter que significa gente de verdade". Porém, por uma simplificação na fala, eles são conhecidos como "Paiter". Após o contato com não indígenas, eles passaram a ser chamados, também, de Suruí.

A TI Sete de Setembro tem 27 aldeias, sendo 25 delas registradas pela Fundação Nacional do Índio (Funai), distribuídas por "estradas vicinais", denominadas "linhas". A aldeia Paiter Linha 09, na cidade de Cacoal, RO, foi aberta em 1982 por duas famílias e, atualmente, há 26 famílias, com um total de 197 pessoas, sendo a segunda maior aldeia da etnia. O nome Sete de Setembro teve sua origem devido ao nome do acampamento da Funai que foi criado no dia sete de setembro de 1968, exatamente um ano antes do primeiro contato.

Os afazeres cotidianos da aldeia são divididos entre homens e mulheres. São destinados às mulheres os afazeres da casa, o cuidado com as crianças e a produção de artesanato. As mulheres são responsáveis pela produção de peças artesanais em cerâmica, como a confecção de panela de barro, pelas cestarias e por tecer o algodão. O algodão é utilizado na confecção de redes, tipoias para carregar as crianças de colo, cintas e colares, bem como para utilizar no arco e flecha. Aos homens, são destinadas as atividades de caça, pesca (mulheres também podem pescar, não sendo com arco e flecha), construção de roças e confecção do arco, flecha e cocares.

A aldeia Paiter possui uma escola, chamada Escola Indígena Estadual Izidoro de Souza Meireles. Esta escola entrou em funcionamento em 1987, originalmente com o ensino fundamental. A partir de 2014, passou a ter o ensino médio, tendo sua primeira turma formada em 2016, com sete alunos. Conta com cinco professores indígenas e 13 professores não indígenas que atuam por revezamento. Em 2017/2018, atuavam na escola sete professores não indígenas. A escola tinha 35 alunos no ensino fundamental e 13 alunos no ensino médio.

A escola trabalha, no ensino fundamental, com a Pedagogia de Projetos, por meio do Projeto Mais Educação do governo federal. O Projeto Mais Educação visa fomentar, por meio de sensibilização, incentivo e apoio, outros projetos e ações 
de articulação de políticas sociais e implementação de atividades socioeducativas, oferecidas gratuitamente às crianças, adolescentes e jovens, para o fortalecimento cultural e o uso da língua Paiter. Agroecologia, cultura, artes, memória e histórias das comunidades tradicionais, artesanatos e acompanhamento pedagógico são as áreas desse projeto, que são trabalhadas na escola. Nessa perspectiva, o Projeto Mais Educação fortalece o trabalho do professor indígena em sala de aula, valorizando a cultura, a memória e a história do povo, por meio da participação e das práticas dos idosos, sabedores dos conhecimentos socioculturais da etnia.

A introdução da cultura, história, saberes e fazeres da etnia Paiter Suruí na escola não significa rejeição à cultura do não indígena em suas práticas escolares, mas um resgate do respeito e da valorização da identidade deles. Dessa forma, corrobora D’Ambrosio (2011, p. 43), quando este afirma que "conhecer e assimilar a cultura do dominador se torna positivo desde que as raízes do dominado sejam fortes". E, mais ainda, a "boa matemática acadêmica" (D’AMBROSIO, 2011, p. 43) só se torna boa para um povo quando ela se faz presente crítica e reflexivamente e se torna eficaz para o povo que pode percebê-la em suas práticas diárias.

O Programa Etnomatemática tem abraçado esse viés de respeito para com as culturas dos diferentes povos e etnias, conferindo dignidade aos saberes e fazeres produzidos e difundidos por eles. Segundo Vergani (2007, p. 32), "há uma ética associada ao conhecimento matemático, cuja prática é guiada pelo conhecimento de nós próprios, pela diluição das barreiras entre indivíduos, pela construção de uma harmonia ancorada no respeito, solidariedade e cooperação". Assim sendo, a plenitude de alunos e professor está associada à sua realidade sociocultural e ambiental.

Corrobora, ainda, Scandiuzzi (2009, p. 17), quando afirma que devemos "olhar para o indivíduo integral", inserido em um meio que se relaciona com outros socioculturalmente, e que cada qual tem uma história específica. Mas não podemos nos esquecer de que o meio ambiente desse povo "está inserido em outros meios ambientes", exigindo do professor "a busca do(s) caminho(s) escolhidos(s) e desejado(s) por esses indivíduos e/ou sociedades". Bicho (2018) reconhece que a Etnomatemática auxilia os professores indígenas a refletirem e planejarem práticas pedagógicas que marquem o lugar dos saberes e fazeres tradicionais indígenas. De acordo com o autor, "a Etnomatemática pode contribuir com o ensino da matemática escolar, uma vez 
que acena para o reconhecimento, valorização e dinamização cultural" (BICHO, 2018, p. 179), desconstruindo o ensino ocidental e abrindo espaço para práticas docentes que incorporem os conhecimentos indígenas.

\section{PRÁTICAS PISCATÓRIAS DOS PAITER SURUÍ: SABERES E FAZERES ANCESTRAIS}

Os saberes e fazeres indígenas guardam os valores, as crenças e os costumes que são passados pela cultura oral desse povo. Esses saberes e fazeres são formas de preservar, valorizar e garantir a transmissão dos hábitos tradicionais da etnia aos jovens. O manejo com a terra, o preparo da roça, a região e época de pesca são alguns desses saberes e fazeres que são desenvolvidos de maneira sustentável. Passar a tradição aos jovens é direito assegurado pela Drips (ONU, 2008), em que seus artigos 11 e 12 garantem a prática e revitalização de suas tradições e costumes culturais. Da mesma forma, o artigo 31 garante "o direito de manter, controlar, proteger e desenvolver o patrimônio cultural, seus conhecimentos tradicionais, suas expressões tradicionais e suas manifestações [...]" (ONU, 2008, p. 16), entre elas, a tradição oral para assegurar a propriedade intelectual do patrimônio cultural. É garantido, também, nos artigos 14 e 15, o direito à educação em consonância com seus métodos culturais de ensino e de aprendizagem, refletindo a diversidade cultural, suas histórias e suas tradições.

Segundo Grupioni (1994, p. 23), os indígenas não só defendem a natureza como são parte dela, "vivendo integrados à natureza, são ecológicos em essência e, assim, devem ser protegidos e preservados" tanto em sua cultura como em sua forma de manter as tradições e os costumes de alimentação. Sua sobrevivência depende do equilíbrio entre os saberes e fazeres ancestrais com a natureza. Para Gallois (2006, p. 80), "Um inventário de tradições culturais remete diretamente a questões metodológicas relacionadas à produção de conhecimento. Entre essas questões, uma das mais interessantes é a relação entre conhecimento e prática". Nesta perspectiva, as práticas piscatórias dos Paiter Suruí agregam saberes e fazeres restritos ao seu povo, renovado pela oralidade e pela prática aos seus descendentes.

De acordo com Sampaio (2006, p. 165 grifos do autor), "a cultura indígena aparece como o domínio social por excelência através do qual tais valores se expressam e a escola indígena como a via institucional para sua formalização e reprodução". 
Portanto o manejo piscatório faz parte da cultura indígena e sua preservação depende tanto da prática como da transmissão oral dos sabedores culturais. Ressaltamos que, após o contato com o não indígena, os Paiter Suruí apresentaram mudanças em suas tradições. Entretanto alguns hábitos continuam sendo desenvolvidos do mesmo jeito que o eram antes desse contato, como é o caso de algumas práticas piscatórias. Práticas essas perpetuadas pela necessidade de sobrevivência, preservação ambiental e manutenção da alimentação de subsistência.

O manejo ambiental do território indígena e a preservação da biodiversidade estão imbricados na cotidianidade sociocultural, sobretudo na sabedoria ancestral de como realizar a pesca. O peixe, alimento apreciado pelos indígenas, é importante para garantir a nutrição dos povos, mas, se não for preservado, pode entrar em extinção. Na etnia Paiter Suruí, as técnicas tradicionais para pescar são o arco e flecha e o bater timbó em épocas de seca. Tanto os homens como as mulheres realizam o bater timbó. Após o contato, houve o acréscimo da pesca com anzol, tarrafa e rede. A zona de pesca, o Morip ey Pãyah, é descrita como a região resguardada ao longo dos rios e igarapés onde o povo indígena Paiter Suruí realiza a pesca.

Este etnozoneamento é desenvolvido para a preservação da biodiversidade local. Geralmente, é realizada a pesca de subsistência, em que os indígenas adquirem o necessário ao consumo da família. Essa pesca é realizada de novembro a junho e somente com arco e flecha. Se atentarmos para a época realizada com arco e flecha, observamos que ela ocorre no período da desova dos peixes amazonenses, que varia de setembro a junho. É, portanto, uma forma de preservação dos ninhos reprodutivos e dos peixes em desenvolvimento, já que podem escolher qual peixe pegar, o que é uma maneira sustentável de garantir alimento para as gerações futuras.

No dia anterior à pescaria de bater timbó, os indígenas apanham o cipó de uma planta conhecida por eles como Markap, que é cortado em pedaços a serem armazenados em sacos. Pegam, ainda, cascas da árvore conhecida como Ibirema ou da árvore Parãh (palmeira barriguda), com as quais serão elaboradas as circunferências onde será inserido o cipó, juntamente de algumas outras cascas de outra árvore conhecida por Tamburi. Constatamos que são utilizados três tipos de espécies nativas da floresta. Entretanto há o cuidado em não as arrancar, somente retiram o que vai ser utilizado na pescaria. 
Para bater timbó, é necessário ter o conhecimento dos sabedores desde a escolha do cipó até a pesca propriamente dita. O timbó é uma planta da região norte do país. É um tipo de cipó que contém uma substância capaz de impedir a respiração dos peixes, asfixiando-os até a morte ou quase, quando eles ficam atordoados. Conhecido como tinguijada, o cipó timbó é cortado em pedaços, os quais são amarrados e, já dentro da água, golpeados por um pedaço de madeira para liberar a substância. É uma técnica realizada pelos Paiter Suruí em época de águas baixas, quando ocorre maior diluição da substância e menor dispersão na água.

Os peixes atordoados ou mortos ficam na superfície e são capturados com as mãos. Segundo a cultura Paiter, não se pode ficar na margem do rio olhando o peixe morrer, quando está batendo timbó, pois, senão, os peixes não morrem ou então afundam no rio e não são pegos. De acordo com um indígena Paiter Suruí: "O processo de bater timbó é um método de pesca tradicional do povo Paiter, ou seja, é um costume deste povo". Portanto, esse costume é passado de geração a geração como técnica piscatória, realizada somente na época de baixa das águas dos rios e igarapés. Ainda, segundo esse indígena, prevalece o costume na cultura da etnia e "mesmo sabendo que afeta o rio [...]" ocorre essa prática até os dias de hoje. Há, entretanto, o cuidado de realizá-la em épocas apropriadas. Segundo esse indígena, "o mês ideal de bater timbó é de julho a agosto. Nesta época, o rio fica bem estreito, principalmente igarapé", minimizando assim a dispersão da substância nas águas.

Desse modo, eles compreendem que bater timbó mata qualquer tipo de peixe, "mas quando começa a chover, o rio enche e traz tudo de novo, os peixes, por isso o Paiter precisa conhecer a nascente do rio ou do igarapé antes de bater o timbó" (relato de um indígena Paiter Suruí, 2018). Os Paiter Suruí reconhecem que a preservação dos recursos hídricos existentes na região é de suma importância para que os peixes se reproduzam e, consequentemente, assegurem alimentação para as gerações futuras. Por isso, torna-se essencial passar aos mais jovens como realizar o bater timbó, onde e porque fazê-lo. Um indígena afirma: "Se for minas de água", que têm alguns lambaris, não é recomendado bater timbó. Só pode aquele igarapé que tem condição de encher de novo na época da chuva".

\footnotetext{
${ }^{4}$ Entendemos minas de água como nascente ou cabeceira de rios e igarapés, em outras palavras, é o local onde tem início o curso d'água. É o aparecimento na superfície de um lençol subterrâneo d'água, originando os rios, riachos, córregos, igarapés etc.
} 
Ressaltamos que a época de bater timbó, restrita aos meses de julho e agosto, é respeitada por todos, como nos conta um indígena: "Diz Paiter, se acontecer bater timbó mais cedo da época seca, por exemplo, mês de junho, daí provoca chuva, e também bater timbó quando rio está cheio não dá efeito para matar os peixes, porque a quantidade da substância que sai do timbó fica pouco para água". Assim, eles preservam a desova dos peixes nos ninhos reprodutivos que ocorre na época da cheia.

Em depoimento, um indígena afirma: "Por isso quando a água está bem estreita, quase secando, a quantidade da substância fica equilibrada com a água. Daí dá efeito aos peixes". Esta técnica piscatória sempre foi realizada pelos Paiter Suruí, sendo uma técnica remanescente dos costumes e tradições da etnia. Porém eles priorizavam a pesca com flecha antes do contato com o não indígena, como pudemos constatar neste depoimento: "Lembrando, época da chuva, Paiter antes do contato com a sociedade envolvente sempre pescava com flecha". Após o contato com o não indígena, a preocupação está nas práticas ilegais na região, que provocam alterações climáticas.

\section{ASPECTOS METODOLÓGICOS E OS CAMINHOS QUE ORIENTARAM A PESQUISA}

Uma pesquisa sempre é direcionada por alguns aspectos metodológicos, os quais envolvem a escolha de caminhos que a orientarão. Partindo do objetivo de pesquisa que era mostrar conexões de conteúdos escolares da educação escolar indígena com a prática piscatória bater timbó da etnia Paiter Suruí, deparamo-nos com práticas docentes já desenvolvidas por professores indígenas, nas quais havia relação com essa atividade tradicional e cultural da etnia. Portanto esse recorte faz parte de uma pesquisa maior sobre a etnia Paiter Suruí e o desenvolvimento de práticas docentes que reportem às atividades e aos conhecimentos tradicionais desse povo.

Observamos que se trata de um estudo de caso, por entendermos que, nesse tipo de abordagem, recolhem-se e analisam-se provas empíricas, bem como se focaliza nos fenômenos e acontecimentos dentro do contexto da vida real. De acordo com Yin (1994), um estudo de caso "é um inquérito empírico que investiga um fenômeno contemporâneo dentro do seu conceito de vida real, especialmente quando as fronteiras entre fenômeno e contextos não são claramente evidentes" (YIN, 1994, p. 
24). Isso significa que estamos perpassando o contexto de pesquisa, articulando-nos com os sujeitos envolvidos, para o desenvolvimento de conhecimentos acerca das práticas docentes elaboradas pelos professores indígenas da aldeia.

Não podemos relatar sistematicamente como foram desenvolvidas essas práticas docentes, mas podemos ressaltar que elas foram abordadas pelos professores como estratégias para ressignificar os conteúdos matemáticos escolares, que, segundo os próprios professores, são atividades realizadas cotidianamente e que fazem parte dos saberes e fazeres da etnia. Portanto o trabalho de campo desses professores com seus alunos ocorre naturalmente, sem necessidade de sistematização ou quaisquer outros modelos que estamos acostumados a realizar em uma pesquisa. Entretanto, como cientificamente necessitamos fazê-la, recorremos aos relatos desses professores e constatamos que a utilização em sala de aula dessa prática piscatória envolve reviver o vivido cotidianamente por todos, ou seja, a própria prática.

Utilizamos alguns instrumentos de pesquisa, tais como a observação participante direta, realizada em uma atividade tradicional da etnia Paiter Suruí; a captação de imagens e áudios por meio de rodas de conversa e entrevistas; e a utilização de um diário de campo, no qual registramos os acontecimentos diários e nossas impressões a respeito desses acontecimentos. A convivência de alguns anos com o povo Paiter possibilitou-nos participar da prática piscatória de bater timbó, aspecto essencial para compreendermos os saberes e fazeres envolvidos em tal prática. Possibilitou-nos, ainda, um maior entrosamento com os sujeitos de pesquisa selecionados, que foram os professores indígenas, alguns sabedores e alguns outros membros da etnia. Os autores são profundos conhecedores da cultura Paiter, sendo um deles indígena morador na aldeia.

A análise e as discussões dos dados recaíram sobre o que foi relatado pelos sujeitos de pesquisa e nossas observações em campo. Em uma pesquisa qualitativa, a coleta de dados não se realiza separadamente. Há um intercâmbio entre os diferentes instrumentos, as impressões dos pesquisadores e as respostas dos participantes para a estruturação das análises e dos resultados encontrados. Existem, em uma pesquisa qualitativa, alguns critérios que devem ser seguidos quando se utilizam variados instrumentos, os quais sofrem triangulação que possibilita as discussões pertinentes ao que se pretender atingir. 
A transformação do material recolhido em dados envolveu organizar, categorizar e analisar respostas. A produtividade ocorrida na análise das respostas obtidas está na apreensão da subjetividade contida, latente ou subentendida, nas mensagens expressas pelos sujeitos de pesquisa. Diante disso, a análise dos dados baseou-se no referencial teórico e nas informações coletadas. Os resultados apontam para a necessidade de aliar a cultura do povo Paiter Suruí às práticas docentes realizadas em sala de aula e que isso já vem acontecendo na escola da aldeia.

Esses resultados são corroborados por Mattos e Ferreira Neto (2019, p. 166), quando afirmam que "para a escola indígena, o saber, não só de matemática, deve estar a serviço de sua comunidade, respondendo aos seus anseios e atendendo as suas demandas, formando as crianças e jovens de acordo com seus ideais e padrões culturais". Para que isso ocorra, os professores indígenas devem possuir formação, no caso licenciatura intercultural, e ter respeito e comprometimento com a própria cultura e com seu povo.

Mattos (2020, p. 99) também nos ajuda na reafirmação dos resultados quando afirma que o sentido e os significados atribuídos pelos membros de um grupo encontram-se "[...] interligados pela cultura que se relaciona aos sentimentos, ao sentido de pertencimento que revela a identidade de cada um e do grupo social e aos conceitos, valores e ideias compartilhados". O papel que cada um assume dentro da comunidade é o que os torna socialmente reconhecidos pelos demais. Consequentemente, os professores indígenas da aldeia Paiter tomaram posse desse papel para resguardar a própria cultura.

\section{EDUCAÇÃO ESCOLAR INDÍGENA: PRESERVAÇÃO DA BIODIVERSIDADE E SUSTENTABILIDADE}

Competência do Ministério da Educação do Brasil (MEC), a educação escolar indígena é realizada de forma específica, diferenciada, intercultural, bilíngue e comunitária. Referenciada por legislação específica, a começar pela Constituição Federal de 1988 (BRASIL, 1988), reconhecendo os indígenas como organização social com costumes, crenças e tradições próprias, em que a educação escolar deve assegurar a língua materna e processos próprios de ensino e de aprendizagem. Em 1991, a Portaria Interministerial n. 559, de 16 de abril, em seu art. 4으, criou a Coordenação Nacional da Educação Indígena (Cnei), com a finalidade de coordenar, 
acompanhar e avaliar as ações pedagógicas da Educação Indígena no País. Já no art. 5o é estimulada a criação dos Núcleos de Educação Escolar Indígenas (Neei), com a finalidade de apoiar e assessorar as escolas indígenas (BRASIL, 1991) em sua regularização, bem como assegurar a formação docente. Em 1993, foram instituídas as Diretrizes para a Política Nacional de Educação Escolar Indígena (BRASIL, 1993), reafirmando a especificidade dessa educação.

Houve avanço significativo referente à educação escolar indígena, mas é com a Lei de Diretrizes e Bases da Educação Nacional (Ldben), de 1996 (BRASIL, 1996), em seus artigos 26, 32, 78 e 79, que se afirma ser a educação escolar indígena intercultural e bilíngue, preservando às etnias sua identidade, seus costumes e suas tradições. O lançamento do Referencial Curricular Nacional para as escolas indígenas de 1998 (BRASIL, 1998) assegurou um currículo local, priorizando os anseios e interesses das comunidades indígenas. Assim, a educação escolar indígena se faz comunitária, valorizando seus princípios e concepções; intercultural, reconhecendo a diversidade cultural e linguística das etnias; bilíngue, dando oportunidade em aprender a língua materna e o português; e diferenciada, refletindo as particularidades e autonomia de cada etnia.

Ressaltamos que a educação dos povos indígenas não se realiza somente pela educação escolar indígena. A educação indígena sempre existiu por meio da transmissão oral e da prática. Naturalmente, cada etnia encontra sua maneira de passar aos mais jovens os costumes, as crenças, os valores e as tradições. Geralmente, os anciãos transmitem os saberes e fazeres ancestrais, tais como os mitos e os rituais, manejo e confecção dos instrumentos de caça e pesca, artesanatos, cestarias etc. Não há sistematização nesse tipo de educação, mas ela é importante para a preservação de técnicas e costumes tradicionais de cada etnia. Qualquer indígena pode ensinar algo no dia a dia da comunidade, e esses saberes podem ser utilizados pelo professor indígena em sala de aula, pois, de acordo com Mattos e Ferreira Neto (2016, p. 84):

É bom atentarmos para a naturalidade do implemento da realidade do aluno dentro da sala de aula. A prática educacional embebida da realidade vivenciada em uma aldeia torna as aulas para o aluno indígena, mais atrativas e interessantes, pois esse estudante passa a vivenciar na prática tudo aquilo que o rodeia diariamente. 
Nesta perspectiva, existe na grade curricular das escolas indígenas duas disciplinas voltadas para preservação da cultura da etnia. A primeira, Cultura do Povo, que contempla as tradições, mitos e rituais indígenas, e a segunda, Língua Materna, que ensina a linguagem do povo a que pertence. Na etnia Paiter Suruí, para saber o que ensinar na primeira disciplina, o professor vai às casas realizar pesquisa. Faz uma enquete sobre o que ensinar e, assim, de acordo com a comunidade local, são escolhidos os temas. Desse modo, é na primeira disciplina que se ensina, entre outros saberes e fazeres, as técnicas piscatórias.

Há dois momentos de ensino dessas técnicas, conforme nos explicou um professor indígena. O primeiro momento, teórico, realizado em sala de aula, que utiliza os conhecimentos da pesca com flecha e do bater timbó para contextualizar conteúdos escolares. O segundo momento, prático, é diferenciado. Para o bater timbó, o professor, três sabedores da cultura e os alunos, quando vão realizar a pesca propriamente dita, organizam-se segundo o rio e os igarapés que podem utilizar para esse tipo de pesca. Ao final do processo, os alunos realizam as transcrições do que fizeram em campo e, para ajudá-los, um sabedor vai à sala de aula falar sobre mito e tradição do povo. Isso faz parte do Projeto Mais Educação da aldeia Paiter.

Para pesca com flecha, é realizada pesquisa junto aos pais, avôs ou tios. Muitas vezes, os pais saem com os filhos para pescar com flecha e, consequentemente, há o aprendizado dessa técnica naturalmente. Na aula teórica sobre a pesca com flecha, é ensinado sobre o material utilizado para confeccionar o instrumento. O material adequado para produzir o arco e a flecha é um tipo de taquara, chamada Makor (Taboca), muito encontrada no estado de Mato Grosso. Em Rondônia, atualmente, é difícil encontrar esse tipo de taquara, que era avistada em Espigão do Oeste, mas eles já estão optando por novos tipos de materiais. Para a confecção da ponta da flecha, os Paiter Suruí retiram o yapeh ou yapeh ohp ah (yapeh vermelho), espécies de plantas que nascem próximas aos rios e são encontradas na Terra Indígena, na parte de Mato Grosso. A flecha é um instrumento utilizado para caçar e para guerrear contra os inimigos. Esses tipos de utilizações também são ensinados na escola.

Na pesca realizada com o anzol, introduzida após o contato, a inovação que os Paiter Suruí trouxeram foi a introdução da isca, que é o Kadeg, uma larva retirada do coquinho do babaçu e, também, considerada uma iguaria típica da etnia. 
Esse tipo de pesca é muito utilizado pela etnia, sendo uma técnica desenvolvida individualmente e que pode ser realizada tanto por homens como por mulheres.

\section{ETNOMATEMÁTICA NA PRÁTICA PISCATÓRIA DE BATER TIMBÓ DA ETNIA PAITER SURUÍ: CONHECIMENTOS TRADICIONAIS E ESCOLARES}

Ao trabalhar com as práticas piscatórias na aula de Matemática, o professor não fica preso somente a uma disciplina, pois esta ocorre interdisciplinarmente. Dessa maneira, o professor vai aliando a matemática ao desenho sobre tudo que foi desenvolvido na pescaria; ao espaço sobre os percursos desenvolvidos até chegar ao local da pesca; a botânica sobre as espécies da floresta que são utilizadas na pescaria; a cultura por meio das histórias e dos mitos que cercam esse tipo de prática piscatória, como a palmeira barriguda, a qual eles dizem que existe um indígena sem uma perna preso em seu interior.

Como o bater timbó é uma prática tradicional que contém inúmeros saberes e fazeres, várias atividades relacionadas a ela são desenvolvidas por alguns professores indígenas em suas práticas docentes. Professores indígenas identificam formas de trabalhar conteúdos matemáticos em sala de aula, o que nos leva a crer que procedimentos etnomatemáticos ocorrem, mesmo que alguns possam não ter conhecimento. Isso corrobora Cunha e Cunha (2018, p. 94), quando afirmam que "o reencontro do professor indígena com sua história, durante seu processo de formação (inicial ou em serviço), aparece como elemento fundamental para que possa dar conta do seu papel como protagonista de uma escola voltada para dentro".

Dessa forma, compreendemos que o papel dos professores indígenas como mantenedores da cultura, auxiliados pelos sabedores, possibilita-os realizar diversas atividades escolares com os alunos. Em nossa caminhada pela floresta até chegar ao local da pesca, um professor indígena comentou sobre o fato de eles cortarem o cipó e arrumarem os pedaços em sacos de $60 \mathrm{~kg}$, para levarem ao local em que vão bater o timbó. O tamanho de cada pedaço do cipó é de, aproximadamente, $40 \mathrm{~cm}$ (Figura 1). Ele nos disse que uma atividade de sala de aula para os alunos diz respeito à razão e proporção, envolvendo a quantidade de pedaços que cabem em um saco e o número de sacos necessários para carregar todo o cipó. 
Figura 1 - Cipó para ser amarrado e utilizado na pescaria de bater timbó

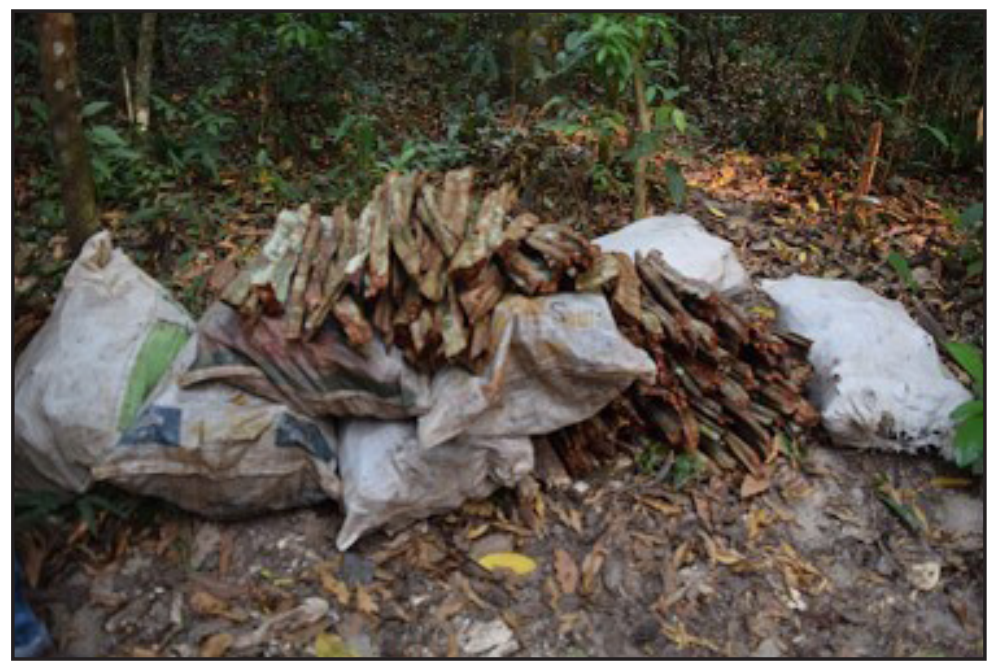

Fonte: Autores.

Antes de iniciar a pescaria, é feita a limpeza de uma área na mata, local no qual as mulheres colocam as redes, preparam a comida para todos e, também, armazenam água e café que será servido aos que estão batendo timbó. A limpeza é feita retirando pequenos galhos e matos, cortados com terçado (tipo de facão grande), que possam atrapalhar o preparo da comida. O tamanho da região é estimado pela quantidade de pessoas que participa da pescaria. Essa estratégia de natureza matemática de estimar o tamanho de uma região é usada pelos Paiter e outros povos indígenas na limpeza de um local para fazerem uma horta.

Também, há a necessidade de recolher uma certa quantidade de cipó para que haja uma boa concentração da substância na água, a fim de ocorrer a asfixia dos peixes. Quanto maior for a quantidade de água, maior deverá ser a concentração. Assim, em um igarapé, é menor a quantidade de timbó utilizado do que para um rio. Todas as estimativas são realizadas pelos sabedores, por exemplo, a circunferência para colocar o timbó, que tem aproximadamente $30 \mathrm{~cm}$ de diâmetro, é produzida por um sabedor antes de serem colocados os pedaços de cipó.

Na Figura 2, temos um sabedor indígena inserindo o timbó em uma circunferência que ele amarrou, cujos tamanhos dos pedaços dos cipós e o diâmetro da circunferência foram estimados, por ele, com o palmo. O professor indígena 
informou que essa circunferência é utilizada como contextualização em sala de aula, para ensinar raio, diâmetro, comprimento e área do círculo.

Nessa ótica, o professor indígena leva para sala de aula um aspecto do cotidiano da pescaria de bater timbó para contextualizar conceitos da matemática escolar. Entendemos que, mesmo sem saber, o professor indígena está praticando um ensino que leva à aprendizagem significativa (AUSUBEL, 2000), pois, de acordo com Mattos e Mattos (2019), o conhecimento adquirido ancora-se na estrutura cognitiva dos alunos, afetando-os e possibilitando a organização mental e o armazenamento sequenciado desse conhecimento, já que este foi contextualizado, em parte, na cultura deles.

Figura 2 - Sabedor ensinando a confecção do amarrado de timbó

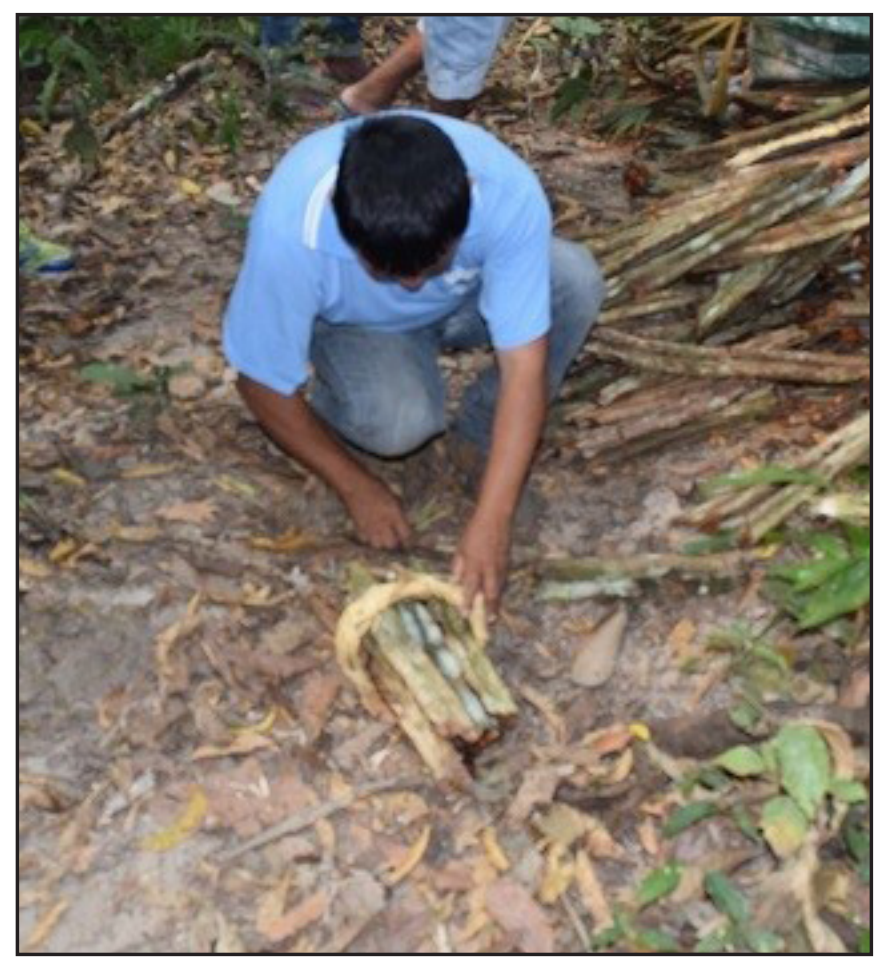

Fonte: Autores.

Voltando a nossa experiência na participação da pescaria de bater timbó, observamos que alguns indígenas ficam posicionados em locais apropriados para pegar os peixes atordoados que tentam escapar. Uma estratégia utilizada por eles 
é a colocação de redes em duas extremidades do rio ou igarapé, como observamos na Figura 3. A escolha do local em que serão posicionadas as redes depende da quantidade de água e da concentração da substância nela. Nos extremos, onde serão colocadas as redes, deve-se estar atento até onde esta substância pode alcançar. Portanto, segundo o professor indígena, estimar essa distância é importante na prática da pescaria de bater timbó.

Figura 3 - Colocação da rede para a pesca de bater timbó

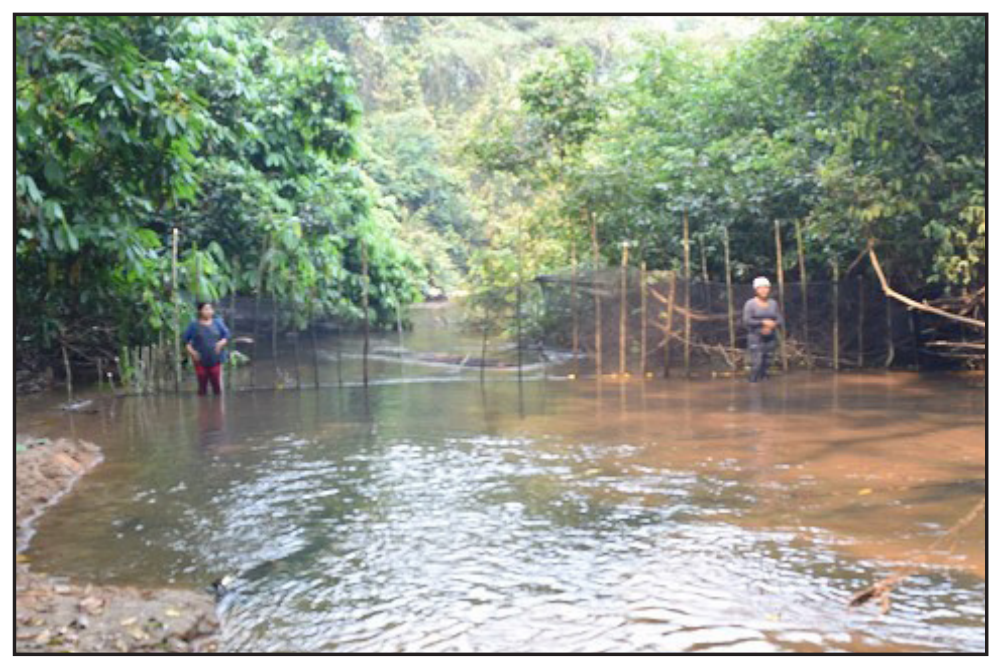

Fonte: Autores.

Constatamos que é possível contextualizar conteúdos escolares com os conhecimentos já estabelecidos pelos alunos em seu cotidiano na aldeia. Para Mattos (2020, p. 70), "a contextualização está diretamente vinculada ao conhecimento de origem do conteúdo e/ou dos alunos e a sua aplicação na realidade, na qual os estudantes estão inseridos". É interessante notar que o professor indígena reconhece a contextualização, em sua prática docente, como uma maneira de facilitar a aprendizagem dos alunos, aspecto importante quando se utilizam manifestações matemáticas, de acordo com o Programa Etnomatemática, estabelecido por D'Ambrosio (2011), que nos alerta que a contextualização é essencial para qualquer programa de educação com povos tradicionais. Em uma prática docente que utilize trajetórias hipotéticas de aprendizagem, o professor vai elaborar um conjunto de tarefas de ensino, de tal modo organizadas, que 
ativem as ações mentais dos alunos e os levem à aprendizagem significativa (MATTOS, 2020).

Observamos que os amarrados de timbó são colocados em cima de pedras que estão dentro do rio. Um indígena bate no amarrado e outro joga água; desta forma, a substância do timbó cai na água, que fica repleta de espuma e escurece. Em alguns lugares, em que as pedras estão afastadas, há a necessidade de colocar dois troncos de árvores juntos, apoiados em duas pedras ou em uma pedra e na margem do rio, que servirão de suporte para colocar os amarrados de cipó. Esses troncos são cortados e carregados pelos indígenas mais jovens. Na Figura 4, podemos ver os indígenas batendo timbó sobre os troncos de árvores e pedras. Eles relataram que o tronco escolhido precisa ser um pouco maior que a distância entre a pedra e a extremidade do rio, para dar firmeza na hora de bater timbó e dar segurança aos indígenas. Essa margem de segurança tem a função de garantir que o tronco não caia e não os machuque.

Figura 4 - Duplas de batedores de timbó

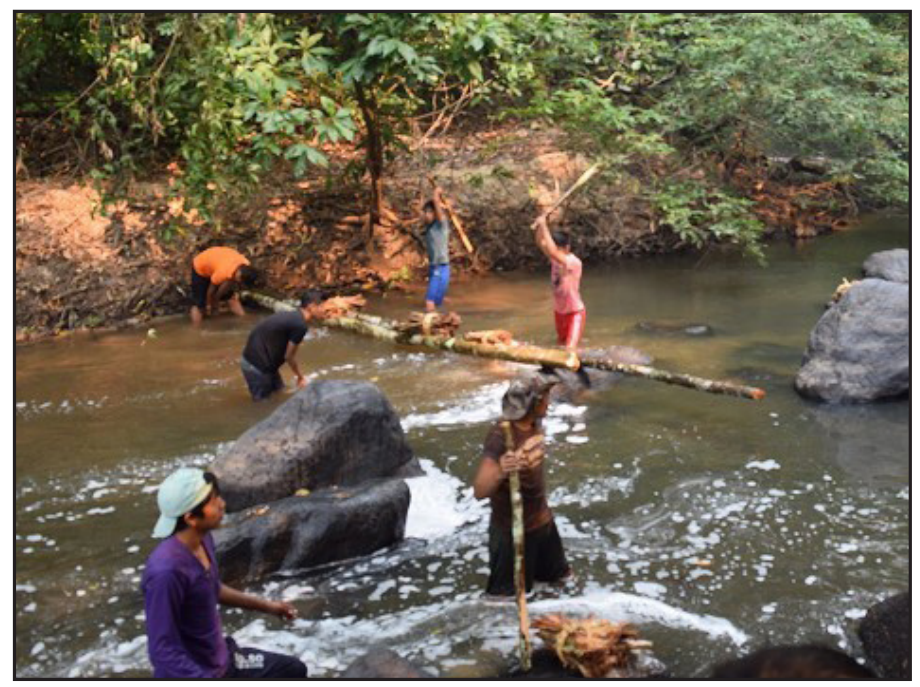

Fonte: Autores.

Como a pescaria de bater timbó é realizada coletivamente, ao fim de cada dia da pescaria, os peixes capturados e que foram guardados nos sacos de 60 kg são distribuídos, pelo mais velho, aos membros participantes, separados por família. Para fazer a distribuição dos peixes, eles são classificados por espécies, 
depois são colocados em sacos menores para cada membro participante receber a mesma quantidade. A separação dos peixes por espécie é realizada pelas muIheres, na mesma área que foi limpa pelos homens no início da pescaria. Todos assistem a essa etapa, em especial as crianças e os jovens. Os peixes separados são colocados sobre folhas de palmeira (Figuras 5(a) e 5(b)).

Figura 5 - Peixes coletados e distribuição aos membros participantes

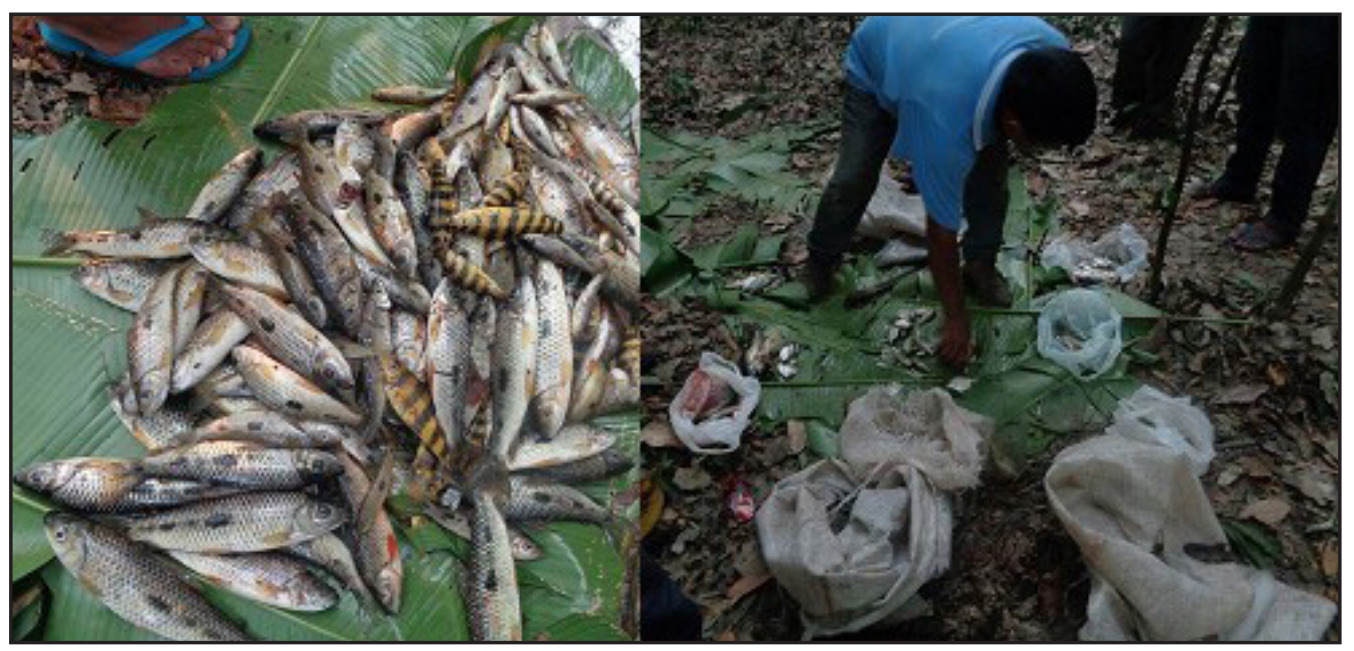

Fonte: Autores.

Um professor indígena que leciona para as crianças nos relatou que, em relação à divisão de peixes, ele pode pedir aos alunos para desenharem os diferentes tipos de peixes pescados, aproveitando para falar sobre a alimentação indígena e o porquê de pescarem em época de águas baixas, podendo explorar, ainda, os nomes dos peixes e como é o corpo deles. Constatamos que esse professor, em sua prática docente, pode utilizar a interdisciplinaridade, apropriando-se da educação artística para explorar conceitos de ciências, de forma a explanar sobre as diferentes características dos peixes, além de abordar sobre a alimentação indígena.

Essa prática é corroborada pelo Rcnei (BRASIL, 1998, p, 256), quando afirma que os povos indígenas "[...] podem aproveitar estudos sobre ambiente aquático, pois o rio e seu barranco são bons contextos para o estudo de água e solo, seres vivos da água e da mata de galeria", e isso é reforçado pelo Manual de Orientação para a Alimentação Escolar na Educação Infantil, Ensino Fundamental, Ensino Médio e na 
Educação de Jovens e Adultos (BRASIL, 2012, p. 29), quando este afirma que toda comunidade escolar deve estar envolvida "[...] nas atividades de educação alimentar e nutricional potencializando os resultados de tais ações". É importante ressaltar que os professores indígenas desenvolvem suas práticas baseados em sua experiência cotidiana na aldeia e naquilo que "experienciaram" na licenciatura intercultural.

Em geral, as famílias, após a pesca do timbó, preparam uma comida feita com os peixes, conhecida como caldeirada. É a hora da confraternização pela pesca realizada. Com relação ao preparo dessa comida, o mesmo professor indígena nos informou que aproveita para explicar aos alunos o que é utilizado e a importância dos ingredientes para a saúde deles. Além disso, aproveita para explorar outras receitas por eles utilizadas. Para isso, as crianças dizem o que seus familiares preparam à base de peixe, e ele aproveita para trabalhar a língua materna, conceitos de matemática envolvendo as quantidades utilizadas nas receitas, bem como falar sobre os festejos em que o peixe está presente.

Como pudemos constatar, a prática docente desse professor orienta-se por algumas legislações, como as Dcneei (BRASIL, 2012) e as Diretrizes Curriculares Nacionais para a Educação Básica (Dcneb) (BRASIL, 2013). De acordo com as Dcneei (BRASIL, 2012, p. 8), a organização curricular dos povos indígenas pode ser desenvolvida "por eixos temáticos, projetos de pesquisa, eixos geradores ou matrizes conceituais, em que os conteúdos das diversas disciplinas podem ser trabalhados numa perspectiva interdisciplinar". Essa mesma perspectiva é reforçada pelas Dcneb (BRASIL, 2013, p.) quando aborda a utilização da "interdisciplinaridade e contextualização na articulação entre os diferentes campos do conhecimento, por meio do diálogo transversal entre disciplinas diversas e do estudo e pesquisa de temas da realidade dos estudantes e de suas comunidades", auxiliando na elaboração de práticas docentes aliadas às do cotidiano da aldeia.

Em conversas com os professores indígenas de Matemática, Língua Materna e Cultura do Povo, bem como com os professores dos anos iniciais do ensino fundamental, da Escola Indígena Estadual Izidoro de Souza Meireles, da aldeia Paiter, Linha 09, soubemos de algumas atividades presentes em suas práticas docentes, relacionadas à pescaria de bater timbó. Tais atividades ratificam as ações dos tipos que descrevemos anteriormente, para o ensino em sala de aula, utilizando essa prática tradicional. O diretor da escola e professor indígena das disciplinas Língua Materna e Cultura do Povo, Gamalonô Surui, planeja com outros profes- 
sores indígenas os conteúdos que estão relacionados interdisciplinarmente com o bater timbó. De acordo com esse professor:

Em relação ao bater timbó trabalhado em sala de aula, eu tenho que planejar as aulas as quais disciplina que pode estar envolvido nessa atividade pra que o trabalho seja interdisciplinar, porque a escola indígena trabalha de forma interdisciplinar. Ela tá envolvida Matemática, Língua Materna, Cultura do Povo, Arte, tudo isso, Ciência, Geografia, História, todo esses disciplina citado está dentro do trabalho de bater timbó, que está envolvido na sala de aula. (Gamalonô Surui, 2018).

Segundo esse professor, a história da prática tradicional de bater timbó envolve vários assuntos da disciplina Cultura do Povo, como a arte com as pinturas corporais que eram realizadas pelos Paiter e as músicas cantadas pelo chefe do grupo depois do bater timbó. Também, na disciplina Língua Materna, são trabaIhados nomes das plantas envolvidas no bater timbó e nomes dos peixes, tanto na norma culta da língua Paiter quanto na linguagem popular.

A disciplina Cultura do Povo ela tá falando respeito da cultura tradicionais, atividade tradicionais do povo, a regra, todas as técnicas transmitido durante o bater timbó, mas tudo isso tem regulamento. Na Arte ele vai tá envolvido nas músicas, nas pinturas, e cada desenho das músicas ela é feito pelo chefe do grupo. E em relação à língua materna, o trabalho será dentro de todas aquela linguagem que os alunos não conhecem ainda. Existe uma linguagem culta, que assim como também na língua portuguesa, existe linguagem popular, como acontece na língua portuguesa. Então, a gente trabalha dentro dessas linguagem. Nome dos peixes que os alunos não conhece ainda a gente trabalhamos também. Hoje o jovem não sabe achar timbó. Nem aquela casca de árvore tamburi que a gente usa durante o processo de timbó, o jovem não sabe achar na mata. Então tudo isso trabalhamos na língua materna, principalmente os nomes, a importância de bater timbó para a cultura. Por que existe bater timbó? Como surgiu bater timbó? Tempo, duração de tempo do processo de bater timbó, quanto tempo leva, tudo isso a gente trabalha na língua materna. (Gamalonô Surui, 2018).

Já na alfabetização das crianças e nos anos iniciais do ensino fundamental, o professor indígena Garixamá Surui disse que utiliza o bater timbó. Ele corrobora a fala do professor Gamalonô, com respeito ao ensino das crianças em sala de aula, utilizando essa prática tradicional. Ele disse que trabalha com as crianças na sala de aula começando com os nomes dos materiais que eles têm que buscar 
para bater timbó. Em Ciências, ele trabalha os nomes das frutas de que os peixes se alimentam. Em Geografia, ele disse que trabalha qual o melhor local que eles acham que podem bater timbó. Em Língua Materna, ele disse trabalhar com a escrita dos nomes dos peixes. E a matemática em sala de aula também é trabalhada com o bater timbó: "dentro da matemática, a gente trabalha de estuda peixes, né, quais tipo do peixe que têm no rio, né, então ensina ele o nome do peixe, quanto tipo tem peixe". (Garixamá Surui, 2018).

Ainda com relação à matemática, o professor indígena de Matemática Mopidaor Surui informou que a atividade tradicional de bater timbó possibilita ao professor trabalhar em sala de aula com vários assuntos na disciplina Matemática. Números naturais, paridade de números inteiros, medidas de comprimento, conceitos de máximo e mínimo e operações numéricas de soma, subtração, multiplicação e divisão são alguns exemplos diretos relacionados ao bater timbó. De acordo com esse professor:

A gente Paiter não temos quantidade de pessoas certo que vai bater timbó, são várias quantidades. E outra coisa, quem for bater timbó, as pessoa são em duplas, no caso isso tá relacionado a números pares, porque cada um tem a sua dupla e não pode ter números ímpares. Então é infinita, né, quantidade de pessoas que vão ser trabalhada ali, e também a quantidade do timbó que foi cortada, que foi buscada na mata, são infinita em números também, porque a gente não tem quantidade certa pra bate timbó. E outra coisa, o timbó será só cortado em $40 \mathrm{~cm}$ o tamanho, e desses pedaço de 40 $\mathrm{cm}$, a quantidade máximo poderá ter 15 timbó, que onde a gente amarra e prepara pra bater. E temos o pau que vai bate o timbó, terá no máximo um metro de comprimento. São muitas coisas que tão envolvido da matemática aí, números naturais, números inteiro e outras coisa. Eu acredito que tem a área de multiplicação aí, porque a quantidade de pessoas que vão trabalha no bater timbó são que ganha os seus peixe, mais o dobro ou triplo mesmo da quantidade de pessoa que foi trabalhado ali. E outra coisa que pode ser também, toda vez que o líder, que ele dividia, né, as quantidade dos peixes pros trabalhadores, então ali tem uma divisão. Então há muitas outras coisa que pode ser trabalhada em cima de área de matemática ali. (Mopidaor Surui, 2018).

Assim, vemos que a prática piscatória tradicional de bater timbó possibilita trabalhar com vários conteúdos curriculares na escola indígena. Muitos conteúdos escolares foram ensinados utilizando essa prática, confirmados nos depoimentos de 
professores indígenas Paiter. Logo, o uso do bater timbó em sala de aula, além de fortalecer os conhecimentos culturais dos alunos, permite uma ressignificação de conteúdos escolares por meio de conhecimentos próprios, em especial, de matemática.

\section{CONSIDERAÇÕES FINAIS}

A utilização da cultura Paiter na escola indígena torna não só a sala de aula, mas toda a aldeia uma fonte de aprendizado e preservação das tradições da etnia. Ressignificar conteúdos escolares, como os de matemática, com a prática piscatória de bater timbó, reaviva os conhecimentos tradicionais inerentes aos indígenas e proporciona uma aprendizagem significativa para os alunos, ou seja, aquela aprendizagem em que as novas aquisições de conhecimento são baseadas e relacionadas, culturalmente, aos conhecimentos anteriores relevantes da estrutura cognitiva do educando (AUSUBEL, 2000). Dessa forma, os alunos indígenas não ficam atrelados somente à sala de aula, já que entendem que fora dela os saberes e fazeres da cultura indígena contêm conhecimentos empíricos, sejam matemáticos, sejam quaisquer outros, próprios do seu povo.

As possibilidades de ensino e de aprendizagem dos conteúdos escolares, mais especificamente os de matemática, que a prática piscatória de bater timbó apresenta, são inúmeras. Os Paiter Suruí percebem o potencial que a cultura deles tem, pois, nas atividades cotidianas, por mais simples que sejam, transbordam conhecimentos. Neste trabalho, utilizamos uma atividade desenvolvida pelo povo Paiter Suruí como suporte ao ensino e à aprendizagem da matemática escolar, bem como de outras disciplinas. Isso nos permite afirmar que é possível contextualizar os conteúdos matemáticos escolares com as práticas cotidianas de um povo para que os alunos ressignifiquem sua aprendizagem. Nessa lógica, constatamos que as práticas docentes relatadas estão em sintonia com o Programa Etnomatemática de D’Ambrosio (2011), quando este afirma que não tem como não contextualizar a matemática acadêmica e escolar com as manifestações culturais de povos tradicionais, que também são produtores de conhecimentos.

Entre as várias estratégias de natureza matemática que os povos indígenas utilizam em seu dia a dia, está a de estimar. Conforme podemos ver em Domite (2009), Mattos (2018), Mattos e Ferreira Neto (2019) e Mattos e Mattos (2019), os indígenas estão sempre estimando tempo, espaço, medidas e quantidades. 
Quer seja para saberem quando voltar da mata, quer seja para medirem o espaço que têm de limpar para fazerem sua horta, as dimensões internas de suas construções, a largura de seus rios, ou ainda para saberem a quantidade de comida e bebida em uma festividade. Observamos que essa estratégia etnomatemática de estimar está presente na atividade tradicional de bater timbó, como na limpeza da área na mata, na confecção da circunferência para colocar os pedaços de cipó e na distância até a rede no rio. De acordo com os professores indígenas Paiter, isso é utilizado em sala de aula, na educação escolar indígena.

A utilização de uma abordagem didático-pedagógica, baseada na Pedagogia de Projetos, "consiste em permitir que os estudantes confrontem as questões e os problemas do mundo real que considerem significativos, determinando como abordá-los e, então, agindo de forma cooperativa em busca de soluções" (BENDER, 2014, p. 9). Com esse entendimento, constatamos que o Projeto Mais Educação, desenvolvido na aldeia Paiter, possibilita ao professor indígena realizar a intersecção entre os conhecimentos culturais e acadêmicos com os escolares. São práticas docentes corroboradas pelo Rcnei (BRASIL, 1998), quando o referencial aborda que os currículos para as escolas indígenas devem ser ancorados em materiais específicos, elaborados por professores e alunos, e refletir a perspectiva intercultural de uma educação diferenciada.

Afirmamos haver aproximação entre a prática docente dos professores indígenas investigados com a cultura e a natureza circundante. Corroboramos D’Ambrosio (2008, p. 9), quando este constata que "ensinar a matemática ocidental nas comunidades indígenas é um desafio", mas que o ensino pode ser flexibilizado por introdução de práticas docentes diferenciadas, com o reconhecimento, por parte dos professores, das especificidades inerentes ao ensino e à aprendizagem dos conteúdos escolares, alguns distantes da realidade deles. Como eles mesmos afirmam, "ensinar a matemática do branco" torna-se mais eficaz quando contextualizada na própria cultura, reavivando conhecimentos tradicionais da etnia. Nessa perspectiva, é essencial promover a adequação das metodologias didático-pedagógicas às características das comunidades indígenas, cada qual com suas especificidades, respeitando, ainda, os modos próprios que os professores desenvolvem suas práticas docentes.

A observação desses critérios pelos órgãos responsáveis demanda certas condições para a elaboração de um currículo viável e centrado na realidade de cada povo 
indígena. Da mesma forma, a preparação de material didático específico deve ser de responsabilidade dos próprios indígenas. As ações colaborativas entre órgãos governamentais e os indígenas devem primar pela garantia dos direitos dos indígenas, pela autonomia na administração de suas escolas, possibilitando a legitimidade de suas práticas docentes para o reconhecimento e respeito às diferenças. Destacamos, ainda, que há necessidade de garantir a formação inicial e continuada dos professores indígenas e valorizar o exercício profissional deles. Consequentemente, para garantir os princípios da educação escolar indígena, esta deve constituir-se como um espaço de diálogo entre culturas, centrar-se em atividades que promovam o viver bem indígena e ter exclusividade de sua cultura sobre outras.

Possibilidades existem, como constatamos neste trabalho, de atividades centradas e organizadas por práticas socioculturais, inspiradas por professores indígenas que sentem a necessidade de facilitar a aprendizagem dos alunos indígenas. Observamos que os saberes e as práticas dos alunos indígenas ancoram outros conhecimentos, valorizando seus modos próprios de viver, sua oralidade e sua história. A articulação de projetos comunitários - que são desenvolvidos cotidianamente na aldeia - com os ensinamentos escolares reflete a autonomia desses professores para as diversas necessidades e dificuldades encontradas em sua prática docente.

Por fim, podemos afirmar que os pressupostos etnomatemáticos, enfatizados pela entrada, em sala de aula, dos saberes e fazeres gerados e difundidos por meio da cultura de um povo, empoderam seus membros, cultural, social, política e afetivamente (DOMITE, 2009). Por outro lado, ensinar e aprender tornam-se processos entrelaçados às tradições, saberes e fazeres da etnia, renovando-os e ressignificando-os para que o professor indígena tenha um novo olhar sobre eles.

\section{REFERÊNCIAS}

AUSUBEL, D. P. Aquisição e retenção de conhecimentos: uma perspectiva cognitiva. Lisboa: Plátano Edições Técnicas, 2000.

BENDER, W. N. Aprendizagem baseada em projetos: educação diferenciada para o século XXI. Porto Alegre: Penso, 2014.

BICHO, J. S. Etnomatemática e práticas pedagógicas: saberes matemáticos escolares e tradicionais na educação escolar indígena Karipuna. 2018. Tese (Doutorado em Educação em Ciências e Matemática) - Universidade Federal de Mato Grosso, Cuiabá, 2018. 
BRASIL. Ministério da Educação. Diretrizes Curriculares Nacionais para a Educação Básica. Brasília-DF: MEC, 2013. Disponível em: http://portal.mec.gov.br/docman/julho-2013pdf/13677-diretrizes-educacao-basica-2013-pdf/file. Acesso em: 7 jan. 2020.

BRASIL. Ministério da Educação. Manual de orientação para a alimentação escolar na educação infantil, ensino fundamental, ensino médio e na educação de jovens e adultos. 2. ed. Brasília: Pnae, 2012.

BRASIL. Ministério da Educação. Referencial Curricular Nacional para as Escolas Indígenas. Brasília: MEC, 1998. Disponível em: http://www.dominiopublico.gov.br/pesquisa/ DetalheObraForm.do?select_action=\&co_obra=26700. Acesso em: 7 jan. 2020.

BRASIL. Ministério da Educação. Lei 9.394 de 20 de dezembro de 1996. Estabelece as diretrizes e bases da Educação Nacional. Brasília: MEC, 1996. Disponível em: http://www. planalto.gov.br/ccivil_03/leis/L9394.htm. Acesso em: 7 jan. 2020.

BRASIL. Ministério da Educação. Diretrizes para a Política Nacional de Educação Escolar Indígena. Brasília: MEC, 1993. (Cadernos de Educação Básica, Série Institucional 2). Disponível em: http://www.dominiopublico.gov.br/download/texto/me001778.pdf. Acesso em: 07 jan. 2020.

BRASIL. Ministério da Educação. Portaria Interministerial MJ/MEC n. 559, de 16 de abril de 1991. Dispõe sobre a Educação Escolar para as populações indígenas. Brasília: MEC, 1991. Disponível em: https://cimi.org.br/2004/06/21816/. Acesso em: 7 jan. 2020.

BRASIL. Constituição da República Federativa do Brasil. Brasília: Senado Federal, 1988. Disponível em: http://www.planalto.gov.br/ccivil_03/constituicao/constituicaocompilado. htm. Acesso em: 7 jan. 2020.

CUNHA, A. C.; CUNHA, J. S. M. A formação de professores indígenas "Povos do Pantanal" e "Teko Arandu". In: MATTOS, S. M. N. (Org.). Currículo, formação e práticas docentes. Curitiba: CRV, 2018. p. 85-100.

D’AMBROSIO, U. Etnomatemática - elo entre as tradições e a modernidade. 4. ed. Belo Horizonte: Autêntica, 2011.

D’AMBRosio, U. O Programa Etnomatemática: uma síntese. Acta Scientiae. v. 10, n. 1, p. 7-16, 2008. Disponível em: www.periodicos.ulbra.br/index.php/acta/article/ download/74/66. Acesso em: 7 jan. 2020.

DOMITE, M. C. S. Perspectivas e desafios da formação do professor indígena: o formador externo à cultura no centro das atenções. In: FANTINATO, M. C. C. B. (Org.), 
Etnomatemática: novos desafios teóricos e pedagógicos. Niterói: Editora da Universidade Federal Fluminense, 2009. p. 181-92.

GALLOIS, D. T. (Org.). Patrimônio cultural imaterial e povos indígenas: exemplos no Amapá e norte do Pará. São Paulo: lepé, 2006.

GRUPIONE, L. D. B. (Org.). Índios no Brasil. Brasília: MEC, 1994.

MATTOS, S. M. N. O sentido da matemática e a matemática do sentido: aproximações com o programa etnomatemática. São Paulo: Editora Livraria da Física, 2020.

MATTOS, J. R. L.; FERREIRA NETO, A. Etnomatemática e educação escolar indígena Paiter Suruí. São Paulo: Editora Livraria da Física, 2019.

MATTOS, J. R. L.; FERREIRA NETO, A. O povo Paiter Suruí e a etnomatemática. In: BANDEIRA, F. A.; GONÇALVES, P. G. F. (Org.). Etnomatemáticas pelo Brasil: aspectos teóricos, ticas de matema e práticas escolares. Curitiba: CRV, 2016. p. 79-100.

MATTOS, S. M. N.; MATTOS, J. R. L. Etnomatemática e prática docente indígena: a cultura como eixo integrador. Hipátia, São Paulo, v. 4, n. 1, p. 102-15, jun. 2019.

MATTOS, S. M. N.; MATTOS, J. R. L. Preservação ambiental e cultural na educação escolar indígena. In: MATTOS, J. R. L.; MATTOS, S. M. N. (Org.). Etnomatemática e Práticas Docentes Indígenas. Jundiaí: Paco Editorial, 2018. p. 185-214.

MATTOS, J. R. L. Matemática e cultura em ação na educação escolar indígena. In: MATTOS, J. R. L.; MATTOS, S. M. N. (Org.). Etnomatemática e Práticas Docentes Indígenas. Jundiaí: Paco Editorial, 2018. p. 185-214.

MINDLIN, B. Diários da floresta. 1. Ed. São Paulo: Editora Terceiro Nome, 2006.

MINDLIN, B. Nós Paiter: os Suruí de Rondônia. Petrópolis: Editora Vozes, 1985.

ORGANIZAÇÃO DAS NAÇÕES UNIDAS. Declaração das Nações Unidas sobre os direitos dos povos indígenas - Drips. Rio de Janeiro: Unesco, 2008.

SAMPAIO, J. A. L. O "resgaste cultural" como valor: reflexões antropológicas sobre a formação dos professores indígenas. In: GRUPIONE, L. D. B. (Org.). Formação de professores indígenas: repensando trajetórias. Brasília: MEC/Unesco, 2006. p. 165-74.

SCANDIUZZI, P. P. Educação indígena x educação escolar indígena: uma relação etnocida em uma pesquisa Etnomatemática. São Paulo: Editora Unesp, 2009. 
VERGANI, T. Educação Etnomatemática: o que é? Natal: Flecha do Tempo, 2007.

YIN, R. K. Pesquisa estudo de caso - desenho e métodos. 2. ed. Porto Alegre: Bookman, 1994.

\section{Sobre os autores:}

JoséRoberto Linhares de Mattos: Pós-doutor em Educação pela Universidadede Lisboa. Professor do Programa de Doutorado da Rede Amazônica de Educação em Ciências e Matemática; do Programa de Pós-Graduação em Educação Agrícola da Universidade Federal Rural do Rio de Janeiro; e da Universidade Federal Fluminense. E-mail: mattos@campus.ul.pt, Orcid: http://orcid.org/0000-0002-4075-6764

Sandra Maria Nascimento de Mattos: Doutora em Educação pela Pontifícia Universidade Católica de São Paulo (PUC-SP)/Universidade Católica Portuguesa. Professora do Programa de Pós-Graduação em Educação Agrícola da Universidade Federal Rural do Rio de Janeiro. E-mail: smnmattos@gmail.com, Orcid: http://orcid.org/0000-0003-2622-0506

Gamalonô Surui: Mestre em Educação pela Universidade Federal Rural do Rio de Janeiro (UFRRJ). Professor da Escola Indígena Estadual Izidoro de Souza Meireles. E-mail: gmInsurui@gmail.com, Orcid: http://orcid.org/0000-0001-6576-5467

Recebido em 1으 de abril de 2020.

Aprovado para publicação em 5 de junho de 2020. 


\title{
Localização, orientação e representação espacial como expressão de territorialidades indígenas
}

\author{
Positioning, orientation and spatial representation as \\ expression of indigenous territorialities
}

\author{
Ozirlei Teresa Marcilino ${ }^{1}$ \\ Vanessa Sena Tomaz ${ }^{2}$
}

DOI: http://dx.doi.org/10.20435/tellus.v0i42.669

\begin{abstract}
Resumo: O artigo analisa tensões entre práticas de localização, orientação e representação espacial próprias dos Indígenas Xakriabá e aquelas que se configuram quando estudantes desse povo participam de uma disciplina, ministrada na universidade e no território indígena, em uma licenciatura intercultural. Sendo tais práticas iluminadas pelo pensamento decolonial e fundamentadas em formulações indígena e não indígena, território é entendido como um espaço de poder, luta, resistência e uso, uma herança que passa de geração para geração, um dos sentidos da interculturalidade na vida contemporânea Xakriabá. Embasada nessa formulação, a análise da participação e dos registros dos estudantes - mapas, desenhos, textos - e os relatos orais mostram que tensões surgem nas práticas, tanto na universidade quanto no território indígena, porque os estudantes constroem representações espaciais em estreita relação com a dinâmica de uso do seu território que, muitas vezes, não podem ser representadas pelos elementos técnicos de projeção do espaço no plano ou mesmo pelas referências geográficas. Concluise que as práticas de formação vivenciadas pelos estudantes contribuíram para a construção de novas territorialidades e que o estudo dessas noções pode compor um currículo como ferramenta político-pedagógica de fortalecimento das relações etnoterritoriais de professores indígenas.
\end{abstract}

Palavras-chave: território; licenciatura intercultural; indígenas Xakriabá.

Abstract: The article analyzes tensions between practices of positioning, orientation, and spatial representation of Xakriabá Indigenous people, and those established when Indigenous students attend, taught at the university and in the Indigenous territory, an intercultural teacher education course. With such practices being illuminated by the decolonial perspective and based on

1 Universidade Federal do Espírito Santo (Ufes), Vitória, Espírito Santo, Brasil.

2 Universidade Federal de Minas Gerais (UFMG), Belo Horizonte, Minas Gerais, Brasil. 
Indigenous and non-Indigenous ideas, the territory is understood as a space of power, fight, resistance, and use - an inheritance transmitted through generations, one of the meanings of interculturality in Xakriabá's contemporary life. Based on this idea, the analysis of the students' participation and registries - maps, drawings, texts -, and the oral reports show that the tensions arise in the practices, both at the university and the Indigenous territory, because the students establish spatial representations in close relation to the dynamics of the use of their territory that, often, cannot be represented by the technical elements of space projection in a flat surface or even through geographical references. We concluded that the training practices experienced by students contributed to the construction of new territorialities and that the study of these notions can be incorporated in a curriculum as a political-pedagogical tool to strengthen the ethnoterritorial relations of Indigenous teachers.

Keywords: Territory; Intercultural teacher education; Xakriabá Indigenous.

\section{INTRODUÇÃO}

A colaboração, a negociação e a parceria entre sujeitos de diferentes identidades e instituições interessadas para a formação de professores indígenas são permanentemente desafiadas a formular currículos que atendam às reivindicações dos indígenas por uma educação que valorize a diversidade cultural, promova o diálogo intercultural e garanta a participação e o protagonismo indígena. Ou seja, um currículo visto como um projeto político, social, ético e também epistêmico que atravessa fronteiras culturais. Particularmente, se esse currículo contempla práticas de orientação, localização e representação espacial dentro da educação matemática, surgem tensionamentos ao serem colocadas em contato as diferentes formas de conceber o espaço, originadas em racionalidades diferentes - ocidental hegemônica e indígenas.

A tradução literal da palavra Geometria seria "medir a terra", tendo sua origem atribuída aos egípcios, diante da necessidade de fazer medições de terra após cada inundação anual no vale do rio Nilo, e aos babilônios, para desenvolver suas atividades de agricultura. Assim, desde a sua origem, conflitos territoriais já faziam parte do seu escopo, pois tanto os egípcios quanto os babilônios tinham de demarcar suas terras para que os agricultores soubessem qual era sua propriedade para cultivar e para o pagamento dos impostos. Com as mudanças políticas e econômicas ocorridas nos últimos séculos do segundo milênio a.C., quando os gregos tiveram grande ascensão, o poder dessas nações diminuiu. A geometria 
passou a ser estabelecida não por procedimentos empíricos em busca de solução para problemas concretos, mas como uma ciência de natureza lógica e dedutiva.

As concepções ocidentais de espaço estão desvinculadas da noção de tempo e são codificadas em linguagem usada tanto no discurso cotidiano quanto no acadêmico. A noção de espaço foi "apropriada pela matemática", cuja linguagem tenta definir com exatidão absoluta os parâmetros, dimensões, qualidades e possibilidades de espaço. Tal apropriação influenciou a forma de o Ocidente pensar o mundo além da Terra e as formas nas quais a sociedade é vista, isto é, como um "espaço compartimento que pode ser melhor definido e medido" (HENRI LEFEBVRE, 1991 apud TUHIWAI SMITH, 2012, p. 53). Diferentemente, em algumas línguas indígenas, não há palavras que expressem distinção clara entre a noção de espaço e de tempo, o que reflete uma visão de mundo indígena em que o controle não condiz com suas relações etnoterritoriais. Há posições no tempo e no espaço nas quais as pessoas e os eventos estão localizados, mas essas não podem necessariamente ser descritas por categorias distintas de pensamento.

Como conteúdo de ensino, os aspectos de orientação, localização e representação espacial integram o estudo da geometria visando desenvolver o pensamento espacial dos estudantes, associado ao desenvolvimento intelectual não somente por meio da Matemática, mas também de áreas como Geografia, Ciência, Arte e Literatura. Na referência do conhecimento ocidental, a localização no espaço possui sentido estático e diz respeito à capacidade de localizar-se e localizar objetos em meio a outros objetos e pessoas em determinado espaço (em cima, ao lado etc.). A orientação espacial tem sentido dinâmico, utiliza pontos de referências conhecidos e explora sentidos de direção e movimento (à direita, descrição de trajetos, em frente etc.). Já a representação espacial registra a percepção do espaço e o expressa simbolicamente sem, necessariamente, estar em seu campo de visão (mapas, maquetes, croquis).

Em geral, na escola, a Geometria representa o pensamento matemático moderno ocidental que, historicamente, teve o papel de garantir a abstração, o raciocínio dedutivo e o formalismo. Nesse, o espaço e o tempo são considerados bases da matemática, não sendo reconhecidos por meio da experiência, são formas de nossa faculdade perceber as coisas (MENEGHETTI, 2010, p. 160). Espaço é o fundamento das verdades geométricas (MENEGHETTI, 2010, p. 86). Transpostas 
para a escola indígena, essas noções trazem a marca da colonização epistêmica que vem sendo praticada à luz do pensamento europeu, desde o século XVI. Esse instituiu padrões de poder/ser/saber que invisibilizam outras formas não hegemônicas de conceber o espaço e reforçam a ideia de uma Matemática exclusiva dos homens brancos e europeus.

Tendo clareza do papel que a Geometria pode exercer na escolarização dos indígenas, questionamos: por que incluir noções de orientação, localização e representação espacial nos currículos nas licenciaturas destinadas à formação dos professores indígenas? Sem dúvida, trata-se de uma questão complexa que nos remete à outra mais ampla, sobre a necessidade dos povos indígenas de uma Escola Indígena ${ }^{3}$ em suas comunidades. Recorremos aos argumentos de Luciano, indígena do povo Baniwa, quando afirma que eles almejam uma escola indígena que atenda tanto às perspectivas de "continuidade dos processos próprios e particulares de vida do povo indígena quanto às perspectivas novas de acesso aos conhecimentos, técnicas e aos modos de ser e de viver das sociedades modernas" (LUCIANO, 2010, p. 7). Com essa referência, a escola indígena é vista como a apropriação estratégica de uma instituição da sociedade envolvente que possibilita aos indígenas garantir e concretizar o direito e o desejo de melhorar suas condições históricas de vida, sem ceder lugar, espaço, tempo e significação cosmológica aos modos de vida moderna (LUCIANO, 2010). Isso posto, questionamos: como enfrentar os desafios das práticas colonizadoras enraizadas nas escolas indígenas e nos cursos de formação de professores ao discutir noções de orientação, localização e representação no espaço, de modo a valorizar outras epistemologias indígenas?

Estudos dentro do campo da educação matemática têm focado na investigação de saberes e práticas matemáticas na educação (escolar) indígena, discutindo a promoção da educação escolar no campo da matemática, nos contextos das populações indígenas de distintos lugares geopolíticos e epistemológicos, de diferentes tensões, lutas e resistências (MENDES; TAMAYO-OSORIO, 2018). Esses trabalhos têm se filiado ao campo da Etnomatemática, que, segundo D’Ambrósio (2011, p. 9), dedica-se ao estudo da

Luciano (2010) refere-se à escola indígena contemporânea como instrumento de transmissão, produção e reprodução de um conjunto de saberes e valores necessários e desejados por um determinado povo indígena. 
[...] matemática praticada por grupos culturais, tais como comunidades urbanas e rurais, grupos de trabalhadores, classes profissionais, crianças de uma certa faixa etária, sociedades indígenas, e tantos outros grupos que se identificam por objetivos e tradições comuns.

Tal perspectiva, conforme proposta por D’Ambrósio, permite-nos pensar a matemática a partir de processos escolares e não escolares. Permite-nos também considerar as especificidades envolvidas nos processos de aprendizagem de diferentes povos, levando em conta suas próprias referências culturais. Entre os estudos nesse campo, destacamos trabalhos como os de Ferreira (2004; 2000), que optaram por trazer à tona na escola e nos cursos de formação os conhecimentos matemáticos tradicionais indígenas, visando revelar as formas distintas de manejar quantidades, números, medidas, formas e relações geométricas presentes nas atividades cotidianas, na organização social e na cosmologia de sociedades como a dos indígenas brasileiros.

Analisando uma experiência de formação continuada no Espírito Santo, que teve participação da primeira autora deste artigo, os pesquisadores/formadores observaram os saberes/fazeres do povo Guarani na produção de cestos como "meios de afirmação cultural dentro e fora do grupo e de comunicação interétnica que expressam e se relacionam com outras formas simbólicas da mesma cultura" (LORENZONI, 2010, p. 22). Nesse caso, os professores indígenas foram desafiados a refletir sobre o papel dos saberes tradicionais nos contextos do ensino de matemática na educação escolar indígena, da formação de professores indígenas e da produção de material didático específico e diferenciado para suas escolas. Ainda discutindo uma ação de formação continuada com etnias indígenas de recente contato na região do alto Rio Negro (AM), Stumpf (2019) aponta a importância de ações interculturais que incluem eixos temáticos como "Etnomatemática, Matemática e Numeramento", visando à valorização cultural e instrumentalização dos indígenas para lidar com exigências da sociedade ocidental. Na visão dessa autora, a formação de professores indígenas precisa ser intercultural, a fim de capacitar para a concretização de escolas realmente interculturais.

Especificamente envolvendo o povo indígena Xakriabá, Mendonça (2007) analisa práticas educativas dos professores que ensinam matemática em suas escolas e reconhece que a Matemática na escola Xakriabá não existe como uma verdade única, porque sofre "influências ideológicas, políticas, culturais, sociais, 
uma vez que dialoga com a política mais ampla da educação escolar indígena" (MENDONÇA, 2007, p. 107). A observação das práticas dos professores, à época da pesquisa, mostrou indícios de que havia pouca circulação dos conhecimentos matemáticos que são próprios do próprio povo.

Ademais, as discussões com a temática da Geometria na formação dos professores indígenas não tiveram foco nas questões sociais e políticas relacionadas às lutas em defesa do território. Assim, para melhor explorar as questões sociais e territoriais que estruturam a participação de professores indígenas nos cursos de formação, focaremos nossa discussão em um grupo específico de licenciandos, Indígenas Xakriabá, do curso de Formação Intercultural para Educadores Indígenas da Universidade Federal de Minas Gerais (Fiei-UFMG).

A escolha desse curso se deve ao fato de ser onde atua uma das autoras deste artigo como professora e por este curso estar se consolidando como um fértil campo de pesquisa para investigar questões ligadas à formação de professores indígenas (BRITO, 2012; TOMAZ; CAMPOS, 2018; ARAÚJO, 2019). O povo Xakriabá vem de longa parceria que esse povo tem com o curso, desde a sua concepção, mantendo-se ativo em todas as turmas oferecidas. Entendemos ainda que há um acúmulo de discussão entre os Xakriabá sobre o currículo da escola, estruturado a partir do calendário sociocultural das aldeias que, como afirma Araújo (2018), possibilitou aproximar a escola do que ocorre no território.

Portanto, neste artigo, nosso objetivo é analisar tensões que ocorrem entre as práticas de localização, orientação e representação espacial, desenvolvidas na universidade e no território indígena, quando delas participam um grupo de estudantes Xakriabá, cursando a licenciatura intercultural. Mais amplamente, discutimos como o estudo dessas noções pode compor um currículo que se configura como uma ferramenta político-pedagógica de fortalecimento das relações etnoterritoriais, no contexto da formação de professores indígenas.

Para tanto, nas próximas seções, apresentamos o povo Xakriabá e as atividades em que foram abordados aspectos de orientação, localização e representação no/do espaço no âmbito de uma disciplina de geometria. Para subsidiar a análise das atividades, situamos os conceitos que embasam a investigação aqui proposta, orientadas por formulações dos próprios indígenas. Em seguida, analisamos as tensões que surgem nas práticas, quando os estudantes participam das 
atividades, mostrando como se orientam na universidade e no território Xakriabá, e concluímos com apontamentos sobre as relações identitárias criadas e seus desdobramentos para o ensino da geometria nas escolas indígenas.

\section{POVO XAKRIABÁ}

Para apresentar o povo Xakriabá tomaremos como referência textos dos próprios indígenas e o documento oficial (BRASIL, 2014). A trajetória dos Xakriabá é marcada, a exemplo de outros, pela luta pela demarcação do seu território, ocorrida em 1987, somente após o assassinato dos principais líderes. Os relatos dos líderes atuais mostram que o direito à terra Xakriabá também envolveu a reafirmação da identidade indígena (RIBEIRO, 2019; ABREU, 2018).

Segundo dados do relatório da Fundação Nacional do Índio (Funai) (BRASIL, 2014), o território Xakriabá está localizado no Município de São João das Missões, no norte de Minas Gerais, onde vivem cerca de 10.000 indígenas, divididos em 36 aldeias, em torno de 54.000 hectares de terra, caracterizada pela pouca disponibilidade de água e pela escassez de saneamento básico e rede de abastecimento. De acordo com Bizerra (2018, p. 13), "há ainda uma grande área pertencente ao povo Xakriabá, não demarcada, ocupada por não índios, fazendeiros e empresas agrícolas". O Português Xakriabá é a língua falada entre eles, com as variações linguísticas próprias de cada aldeia. Mas, como explica Silva (2018), os Xakriabá sempre enfatizam suas raízes linguísticas no tronco Macro-Jê, família Jê, subgrupo Akwen, e não se cansam de dizer: "A língua Xakriabá nunca morreu, ela apenas adormeceu" (SILVA, 2018, p. 25). A cultura Xakriabá também se mantém na forma de convivência das famílias, nos cantos, nas cantigas de roda, nas pinturas, nas danças, nos adereços, na cerâmica e no ritual sagrado com o culto à onça (Yaya) cabocla, o Toré (BIZERRA, 2018, p. 13).

A principal atividade econômica desse povo é a agricultura, encontrando comunidades que vivem, basicamente, do artesanato e do extrativismo de buriti e frutos do cerrado (BRASIL, 2014). De um modo geral, o sistema sociopolítico Xakriabá é baseado em uma liderança hegemônica, no caso, advinda de um cacique-geral, que ganha sustentação em lideranças familiares locais que participam ativamente das atividades da aldeia. 
As relações internas entre os Xakriabá estão marcadas por suas relações mais amplas com outros povos indígenas e não indígenas. A complexa rede de relações e as heterogêneas formas de vida movimentam o interior das comunidades fazendo a conscientização sobre novas formas de luta e de mobilização diante dos desafios contemporâneos que precisam enfrentar, especialmente o aumento da população no território. Em seus relatos, orais ou escritos, os Xakriabá mostram que estão sempre atentos ao fato de que a manutenção de direitos conquistados depende, externamente, das circunstâncias econômicas e políticas do país e, internamente, da constante mobilização do seu povo na luta por esses direitos, principalmente de seus jovens (SILVA, 2018; BIZERRA, 2018).

A escola Xakriabá tem intensa atuação no cotidiano de suas comunidades e nas lutas para retomada das áreas reivindicadas. Como enfatiza Oliveira (2018, p. 8), "Além da demarcação da terra, nosso território tem um marco histórico que é a educação indígena diferenciada, que conseguimos por meio de muitas lutas das nossas lideranças - não foi fácil para conseguirmos". Alkimin e Santos (2019) também alertam que a escola indígena Xakriabá tem o dever de preparar o aluno para a vida social, dentro e fora da aldeia, buscando soluções dos problemas junto da comunidade. Como já informado, o currículo é estruturado a partir do Calendário Sociocultural da aldeia, que é "uma prática educativa desenvolvida nas escolas indígenas Xakriabá, em que é feita a junção entre o conhecimento científico e conhecimento tradicional" (ARAÚJO, 2018, p. 16). Desse modo, podemos dizer que as práticas escolares desse povo estão intrinsecamente atreladas à luta pela terra.

\section{A LICENCIATURA EM FORMAÇÃO INTERCULTURAL PARA EDUCADORES INDÍGENAS (FIEI-UFMG)}

Os processos de aprendizagem indígena ocorrem em diferentes espaços da comunidade e em qualquer tempo, envolvendo diversos participantes da comunidade que também são responsáveis pela educação das pessoas. Assim, a educação indígena já existia antes dos processos colonizadores e da demarcação europeia de lugares específicos de aprendizagem, a escola, e de pessoas específicas para ensinar, o professor ${ }^{4}$.

4 O Censo Escolar de 2018, registra a presença de 22.166 profissionais escolares em sala de aula na educação escolar indígena. Desses, 7.787 tinham formação em nível superior, e 13.625, em 
Contudo a garantia de uma escola indígena a partir dos anos 1990 gerou ampliação da rede de escolas nos territórios, demandando projetos de formação de professores indígenas, tanto no nível de magistério quanto em nível superior. O magistério indígena é uma das iniciativas pioneiras de formação de nível médio, não podendo deixar de citar também os cursos de aperfeiçoamento que são registrados em todas as regiões do país que possuem aldeamentos e professores indígenas (MARCILINO, 2014). Já a implantação das licenciaturas específicas para formação de professores indígenas ocorreu ao final dos anos 2000, por meio de edital do Programa de Licenciatura Intercultural Indígena (Prolind), pelo Ministério de Educação. Em 2017, havia 18 instituições oferecendo cursos de licenciatura intercultural indígena no Brasil, sendo 17 em instituições públicas, totalizando 2.049 matrículas, em 21 cursos (INEP, 2017).

A licenciatura em Formação Intercultural para Educadores Indígenas (Fiei), ofertada pela UFMG, surgiu de uma parceria com a Secretaria de Estado de Educação de Minas Gerais (SEE-MG), por meio edital do Prolind, recebendo povos de Minas Gerais, entre eles, o povo Xakriabá. Em 2008, dentro do programa de Reestruturação e Expansão das Universidades Federais (Reuni), este curso tornou-se a licenciatura intercultural (Fiei) de oferta regular da UFMG, ampliando o público de estudantes indígenas de várias partes do país. Ao todo, são 140 vagas, distribuídas em quatro habilitações: Ciências Sociais e Humanidades; Ciências da Vida e da Natureza; Letras, Artes e Literatura; e Matemática. Cada habilitação tem duração mínima de quatro anos, alternando a oferta de 35 vagas anuais. As turmas são formadas por estudantes de diferentes povos vindos de vários estados brasileiros: Xakriabá, Pataxó, Pataxó Hãhãhãe, Guarani, Maxakali, Pankararu e Tupiniquim.

O currículo do curso Fiei se organiza a partir dos grandes temas: Território e Línguas Indígenas (UFMG, 2009). Esses temas estruturam uma matriz curricular em eixos: conhecimentos socioambientais e múltiplas linguagens. Cada um desses eixos abriga habilitações, sendo elas: Ciências Sociais e Humanidades; Ciências da Vida e da Natureza, no primeiro eixo; e, no segundo, Matemática; Línguas, Artes e Literatura. Perpassando os eixos e as habilitações, alguns componentes curriculares fazem a integração do currículo: a pesquisa de autoria indígena, uso

nível médio (INEP, 2018). 
do território e a escola como espaço de formação intercultural. As atividades do curso são concentradas em duas etapas semestrais, articuladas entre si, ambas em horário integral: uma intensiva, em um período de cinco semanas nos espaços da UFMG, com participação de todos os estudantes indígenas; e outra com duração de sete a dez dias, nas aldeias, com estudantes reunidos por povo, quando a equipe da universidade se desloca para os territórios indígenas. Essa organização de tempos e espaços garante uma experiência concreta de encontro e convivência entre indígenas de diferentes povos e não indígenas, em espaços diversificados e em diferentes territórios.

Dentro do eixo múltiplas linguagens, onde é oferecida a habilitação em Matemática, a matriz curricular situa a formação de professores indígenas na diversidade de linguagens presentes em práticas sociais de múltiplos letramentos (STREET, 2003, p. 77). A abordagem dos componentes curriculares enfatiza e valoriza formas de comunicação que as pessoas usam - fala, imagem, gesto, olhar, postura - e a relação entre elas. No campo da Educação Matemática, essa comunicação inclui ainda diagramas, desenhos, equações, croquis, layout e símbolos alfanuméricos. Assim, dada a diversidade cultural e linguística, característica dos estudantes que participam desse curso, a habilitação em Matemática busca se constituir em um espaço de formação que possibilite ao licenciando se apropriar de uma linguagem que reconheça e reafirme suas lutas históricas, visões de mundo e seus modos próprios de produção de conhecimento, bem como a interlocução com a realidade e os códigos da sociedade nacional e global. Adotando uma perspectiva de interculturalidade (WALSH, 2012) como uma ferramenta político- pedagógica, as práticas nesta habilitação buscam tornar visíveis formas diferentes de acessar, usar e comunicar informações e ideias matemáticas.

A configuração das turmas do Fiei possibilita que diferentes concepções de espaço e modos de representá-lo sejam colocadas em contato, o que sem dúvida é uma rica experiência de formação docente. No entanto essa configuração multiétnica, por si só, não é garantia de um diálogo entre saberes e culturas, de modo que surgem tensionamentos entre práticas culturais, quando conhecimentos tradicionais de cada povo e aqueles associados à matemática da escola entram em contato, pois nelas concorrem diferentes racionalidades. Especificamente, neste artigo, interessa-nos discutir como o estudo de noções de localização, orientação e representação espacial, desenvolvido em uma disciplina da habilitação em 
Matemática do Fiei, produz experiências concretas dinâmicas socioespaciais em interlocução direta com o território do povo Xakriabá.

De fato, discutir a abordagem de noções de geometria na formação de professores nos faz refletir sobre o currículo da escola indígena, pois esse não necessariamente tem de reproduzir os conteúdos tradicionalmente estudados nas escolas não indígenas. O Referencial Curricular Nacional para as Escolas Indígenas (Rcnei) (BRASIL, 1998) aponta pelo menos três razões para se estudar matemática na escola indígena: por causa da situação de contato entre os diferentes povos e a sociedade mais ampla; porque mostra que existem muitas matemáticas, o que significa reconhecer "que cada sociedade tem uma maneira muito específica de entender o mundo que a cerca e formas específicas de contar e manejar quantidades" (BRASIL, 1998, p. 148); e porque ela é necessária para a construção de conhecimentos relacionados às outras áreas do currículo. Especificamente sobre a Geometria, o Rcnei sugere que o estudo do espaço e das formas é muito útil para descrever ou representar o mundo que nos cerca, mas destaca que, se os povos têm maneiras distintas de conceber o espaço, o pensamento geométrico vai variar de grupo em grupo.

Dentro do currículo da habilitação em Matemática do Fiei, o estudo da Geometria está estruturado a partir de um dos seus princípios fundamentais - o Território. O eixo território abre possibilidades de resgatar, por meio do ensino da geometria, a importância das relações etnoterritoriais - interação orgânica homem-natureza - constituídas pelos povos indígenas. Além disso, do ponto de vista da formação matemática dos professores, o ensino de Geometria estruturado pelo eixo territorial adquire importância pela sua dimensão política, ao envolver os estudantes em dinâmicas de aprendizagem que explicitam as transformações que ocorrem na relação do seu povo com o território, advindas dos processos de colonização a que foram submetidos.

Por isso, entendemos que discutir as práticas de formação nas licenciaturas interculturais que têm participação de estudantes Xakriabá, movimentando em diferentes territórios - indígena e acadêmico -, para analisar as tensões que ocorrem quando os diferentes modos de orientar, localizar e representar o espaço concorrem nessas práticas, pode contribuir para a formulação de um currículo, visto como uma ferramenta político-pedagógica para a construção de identidades e de territorialidades. 


\section{TERRITÓRIO, TERRITORIALIDADES E INTERCULTURALIDADE NO DIZER XAKRIABÁ}

Ao reivindicar que a educação intercultural indígena seja um processo de estudo e aprendizagem interepistêmico que requer novas práticas e políticas educativas, aproximamo-nos do pensamento decolonial (WALSH, 2012). Este pensamento surge em oposição ao poder epistêmico entre o colonizado e colonizador que caracteriza a dominação europeia, pela formulação de uma crítica ao eurocentrismo por parte dos saberes silenciados e subalternizados (WALSH, 2012).

Como alternativa, autores como Walsh (2012) destacam que precisamos encontrar novos conceitos e novas linguagens que explicam a complexidade de gêneros, etnias, classes, sexualidades, conhecimentos e espiritualidades dentro dos processos geopolíticos, geoculturais e geoeconômicos do sistema operante. Assim, essa autora assume a interculturalidade e decolonidade como projetos que caminham juntos, e "construir a interculturalidade - assim, criticamente compreendida - requer transgredir, interromper e desmantelar a matriz colonial ainda presente e criar outras condições de poder, saber, ser, viver e ser que se distanciam do capitalismo e de sua razão única" (WALSH, 2012, p. 69, tradução nossa). Assim, uma perspectiva de educação dentro dessa matriz só teria sentido quando assumida como "ato político-pedagógico que busca intervir na refundação da sociedade, como disse Paulo FREIRE (2004, p. 18 apud WALSH, 2010, p. 76). Entretanto Walsh (2012) alerta que essa perspectiva de interculturalidade critica ainda não existe, pois se faria necessário transgredir, romper com a matriz colonial que ainda se faz presente e criar outras formas de poder, saber, ser e viver. Consciente da longa caminhada de luta, Sousa (2018), ao comentar sobre as suas experiências como estudante do curso Fiei, afirma: "Os conhecimentos que são passados pelo curso do Fiei, é todo voltado para a interculturalidade, uma troca de conhecimentos e saberes entre os povos indígenas" (SOUSA, 2018, p. 36-37).

Nesse sentido, ao discutir aspectos de localização, orientação e representação espacial com estudantes indígenas, no âmbito de um curso de licenciatura intercultural, abrimo-nos para a produção de "outro" conhecimento que confronta a matriz do poder colonial, ainda que se configure um rompimento, pois relativiza o modelo de conhecimento matemático escolar ocidental vigente e sinaliza para outras formas de conceber o espaço e sua relação com o território. Assim, con- 
siderando a vinculação primeira do indígena com seu território e suas diferentes formas de concebê-lo e utilizá-lo, buscaremos construir ferramentas teóricas para analisar as atividades aqui propostas, partindo de uma disponibilidade conceitual que considere referências não indígenas e dos próprios Xakriabá.

Partimos de formulações que se referem a território como espaço habitado, usado, apropriado, representado, um lugar com um nome, uma referência forte no imaginário de um grupo que se reconhece como coletivo, construindo noções de pertencimento. Nesse sentido, descartamos, de antemão, conceitos de territórios que o concebem somente como um espaço físico. Como afirma Milton Santos (2006):

[...] o território não é apenas o conjunto dos sistemas naturais e de sistemas de coisas superpostas; o território tem que ser entendido como o território usado, não o território em si. O território usado é o chão mais a identidade. A identidade é o sentimento de pertencer àquilo que nos pertence. $O$ território é o fundamento do trabalho; o lugar da residência, das trocas materiais e espirituais e do exercício da vida. (SANTOS, 2006, p. 14).

Buscamos em Haesbaert (1997) a formulação de que território é um espaço delimitado e controlado, por meio do qual se exerce um determinado poder, um elemento central no estudo das relações espaço-poder. O "território não seria um simples instrumento de domínio político e/ou espaço público de exercício de uma (pretensa) cidadania, mas efetivamente um espaço de identificação e (re) criação do/com o mundo, 'a natureza'” (HAESBAERT, 1997, p. 35). Território, então, assume uma dimensão espacial com um viés multidimensional (político-jurídico, econômico e culturalista) que se revela em processos de dominação.

A territorialidade trata das relações econômicas, culturais e políticas, bem como do modo que as pessoas utilizam a terra, organizam-se no espaço e dão significado ao lugar (SACK, 1986). Especificamente, Sack (1986, p. 219) considera que "a territorialidade, como um componente do poder, não é apenas um meio para criar e manter a ordem, mas é uma estratégia para criar e manter grande parte do contexto geográfico através do qual nós experimentamos o mundo e o dotamos de significado". Com base nessa formulação que estabelece uma permanente relação entre território e poder, podemos afirmar que o processo de territorialização está assentado em representações do espaço.

Contudo, dado o histórico de expropriação de terras indígenas, a territorialidade própria desses povos possui uma conotação de resistência, que tem 
na identidade étnica e nas referências culturais específicas a sua base principal. Portanto não podemos falar sobre território e territorialidade indígena sem considerar o fenômeno vivido por indígenas de colonialidade do poder, do saber e do ser (QUIJANO, 2005), ou seja, "um fenômeno histórico complexo, relativo a um padrão de poder global, que naturaliza hierarquias (territoriais, raciais, culturais e epistêmicas), reproduzindo relações de dominação e subalternização" (MUNSBERG; FERREIRA DA SILVA, 2018, p. 5).

Especificamente, tensionamos marcas da colonialidade do $\operatorname{saber}^{5}$ (QUIJANO, 2005), que toma lugar nos programas de formação de professores indígenas que transitam entre diferentes territórios - acadêmico e tradicional indígena -, de modo que somente as conceituações elaboradas por pesquisadores não indígenas, ainda que esses busquem romper com preceitos hegemônicos colonizadores, não são suficientes para discutir práticas de formação nesse contexto. A concepção de espaço ocidental para indígenas tornou-se somente mais uma forma de colonização, ou seja, de controle social sobre eles.

Nas palavras de Correa Xakriabá (2018, p. 8), "a terra é território e não somente terreno. É sagrada, é luta, é barro do pó que se resume também em um só". Quando expressam a conexão entre o seu modo de vida e seu território, os Xakriabá questionam profundamente a lógica territorial do capitalismo e apontam para um outro ordenamento social.

Quando se referem ao território, os Xakriabá (2018) afirmam:

[...] precisa considerar o território como um importante elemento que nos alimenta e constitui o nosso ser pessoa no mundo, não sendo possível nos ver apartados do território, pois somos também parte indissociável dele, nosso próprio corpo (p. 80) [...] O corpo precisa estar em movimento e reagindo na luta, porque o nosso corpo é território e é isso que segura o movimento indígena. (p. 87).

Nosso povo Xakriabá vem de uma luta muito sofrida, uma delas é pela garantia de nossos direitos, ou seja, pela demarcação de nossas terras, pelo respeito da nossa identidade. (SILVA, 2018, p. 16).

Não teria como falar da educação sem falar da luta pelo território. [...] A cada direito conquistado novos desafios eram traçados, assim, a luta pela demarcação dos

Colonialidade do saber se refere ao campo epistemológico e seus meios de reprodução, onde há repressão das formas de conhecimentos não europeias, não considerando como válidos outros conhecimentos diferentes da "ciência" europeia (QUIJANO, 2005). 
territórios foi acompanhada pelo direito dos povos indígenas a terem uma educação escolar diferenciada, tanto na educação básica quanto na educação superior. (ARAÚJO, 2018, p. 13-14).

Como vemos nos enunciados acima, território para os Xakriabá é resistência, é a expressão da identidade, é a motivação primeira do movimento indígena. A luta pela terra é uma herança que se passa de geração em geração, porque não se pode abrir mão dela, porque, para não "perder o fio de meada, aí nós trabalha para isso não ir abaixo" (Valdemar da Prata, liderança Xakriabá, 2015). É um local de relações variadas que inclui um lugar de importância, afetiva, simbólica e política, onde se constrói territorialidade: uma força latente que move os Xakriabá, cuja manifestação explícita depende de contingências históricas. Portanto não se concebe um currículo para essa escola indígena sem incluir a discussão sobre a luta pelo território que move a vida Xakriabá. Da mesma forma, não se desconsidera que as territorialidades se constroem nas dinâmicas, identidades e subjetividades que são produzidas com o espaço, onde interagem epistemologias próprias, alimentadas "na ciência do território" (CORRÊA XAKRIABÁ, 2018, p. 20).

Assim, refletindo sobre as formulações de território e territorialidade apresentadas acima, para embasarmos nossa análise, neste trabalho, território pode ser entendido como um espaço de poder, de luta, resistência e uso - herança que passa de geração para geração, um dos sentidos da interculturalidade na vida contemporânea indígena Xakriabá.

Nossa hipótese é de que o estudo de noções de orientação, localização e representação espacial como componente curricular nas licenciaturas interculturais, se, por um lado, pode promover processos de desterritorização dos indígenas, de outro, pode promover territorialidades, pela apropriação de uma linguagem com códigos da sociedade nacional que cria uma comunicação que possibilita expressar o fluxo entre territórios, em suas múltiplas dimensões, dos modos próprios como usa e dá significado à terra, organiza-se e ressignifica as experiências vividas.

\section{LOCALIZAÇÃO, ORIENTAÇÃO, REPRESENTAÇÃO ESPACIAL E AS RELAÇÕES ETNOTERRITORIAIS}

O uso da terra é um saber essencial entre os povos indígenas, por exemplo, para os Xakriabá, medir a terra para plantar a roça é uma prática tradicional. 
Tomaz e Knijnik (2018) analisaram uma proposta intercultural de trabalho de campo desenvolvido em uma escola, centrado no "medir a terra pra fazer a roça", e argumentam que, ainda que seja explícito no currículo da licenciatura o compromisso como uma formação intercultural, "há tensionamentos nesse currículo que impossibilitaram o equilíbrio entre as relações de forças dos diferentes tipos de conhecimentos que circulam na escola, ao promover essa educação intercultural" (TOMAZ; KNIJNIK, 2018, p. 23).

Logo, ao considerar a possibilidade de que diferentes racionalidades concorrem na escola indígena e, por conseguinte, nos cursos de formação, problematizamos a existência de uma única linguagem da Geometria que urge questionar práticas que simplesmente retomam a abordagem empírica egípcia e babilônica, somente porque esses povos também mediam a terra para plantar, outrossim, consideramos aspectos das relações etnoterritoriais que envolvem noções de orientação, localização e representação do espaço. Para tanto, apresentamos, a seguir, algumas práticas que envolvem essas noções, desenvolvidas no Fiei, habilitação em Matemática, registradas por meio de textos, desenhos, relatos orais e circulação nos espaços.

A princípio, os dados foram coletados para auxiliar os docentes no acompanhamento dos estudantes e no planejamento das atividades da disciplina. À medida que as atividades progrediam e eram repetidas em outras edições da disciplina, percebíamos que elas traziam interessantes elementos para subsidiar discussões em torno do currículo das licenciaturas interculturais para indígenas, particularmente para o ensino de geometria na habilitação em matemática.

Para este artigo, selecionamos um conjunto de dados produzidos em duas edições da disciplina de Geometria, no ano de 2012 e 2018, composto de registros dos estudantes Xakriabá: mapa de uma aldeia produzido no ano de 2012; mapa da faculdade de educação; fotografias e desenhos de lugares do território Xakriabá; texto coletivo produzido pelos estudantes sobre práticas tradicionais de suas aldeias, todos esses registros produzidos em 2018. Também utilizamos os registros em áudio de uma conversa com os estudantes que cursaram a disciplina em 2018, quando orientamos a revisão de texto coletivo sobre práticas tradicionais Xakriabá e quando esclarecemos também algumas dúvidas sobre a participação dos estudantes nas atividades. Ainda, utilizamos as notas de campo produzidas pelas autoras durante as aulas, nas edições em que a disciplina foi ofertada. 
Todos os registros foram copiados para o formato digital e a conversa com os estudantes foi transcrita. Entre as imagens digitalizadas, selecionamos aquelas que melhor expressavam os pontos de referências e o modo como os estudantes percebiam e se orientavam na universidade e no território Xakriabá. Procedemos uma análise das interações discursivas, englobando diferentes modos comunicacionais (imagem, falas, gestos e escrita), de modo a identificar tensões que surgiam ao produzir suas representações espaciais e falar sobre elas e sobre suas percepções ao se movimentar nos espaços visitados.

\section{AS ATIVIDADES DE GEOMETRIA NO FIEI}

O estudo da geometria na habilitação em matemática divide-se em três disciplinas: Ensino de Geometria Plana e Espacial; Geometria Espacial; e Geometria Analítica. As atividades que descreveremos neste artigo foram desenvolvidas na disciplina Ensino de Geometria Plana e Espacial. Esta disciplina propõe o estudo sobre localização, representação e sistemas de referências; ideias e demandas que levem ao estudo das formas geométricas no espaço e no plano nos contextos interculturais: observação, classificação e exploração de propriedades das figuras; usos e estética do espaço e das formas. Além das disciplinas específicas de geometria, os licenciandos também cursam a disciplina Uso do Território ${ }^{6}$, que faz uma direta interlocução com as comunidades envolvidas no curso e realiza mapeamentos vários das terras indígenas de onde provêm os estudantes.

Ao elaborar as atividades da disciplina Ensino de Geometria Plana e Espacial, ofertada no primeiro período do curso, partimos do fato de que os estudantes se deslocam de seus territórios para cursar a universidade e que, para a maioria, este é o primeiro contato com esse espaço. Assim, fazemos a apresentação da universidade, destacando sua estrutura física e organização política e administrativa. Tal apresentação é acompanhada de visitas guiadas aos espaços da universidade, quando os estudantes são orientados a observar os detalhes e pontos de referência para se movimentarem no campus e no prédio onde o curso é realizado. O objetivo dessa atividade é que o estudante indígena possa se orientar e se localizar nesse novo território e que as experiências iniciais na universidade proporcionem a ele

6 Nas turmas 2012 e 2019, por questões internas da organização do curso, esta disciplina foi oferecida após o estudo da geometria plana e espacial. 
não somente o contato com o seu espaço físico, mas também político e cultural. Ou seja, que ele comece a perceber a universidade como espaço de relações sociais diversas e de produção coletiva de conhecimento.

A visita guiada é feita a pé e alcança o entorno da Faculdade de Educação (FaE), onde o curso é ofertado, e o quarteirão da Reitoria até a Praça de Serviços. Neste percurso, concentram-se vários prédios, incluindo a Reitoria e os principais serviços que o estudante pode acessar em sua estadia na universidade: restaurante, biblioteca, bancos, farmácia, livraria, fundação de assistência estudantil etc. Ao longo do percurso, os estudantes são orientados a observar o ambiente, anotar pontos de referência, sentido de circulação das pessoas e placas indicativas que os ajudem a se localizar dentro do campus. Durante a visita, conhecem um pouco da história da universidade e sua importância política no contexto local e nacional. Fazemos paradas para explicações sobre características arquitetônicas e funcionais dos prédios, sobre as placas indicativas e sobre o paisagismo (tipos de árvores; animais e outros espaços de convivência). O reconhecimento do prédio da FaE é detalhado com a visita em todos os ambientes internos e externos.

No retorno em sala, os estudantes, em grupos, fazem um relato das observações e localizam alguns pontos do campus, utilizando a plataforma Google Maps. Na sequência, em duplas, eles produzem mapas da FaE (Figura 1), explicando as referências tomadas para a produção desses. Após a apresentação oral desses mapas, os estudantes têm de localizar pontos indicados pelos professores e/ou pelos próprios colegas e traçar no mapa o percurso até o local sugerido (Figura 1). 
Figura 1 - Desenho da FaE e seu entorno. A linha ilustra o percurso traçado para deslocamento entre a sala de aula e o restaurante universitário

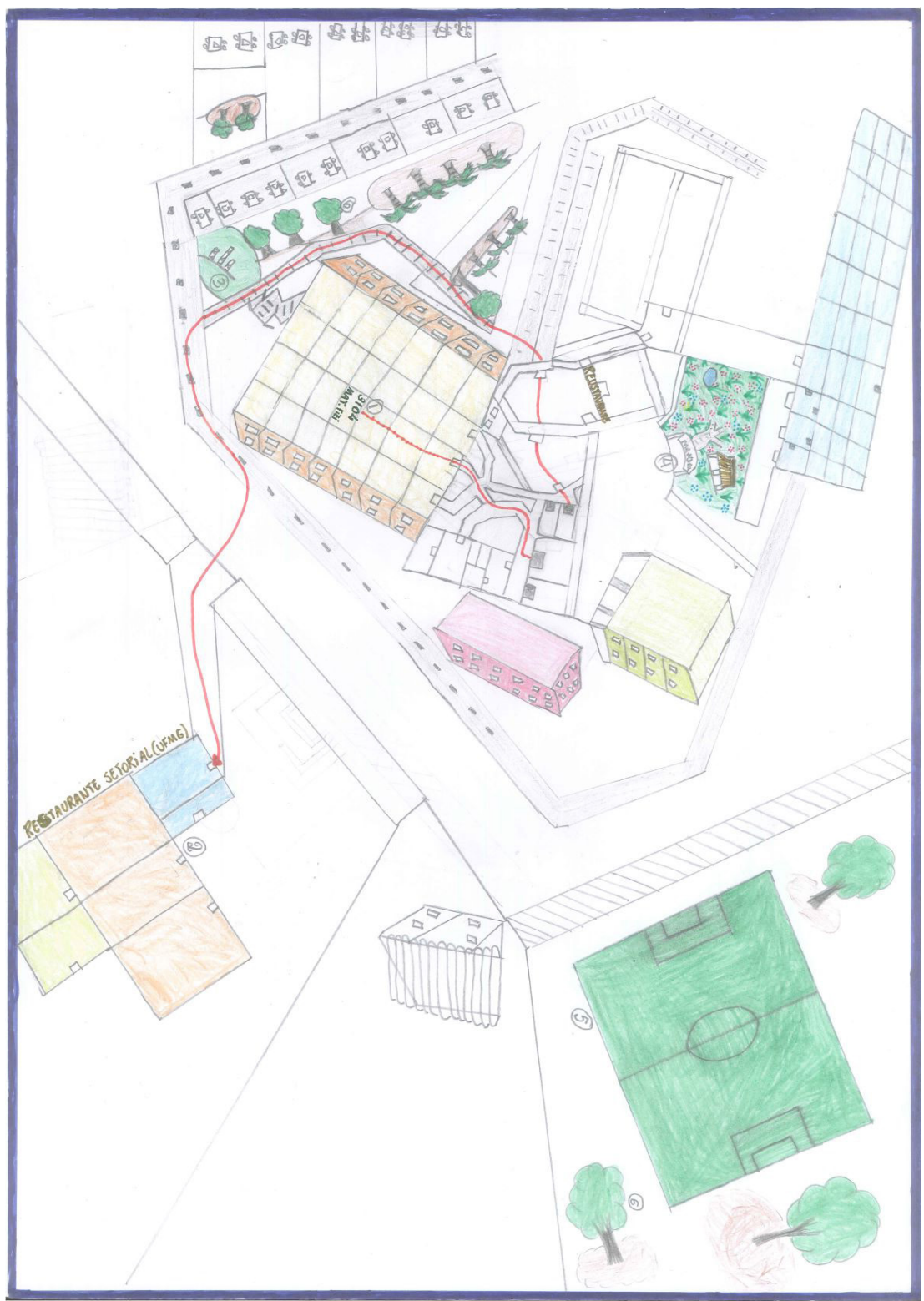

Fonte: Estudantes Deusivam Farias Mota e Valdirene Pinheiro da Silva, 2018. 
Analisando a representação da Faculdade de Educação nos desenhos dos estudantes (Figura 1), ainda que tenham sido produzidos nos primeiros dias de contato dos estudantes com aquele espaço, percebemos como retratam o cotidiano que estabelecem no curto período de interação, assim como as possibilidades a serem exploradas: (1) a sala de aula no terceiro andar; (2) o restaurante universitário, onde fazem as refeições diárias; (3) o mimanam ${ }^{7}$, onde realizam os rituais; (4) o Jardim Mandala8, espaço de acolhimento e onde foi construída uma casa tradicional Xakriabá; (5) o campo de futebol, onde praticam esporte aos fins de semana; e (6) as árvores no espaço externo da FaE. Portanto os estudantes expressam um modo de vida, apontando possibilidades de uso coletivo daquele espaço, destacando pontos de referência e vínculos que estão sendo construídos, ao mesmo tempo em que demarcam a presença indígena naquele novo território.

Ainda explorando o espaço da $\mathrm{FaE}$, os estudantes escolhem um objeto nele encontrado durante a visita, para reproduzi-lo por meio de desenho. Eles apresentam o desenho para os demais, esclarecendo o material de que ele é feito, o uso, a localização e por que escolheu desenhá-lo (Figura 2). A partir desses desenhos, exploramos como se orientar na FaE, tendo o objeto como referência, e as formas geométricas neles reconhecidas, fazendo uma primeira classificação dessas. Também confeccionam embalagens com formatos de sólidos geométricos e desenham sólidos com vistas e perspectivas diferentes.

\footnotetext{
Mimanam é um mastro sagrado de ritual do povo Maxakali que ocupa uma área em frente ao prédio da Faculdade de Educação, onde os indígenas se reúnem para rituais e outros encontros no período de aulas na universidade.

8 Jardim Mandala é um espaço verde de convivência da Faculdade de Educação, onde são cultivadas plantas medicinais; nele, existem duas casas de construção tradicional indígenas e vários tipos de árvores.
} 
Figura 2 - Objeto selecionado e descrição da sua localização

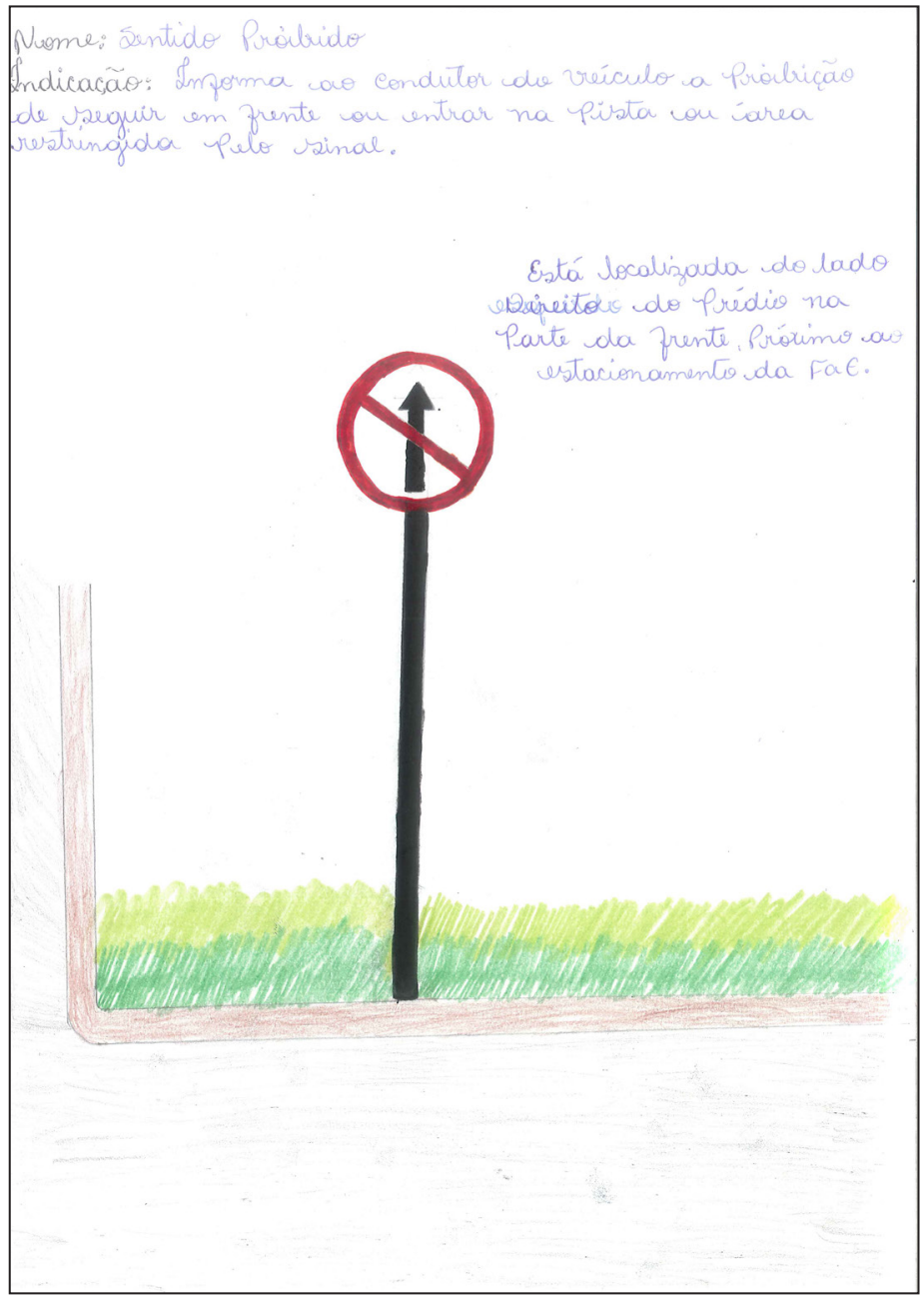

Fonte: Estudante Solange Lima de Alkmim, 2018.

O objeto escolhido pela estudante Solange fica na entrada do estacionamento do prédio e traz uma linguagem que orienta a movimentação naquele território. O desenho mostra como ela está atenta às regras de circulação e às regras de uso desse território. Apropriar-se dos códigos desse novo espaço garante-lhe autonomia para estar em um mundo que ela acaba de se adentrar. Em geral, o mapa e os objetos nele destacados pelos estudantes como referência para orientação 
mostram um esforço coletivo de estabelecer relações com o ambiente biofísico da FaE, de modo a reconhecê-lo como seu território.

Uma segunda parte deste estudo que acontece durante a primeira etapa intensiva no território Xakriabá ${ }^{9}$ visa à orientação e localização dos professores da universidade no território indígena, motivo pelo qual os estudantes desenham e apresentam um mapa da sua aldeia (Figura 3), indicando pontos de referência.

Figura 3a - Mapa da Aldeia Imbaúba II

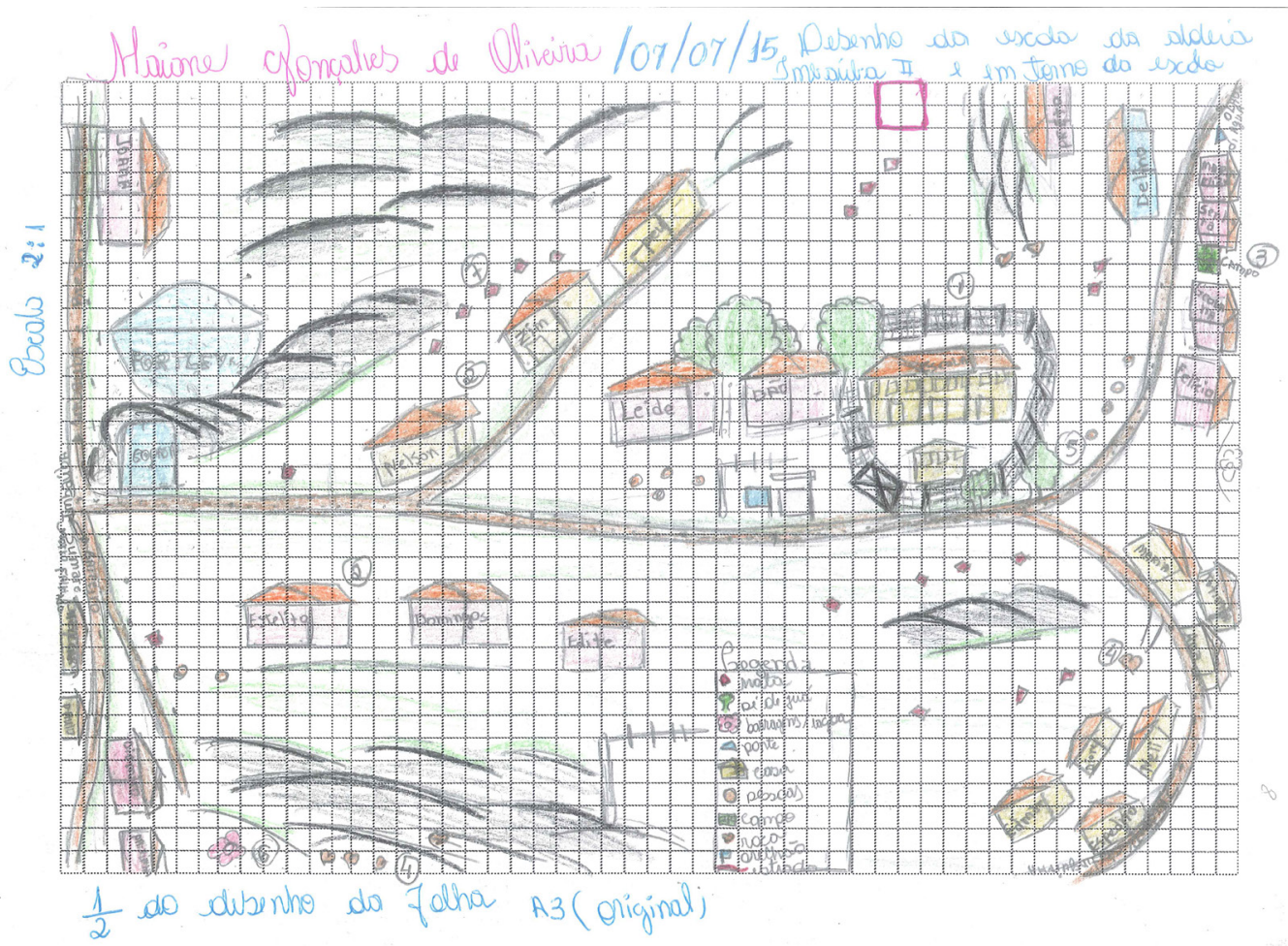

Fonte: Maiane Gonçalves de Oliveira, 2015.

9 Nas atividades no território indígena, os estudantes são reunidos em uma aldeia para viabilizar o trabalho. 
Figura 3b - Mapa do território Xakriabá

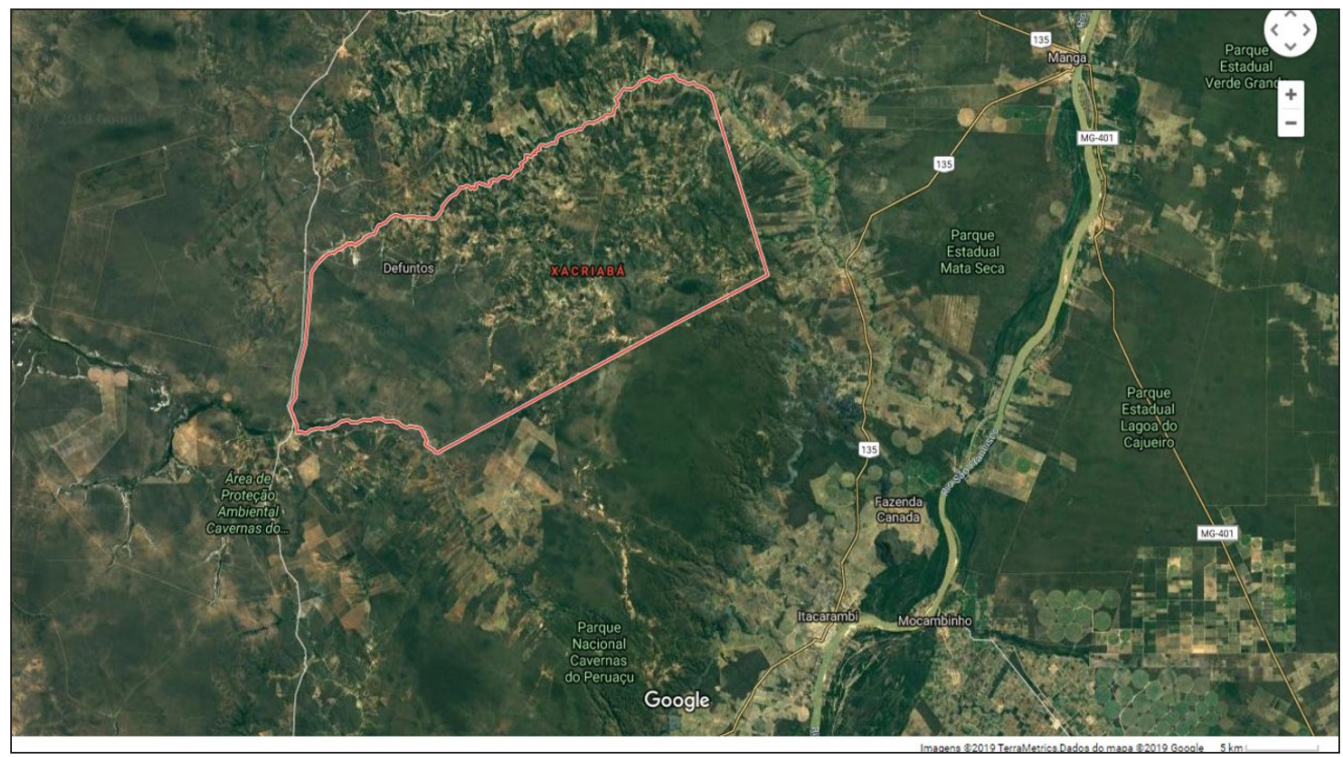

Fonte: Xacriabá, MG, 2019.

Ao apresentar o mapa, os estudantes relatam as práticas pesquisadas na aldeia, descrevem os elementos incluídos no mapa ou mesmo incluem informações que exemplificam as relações sociais que regulam o modo de vida. Destacam problemas vividos em função das mudanças no meio ambiente, nas práticas econômicas e reforçam o forte vínculo com a luta pela permanência no território, ainda que tenham de passar pelas dificuldades da falta d'água, da pouca produção das roças, do desemprego etc. Depois dessa apresentação, os estudantes fazem ampliações e reduções do desenho, utilizando escala decimal.

O mapa dos estudantes é uma representação gráfica da geopolítica da aldeia; diferentemente do mapa do território Xacriabá (Figura 3b), que caracteriza sua extensão e os limites, é um "discurso político a serviço do Estado". No seu mapa, elementos do cotidiano, da cultura e do modo como se vive na comunidade são percebidos: (1) a escola, (2) as casas das pessoas da comunidade (todas identificadas com o nome do morador), (3) o campo de futebol, (4) a roça, (5) pé de juá, (6) barragens e lagoas, (7) mata e outros espaços coletivos. Com destaque, incluem-se as nascentes, a mata seca, a árvore barriguda e os animais. Também identificamos alguns elementos que expressam mudanças recentes no modo 
vida, como rede elétrica, antenas de telefonia, aparelho de telefone público, reservatórios de água, entre outros.

Em conversa com os estudantes da turma de 2018, após a finalização das atividades, eles consideraram mais difícil fazer o desenho da FaE do que da aldeia, pois esta é o "seu lugar, é mais conhecido". Por causa do conhecimento que eles possuem do lugar, do território, representar a aldeia por meio de mapa é mais fácil, afinal, é onde fazem os trajetos. Eles reforçam que a referência de território

é a nossa casa, a terra que o Xakriabá ocupa [...] é a identificação das pessoas com o lugar [...] com a natureza, têm uma ligação sentimental [...] quando a gente coloca o pé no território, a gente já se sente em casa, mesmo que ainda não tenha chegado em nossa aldeia. (Conversa coletiva, 06/09/2019).

A afirmação dos direitos de reconhecimento do espaço e de sua representação surge anteriormente ao estudo prévio do território, ou seja, "para os índios, em certas circunstâncias, ao contrário da epistemologia ocidental, 'o mapa é o território'” (ACSELRAD, 2015, p. 16). Como vimos nos mapas da FaE, no momento em que os estudantes saem do território de origem e chegam à universidade, explorar e conhecer esse novo espaço torna-se um "esforço coletivo de um grupo social para ocupar, usar, controlar e se identificar com uma parcela específica de seu ambiente biofísico, convertendo-se assim em seu 'território'" (LITTLE, 2002, p. 3), um esforço de construção de territorialidades. Afinal, como relatado por Ribeiro (2019, p. 15), estudante Xakriabá que ingressou em 2015: “Claro que a primeira semana que cheguei em $\mathrm{BH}$ foi muito difícil, pois eu não conhecia quase ninguém, até mesmo dos Xakriabá".

Nesse sentido, as atividades de orientação, localização e representação do espaço da FaE contribuem para que os estudantes explorem o novo território, na perspectiva de Santos (2006), ou seja, como o "território usado", ampliado para um lugar de pertencimento, de apropriação, de construção de territorialidades, em que há "identificação das pessoas com o lugar". Ao mesmo tempo, ao identificarem dentro desse espaço elementos da cultura indígena (mastro ritual, casa de arquitetura Xakriabá, jardim de ervas medicinais) e interagirem com eles, praticando suas danças e cantos, experimentando seus remédios, fortalecem vínculos com a universidade, pois "o corpo precisa estar em movimento e reagindo na luta" (CORREA XAKRIABÁ, 2018, p. 87), demarcando a presença indígena 
naquele espaço. Nesse sentido, conectam-se com as suas origens e estabelecem territorialidades como uma estratégia de contextualização geográfica e construção de identidades (SACK, 1986).

Na opinião de Stavenhagen (2006, p. 145), os povos indígenas tendem a ver a terra como parte de algo mais amplo, estabelecem uma relação especial com a terra, sua fonte de sobrevivência e sustento e a base de sua existência como comunidades territoriais identificáveis. Assim, ao expressar em seus mapas o uso que fazem da terra (agricultura, extrativismo, pastagens), individual e coletivo, os Xakriabá demarcam relações para assegurar sua sobrevivência social, econômica e cultural, o que percebemos ser prioridade em suas representações do espaço. Porém, como adverte Acselrad (2015), se, por um lado, historicamente, "os mapas serviram como instrumentos do império para despossuir os indígenas e os povos negros rurais de suas terras" (p. 11), por outro, ganham força os movimentos de cartografia participativa, principalmente entre os indígenas e quilombolas, pois

Os mapas podem ser constitutivos de, e ao mesmo tempo, constituídos por, relações sociais que conectam pessoas a lugares, identidades a territórios, e, por essa razão, têm o potencial de criar novas, e com frequência, perturbadoras relações de poder. Isto porque os mapas tanto as conformam, como as refletem. (ACSELRAD, 2015, p. 11).

Entre os Xakriabá, esse movimento surge dentro de uma organização interna entendida por eles próprios, como evidencia a liderança e ancião:

[...] porque para nós é a organização interna, antiga... dos mais velhos... aí nós trabalha para isso não ir abaixo [...] até isso merece ser explicado para os estudantes... muitos estudantes não conhecem a realidade desse território... acha que essa terra é muita... pra tira a diferença nela... a serra... as grota... os lugar impossíve que ninguém pode nem anda... ela se torna muito pouca... porque a terra mesmo onde nóis pode usa... é muito pouco... (Entrevista com Sr. Valdemar da Prata, 2015).

Na sequência do mapa da aldeia, aspectos de localização no território são explorados pelos estudantes por meio de fotografias de um ponto de referência escolhido em sua aldeia, tais como: casa de cultura, escola, centro social comunitário, a própria casa, quintais, árvores, montanhas, estradas e encruzilhadas. Cada estudante informa sua posição no momento em que a foto foi tirada e explica o motivo da escolha do lugar, fazendo a descrição detalhada dos elementos 
que aparecem. Para finalizar, imaginando-se em outro ponto de referência, faz a representação gráfica por meio de desenho e compara a nova imagem com a foto original.

A exemplo do mapa da aldeia, as fotografias tiradas no território expressam não só o espaço físico, mas toda a dinâmica da vida Xakriabá, o fazer coletivo, o espaço privilegiado de praticar sua cultura, a forte presença da escola, as formas de circulação no território etc. Todavia, em suas representações, os limites e o espaço, como retratados na fotografia e no desenho apresentados da casa da estudante Leia (Figura 4a e 4b), não têm o propósito de indicar a divisão territorial em lotes para cada núcleo familiar, longe disso. Leia explica que a "cerca" no terreno da sua casa existe para "proteger o espaço para que nenhum animal coma as plantas". Os pontos de referência para localização naquela fração do território são o pé de fruta, o fogão a lenha, o brinquedo no chão, o franguinho no quintal, expressões de um modo construtivo do próprio povo, de hábitos alimentares e da presença de crianças.

Figura 4a - Fotografia da casa e quintal da estudante Leia

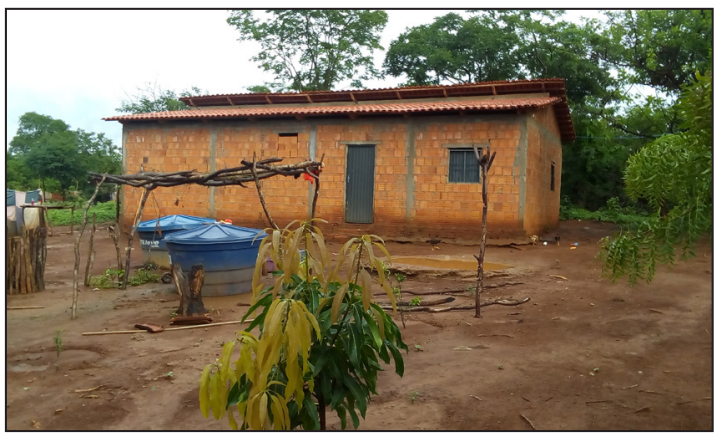

Figura 4b - Desenho da casa e do quintal da estudante Leia, vistos de outra posição em relação à fotografia

Fonte: Estudante Leia Gomes de Araújo, 2018.

Existem outros fatores envolvidos nas relações etnoterritoriais Xakriabá, como a espiritualidade e a história com suas terras de origem. Ao formular uma noção de território como fizemos acima e a utilizarmos para analisar as representações espaciais, destacamos que, no território, sociedade e cultura se desenvolvem e se reproduzem ao longo das gerações (STAVENHAGEN, 2016, p. 146), pois, 
como argumenta Corrêa Xakriabá (2018, p. 8), "o território é cheio de ciência, o limite de uma terra está em nossa consciência".

Figura 5a - Fotografia da estrada da aldeia de Imbaúba

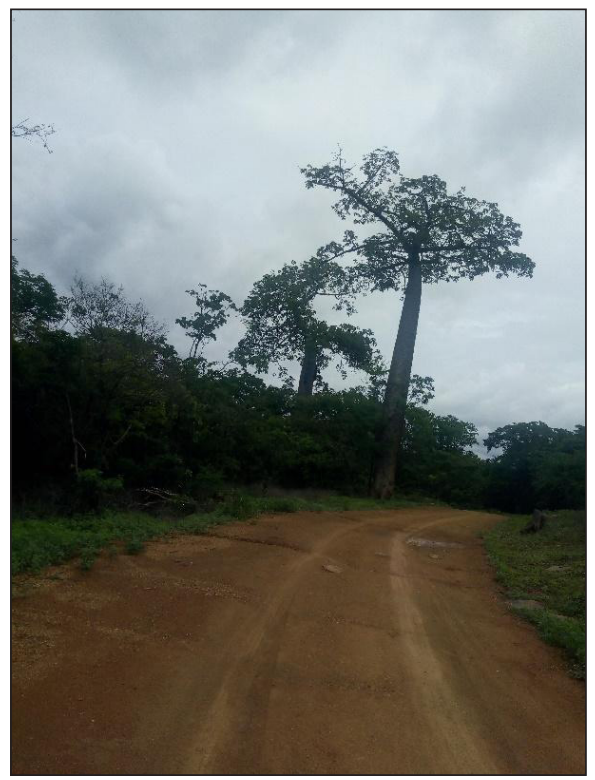

Figura 5b - Desenho de um caminho de acesso à aldeia (vista de outra posição em relação à fotografia)

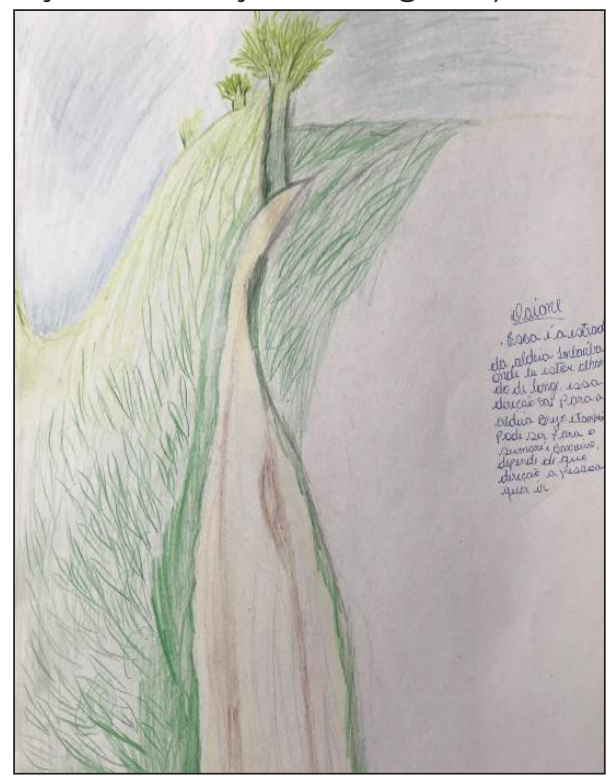

Fonte: Estudante Daiane Gonçalves de Oliveira, 2018.

Para fazer o desenho (Figura 5b), a estudante Daiane escolheu uma estrada de acesso a sua aldeia e destacou a árvore barriguda como ponto de referência. Ela explica:

Essa é a estrada da aldeia Imbaúba onde eu estou olhando de longe. Essa direção vai para a aldeia Brejo e também pode ser para a Sumaré e Barreiro, depende de que direção a pessoa quer ir. (Texto retirado do desenho de Daiane, 03/12/2018).

Da mesma forma, no desenho de Leia (Figura 4b), feito a partir da fotografia, em que ela representa sua casa deslocando-se para direita e aproximando-se, ela explica seu novo ponto de vista para o desenho:

Minha casa. Lado direito: tem um pé de uma fruta chamada Imbú, ao lado dele tem uma cerca que tem como função proteger o espaço para que nenhum animal coma as plantas; por fora da cerca tem uma estrada que é acessada pelos vizinhos 
e visitantes. Lado esquerdo: tem um fogão a lenha, continua a cerca, onde é a divisa do espaço da casa com o espaço da casa da vizinha. (Texto retirado do desenho de Leia, 03/12/2018).

Assim, a exemplo da atividade realizada no período de aulas na universidade, as formas de localização e orientação espacial do território utilizadas pelos estudantes tensionam o uso de noções como perspectiva e representação no plano de objetos tridimensionais, como foi feito pelos estudantes. Como vimos, a prioridade nessas representações é a função social e os modos indígenas de elaborar seus conhecimentos sobre o espaço representado, formas de reforçar a identidade étnico-cultural.

\section{A GEOMETRIA COMO EXPRESSÃO DE TERRITORIALIDADES XAKRIABÁ}

A análise que empreendemos na seção anterior nos permite afirmar que o estudo realizado pelos estudantes Xakriabá explorando noções de orientação, localização e representação espacial não adota os mesmos critérios estáticos e dinâmicos que estruturam a abordagem ocidental para orientação, localização e, principalmente, representação espacial nos mapas. Os mapas ressaltam seu modo de vida e suas relações com os territórios. Nessa perspectiva, o estudo configurou-se como uma ação político-pedagógica, que problematizou o processo histórico de constituição desse conteúdo no currículo de formação de professores indígenas que atuam em escola específica, diferenciada e intercultural, ressaltando outros aspectos a serem explorados na escola. Como afirma a ativista política Célia Corrêa Xakriabá (2018, p. 19), “a escola precisa servir para valorizar as experiências que o indígena vive em seu território".

Nas atividades tanto na universidade quanto nos territórios, as noções de localização, orientação e representação espacial foram tensionadas pelas formas como os estudantes estabeleceram suas territorialidades, mostrando a estreita relação com as dinâmicas do território. Na escola indígena, ensinar essas noções é uma tarefa que envolve os anciãos, pois eles que detêm conhecimento dos seus territórios, independentemente da demarcação política expressa nos mapas oficiais. Como enfatizam os licenciandos, em texto produzido sobre as práticas tradicionais em 2018, os anciãos e as lideranças são fontes de pesquisa, são "referências, conhecedores, agentes e guardiões de objetos e instrumentos" das práticas Xakriabá. 
Quando os estudantes indígenas passam a se mover em diferentes territórios (nas aldeias e na universidade), surgem tensões, uma vez que as dinâmicas de uso são muito diferentes. Ao chegarem à universidade, os estudantes ainda não têm vínculo de pertencimento com esse espaço. No decorrer das atividades, desenvolvidas por meio de exploração do espaço físico da universidade, principalmente da $\mathrm{FaE}$, começam a percebê-lo como um espaço socialmente construído, experimentando-o e dotando-o de significado, ou seja, construindo suas territorialidades. Como afirma Haesbaert (2004), território está relacionado ao poder de apropriação, neste caso específico, de apropriação política. Mas, no dizer dos estudantes, território "é uma ligação sentimental", por isso a formação dos licenciandos não pode se basear apenas no conhecimento ocidental europeu, é importante entender o modo de produção do conhecimento dos indígenas e o uso político que se faz dele.

\section{CONSIDERAÇÕES FINAIS}

Neste artigo, analisamos os tensionamentos que ocorrem nas práticas de formação de professores indígenas, quando se abordam noções de localização, orientação e representação espacial. Pontuamos as relações que essas noções suscitam nas práticas do território e mostramos como as representações do espaço destacam mais o seu uso e as dinâmicas que nele ocorrem do que elementos técnicos de projeção do espaço no plano ou mesmo as referências geográficas.

Todavia alertamos que as formas de orientação, localização e representação no espaço, próprias do povo Xakriabá, não esgotam as discussões em uma turma multiétnica, pois outras formas de conceber o espaço concorrem em uma licenciatura que reúne indígenas de etnias diferentes. De todo modo, as experiências vivenciadas por um povo no território fortalecem suas relações etnoterritoriais e configuram uma ferramenta político-pedagógica para a promoção de sua escola diferenciada.

Finalmente, considerando as relações que os estudantes indígenas estabelecem com o uso do território em suas aldeias e na universidade, não se pode transpor para a escola indígena o papel que a geometria tem na escola não indígena, qual seja, o desenvolvimento do raciocínio para compreender, descrever e representar, de forma organizada, o mundo em que se vive, sendo essencial na 
formação do indivíduo (FONSECA et al. 2001). Além de desenvolver pensamento geométrico, outros ensinamentos transmitidos dos anciãos, experiências em diferentes territórios, que se identificam com os conhecimentos acadêmicos da matemática, contribuem para construir as referências de saberes espaciais para o trabalho em suas escolas. Dessa forma, a reinvindicação de uma escola diferenciada indígena que promova uma educação intercultural tensiona o ensino de geometria nas aldeias, de modo a incorporar discussões mais amplas e profundas sobre o uso do território, das relações econômicas, culturais e políticas que nele tomam lugar. Da mesma forma, os cursos de licenciatura não podem se isentar de tais discussões, seja na habilitação em matemática, seja na formação mais geral.

\section{AGRADECIMENTOS}

Nossos sinceros agradecimentos aos estudantes Xakriabá, ao seu Valdemar, liderança da Aldeia Prata, pelos ensinamentos, pela confiança e disponibilidade em colaborar com o nosso trabalho.

Agradecemos também à Fundação de Amparo à Pesquisa de Minas Gerais (Fapemig) - Programa Pesquisador Mineiro, PPM X. Proc. CHE - PPM-00701-16, e ao Conselho Nacional de Pesquisa (CNPq), Proc. 470960/2014-0.

\section{REFERÊNCIAS}

ABREU, Werly Pinheiro de Abreu (Dogllas). Onde houver Xakriabá, haverá resistência! Violações dos direitos indígenas no caso Xakriabá durante a ditadura militar. 2018. 60 f. Trabalho de Conclusão de Curso (Graduação em Educação) - Universidade Federal de Minas Gerais, Belo Horizonte, MG, 2018.

ACSELRAD, Henri. Introdução: o debate sobre cartografia e processos de territorialização - anotações de leitura. In: ACSELRAD, Henri; GUEDES, André Dumas; MAIA, Laís Jabace (Org.). Cartografias sociais, lutas por terra e lutas por território. Universidade Federal do Rio de Janeiro, Instituto de Pesquisa e Planejamento Urbano e Regional, Rio de Janeiro: 2015.166 p. (Coleção Território, Ambiente e Conflitos Sociais, n. 5).

ALKIMIM, Erick Correa; SANTOS, Marilene de Oliveira. Casa de cultura Xakriabá: lugar de conhecimento, cultura, memória e história. 2019. 94 f. Trabalho de Conclusão de Curso (Graduação em Formação Intercultural de Educadores Indígenas)- Faculdade de Educação, UFMG. Belo Horizonte, MG, 2019. 
ARAÚJO, Edilene dos Santos. Análise de uma atividade a partir do calendário sociocultural numa escola da aldeia indígena da Prata, povo Xakriabá. 2018. 48 f. Trabalho de Conclusão de Curso (Graduação em Educação) - Universidade Federal de Minas Gerais, Belo Horizonte, MG, 2018.

ARAÚJO, Mariane Dias. "Demarcando território": tensionamentos nas pesquisas de autoria indígena no contexto da Formação Intercultural para Educadores Indígenas (Fiei). 2019. 152 f. Dissertação (Mestrado em Educação) - Programa de Pós-Graduação Conhecimento e Inclusão Social, Faculdade de Educação, Universidade Federal de Minas Gerais, Belo Horizonte, MG, 2019.

BIZERRA, Ednaldo Gonçalves. Meio ambiente, sustentabilidade e economia do povo Xacriabá e da Aldeia barreiro Preto. Trabalho de Conclusão de Curso (Formação Intercultural de Educadores Indígenas)- Faculdade de Educação, UFMG. Belo Horizonte, MG, 2018.

BRASIL. Resumo do relatório circunstanciado de reestudo de limites da terra indígena Xacriabá. Anexo. Fundação Nacional do Índio (Funai). Diário Oficial da União, Brasília, DF, n. 192, p. 30-36, 6 de outubro de 2014.

BRASIL. Referencial curricular nacional para as escolas indígenas. Ministério da Educação e do Desporto, Secretaria de Educação Fundamental. Brasília: MEC/SEF, 1998. 331 p.

BRITO, Ruana Priscila da Silva. Apropriação das práticas de numeramento em um contexto de formação de educadores indígenas. 2012. 268 f. Dissertação (Mestrado em Educação) - Faculdade de Educação da Universidade Federal de Minas Gerais, Belo Horizonte, MG, 2012.

CORREA XAKRIABÁ, Célia Nunes. O barro, o genipapo e o giz no fazer epistemológico de Autoria Xakriabá: reativação da memória por uma educação territorializada. 2018. 218 f. Dissertação (Mestrado Profissional em Sustentabilidade Junto a Povos e Terras Tradicionais) - Centro de Desenvolvimento Sustentável, Universidade de Brasília, Brasília, DF, 2018.

D’AMBROSIO, Ubiratan. Etnomatemática - elo entre as tradições e a modernidade, Belo Horizonte: Ed. Autêntica, 2011.

FERREIRA, Eduardo Sebastiani. Os índios Waimiri-Atroari e a Etnomatemática. In: KNIJNIK, Gelsa; WANDERER, Fernanda; OLIVEIRA, Claudia. Etnomatemática, currículo e formação. Santa Cruz do Sul: Edunisc, 2004. p. 70-88.

FERREIRA, Mariana Kawall (Org.) Idéias matemáticas de povos culturalmente distintos. São Paulo: Global, 2000. (Série Antropologia e Educação). 
FONSECA, Maria da Conceição F. R.; LOPES, Maria da Penha; BARBOSA, Maria das Graças Gomes; GOMES, Maria Laura M.; DAYRELL, Monica M. M. L. M. O ensino de Geometria na escola fundamental: três questões para a formação do professor dos ciclos iniciais. Belo Horizonte: Autêntica, 2001.

HAESBAERT, Rogério. O mito da desterritorialização: do "fim dos territórios" à multiterritorialidade. Rio de Janeiro: Bertrand Brasil, 2004.

HAESBAERT, Rogério. Território, poesia e identidade. Espaço e cultura, n. 3, p. 20-32, jan. 1997.

INSTITUTO NACIONAL DE ESTUDOS E PESQUISAS EDUCACIONAIS ANÍSIO TEIXEIRA (Brasil). Censo Escolar, 2018. Brasília: Inep, 2018. Disponível em: http://portal.inep.gov. br/artigo/-/asset_publisher/B4AQV9zFY7Bv/content/dados-finais-do-censo-escolar-2018sao-publicados-no-diario-oficial-da-uniao/21206. Acesso em: 18 nov. 2019.

INSTITUTO NACIONAL DE ESTUDOS E PESQUISAS EDUCACIONAIS ANÍSIO TEIXEIRA (Brasil). Sinopse Estatística da Educação Superior 2016. Brasília: Inep, 2017. Disponível em: http:// portal.inep.gov.br/web/guest/sinopses-estatisticas-da-educacao-superior. Acesso em: 6 fev. 2018.

LITTLE, Paul E. Territórios sociais e povos tradicionais no Brasil: por uma antropologia da territorialidade, 2002.

LORENZONI, Claudia A. C. Araujo. Cestaria Guarani do Espírito Santo numa perspectiva Etnomatemática. 2010. Tese (Doutorado em Educação) - Universidade Federal do Espírito Santo, Centro de Educação, Vitória, ES, 2010.

LUCIANO, Gersem José dos Santos. Os saberes indígenas e a escola. É possível e desejável uma escola indígena diferenciada e intercultural? In: ENDIPE, 15., Convergências e tensões no campo da formação e do trabalho docente: políticas e práticas educacionais. Belo Horizonte, 20 a 23 de abril, 2010. Anais [...]. Belo Horizonte: Endipe, 2010. p. 1-12.

MARCILINO, Ozirlei Teresa. Educação escolar Tupinikim e Guarani: experiências de interculturalidade em aldeias de Aracruz, no Estado do Espírito Santo. 2014. Tese (Doutorado em Educação)- Universidade Federal do Espírito Santo, Vitória, ES, 2014.

MENDES, Jackeline Rodrigues; TAMAYO-OSORIO, Carolina. Saberes e práticas matemáticas na educação (escolar) indígena. Zetetiké, Campinas, v. 26, n. 1, p. 1-7, jan./abr. 2018. [Dossiê Temático]. 
MENDONÇA, Augusta Aparecida Neves. Reflexões sobre as práticas educativas dos professores indígenas Xacriabá: contribuições da Etnomatemática e da Educação Matemática Crítica. In: ARAÚJO, Jussara Loiola. Educação matemática crítica: reflexões e diálogos. Belo Horizonte: Argvmentvm, 2007. p. 97-109.

MENEGHETTI, Renata C. Geromel. Constituição do saber matemático: reflexões filosóficas e históricas. Londrina: Eduel, 2010.

MUSBERG, João Alberto Steffen; FERREIRA DA SILVA, Gilberto. Interculturalidade na perspectiva da descolonialidade: possibilidades via educação. Revista Ibero-Americana de Estudos em Educação, Araraquara, v. 13, n. 1, p. 140-54, jan./mar. 2018.

OLIVEIRA, Neuza Rodrigues da Silva. Roupas de palha tradicionais Xakriabá. 2018. 51 f. Trabalho de Conclusão de Curso (Graduação em Educação)- Universidade Federal de Minas Gerais, Belo Horizonte, MG, 2018.

QUIJANO, Aníbal. Colonialidade do poder, eurocentrismo e América Latina. In: LANDER, E. (ed.). A colonialidade do saber: eurocentrismo e Ciências Sociais. Buenos Aires: Clacso, 2005. p. 227-78.

RIBEIRO, Laurisaura da mota. O milho nas vidas e lutas do povo Xakriabá. 2019. 83 f. Trabalho de Conclusão de Curso (Licenciatura em Formação Intercultural para Educadores Indígena, Habilitação em Ciências da Vida e da Natureza.) - Faculdade de Educação, Universidade Federal de Minas Gerais, Belo Horizonte, 2019.

SACK, Robert David. Human territoriality: its theory and history. Cambridge: Cambridge University Press, 1986.

SANTOS, Milton. A natureza do espaço: técnica e tempo, razão e emoção. 4. ed. 2 reimpr. São Paulo: Editora da Universidade de São Paulo, 2006. (Coleção Milton Santos, v. 1).

SILVA, Manoel Antônio de Oliveira. "A única herança que um índio deixa para outro índio é a luta": a história da língua Akwen do Povo Xakriabá. 2018. 47 f. Trabalho de Conclusão de Curso (Graduação em Educação)- Universidade Federal de Minas Gerais, Belo Horizonte, MG, 2018.

SOUSA, Abedias Pereira de Sousa. Mudanças na vida e na cultura Xakriabá: das alterações econômicas e climáticas. 2019. Trabalho de conclusão de curso (Formação Intercultural de Educadores Indígenas) - Universidade Federal de Minas Gerais, Belo Horizonte, MG, 2018.

STAVENHAGEN, Rodolfo. Land and Territory. In: ACSELRAD, Henri; GUEDES, André Dumas; MAIA, Laís Jabace (Org.). Cartografias sociais, lutas por terra e lutas por território. Rio de 
Janeiro: UFRJ; Instituto de Pesquisa e Planejamento Urbano e Regional, 2016. p. 143-6.

STREET, Brian. What's 'new' in New Literacy Studies? Critical Approaches to Literacy in Theory and Practice. Current Issues in Comparative Education, v. 5, n. 2, p. 77-91, Columbia, 2003.

STUMPF, Beatriz Osorio. Reflexões sobre interdisciplinaridade, interculturalidade e interinstitucionalidade em processo formativo de professores indígenas. Tellus, ano 19, n. 38, jan./abr. 2019, p. 319-40.

TOMAZ, Vanessa Sena; CAMPOS, Ilaine da Silva. Práticas sociais (matemáticas) de produção de um planejamento financeiro na formação de educadores indígenas. Reveduc - Revista Eletrônica de Educação, v. 12, 2018, p. 556-76.

TOMAZ, Vanessa Sena; KNIJNIK, Gelsa. Tensionamentos na formação intercultural de professores indígenas: um estudo da escola Xakriabá. Educação em Revista, Belo Horizonte, v. 34, 2018, p. 1-27.

TUHIWAI SMITH, Linda. Decolonizing methodologies. Research and indigenous peoples. 2a. ed. London \& New York: Zed Books, 2012.

UNIVERSIDADE FEDERAL DE MINAS GERAIS. Projeto político-pedagógico do curso de Formação Intercultural para Educadores Indígenas. Belo Horizonte: Fiei, 2009.

WALSH, Catherine. Interculturalidad y (de)colonialidad: perspectivas críticas y políticas. Visão Global, Joaçaba, v. 15, n. 1-2, p. 61-74, jan./dez. 2012.

WALSH, Catherine. Interculturalidad crítica y educación intercultural. In: UZIEDA, Jorge Viaña; MEALLA, Luis Tapia; WALSH, Catherine E. Construyendo interculturalidad crítica. La Paz: Convenio Andrés Bello; Instituto Interamericano de Integración, 2010.

XACRIABÁ, MG. (2019). Google Maps. Google. Disponível em: https://www.google.com.br/ maps/place/Xacriab\%C3\%A1,+S\%C3\%A3o+Jo\%C3\%A3o+das+Miss\%C3\%B5es+-+MG/@$14.8769513,-44.4298601,46120 \mathrm{~m} / \mathrm{data}=! 3 \mathrm{~m} 2$ ! 1e3!4b1!4m5!3m4!1s0x756fda6b3d22 c6d:0xf672efadc99ebb1d!8m2!3d-14.8813627!4d-44.2515683?hl=pt-BR\&authuser=0. Acesso em: 29 nov. 2019.

\section{Sobre as autoras:}

Ozirlei Teresa Marcilino: Pós-Doutora em Conhecimento e Inclusão Social em Educação pela Universidade Federal de Minas Gerais (UFMG). Doutora e mestre 
em Educação pela Universidade Federal do Espírito Santo (Ufes). Especialista em Administração e Supervisão Escolar e Matemática. Graduada em Pedagogia pela Escola Superior São Francisco de Assis; em Licenciatura Plena no Curso de Ciências: habilitação em Matemática, pela Faculdade de Filosofia, Ciências e Letras Madre Gertrudes de São José; e em Administração, pela Faculdade de Ciências Econômicas de Colatina. Pesquisadora com interesse em Educação Matemática Indígena, Educação Étnico-Racial, Educação do Campo, Culturas e Povos Tradicionais. Professora do Departamento de Teorias do Ensino e Práticas Educacionais do Centro de Educação da Universidade Federal do Espírito Santo. E-mail: otmarcilino@yahoo.com.br, Orcid:http://orcid.org/0000-0001-6694-8687 Vanessa Sena Tomaz: Pós-doutora pela Universidade do Vale do Rio dos Sinos (Unisinos-RS), incluindo estágio de pesquisa no Center for Research on Activity, Development and Learning (Cradle) - University of Helsinki. Doutora e mestre em Educação pela Faculdade de Educação da Universidade Federal de Minas Gerais. Licenciada em Matemática pela Universidade Federal de Minas Gerais (UFMG). Atualmente, é professora associada do Departamento de Métodos e Técnicas da Faculdade de Educação da Universidade Federal de Minas Gerais. Membro do colegiado da Licenciatura Intercultural para Educadores Indígenas, onde é coordenadora da turma de habilitação em Matemática. Coordena o Grupo de Estudos e Pesquisas em Educação Escolar Intercultural Indigena (Gepeei), situado na Faculdade de Educação da UFMG. Atua na área de Educação, com ênfase em Educação Matemática. Desenvolve pesquisas sobre aprendizagem matemática dentro da perspectiva da teoria da atividade histórico-cultural, com foco em: práticas matemáticas em sala de aula, aprendizagem expansiva, educação escolar indígena, interdisciplinaridade e docência na educação básica e superior. E-mail: vanessastomaz@gmail.com, Orcid: http://orcid.org/0000-0002-4903-6405

Recebido em 17 de dezembro de 2019.

Aprovado para publicação em 6 de maio de 2020. 



\title{
A caça e os caçadores Tapirapé da Aldeia Tapi'itãwa The Tapirapé Hunt and hunters of the Village Tapi'itãwa
}

\author{
Edivaldo Soares Silva ${ }^{1}$ \\ Flávio Bezerra Barros ${ }^{2}$
}

DOI: http://dx.doi.org/10.20435/tellus.v0i42.686

\begin{abstract}
Resumo: $O$ artigo discute a importância da caça no universo do povo Tapirapé. Estudamos as práticas de caça, as cosmologias, os rituais e o processo de formação do homem caçador a partir dos princípios da cultura Tapirapé. A caça exerce papel fundamental na soberania e segurança alimentar das famílias indígenas, sendo o porcão/queixada uma das carnes preferidas, tanto para a alimentação cotidiana como para os rituais e festas. Desenvolvemos o estudo a partir de uma perspectiva etnográfica, com o emprego de entrevistas e observação participante. O estudo foi conduzido na aldeia Tapi'itãwa, em Mato Grosso, durante o período de abril a dezembro de 2018. A caça, por fim, é um universo que envolve questões de ordem material e simbólica, por isso é tão fundamental na cultura e na vida do povo Tapirapé.
\end{abstract}

Palavras-chave: conhecimento tradicional; alimentação; povos indígenas; Mato Grosso.

\begin{abstract}
The paper discusses the importance of hunting in the universe of the Tapirapé people. We study hunting practices, cosmologies, rituals, and the process of learning hunters based on the principles of Tapirapé culture. Hunting plays a fundamental role in the sovereignty and food security of the indigenous families, with peccaries being one of the preferred meats, both for daily food and for rituals and parties. We developed the study from an ethnographic perspective, using interviews and participant observation. The study was conducted in the Tapi'itãwa village, Mato Grosso State, from April to December 2018. The hunting, finally, is a universe that involves material and symbolic issues, which is why it is so fundamental in culture and in the life of the Tapirapé people.
\end{abstract}

Keywords: traditional knowledge; food; indigenous peoples; Mato Grosso State.

1 Universidade do Estado de Mato Grosso (Unemat), Cáceres, Mato Grosso, Brasil.

2 Universidade Federal do Pará (UFPA), Belém, Pará, Brasil. 


\section{INTRODUÇÃO}

O trabalho aqui apresentado é um recorte de uma pesquisa de mestrado do primeiro autor, efetivada na comunidade indígena da aldeia Tapi'itãwa, do povo Tapirapé, situada no Território Indígena Urubu-Branco, no Nordeste do Estado de Mato Grosso. Os limites geográficos desse território atingem os municípios de Confresa, Santa Terezinha e Porto Alegre do Norte. Trata-se de um povo que pertence ao tronco linguístico Tupi-Guarani, o qual habita a região desde o século XVIII (Cf. BALDUS, 1970; WAGLEY, 1988).

O objetivo deste artigo é descrever os aspectos cosmológicos, os conhecimentos tradicionais, os rituais e a constituição do sujeito caçador, destacando o papel da caça na vida e alimentação das famílias indígenas. A caça, enquanto atividade humana produtiva para os Tapirapé, configura-se como uma das mais importantes, pois demarca a identidade, ao mesmo tempo que garante a segurança alimentar. Apresentamos a identidade do homem Tapirapé, destacando as exigências culturais para tornar-se um caçador. Como a caça constitui elemento essencial da cultura alimentar dos Tapirapé, fez-se importante em nossa investigação descrever os tipos de animais consumidos e quais são os fatores, cosmológicos, culturais e ambientais, que determinam e interferem nesse processo que faz parte do modelo de organização social e do modo de vida desse povo.

Estudos sobre caça estão presentes nas etnografias clássicas e serviram para lançar luz a diversas teorias, como o perspectivismo, por exemplo (VIVEIROS DE CASTRO, 1996). Este autor conduziu pesquisa com o povo Araweté e percebeu como ocorria a relação dos indígenas com os animais. Para os Araweté, os animais são compreendidos como parentes humanos disfarçados em roupas. Silverwood-Cope (1990) também trouxe importante contribuição para a leitura da vida dos Makú, um povo caçador habitante da fronteira entre Colômbia e Brasil. De acordo com este autor, a caça é tão fundamental na vida dos Makú que os homens dedicam todo o seu tempo e sua energia a caçar e só se preocupam com a pesca ao voltarem de uma caçada malsucedida, para trazer alguma coisa para a refeição da noite.

Bechelany (2017) também desenvolveu uma etnografia da caça entre os Panará, com interesse, sobretudo, nas relações entre a caça, a produção do parentesco e relações de gênero; a constituição do corpo e as formas da pessoa masculina; a relação com entes não humanos; as formas do movimento que a caça enseja; a gênese do caçador na relação com a arma e os animais predados. Barros (2017) e 
Santos-Fita, Naranjo e Rangel-Salazar (2012) trazem diferentes abordagens sobre o papel da caça na vida de diversos grupos sociais. O primeiro pesquisou os ribeirinhos da Reserva Extrativista Riozinho do Anfrísio, no Pará, demonstrando que a caça está permeada de elementos simbólicos, saberes e organiza-se a partir de regras e condicionantes cuja clássica dissociação cultura e natureza não seria possível. Santos-Fita, Naranjo e Rangel-Salazar (2012), por conseguinte, estudaram os usos e os padrões de caça em comunidades rurais da Península de Yucatan (México), demonstrando aspectos espirituais e cosmológicos da caça.

O artigo está dividido em oito seções, sendo a introdução a primeira delas. Este estudo foi conduzido durante os anos de 2017 e 2018, na aldeia Tapi'itãwa (Figura 1), a qual se configura como a maior aldeia em relação às demais aldeias no Território Indígena Urubu Branco.

Figura 1 - Mapa do Território Indígena Urubu Branco e os limites municipais de Confresa, Santa Terezinha e Porto Alegre do Norte, MT

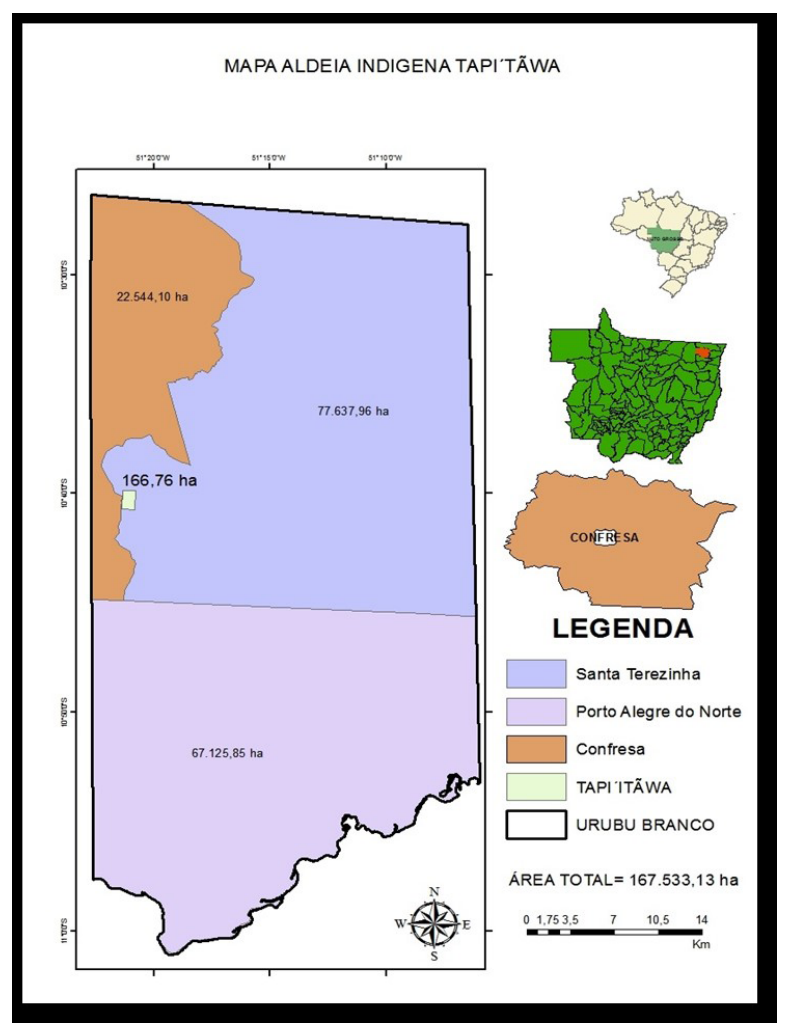

Fonte: Elaboração de Waynne Lima, mar./2019, dados do IBGE. 


\section{PROCEDIMENTOS METODOLÓGICOS}

Adotamos, por exigência da natureza do trabalho, abordagem qualitativa, procurando entender as representações socioculturais dos índios Tapirapé da aldeia Tapi'itãwa. Múltiplas perspectivas metodológicas foram empregadas no sentido de uma complementar a outra, enfatizando especialmente as diversas dimensões da comida a partir da atividade da caça.

A partir dessa abordagem multifacetada assentada no campo da Antropologia Social, tornou-se possível identificar elementos ou discriminantes de uma dada população aos eixos explicativos, conforme propôs Almeida (2001). Assim, a abordagem qualitativa foi definida considerando o universo de significados, motivos, aspirações, crenças, valores e atitudes circunscritas em um determinado espaço das relações, dos processos e fenômenos que não podem ser reduzidos à operacionalização de variáveis. Para Ludke e André (1986, p. 18), “o estudo qualitativo se desenvolve em uma situação natural, é rico em dados descritivos, tem um plano aberto e flexível e focaliza a realidade de forma complexa e contextualizada".

Conforme Maia (2009, p. 24), “uma vez definidos os objetivos do estudo, é preciso, então, definir o caminho que leva, de maneira científica, ao destino almejado". Assim, depende do pesquisador a escolha dos procedimentos, elaborando instrumentos diversos e organizando sua análise pela captura de seus conteúdos.

Dessa forma, a pesquisa foi desenvolvida a partir da "perspectiva etnográfica" (GEERTZ, 1978), por meio de entrevistas e acompanhamento das atividades voltadas à caça na aldeia Tapi'itãwa. Os trâmites para realização da pesquisa atenderam às exigências dos Tapirapé, da Fundação Nacional do Índio (Funai) - processo n. 08755.001217/2017-72, e do Comitê de Ética em Pesquisa (CEP) da Unemat, autorização n. 2656428. O projeto, intitulado "Caça e comida: uma etnografia dos saberes e práticas alimentares entre o povo Tapirapé na aldeia Tapi'itãwa”, foi primeiramente apresentado ao cacique Kamoriwa'i Elber Tapirapé, que, em seguida, foi levado em reunião específica, ao conhecimento das demais lideranças da comunidade e dos homens caçadores. A reunião foi registrada em ata.

Depois que o projeto foi apresentado, discutido com a comunidade e acolhido pelos interlocutores, as lideranças e caçadores que se dispuseram a participar da pesquisa assinaram o Termo de Anuência Prévia (TAP) e o Termo de Consentimento Livre e Esclarecido (TCLE). Ao todo, foram 14 homens caçadores; 
destes, um é cacique e três são pajés. Depois, deu-se seguimento ao protocolo de solicitação de autorização para realização da pesquisa, junto à Funai, que posteriormente foi encaminhado ao CEP. Somente depois que o comitê emitiu parecer favorável à realização da pesquisa, é que iniciamos os trabalhos de entrevista, participação nas caçadas e observação das festas e rituais em que se preparavam e serviam a comida.

O trabalho de campo ocorreu entre os meses de abril e dezembro de 2018. Para a coleta de dados sobre os conhecimentos tradicionais e as práticas sociais para a obtenção de alimento por meio do acesso à fauna, realizamos um empreendimento etnográfico a fim de compreender os processos que permeiam esse universo. O método etnográfico consiste em descrever significados culturais (conhecimentos, crenças, valores, modo de vida) de determinado grupo tradicional, por meio de um convívio entre o pesquisador e o grupo formado pela aproximação ao longo de anos (OLIVEIRA, 2000, p. 24).

Com base nas contribuições de Arruda (2005), segundo o qual o pesquisador deve "fazer o registro de dados e fotos que poderão posteriormente servir como auxiliar na análise interpretativa dos dados", utilizamos também o diário de campo a fim de registrar os dados da observação participante voltada a compreender as práticas da caçada e os respectivos processos realizados pelos indígenas até a transformação da caça em comida. Como maneira de enriquecer o texto etnográfico, valorizamos o recurso visual para dialogar com a escrita. Para tal, nós nos embasamos nos princípios da Antropologia Visual, trazendo para a escrita os desenhos elaborados pelo jovem indígena Apaxigoo, os quais, em nossa visão, trouxeram beleza para as narrativas da realidade investigada.

\section{DIREITO, PRÁTICAS, TÉCNICAS E COSMOLOGIA ENVOLVIDOS NAS CAÇADAS DO POVO TAPIRAPÉ}

A questão alimentar na aldeia Tapi'Itãwa é uma preocupação cotidiana, haja vista que a relação estabelecida com a comida transpõe meras práticas alimentares e constitui-se como fator determinante para a sobrevivência não só das pessoas, mas também da cultura.

O direito à manutenção da cultura dos povos indígenas, inclusive em relação à caça de animais silvestres, está assegurado na legislação brasileira por meio 
da Lei 6.001/1973 - Estatuto do Índio; Constituição Federal de 1988 e Decreto 6.040/2007, este último que institui a Política Nacional de Desenvolvimento Sustentável dos Povos e Comunidades Tradicionais.

Tais direitos se instauram para além de uma política de Estado laico, na garantia de resguardar ritos, costumes e práticas culturais, assegurando a liberdade para o exercício dessas, e qualquer tipo de censura, ridicularização ou hostilização de tais direitos constitui-se em crime, conforme o Estatuto do Índio, Artigo 58으, que descreve: "Constituem crimes contra os índios e a cultura indígena": inciso I"escarnecer de cerimônia, rito, uso, costume ou tradições culturais indígenas, vilipendiá-los ou perturbar, de qualquer modo, a sua prática".

No seio dessas garantias, destacamos as práticas culturais relacionadas aos rituais sagrados, sobretudo os que envolvem a questão da caça de animais silvestres, a partir das concepções sobre o que é comida e o que é alimento, como bem pontuou DaMatta (1986).

O conceito de sagrado ao qual nos inscrevemos é o da perspectiva etnológica, tomando-o dentro do conceito de cosmologia, que, segundo Ramos (1988), é a integração do material e do imaterial que permeia e sustenta a crença das sociedades indígenas, tendo a ver com o conjunto que se estrutura por meio dos mitos no conjunto que se faz pela articulação de elementos metafísicos, espirituais, com a natureza e o humano. Nas palavras da autora:

As cosmologias indígenas representam modelos complexos, mas integrados dos quais fazem parte a sociedade humana. Os mitos são veículos de informação sobre a composição do Universo, incluindo temas sobre a criação do mundo, a origem da agricultura, as relações ecológicas entre animais, plantas e outros elementos, a metamorfose de seres humanos em animais e vice-versa e de ambos em espíritos de vários tipos e índoles, a razão de ser de certas relações sociais culturalmente importantes e até mesmo o surgimento do "homem branco" e a avalanche de fatores desagregadores que o acompanham. (RAMOS, 1988, p. 85).

No caso do povo Tapirapé, as práticas culturais continuam fortemente marcadas pela manutenção dos mitos e, portanto, de rituais. Neste trabalho, nosso interesse é pensar nos rituais voltados para a atividade da caça a animais silvestres, desde a formação do homem caçador até o ato de caçar o animal, perpassando por sua transformação em comida, até os rituais para sua ingestão. 
É importante considerar que tratar a caçada de animais silvestres como atividade de subsistência e prática simbólica que remete à crença de um grupo social implica considerar estudos que apontam a caçada como uma prática que há tempos faz parte dos modos de produção social, simbólica e cultural do ser humano, sobretudo de comunidades tradicionais, famílias rurais e grupos indígenas. Tal prática constitui-se como costumes permeados por valores míticos e espirituais que permitem a construção de relações entre ser humano e natureza (FIGUEIREDO; BARROS, 2015).

Trata-se de atividades que, em sua maioria, são associadas a conhecimentos tradicionais que se destacam pelo uso do recurso cinegético ${ }^{3}$ como fonte de alimento. Contudo, apesar de diversos estudos tratarem do uso de animais silvestres na alimentação do ser humano, entre os quais se destacam Beltrán (1966), Linares (1976), Cooke (1981), para Figueiredo e Barros (2016a), há variadas dimensões que permeiam o uso de recursos faunísticos que, do ponto de vista científico, ainda demandam estudos mais aprofundados, sendo a Antropologia um dos campos importantes para se destacar os aspectos simbólicos e materiais envolvidos.

No bojo das discussões antropológicas, comida e alimento não têm o mesmo significado, ou seja, são categorias distintas. Segundo DaMatta (1986, p. 46), por alimento se compreende aquilo que serve ou pode ser ingerido para manter a vida, enquanto a comida marca a relação com a identidade, tem a ver com a escolha do alimento, prazer e comunhão. Nas palavras do autor, "O alimento é algo universal e geral. [...] Por outro lado, comida se refere a algo costumeiro e sadio, alguma coisa que ajuda a estabelecer uma identidade, definindo por isso mesmo um grupo, classe ou pessoa" (DAMATTA, 1986, p. 46).

A dicotomia que se estabelece no campo dos gêneros alimentícios não se limita ao que é aceito por determinado grupo enquanto alimento, ou acolhido como comida. De acordo com Woortmann (2008), há em várias regiões do Brasil e em parte da América Latina um jogo de oposição entre os alimentos, os quais são geralmente classificados em "quente/frio" ou "manso/reimoso".

Interessante observar que o trabalho realizado por Woortmann (2008) remonta ao caráter cultural da alimentação. Segundo o autor, essa classificação é feita sempre em relação ao organismo humano, e o mesmo alimento pode ser

3 Relativo à caça. 
considerado quente ou reimoso pela população de uma determinada região, e frio ou manso para populações de outras regiões.

Contudo a díade "quente $x$ frio" estende-se, segundo o autor, a outras partes que constituem o universo, como é o caso da percepção sobre o solo na relação com o cultivo:

De fato, a oposição complementar "quente - frio" transcende o domínio estrito dos alimentos. Como disse um camponês nordestino, referindo-se ao cultivo da terra, "tudo nesse mundo de Deus ou é quente ou é frio". Assim, existem solos "quentes" e outros "frios". (WOORTMANN, 2008, p. 19).

As abordagens propiciam outra reflexão - a relação cosmológica - que permeia a existência do ser humano, deslocando da classificação dos alimentos, "quente x frio", para sua constituição em seus aspectos dicotômicos desde as relações afetivas, profissionais e fisiológicas. Conforme Woortmann (2008):

O corpo humano é parte do universo, e uma parte muito especial, pois é nele que existe o próprio indivíduo que percebe o universo. Esse corpo é também percebido como composto de partes "quentes" e "frias" (sanguíneas e sem sangue; vermelhas e brancas) que se opõem mas que também se integram complementarmente numa totalidade harmônica. (WOORTMANN, 2008, p. 20).

Essa dualidade que se opõe é necessária ao equilíbrio do cosmo, desde que um não invada o domínio do outro, pois, como diz o autor, é crucial que esses campos sejam harmônicos e complementares. Percebe-se que a cultura alimentar dos povos Tapirapé é orientada, em primeiro plano, por princípios cosmológicos, mantendo-se a tradição de selecionar os alimentos por faixa etária, gênero e rituais festivos ou comunitários. Esse funcionamento cosmológico compreende desde as questões de proteção à saúde e à biodiversidade, até o respeito aos espíritos.

Nessa perspectiva, Ojasti e Dallmeier (2000, p. 2) classificam o caçador pioneiro e caçador-coletor, e ainda a caça a partir de sua finalidade principal, o que é também regulado por legislações específicas de proteção da fauna silvestre em diversos países: "caça esportiva; caça de subsistência e autoconsumo; caça comercial; caça de controle; caça com finalidade científica" (OJASTI; DALLMEIER, 2000, p. 35).

Quanto à caça de subsistência, dizem os autores: 
Os indígenas das selvas neotropicais são caçadores primários que dependem inteiramente dos ecossistemas onde vivem. A caça é a principal ocupação produtiva de quase todos os homens, e a fauna nativa, selvagem ou fluvial, fornece a maior parte da alimentação proteica da comunidade. [...] São originalmente caçadores diurnos e praticam a caça de excursão, combinando-a com o rastreamento, reivindicações etc. A caça é mais intensa em áreas mais próximas das casas. (OJASTI; DALLMEIER, 2000, p. 38).

A atividade de caçada está inserida numa trama complexa de relações sociais e ecológicas que envolvem importantes elementos de ordem simbólica, em que o conhecimento tradicional encontra-se profundamente envolvido com outros conceitos socioculturais e cosmológicos (FIGUEIREDO; BARROS, 2016b, p. 227).

Para tanto, é importante descrever um dos rituais de caçada do povo Tapirapé segundo o ponto de vista do Xawatamy Nélio Tapirapé, da aldeia Tapi'Itãwa:

No ritual do cara grande (Tawã), quando a gente quer caçar, chama os homens na Takãra, lá é passado cada cerimonial, de lá é passado os locais, os pajés já podem saber onde tem caça e onde seria bom para os homens caçar. O pajé tem visão do lugar onde a caça está. O cara grande contribui com os Pajés para mostrar onde estão as caças. Os pajés já sabem o funcionamento da natureza, fica ligado com os espíritos para levar mais próximo, se não for o pajé os caçadores podem ir muito distante para encontrar a caça. Os homens caçadores têm que valorizar o trabalho do pajé. Antes de ir caçar os homens caçadores têm que fazer uma dieta que é a invocação dos espiritos. É juntado em círculo todos os caçadores em roda dentro da Takãra e faz Hoô, que quer dizer o agradecimento do espírito que vai trazer porcão para perto dos caçadores, esse ritual também pode ser feito no acampamento. O pajé sempre vai na caçada e vai guiar o direcionamento dos caçadores porque estão conectados. Cada caça tem um dono, e o pajé pede licença para os espíritos para soltar a criação que ele tem. Tem que matar com cuidado, os espíritos zangam se matar para desperdiçar, pode fazer mal para qualquer caçador, pode pegar o espírito das pessoas e a pessoa pode ficar com febre, podendo até morrer. (Xawatamy Nélio Tapirapé, 2018).

O relato do pajé Nélio Tapirapé reafirma o que diz Wagley (1988, p. 189), salientando que a abundância da caça era também imputada aos pajés. Assim, a crença era generalizada entre os Tapirapé, onde alguns xamãs tinham a capacidade de controlar os movimentos das varas de queixadas.

Entre as técnicas utilizadas nas caçadas, temos a takãja, para caçar e matar aves. Segundo Kamoriwaí Elber Tapirapé (cacique), trata-se de uma casinha 
construída próxima a uma aguada, que são ambientes como lagos, córregos e rios, os quais servem somente para caçada de aves silvestres.

Cunha e Almeida (2002) descrevem que existem outras armadilhas para capturas de animais silvestres, por exemplo, nas trilhas onde os animais costumam passar; usa-se a espingarda, que é ajustada de acordo com a altura do animal que se pretende matar. Uma observação interessante feita pelos homens caçadores é a influência da lua: a caça miúda anda mais na lua nova, que é a época do escuro, a exemplo da paca e do tatu, que não andam em noites claras.

Há ainda armadilhas para pegar aves e animais pequenos. Geralmente, os caçadores usam a arapuca que é feita com vara de árvores e tabocas, assim como o jequi, que é uma espécie de cesto que o caçador coloca na boca do buraco para captura do tatu.

Conforme apresentado na Figura 2, a casinha, a takãja, é construída com folha de bananeira-brava e é uma armadilha usada somente na época da seca. Serve principalmente para a captura de aves, quando vão à procura de água. A arma usada para matar os animais nesse tipo de armadilha é a flecha, a qual possui cera na ponta para não machucar a carne.

Figura 2 - Parte externa da takãja

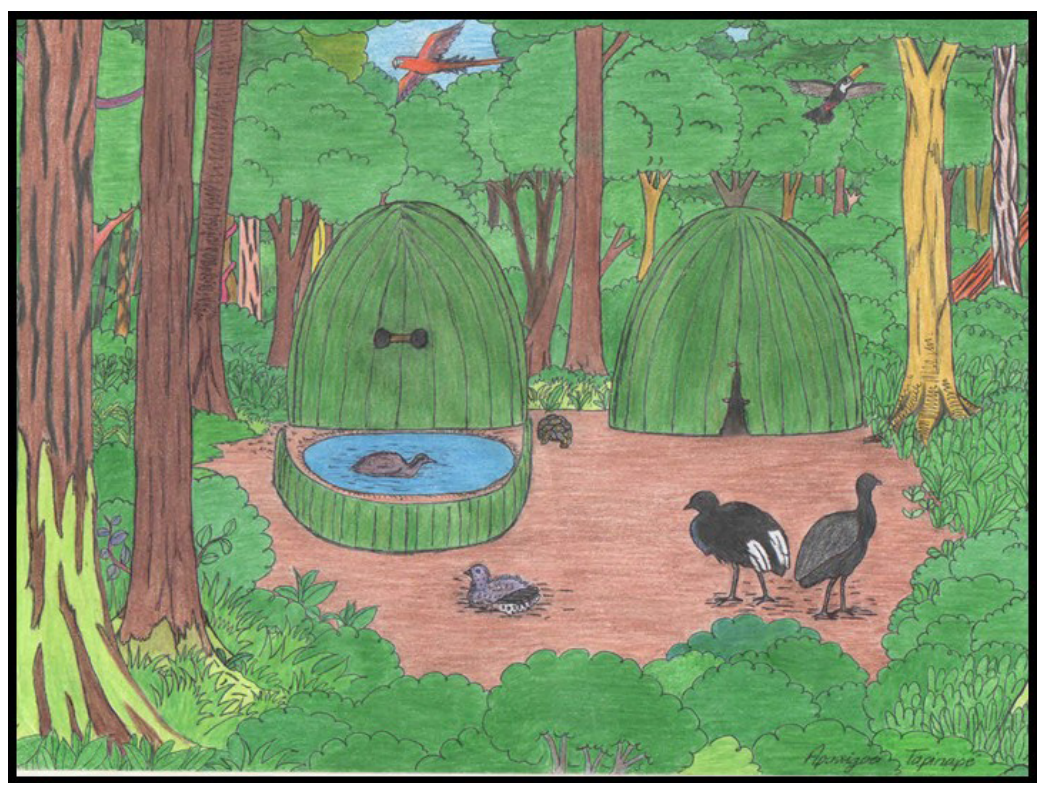

Fonte: Desenho de Apaxigoo Tapirapé (2018). 
Na takãja, é permitido ficar um caçador dentro da armadilha, o qual entra nas primeiras horas do dia e só deixa o seu interior no fim da tarde, quando retorna para a aldeia. A parte interna da takãja pode ser visualizada na Figura 3, que apresenta a ilustração de um jirau de madeira para guardar as aves abatidas.

Figura 3 - Parte interna da takãja

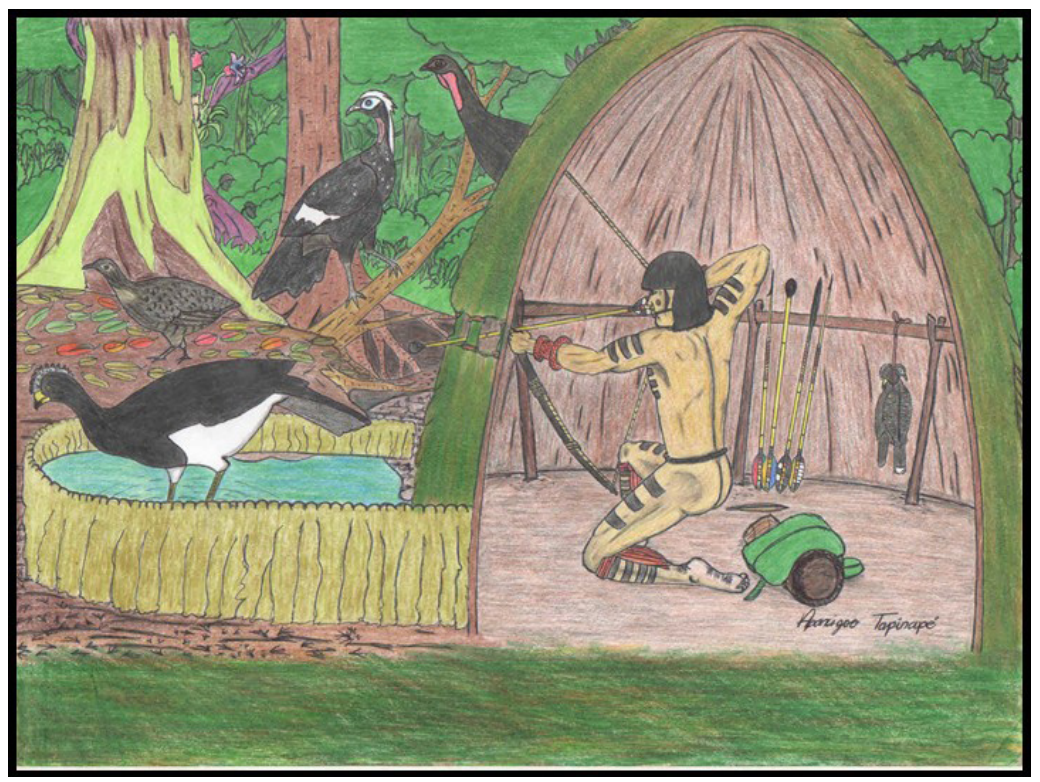

Fonte: Desenho de Apaxigoo Tapirapé (2018).

\section{A TAKÃRA: LOCAL SAGRADO - ASPECTOS CULTURAIS, MATERIAIS E IMATERIAIS}

A takãra, que significa "Casa dos Homens", apresenta-se como o ponto de partida para os rituais de iniciação cultural, pois é nessa casa onde acontece a maior concentração dos homens Tapirapé, principalmente no período noturno, para discutir as ações que dizem respeito às decisões da comunidade e os assuntos relacionados aos rituais do povo Tapirapé.

Desde a estrutura, organização e simbologia, tem uma relação direta com a ordem social e cultural do povo Apyãwa. Sua arquitetura, relativamente oval, traz em si a representação de dois grandes grupos de homens, os wirã, dois grandes clãs, o Yraxiga e o Araxã. 
Conforme a Figura 4, o grupo Yraxiga, situado no lado sul, subdivide-se em três grupos: Wyraonoo, Wyraxygio e Wyraxiga; enquanto o Araxã, situado geograficamente ao norte, é subdividido pelos grupos: Tarawe, Araxã e Warakorã. Esses grupos não têm rivalidades entre si, mas competem na captura de animais para as festas e os rituais programados pela comunidade.

Figura 4 - Desenho da divisão dos grupos dentro da takãra, aldeia Tapi'itãwa, Confresa, MT

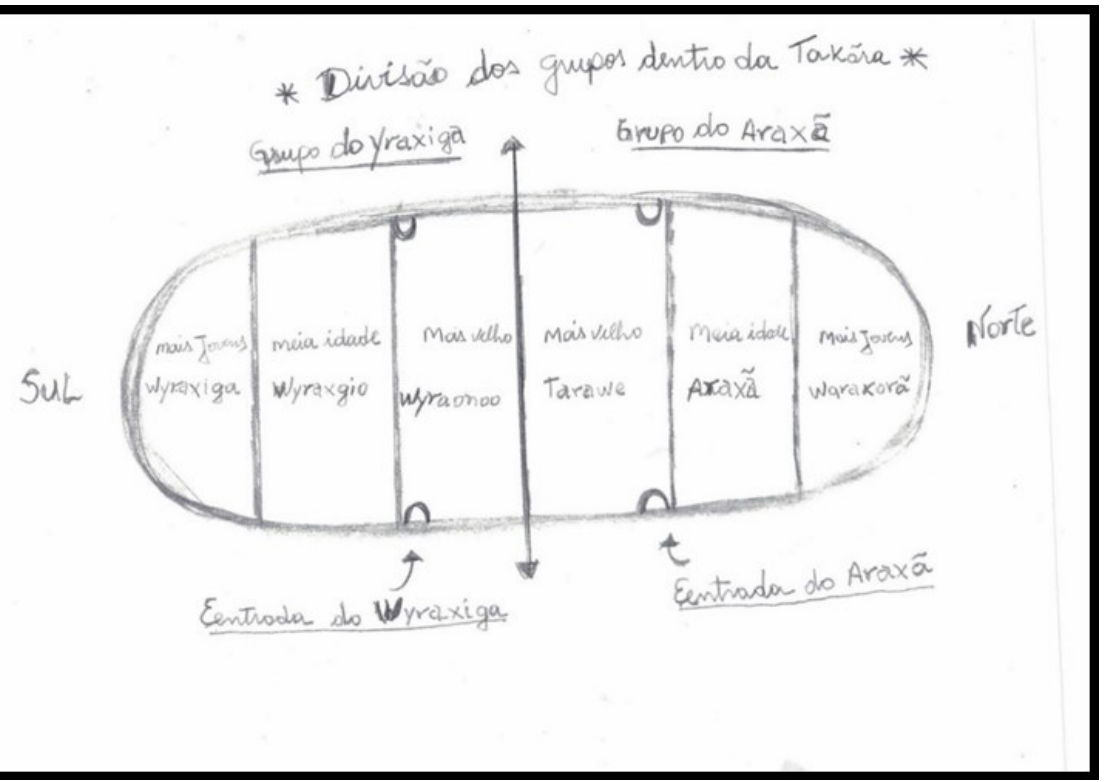

Fonte: Desenho de Apaxigoo Tapirapé (2018).

Considerando a divisão dos grupos, Xawatamy Nélio Tapirapé diz que:

O local da takãra é um lugar sagrado, como existe as igrejas do maíra assim é a takãra. Os grupos e os subgrupos que se dividem dentro da takãra são considerados como se fosse uma igreja, cada um tem que respeitar seu espaço porque, se desobedecer, será condenado; por exemplo: o grupo Araxã, se não respeitar o local demarcado dentro da takãra, se passar na frente onde acontece o ritual de cada grupo, no dia do falecimento, o piolho dos pássaros, que é conhecido como o grupo de Wyraxiga, vai aparecer no corpo da pessoa que não respeita. Por isso que nós respeitamos os rituais das festas. Em relação às igrejas é a mesma coisa, se desobedecer às regras, a pessoa também será punida. O povo Apyãwa respeita a cultura, nunca 
aconteceu nada com as pessoas que participam da festa. Mas antigamente, há muito tempo atrás, já aconteceu desobediência na comunidade. Por isso nós nunca fazemos errado, nós não temos igreja na aldeia, por isso, a takãra é vista como uma igreja, onde é feito todos os ensinamentos pra se tornar um bom representante da comunidade Apyãwa. E o bom caçador deve respeitar rigorosamente a cultura para não trazer maldição dentro da takãra. (Xawatamy Nélio Tapirapé, 2018).

Além da demarcação dada a partir dos espaços específicos dos grupos, a takãra também tem outras linhas imaginárias que a dividem em três espaços, os quais determinam a estrutura no seu interior e que, segundo a tradição do povo Tapirapé, são permanentemente habitados por espíritos de antepassados, o Tapaxo, Koreweka e Xyreni.

É possível observar na imagem produzida por um dos entrevistados (Figura 5) os aspectos específicos da arquitetura e do material utilizado na construção da takãra.

Figura 5 - Estrutura da construção da takãra, aldeia Tapi'itãwa, Confresa, MT

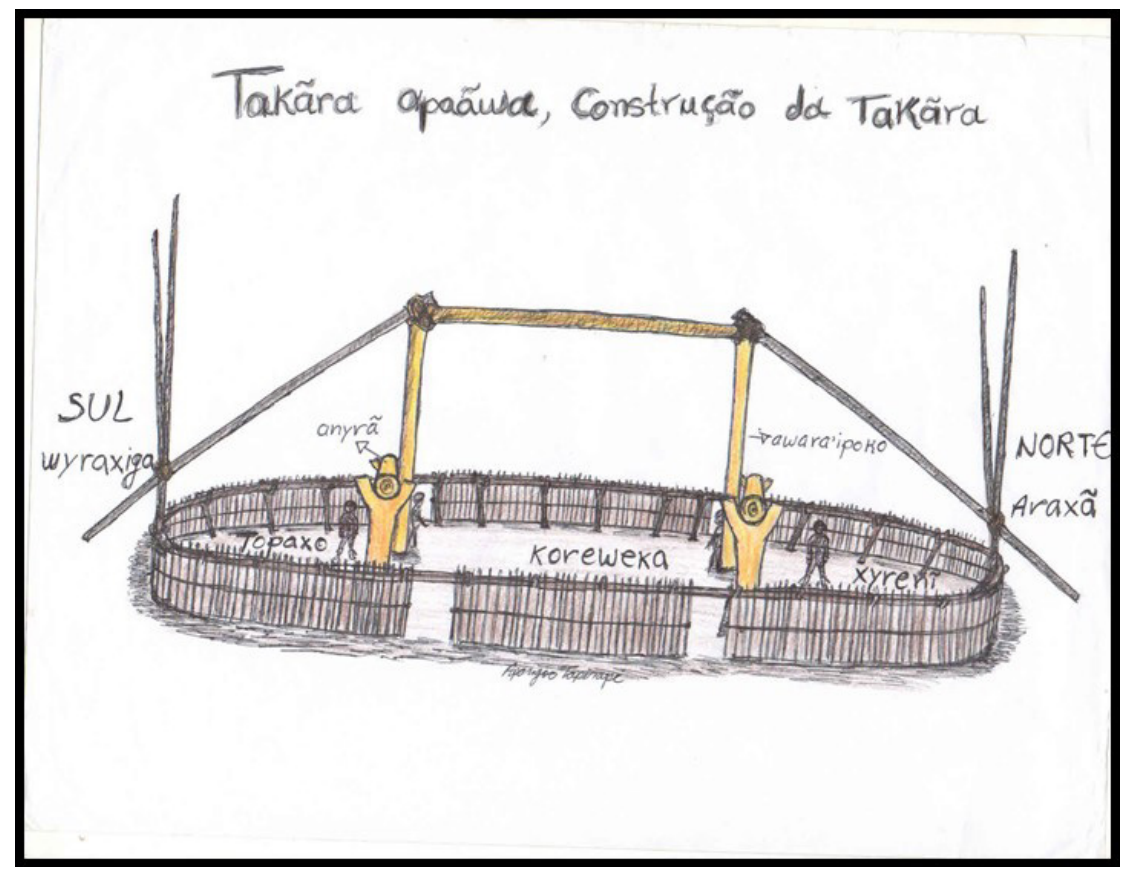

Fonte: Desenho de Apaxigoo Tapirapé (2018). 
Em entrevista com o caçador Kamajrao Carlos Tapirapé, ele nos relatou que, desde o local em que a takãra está disposta no espaço da aldeia, até o formato e a seleção dos materiais utilizados em sua construção e/ou reforma, tudo tem uma relação cosmológica, simbólica e espiritual. Ela é o lugar sagrado, é o espaço que abriga os espíritos que cuidam do povo Tapirapé. É o eixo da organização social da comunidade, não sendo ao acaso a localização no centro da aldeia, e é o lugar em que são tomadas as decisões pela comunidade. É nessa casa e no terreiro dela que os saberes dos antepassados vão sendo transmitidos às novas gerações de homens.

O formato da takãra tinha uma estreita relação com o modelo que era usado para construir a aldeia, sempre em forma circular. Hoje, por uma série de questões, inclusive ambientais, esse formato foi perdendo o padrão. Nos dias atuais, a maioria das casas é construída com tijolo de barro e a cobertura é feita com telha de barro; por usar esse tipo de material, a aldeia foi se moldando a um formato quadrado. Kamajrao Carlos Tapirapé fala sobre as alterações no modo de organização e da construção das casas na aldeia:

O formato oval da takãra representa o desenho da Aldeia do povo Apyãwa. Hoje a aldeia possui um novo formato, sendo quadrado, que não é o desenho dos nossos antepassados. As casas também não possuem o formato desenhado, que era arredondado e coberto com folha do pja, que quer dizer piaçava. Hoje tem muitas casas cobertas com telhas, cercada com tijolo, aí dificulta muito a manter esse desenho da aldeia. Um fato que contribuiu para essa modificação das estruturas das casas foi devido à distância de pja, pois antes encontrava próximo da aldeia, hoje só encontra aproximadamente a 80 $\mathrm{km}$. O fogo e as pastagens também fizeram com que a pja diminuísse. Com isso, o povo Apyãwa fica triste, pois o certo mesmo é viver com os produtos naturais, porque é bom para as crianças crescerem sadias, fresquinho pra dormir, com cobertura de pja é bom tanto na época da chuva quanto no verão, são mais agradáveis. (Kamajrao Carlos Tapirapé, 2018).

Anualmente, tem-se a construção ou a reforma da takãra, que acontece de forma planejada pelos homens, geralmente entre os meses de dezembro e janeiro, cujo período marca também o início das festas. Tanto a seleção dos materiais quanto os rituais empreendidos na construção fazem parte das práticas cotidianas permeadas de conhecimentos tradicionais.

É importante ressaltar que há uma interferência climática, que favorece o acesso a certos materiais usados na construção, bem como o respeito às fases 
da lua, sendo, portanto, a fase da lua cheia o período específico para a retirada de todo o material necessário.

Segundo os entrevistados, a fase da lua produz influência sobre todo o material usado na construção ou reforma da takãra. A retirada do material no período de lua cheia é determinante para que haja resistência a pragas e doenças.

A construção coletiva envolve, a princípio, homens e mulheres, que devem seguir rigorosamente um planejamento sequencial, determinado tradicionalmente e transmitido de geração a geração, sob a coordenação de dois anciãos, sendo um do Araxã e o outro do Wyraxiga.

No primeiro dia, os dois grupos de homens, Araxã e Wyraxiga, dedicam-se a uma reunião de planejamento, geralmente durante a tarde. Para tanto, solicitam que as mulheres preparem o Kawi (mingau de arroz) para os homens tomarem. Tomar essa bebida durante a construção da takãra simboliza um pedido de proteção aos espíritos para não acontecer nada de ruim com os homens durante esse trabalho, por exemplo, para evitar acidente ou mesmo complicações de ordem espiritual. A bebida é tomada sempre no fim do dia.

A estrutura da takãra é amarrada por uma embira retirada de uma árvore chamada Ywira (pindaíba), que possui uma casca resistente. Sua fibra pode durar de 2 a 3 anos. O período chuvoso facilita a retirada da embira. Na estrutura, há uma série de forquilhas laterais que reforçam as paredes feitas de pau a pique. Tanto essas forquilhas quanto as travessas que vão sobre elas são de um tipo de madeira, nomeada na língua Tapirapé como ywyrapytyga. Essas forquilhas e travessas têm o diâmetro de 20 a 30 centímetros, sendo que essas forquilhas têm tamanho de aproximadamente dois metros de altura.

É no segundo dia que os homens saem para retirar ywyrapytyga. Eles se reúnem bem cedo para escolher onde vão buscar essa madeira para fazer as forquilhas laterais (que na língua Tapirapé são definidas como Ywyraj'i) e, enquanto uns vão apanhar a madeira, outros preparam os buracos onde as forquilhas serão colocadas. Para tanto, um número indeterminado vai para à mata e são escolhidos quatro homens do Araxã e quatro do Wyraxiga para perfurar os buracos da construção da takãra. 
No terceiro dia, os homens saem bem cedo para buscar outra madeira, a pinanywa $a^{4}$, utilizada na cumeeira, nos caibros, nas paredes de pau a pique (ixarakyga) e em quatro balizas que ficam do lado de fora, no alto da takãra, com a finalidade de representar a direção dos wirã, ao norte, o Araxã, e ao sul, o Yraxiga.

Pelo formato ligeiramente arredondado da cumeeira (Ywyrayja), a madeira usada para os caibros precisa ser envergada, uma vez que não se usam pregos ou parafusos para ajustar essa parte da estrutura à cumeeira, e a pinanywa tem flexibilidade que permite os ajustes no ângulo necessário.

No quarto dia, cada grupo, tanto Wyraxiga quanto Araxã, vai tirar quatro grandes forquilhas que são conhecidas como Ywyrayjoo (Eymawa'ywa-Garapa), em que é feita a divisão dos grupos dentro da takãra. O quinto dia é dedicado para a retirada da madeira da cumeeira, lapytekyga Tamexo'ywa (madeira cega-machado), a madeira de duas travessas grandes (Xorao) e dos esteios da takãra. Esses esteios constituem-se como duas forquilhas de pau d'arco (madeira nomeada na língua Tapirapé como Myteripewara Xeke'iakanywa) que ficam localizadas no centro.

São nessas forquilhas (awaraiipoko) que os meninos (xyré) ficam encostados após tomar banho no fim do dia, em uma das fases do ritual de preparação e crescimento do homem. Xywaeri José Pio Tapirapé (2018) afirma que o awaraiipoko quer dizer "local onde a criança fica encostada para se enxugar depois do banho, para crescer, porque esta forquilha é grande e a criança encosta para ficar grandão".

O último passo da construção é a cobertura, feita com folhas de bananeira-brava na primeira camada e palhas de bacaba nas demais camadas, todas bem trançadas para que não haja penetração de sol e de chuva. No sexto dia, são tiradas as palhas de bacaba e, no sétimo dia, são tiradas as folhas de bananeira-brava.

É importante ressaltar que todos os dias as mulheres seguem preparando o kawi de arroz para os homens tomarem no local da construção. Para o povo Tapirapé, a takãra é um local místico, em que todos devem respeito e devoção. Segundo Apaxigoo Tapirapé (2018), entre os espíritos que habitam o local, vive a Koreweka. Ela é uma mulher velhinha chamada de xaryja (vovó), que mora na takãra e é sempre convidada para dançar na festa do Iraxao, que é a festa da Aruanã. Ela sempre está

4 Pinanywa, que significa vara de pescar, é uma árvore cuja madeira pode ser utilizada para fazer varas flexíveis. 
grávida e nunca nasce o menino. Ela só dança fora da takãra e, quando ela está lá dentro, fica o tempo todo vigiando para as outras mulheres não entrarem, pois é muito perigoso e proibido o acesso de mulheres nesse local.

Ainda de acordo com o relato, a Koreweka é o espírito que protege as mulheres, não permitindo que aconteça nenhuma maldade com elas, como uma guardiã para que as mulheres não consigam adentrar este local, pois dentro da takãra é um local sagrado, de acesso proibido para mulher, e se, porventura, uma vir a transgredir a regra e adentrar a takãra, ela pode ser submetida a relações sexuais com quantos homens a desejarem, o que funciona como medida disciplinar.

Segundo o ancião da aldeia, Xywaeri José Pio Tapirapé, quando acontecem as festas Xyreni, o espírito Koreweka, também chamado de "vozinha", canta com eles, participando dos rituais à noite; ele diz ainda que ela foi morta e enterrada no meio da takãra, na divisa do Araxã com o Wyraxigio. Conforme foi observado, nos costumes e na tradição do povo Apyãwa, há nas festas de rituais regras estabelecidas que não podem ser descumpridas, pois a desobediência a tais regras implica prejuízos para a comunidade, por isso os indígenas as respeitam rigorosamente.

\section{AS FASES DA VIDA DE UM HOMEM TAPIRAPÉ PARA SE TORNAR UM CAÇADOR}

A prática de caçar, entre o povo Tapirapé, é uma responsabilidade exclusiva do homem, que cuida tanto da caçada quanto da formação e iniciação de novos caçadores. Nas palavras do cacique, Kamoriwa'i, os rituais de formação cultural do homem são concomitantes aos de preparação para torná-lo um caçador. Diz Kamoriwa'i:

Todo homem, para se tornar um bom caçador, deve passar por essas fases, senão ele não pode ser caçador, não pode ser instrutor, essa pessoa que não passa pelos rituais não é reconhecida pela comunidade como uma pessoa conhecedora da cultura. Não existem mulheres Tapirapé caçadoras, as muIheres podem pescar, coletar frutos do cerrado, da mata, e alguns produtos da roça, como milho, algodão, cará, melancia, batata-doce, feijão, fava. As mulheres podem até colher banana, mandioca, mas não podem carregar, pois é muito pesado, pois é serviço para homens. (Kamoriwa'i Elber Tapirapé, 2018). 
Tornar-se um caçador, instrutor ou representante da/na comunidade implica passar por todos os rituais das fases de formação que constitui o homem Tapirapé; do contrário, é considerado como alguém que não conhece e não integra culturalmente, portanto, não poderá ocupar posição de liderança, nas palavras do cacique.

É possível perceber também que, embora não haja uma imposição para que o menino participe dos rituais, não o fazer é um modo de negar a apropriação cultural que constitui o homem Tapirapé; o que implica, de certo modo, um descrédito perante a comunidade: "essa pessoa que não passa pelos rituais não é reconhecida pela comunidade como uma pessoa conhecedora da cultura". Sendo assim, é importante que os saberes acerca do caçador Tapirapé sejam ensinados, transmitidos tradicionalmente e integrados à vida do menino, desde o seu nascimento.

Os primeiros rituais do menino Tapirapé são realizados antes mesmo de a criança completar um ano de idade, e eles vão ganhando representações até nas brincadeiras. Assim que o menino nasce, tem acesso a uma das primeiras representações da cultura do povo Tapirapé: o banho em uma calda feita com a raiz do urucum (oroko), como uma medida de purificação e proteção da pele. Entre os três e seis meses de idade, o corpo é pintado até o pescoço com tinta de jenipapo, para prevenir gripes e diarreias.

À medida que vai crescendo, os aspectos culturais vão sendo integrados à vida do menino apyãwa, que, de zero a oito anos, faz parte de uma fase denominada como konomi; a partir daí, passa a ser classificado como xyre'i'i, que corresponde à pré-adolescência.

O xyre'i'i, período entre os 8 e 10 anos de idade, é a fase em que o menino começa a observar e participar de rituais de preparação do caçador, sem, contudo, participar das caçadas. É nessa fase que o menino faz a primeira troca de nome, deixa de dormir na casa de seus pais e começa a dormir na takãra, onde são passados os ensinamentos pelos pais, tios, os mais velhos e o pajé.

O nome que o menino recebe, nessa fase, é escolhido pelos anciãos. Decorrido um dia da troca, o antigo nome não poderá mais ser pronunciado, e um cântico é entoado no terreiro da takãra anunciando o novo nome, para que todos na aldeia possam ouvi-lo. Durante o xyre' $i^{\prime} i$, o menino deve cortar o cabelo em formato de anel, pintar a cabeça com tinta de urucum e, com a tinta do jenipapo, pintar todo o corpo. Essa pintura representa o início da pré-adolescência. 
Destaca-se que é na fase do xyre'i'i que os meninos começam a ensaiar os primeiros passos do caçador por meio das brincadeiras, sobretudo, voltadas para o uso de arco e flecha. Conforme diz Xawatamy Tapirapé:

O primeiro ritual é ensinado pelo pai, pelo avô, pelo tio e os irmãos mais velhos e os mais velhos da aldeia. Coloca a criança sentada próximo dos mais velhos, fabrica a flecha e é ensinado que a criança não pode jogar flecha com ponta de arame ou ponta de osso, só pode usar flecha com ponta de cera para não se machucar. No segundo passo é ensinado à criança jogar flecha dentro da água para matar peixinhos, flechar cambitos e passarinhos. (Xawatamy Nélio Tapirapé, 2018).

Desse modo, observa-se que o importante não é acertar a flecha no alvo, mas o processo que leva os meninos a se constituírem como bons atiradores de flechas. São vários conhecimentos transmitidos pelos adultos e, principalmente, pelos idosos.

Na fase do xyre'i'i, as crianças passam a conhecer e a fabricar os instrumentos com os quais se fazem as caçadas. Aprendem que há instruções a serem seguidas para não se ferirem e/ou prejudicar a caçada e, durante o período em que estiverem passando pelos rituais, deverão dormir na takãra. Em determinado momento, passam por uma reclusão de vinte e quatro horas dentro da takãra; logo em seguida, são submetidos à caça de passarinho, cambitos, lagartixas e peixes, a ser entregue para o instrutor da criança. Essa prova é um marco importante na vida do caçador Apyãwa. Ainda de acordo com Xawatamy, quando o menino começa a matar lagartixa, passa a ser visto, pela comunidade, como um iniciante de caçador.

Com base em Xario'i Carlos Tapirapé, os rituais para marcar as fases da vida do homem iniciam-se logo após seu nascimento e são cruciais para a formação do caráter e a constituição da identidade. É nesse mesmo processo que o caçador vai sendo formado e, ainda segundo Xario'i, os rituais voltados especificamente para o caçador iniciam-se quando:

[...] fura o beiço e coloca um ossinho de macaco ou de porcão, porque é resistente (temekwãra). Entre 8 e 10 anos de idade faz a troca do temekrãra e coloca o ytymekwãra, que é feito com o osso de lesma. Com essa idade, começam a participar dos rituais para aprender a caçar e faz a primeira troca de nome. Tem que dormir na takãja, tem que obedecer às ordens do 
pai, dos tios, do avô, do cacique e, principalmente, do Pajé; se não obedecer, vai ser malvisto na comunidade. Entre os 15 e 16 anos Awa'yao'i, continuam dormindo na takãra e é feito a segunda troca de nomes, fazem o corte de cabelo somente na franja e na nuca, nesta fase eles já estão prontos para participarem das caçadas. A terceira troca de nomes ocorre entre os $17 \mathrm{e}$ 18 anos, onde são chamados de Awa'yao. Xema'awa trocam o nome e já podem usar o cocar na cabeça e podem deixar o cabelo crescer ou cortar, podendo trocar temekwãra de espinho da paineira para o de osso no beiço e na orelha. (Xario'i Carlos Tapirapé, 2018).

Xario'i apresenta um panorama das fases e de aspectos culturais que representam o percurso formativo do homem Tapirapé até que se torne um caçador. Entretanto vale dizer que há marcos e elementos específicos que caracterizam o homem apyãwa em todo o tempo, desde a fase da infância, o konomi, até quando se torna um ancião (maryke'yri).

\section{OS TIPOS DE ANIMAIS CAÇADOS PELOS TAPIRAPÉ}

Entre as espécies de animais descritos na Tabela 1, a carne do porcão é a preferida do povo Tapirapé, tanto como alimento do cotidiano quanto como comida nos rituais festivos. A preferência pela carne desse animal tem a ver com o fato de ser, na concepção desse povo, uma carne nobre, saborosa e pelo fato de haver grande quantidade dentro do Território Urubu Branco. De acordo com relato do cacique Waere'i Elber Tapirapé, a carne do porcão é usada nas festas da comunidade do povo Apyãwa. A carne de porcão, nesse sentido, pode ser considerada comida de festa (ver SOUSA; VIEIRA-DA-SILVA; BARROS, 2016). Já durante as festas tradicionais, como Aruanã e Tawã, o porcão e o caititu são as únicas caças que podem ser servidas nos rituais. Entretanto as demais caças têm seu valor de consumo e simbologia entre esse povo. Os principais animais silvestres caçados pelo povo Tapirapé são os relacionados na Tabela 1 abaixo. 
Tabela 1 - Caças que os Tapirapé podem comer

\begin{tabular}{l|l|l}
\hline \multicolumn{1}{c|}{ Nome local } & \multicolumn{1}{c|}{ Nome científico } & Nome Tapirapé \\
\hline Porcão/queixada & Tayassu pecari & Taxao \\
\hline Caititu & Pecari tajacu & Xiwa'a \\
\hline Quati & Nasua nasua & Kwaxi \\
\hline Jabuti & Chelonoidis sp. & Xawaxi \\
\hline Tatu-galinha & Dasypus novemcinctus & Tato \\
\hline Macaco-prego & Sapajus sp. & Ka'i \\
\hline Veado-mateiro & Mazama americana & Miara \\
\hline Veado-campeiro & Ozotoceros bezoarticus & Miara \\
\hline Paca & Cuniculus paca & Karowaroo \\
\hline Cutia & Dasyprocta leporina & Akoxi \\
\hline Tamanduá-bandeira & Myrmecophaga tridactyla & Tamanowa \\
\hline Mutum-castanha/cavalo & Mitu tuberosum & Mytoona \\
\hline Mutum-de-penacho/pintado & Crax fasciolata & Mytopinima \\
\hline Jacu-verdadeiro & Penelope jacucaca & Xako'iete \\
\hline Jacutinga & Aburria jacutinga & Xakopeiga \\
\hline Jaó & Crypturellus undulatus & Tepawa \\
\hline Azulona & Tinamus tao & Inamo \\
\hline Pato-do-mato & Cairina moschata & Ypewoo \\
\hline
\end{tabular}

Fonte: Dados de campo.

O porcão é tão apreciado entre os Tapirapé, que mesmo quando não há caçada marcada na comunidade, se tiverem oportunidade ou avistarem uma vara de porcos dentro ou próximo ao Território Indígena, eles podem deixar as prioridades para caçar. Um episódio que deixou isso bem evidente durante o desenvolvimento da pesquisa foi um dia que, às $6 \mathrm{~h}$, um rapaz estava indo para a cidade de Confresa, MT, quando avistou um porcão na estrada. O rapaz voltou para a aldeia e chamou alguns caçadores. Ele não pôde participar da caçada porque tinha um compromisso na cidade, seguiu sua viagem, e os caçadores em pouco tempo chegaram ao local. Às 6h30, iniciou-se a caçada; por volta de 11h30, já tinham matado seis porcões. Essa caçada foi realizada no Maíra Xaokãwa (Córrego 
do Não Índio), na Fazenda Luta, localizado a 2 km da aldeia Tapi'Itãwa. Abaixo, apresentamos a Figura 6, que traz a representação do dia dessa caçada em que os homens foram avisados e, rapidamente, foram atrás do animal.

Figura 6 - Caçada de porcão

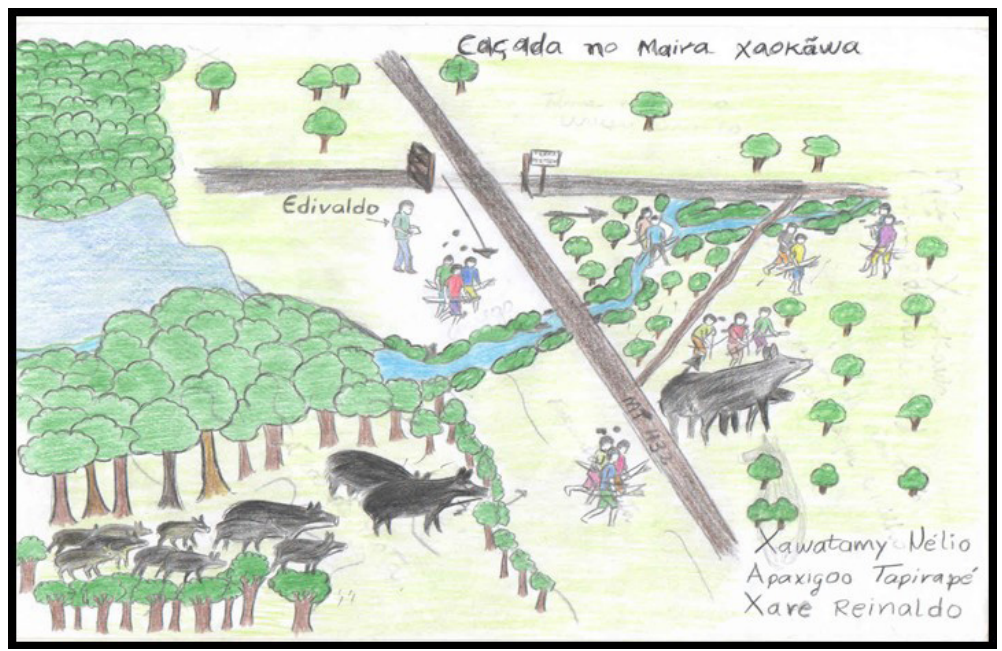

Fonte: Desenho de Xawatamy Nélio, Apaxigoo Tapirapé e Xare Reinaldo (2018).

De acordo com Xare Reinaldo Tapirapé (2018), há regras que são adotadas durante a caçada, por exemplo: o caçador deve ter um olhar focado para não perder a caça; quando a caçada é realizada em grupo, todos os participantes devem ficar atentos e muito bem concentrados. Os grupos são divididos entre três a cinco homens e devem manter uma distância entre 200 e 300 metros. Os caçadores devem ter muita atenção para não machucar os companheiros, pois se usa borduna, arco e flecha, facão e arma de fogo.

Outro tipo de animal que também é caçado pelos Tapirapé é o quati, mesmo sendo um animal de pouca importância na alimentação do povo Apyãwa, por ser um animal muito nervoso. O homem é liberado pela cultura para comer a carne do quati, mas a mulher grávida ou em lactação é proibida pela cultura do povo Apyãwa. Se a criança que está na barriga da mãe ou sendo amamentada tomar leite de uma mulher que comeu a carne de quati, a criança corre sério risco de ficar nervosa, não dormir, não consegue aprender os ensinamentos transmitidos 
pelos pais, adoece, podendo até morrer.

O quati é simbolizado pelo povo Apyãwa como se fosse uma lagarta, por isso que há essa restrição na alimentação do povo Apyãwa. Os Tapirapé acreditam que é como se estivessem comendo folha de árvore. Mesmo com valor simbólico espiritual considerado pelos Tapirapé como negativo, esse animal hoje é representado pelos rapazes. Usa-se uma pintura corporal, nas festas tradicionais, que o simboliza. Essa pintura tem um formato semelhante às listras pretas que existem no rabo do quati, parecidas com a borduna, uma arma indígena, em formato de cassetete mais alongado, usada nas caçadas.

Já em relação às aves descritas na Tabela 2, os líderes indígenas Ipawygi Rinaldo Tapirapé e Ware'i Elber Tapirapé relataram que o mutum-castanha é a ave mais preferida na alimentação da comunidade do povo Apyãwa, por se tratar de uma ave que tem carne saborosa.

O mutum-castanha (Mytõ) tem grande representação espiritual para o povo Tapirapé, uma vez que, segundo o relato dos entrevistados, o espírito dessa ave é responsável por ir em todas as casas onde há crianças recém-nascidas, fazendo a benzeção para as crianças crescerem sadias, alegres e cheias de energia.

Segundo Ipawygi Rinaldo Tapirapé, os meninos e as meninas não podem comer qualquer tipo de ave, é proibido pela cultura. Os jovens, homem ou mulher, só são liberados para comer esse tipo de caça depois de autorizado pelos avós paternos e maternos, o que ocorre, no caso das meninas, decorridos seis meses após a segunda menstruação, e, no caso dos meninos, passados seis meses da conclusão de todos os rituais de passagem para a fase adulta.

O consumo de aves pelas moças ou rapazes antes da autorização dos avós pode causar sérios comprometimentos no aparelho digestivo, inclusive com perda parcial deste. Na Tabela 2, a seguir, estão relacionadas as caças e aves que as mulheres e os esposos não podem comer no período de gestação e resguardo do parto. 
Tabela 2 - As caças que as mulheres grávidas ou de resguardo do parto e os maridos não podem comer

\begin{tabular}{l|l|l}
\hline Nome local & Nome científico & Nome Tapirapé \\
\hline Mutum-de-penacho/pintado & Crax fasciolata & Mytopinima \\
\hline Jacu-verdadeiro & Penelope jacucaca & Xaro'iete \\
\hline Pato-do-mato & Cairina moschata & Ypewoo \\
\hline Galinha & Gallus gallus domesticus & Wyrakaja \\
\hline Galinha-d'angola & Numida meleagris & Kokani \\
\hline Filhote de porcão & Tayassu pecari & Taxãoa'yroo \\
\hline Filhote de caititu & Pecari tajacu & Xiwa'a'yroo \\
\hline Quati & Nasua nasua & Kwaxi \\
\hline Veado-mateiro & Mazama americana & Miara \\
\hline Veado-campeiro & Ozotoceros bezoarticus & Miara \\
\hline
\end{tabular}

Fonte: Dados de campo.

As caças relacionadas na Tabela 2 são consideradas impróprias para determinadas fases da vida do homem e da mulher Tapirapé, de acordo com Ipawygi Rinaldo Tapirapé e Ware'i Elber Tapirapé. Para ambos, de acordo com a cultura Tapirapé, a caça mais perigosa de se ingerir no período de gestação e até um ano após o parto é o mutum, principalmente o mutum-de-penacho, uma vez que essa ave come frutos nocivos aos humanos e sua carne torna-se reimosa. Se a mulher grávida ou o seu marido comer a carne dessa ave, a criança pode nascer com deficiência ou má-formação, por esse motivo, é culturalmente proibida sua ingestão durante o período de gravidez e por um ano após o parto, ou enquanto a criança estiver sendo amamentada. Entre os Araweté, como destacou Viveiros de Castro (1992), também há diversos interditos para o casal. Por exemplo, nesta cultura, os pais da criança não devem comer carne de anta em hipótese nenhuma, pois o espírito desse animal pisotearia a barriga da mãe. Não devem também comer coxas de veado e mutum, o que enfraqueceria as pernas da criança.

Do mesmo modo, as demais caças relacionadas na Tabela 2 não devem ser ingeridas durante a gestação e nem em um período menor que um ano, tanto pela mulher grávida ou parida quanto por seu esposo, sob o risco de a criança 
desenvolver deficiência ou atrair para si (pais) ou para a criança outro mal qualquer.

\section{RETORNO DOS CAÇADORES À ALDEIA E O INÍCIO DO PROCESSO DA TRANSFORMAÇÃO DA CAÇA EM COMIDA}

Ao retornarem das caçadas coletivas, os caçadores são recebidos com um ritual Ka'o pelos homens que ficaram na aldeia. Esse ritual consiste em uma dança que dura toda a noite. Durante o ritual, é feita a distribuição da caça abatida, o que ocorre de duas maneiras. Na primeira, o caçador detém as melhores partes da caça, sendo o quarto traseiro para o dono da caça e a parte dianteira e a cabeça distribuídas para a família e os vizinhos. Quando são dois caçadores, é feita divisão em partes iguais.

Nos rituais, a transformação da caça em comida ocorre de dois modos, em que o primeiro se dá dentro da takãra. Durante o ritual da festa, as caças podem ser preparadas assadas, cozidas ou moqueadas. Esse processo é realizado somente pelos homens mais velhos, e os mais novos observam.

Já o segundo modo consiste em um ritual chamado Tawã (Cara Grande) e Iraxão, em que os espíritos dos Karajá, Kayapó e dos Kopi se transformam em Tawã por meio de uma dança; depois, os pajés rezam e, por meio de um ritual do avô (Xaneramoia) dos Tapirapé, o cacique convida os homens da comunidade a se servirem, e ele é o primeiro a comer.

Depois de meia-noite, o grupo lança um convite à aldeia para as mulheres prepararem um prato para levarem para a festa no dia seguinte, e a mulher do Xaneramoia leva um prato feito para o marido que faz parte do grupo; depois que esse grupo come, os demais podem fazer a refeição. Esse ritual demora o dia inteiro. Os temperos usados mais comumente são a pimenta e o sal, além do mel de abelha como acompanhamento. As carnes são cortadas em pedaços e quem serve a comida para os participantes do ritual é um rapaz.

No caso de abate de animais em caçadas individuais ou em grupos menores fora dos rituais festivos, não há regra quanto ao preparo e o modo de servir. Geralmente, a esposa é quem prepara, e qualquer pessoa pode ser a primeira a servir. Na Figura 7, demonstramos o processo de conservação da carne de caças abatidas para o ritual do Tawã, em que os animais são dispostos em cima de um 
jirau construído com forquilhas de pindaíba e travessas de cega-machado onde as carnes são moqueadas e defumadas com lenha de murici, garapa e casca de landi. O uso dessas madeiras para o processo de defumação justifica-se, segundo os caçadores, pela duração das brasas e pelo aroma da fumaça, impregnando cheiro e sabor agradável à carne.

No ritual de caçadas, ao abater um animal, o caçador deve levá-lo até o acampamento, abri-lo, retirar as vísceras e reservar para si e, em seguida, deve passar o animal ao dono da festa, ficando proibido de voltar a tocá-lo ou dele comer até que seja concluído o ritual de preparação e consagração da comida durante a festa, na takãra.

Ainda que o dono da festa tenha de se ausentar do acampamento e um caçador fique sozinho no acampamento com os animais, não é permitido a este comer da carne moqueada, porque o espírito do Tawã (Cara Grande) está presente no acampamento, o que se configura em um risco para o caçador que comer, podendo adoecer ou até morrer. Os pajés estão sempre cuidando para que esse mal não aconteça.

Figura 7 - Processo de conservação de animais abatidos

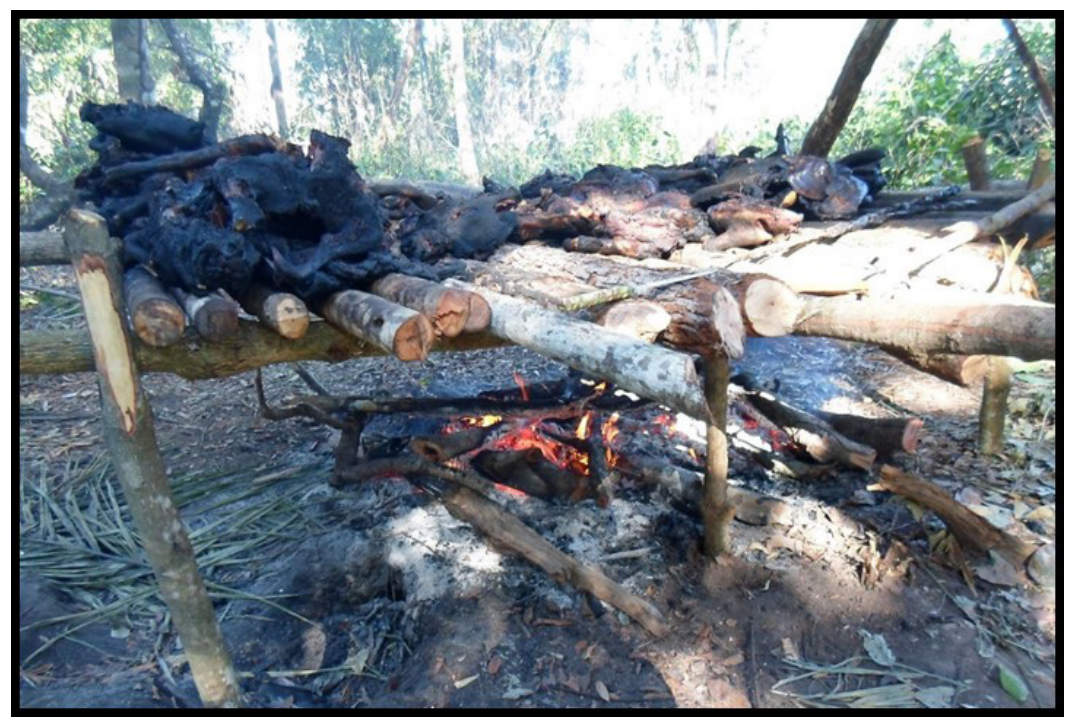

Fonte: Kamoriwa'i Elber Tapirapé (2018). 
Os animais abatidos são levados até o acampamento com o uso da Peeyra, conforme pode ser visualizado na Figura 8. Ela é confeccionada com folha da palmeira bacaba (Pinawa). Trata-se de um objeto que ainda se mantém até os dias atuais sendo usado para carregar os pertences dos homens caçadores, servindo também para levar as caças abatidas para o acampamento ou para a aldeia.

Figura 8 - Retorno da caçada para a aldeia

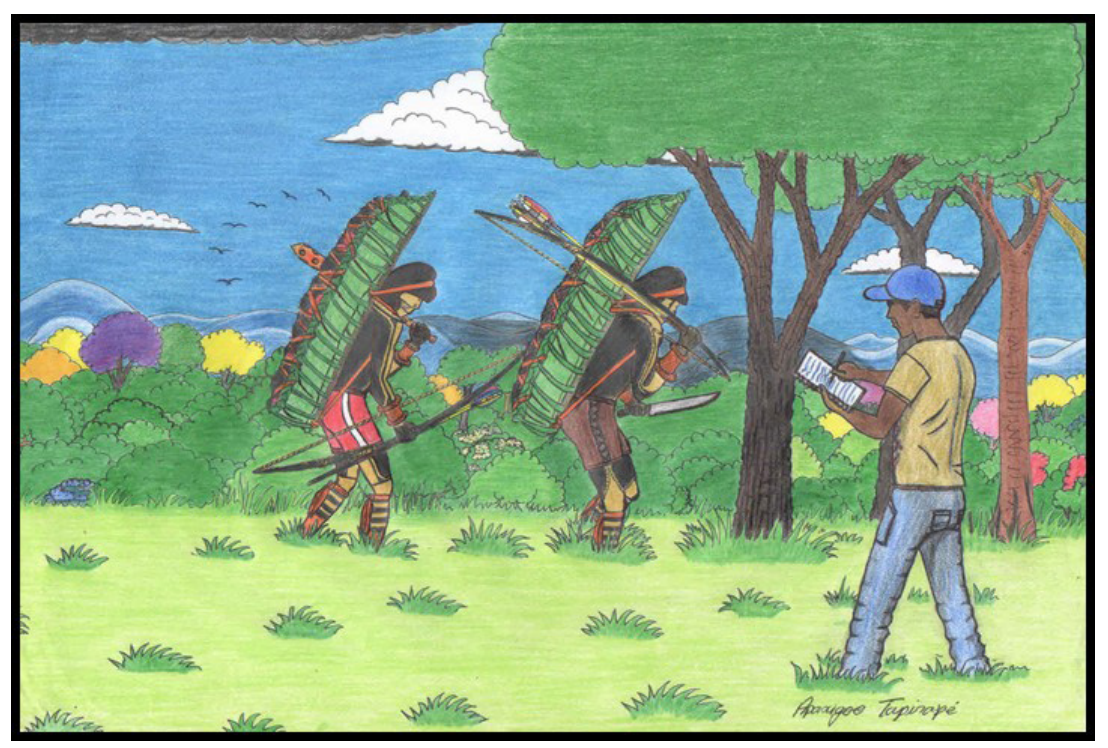

Fonte: Desenho de Apaxigoo Tapirapé (2018).

A chegada dos caçadores à aldeia ocasiona alegria entre o povo, por levarem muitas caças. A esse respeito, o Diário das Irmãzinhas de Jesus ${ }^{5}$ registra um momento de alegria relacionado à caçada, em que, no ano de 1953, em uma dessas chegadas com as caças, os Tapirapé estavam felizes e orgulhosos por terem matado vários porcos em uma caçada, motivo pelo qual estavam todos reunidos no meio da aldeia ao lado da casa dos homens, ainda inacabada, para celebrar.

O retorno da caçada com os animais abatidos é motivo de muito orgulho para os homens Tapirapé, porque significa que conseguiram cumprir seu papel de 
pai de família e garantir fartura. Simboliza também a prosperidade do seu povo, agradando aos espíritos donos das caças, o que traz muita alegria para a comunidade e torna-se motivo de festejos, com cânticos e danças com a participação das mulheres e dos outros homens que ficaram na aldeia.

\section{CONSIDERAÇÕES FINAIS}

As práticas culturais do povo Tapirapé permanecem vivas no cotidiano da comunidade. As heranças e os saberes são mantidos a partir dos ensinamentos transmitidos pelos anciãos. Percebemos o cuidado entre os homens caçadores em manter os ensinamentos repassados nas reuniões no terreiro da takãra e dentro dela. A caça se apresenta como importante atividade na vida do povo Tapirapé, sendo fundamental do ponto de vista da alimentação, sobretudo nas festas e rituais. Tornar-se caçador exige do ser masculino Tapirapé todo um processo de aprendizagem, dedicação e observação de regras, tudo centrado na transmissão de saberes e aconselhamentos dos mais velhos e experientes. De acordo com os anciãos e a cultura Tapirapé, não se concebe um homem que não saiba caçar para suprir sua família e as festas importantes da aldeia.

De acordo com nossas observações, o ato de comer é permeado por simbologias que envolvem aberturas e proibições quanto ao que se pode ou não comer, a exemplo do quati, estritamente pernicioso na fase de gestação ou de amamentação da criança. Como disseram os indígenas: quem se atrever a consumir essa caça, pode o filho ficar nervoso e ter problemas. O porcão/queixada é a caça predileta na aldeia, sendo ricamente consumida durante festas e rituais. Há diferentes maneiras de se preparar carnes na aldeia, podendo ser consumidas assadas, moqueadas ou cozidas. Com efeito, destacamos que a caça é fundamental para a sobrevivência do povo Tapirapé, devendo ser valorizada enquanto uma prática cultural que envolve questões de ordem simbólica e material, além de ecológicas. A investigação demonstrou o quanto é forte as questões espirituais nas atividades e no significado de cada fazer do povo Tapirapé. A caça significa, mais que tudo, a prosperidade da aldeia, tudo em equilíbrio com o ambiente, com os valores éticos e morais e dentro dos saberes adquiridos dos antepassados do povo Tapirapé. 


\section{REFERÊNCIAS}

ALMEIDA, Angela Maria de Oliveira. A pesquisa em representações sociais: fundamentos teórico-metodológicos. Serviço Social, v. 9, p. 129-58, 2001.

ARRUDA, Angela. Despertando do pesadelo: a interpretação. In: MOREIRA, A. S. P et al. Perspectivas teórico-metodológicas em representações sociais. João Pessoa: Editora Universitária - UFPB, 2005.

BALDUS, Herbert. Tapirapé: tribo Tupi no Brasil Central. São Paulo: Companhia Editora Nacional, 1970.

BARROS, Flávio Bezerra. Os caçadores do Riozinho do Anfrísio: saberes e práticas culturais entre narrativas e imagens. Muiraquitãa: Revista de Letras e Humanidades, v. 5, n. 1, p. 152-86, 2017.

BECHELANY, Fabiano Campelo. Suasêri: a caça e suas transformações com os Panará. 2017. 316 f. Tese (Doutorado em Antropologia)- Universidade de Brasília, Brasília, 2017.

BELTRÁN, Enrique. La administración de la fauna silvestre. In: INSTITUTO MEXICANO DE RECURSOS NATURALES RENOVABLES. Mesas redondas sobre problemas de caza y pesca deportivas en México. México: Ediciones del Instituto Mexicano de Recursos Naturales Renovables, 1966. p. 225-59.

BRASIL. Decreto de 8 de setembro de 1998. Homologa a Terra Indígena Urubu Branco, no Estado de Mato Grosso. Disponível em: http://www.planalto.gov.br/ccivil_03/dnn/ Anterior\%.htm. Acesso em: 19 mar. 2019.

COOKE, Richard G. Los habitos alimentarios de los indigenas precolombinos de Panama. Revista Médica Panamá, v. 6, n. 1, p. 65-89, 1981.

CUNHA, Manuela Carneiro; ALMEIDA, Mauro Barbosa. Enciclopédia da Floresta. São Paulo: Companhia das Letras, 2002.

DAMATTA, Roberto. O que faz o Brasil, Brasil? Rio de Janeiro: Rocco, 1986.

FIGUEIREDO, Rodrigo Augusto Alves; BARROS, Flávio Bezerra. A comida que vem da mata: conhecimentos tradicionais e práticas culturais de caçadores na Reserva Extrativista IpaúAnilzinho. Fragmentos de Cultura, v. 25, n. 2, p. 193-212, abr./jun. 2015.

FIGUEIREDO, Rodrigo Augusto Alves de; BARROS, Flávio Bezerra. Caçar, preparar e comer o 'bicho do mato': práticas alimentares entre os quilombolas na Reserva Extrativista 
Ipaú-Anilzinho (Pará). Boletim do Museu Paraense Emílio Goeldi, Ciências Humanas, v. 11, n. 3, p. 691-713, set./dez. 2016a.

FIGUEIREDO, Rodrigo Augusto Alves de; BARROS, Flávio Bezerra. Sabedorias, cosmologias e estratégias de caçadores numa unidade de conservação da Amazônia. Desenvolvimento e Meio Ambiente, v. 36, p. 223-37, abr. 2016b.

GEERTZ, Clifford. A interpretação das culturas. Rio de Janeiro: Jorge Zahar Editor, 1978.

LINARES, Olga F. "Garden Hunting" in the American Tropics. Human Ecology, v. 4, n. 4, p. 331-49, 1976.

LUDKE, Menga; ANDRÉ, Marli Eliza Dalmazo Afonso. A Pesquisa em educação: abordagem qualitativas. São Paulo: EPU, 1986.

MAIA, Lícia de Souza Leal. Vale a pena ensinar matemática. In: BORBA, Rute; GUIMARÃES, Gilda (Org.) A pesquisa em educação Matemática: repercussões na sala de aula. São Paulo: Cortez, 2009.

OJASTI, Juhani; DALLMEIER, Francisco (Ed.). Manejo de Fauna Silvestre Neotropical. SI/ MAB. Washington D.C: Smithsonian Institution/MAB Biodiversity Program, 2000. [Series \# 5].

OLIVEIRA, Roberto Cardoso de. O trabalho do antropólogo. 2. ed. Brasília: Paralelo 15; São Paulo: Editora Unesp, 2000.

RAMOS, Alcida Rita. Sociedades Indígenas. São Paulo: Editora Ática, 1988.

SANTOS-FITA, Dídac; NARANJO, Eduardo; RANGEL-SALAZAR, José Luís. Wildlife uses and hunting patterns in rural communities of the Yucatan Peninsula, Mexico. Journal of Ethnobiology and Ethnomedicine, v. 8, n. 28, 2012.

SILVERWOOD-COPE, Peter L. Os makú: povo caçador do Noroeste da Amazônia. Brasília: Editora da UnB. Coleção Pensamento Antropológico, 1990.

SOUSA, Fagner Freires de; VIEIRA-DA-SILVA, Camila; BARROS, Flávio Bezerra. 'Comida do sítio, comida de festa': apropriações e usos alimentares do miriti nos contextos rural e urbano de Abaetetuba, Pará. Acta Scientiarum: Humam and Social Science, Maringá, v. 38, n. 2, p. 143-51, 2016.

VIVEIROS DE CASTRO, Eduardo. Araweté: o povo do Ipixuna. São Paulo: Cedi, 1992. 
VIVEIROS DE CASTRO, Eduardo. Os pronomes cosmológicos e o perspectivismo ameríndio. Mana, v. 2, n. 2, p. 115-44, 1996.

WAGLEY, Charles. Lágrimas de boas-vindas: os índios Tapirapé do Brasil. Tradução de Elizabeth Mafra Cabral Nasser; revisão técnica de Berta G. Ribeiro. Belo Horizonte: Itatiaia; São Paulo: Editora da Universidade de São Paulo, 1988. (Coleção Reconquista do Brasil, 2a série; v. 147).

WOORTMANN, Klaas. Quente, frio e reimoso: alimentos, corpo humano e pessoas. Caderno Espaço Feminino, v. 19, n. 1, jan./jul. 2008.

\section{Sobre os autores:}

Edivaldo Soares Silva: Mestre em Ciências Ambientais pela Universidade do Estado de Mato Grosso (Unemat). Secretário Municipal de Agricultura e Meio Ambiente, Turismo e Comércio de Confresa, MT. E-mail: agrobio.confresa@gmail.com, Orcid: https://orcid.org/0000-0002-4893-5345

Flávio Bezerra Barros: Mestre em Ciências Biológicas (Zoologia) pela Universidade Federal da Paraíba (UFPB). Doutor em Biologia da Conservação pela Universidade de Lisboa, Portugal. Professor associado do Instituto Amazônico de Agriculturas Familiares da Universidade Federal do Pará (INEAF/UFPA). Professor permanente nos Programas de Pós-Graduação em Antropologia (PPGA) e Agriculturas Amazônicas (PPGAA) da UFPA e em Ciências Ambientais (PPGCA) da Universidade do Estado de Mato Grosso (Unemat). Bolsista de produtividade em pesquisa do CNPq. Líder do Grupo de Estudos Interdisciplinares sobre Biodiversidade, Sociedade e Educação na Amazônia (BioSE/CNPq). E-mail: flaviobb@ufpa.br, Orcid: https://orcid.org/0000-0002-6155-0511.

Recebido em 10 de março de 2020.

Aprovado para publicação em 19 de junho de 2020. 



\title{
Para além das demarcações territoriais: a inserção e permanência da/o estudante Kaingang na Universidade Federal do Pampa
}

\author{
Beyond territorial demarcations: the insertion and \\ permanence of the student Kaingang at the Federal \\ University of Pampa
}

\author{
Tatiane Motta da Costa e Silva ${ }^{1}$ \\ Suzana Cavalheiro de Jesus ${ }^{1}$ \\ Renata Colbeich da Silva²
}

DOI: http://dx.doi.org/10.20435/tellus.v0i42.690

\begin{abstract}
Resumo: Esta pesquisa caracteriza-se como um estudo etnográfico, realizado com estudantes indígenas ingressantes no ano de 2017, na Universidade Federal do Pampa, campus Uruguaiana. Para tanto, utilizamo-nos da observação participante e dos registros nos diários de campo para refletir, a partir do ingresso, o processo de permanência das/os estudantes indígenas no referido contexto. Ao longo do texto, buscamos tecer reflexões acerca dos avanços históricos conquistados pelos povos indígenas no que se refere ao acesso ao ensino superior em universidades públicas, bem como trazemos uma breve apresentação do percurso das/os estudantes Kaingang até o ingresso na universidade. Buscamos, ainda, compreender os aspectos que dificultam a permanência na universidade e ressaltamos as contribuições dos espaços de estudo e de convivência em grupo para o fortalecimento individual e coletivo das/os estudantes.
\end{abstract}

Palavras-chave: etnografia; ensino superior; indígenas Kaingang.

Abstract: This research is characterized as an ethnographic study, carried out with indigenous students entering the year 2017 at the Federal University of Pampa, Uruguaiana campus. For this purpose, we use participant observation and the records in the field diaries to reflect, from the time of entry, the process of permanence of indigenous students in that context. Throughout the text, we seek to reflect on the historical advances achieved by indigenous concerning access to higher education in public universities, as well as bring a brief

1 Universidade Federal do Pampa (Unipampa), Rio Grande do Sul, Brasil.

2 Universidade Federal de Santa Maria (UFSM), Santa Maria, Rio Grande do Sul, Brasil 
presentation of the Kaingang students' journey to university. During the text, we also seek to understand the aspects that hinder their stay at the university, and we emphasize the contributions of spaces for study and collective coexistence for the individual and collective strengthening of students.

Keywords: ethnography; higher education; Kaingang indigenous people.

\section{PRIMEIRAS PALAVRAS}

O presente texto remete a reflexões etnográficas desenvolvidas no ano de 2017, a respeito da permanência de estudantes indígenas da etnia Kaingang na Universidade Federal do Pampa, campus Uruguaiana, Rio Grande do Sul. Estas/ es, matriculadas/os nos cursos de Enfermagem, Farmácia, Educação Física e Tecnologia em Aquicultura, ingressaram no primeiro semestre de 2017 e pertencem a comunidades originárias do Rio Grande do Sul e Santa Catarina.

A problemática central de pesquisa partiu das formas como foram sendo construídos os espaços de estudo e de convivência coletiva. Questionou-se, ainda, o lugar dos saberes indígenas no contexto universitário, considerando as particularidades impostas pela Instituição de Ensino Superior (IES). O desejo de investigação, iniciado em diferentes formas de inserção na temática, deu-se dentro do Núcleo de Estudos Afro-Brasileiros e Indígenas (Neabi) ${ }^{3}$, onde foi possível aprofundar debates sobre questões étnico-raciais. A partir de então, iniciou-se um processo de desconstrução de percepções e conjecturas, ampliando reflexões sobre os estudantes indígenas enquanto sujeitos políticos dentro da universidade.

Neste artigo, apresentamos, inicialmente, o percurso metodológico traçado para o desenvolvimento da etnografia e seus desdobramentos. Em um segundo momento, pontuamos alguns avanços históricos conquistados pelos povos indígenas, no que se refere ao acesso ao ensino superior em universidades públicas e, ainda, no que diz respeito ao ingresso na Unipampa. Na sequência, organizamos uma breve apresentação das/dos estudantes, caracterizando suas comunidades

3 O Núcleo de Estudos Afro-Brasileiro e Indígena (Neabi) foi fundado em 2010, a partir da necessidade de instituir na Unipampa - Campus de Uruguaiana um núcleo de pesquisa que proporcionasse discussões e reflexões no âmbito acadêmico, à luz das Leis Federais 10.639/03 e 11.645/08, indo ao encontro da necessidade de promover projetos de pesquisa, extensão e discussões sobre a questão da discriminação racial e a implementação das ações afirmativas no ensino superior. 
originárias e diferentes vivências no espaço universitário. Por fim, analisamos o processo de permanência na universidade e a valorização dos saberes indígenas no âmbito da IES.

\section{O PERCURSO METODOLÓGICO}

Para a construção etnográfica, a utilização da tríade "olhar, ouvir e escrever", descrita por Roberto Cardoso de Oliveira (2000), fez-se como um dos primeiros passos da pesquisa que originou este texto. Neste sentido, o estudo etnográfico partiu da observação participante e da convivência diária com os/as interlocutores/as de pesquisa.

[...] enquanto no olhar e no ouvir "disciplinados" - a saber, disciplinados pela disciplina - realiza-se nossa percepção, será no escrever que o nosso pensamento exercitar-se-á da forma mais cabal, como produtor de um discurso que seja tão criativo como próprio das ciências voltadas à construção da teoria social [...] Se o olhar e o ouvir constituem a nossa percepção da realidade focalizada na pesquisa empírica, o escrever passa a ser parte quase indissociável do nosso pensamento, uma vez que o ato de escrever é simultâneo ao ato de pensar [...] Nesse sentido, os atos de olhar e de ouvir são, a rigor, funções de um gênero de observação muito peculiar - isto é, peculiar à antropologia -, por meio da qual o pesquisador busca interpretar - ou compreender - a sociedade e a cultura do outro "de dentro", em sua verdadeira interioridade. (CARDOSO DE OLIVEIRA, 2000, p. 18, 31 e 34).

As observações foram registradas em diário de campo, traçado a partir das contribuições de Tim Ingold (2015) sobre o engajamento pessoa-mundo, tendo em vista caminhar a pequenos passos para um processo de formação, não possuindo visão de totalidade, nem pressuposto de como será seu fim. É estado contínuo de atenção e alerta para todos os elementos presentes no percurso. É uma forma de aprender o mundo em que se está inserido, por meio da experiência (INGOLD, 2015).

Os trabalhos de campo estiveram estruturados em diversos espaços de estudo, de lazer e de convivência coletiva: a biblioteca, o hall do prédio principal da universidade, o Núcleo de Estudos Afro-Brasileiros e Indígenas (Neabi) e o Grupo de Pesquisa Tuna ${ }^{4}$ - Gênero, Educação e Diferença. A pesquisa desenvolveu-se,

4 O grupo inspira-se no simbolismo da cactácea Opuntia, a tuna, planta nativa do Pampa gaúcho, extremamente resistente, nascida nas brechas dos solos rochosos, protegida por espinhos e 
ainda, em ambientes externos à universidade, como restaurantes e lanchonetes da cidade de Uruguaiana; e uma visita de estudos à Terra Indígena Guarita6, RS.

Em seu caráter multissituado, essa investigação permitiu acompanhar diferentes faces das vivências universitárias "experienciadas" pelas/os Kaingang. Foram sucessões de experiências, desenvolvendo estratégias, que consideraram os indivíduos e seus símbolos, ultrapassando lugares e fronteiras, estabelecendo conexões ao longo de várias escalas etnográficas (MARCUS, 1995).

A região onde a maior parte do estudo se desenvolveu caracteriza-se como a Fronteira Oeste do Rio Grande do Sul. O município de Uruguaiana, que abriga o campus onde os estudantes estão matriculados, conta com uma população estimada de 129.580 pessoas (IBGE, 2014), sendo 93,6\% residentes na área urbana. Em 2008, o município recebeu a Universidade Federal do Pampa (Unipampa), que tem como finalidade promover e fortalecer o desenvolvimento social e econômico da região, a partir da oferta de uma educação superior gratuita e de qualidade. Nesse sentido, a Unipampa faz parte do programa de expansão das Universidades Federais no Brasil e atualmente tem 10.883 estudantes matriculadas/os nos cursos de graduação. Destas/es, até a data de realização do estudo (dez/2017), oito ingressaram por meio do processo seletivo para indígenas e estão distribuídas/ os em três campi (Uruguaiana, Santana do Livramento e São Borja7).

embelezada por flores peculiares. Visa produzir conhecimentos sobre temas áridos na paisagem das universidades brasileiras, sobretudo no contexto da fronteira oeste do Rio Grande do Sul. Reúne pesquisadoras e pesquisadores de diferentes áreas do conhecimento, numa perspectiva interdisciplinar transitando por temáticas como diferença, gênero, sexualidade, processos de socialização, sociedade, poder, currículo, gestão e políticas e que compreendem os espaços sociais como territórios em disputas, constituídos por alianças discursivas, sobre as quais se debruçam na busca de produção e socialização do conhecimento. Informações disponíveis em: http://dgp.cnpq.br/dgp/espelhogrupo/245223.

5 A visita à Terra Indígena Guarita, RS, foi instigada a partir das discussões durante a componente curricular "Educação e Cultura Indígena" do curso de Especialização em História e Cultura Africana, Afro-Brasileira e Indígena da Universidade Federal do Pampa, sendo organizada em parceria com a professora e alunas/os da componente curricular. O curso de Especialização foi criado a partir da Comissão Especial de Estudos sobre "História e Cultura Afro-Brasileira e Indígena" - HiCABI/Unipampa, constituída na universidade por meio da Portaria n. 1356, de 3 de agosto de 2010.

6 A Terra Indígena Guarita, RS, está localizada no noroeste do estado do Rio Grande do Sul, entre os municípios de Tenente Portela, Redentora e Erval Seco, dos quais é pertencente. Sua extensão é de 23.406,87 hectares, com uma população de aproximadamente 5.320 indígenas Kaingang, divididos em dezesseis setores.

7 O estudante ingressou em 2012, no curso de Engenharia de Software, alocado no campus 
O estudo seguiu as orientações do código de ética da Associação Brasileira de Antropologia, tendo as/os interlocutoras/es de pesquisa o direito de preservação de sua intimidade, de acordo com seus padrões culturais. Assim, a colaboração prestada à investigação Ihes garante o direito de acesso aos resultados e a premissa de que o grupo não venha a ser prejudicado em nenhuma etapa da pesquisa.

Dessa forma, a proposta de etnografia foi apresentada às/aos estudantes, antes de ser iniciada, tendo recebido o consentimento livre e esclarecido de forma oral. O texto ainda preserva a identidade das/os estudantes, de modo que nomes fictícios foram empregados às cenas etnográficas.

\section{O ACESSO AO ENSINO SUPERIOR EM UNIVERSIDADES PÚBLICAS}

Tendo em vista a história dos povos indígenas no Brasil, Paiva (2015) afirma que, ao longo de mais de 500 anos de colonização, esses sujeitos padeceram de repressão física e cultural, sendo forçados a reprimir suas culturas e identidades. É pensando nesses entraves que se faz possível afirmar que o cenário violento, mesmo que em diferentes formas e contextos, persiste. As/os indígenas, de modo geral, adotaram estratégias de sobrevivência nos contornos eurocêntricos dados de maneira hegemônica na construção do que é aceito como sociedade no Brasil:

Ao longo do século XX, as populações indígenas foram forçadas a ocupar espaços sociais e geográficos determinados pela política tutelar implementada pelo Estado brasileiro, por meio dos órgãos como o Serviço de Proteção aos Índios (SPI), criado em 1910 e a Funai, criada em 1967, na sequência da extinção do SPI. Sob a atuação do SPI os grupos indígenas sofreram um processo de "territorialização" compulsória. (MATOS, 2013, p. 216).

Essas questões tiveram forte influência quanto ao processo de escolarização indígena. Kleber Gesteira Matos (2013, p. 217) relata que a "oferta da educação escolar às populações indígenas foi fortemente condicionada pela estratégia de 'territorialização' imposta a estes povos". Somente a partir da década de 1970, de acordo com Gersem Baniwa (2006, p. 107), "os povos

Alegrete; posteriormente, migrou para o curso de Relações Públicas, campus São Borja, no qual, formou-se em 2017. O estudante será identificado no estudo pelo nome fictício de Daniel. Daniel é Kaingang e pertence à Terra Indígena de Serrinha.

8 Gersem José dos Santos Luciano é índio Baniwa e atualmente é professor adjunto da Faculdade de Educação e diretor de Políticas Afirmativas da Universidade Federal do Amazonas (Ufam). 
indígenas do Brasil iniciaram um período de recuperação demográfica e de autoestima identitária".

Essa reviravolta histórica ocorreu por ganhos sociais na esfera internacional e nacional, como a Convenção 169 da Organização Internacional do Trabalho (OIT), ratificada pelo Brasil em 2003. Isso assegurou o direito das/os indígenas serem reconhecidas/os como povos, em consonância com o disposto na Constituição Federal de 1988, que garante o reconhecimento dos seus direitos sociais (BANIWA, 2006).

O reconhecimento da cidadania indígena brasileira e, consequentemente, a valorização das culturas indígenas possibilitaram uma nova consciência étnica dos povos indígenas do Brasil. Ser índio transformou-se em sinônimo de orgulho identitário. (BANIWA, 2006, p. 38).

As identidades indígenas, rejeitadas e escondidas historicamente como "estratégia de sobrevivência, são atualmente reafirmadas e muitas vezes recriadas por esses povos" (BANIWA, 2006, p. 42). A recriação tange, inclusive, à necessidade de acesso ao ensino superior e à valorização do conhecimento dos povos originários.

A história do ingresso dos povos indígenas ao ensino superior teve início ainda na década de 1990, a partir das propostas de políticas de ações afirmativas ${ }^{9}$ adotadas pelos governos, pelas instituições de ensino e pelas iniciativas privadas (BANIWA, 2006). Segundo o estudo de Antônio Carlos de Souza Lima (2018, p. 390), em 2001 teve início o Projeto Trilhas de Conhecimento, com a demanda de formação de professoras/es para atuar nas escolas indígenas. O projeto foi desenhado conforme a política específica de educação escolar indígena, intercultural, bilíngue e diferenciada, bem como a reivindicação de participação política dessas populações. O objetivo foi acessar conhecimentos e espaços de escolarização, de modo a não depender da mediação de não indígenas.

Em 1998-1999, uma comissão interinstitucional e paritária desenhou e redigiu o projeto do que veio a ser o curso de Licenciatura Intercultural Indígena

É graduado em Filosofia pela Universidade Federal do Amazonas (1995), mestre e doutor em Antropologia Social pela Universidade de Brasília (2006-2011), sendo o primeiro doutor indígena. Foi coordenador-geral de educação escolar indígena.

${ }^{9}$ Conforme Cajueiro (2007), as ações afirmativas reconfiguram as políticas de educação superior no Brasil, a partir de ações voltadas para o acesso e permanência de grupos socialmente desfavorecidos nas IESs. 
da Universidade do Estado de Mato Grosso (Unemat), hoje Faculdade Intercultural Indígena. O curso teve seu início efetivo em 2001, após um ano de negociações políticas e financeiras. Para lá afluíram professores indígenas das mais variadas partes do Brasil, em busca de um curso marcado pela estrutura modular e pela formação em serviço. Em 2006 a primeira turma concluiu o ciclo da formação, e nela formaram-se 186 indígenas. (SOUZA LIMA, 2018, p. 390).

Melo (2013) afirma que, a partir desse processo, houve um movimento de valorização das experiências de licenciaturas interculturais indígenas. A autora explica que essas surgem como mecanismo de acesso e possibilidade de trânsito entre realidades distintas, bem como de valorização dos saberes indígenas. Problematizam-se possibilidades de diálogo entre diferentes saberes e conexões de saberes. O indígena passa a ver-se como o protagonista de seu próprio conhecimento, em um espaço historicamente negado para seu povo.

Os anos de 2001 e 2002 foram importantes para se colocar em prática planos elaborados durante a década de 1990, convergindo para medidas e debates que se seguiram. Inserem-se aí marcos históricos nas políticas de ações afirmativas, como a implementação das leis estaduais n. 3.524/2000 e n. 3.708/2001 no estado do Rio de Janeiro. Os avanços continuaram, quando, em 2003, na Universidade Estadual de Mato Grosso do Sul (Uems), começaram a ser realizados processos seletivos diferenciados para o ingresso de estudantes indígenas (SOUZA LIMA, 2018, p. 428).

Os cursos de Licenciaturas Interculturais Indígenas têm sido as principais formas de acesso ao ensino superior juntamente com a reserva de vagas. Todavia, as Licenciaturas Interculturais se diferenciam pelo apoio e disponibilidade de financiamento, de alimentação, alojamento e transporte, fatores essenciais para a permanência dos estudantes. Ao tratarmos de políticas de inclusão, reserva de vagas e Ações Afirmativas, percebemos a dimensão e complexidade do tema, que envolve desde a necessidade de acesso diferenciado, apoio à permanência, e principalmente, embates epistemológicos. (MELO, 2013, p. 125).

No entanto, mesmo diante dos avanços já citados, o número de estudantes indígenas que estão matriculadas/os nas universidades públicas ainda é inferior ao de matriculadas/os em instituições privadas. De acordo com os dados fornecidos pelo Instituto de Estudos e Pesquisas Educacionais Anísio Teixeira (Inep), 
no ano de 2015, estavam matriculadas/os no ensino superior 32.147 indígenas, sendo $9.810^{10}$ em instituições públicas e 22.337 em instituições privadas (INEP, 2016). Porém esses dados representam a expansão do ensino superior no país, "se o ensino público federal cresceu, ainda mais substancialmente o ensino privado" (SOUZA LIMA, 2018, p. 428). Esse fator se dá, ainda, pela proximidade ${ }^{11}$ de universidades privadas às terras indígenas, favorecendo a mobilidade entre terra originária e instituição de ensino superior.

Diante desses dados, é perceptível que a educação se tornou um objeto de desejo e interesse entre as/os indígenas, sendo, como se refere Souza Lima, "indicativo das grandes transformações na vida social dos povos indígenas nas mais variadas regiões do país" (SOUZA LIMA, 2018, p. 428). Ao mesmo tempo, esse movimento possibilitou inovações importantes no espaço universitário: a partir do ingresso desses povos no ensino superior, passou-se a ampliar as discussões quanto às políticas de ações afirmativas e programas de permanência.

Quanto às políticas de ações afirmativas, sua implementação ainda é recente, apesar da importante jornada já traçada. Tais discussões foram iniciadas, no Brasil, na década de 1980, a partir do desencadeamento do processo de abertura política e redemocratização da sociedade brasileira (MOEHLECKE, 2002). Sabrina Moehlecke explica que:

Com a redemocratização do país, alguns movimentos sociais começaram a exigir uma postura mais ativa do Poder Público diante das questões como raça, gênero, etnia, e a adoção de medidas específicas para sua solução, como as ações afirmativas. Somente a partir de 1990 as discussões relativas às políticas de ação afirmativa tomaram espaço. Minorias étnicas, raciais e sociais passam a reivindicar direito ao mercado de trabalho, à educação e à saúde diferenciada. (MOEHLECKE, 2002, p. 203).

Apesar disso, um projeto de lei que instituísse políticas de ações afirmativas, nas instituições federais de ensino superior, foi criado somente em 2008. Com isso, é apenas em 2012, quando aprovada a lei n. 12.711, de 29 de agosto, é que

${ }^{10}$ Das/os 9.810 estudantes indígenas matriculadas/os em universidade públicas, 7.392 estão em instituições federais, 2.268 em instituições estaduais e 150 em instituições municipais.

${ }^{11}$ A exemplo da Terra Indígena Guarita (Divisa NE pelo Rio Guarita [mg esquerda]. Municípios de Tenente Portela, Miraguaí e Redentora), no Rio Grande do Sul, que está rodeada por cidades onde há Universidades Privadas, como a Universidade Regional do Noroeste do Estado do Rio Grande do Sul (Unijuí) e Universidade Regional Integrada do Alto Uruguai e das Missões (URI). 
o Brasil tem uma legislação específica, relacionada ao ingresso de povos historicamente subjugados ao ensino superior federal - a denominada Lei de Cotas.

As políticas de ações afirmativas ainda enfrentam o desafio de conhecer a realidade da educação escolar indígena e ignoram as especificidades de cada um desses povos. O foco das políticas tem sido construções de trajetórias acadêmicas individuais: acesso ao ensino superior para compensação histórica da desigualdade. Tal perspectiva não contempla a diferença histórica e cultural que marca a relação entre indígenas, descendentes de conquistadores e de populações por eles transmigradas - por isso, constitui-se ameaçada de reproduzir as mesmas marcas de preconceito (SOUZA LIMA; BARROSO, 2013, p. 58).

No que tange ao acesso ao Ensino Superior na Unipampa, por meio de dados etnográficos, foi perceptível que esse instaurou-se em longo prazo. No ano de 2011, a Unipampa realizou o I Encontro com Líderes Indígenas, em sua reitoria, na cidade de Bagé, RS. Na ocasião, líderes indígenas e gestoras/es da universidade debateram formas de ingresso no Ensino Superior. Com o levantamento de demandas, pretendia-se encontrar soluções adequadas, do ponto de vista institucional, para o atendimento dos anseios das populações indígenas. Foram discutidas, também, as possibilidades de implantação de assistência estudantil. O ponto de maior debate levantado pelas lideranças indígenas foi em relação às dificuldades de convivência entre jovens de culturas diferentes, sendo propostos mecanismos para que as/os estudantes ameríndias/os não ingressassem isoladas/ os nos cursos, mantendo as/os estudantes conectadas/os a sua cultura.

As lideranças demonstraram-se insatisfeitas com a forma de ingresso pelo Exame Nacional do Ensino Médio (Enem), pois colocava no mesmo patamar negros, pardos e indígenas - não considerando características socioculturais de seus povos, especialmente aqueles oriundos do Rio Grande do Sul. Na época, a Unipampa reservava 1.554 vagas (50\% do total) para as políticas de ações afirmativas, destinadas a alunos afrodescendentes, pardos, indígenas, oriundos de escolas públicas e com deficiência, sem distinções socioculturais, conforme as especificações na Lei Federal 12.711/2012.

Por meio dos acordos com as lideranças em 2011, foi instituído o Programa Anau $\hat{e}^{12}$, tendo como objetivo inserir indígenas, residentes em aldeias, no universo

${ }^{12}$ Anauê, expressão que vem do Tupi e significa "você é bem-vindo", parte do pressuposto que a 
estudantil da universidade, buscando garantir a sua permanência e autonomia. Em sua constituição, o Anauê (hoje extinto) colocava-se como um programa de valorização da cultura indígena, que auxiliaria as/os estudantes na familiarização dos espaços acadêmicos, para que não acontecessem casos de evasão. Entendiase que, deste modo, a universidade conseguiria garantir a efetivação e valorização de direitos dos estudantes indígenas e suas inserções em processos coletivos de construção de conhecimentos.

A partir de então, o processo seletivo para indígenas aldeados ${ }^{13}$ passou a constituir-se em uma prova de redação, na modalidade dissertativa. Os critérios de avaliação se dividem em: atendimento ao tema; progressão temática; predomínio da tipologia dissertativa e adequação à norma culta do português brasileiro. No ato da prova, a/o candidata/o deve apresentar uma (auto)declaração de indígena aldeado, um documento contendo a nomenclatura da terra indígena a que pertence e assinatura de lideranças, bem como uma declaração de pertencimento étnico.

No primeiro semestre de 2012, as/os primeiras/os estudantes indígenas ingressaram na Unipampa. O ingresso esteve amparado pelo programa de assistência estudantil especial, com suporte financeiro por meio do Programa de Bolsas Desenvolvimento Indígena (Pbdai) e Programa de Bolsas Permanência (PBP). Esses estudantes passaram a ter apoio pedagógico e social e, ainda, monitoramento de professoras/es-tutoras/es e colegas de curso.

Em 2013, o Ministério da Educação (MEC) instituiu o Programa de Bolsas Permanência, buscando viabilizar a permanência de estudantes em vulnerabilidade socioeconômica, entre os quais indígenas, nas universidades federais (BERGAMASCHI; DOEBBER; BRITO, 2018). Conforme as autoras, desde então, as/os estudantes indígenas passaram a ter direito a uma bolsa diferenciada, com valor superior ao da bolsa das/os demais estudantes, o que se justifica em decorrência de suas especificidades (BERGAMASCHI; DOEBBER; BRITO, 2018).

Unipampa deve conhecer, a partir das/os indígenas inseridas/os no contexto do ensino superior, os diversos modos de ser indígena, mediante trocas de experiência e diálogo entre a universidade e suas comunidades originárias.

${ }^{13}$ Compreendemos que o termo "indígenas aldeados" é inadequado, no entanto utilizamos, neste momento do texto, pois é o termo que a instituição utiliza. 
Já em 2014, foi aprovada a Resolução n. 84, que dispõe sobre a Política de Assistência Estudantil na Unipampa. A resolução visa criar condições para garantir o acesso e a permanência das/os estudantes, de forma a atender a comunidade universitária multicampi, em uma perspectiva inclusiva. As ações são norteadas pelos princípios da inclusão social, da isonomia nos processos de seleção, da garantia dos direitos da comunidade discente e da autonomia política nas instâncias consultivas e deliberativas da Universidade. Quanto aos Programas de Assistência Estudantil, apresentados no Art. 5o da Resolução, destacamos o Plano de Permanência, composto por: Programa de Alimentação Subsidiada; Programa de Moradia Estudantil; Programa de Apoio ao Transporte; e Programa de AuxílioCreche. Os beneficiários do Plano de Permanência são as/os estudantes regularmente matriculadas/os nos cursos de graduação que apresentem comprovada situação de vulnerabilidade socioeconômica.

Com esse suporte, no ano de 2017, o processo seletivo específico para indígenas ofertou 21 vagas, em quatro campi (Uruguaiana, São Gabriel, Santana do Livramento e Jaguarão), totalizando 12 cursos de graduação. O campus Uruguaiana ofertou oito vagas em cinco cursos. Foram preenchidas sete vagas, com a desistência ${ }^{14}$ de uma estudante. Permaneceram então seis estudantes, todos Kaingang, nos seguintes cursos: Enfermagem, Farmácia, Fisioterapia e Licenciatura em Educação Física.

\section{A/O ESTUDANTE KAINGANG}

Antes de adentrarmos na temática da inserção e permanência das/os estudantes na Unipampa, é preciso situar alguns percursos "experienciados" por elas/es. Oriundas/os de diferentes terras indígenas ${ }^{15}$, do Rio Grande de Sul e Santa Catarina, três das/os seis estudantes indígenas transitaram por diferentes terras Kaingang, residindo, na época da pesquisa, nas localidades indicadas no Quadro 1. Os motivos de mudança variam desde conflitos internos, até

\footnotetext{
${ }^{14}$ A desistência de uma das estudantes foi motivada a sua aprovação no curso de Direito na Universidade Federal do Rio Grande (Furg), em Rio Grande, RS; e, como era sua primeira opção, preferiu desistir do curso de Licenciatura em Educação Física e optou por cursar Direito na Furg.

${ }^{15}$ Optamos por padronizar a nomenclatura "Terra Indígena" para as atuais áreas indígenas, quer estejam ou não demarcadas, mesmo constando no artigo 231, da Constituição Federal Brasileira de 1988, que o termo "Terra Indígena" é atribuído a áreas demarcadas oficialmente pela União (BRASIL, 1988).
} 
oportunidades de trabalho em outros municípios. Logo, o território ao qual estas/ es estudantes pertencem não é fixo, sendo importante destacar que as dinâmicas culturais e o processo de escolarização antecedem a chegada na universidade.

Quadro 1 - Apresenta as Terras Indígenas onde as/os estudantes residem

\begin{tabular}{ccccc}
\hline Nome & $\begin{array}{c}\text { Terra Indígena } \\
\text { de Origem }\end{array}$ & $\begin{array}{c}\text { Terra Indígena } \\
\text { Atual }\end{array}$ & $\begin{array}{c}\text { População } \\
\text { Kaingang }^{16}\end{array}$ & $\begin{array}{c}\text { Área } \\
\text { Territorial }^{17}\end{array}$ \\
\hline Carlos & Ligeiro, RS & Ligeiro, RS & 1.604 & $4.565,8$ \\
Daniela & Xapecó, SC & Xapecó, SC & 4.000 & 15.623 \\
Fernando & Guarita, RS ${ }^{18}$ & Cacique Doble, RS & 820 & 4.426 \\
Patrícia & Cacique Doble, RS & Cacique Doble, RS & 820 & 4.426 \\
Pedro & Guarita, RS & Monte Caseros, RS & 544 & $1.112,41$ \\
Sara & Guarita, RS & Pó NãnhMág, RS ${ }^{19}$ & & \\
\hline
\end{tabular}

Fonte: Elaborado pelas autoras, 2018.

O povo Kaingang está entre os mais numerosos povos indígenas do Brasil, distribuindo-se na região Sul e Sudeste do país, ocupando os estados de São Paulo, Paraná, Santa Catarina e Rio Grande do Sul ${ }^{20}$. Do ponto de vista linguístico, os Kaingang ${ }^{21}$

[...] pertencem à Família Jê do Tronco Macro Jê, e, juntamente com os Xokleng, compõe o grupo de sociedades indígenas Jê meridionais. Culturalmente, os Kaingang estão vinculados às sociedades Jê-Bororo, especialmente aos Jê setentrionais e centrais: Akwén, Apinayé, Kayapó, Kren-akarôre, Suyá e Timbira. (SILVA, 2002, p. 189).

No que tange à organização da sociedade, os Kaingang se organizam por

${ }^{16}$ A Terra Indígena Guarita, RS, tem uma população de 5.320 indígenas Kaingangs e sua área territorial conta com 23.406,87 hectares.

17 Não é uma área oficialmente demarcada.

${ }^{18}$ A Terra Indígena Guarita, RS, tem uma população de 5.320 indígenas Kaingangs e sua área territorial conta com 23.406,87 hectares.

${ }^{19}$ Não é uma área oficialmente demarcada.

${ }^{20}$ Em nível de Brasil, são 31 áreas, distribuídas entre Rio Grande do Sul, Santa Catariana, Paraná e São Paulo, com uma população de 34.116 indígenas Kaingang. Entre os estados citados, o Rio Grande do Sul é o estado que possui a maior população e o maior número de áreas indígenas, tendo 17.231 indígenas pertencentes a 13 áreas.

${ }^{21}$ Os Kaingang representam cerca de $45 \%$ de toda a população dos povos de língua Jê e estão entre os 5 povos indígenas mais populosos no Brasil (D’ANGELIS, 2002). 
meio do sistema dualista. Para os Kaingang, o dualismo é representado por intermédio de duas metades, sendo elas Kamẽ e Kainru, por meio do qual compreende-se que todos os seres, objetos e fenômenos naturais são divididos em duas categorias cosmológicas, uma ligada ao gêmeo ancestral Kamẽ, e a outra vinculada ao gêmeo ancestral Kainru (SILVA, 2002).

Sergio Baptista da Silva (2002) explica ainda que o dualismo Kaingang engloba todo o cosmo, incluindo, entre outros, os elementos classificatórios no âmbito da natureza e de sua exploração, em que as relações humanas se dão por meio de pares antagônicos. Estes se caracterizam por uma bipolarização contrastante, opositora e complementar, modo como se apresenta, também, o sistema de representações visuais Kaingang (SILVA, 2002).

Para as/os estudantes indígenas, explicar que a organização social e cosmológica Kaingang é organizada pelas metades Kamẽ e Kairu é uma forma de valorização e reconhecimento de sua cultura. Conforme Diário de Campo (06/12/2017): Pedro explica que as metades Kamẽ e Kairu estão associadas ao Sol e a Lua, sendo Kamẽ ao Sol e Kairu à Lua. Patrícia complementa explicando que as metades passam de pai para filha/o, sendo sempre a metade do pai que vai passar para as/os filhas/os. Também Fernando, logo na primeira reunião do Grupo de Pesquisa "Tuna - gênero, educação e diferença", explica que Kamẽ não pode casar com Kamẽ e que Kairu não pode casar com Kairu, só podendo haver casamento de Kamẽ com Kairu, pois, se casar Kamẽ com Kamẽ ou Kairu com Kairu, ocorre o risco das/os filhas/os nascerem com má-formação e do casamento não dar certo (Diário de Campo, 23/08/2017).

As divisões Kamẽ e Kairu são representadas pelas marcas rá téj (comprida ) e rá ror (redonda •), conforme exemplificado no estudo de Sueli Krengre Candido (2014). Essas representações das marcas são vistas em pinturas no rosto e no corpo para performances em eventos e nos rituais, podendo também serem vistas em artesanatos feitos pelos artesãos do povo Kaingang (CANDIDO, 2014).

Entre os diferentes espaços etnográficos construídos nesta pesquisa, a visita de estudo à Terra Indígena Guarita, RS, fez-se como um importante componente de entendimento sobre as relações estabelecidas por estudantes indígenas dentro da Unipampa. Estivemos na Escola Estadual Indígena de Ensino Fundamental Mukej e, ao chegarmos, fomos convidadas e convidados a participar de uma performance 
(LANGDON, 2008), desenvolvida pelas/os alunas/os da escola. Após, o professor de Educação Física Kaingang, da escola Mukej, Leandro, convidou todas e todos para nos reunirmos no centro da quadra de esportes, onde explicou a dança realizada, o grafismo expresso no corpo das/os alunas/os, falou sobre a organização social e cosmológica Kaingang e as metades Kamẽ e Kairu.

Esses espaços que fortalecem o pertencimento dos estudantes remetem às considerações de Gersem José dos Santos Luciano Baniwa (2006), sobre modos indígenas de colocar-se no mundo:

A riqueza da diversidade sociocultural dos povos indígenas representa uma poderosa arma na defesa dos seus direitos e hoje alimenta o orgulho de pertencer a uma cultura própria e de ser brasileiro originário. A cultura indígena em nada se refere ao grau de interação com a sociedade nacional, mas com a maneira de ver e de se situar no mundo; com a forma de organizar a vida social, política, econômica e espiritual de cada povo. Neste sentido, cada povo tem uma cultura distinta da outra, porque se situa no mundo e se relaciona com ele de maneira própria. (BANIWA, 2006, p. 46).

Os discursos dualistas permeiam a vida em comunidade e na universidade. Questões de personalidade são explicadas em cima de um ideal de ser Kamẽ, e outro ideal de ser Kairu. Essas demarcam possibilidades de lideranças, alianças e, ainda, conflitos.

Assim, entendemos que ocupar espaços dentro da universidade é uma forma de manutenção de fronteiras étnicas. Para Frederick Barth (2000), essas são criadas pelas diferenças culturais, que distinguem quem está do lado de fora e quem está do lado do pertencimento. Pertencer está para além do sentido organizacional, mas perpassa a identificação dos atores, que aqui são estudantes indígenas, e suas subjetividades representadas em formas de simbolismos e os sinais diacríticos. Esses estudantes, por sua vez, podem até mesmo se sentir à vontade para conversar em Kaingang num espaço em que há uma construção de mecanismo para o reconhecer como também seu. De maneira geral, as subjetividades são manifestadas pelas/os estudantes indígenas como uma possibilidade de amenizar os percalços do permanecer.

Da quadra de esportes onde foi realizada a performance, visualizamos uma igreja, fato frisado pelo professor de Educação Física. Ele ressalta que as igrejas evangélicas são muito presentes nas Terras Indígenas e interferem no cotidiano da escola. 
Cita o exemplo de alunas e alunos Kaingang que participavam daquele mesmo grupo que havia desenvolvido a performance, mas que, em função da igreja, deixaram de participar. A dança e as vestimentas rituais eram consideradas, pela instituição religiosa, como impuras. Em sua fala, Leandro ressalta a importância de professoras/es indígenas atuando nas escolas indígenas. Isso possibilita, segundo ele, a valorização da cultura e a continuidade de práticas Kaingang, além do ensino diferenciado.

O relato de Leandro vai ao encontro dos motivos, elencados pelos estudantes Kaingang do campus Uruguaiana, de se buscar um curso superior. Todos mencionam a necessidade de profissionais de seu povo atuando nas terras indígenas. Justificam, assim, a busca pelos cursos da área da saúde durante o processo seletivo: das/os 19 candidatas/os classificadas/os, 11 buscam os cursos da área da saúde, como Enfermagem, Farmácia e Fisioterapia. Com exceção de Sara ${ }^{22}$, as/os demais estudantes ingressaram nos cursos que escolheram como primeira opção durante o processo seletivo. Carlos afirma que, quando concluir seu curso, pretende retornar para Ligeiro e trabalhar na escola, pois o professor da escola não é indígena e ele percebe que o mesmo deixa de ensinar a cultura Kaingang, por falta de conhecimento sobre ela (Diário de Campo - Tatiane Motta da Costa e Silva, dia 05/07/2017).

Quanto ao processo de escolarização, as/os seis estudantes indígenas são egressas/os de escolas públicas, transitando entre escolas indígenas e não indígenas, durante a realização do ensino fundamental e médio. A estudante Daniela está em sua segunda graduação, tendo concluído o Curso de Graduação em Direito, na Universidade Comunitária da Região de Chapecó (Unochapecó), no ano de 2014.

O direito à educação escolar diferenciada é assegurado, na Constituição de 1988, na Lei de Diretrizes e Bases da Educação Nacional (Lei n. 9.394 de 1996) e no Plano Nacional de Educação (2014). Renata Gérard Bondim, em seu estudo "Educação superior indígena: de que estamos falando?", cita que

Em julho de 2004, o MEC criou a Secretaria de Educação Continuada, Alfabetização e Diversidade (Secad) ${ }^{23}$ onde está situada a Coordenação

${ }^{22}$ A estudante escolheu o curso de graduação em Direito como primeira opção, porém ficou de 1a suplente, optando por matricular- se no curso de Tecnologia em Aquicultura, sua segunda opção.

${ }^{23}$ Em 2011, a Secad foi incorporada à Secretaria de Educação Especial (Seesp) e transformou-se 
Geral de Educação Escolar Indígena (CGEEI). A CGEEI que tem como missão planejar, orientar, coordenar e acompanhar a formulação e a implementação de políticas educacionais voltadas para as comunidades indígenas, apoiando técnica e financeiramente a formação de professores indígenas e o desenvolvimento de materiais pedagógicos específicos para as escolas indígenas, em harmonia com os projetos de futuro de cada povo. (BONDIM, 2013, p. 126).

Embora essa organização esteja, hoje, bastante alterada, a educação escolar indígena segue sendo planejada enquanto modalidade da educação básica. Entre as diretrizes norteadoras, destacamos as Diretrizes Curriculares Nacionais Gerais da Educação Básica, as quais são responsáveis por orientar a organização, a articulação, o desenvolvimento e a avaliação das PROPOSTAS pedagógicas de todas as redes de ensino brasileiras. Estas incluem as Diretrizes Curriculares Nacionais para a Educação Escolar Indígena (BRASIL, 1999), organizadoras do ensino bilíngue e intercultural.

Sueli Krengre Candido, que atua como docente de língua Kaingang e de anos iniciais na Escola Bento Pi Góg, na TI Guarita, setor Pedra Lisa, enfatiza esses aspectos, ao nos receber durante a visita de estudos. A professora revisitava suas lembranças enquanto acadêmica do Curso de Licenciatura Intercultural Indígena do Sul da Mata Atlântica, da Universidade Federal de Santa Catarina (UFSC), compartilhando também suas vivências enquanto professora Kaingang. Destacou o estranhamento inicial da universidade, as dificuldades e a importância de as/os estudantes indígenas ocuparem os espaços universitários.

Sueli, assim como Leandro, ressalta a importância de profissionais indígenas atuando nas escolas das comunidades, tendo em vista que a/o docente não indígena costuma limitar as expressões das/dos estudantes. Cita o exemplo de alunas e alunos que não ficam sentadas/os nas cadeiras, que gostam de ficar em pé, enquanto desenham ou escrevem, ou seja, que têm um jeito diferente de se relacionar com o corpo e com o espaço onde estão. No entanto as/os professoras/es não compreendem, exigindo das crianças um comportamento estático, sem movimento, causando um estranhamento na/o aluna/o. Ela conta sobre o cotidiano na escola indígena, a organização, as refeições, os momentos de lazer, as relações pessoais entre colegas e a dinâmica do ensino bilíngue no processo de alfabetização das crianças.

em Secretaria de Educação Continuada, Alfabetização, Diversidade e Inclusão (Secadi). 
Sueli explica que o ensino da língua Kaingang na escola justifica-se para que o idioma não se perca. Junto à questão linguística, estão os costumes, as brincadeiras, os mitos, enfim, o modo de ser Kaingang. Isac ${ }^{24}$ contribui com Sueli ao ressaltar o desafio e enfatiza que a educação caminha com a cultura local daquela comunidade, devendo ser valorizados os saberes indígenas. Renata Gérard Bondim aponta que

[...] com base na OIT, o reconhecimento efetivo da educação indígena diferenciada e de qualidade aponta inclusive para o direito desses povos de criarem suas próprias instituições e meios de educação, possibilitando o ensino ministrado também na língua indígena, a formação de membros desses povos e a participação na formulação e execução de programas de educação de modo a atender as suas necessidades particulares, abrangendo sua história, seus conhecimentos e técnicas, seus sistemas de valores e todas as suas demais aspirações sociais, econômicas e culturais. (BONDIM, 2013, p. 78).

Em relação ao domínio da língua Kaingang, apenas Carlos e Patrícia dominam a língua e conversam entre si. Pedro apenas compreende Kaingang, não se arrisca a falar. Na universidade, Patrícia e Carlos conversam em Kaingang quando estão na sala do Neabi, bem como quando atendem o celular. Na TI Guarita, durante a visita de estudos, Carlos, Patrícia e Isac se comunicavam em Kaingang com as/ os moradoras/es. Patrícia e Isac eram conhecidos na comunidade e Carlos fez várias amizades.

No âmbito da escola indígena, a escolarização de povos Kaingang, citada por Benjamim Perokag Crespo (2015), esteve vinculada ao ensino bilíngue. O empoderamento da língua serve como modo de valorização da cultura e da manutenção de uma educação diferenciada. O autor menciona que no projeto pedagógico da escola indígena em que leciona todas as disciplinas devem ser trabalhadas com base no ensino bilíngue e intercultural, inclusive disciplinas vinculadas às ciências naturais e exatas, como a matemática.

Diante do exposto por Benjamim Perokag Crespo (2015), unindo as falas e reflexões de Sueli Krengre Candido, compreende-se que, para a garantia de uma

\footnotetext{
${ }^{24}$ Isac é o companheiro de Patrícia, também Kaingang e estudante do curso de Direito na Unipampa, campus Santana do Livramento. Durante a viagem de estudo, ele nos acompanhou e conquistou a todas/os com seu conhecimento. Isac tem graduação em Pedagogia e trabalhou com Sueli no Projeto Rede de Saberes Indígenas na Escola.
} 
educação escolar indígena plena, a escola indígena precisa estar alicerçada em uma política que assegure e valorize a prática do bilinguismo, além da efetivação de projetos escolares que expressem os projetos societários e visões de mundo e de futuro dos diferentes povos indígenas que vivem no território nacional (BRASIL, 2013).

Juliana Schneider Medeiros (2012), ao investigar processos de escolarização em território indígena, constatou que a escola tinha uma organização que pouco colaborava para afirmação da identidade étnica. Ainda, segundo a autora, essa escola reproduz uma educação que "uniformiza as pessoas, que impõe verdades únicas e que perpetua preconceitos" (MEDEIROS, 2012, p. 121). Afirma que a escola está ajudando os Kaingang a "desaprenderem" a ser Kaingang, ressaltando que o grande número de crianças que entram na escola falando "mais Kaingang" saem da escola falando "mais português" (MEDEIROS, 2012).

Diante do exposto, a autora constata que as/os Kaingang enfrentaram e ainda enfrentam um duro processo de ocidentalização. Ainda busca-se civilizá-los e formá-los para o trabalho produtivo e a geração de renda na lógica capitalista (MEDEIROS, 2012). Para a autora, desconsideram-se as diferenças culturais e demais formas de ser e sentir, instituindo um modelo ocidental de comportamento. A universidade, no que the concerne, sendo parte da sociedade, acaba por impor esse modelo único no processo de formação, culminando na formação de profissionais pouco preparados para o trato com as diferenças.

Entendemos que tanto a instituição escolar quanto a universidade são expressão de uma cultura eurocêntrica. Desta maneira, a/o estudante indígena, ao chegar a um contexto universitário, depara-se com modos de ser e de compreender o mundo que muitas vezes não correspondem ao seu cotidiano, resultando em diversas dificuldades. São apontados como entraves principais: a estrutura da universidade; a construção das relações e comunicação com professoras/es e colegas; as dificuldades de compreensão de conteúdo, leitura, escrita; e o domínio na utilização de equipamentos eletrônicos. Tais aspectos nos convidam a analisar com mais atenção os processos de ensino e aprendizagem no ambiente universitário e os diálogos possíveis com os saberes indígenas. 


\section{DA PRODUÇÃO DO CONHECIMENTO CIENTÍFICO À VALORIZAÇÃO DOS SABERES INDÍGENAS}

Vindas/os de diferentes terras indígenas do Rio Grande de Sul e Santa Catarina, como já relatado anteriormente, as/os seis acadêmicas/os chegam ao município de Uruguaiana, no primeiro semestre de 2017, no início do mês de março. Logo na chegada, as/os estudantes indígenas se deparam com a distância da universidade em relação ao centro da cidade. Após a realização da matrícula, os primeiros desafios foram surgindo, como moradia, alimentação e transporte.

Por meio da articulação das/os membros do Neabi, arrecadaram-se alimentos e organizou-se uma moradia provisória. Com o passar de algumas semanas, as/os estudantes buscaram um novo local para residir, batizando-o como "república indígena".

A república indígena, local onde Sara, Carlos, Pedro e Fernando residiam no período da realização da pesquisa, está localizada no terceiro andar de uma casa. Nesta casa, os dois primeiros andares são destinados para a moradia da dona e de seu filho. O terceiro andar é separado em dois apartamentos, sendo um alugado por uma família e o outro pelos estudantes. $O$ apartamento tem três quartos, um banheiro, uma sala e cozinha conjugada. A casa está localizada em um bairro periférico de Uruguaiana, porém, não muito afastado do centro da cidade - próximo a supermercado, farmácia e parada de ônibus. Cerca de cinco quadras da república, residem Daniela e Patrícia, em um apartamento aos fundos de uma casa que contém dois quartos, banheiro e cozinha. Daniela e Patrícia escolheram morar juntas em outra casa, devido ao espaço reduzido dos cômodos na república indígena.

Passado o impacto da chegada ao município de Uruguaiana, perceberam que era somente o início da jornada. Ao longo do primeiro e segundo semestres, os desafios para a permanência no ensino superior foram aumentando.

Devido a uma reforma, a universidade permaneceu durante o segundo semestre de 2017 sem o funcionamento do restaurante universitário, refletindo diretamente na alimentação das/os estudantes da instituição, e em especial das/ os estudantes indígenas. Elas/es faziam as refeições diariamente no restaurante e, sem o funcionamento, elas/es passaram a não se alimentar no horário do almoço ou fazer lanches. Raras as exceções em que traziam ou compravam comida. Esse 
fato preocupou o monitor de Pedro: Jeferson ${ }^{25}$ mostra-se preocupado com a situação de Pedro, que tem passado o dia na universidade e não está almoçando. No final do dia, geralmente quando ocorre a monitoria, Pedro demonstra dificuldade de concentração e, por vezes, relata sentir tontura (Diário de Campo - Tatiane Motta da Costa e Silva, dia 26/08/2017).

Além do restaurante universitário e da distância do centro da cidade para o campus, a Unipampa também não oferece, no campus Uruguaiana, a moradia estudantil - o que contribui para aumentar as dificuldades de permanência, tendo em vista os gastos mensais com alimentação, moradia e transporte. Por diversas vezes, as/os estudantes relataram que, quando foram realizar o processo seletivo, foi mencionado a elas e eles que a Unipampa oferecia moradia estudantil, restaurante universitário e auxílios. No entanto a realidade encontrada foi outra.

As dificuldades na construção de relações e comunicação com professoras/ es e colegas são expressas por meio de comportamentos e relatos, como o registrado no seguinte extrato de Diário de Campo:

[...] encontro com Sara ${ }^{26}$ na parada de ônibus, ela estava sentada com as pernas sobre o banco, me aproximo, a cumprimento e questiono se já está indo embora, ela relata que não, que ainda tem mais uma aula, continuo a conversa, questiono se no tempo de um intervalo e outro das aulas ela sempre fica na parada, ela diz que na maioria das vezes sim, que às vezes a aula é até as 14h30min e depois só às $15 \mathrm{~h}$ ou 15h30min, então ela fica ali, pergunto se ela gosta de estar no hall do prédio principal ou em outro local com os colegas, ela diz que não muito, pois está sempre cheio de gente e ali na parada ninguém a incomoda. (Diário de Campo - Tatiane Motta da Costa e Silva, dia 21/09/2017).

Patrícia, Daniela, Pedro e Fernando, entre o intervalo de uma aula e outra, costumam ir para a sala do Neabi - um espaço de convivência coletiva para as/ os estudantes. Em diversos relatos de diário de campo, constam observações de Pedro, de Patrícia e de Daniela chegando ao Neabi após as aulas. Carlos ${ }^{27}$, por

25 Jeferson é estudante do curso de graduação em Farmácia e monitor de Pedro e Daniela, participou da visita de estudo à Terra Indígena Guarita, RS.

${ }^{26}$ Ao final do semestre letivo de 2017, Sara desistiu do curso de Tecnologia em Aquicultura, os motivos que levaram a sua desistência não foram revelados. Ao recorrermos à coordenação do curso buscando informações, esses ao menos tinham conhecimento sobre a desistência.

27 Carlos, devido a um conflito em sua comunidade, retornou a sua terra indígena no início do mês de agosto e permaneceu lá até o conflito ser parcialmente resolvido; retornou a Uruguaiana no 
estudar à noite, tende a frequentar a sala do Neabi geralmente no fim da tarde, quando ocorre sua monitoria. Patrícia e Daniela costumam andar pela universidade e fazer os trabalhos em conjunto, mas, em caso de componentes curriculares que fazem sozinhas, Patrícia costuma realizar individualmente os trabalhos que deveriam ser em grupo.

Ao analisar os percursos das/os acadêmicas/os indígenas no ensino superior, Wagner Roberto do Amaral (2010) destaca os preconceitos cotidianos vivenciados por esses sujeitos, enquanto reflexo continuado das trajetórias trilhadas por elas/ es nas escolas públicas. Maria José Guerra e Wagner Roberto do Amaral (2014) explicam que a realidade apresentada no espaço acadêmico provoca às/aos estudantes indígenas várias situações de conflito, em que o estranhamento, a falta de pertencimento e a presença quase silenciosa fazem com que a distância e o sentimento de inadequação as/os tornem cada vez mais estranhas/os.

Estranhamento que não é percebido ou não ocorre quando as/os estudantes estão em espaços familiares que os fazem lembrar de "casa", como demonstra o comentário de Daniela ao chegarmos à Terra Indígena Guarita, RS, no setor de Pedra Lisa: Como é bom estar em terra conhecida, estou me sentindo em casa, essa aldeia me lembra a minha, me sinto tão bem aqui (Diário de Campo - Tatiane Motta da Costa e Silva, dia 11/10/2017). Reação também expressada pelos estudantes do gênero masculino:

[...] após todas/os se acomodarem, nos reunimos no saguão da escola, enquanto a janta estava sendo preparada. Antônio (amigo de Fernando) senta-se, pega o violão e começa a cantar. O repertório incluía músicas sertanejas. Aos poucos, Carlos, Pedro, Fernando, Daniel e Isac aproximam-se $e$, sem esconder a expressão de felicidade no rosto, acompanham Antônio ${ }^{28}$ na cantoria. Fica evidente o quão acolhidos e familiarizados com o local os estudantes indígenas estavam se sentindo naquele momento. (Diário de Campo - Tatiane Motta da Costa e Silva, dia 13/10/2017).

Em decorrência das demandas que surgiam diante de tantos conflitos, o Grupo de Pesquisa "Tuna29- Gênero, Educação e Diferença” propôs um espaço

início do mês de outubro.

${ }^{28}$ Antônio reside no município de Tenente Portela, RS, e tem amizade com Fernando. A convite de Fernando, Antônio, com seu violão, acompanhou a visita de estudo à Terra Indígena Guarita, RS.

${ }^{29}$ Os encontros ofertados pelo grupo reuniam a coordenadora e mediadora das discussões, as/os 
de estudo acerca das culturas indígenas, caracterizando-se como um momento de discussão, de fortalecimento e de valorização dos saberes indígenas. Ao longo do segundo semestre, o Grupo de Pesquisa Tuna passou a ser frequentado por todas/os as/os estudantes indígenas, com exceção de Carlos, que tinha aula durante o horário do grupo.

As discussões realizadas eram fomentadas por leituras de artigos relacionados à história dos povos indígenas, ao ingresso dos povos indígenas nas universidades brasileiras e aos desafios encontrados ao se propor uma universidade pluriétnica no Brasil. Ao longo dos encontros, diversos aspectos foram discutidos, as/os estudantes relatavam sobre as suas vivências nas comunidades indígenas, o estranhamento quando chegaram à universidade e os desafios encontrados diariamente, tanto no que se refere ao entendimento dos conteúdos como às relações interpessoais.

O relato de Patrícia sobre uma situação de discriminação sofrida marcou um dos encontros. A estudante conta que, após apresentar um trabalho em sala de aula, ouviu de uma colega que o trabalho tinha sido mal elaborado e apresentado, que havia faltado esforço e que suas dificuldades justificavam-se por ser indígena. Não bastasse isso, a professora que estava presente em aula concordou com a "análise" da aluna e reforçou que Patrícia estava se vitimizando diante da situação. A exposição do ocorrido levou o grupo a refletir e concluir que a universidade, com seu modo de avaliação pautado na meritocracia liberal, não contempla as especificidades de suas/seus estudantes e, por consequência, acaba os inferiorizando e excluindo.

Destacamos o quanto o debate sobre a ideia de mérito é, ainda, incipiente no espaço acadêmico. Do mesmo modo, percebemos que este é um tema que aos poucos avança, em função da consolidação de ações afirmativas. Concordamos com Luis Carlos de Freitas, quando este destaca que a meritocracia:

[...] está na base da proposta política liberal: igualdade de oportunidades e não de resultados. Para ela, dadas as oportunidades, o que faz a diferença

estudantes indígenas, bem como suas e seus monitoras/es e demais interessadas/os no estudo da temática. A dinâmica dos encontros consistia na leitura coletiva dos textos, em que uma ou um participante por vez lia uma parte do texto e, quando necessário, a leitura era interrompida e o debate coletivo era iniciado. 
entre as pessoas é o esforço pessoal, o mérito de cada um. Nada é dito sobre a igualdade de condições no ponto de partida. No caso da escola, diferenças sociais são transmutadas em diferenças de desempenho e o que passa a ser discutido é se a escola teve equidade ou não, se conseguiu ou não corrigir as "distorções" de origem, e esta discussão tira de foco a questão da própria desigualdade social, base da construção da desigualdade de resultados. (FREITAS, 2012, p. 383).

Assim, discutir meritocracia no ensino superior implica também evidenciar que práticas discriminatórias não se configuram como problema a ser enfrentado exclusivamente por pessoas indígenas ou de grupos subalternos: trata-se de uma construção que atravessa um modelo de sociedade e que atinge toda a população brasileira. Logo, não faz sentido buscar fortalecer a identidade da/o estudante indígena se não educar o não indígena no combate à discriminação. Daniela menciona, em um de seus relatos, dificuldades de interação com colegas para fazer um trabalho e falta de sensibilidade de uma professora em mediar a situação:

[...] Daniela conta que está fazendo uma componente curricular com o 8ㅇ semestre de um curso da área da saúde. A professora passou um texto para discussão e apresentação em grupo. A estudante sentiu dificuldade em compreender o texto, pois o mesmo abordava termos específicos daquela profissão, sendo este um conhecimento que ela ainda não possuía, pois, além de estar no 2 o semestre, o curso era diferente do dela [...] Daniela frisa que as dificuldades foram inúmeras, iniciando pela falta de acolhimento da turma. "Eles eram muito individualista", ela ressalta. Durante a apresentação do trabalho, Daniela falou das dificuldades que teve com o texto, a professora contrapôs, argumentando que a dificuldade era de todas/os e não deveria ser uma desculpa ou motivo de queixa [...]. (Diário de Campo - Tatiane Motta da Costa e Silva, dia 22/09/2017).

Diante dessas situações, novamente as palavras de Wagner Roberto Amaral:

As experiências de ensino superior revelaram que o conhecimento acadêmico produzido na universidade pelos estudantes e pesquisadores indígenas passa a ser estratégico para a afirmação cultural e política dos grupos étnicos aos quais pertencem, assim como para o desenvolvimento das suas comunidades. Contudo, o ingresso e a permanência dos indígenas no espaço universitário e urbano (no caso daqueles que passam a residir nas cidades) tornam-se desafiadores para esses sujeitos que passam a aprender, a vivenciar e a intercambiar diferentes perspectivas, concepções e experiências, provocando e sendo por elas provocados a refletirem sobre sua identidade étnica. (AMARAL, 2010, p. 358). 
Conforme mencionamos anteriormente, com vistas a contribuir com o processo de aprendizagem das/os estudantes indígenas, foi disponibilizado um monitor para cada curso que tenha indígenas matriculados. Sendo assim, o campus Uruguaiana tem cinco estudantes de graduação que atuam como monitoras/es. Há um processo seletivo específico de acompanhamento à/ao estudante indígena, realizado pelo próprio programa de ações afirmativas. Para ocupar uma dessas vagas, alunos e alunas dos cursos de graduação em que as/os indígenas estão regularmente matriculadas/os se inscrevem e concorrem à bolsa de monitoria no valor de $\mathrm{R} \$ 300,00$ (trezentos reais) mensais, numa carga horária de 12 horas semanais. As atividades de monitoria, na sua maioria, acontecem na sala do Neabi e/ou na biblioteca da universidade. No entanto muitas são as dificuldades encontradas pelas/os indígenas ao se depararem com os conteúdos e com a exigência das/os professoras/es, sendo a monitoria, por vezes, insuficiente nesse processo. Conforme conta Arthur ${ }^{30}$, monitor de Fernando: "[...] no início foi difícil, porque eu não consegui entender que o que era óbvio para mim não era para ele, eu ficava muito estressado durante as monitorias, sofria com tanta cobrança [...] os professores cobravam de mim o desempenho do Fernando" (Diário de Campo - Tatiane Motta da Costa e Silva, dia 23/08/2017). Izabel ${ }^{31}$, monitora de Patrícia, também relata suas dificuldades: "Patrícia possui muitas dificuldades, ela fala pouco e nossa comunicação é difícil [...] a maior dificuldade é na compreensão dos textos, também não consegue mexer no computador, preciso tá sempre ajudando ela" relata Izabel, monitora de Patrícia (Diário de Campo - Tatiane Motta da Costa e Silva, dia 23/08/2017).

A partir do relato de Arthur e de Izabel, percebemos a complexidade do processo educacional em que estamos inseridas/os, no qual a universidade, com seu modo de avaliação pautado na meritocracia liberal e eurocêntrica, não dialoga com saberes indígenas. As/os monitoras/es, por sua vez, sendo fruto desse contexto, também não estão preparadas/os para lidar com as particularidades

\footnotetext{
${ }^{30}$ Arthur é estudante do curso de graduação em Enfermagem e monitor de Fernando, participa dos encontros do Grupo de Pesquisa Tuna - Gênero, Educação e Diferença e das atividades promovidas pelo Neabi.

31 Izabel é estudante do curso de graduação em Fisioterapia e monitora de Patrícia, participa dos encontros do Grupo de Pesquisa Tuna - Gênero, Educação e Diferença e das atividades promovidas pelo Neabi. Ela acompanhou a visita de estudo à Terra Indígena Guarita, RS.
} 
das/os estudantes indígenas, gerando situações de estresse e desconforto para monitoras/es e monitorandas/os.

Maria José Guerra e Wagner Roberto Amaral (2014) afirmam que esse processo ocorre como reflexo da sociedade. Os preconceitos contra os/as indígenas são manifestados no ambiente escolar e no espaço acadêmico, sendo por elas/ es incorporados ou delas/es exigidas estratégias de sobrevivência ou resistência. A autora e o autor ressaltam que é neste momento que as relações tornam-se mais tensas e as paixões mais conflitantes.

A universidade, ao mesmo tempo em que oferece a possibilidade de uma nova identidade coletiva, de nós brasileiros, provoca a vergonha da diferença inferiorizada frente a nós brasileiros; dessa forma, acaba por impor o medo e o retorno ao ele e à segregação. (GUERRA; AMARAL, 2014, p. 66).

A partir desta discussão, retomamos a reflexão sobre em que medida a universidade consegue incorporar referências culturais trazidas pelas/os estudantes indígenas. No caso das/os estudantes Kaingang, além de verem ignoradas as suas referências culturais, ainda são impostos padrões e costumes não indígenas que não condizem com os seus.

Em novembro de 2017, a Coordenadoria de Ações Afirmativas (CAF) promoveu uma reunião do Fórum dos Neabis que ocorreu durante o 9ㅇ Salão Internacional de Ensino, Pesquisa e Extensão (Siepe) da Unipampa, em Santana do Livramento. Os estudantes Isac e Daniel apresentaram uma carta de reivindicações e propostas. A carta foi escrita em conjunto com todas/os os estudantes indígenas da Unipampa; nela, constava uma proposta de recepção às/aos novas/ os estudantes indígenas que ingressariam nos próximos semestres. Propunha-se, ainda, a expansão do debate sobre as vagas disponibilizadas no processo seletivo específico para Indígenas de 2018; a reivindicação do direito à moradia estudantil; e a criação de um Programa de Educação Tutorial (PET) Indígena, a partir do modelo estabelecido por outras universidades federais. Durante a apresentação da carta, Daniel fez uma breve explanação, sendo interrompido em alguns momentos: Daniel, lê algumas partes da carta, ressalta que a maioria das propostas não necessita de recursos financeiros, possibilitando a execução das mesmas. Ele entrega a carta ao reitor da universidade, o mesmo salienta que irá levar a proposta para discussão e em breve dará um retorno (Diário de Campo - Tatiane Motta da Costa e Silva, dia 22/11/2017). 
Não foi possível acessar os desdobramentos das demandas, mas gostaríamos de destacar a organização dos estudantes em prol de pautas comuns. Tais articulações mostram-se de acordo com o que Maria Aparecida Bergamaschi, Michele Barcelos Doebber e Patricia Oliveira Brito (2018) defenderam sobre a mobilização da instituição de ensino superior e seus múltiplos atores. Com a carta entregue ao então Reitor, os estudantes denunciam, de certa forma, a inexistência de um planejamento eficaz de acesso e permanência dos indígenas na instituição, ressaltando a urgência de estratégias e discussões que perpassem os auxílios financeiros, bolsas acadêmicas e programas de orientação e monitoria. Torna-se evidente que não basta garantir o acesso ao sistema de ensino, é necessário dar condições para continuidade dos estudos. Entende-se, com isso, que, se o acesso está sendo realizado de forma diferenciada, as condições de permanência também devem ser, adequando-se às demandas das/os estudantes indígenas.

\section{ALGUMAS CONSIDERAÇÕES}

Figura 1 - Terra Indígena Guarita, RS, setor de Pedra Lisa

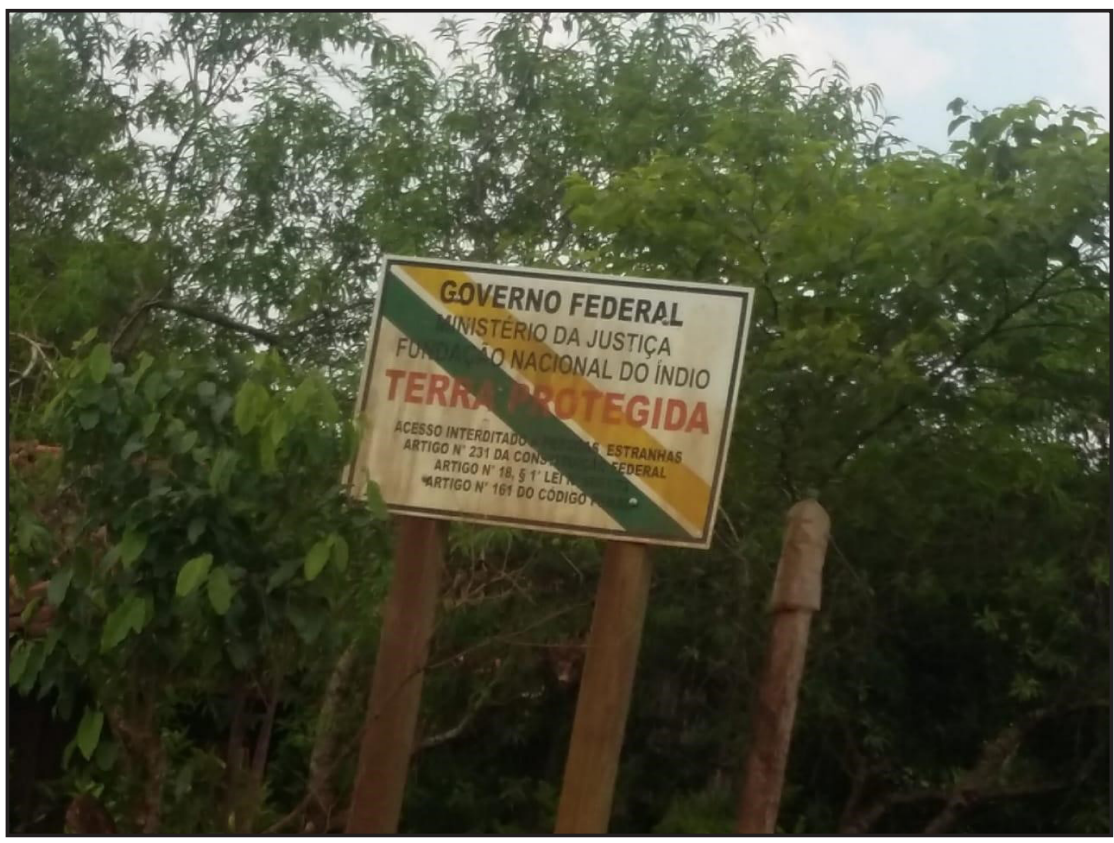

Fonte: Fotografia de Tatiane Motta da Costa e Silva, 11/10/2017. 
A Figura 1 foi registrada durante a visita de estudos à Terra Indígena Guarita, RS, no setor de Pedra Lisa. A placa indicava que estávamos em território indígena, demarcando um espaço geográfico pertencente aos povos Kaingang daquela região. Ao transgredir essas limitações territoriais e ocupar seus outros espaços, a/o indígena enfrenta, muitas vezes, diversas formas de discriminação e preconceito, tendo que, em alguns casos, retornar, de forma forçada, à terra onde se sentem "protegidos".

A escolha da imagem, acompanhada desta reflexão, demarca as considerações finais deste texto. Esta imagem representa o primeiro contato com uma terra indígena, é a primeira coisa que quem chega consegue ver. Em meio a tantos outros elementos, simboliza o início de uma reflexão acerca da territorialidade e do sentimento de pertencimento expressado pelas/os estudantes indígenas enquanto visitávamos a TI Guarita.

A mudança de comportamento foi visível, elas/es demonstraram estar se sentindo seguras/os, diríamos que, além de seguras/os, estavam à vontade naqueles espaços. Expressando-se mais com o corpo, riam alto e estavam mais falantes. Mostravam-se muito diferentes do comportamento expresso no ambiente universitário, onde geralmente falam pouco e em tom de voz mais baixo, mantendo uma expressão mais séria no rosto.

Quanto aos espaços ocupados pelas/os estudantes dentro da universidade, destacava-se a convivência na sala do Neabi, local onde elas/es ficavam entre as aulas e onde faziam a monitoria. Lá podiam conversar em Kaingang, fazer suas refeições, estudar e conversar de forma descontraída uns com os outros. A sala do Neabi caracterizou-se como um espaço de convivência coletiva e de acolhimento, um lugar, dentro da Universidade, que é tomado como movimento de territorialização, nos termos do que Michel de Certeau (2008) denomina de lugar praticado. A existência da sala, por si só, não consolida espaços indígenas na universidade, mas a presença dos estudantes Kaingang e das práticas criadas, cotidianamente, transforma a sala do Neabi em um espaço indígena.

Espaços de convivência coletiva e de acolhimento, como a sala do Neabi, bem como espaços de estudo e discussão como o Grupo de Pesquisa Tuna, foram e ainda estão sendo fundamentais para garantir a permanência das/os estudantes na Unipampa, em meio a tantas dificuldades enfrentadas por elas/es - tanto no que 
tange à questão financeira quanto às relações pessoais com colegas e professoras/ es. Nesse sentido, compreende-se que o processo de ingresso e permanência da/o indígena no ensino superior é muito mais complexo e merece mais importância do que vem recebendo. Não basta garantir o ingresso, é necessário dar condições para a sua permanência: condições integrais, como o apoio financeiro, estrutura institucional, de moradia, alimentação e transporte; apoio pedagógico; lugares de acolhimento; e espaços de discussão sobre ser indígena na universidade.

Por fim, cabe destacar que o ingresso dessas e desses estudantes na Unipampa, campus Uruguaiana, contribuiu para iniciar uma discussão acerca das culturas indígenas, antes não visibilizadas na instituição. Suas presenças trazem a necessidade de se falar sobre dualismo, território, bilinguismo e interculturalidade. Mas, mais que isso, marcam a necessidade de uma atenção maior, por parte do ensino superior, à multiplicidade de identidades, línguas, culturas e conflitos vividos pelos povos indígenas, em nosso país.

\section{REFERÊNCIAS}

AMARAL, Wagner R. As trajetórias dos estudantes indígenas nas Universidades Estaduais do Paraná: sujeitos e pertencimentos. 2010. Tese (Doutorado em Educação) - Universidade Federal do Paraná, Curitiba, 2010.

BANIWA, Gersem José dos Santos Luciano. O Índio Brasileiro: o que você precisa saber sobre os povos indígenas no Brasil de hoje. Brasília: Ministério da Educação, Secretaria de Educação Continuada, Alfabetização e Diversidade; LACED/Museu Nacional, 2006.

BARTH, Fredrik. O guru, o iniciador e outras variações antropológicas (organização de Tomke Lask). Rio de Janeiro: Contra Capa Livraria, 2000.

BERGAMASCHI, Maria Aparecida; DOEBBER, Michele Barcelos; BRITO, Patricia Oliveira. Estudantes indígenas em universidades brasileiras: um estudo das políticas de acesso e permanência. Revista Brasileira de Estudos Pedagógicos, Brasília, v. 99, n. 251, p. 37-53, 2018.

BONDIM, Renata Gérard. Educação superior indígena: de que estamos falando? In: SOUZA LIMA, Antônio Carlos; BARROSO, Maria Macedo (Org.). Povos indígenas e universidade no Brasil: contextos e perspectivas, 2004-2008. Rio de Janeiro: E-papers, 2013. p. 119-32.

BRASIL. Constituição da República Federativa do Brasil. Brasília, DF: Senado Federal: Centro Gráfico, 1988. 
Para além das demarcações territoriais: a inserção e permanência da/o estudante Kaingang na Universidade Federal do Pampa

BRASIL. Lei n. 9.394, de 20 de dezembro de 1996. Lei de Diretrizes e Bases da Educação Nacional (LDB). Brasília-DF, 1996.

BRASIL. Ministério da Educação. Conselho Nacional de Educação. Diretrizes Curriculares Nacionais da Educação Escolar Indígena. Brasília, 1999.

BRASIL. Ministério da Educação. Diretrizes Curriculares Nacionais Gerais da Educação Básica. Brasília: MEC, SEB, Dicei, 2013.

CÂNDIDO, Sueli Krengre. Histórias Kaingang. 2014. Trabalho de Conclusão de Curso (Graduação em Licenciatura Intercultural Indígena do Sul da Mata Atlântica)- Universidade Federal de Santa Catarina, Florianópolis, SC, 2014.

CARDOSO DE OLIVEIRA, Roberto. O trabalho do Antropólogo. 2. ed. Brasília: Paralelo 15; São Paulo: Editora Unesp, 2000.

CAJUEIRO, Rodrigo. Os povos indígenas em instituições de ensino superior públicas federais e estaduais do Brasil: levantamento provisório de ações afirmativas e de licenciaturas interculturais. Projeto Trilhas de Conhecimento: o Ensino Superior de indígenas no Brasil. Rio de Janeiro: Laced/Museu Nacional, 2007.

CRESPO, Benjamin Perokag. As práticas de ensino bilíngue na Escola Estadual Indígena de Fundamental Davi Rygjo Fernandes. 2015. Trabalho de Conclusão de Curso (Graduação em Licenciatura Intercultural Indígena do Sul da Mata Atlântica)- Universidade Federal de Santa Catarina, Florianópolis, SC, 2015.

D'ANGELIS, Wilmar da Rocha. Kaingang: questões de língua e identidade. Liames: Línguas Indígenas Americanas, v. 2, n. 1, p. 105-28, 2002.

DE CERTEAU, Michel. A invenção do cotidiano - artes de fazer. Petrópolis, RJ: Editora Vozes, 2008.

FREITAS, Luiz Carlos. Os reformadores empresariais da educação: da desmoralização do magistério à destruição do sistema público de educação. Educação e Sociedade, Campinas, v. 33, n. 119, p. 379-404, 2012.

INSTITUTO BRASILEIRO DE GEOGRAFIA E ESTATÍSTICA. Censo demográfico 2014. IBGE, 2014. Disponível em http://www.cidades.ibge.gov.br/xtras/perfil.php?lang=\&codmun= 432240\&search=riogrande-do-sul| uruguaiana|infograficos:-informacoes-completas. Acesso em: 25 ago. 2018. 
INSTITUTO DE ESTUDOS E PESQUISAS EDUCACIONAIS ANÍSIO TEIXEIRA. Sinopse estatística da educação superior 2015. Brasília-DF, 2016. Disponível em: http:// download.inep. gov.br/informacoes_estatisticas/sinopses_estatisticas/sinopses_educacao_superi or/ sinopse_educacao_superior_2015.zip. Acesso em: 1ㅇo out. 2018.

GUERRA, Maria José; AMARAL, Wagner Roberto. A construção da identidade e os regimes de visibilidade dos povos indígenas na universidade. Muitas Vozes, Ponta Grossa, v. 3, n. 1, p. 53-68, 2014.

INGOLD, Tim. That's enough about ethnography! Hau: Journal of Ethnographic Theory, v. 4, p. 383-95, 2015.

LANGDON, Esther Jean. Performance e sua diversidade como paradigma analítico: a contribuição da abordagem de Bauman e Briggs. Revista Ilha, v. 8, n. 1, p. 163-83, 2008.

MARCUS, George E. Ethnography in/of the world system: the emergence of multi-sited ethnography. Annual Review of Anthropology, v. 24, p. 95-117, 1995.

MATOS, Kleber Gesteira. Ensino superior e povos indígenas. In: SOUZA LIMA, Antonio Carlos; BARROSO; Maria Macedo (Org.). Povos indígenas e universidade no Brasil: contextos e perspectivas, 2004-2008. Rio de Janeiro: E-papers, 2013. p. 207-39.

MEDEIROS, Juliana Schneider. Escola indígena e ensino de história: um estudo em uma escola Kaingang da terra indígena Guarita/RS. Dissertação (Mestrado em Educação) Universidade Federal do Rio Grande do Sul, Porto Alegre, RS, 2012.

MELO, Clarissa Rocha. A experiência no Curso de Licenciatura Intercultural Indígena do Sul da Mata Atlântica. Século XXI - Revista de Ciências Sociais, v. 3, n. 1, p. 120-48, 2013.

MOEHLECKE, Sabrina. Ação afirmativa: história e debates no Brasil. Cadernos de Pesquisa, n. 117, p. 197-217, 2002.

PAIVA, Eliane Bezerra. A construção da identidade indígena em fontes de informação. In: XVI ENCONTRO NACIONAL DE PESQUISA EM CIÊNCIA DA INFORMAÇÃO - ENANCIB, 16., João Pessoa, 2015. Anais [...]. João Pessoa: ENANCIB, 2015.

PORTAL KAINGANG. População Kaingang (por áreas e por estados). [S.I.], 2013. Disponível em: http://www.portalkaingang.org/index_povo_1default.htm. Acesso em: 10 ago. 2017.

SILVA, Sergio Baptista. Dualismo e cosmologia Kaingang: o xamã e o domínio da floresta. Horizontes Antropológicos, Porto Alegre, v. 8, n. 18, p. 189-209, 2002. 
SOUZA LIMA, Antonio Carlos de. Ações afirmativas no ensino superior e povos indígenas no Brasil: uma trajetória de trabalho. Horizontes Antropológicos, Porto Alegre, v. 24, n. 50, p. 377-448, 2018.

SOUZA LIMA, Antônio Carlos de; BARROSO, Maria Macedo. A presença indígena na construção de uma educação superior universal, diferenciada e de qualidade. In: SOUZA LIMA, Antonio Carlos; BARROSO, Maria Macedo (Org.). Povos indígenas e universidade no Brasil: contextos e perspectivas, 2004-2008. Rio de Janeiro: E-papers, 2013. p. 45-77.

UNIVERSIDADE FEDERAL DO PAMPA. Conselho Universitário. Resolução n. 84, de 30 de outubro de 2014. Dispõe sobre o Programa Nacional de Assistência Estudantil (Pnaes), e na Portaria Normativa 39, de 12 de dezembro de 2007, do MEC/Sesu, que institui o Programa Nacional de Assistência Estudantil (Pnaes). Bagé: Unipampa, 2014.

\section{Sobre as autoras:}

Tatiane Motta da Costa e Silva: Doutoranda em Educação em Ciências pelo Programa de Pós-Graduação em Educação em Ciências: Química da Vida e Saúde na Universidade Federal do Pampa (Unipampa). Mestra em Educação em Ciências pelo Programa de Pós-Graduação em Educação em Ciências: Química da Vida e Saúde pelo Unipampa. Especialista em Saúde Mental Coletiva pelo Programa de Residência Integrada Multiprofissional em Saúde; e em História e Cultura Africana, Afro-Brasileira e Indígena pela Unipampa. Licenciada em Educação Física pela Unipampa. Professora da Rede Municipal de Ensino de Uruguaiana, RS. E-mail: tati_mcs@hotmail.com, Orcid: http://orcid.org/0000-0001-7232-2357

Suzana Cavalheiro de Jesus: Doutora em Antropologia Social pela Universidade Federal de Santa Catarina (UFSC). Graduação em Educação Especial e em Sociologia; especialização em Gestão Educacional; e mestrado em Ciências Sociais, pela Universidade Federal de Santa Maria (UFSM). Professora adjunta da Universidade Federal do Pampa (Unipampa), Campus Dom Pedrito. E-mail: suzanacavalheiro@yahoo.com.br, Orcid: http://orcid.org/0000-0002-5218-9816

Renata Colbeich da Silva: Doutoranda e mestra em Ciências Sociais e licenciada em Sociologia pela Universidade Federal de Santa Maria (UFSM). Tem experiência com Antropologia da Educação, entre os temas de narrativas (auto)biográficas, processo de escolarização e epistemologias oriundas de saberes tradicionais. E-mail: rcolbeich@gmail.com, Orcid: http://orcid.org/0000-0002-2293-5451

Recebido em 29 de março de 2020.

Aprovado para publicação em 5 de junho de 2020. 



\title{
Substancialidade A'uwê no espelho Waradzu: escutar o corpo indígena Xavante em contexto de trânsito espacial e cultural
}

\author{
A'uwê substanciality on Waradzu mirror: listening to \\ indigenous Xavante's body within a spatial and cultural \\ exchange context
}

\author{
Maria Clara Campos ${ }^{1}$ \\ José Francisco Miguel Henriques Bairrão ${ }^{1}$
}

DOI: http://dx.doi.org/10.20435/tellus.v0i42.689

Resumo: Para os Xavante, um melhor entendimento do mundo dos brancos e a capacidade de trazer melhorias para seu povo mediante estadias fora de seu território é habilidade crucial na competência de um líder. Em meados do século XX, o cacique Apöena, da Terra Indígena de Pimentel Barbosa, estabeleceu vínculos com um grupo de brancos de Ribeirão Preto, SP, e determinou a migração de oito de seus netos, todos do sexo masculino, para a cidade de origem do grupo. O presente artigo tem como enfoque a história de alguns protagonistas atuais desse intercâmbio. Objetivou-se perscrutar, mediante inclusive a sua expressão em práticas corporais, as suas perspectivas de si e de futuro e os seus efeitos na construção e transformação identitária. Para esse efeito, foram realizadas análises de entrevistas não estruturadas, realizadas com os jovens e suas famílias brancas, sob o enfoque metodológico da etnopsicanálise. Elucidou-se que esse encontro engendrou formas ativas e singulares de construção identitária e de ressignificação da tradição e memória Xavante por parte desses jovens, tanto no atinente às suas respectivas biografias quanto no entendimento dessas como uma forma de resposta à missão que Ihes foi confiada pelo seu povo. Evidencia-se, nessa perspectiva, a importância de se ultrapassar concepções atidas à aculturação de indivíduos indígenas em contato com o meio urbano, levando em conta suas sociocosmologias particulares.

Palavras-chave: etnopsicologia; etnopsicanálise; povos indígenas; Xavante; corporalidade 


\begin{abstract}
A better understanding of the white man's world and the ability to improve the natives' lifes are crucial skills for a Xavante leader. During the mid-20th century, Pimentel Barbosa's Indigenous Land Chief Apöena established bonds with a group of white men from Ribeirão Preto, SP, and ordered the migration of eight of his male grandchildren to the countryside city. This study focuses on the story of a few of the current protagonists of this cultural exchange. Their perspectives on self, future and its effects on identity construction and transformation were probed, including the manifestation of these elements in corporal practices. To achieve this objective, we conducted non-structured interviews with the young indigenous men and their host white families, which were later analyzed under the ethnopsychanalysis methodological framework. It became clear that this cultural exchange resulted in active and singular ways of identitary construction and meaning construction about Xavante memory and tradition for these young men, in what it relates to their biographies, and the understanding of them as a way to respond to the mission that was bestowed on them by their people. In this perspective, it becomes evident the importance of going beyond conceptions of acculturation of indigenous individuals in contact with the urban setting, and the necessity to take into account their particular sociocosmologies.
\end{abstract}

Keywords: ethnopsychology; ethnopsychanalysis; indigenous people; Xavante; corporeality

\title{
1 INTRODUÇÃO
}

Na contramão do quase consenso de que os povos indígenas não possuíram meios de defesa diante das investidas dos brancos - seja na guerra, seja na resistência biológica, na conversão religiosa ou na esfera política -, o povo Xavante (os $a^{\prime} u w e ̂$ ) desenvolveu diversas estratégias de relacionamento com os não índios (os waradzu), a fim de favorecer a sua sobrevivência. É possível observar, com efeito, diversos processos desenvolvidos por essa etnia direcionados a um aprendizado das sistematizações do mundo do branco e toda a sua inerente complexidade. Por meio desses procedimentos, os Xavante buscam, entre outros aspectos, retomar e fortalecer suas capacidades de ação, bem como reverter o quadro pessimista para sua população - determinado por perdas territoriais e demográficas ocasionadas nos primeiros anos de contato com os não nativos (GORDON, 2014).

A obtenção de conquistas para esse povo se deu, ademais, pela extrema habilidade com a qual administrou as relações que foi estabelecendo com o branco. Tal competência se embasa, entre outras razões, na organização social dualista inerente ao sistema Xavante, marcada por divisões em metades opostas, contrastivas 
e complementares - característica comum aos demais povos Jê. A fragmentação de toda a sociedade em duas metades clânicas que, ao mesmo tempo em que se contrapõem, consolidam alianças entre si (sobretudo matrimoniais) beneficia a coesão interna do grupo por meio de uma lógica em que se "divide para somar", em que o nós não existe sem o outro, este que vem a complementar e agregar. Por essa razão, os Xavante aparentam dominar mais facilmente o jogo sutil e arriscado das relações mutuamente constitutivas entre eu e outro, de forma a manter os "antagonismos em equilíbrio" (GORDON, 2014; SOARES, 2008).

Baseando-se nessas propensões, somadas ao crescimento de seu contato com os waradzu, os Xavante engendraram processos migratórios para centros urbanos, especificamente para cidades localizadas nos estados do Rio de Janeiro, São Paulo, Paraná, Minas Gerais e, sobremaneira, Goiás. A capacidade de obter melhoramentos por meio dos deslocamentos fora da aldeia tornou-se, assim, qualidade imprescindível na determinação da competência de um líder (TORAL, 1986).

Por esse prisma, o cacique Apöena, da Terra Indígena de Pimentel Barbosa, estabeleceu contato e vinculação com um grupo de brancos de Ribeirão Preto, SP, em visita às aldeias, ao fim da década de 1950 e início da conseguinte. Alicerçado nessa proximidade, o líder indígena determinou a migração de oito de seus netos, todos do sexo masculino, para a cidade de origem do grupo, com o objetivo de os jovens aprenderem a língua e a cultura do waradzu sob tutela de famílias não índias, as quais, em comum acordo, se dispuseram a zelar pelas crianças e thes fornecer a educação formal do branco (ESTRATÉGIA..., 2006).

O fenômeno engendrado pelo antigo cacique tem sua continuação na contemporaneidade. Alguns jovens Xavante atualmente trilham caminhos semelhantes aos de seus ascendentes, residindo hodiernamente na cidade de Ribeirão Preto com o intuito de viver e de se socializar no mundo branco, imersos em famílias não indígenas. Entre diversas consequências individuais e coletivas, a experiência de trânsito vivenciada ocasiona aos jovens indígenas efeitos sobre seus processos de construção identitária, sobretudo em função da dinamicidade que se opera na simbolização e síntese dos dois universos em que passam a cursar. O trânsito entre dois universos culturalmente e espacialmente distintos impacta, nesse sentido, a elaboração da autoimagem desses jovens, tal como as suas perspectivas de futuro e formas de ação. 
Caiuby Novaes (1993), ao utilizar-se do recurso metafórico do "jogo de espeIhos", permite uma análise dinâmica desse fenômeno da construção da identidade. Segundo essa, ao focalizar um segmento populacional, um grupo simultaneamente constitui uma imagem de si próprio, a partir de sua percepção aos olhos desse outro segmento. O outro, deste modo, torna-se uma espécie de espelho, em que a cada imagem refletida simetriza-se uma possibilidade de atuação, sendo essa corroborativa da imagem ou buscando corrigi-la. O prisma de visão dos grupos uns sobre os outros não implica uma visão unívoca, mas uma mescla de óticas e interpretações que se refletem e interpõem, gerando, assim, um caleidoscópio de imagens e posicionamentos possíveis, resultados dessa interação.

Semelhante noção é abordada pela psicanálise lacaniana por meio do Estádio do Espelho, salientando a importância fundamental do outro na imagem assumida pelo sujeito desde os primórdios da vida, tendo a identificação com essa imagem implicações diretas nesse último (CUKIERT; PRISZKULNIK, 2002; LACAN, 1998). Marcado pelo desconhecimento e a alienação, a imagem do eu constrói-se, desse modo, a partir da imagem devolvida por seu semelhante, constituindo uma fusão do desejo do sujeito alienado ao desejo do outro (CUKIERT; PRISZKULNIK, 2002). Os jovens abordados, direcionando-se a diferentes famílias, essas com formas dissemelhantes de relacionar-se com o quadro que se constrói a partir do acordo selado entre os povos, têm diante de si "espelhos-outros" de diferentes configurações. Logo, apreenderão dissemelhantes imagens de si e distintas formas de atuação a partir dessas. Tais disparidades, por sua vez, presumivelmente devem ocasionar reconfigurações, eventualmente ampliações ou supressões, no modo pelo qual esses passam a significar e apropriar-se das marcas identitárias corporais Xavante e expressar suas próprias corporalidades.

Conforme Müller (1976), a ornamentação corporal indígena corresponde a uma linguagem simbólica referente à ordem social, outorgando um modelo de como a sociedade em questão é idealmente estruturada por aqueles pertencentes a ela. Entre os Xavante, relaciona-se à divisão da sociedade em grupos sociais, a diferentes status e à passagem por esses. Não concerne, desse modo, a mera ilustração visual, mas é um sistema detentor de estrutura lógica particular, consonante a outras estruturas da sociedade em questão, referentes a grupos de idade, de parentesco e atuações ritualísticas, por exemplo. 
A expressão de certos aspectos da corporalidade Xavante, tal como as experiências suscitadas por esses usos e modelações do corpo, nessa perspectiva, configura-se substancial na construção e socialização dos sujeitos enquanto constituintes da coletividade e em suas subjetividades. Nessa direção, ultrapassa-se o sentido individualizante do corpo, passando a uma abordagem desse como componente social que atua, identifica-se e produz disparidades na relação com outros corpos, considerando os tipos de interação em questão (SPAOLONSE, 2006). Citando diretamente o autor:

Por um lado, pode se dizer que o corpo é modelado socialmente conforme os papéis assumidos ao longo da vida, e por outro, que a experiência desta modelação corporal, dotada de um valor social específico, transforma não somente o corpo, mas o próprio entendimento que se tem dele e do papel social assumido através de sua modelação. A experiência é marcada na pele e na carne, e o valor atribuído a ela pelo coletivo funde-se às próprias expectativas e sensações vivenciadas. (SPAOLONSE, 2006, p. 51-2).

Para além das concepções consuetudinárias em contexto tradicional Xavante, Borges (2013) propõe reflexionar o corpo do sujeito Xavante entremeado ao da cidade, constituindo materialidades discursivas que se amalgamam, enredam-se. Aludindo à noção defendida por Orlandi (2004) de que em espaços distintos pronunciam-se diferentes permissividades a determinados tipos de corpos, abrigando-os ou excluindo-os, e, dessarte, posicionam-se os sujeitos dentro desse meio de modo singular, a autora afirma haver uma interconstitutividade entre espaço e corpo na identificação do sujeito em seu discurso. O corpo pode ser visto, dessa forma, como materialidade significante que posiciona os sujeitos em determinados locais de fala, sendo o primeiro desses materiais simbólicos a abrir-se à significação para o outro, considerando o discurso no âmbito do visual, na relação entre sujeitos (HASHIGUTI, 2007).

Dessa forma, discorrer sobre o corpo sob o prisma simbólico é ultrapassá-lo do âmbito do imaginário, da formação do eu e da imagem, como exposto brevemente anteriormente. Concretiza-se o corpo como lugar primeiro do Outro, coincidindo-o com a borda em que os significantes, elementos topologicamente apreensíveis dessa estrutura, inscrevem-se (BAIRRÃO, 2003), compondo esse mesmo corpo e dialogando entre si (NASIO, 1993). É nessa perspectiva que, enquanto corpo, sucede-se o sujeito da enunciação. É o corpo que se faz objeto, mas 
é primordialmente sujeito, "sensível ao sopro de outros corpos, 'materialmente' sujeitado pelo simbólico e pulsar continente de todas as possibilidades de criação de significações" (BAIRRÃO, 2003, p. 48).

É embasando-se em todas essas noções que se almeja, no presente estudo, entender de que forma a construção identitária, da imagem do eu e das perspectivas de vida dos jovens Xavante, viventes na experiência de trânsito entre dois universos espacialmente e culturalmente díspares, reflete-se nas apropriações e expressões de seus corpos-sujeito.

\section{MÉTODO}

A fim de cumprir com o objetivo proposto, foram realizadas entrevistas não estruturadas com três dos jovens situados na experiência de trânsito em questão e membros de suas famílias brancas, no intuito de compreender a inserção e especificidade simbólica dos entrevistados, em um quadro de encontros e desencontros interculturais. Todos os diálogos foram estabelecidos na cidade de Ribeirão Preto, ambiente urbano habitado pelos jovens.

Embasou-se a coleta e análise de dados na abordagem etnopsicanalítica, localizada na intersecção entre os saberes psicanalíticos e etnográficos. Essa confluência, antes de tudo, não deve ser entendida como de natureza interdisciplinar, mas configurando-se em uma pluridisciplinaridade diante da efetuação de uma dupla análise de determinados fatos, cada qual sob o prisma de ambos os campos do saber. Enuncia-se, deste modo, a relação de complementaridade entre esses dois sistemas de explicação (DEVEREUX, 1972).

Nessa perspectiva, enquanto a psicanálise, em sua capacidade de permitir uma escuta afinada do Outro enunciante, contribui com um olhar complexo sobre o outro, e também do Outro em nós mesmos, a antropologia auxilia no conhecimento desse em sua alteridade. Propõe-se, nesse caso, que o desconhecido se torne agente de investigação, desconhecido este que reside na alteridade e no que se refere aos processos inconscientes, manifestos na parte em falta em um discurso concreto da cadeia significante efetivamente proferida (BAIRRÃO, 2003; BAIRRÃO, 2015).

Considerando as noções acima descritas e entendendo que o significante em psicanálise é o que perfaz sentido, e não mera e exclusivamente algo atrelado 
à linguagem verbal (BAIRRÃO, 2011), sublinha-se que a atenção à expressão da corporalidade dos jovens em suas vivências de trânsito entre o urbano e seus locais de origem sustenta-se no exercício da etnopsicanálise em suas bases epistemológicas, antropológica e psicanalítica.

Müller (1976), citando Deetz (1967), dispõe conhecimentos da arqueologia para demonstrar a aplicabilidade de conceitos linguísticos a produções concretas humanas. Nessa perspectiva, artefatos, objetos ritualísticos e, no caso, produções no corpo, sendo resultado da atividade física e mental humana, comporiam parte da comunicação linguística, constituindo diferentes modos de expressão para um mesmo sistema (MÜLLER, 1976).

Partindo de semelhante perspectiva, sob outro prisma, Bairrão (2011), em anuência à leitura lacaniana de enunciação - podendo essa ser tida como verbal, corporal, estética, ou ainda de outras formas -, admite o figurativo, em si mesmo, constituindo-se como linguagem. Como já aqui descrito, o corpo é tido como abrigo do Outro, lugar onde se inscreve o significante, atuando como mediador e agente da produção de sentido. Situando-se no corpo, o Outro atua como simbólico, articulado ao sujeito agente. $\mathrm{O}$ inconsciente, esse que reside na parcela do enunciado em falta que revelaria o enunciante, diz e "diz-se" no corpo. Nesta perspectiva, aquilo que é ação, o que está além do verbal e pode ser etnografado (observado), pode ser também reconhecido e entendido como dito, logo, passível de escuta (BAIRRÃO, 2011; BAIRRÃO, 2015; BAIRRÃO, 2003). Citando Lacan (1986, p. 303):

Somos pois levados pela descoberta freudiana a escutar no discurso essa palavra que se manifesta através, ou mesmo apesar, do sujeito. Pelo seu corpo mesmo, o sujeito emite uma palavra que é, como tal, palavra da verdade, uma palavra que ele nem mesmo sabe que emite como significante. É que ele diz sempre mais do que quer dizer, sempre mais do que sabe dizer.

Atentando-se a essas noções e empregando a escuta flutuante, foram consideradas na análise relações e repetições dentre os relatos obtidos, bem como associações livres, conteúdos implícitos e até mesmo o que não foi efetivamente proferido, o que se refere ao inconsciente. Vale ressaltar que a tais dados não é atribuído sentido pelo pesquisador, mas sim pelos próprios participantes, ainda que o façam pelos ouvidos do primeiro. Isso se dá, pois o papel da psicanálise 
como embasamento metodológico não é o de fornecer explicações, mas de dar abrigo ao discurso do Outro, que por si só interpreta (BAIRRÃO, 2015).

É ponderosa a observação de que a sobressaliência do enfoque eleito para o presente artigo é resultado do efeito do campo no pesquisador. Aqui, não se trata apenas das repercussões do campo concreto, mas do inconsciente como campo, constituinte desse campo que possibilita e provoca as associações que conduzem a construção do estudo.

\section{RESULTADOS}

O contato com os conteúdos aqui discorridos se deu por meio de duas famílias residentes em Ribeirão Preto, cada qual abrigando dois irmãos Xavante, cujas trajetórias serão brevemente explanadas a fins de contextualização.

A primeira das famílias foi responsável por abrigar duas gerações de meninos Xavante: Canãbre (pai), que convivera com os brancos durante vinte anos, cumprindo com sua missão, formando-se em Enfermagem e retornando à aldeia de origem a fim de auxiliar seu povo, até vir a falecer pouco tempo depois por causas desconhecidas; e seus filhos Siwari e Canãbre, que passaram a residir em Ribeirão Preto desde que o segundo, mais novo, completara dois anos e meio. A história, destarte, produz seus ecos até a presente geração, em que os jovens filhos trilham o mesmo caminho do pai.

A questão do corpo já se apresenta relevante desde os princípios da formação da família: os índios mais velhos elegeram a mãe e avó branca dos Xavante supracitados, Vilma, entre as outras famílias candidatas à recepção de Canãbre (pai), por essa ser fisicamente parecida com eles. Fernandes (2015) discorre sobre o fato de que, ao pensar-se comparativamente nos corpos de brancos e Xavante, na visão desses últimos, não se trata de uma concepção genética ou biológica do corpo, mas de uma posição relacional dotada de fluidez, onde se está, e não se é. Ainda, tal posição relacional varia em conformidade com o grau de personitude que se confere ao outro, no caso, ao não índio (FERNANDES, 2015). A constituição corporal de Vilma, dessa forma, foi significativa na identificação e aproximação dos Xavante com ela, salientando a importância das marcas visuais no estabelecimento de relações com o outro para esse povo. Vilma foi, naquele momento, a partir de seus atributos físicos, associada à lógica Xavante - não sendo indígena, mas estando indígena. 
Nessa direção, aludiu-se a um estreitamento de vínculos entre tal família branca e os Xavante, havendo uma incorporação dessa em posições sociais desse povo. Os familiares ribeirão-pretanos parecem ter passado pelo processo de "captura" do outro descrito por Falleiros (2013). Trata-se de uma transformação do outro, capturado (há uma correspondência semântica na tradução dos verbos acolher, tomar e caçar para o Xavante: mrami, que pode ser interpretado no escopo da captura) em captor potencial, que passa a dotar das mesmas responsabilidades e atributos, quase encerrando um ciclo de transformação da presa em predador, predador da potência que reside no exterior, envolvendo o poder de dar e distribuir (FALLEIROS, 2013). Incorporados como membros da família Xavante, os não índios em questão passam a comprometer-se em trazer benefícios a esses, transmitindo esse ideal aos jovens por quem são responsáveis. Nesse sentido, os jovens abrigados por tal família expressam intencionar cumprir com seus objetivos primordiais no contato com o branco.

O mais velho deles, Siwari, havia retornado à aldeia temporariamente, tendo dado início à composição de sua família indígena: tivera, há pouco, sua segunda filha. Essa provocara ainda mais apego no jovem comparativamente à primeira filha, já que Siwari retornara à cidade pouco tempo após o nascimento da mais velha e não conseguira acompanhar de perto seu desenvolvimento. No momento presente, tem se aproximado, portanto, de seus semelhantes Xavante, de seus laços familiares originais.

Na ocasião da entrevista, havia retornado a Ribeirão Preto a fim de concluir seus estudos no ensino médio e iniciar formação no ensino superior, em Nutrição ou Educação Física. A escolha de tais cursos, além de consonantes com seus interesses pessoais, foi pensada considerando-se os benefícios que poderiam vir no cotidiano de suas aldeias de origem. Verificou-se, inclusive, uma renúncia a aspirações pessoais em prol de seu povo:

Siwari: É... ah, vamo falar assim, que essa vida [de jogador de futebol] não era pra... ter, né? Cê tá entendendo, né?

Canãbre: Porque se ele entrasse [no clube], com isso o que que ele ajudaria a aldeia?

S: É, é... Eu até pensava, assim, se eu for jogador eu até ajudava, mas é... ajudar com dinheiro é fácil, assim. Mas eu quero ajudar, tipo... ajudando lá, não ajudando longe. Isso que é o... 
Seu irmão Canãbre, por sua vez, trilhava no momento um caminho de retorno definitivo à aldeia. O jovem enfrentara algumas perturbações de sofrimento psíquico durante sua estadia no meio urbano, segundo ele atreladas a uma dificuldade em amoldar-se à rotina e às cobranças inerentes ao universo cotidiano e escolar ocidental. Tendo passado, em meio a essa experiência, por um importante processo inerente aos homens Xavante, composto por diversos rituais determinantes na transformação e entrada na vida adulta, Canãbre pôde entrar em contato mais profundo com sua ancestralidade. Tal processo simbolizou não apenas uma mudança em seu grupo de idade na aldeia, mas em sua autoimagem e concepção de ser: havia encontrado seu espírito a'uwe, havia se descoberto, de fato, um Xavante. Diante dessa nova perspectiva de si, seu retorno definitivo à aldeia de sua mãe resultou em uma melhora significativa em seu quadro.

A opção pelo retorno a suas raízes não significa, contudo, que Canãbre considere sua missão entre os brancos finalizada. O jovem expressou aspirar uma formação superior em Pedagogia, com o intuito de lecionar nas escolas existentes nas aldeias de seus familiares, direcionada à educação formal das crianças e jovens que lá habitam.

A escolha de Canãbre tem relação direta com a experiência escolar positiva vivenciada por ele e seu irmão. Eles frequentaram, durante a estadia em Ribeirão Preto, uma instituição de ensino de metodologia pedagógica Waldorf. Fernandes (2013) aponta para a importância de atentar-se ao papel desempenhado pelo aspecto corporal e da ideologia indígena referente aos sentidos em seus processos de apreensão do mundo, de aprendizagem. Salienta a relevância da dimensão do ouvir para os Xavante, referindo-se a uma sinonímia para as palavras "ouvir" e "aprender" para esse povo. Nesse sentido, por meio de abordagens metodológicas que ultrapassam o âmbito do "ver" e da escrita, a escola em questão parece trabalhar de maneira mais inclusiva e consonante com o modo de apreender o mundo indígena, o que a leva até a uma aproximação com o ensino propagado nas aldeias, aspecto presente na fala de Canãbre.

Para além da semelhança pedagógica por eles identificada, os irmãos em questão relatam ter tido um acolhimento positivo na instituição de ensino frequentada. Ao contrário dos Xavante de Rosa (2008) e de Oliveira (2010), que se depararam com um discurso etnocêntrico de inferioridade do outro defendido por alguns docentes e com incompreensão por parte de colegas a respeito de seus costumes e comportamentos, 
os irmãos expõem terem tido suas identidades respeitadas e exaltadas no contexto escolar, somando a uma convivência mista com os colegas brancos, isenta de grandes episódios de discriminação. Siwari, por exemplo, menciona como positiva a ocasião em que, no Dia do Índio, foi à escola ornamentado e pintado como de costume na aldeia, tendo recebido aprovação dos colegas e professores.

Todas essas minúcias brevemente discorridas acima parecem ser fundamentais na compreensão do movimento de forte autoafirmação como indígenas e perspectivas de futuro aliadas a seu povo, cada qual ao seu modo, realizado por Siwari e Canãbre.

O terceiro jovem abordado foi Serê, que reside hodiernamente em Ribeirão Preto, juntamente a seu irmão mais novo e à família branca que os abrigara. Serê veio a Ribeirão Preto pela primeira vez juntamente de seu avô paterno, quando tinha quatro anos de idade, por volta dos anos 2000. Conheceu sua família não indígena por intermédio de Vilma, em razão do Centro Espírita que os dois grupos familiares frequentam comumente. Diferentemente dos filhos e netos indígenas de Vilma, os quais ela expressou enfaticamente não serem de sua guarda formalmente, no caso de Serê um acordo de transferência de guarda chegou de fato a tramitar na Justiça. $O$ processo foi vagaroso, visto que os profissionais responsáveis alegavam que conceder a guarda do menino seria retirá-lo de suas origens. Decorridos dois meses, o avô e o tio de Serê intervieram no processo, argumentando a favor da transferência de guarda e conquistando a sentença favorável do juiz. O irmão mais novo veio pouco tempo depois, com a mesma idade em que viera o primeiro.

Serê relata que fora cotado para assumir a posição de liderança em sua aldeia desde pequeno, devido a sua fisionomia - sublinhando, nesse aspecto, mais uma vez a importância da construção e composição do corpo na sociedade Xavante - e atitude, descrevendo-se como um indivíduo "maduro" desde sempre. Sua decisão acerca de seu destino, todavia, vai na contramão dos planos que seus familiares e lideranças de seu povo idealizaram: quando terminou o ensino médio, fez cursos de eletricista residencial e técnico de segurança do trabalho, áreas ditas de seu interesse desde criança. Atualmente, trabalha em uma gráfica e intenciona seguir residindo em Ribeirão Preto. Tal decisão acabou por suscitar alguns conflitos, tendo o jovem declarado: 
Tipo assim, não faria muito sentido assim, de eu... Eu tá estudando, morar aqui e depois voltar pra assumir uma responsabilidade que, tipo, num... Vai ter muito sentido pra mim lá, entendeu? Aí essa parte eles num entende muito, não aceitam. Eles pensam, assim, que eu 'tô' deixando a tradição, assim, dos povo lá de... de lá mesmo. Aí, mas assim, na parte de mim num é... num é isso. Eu só, tipo... [vou] viver aqui, mas de outra forma ajudar eles lá. Eu quero ajudar, mas não, tipo, indo lá e ficando lá.

Não soube me dizer de imediato, no entanto, se já havia pensado em formas concretas de realizar essa pretensão. Os conflitos se estenderam para outros âmbitos, desde questões matrimoniais até o comparecimento do jovem em ocasiões rituais importantes em sua aldeia de origem, conflitantes com sua agenda de trabalho na cidade, entre outras incongruências.

A escolha de Serê por um caminho distinto do trilhado por seus primos enviados a Ribeirão Preto com o mesmo propósito pode estar atrelado a uma vivência também diversa no ambiente citadino. Como já descrito, a transferência de guarda de Serê e de seu irmão passou pelo âmbito formal judiciário, o que agrega um peso simbólico de maior significância nessa transição. Nesse quadro de concretude da guarda dos meninos, a família branca pareceu empenhar-se em menor medida em alimentar o elo com os membros da família de origem desses, produzindo ruídos na comunicação e afeição dos jovens em relação a seus familiares consanguíneos e a seu povo.

Ainda comparativamente, o jovem frequentou uma instituição de ensino distinta da de seus primos, em que enfrentou no princípio algumas dificuldades de convivência:

[...] no início mesmo me incomodava muito, porque eles... eles vinha se... os menino menor vinha queria pegar meu... meu cabelo com a mão, porque era liso, era diferente, era grandão. Aí eu não gostava muito não, quer dizer, mas... eu fui levando, fui criando as amizade, assim...

Nessas ocasiões, conta, chegava a agredir os colegas fisicamente, o que levava a diretora a chamar sua mãe branca na escola. Borges (2013), citando Orlandi (2004), alude a uma aceitação ou exclusão seletiva de determinados corpos, dependente dos contextos espaciais em que esses estão inseridos, reafirmando uma interconstitutividade entre corpo e ambiente na identificação do sujeito no discurso (BORGES, 2013). Tratando-se de um ambiente escolar de viés ocidental 
tradicional, desprovido de uma metodologia diferenciada e inclusiva, pode-se inferir uma contribuição desse para a conformidade de Serê aos padrões brancos e atenuação de suas marcas identitárias Xavante.

Como se pretende demonstrar, a dissimilitude entre as vivências expostas pelas personagens acima descritas se expressa para além de seus discursos, planos e visões de mundo. Ela é conspícua em suas construções de corporalidade, na forma com que externam as marcas identitárias corporais Xavante, seja salientando-as, modificando-as ou as suprimindo.

A temática já emergiu no primeiro contato realizado com Canãbre, juntamente a Vilma, sua avó branca. Logo no início do diálogo, ela apontou que o neto havia cortado o cabelo, que anteriormente se preservava muito comprido.

O cabelo constitui-se uma das principais marcas de identificação corporal dos Xavante, tendo um corte específico e característico e sendo raspado completamente apenas nas ocasiões de luto, em que se deixa todo o corpo nu, sem cor, indicando ausência de ornamentação. O corte de cabelo dos Xavante é uma forma de domesticar o pelo, tornando-o diferente daquele do animal (MÜLLER, 1976). É penteado e paramentado especificamente em eventos ritualísticos, não tendo o cabelo em si alguma propriedade especial, residindo sua importância simbólica no corte (CAMPOS, 2007).

Aprofundando-se sobre o assunto, Canãbre relata que sua avó materna indígena não chegou a conhecer o pai e por isso foi criada pelo irmão dele, esse que possuía um cabelo muito longo. Por isso, segundo ele, tanto sua mãe quanto ele e seu irmão haviam herdado essa característica, tal como a de serem "grandões", como ele. Canãbre conta que deixou o cabelo crescer a fim de assemelhar-se fisicamente ao avô. Quando expõe isso a outros membros da aldeia, é recebido com surpresa e questionamentos acerca do conhecimento do jovem sobre a história do ancestral, aos quais responde afirmativamente. Diz que os demais o incentivam a não cortar seu cabelo, mantê-lo comprido, a fim de deixá-lo igual ao do avô. No entanto todo o seu grupo de idade havia cortado os cabelos para participar da corrida final, da qual não participou por não estar na aldeia. A fim de buscar aproximação e identificação com seu grupo, Canãbre modificou seu corte em adequação ao restante dos jovens Xavante: "Aí cortei mesmo, pra não chegar com o cabelo grande e todo mundo de cabelo curto, e eu maior". 
Em todas as situações descritas, o modo como o jovem trata seu cabelo insere-se na lógica indígena, buscando aceitação e reconhecimento por seu povo, seja em conformidade às tradições Xavante, seja na identificação com seus ancestrais e demonstração dessa frente aos demais, ou na tentativa de misturar-se e assemelhar-se ao seu grupo de idade.

Canãbre e seu irmão, em todas as ocasiões de entrevista, preservavam seu corte consoante à característica específica de seu povo, declarando inclusive ser essa uma marca que permite diferenciar os Xavante de outros povos indígenas com facilidade. Siwari contou utilizá-lo para ilustrar aos amigos não indígenas sua especificidade, visando contrapor-se à imagem do índio genérico comumente difundida entre os brancos. Ambos os irmãos zombaram do fato de muitos questionarem se são Tupi-Guarani, família linguística indígena mais comumente conhecida. Também relatam já terem sido questionados se são chilenos ou indianos. Discorrendo sobre a temática, o mais velho explicita: "[...] Aí, por exemplo, quando a pessoa fala pra mim 'Ah, você é índio e tal..." eu sou, aí eu falo 'Sou Xavante'. Já falo na hora".

Assim como em Spaolonse (2006), delineiam-se contornos de uma expressão da corporalidade própria, que pode ser entendida, diante do contato com a sociedade envolvente, como representativa de uma almejada autenticidade étnica diante dessa em relação aos demais povos ameríndios, o que acaba por configurar-se politicamente vantajoso para esse povo. Considerando-se a noção concebida por Caiuby Novaes (1993), trata-se de assimilar a imagem gerada pela percepção do outro (branco) - neste caso, uma imagem carregada de estereótipos e generalizações - e direcionar suas formas de atuação (como na construção de seus corpos) de forma a corrigir essa imagem.

Ao deparar-se com Serê, por outro lado, pôde notar-se um corte de cabelo rente, muito diferente dos anteriormente observados. A temática emergiu brevemente durante seu relato. Ao retratar eventos de sua infância na cidade, menciona ter na época um corte de cabelo "estilo Chitãozinho e Xororó", como motejou. O corte mais congênere aos padrões brancos, segundo ele, teria sido feito há tempos, em um período tido pelo jovem como de maior adaptação e apreço pela vivência citadina. Em emendação ao tema concernente aos cabelos, o jovem declara:

Tipo assim, é... tava me adaptando, assim, gostando mais, mas não esquecendo o que eles me ensinava lá, assim, de tudo, assim... mesmo eu sendo pequeno eu sempre pensava lá, sabe? Aí... minha mãe sempre me perguntou, assim, se eu tinha saudade de lá e eu... eu falava que não. E isso já era de mim mesmo. 
Serê indica, por conseguinte, que, apesar de não esquecer suas origens e os ensinamentos dessas provindo, não se sente muito ligado afetivamente a elas, optando pela permanência no contexto em que se encontra. O corte de cabelo parece vir juntamente dessa percepção, de adaptação e assimilação do modo de viver ocidental.

Considerando-se Serê e seu irmão, ainda, a questão ganha dimensões mais complexas. Vilma conta que o cabelo de um deles, após três meses de permanência na cidade, mudou de liso, como característico dos Xavante, para crespo: "[...] mudou a textura total, parecia... pensa num cabelo de porco! Tamanha a negação de ser índio. Muito forte".

Alude-se, nesse caso, à noção já explorada na antropologia de aproximação entre transmutações corporais e apropriação de posições sociais, revelando uma lógica em que a natureza humana é delineada, modelada, fabricada pela cultura (VIVEIROS DE CASTRO, 1987).

Outra característica atribuída pelos meninos de Vilma como de grande relevância na identificação e no reconhecimento Xavante, contribuindo na diferenciação entre esse e os demais povos tradicionais, é a inserção de batoques auriculares. Tais adereços marcam passagem de determinado grupo de idade à condição de jovens para adultos, homens plenos. Tal processo mostrou-se relevante na trajetória de Canãbre, que na ocasião de seu primeiro diálogo para o estudo havia acabado de passar pelo ritual de furação de orelhas. A inserção dos batoques auriculares representa o poder de transformação característico da sociedade Xavante, visto que os adolescentes tornam-se, com ele, pessoas com papéis socialmente definidos na comunidade, logo se tornando nominadores, pais e com capacidade de participar da vida política da aldeia. O batoque inserido no lóbulo inferior é também uma forma de simbolizar processos ligados à compreensão e ao entendimento de mundo pelos quais o jovem passou, relacionando-se à função simbólica do "ouvir", associada à compreensão do que é dito, passado pelos mais velhos (FERNANDES, 2010; FERNANDES, 2015). A significação do ritual ganha força ainda maior no caso de Canãbre, este que fora permeado por processos extremamente complexos de compreensão, vindos de dois universos simbolicamente distintos, cuja fusão culminou na certeza de sua substância, sua essência, para a qual deveria direcionar todos os conhecimentos adquiridos em sua história de vida. 
No caso de Serê, por outro lado, os batoques tradicionais de madeira, durante sua vivência urbana, foram substituídos por alargadores de aço. Ele relata ter passado por vários dos rituais tradicionais concernentes a sua idade, tais como a luta com o'ió (ritual de resistência que marca a dualidade clânica estrutural da sociedade Xavante [TSI'RUI'A, 2012]), a corrida com toras de buriti (encenação ritual do roubo do fogo da onça pelos humanos, narrativa central dos povos Jê e Bororo, que marca a ideia de que a condição da existência coletiva indígena decorre da existência de capacidades transformadoras e de apropriação vinculadas à alteridade [VIANNA, 2008]) e o ritual em questão. Com o decorrer de sua vivência no meio urbano, todavia, declarou cansar-se dos brincos tradicionais. Seu irmão mais novo, ainda, teria deixado seus furos se fecharem, conforme comenta.

Considerando a simbologia dos batoques no sentido da representação dos processos de compreensão e entendimento de mundo passados pelos jovens que os recebem, vê-se na expressão da corporalidade de Serê uma associação à visão ocidental de mundo, a manutenção de um traço de identificação Xavante agora aliado a um objeto provindo do universo estético branco, às formas de compreensão desse universo. Em seu irmão mais novo, por sua vez, tido por Serê como ligado às suas raízes originais ainda em menor medida, observa-se a denegação dessas marcas: os furos se fecharam, a abertura para ouvir e incorporar as formas de entendimento Xavante se fechou.

Ainda, apesar de pretensões semelhantes para seus futuros, os irmãos Siwari e Canãbre também vivenciam e expressam suas experiências de formas distintas, particulares de suas formas de ser e estar no mundo. Essas formas de ser aparecem no discurso dos jovens também influenciadas por suas posições no espaço e no tempo. Em um de seus ensaios, Lopes da Silva (1983) defende a consideração dessas duas dimensões na construção da identidade Xavante, levando em conta um processo histórico de migrações constantes desse povo, impulsionado pela expansão da sociedade nacional (sic) sobre as áreas por eles sucessivamente ocupadas. Desse modo, a memória ancestral Xavante mostra-se permeada por noções de historicidade e territorialidade, engendrando um corpo de conhecimentos próprios que se tornam constitutivos do ser Xavante. Ao referir-se a essa dimensão histórica da territorialidade para esse povo, todavia, não se deve tratar de uma apropriação simbólica das referências territoriais em seu modo de ser e visão de mundo. Mais do que isso, em razão da transitoriedade espacial, trata-se 
de representações, ópticas e adoção de atributos pelos Xavante em relação a diversos grupos étnicos contatados durante esse percurso pelo espaço (LOPES DA SILVA, 1983). Essa noção, pensada diante da macro-história Xavante, pode ser aqui redimensionada relativamente aos microprocessos de trânsito vivenciados pelos jovens abordados. Os irmãos demonstram apresentar formas de atuação e um processo de adaptação a essas maneiras particulares de cada um, de acordo com o ambiente em que se encontram em sua trajetória.

Siwari expressa ter facilidade em inserir-se em ambos os contextos, característica corroborada por aqueles que convivem com ele: "É bem estranho, quando eu vou pra lá, tipo, eu viro assim... parece que eu sou uma... outra pessoa [...] é uma coisa boa, assim".

Canãbre, por sua vez, expressa necessitar de um tempo de adaptação quando em transição: "Eu chego... ai eu chego... e tenho que dar um tempo, ai"."

Pode-se observar, assim, certa interdependência entre as formas de ser e o meio atrelada a certa carga da dimensão temporal. Tais formas também repercutem em suas construções corporais e na maneira pela qual se apresentam ao mundo. A avó branca, Vilma, discorreu acerca da composição visual desempenhada por seus netos de acordo com suas formas de lidar com o meio: quando na cidade, Siwari performa sua estética de maneira "moderna", usando roupas "da moda", sendo descrito por Vilma como "vaidoso", enquanto na aldeia compõe o visual de forma a adequar-se ao contexto, não destoando dos demais. Já Canãbre, segundo o relato da matriarca, sempre se vestira de modo mais simples em contexto urbano, mantendo sua composição visual quase constante. Nesse sentido, acaba mostrando-se ligeiramente discrepante em relação aos demais, tanto no ambiente de origem quanto no urbano. O grau de conformidade da exterioridade do ser aos ambientes coaduna, dessarte, com os graus de facilidade em adaptar-se a esses anteriormente descritos, demonstrando Siwari ser mais habilidoso em "camuflar-se" rapidamente, se comparado ao irmão. Introduz-se aqui uma consciência mais clara do ser relacional Xavante, menos fixo em identidades formadas. Trata-se de uma lógica de construção da pessoa relacional e perspectiva, dependente da relação com o outro, tal como exposto por Fernandes (2015).

Como se pode averiguar, portanto, elementos estéticos da construção corporal indígena podem somar-se a sentidos coletivos e cosmológicos próprios, 
possibilitando novos olhares sobre esses e, desse modo, possibilitando uma escuta mais refinada dos processos de construções identitárias vivenciados pelos sujeitos indígenas. É ultrapassando essa significação trivial aparente que se abre a dimensão significante desses elementos corporais, que, por sua vez, permite a abertura a infindáveis sentidos na escuta do corpo. Considerando o corpo em sua dimensão simbólica como o abrigo do Outro, pode-se inferir que essa abertura significante constitui-se uma via à escuta do sujeito inconsciente. É por essa via, pela escuta do corpo como ação, que se pode observar nas minúcias do caso de Serê, por exemplo, que, não obstante seu discurso verbal em direção a uma autoafirmação Xavante e pretensão de contribuir com melhorias a seu povo, goza de uma posição de conformidade aos padrões brancos de ser, inserindo-se, dessarte, em uma forma de discurso mais "branca" dentro de um espectro relacional. Não se trata, aqui, de uma análise direcionada à negação de identidade provinda de um processo de "aculturação" - principalmente se considerarmos que suas modificações corporais acabam por seguir a lógica cosmológica Xavante, ainda que de maneira sutil -, mas de uma identificação do posicionamento do sujeito em seu próprio discurso.

A expressão da corporalidade dos jovens, como se espera ter evidenciado, pode estar também intrinsecamente relacionada à dimensão imaginária desse corpo, referente à identificação do sujeito com uma imagem e à transformação produzida pela assunção desta imagem nesse sujeito (LACAN, 1998). A depender do contexto e dos elementos que permearam suas vivências juntamente aos não índios, os jovens podem ter passado a produzir diferentes imagens de si, entremeadas ao desejo dos outros que pousam sobre eles seus olhares - ou pode-se dizer até, considerando a importância atribuída pelos Xavante à dimensão do ouvir, suas vozes, seus discursos - carregados de impressões e expectativas. Seria a partir dessa imagem formada - produto do embate entre os sistemas de valores envolvidos nas representações em questão (CAIUBY NOVAES, 1993) - que se produzem, desse modo, alterações nas imagens concretas, ou seja, nas marcas corporais produzidas pelos sujeitos indígenas. Escutar tais marcas configura-se, portanto, fonte de vastas percepções acerca desses.

Ainda dentro desse espírito de atenção a nuances e sutilezas que se inscrevem corporalmente no quadro de um diálogo, uma construção singular de um lugar de trânsito entre dois mundos, é também imprescindível considerar 
que os entrevistados não falam apenas por si: cumprem um mandato étnico de serem mediadores, informantes do mundo waradzu junto ao seu povo, tal como foi determinado na origem desse processo. Quaisquer que sejam as posições assumidas no espectro relacional com os brancos, a experiência de "urbanidade" vivenciada pelos jovens constitui-se uma forma de redarguição ao seu povo, a partir da via mais intensa e do ponto mais privilegiado de experimentação, na tentativa de acessar a perspectiva do branco: a inserção no locus de seu conhecimento (NUNES, 2010). A partir disso, o desejo que os habita pode ser visto além da perspectiva individual: os jovens movem-se e constroem-se por meio do Outro. A forma pela qual traçam suas trajetórias e delineiam seus corpos pode ser considerada, portanto, também uma reação e retorno às apostas e indagações originais que embasaram a estratégia étnica desses intercâmbios. Suas decisões aparentemente pessoais, noutro plano, transmitem também uma mensagem e fornecem respostas aos Xavante acerca de como interagir, reconfigurar-se e devir indígena em um contexto de inevitável fricção étnica e cultural.

O teor e os ecos de tais respostas para o povo indagador, no entanto, não são conhecidos até então por limitação do recorte empírico traçado por este estudo no presente momento (restrito à escuta dos personagens apresentados no ambiente citadino) e necessitam de maior aprofundamento.

De qualquer forma, os corpos dos jovens e as mudanças neles implementadas, algumas das quais aqui foram elencadas, podem ser entendidos também significantes, noutra escala, dos limites e das permeabilidades das fronteiras entre a territorialidade a'uwê e os espaços waradzu, sendo os jovens metonímias do povo Xavante, os representantes personificados destas fronteiras. Mediante paciente e acurada escuta etnopsicanalítica, há de se continuar a ouvir tais nuances, neste e provavelmente noutros casos de populações indígenas.

\section{CONSIDERAÇÕES FINAIS}

Pode-se constatar, por meio da escuta dos jovens para além do que efetivamente proferem, que suas apropriações identitárias, perspectivas de si e de seus próprios caminhos a serem trilhados produzem marcas visíveis em seus corpos, essas também passíveis de escuta. Marcas que dizem mais do que os olhos podem ver em um primeiro impacto, que ultrapassam significações puramente estéticas. 
Retomando as perspectivas teóricas em que se embasou o presente estudo, podemos inferir que atentar-se à expressão da corporalidade dos alvos do estudo é escutá-los como de fato se apresentam e representam em sua cultura. O corpo como se mostra é também ação, e é nele que reside o real do sujeito. A compreensão das minúcias acima descritas configura-se, portanto, imprescindível para o entendimento das experiências e visões de mundo dos jovens abordados e até mesmo de seu povo como um todo, quando a escuta é elevada ao plano do Outro Xavante.

Como afirmado por Nunes (2010), ao considerar-se o contato do indivíduo indígena com o meio urbano e os personagens que o permeiam, em oposição a uma generalização de "situação de urbanidade", tem-se que cada caso e suas especificidades envolvem modos e intensidades de relação com esses elementos. Nos processos aqui abordados, podem-se averiguar diferentes níveis de relação dos jovens com os componentes da sociedade envolvente - indivíduos, coletivos, modos de vida e perspectiva... -, tendo alguns incorporado - e corporificado - em maior ou menor medida os discursos predominantes nessa. Não obstante esses fenômenos de transformações e maleabilidade, cada qual ao seu modo, os jovens alcançaram formas de continuarem afirmando e, em alguns casos, performando suas identidades Xavante. Diante disso, evidencia-se no caso a ultrapassagem de concepções atidas à noção de aculturação dos povos ameríndios em contato com o urbano, respeitando suas sociocosmologias próprias.

A consideração dessas nuances, que dizem respeito à perspectiva particular de mundo do povo indígena em questão, sublinha-se também como relevante para o exercício de uma Psicologia crítica, comprometida com as problemáticas psicossociais contemporâneas, que englobe os sujeitos em suas especificidades socioculturais e mostre-se capaz de contribuir em suas lutas. Para tal, aprofundar-se em sutilezas como as aqui abordadas é imprescindível para uma atuação profissional diante dos povos ameríndios.

\section{REFERÊNCIAS}

BAIRRÃO, J. F. M. H. Etnografar com Psicanálise. Psicologias de um ponto de vista empírico. Cultures-Kairós, Les numéros, Anthropologie et psychanalyse: débats et pratiques, 2015. Disponível em: https://revues.mshparisnord.fr/cultureskairos/index.php?id=1197. Acesso em: 13 out. 2017. 
Substancialidade A'uwê no espelho Waradzu: escutar o corpo indígena Xavante em contexto de trânsito espacial e cultural

BAIRRÃO, J. F. M. H. Corpo e inconsciente. Revista Olhar, São Carlos, v. 8, p. 41-9, 2003.

BAIRRÃO, J. F. M. H. Nominação e agência sem palavras: o audível não verbal num transe de possessão. In: O movimento de um pensamento: ensaios em homenagem a Luiz Roberto Monzani. Curitiba: Editora CRV, 2011. p. 155-72.

BORGES, A. A. C. Da aldeia para a cidade: processos de identificação/subjetivação do índio Xavante na cidade de Barra do Garças/MT, alteridade irredutível? 2013. Dissertação (Mestrado em Linguística)- Instituto de Estudos da Linguagem da Universidade Estadual de Campinas, Campinas, SP, 2013.

CAIUBY NOVAES, S. Jogo de espelhos: imagens da representação de si através dos outros. São Paulo: Edusp, 1993.

CAMPOS, M. C. R. O corpo emana: elementos da plástica corporal Xavante. 2007. Dissertação (Mestrado em Artes)- Instituto de Artes, Universidade do Estado do Rio de Janeiro, Rio de Janeiro, RJ, 2007.

CUKIERT, M.; PRISZKULNIK, L. Considerações sobre eu e o corpo em Lacan - uma contribuição à questão do corpo em Psicanálise: Freud, Reich e Lacan. Estudos de Psicologia (Natal), v. 7, n. 1, p. 143-9, 2002. Disponível em: http://www.scielo.br/scielo. php?script=sci_arttext\&pid=S1413-294X2002000100014\&lng=en\&nrm=iso. Acesso em: 18 fev. 2020.

DEVEREUX, G. Ethnopsychanalyse complementariste. Tradução de Jolas, T. e Gobard, R. Paris: Flammarion, 1972.

FALLEIROS, G. L. J. Vir a ser e não ser gente através da participação etnográfica no Brasil Central. Universitas humanística, Bogotá, n. 75, p. 251-74, jan./jun, 2013. Disponível em: http://www.scielo.org.co/scielo.php?script=sci_arttext\&pid=S012048072013000100011\&lng=en\&nrm=iso. Acesso em:10 dez. 2019.

FERNANDES, E. R. Do Tsihuri ao Waradzu: o que as ideologias xavante de concepção, substância e formação da pessoa nos dizem sobre o estatuto ontológico do outro? Horizontes Antropológicos, Porto Alegre, v. 16, n. 34, p. 453-77, 2010. Disponível em: http://www.scielo.br/scielo.php?script=sci_arttext\&pid=S0104-71832010000200019\&ln $\mathrm{g}=\mathrm{en} \& \mathrm{nrm}=$ iso. Acesso em:15 out. 2017.

FERNANDES, E. R. Cosmologias indígenas, exterioridade e educação em contexto culturalmente diferenciado: um olhar a partir dos Xavante, MT. Tellus, Campo Grande, ano 10, n. 19, p. 97-110, jul./dez, 2013. Disponível em: http://tellus.ucdb.br/index.php/ tellus/article/view/219. Acesso em: 2 maio 2018. 
FERNANDES, E. R. Alimentação, corporalidade e doença: regimes de subjetivação do outro a partir de um estudo entre os índios Xavante (Mato Grosso, Brasil). Tessituras, Pelotas, v. 3, n. 2, p. 301-24, jul./dez., 2015. Disponível em: https://periodicos.ufpel.edu.br/ojs2/ index.php/tessituras/article/view/5922. Acesso em: 2 maio 2018.

ESTRATÉGIA Xavante. Direção de Belisário Franca. Rio de Janeiro: Giros, 2006. Disponível em: https://vimeo.com/216711158. Acesso em: 6 set. 2017.

GORDON, C. Os Xavante e suas circunstâncias. In: COIMBRA JR., C. E. A.; WELCH, J. R. (Org.). Antropologia e História Xavante em perspectiva. Rio de Janeiro: Museu do Índio - Funai, 2014.

HASHIGUTI, S. O corpo como materialidade do/no discurso. In: SEMINÁRIO DE ANÁLISE DO DISCURSO, 3., Porto Alegre, 2007. Anais [...]. Porto Alegre: SEAD, 2007. Disponível em: http://www.ufrgs.br/analisedodiscurso/anaisdosead/3SEAD/Simposios/SimoneHashiguti. pdf. Acesso em:18 fev. 2020.

LACAN, J. O Seminário Livro 1: os escritos técnicos de Freud. Rio de Janeiro: Jorge Zahar, 1986. [Texto original publicado em 1975].

LACAN, J. O estádio do espelho como formador da função do eu. In: LACAN, J. Escritos. Tradução de Vera Ribeiro. Rio de Janeiro: Jorge Zahar, 1998. p. 96-103. [Texto original publicado em 1966].

LOPES DA SILVA, A. A expressão mítica da vivência histórica: tempo e espaço na construção da identidade Xavante. Anuário Antropológico/82, 1983, p. 200-14. Acesso em: 5 ago. 2018.

MÜLLER, R. A. P. A pintura do corpo e os ornamentos Xavante: arte visual e comunicação social. 1976. Dissertação (Mestrado em Antropologia Social) - Instituto de Filosofia e Ciências Humanas, Universidade Estadual de Campinas, Campinas, SP, 1976.

NASIO, J. D. Cinco lições sobre a teoria de Jacques Lacan. Rio de Janeiro: Jorge Zahar, 1993.

NUNES, E. S. Aldeias urbanas ou cidades indígenas? Reflexões sobre índios e cidades. Espaço Ameríndio, Porto Alegre, v. 4, n. 1, p. 9-30, jan./jun. 2010. Disponível em: https:// seer.ufrgs.br/EspacoAmerindio/article/view/8289. Acesso em: 15 out. 2017.

OLIVEIRA, N. A. Xavantes, pioneiros e gaúchos: identidade e sociabilidade em Nova Xavantina/MT. 2010. Dissertação (Mestrado em Ciências Sociais) - Faculdade de Ciências Sociais, Universidade do Vale do Rio dos Sinos, São Leopoldo, RS, 2010.

ORLANDI, E. P. Textualização do corpo: a escritura de si. In: Cidade dos Sentidos. Campinas: Pontes, 2004. 
Substancialidade A'uwê no espelho Waradzu: escutar o corpo indígena Xavante em contexto de trânsito espacial e cultural

ROSA, L. M. Encontros e desencontros entre os a'uwê uptabi e os waradzu no espaço urbano de Barra do Garças-MT. 2008. Dissertação (Mestrado em História) - Faculdade de Ciências Humanas e Filosofia, Universidade Federal de Goiás, Goiânia, GO, 2008.

SOARES, J. Aspectos comuns da organização social Kaingang, Xavante e Bororo. Espaço Ameríndio, Porto Alegre, v. 2, n. 1, p. 44-67, jan./jun., 2008. Disponível em: https://seer. ufrgs.br/EspacoAmerindio/article/view/3114. Acesso em: 29 jan. 2020.

SPAOLONSE, M. B. Uma "tradição" em performance: corporalidade, expressividade e intercontextualidade num rito de iniciação social entre os Xavante de Sangradouro. 2006. Dissertação (Mestrado em Antropologia Social)- Centro de Filosofia e Ciências Humanas da Universidade Federal de Santa Catarina, Florianópolis, SC, 2006.

TORAL, A. A. "Xavantaço ou Funailaço?". Aconteceu Especial 17- Povos Indígenas no Brasil -85/86. São Paulo: Centro Ecumênico de Documentação e Informação, 1986. p. 344-47.

TSI'RUI'A, A. T. A sociedade Xavante e a educação: um olhar sobre a escola a partir da pedagogia Xavante. 2012. Dissertação (Mestrado em Educação) - Universidade Católica Dom Bosco, Campo Grande, MS, 2012.

VIANNA, F. L. B. Boleiros do cerrado - índios Xavantes e o futebol. São Paulo: FAPESP/ ISA/Annablume, 2008.

VIVEIROS DE CASTRO, E. A fabricação do corpo na sociedade Xinguana. In: OLIVEIRA FILHO, J. P. (Org.). Sociedades Indígenas e Indigenismo no Brasil. Rio de Janeiro: Editora Marco Zero, 1987.

\section{Sobre os autores:}

Maria Clara Campos: Graduanda em Psicologia pela Faculdade de Filosofia, Ciências e Letras de Ribeirão Preto (FFCLRP) da Universidade de São Paulo (USP) e pesquisadora de iniciação científica no Laboratório de Etnopsicologia da FFCLRP-USP. E-mail: campos.mclara.s@gmail.com, Orcid: http://orcid.org/0000-0001-6046-7209

José Francisco Miguel Henriques Bairrão: Doutor em Filosofia pela Universidade Estadual de Campinas (Unicamp) e livre-docente pela Universidade de São Paulo (USP). Pesquisador e docente de Psicologia Social no Departamento de Psicologia da Faculdade de Filosofia, Ciências e Letras de Ribeirão Preto da USP. Coordena o Laboratório de Etnopsicologia desta instituição, onde orienta e desenvolve pesquisas pautadas pelo interesse em não divorciar reflexão epistemológica 
(Epistemologia da Psicologia, Filosofia da Psicanálise) e pesquisa empírica (Psicologia da Cultura, Psicologia da Religião). E-mail: bairrao@usp.br, Orcid: http://orcid.org/0000-0001-6372-8873

Recebido em 24 de março de 2020.

Aprovado para publicação em 9 de junho de 2020. 


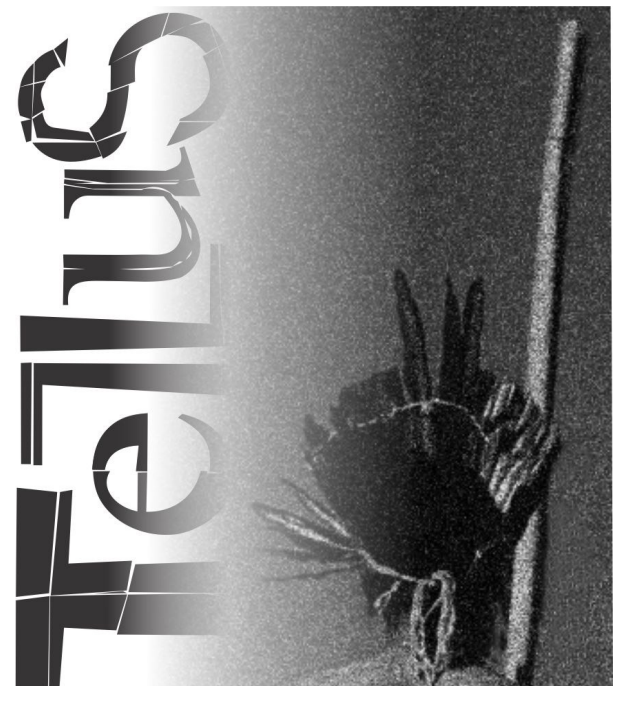

\section{entrevista}




\title{
Pedagogia da contextualização e interculturalidade na formação de professores indígenas: entrevista com Maria do Socorro Pimentel da Silva
}

\author{
Lilian Abram dos Santos ${ }^{1}$
}

DOI: http://dx.doi.org/10.20435/tellus.v0i42.681

Atualmente, existem em torno de 25 cursos de licenciatura indígena no Brasil, destinados exclusivamente à formação de professores indígenas ${ }^{2}$. Tais cursos decorrem da agenda de lutas contínuas do movimento indígena por uma educação intercultural, que começou muito antes da vigência da Constituição Federal de 1988. Território, saúde e educação são os eixos que compõem a resistência indígena ao demorado e incansável processo de colonização que submete os saberes e corpos indígenas historicamente. Felizmente, nos últimos 15 anos, como decorrência das ações do movimento indígena e da implantação das ações afirmativas para outros grupos desfavorecidos, muitas universidades e institutos federais reconheceram sua responsabilidade no processo de exclusão de sujeitos e coletivos minorizados e se mobilizaram para a elaboração de cursos superiores de formação de professores indígenas cujos objetivos são o de contribuir para a construção de uma educação não colonizadora, na qual os saberes indígenas estejam presentes no currículo, nos materiais didáticos e nos projetos pedagógicos das escolas indígenas.

O curso de Educação Intercultural do Núcleo Takinahakỹ de Formação Superior Indígena, da Universidade Federal de Goiás, é uma licenciatura específica para a formação de professores indígenas, iniciada em 2007. O curso atende, atualmente, estudantes de 27 povos indígenas, dos estados de Goiás, Maranhão, Mato Grosso e Tocantins, sendo um exemplo da possibilidade de realização de uma educação escolar indígena verdadeiramente intercultural, bilíngue, específica e diferenciada e, antes de tudo, com o objetivo de romper com o histórico de educação assimilacionista e colonizadora.

1 Universidade Federal de Goiás (UFG), Goiânia, Goiás, Brasil. 
Maria do Socorro Pimentel da Silva esteve à frente da criação do curso de Educação Intercultural. Devido à sua extensa experiência como docente na educação escolar indígena, Maria do Socorro pôde, há 12 anos, conceber, juntamente de representantes indígenas e docentes da UFG, um projeto pedagógico inovador, no sentido de não somente se preocupar com a formação de professores, mas, sobretudo, de se lançar na aventura de compor uma nova base epistêmica para as escolas indígenas e para a própria universidade.

Maria do Socorro Pimentel da Silva é pedagoga, mestra em Letras e Linguística pela UFG e doutora em Linguística Aplicada ao Ensino de Línguas pela Pontifícia Universidade Católica de São Paulo (PUC-SP). Tanto no mestrado quanto no doutorado realizou pesquisas junto ao povo Karajá. Fez seu estágio de pós-doutorado na Unicamp e, em fevereiro de 2019, tornou-se professora titular da Faculdade de Letras da UFG. Com o projeto Maurehi, na aldeia Buridina do povo Karajá (GO), foi uma das pioneiras nos estudos e nas pesquisas de revitalização linguístico-cultural no Brasil ${ }^{3}$. Também demonstrou postura visionária ao criar a Revista Articulando e Construindo Saberes ${ }^{4}$, cujo escopo é a publicação de pesquisas relacionadas à decolonização de saberes e às práticas pedagógicas pluriepistêmicas e interculturais.

Entrevistadora: Professora, conte-nos um pouco sobre como, durante sua juventude, morar numa aldeia Karajá influenciou o trabalho que exerce hoje como docente no curso de Educação Intercultural.

Profa. Maria do Socorro: Se eu não tivesse passado por essa primeira experiência de ser professora numa escola indígena, acho que eu não teria condições e nem capacidade para refletir e pensar, por exemplo, num curso de educação intercultural.

3 Parte do Projeto Maurehi está documentada em PIMENTEL DA SILVA, Maria do Socorro. Reflexões sociolinguísticas - sobre línguas indígenas ameaçadas. Goiânia: Editora da UCG, 2009.

4 Disponível em: https://www.revistas.ufg.br/racs. 
Vou retomar um pouco a minha chegada à aldeia Karajá. A primeira aldeia Karajá em que morei foi a aldeia Fontoura, na Ilha do Bananal, TO. Eu me lembro até hoje do dia em que eu cheguei a essa aldeia. Algo que me marcou muito. Um avião bimotor pousou, a comunidade inteira estava no campo de pouso e eu me encontrei com pessoas alegres, felizes e animadas. E eu assustada. Foi muito difícil para mim, primeiramente, porque não sabia falar nada em Karajá. Nunca havia escutado essa língua. Na realidade, eu nem sabia que existiam línguas indígenas. Depois de uns quatro meses, eu pedi para voltar para perto da minha família e sair da aldeia. Não por conta dos indígenas, mas eu não conseguia me conectar àquele local. E, nessa ocasião, um professor Karajá, que na época ainda era chamado de monitor bilíngue, percebendo a minha aflição, ofereceu-se para me ensinar sua língua. Eu aceitei e ele me ensinou na fala masculina. O Karajá é uma língua que tem diferenças morfológicas/fonológicas entre a fala de homens e mulheres. Daí a primeira vez que eu fui para aldeia conversar, a comunidade inteira ficou rindo de mim, e isso me deixou desesperada. Fiquei muito triste.

Ao retornar para a cidade e morar perto da minha família, algo aconteceu comigo, dentro de mim. Hoje, interpreto que foi algo como um ritual de iniciação, de entrada na sociedade Karajá. Na época, eu não sabia o que estava acontecendo. Hoje, recordando, eu sei que foi exatamente isso que aconteceu. Eu passei por um processo ritual, porque fui eu quem desejou voltar e trabalhar na aldeia. Voltei para a aldeia Itxalá, onde morei e fui professora por muitos anos. Nessa aldeia, aprendi a ser professora, aprendi a dar aulas, a pesquisar sem saber que estava pesquisando, a construir material didático sem saber que estava fazendo. Convivi com as mulheres que me aceitaram no seu grupo e passei a ter companheiras que me ensinavam muito. Por exemplo, eu ia com elas coletar frutas e aprendia o nome das frutas, em Karajá, na experiência de coletar frutas. Eu contei muito com o apoio dessas mulheres que não sabiam nem ler, nem escrever, mas que foram, elas, as minhas professoras, na minha formação de ser professora.

Houve também uma liderança, um sábio indígena, que participava, inclusive, de reuniões em Brasília, que me ensinou muito. Eu estava estudando a língua a partir de uma cartilha produzida por missionários do Summer Institute of Linguistics (SIL). Quando li alguns trechos da cartilha, ele me falou que aquela não era a língua dele, "Essa não é a minha língua. Você já ouviu alguém falando assim aqui na aldeia?". E disse que, se eu quisesse aprender a língua, deveria ir 
todos os dias em sua casa, sentar na esteira, comer peixe, tartaruga, que, assim, eu aprenderia.

O que eu aprendi na convivência com essa família, além de questões linguísticas e culturais, foi como esse povo pensa, como os Karajá pensam o mundo, interagem com sua família, com a comunidade. Aprendi com eles o que eu chamo de pedagogia da cordialidade, o que um tem, todos têm. Com eles, eu aprendi muita coisa. A dar aulas, como compartilhar, como viver na amizade. Também aprendi a conviver no conflito, porque presenciei situações de muitos conflitos internos, o que me deixou muito triste.

Algo de muito precioso da minha experiência na aldeia Itxalá foi a minha formação como professora numa situação em que as crianças falavam uma língua e eu outra. Essa é uma experiência inesquecível.

E como eu atuava nessa situação? Tudo que eu aprendia com as mulheres fora da escola eu levava para a escola. Então, uma simples palavra na língua Inỹ se tornava muitas outras palavras. As crianças colaboravam no "esticamento" daquela palavra, porque aquela palavra era muito mais do que uma palavra. Era um tema. E esse tema estava ligado com outros temas da vida daquelas crianças. Então, desde essa época, eu aprendi o que é trabalhar uma pedagogia da contextualização, aprendi a escutar o que o outro sabe e o que é aprender nesse processo de escuta. Dificilmente você ensina alguém se você não aprender com ele também.

A experiência que eu tive com os Karajá não foi uma experiência acadêmica. A experiência acadêmica é muito interessante, mas ela não te ensina a como voltar para o mundo do outro. Na universidade, você se dedica muito a um projeto seu, a uma formação sua, do indivíduo. Numa comunidade indígena, o projeto não é seu. Ele é coletivo, da comunidade.

Entrevistadora: A senhora fala de pedagogia da contextualização quando ensinava as crianças a partir de palavras-tema, num contexto sociolinguístico em que a língua das crianças não era compartilhada pela professora. Os temas contextuais que organizam e estruturam a matriz curricular do projeto pedagógico do curso de Educação Intercultural da UFG têm sua origem aí? Parece haver uma relação entre ambos... 
Profa. Maria do Socorro: De fato, há uma relação. Eu aprendi na escola que eu não sabia falar a língua, não tinha material. Também percebi que tudo naquela comunidade era vivido, tudo era na interação, na troca. Fui percebendo essa pedagogia, que, agora, estamos chamando de contextualização... A palavra que eu aprendia com as mulheres eu levava para a escola, e essa palavra se conectava com muitas outras palavras, o que me dava um texto oral. Eu começava com a palavra em Karajá, mas eu também esticava para a língua portuguesa. Aliás, foi assim que eu trabalhei a língua portuguesa com eles, sempre partindo da língua Karajá. Não que eu tivesse uma concepção definida de ensino, mas era o que eu conseguia fazer naquele momento. Eu aprendi muito com essa experiência e os alunos da escola também. Aprendemos juntos.

Outra experiência aliada a essa foi o Projeto Maurehi, na aldeia Buridina. Um projeto de reconstrução de espaços culturais e epistêmicos.

Essas duas bases de conhecimento foram fundamentais para eu pensar nos temas contextuais, porque o tema contextual favorece o protagonismo de todos os que estão presentes ali no momento do ensino-aprendizagem, uma vez que evidencia o processo de troca da aprendizagem. Foi assim com as palavras na aldeia Itxalá, quando eu sabia um pouquinho da língua e da cultura Karajá, quando meu papel não era ensinar a língua Karajá, e sim a língua portuguesa, eu começava sempre de uma realidade contextual. E deu certo. O tema contextual, além de favorecer o movimento emancipador de retomada dos saberes indígenas, de conectar a escola, ou a universidade, com os modos e espaços de produção do conhecimento indígena, favorece a articulação entre conhecimentos, sem desprezar o conhecimento indígena.

O tema contextual pode ser intracultural, focado somente no conhecimento indígena, mas ele pode ser alongado, como eu fazia com as palavras em Karajá que nomeavam frutas e eu as esticava para temas da língua portuguesa, para ensinar português.

O mesmo acontece com os temas contextuais do curso de Educação Intercultural. É possível começar com um tema intracultural, em língua materna, e articular esse tema com outros conhecimentos. Do mesmo modo, pode-se trabalhar um tema contextual somente na língua portuguesa, ou de forma bilíngue, que nós chamamos, no Núcleo, de bilinguismo intercultural. Ou, ainda, inicia-se 
um tema contextual em português e se o articula com os conhecimentos indígenas. Então, há liberdade de composição e articulação que não existe no trabalho pedagógico estruturado a partir das disciplinas. A minha experiência pedagógica se deu e se dá muito mais pela contextualização do conhecimento do que pelas disciplinas. Eu nunca fui professora da educação básica para não indígenas, eu sempre trabalhei com povos indígenas. Por exemplo, um grande desejo deles era aprender matemática, principalmente dos adultos. Quando a gente pensa em alfabetização, a gente pensa em textos, jogos... a minha experiência com alfabetização foi por meio da matemática. Os pescadores Karajá vendiam os pirarucus que pescavam e eram explorados nesse processo, então vieram me procurar dizendo que queriam ser alfabetizados. E disseram que queriam aprender troco, lucros, exploração, contas. Mais uma vez, um conjunto de palavras ia construindo um projeto de alfabetização para atender à demanda dos pescadores de pirarucu.

Acredito que o trabalho com temas contextuais remonta toda essa experiência, mas, mais do que isso, cabe perceber que o outro também é parte desse processo pedagógico. O projeto pedagógico não é meu, é de quem o solicita.

Entrevistadora: Sabemos que desde a educação jesuítica - a primeira experiência de escola colonizadora para indígenas - as línguas indígenas são tratadas apenas como línguas de transição para a língua portuguesa. Missões religiosas e propostas do próprio Estado efetivaram o que chamamos de bilinguismo de transição, que é o uso da língua indígena para a alfabetização e o acesso à escrita, para, logo depois, o ensino ser em língua portuguesa. Como a senhora vê saídas para que a escolarização possa ser parte de uma política linguística ampliada de valorização e fortalecimento das línguas indígenas, em suas modalidades oral e escrita, e não uma armadilha para deslocar e diminuir os espaços de uso dessas línguas?

Profa. Maria do Socorro: Bom, vou começar a responder de um modo mais geral. Todos nós sabemos que a globalização dos valores econômicos, sociais e culturais impulsionada pelo desenvolvimento tecnológico oprime as línguas indígenas. Em decorrência dessa realidade e da ameaça de extinção das línguas indígenas, o curso de Educação Intercultural da UFG tem buscado construir bases epistêmicas que apontam para diretrizes inovadoras no campo de educação intercultural de valorização das línguas indígenas. Vou citar quatro referências de 
políticas linguísticas fortes para o processo de formação de professores no curso de Educação Intercultural da UFG: Temas Contextuais, Estudos Complementares, Projetos Extraescolares e Estágios.

Antes de eu falar especificamente a respeito da relação entre política linguística e esses quatro componentes, nós precisamos retomar a discussão de valorização das línguas indígenas com o compromisso de enfrentarmos muitos desafios, pois essa é uma questão que diz respeito à Educação, ou seja, vai muito além das Ciências da Linguagem. É uma questão de política de valorização das línguas indígenas, dos saberes indígenas e de respeito aos povos indígenas. Sendo assim, quero trazer uma reflexão, sobre a qual eu já escrevi e continuo pensando muito sobre isso.

Nossa visão disciplinar vertical dificulta contextualizar as realidades necessárias para o debate. Todos nós sabemos que, na realidade, todos os cursos de formação de professores conhecem muito pouco das línguas indígenas brasileiras. Conhecem menos ainda a situação em que essas línguas se encontram contemporaneamente, a situação entre as gerações, os locais onde as línguas são faladas, quais saberes elas guardam, quais espaços linguísticos são apagados, desatualizados, extintos. Quais são os usos mais especializados dessas línguas, como elas são usadas na vida cotidiana, entre as gerações, nas famílias. Quais saberes existem e quais foram extintos. Essas são reflexões importantes para entendermos a importância de uma política linguística forte a ser colocada em prática nos Temas Contextuais, nos Projetos Extraescolares, nos Estágios e nos Estudos Complementares. Por isso nós precisamos ter um estudo aprofundado do que, para mim, é muito mais do que uma situação sociolinguística, uma vez que nós conhecemos também pouco das ciências indígenas. Por falta do conhecimento das ciências indígenas, elas são apelidadas a partir da perspectiva das ciências científicas, algo a que sou totalmente contrária. Isso acontece em todos os lugares e também no curso de Educação Intercultural da UFG, infelizmente. Esses são pontos importantes para, de fato, firmarmos o compromisso de elaboração e desenvolvimento de políticas linguísticas fortes no espaço do curso e também em outros espaços, como, por exemplo, a escola.

Dito isso, vamos retomar os quatro pilares do curso. O Tema Contextual, como eu sempre falei, é uma composição, uma articulação de conhecimentos e um contexto de problematizações. Ele é que reivindica as línguas que serão usadas. 
Depende se o tema será intracultural, o qual se articula dentro do universo de cada povo indígena, principalmente dos conhecimentos do campo do sagrado e dos saberes especializados. No entanto, ao mesmo tempo, muitos conhecimentos que são primeiramente reconhecidos como pertencentes ao campo dos saberes especializados, ao se esticarem, se articulam com os conhecimentos ocidentais e, aí, nós passamos a ter os temas interculturais. Esses conhecimentos podem ser trabalhados nas línguas indígenas, de modo bilíngue ou, até mesmo, somente na língua portuguesa. A educação é bilíngue, então, poderá haver vários movimentos, e esses movimentos romperão exatamente com aquilo que você me perguntou. Esses movimentos rompem com o império do monolinguismo, que foi chamado, por volta dos anos 1970, como bilinguismo de transição, mas que nada mais é do que uma ponte para o monolinguismo. Uma ponte para a introdução da escrita, para romper barreiras linguísticas a serviço do monolinguismo.

Outra política linguística forte que rompe com o assimilacionismo são os Estudos Complementares. Sem me alongar muito, quero falar do estudo complementar Português Intercultural, que, como o próprio nome já diz, coloca o português em relação a outros contextos de vivências. Em relação às línguas indígenas, a novos contextos de demandas e de articulações. É um português intercultural, e não um português indígena, como é o caso de muitas outras abordagens para o português que temos visto no Brasil. É um português de atendimento de demandas ou, como disse uma vez um estudante Kanela, um português da precisão. Por isso o Português Intercultural está sempre relacionado às demandas do sujeito bilíngue. O que também é uma política linguística, uma vez que as línguas indígenas estão nessa composição.

Já os estudos complementares de Línguas Indígenas são estudos de línguas indígenas, e não de teoria linguística. É claro que a linguística é importantíssima, mas nesses estudos complementares nós contextualizamos a comunicação entre as gerações, os espaços sagrados, os segredos, o cotidiano, as falas mais especializadas. Há uma política de valorização das línguas indígenas, a partir da valorização da oralidade dos saberes tradicionais e, sobretudo, da valorização do papel dos sábios e sábias, dos anciãos e anciãs, dos artesãos e artesãs nesse processo de conhecimento semântico, contextual, cosmológico da língua. Tudo isso precisa ser apropriado pelos estudos em Línguas Indígenas, superando uma 
tendência colonialista e eurocêntrica que exclui as línguas indígenas quando se trata de línguas de conhecimento.

O Projeto Extraescolar é uma política linguística muito forte de retomada de conhecimentos, mas também de criação de outras epistemologias. Quando um estudante está pesquisando com os mais velhos, documentando aquele conhecimento através da escrita ou da oralidade, está ocorrendo não somente um processo de reflexão sobre o conhecimento, mas a própria produção de conhecimentos outros que não são mais conhecimentos tradicionais indígenas, mas que são conhecimentos os quais estou chamando de epistemologias interculturais, ou de coteorização, pois criam novos referenciais. Por exemplo, a retomada de saberes surge nesse contexto. A retomada de saberes ancestrais, a qual traz consigo a retomada de outras lutas, ocorre por meio das línguas indígenas também, pois língua e conhecimento fazem parte de um mesmo corpo cultural. Toda essa orientação aponta para uma necessidade de aportes coteóricos e metodológicos de visibilidade das epistemologias indígenas e das pedagogias de articulações epistêmicas. Somente os espaços tradicionais, hoje, ainda que sejam uma parte muito importante, não são suficientes. Há necessidade de outras criações dentro das relações interculturais, ou, como os indígenas explicam, da atualização.

Há políticas linguísticas indígenas fortes muito importantes, desde a criação de palavras para nomear novas realidades até o estudo das diferenças entre fala masculina e fala feminina, porque tudo isso dá um grande referencial teórico, e coteórico, para a implantação de políticas linguísticas e, também, para a produção de materiais didáticos.

As pesquisas por meio dos Projetos Extraescolares, ou por meio de outros projetos, estão trazendo respostas muito importantes para a adoção de políticas linguísticas, ou dentro do contexto da escolarização, ou para a escola adotar políticas linguísticas de articulação entre os espaços epistêmicos, sejam os tradicionais ou não, entre escola e comunidade.

Outro referencial de política linguística forte da Educação Intercultural é o Estágio, porque, nos estágios, o bilinguismo adotado é muito diferente do bilinguismo de transição. Os estágios possibilitam o bilinguismo da pluralidade. Nós podemos chamá-lo de bilinguismo epistêmico, porque ultrapassa a prática de pensar nas línguas desvinculadas dos conhecimentos, afinal, as línguas são línguas 
de conhecimentos e estão na produção dos conhecimentos, se articulando com a língua portuguesa e com as diferentes ciências. O estágio está criando uma proposta de educação bilíngue e interepistêmica, conjuntamente com todos os outros referenciais sobre os quais eu falei. Eu sou da opinião de que há espaço dentro desse contexto para as línguas indígenas, não somente dentro do bilinguismo, mas há um espaço próprio. Eu quero considerar que as línguas indígenas são línguas ameaçadas, ninguém tem dúvidas disso, então eu sempre estou pensando na criação de outros espaços específicos para as línguas indígenas, tais como projetos de extensão das escolas, com outras demandas de valorização, como, por exemplo, jogos pedagógicos, que estão sendo elaborados pelos Karajá e por outros povos, para as crianças frequentarem essas línguas e acessarem os conhecimentos que estão apagados. Os indígenas estão criando possibilidades para as crianças acessarem a linguagem especializada. Eu considero tudo isso muito importante, porque a língua tem outras dimensões para além da dimensão linguística. As línguas indígenas também passam por momentos de discussão da escrita. Essa discussão também pode ser vista de modo intercultural.

Eu coordeno o projeto "Práticas decoloniais de letramentos em línguas indígenas" e tenho observado diversas funções e razões das línguas indígenas no processo de decolonização, por exemplo, os Projetos Extraescolares. É comum ouvirmos de nossos estudantes afirmações como "eu não conhecia esse fato do meu povo" ou "eu não sabia que essa regra existia". A ideia de criar contextos para a criança acessar e aprender conhecimentos, como, por exemplo, nomes de frutas, que as crianças só sabem em português. É muito importante problematizarmos essa situação, pois é admissível que usem o português para nomear as frutas, mas que essa prática não mate o nomear na língua materna. A escrita está ajudando a movimentar a oralidade, a relembrar conhecimentos. Uma vez eu distribuí um livro de histórias Karajá em Buridina. Como pesquisadora e curiosa, eu voltei à aldeia no final do dia e, para minha surpresa, as pessoas estavam lendo o livro, relembrando as histórias, relembrando de seus avós. Eu também vejo a escrita em língua indígena na produção de textos coteóricos, como podemos encontrar na Revista Articulando e Construindo Saberes. Há textos de conhecimentos tradicionais e há um texto sobre fonologia escrito em língua Iny/Karajá. 
Entrevistadora: Professora, os temas contextuais, pelo que entendi, fazem parte de uma proposta maior do curso que consiste em não operar com a noção de disciplina. Inclusive, os temas contextuais são a metodologia utilizada para o desenvolvimento dos estágios realizados pelos estudantes durante o curso. Os temas contextuais podem ser realizados tanto na língua indígena como no português, como nas duas. Ele traz para a sala de aula os conhecimentos e saberes indígenas. Além dos temas contextuais, quais outras características do curso de Educação Intercultural são relevantes para compor uma matriz de conhecimentos indígenas?

Profa. Maria do Socorro: Quando você fala de conhecimentos indígenas, você está falando de conhecimentos ancestrais e tradicionais ou não?

Entrevistadora: Estou me referindo ao que parte do corpo docente do curso de Educação Intercultural tem chamado de novas bases epistêmicas.

Profa. Maria do Socorro: Eu penso que são várias características, mas o curso tem uma composição que favorece sempre a articulação, sempre o movimento. E o curso tem duas ações que eu coloco sempre em destaque. O Tema Contextual, sobre o qual nós terminamos de falar, e o Projeto Extraescolar. O Projeto Extraescolar nasceu desse desejo mesmo de reconhecer que as línguas indígenas estão ameaçadas de extinção, de entender, como linguista, que as línguas indígenas, como qualquer outra língua, são muito importantes para seu povo, não somente para a educação das gerações ou para a comunicação familiar, mas para outras conexões que são fundamentais para a manutenção do ser. Como cantar um hetohokỹ em língua portuguesa? Não tem como! Como chorar, fazer um canto de lamento pela morte de alguém em língua portuguesa? Não tem como fazer em língua portuguesa. Conhecendo essas características, que não são pertinentes somente aos indígenas, mas são eles o nosso assunto, como colocar num curso de educação intercultural dentro de uma universidade alguma ação, alguma composição curricular que pudesse transitar por esses lugares que eu acabei de falar? Um dia, um indígena me disse assim: "Se eu perder a minha língua, como eu vou me comunicar com minha ancestralidade? Quando eu morrer, como eu vou encontrar os meus?". Essas são reflexões profundas que, muitas vezes, a Linguística não traz, mas os indígenas trazem.

O projeto extraescolar é a ação de o próprio indígena pesquisar o conhecimento do seu povo. E nós temos percebido, durante esses doze anos de curso, que 
uma característica fundamental do projeto extraescolar é a retomada dos saberes ancestrais. A reconstrução de muitos espaços epistêmicos que foram apagados, destruídos, silenciados. O avivamento desses espaços culturais não acontece sem as línguas. E se o indígena falasse sua língua somente em espaços cotidianos, ele perderia a conexão com a ancestralidade, a espiritualidade. Como diz Manajè Karajá, o mundo tem várias camadas, porque tem essa camada mais próxima, que é a camada do cotidiano, mas tem outras camadas, como, por exemplo, quando um indígena chega perto de uma árvore e pede licença ao ente muito sabido da espiritualidade que acompanha essa árvore, para tirar a casca ou a folha para virar remédio. Nós temos aprendido com os indígenas que o remédio não é somente aquela folha ou aquela casca. O remédio tem a ver com alguma coisa que a gente não vê na folha, mas é uma substância que está lá.

O projeto extraescolar tem como um de seus objetivos o de formar o professor junto a sua comunidade e também de trazer para a universidade esses conhecimentos, estabelecendo uma relação de diálogo entre a universidade e os espaços culturais ou epistêmicos. As comunidades ganhariam, como também a universidade, porque um canal muito interessante entre saberes foi aberto. Durante esses doze anos, nós percebemos muitos indígenas dizendo "Eu não sabia que minha comunidade tinha tanto conhecimento", "Eu não aprendi isso quando eu era jovem".

Uma vez, um aluno Karajá pegou um livro que foi publicado por nós, leu uma história e me pediu aquele livro. É um livro escrito em Karajá, nas falas masculina e feminina, e em português. Ele leu aquela história para sua avó, na aldeia, e sua avó começou a lembrar daquela história e a contá-la. Então, o projeto extraescolar também é isso: relembrar conhecimento, estabelecer conexões. O rapaz nos disse que sua avó não havia Ihe contado histórias porque não era o tempo que a avó contava histórias e que iria fazer a experiência de contar para seus filhos. E contou para seus filhos, lendo o livro, e as crianças dormiram muito felizes.

O Projeto Extraescolar não chama assim por acaso. Ele é muito mais do que uma etapa da formação do professor. Ele é uma retomada do processo de formação do ser indígena. E há outra coisa muito importante. Quando esses indígenas aprendem esses saberes, eles formam os mais jovens, criando uma outra geopolítica para seus conhecimentos. Eles vão se formando cada vez mais. 
E o indígena, ao fazer o extraescolar, se coloca como protagonista da nossa formação, dos professores não indígenas, havendo um desmanche dos papéis de formadores. Todos nós somos formados e formadores ao mesmo tempo. Além disso, saem ideias fantásticas dos projetos extraescolares, que irão compor uma base epistêmica que vai muito mais além da leitura dos autores decoloniais. São reflexões que criam propostas para uma educação específica e diferenciada, que foi desejada, e não apenas legitimada por uma lei. São os indígenas que estão desejando, que estão compreendendo, na profundidade, a importância que isso tem. É muito bonito.

Para finalizar, uma das características mais importantes desse curso são as bases epistêmicas que os indígenas e nós, não indígenas, estamos construindo. É isso o que eu tenho chamado de coteorização. Além da certeza de que eles podem construir uma escola para atender às suas demandas, que não são apenas demandas de retomada de saberes ancestrais, mas são a retomada do convívio com a sociedade não indígena de maneira mais segura, sem se sentirem inferiorizados, mas sim diferentes e participantes do debate.

Entrevistadora: Não poderíamos deixar de conversar também sobre a política de egressos do curso de Educação Intercultural. Como os docentes têm conseguido acompanhar a trajetória dos egressos do curso?

Profa. Maria do Socorro: Por força das circunstâncias, o curso adotava e ainda adota uma política de egressos muito interessante. Por exemplo, convidar egressos para dar aulas de estudos complementares de Línguas Indígenas ou mesmo de temas contextuais é uma oportunidade para que eles possam contar suas experiências para os atuais estudantes do curso. Contar toda a história de como eles foram aprendendo, refletindo e construindo a sua maneira de discutir educação intercultural é muito interessante. Outro aspecto muito interessante é a participação deles em congressos. Professores têm levado estudantes egressos para participarem de congressos em outros estados para conviverem com outros pesquisadores e participarem do debate, compartilhando suas experiências. Outro componente da política de egressos é a produção de material didático, que acontece também por meio de outros projetos, como o Pibid. Essa política de egressos acontece também na própria aldeia quando eles estão compartilhando, 
entre eles, suas pesquisas. Por exemplo, como produzir um livro para alfabetização. Entre os Karajá, eles acharam bom produzir um livro de alfabetização tendo como eixo a ecologia. Segundo eles, as crianças estão se distanciando de muitos conhecimentos ligados à natureza e, diante dessa observação, resolveram produzir um material didático que retomasse esse conhecimento por meio de suas próprias pesquisas.

Um ponto que considero fazer parte da política de egressos é o apoio desses ex-alunos do curso no movimento indígena, nas discussões em defesa aos direitos indígenas e à educação escolar indígena. Eles(as) estão envolvidos(as) na luta e na defesa por uma educação escolar indígena intercultural, específica e diferenciada.

E algo muito bacana é o desejo dos egressos em continuarem seus estudos. O curso de Especialização Educação Intercultural e Transdisciplinar: gestão pedagógica é fruto desse desejo. Os formandos das primeiras turmas, de 2007 e 2008, ao concluírem o curso, solicitaram uma especialização, porque eles queriam continuar discutindo os projetos político-pedagógicos de suas escolas, uma vez que a maioria das escolas desses professores nunca teve um projeto político-pedagógico próprio. Os Estágios permitem aos nossos estudantes a experiência da construção de uma base epistêmica que pode ser utilizada na construção do projeto político-pedagógico das escolas de suas aldeias. Agora, o desdobramento desse desejo de continuar os estudos está sendo a criação do Mestrado em Educação Intercultural.

Entrevistadora: Para encerrar nossa entrevista, eu gostaria que a senhora falasse um pouco sobre como tem sido a experiência de coteorização com professores indígenas dentro do Núcleo Takinahakỹ de Formação Superior Indígena, uma vez que essa é uma questão que tem se tornado cada vez mais relevante tanto para o debate decolonial quanto para a insurgência de novas epistemologias.

Profa. Maria do Socorro: Eu não sei se posso, de fato, responder por todo o Núcleo, mas vou falar sobre minha experiência de coteorização com os professores indígenas do Núcleo. Para isso, vou retornar à primeira turma de 2007. Essa era uma turma de 50 estudantes, todos muito críticos e problematizadores, que desafiaram todos nós na construção de uma educação intercultural. Os estudantes eram de sete povos diferentes e os docentes não indígenas eram de diversas áreas, 
e quase nenhum possuía experiência com educação escolar indígena. Durante uma reunião, em que todos os estudantes e docentes estavam, e na qual discutíamos os princípios de interculturalidade e decolonização, um estudante Karajá levantou e disse que, da forma como o curso estava sendo organizado, nós, os docentes, seríamos os novos colonizadores. No entendimento desse estudante, o curso estava sendo concebido como uma imposição, porque era um curso muito diferente de todos os outros cursos de graduação. Essa fala foi um murro no meu coração, porque nós havíamos passado dois anos discutindo o projeto do curso com as comunidades indígenas, a fim de achar caminhos possíveis para a interculturalidade e a decolonialidade. O fato de ter vindo de um estudante Karajá me impactou ainda mais. No entanto eu pensei que ele estava muito certo do que estava dizendo e propus que os professores não indígenas saíssem da sala e os estudantes discutissem, ou coletivamente ou cada um com seu povo, o que gostariam de sugerir a nós. Primeiramente, eles se organizaram por povos, depois coletivamente e, então, nos chamaram e disseram que iriam esperar mais um pouco, para terem tempo de conhecer o curso. E, de fato, eles se animaram com o curso, sobretudo com a matriz específica, quando tiveram a oportunidade de entender a nossa proposta. E, durante os primeiros dois anos da matriz básica, nós fomos construindo coletivamente os caminhos do curso.

Também durante a conferência de abertura de um congresso em Cochabamba, ouvi o ministro da Educação, um Aymara, dizer que, para fazermos educação intercultural, primeiramente é preciso conhecermos a colonialidade do saber.

Fiz esses relatos para eu poder explicar melhor o que nos fez pensar em coteorização, como desafios e caminhos possíveis. Uma pergunta que sempre me faço, e que me proporciona uma reflexão sobre coteorização, é como fazer educação intercultural tendo apenas a base de conhecimento ocidental? Quando um curso é disciplinar, com organização predominantemente ocidental, não temos uma educação intercultural, e sim uma educação colonizadora. A pergunta principal que eu me faço é: o que de fato é uma educação intercultural?

Atualmente, muitas universidades contam com programas de ações afirmativas para a inclusão de indígenas, quilombolas e outros segmentos da sociedade que sempre foram mantidos à margem. No entanto eu percebo que são programas de inclusão que acabam por excluir, uma vez que têm como base uma organização 
curricular e política que, de fato, não inclui os indígenas. Não é tão difícil oferecer vagas extras ou por cotas, mas o desafio maior não é esse. O desafio maior é construir currículos que dialoguem com os saberes de indígenas, quilombolas, pescadores e todos os outros. A educação intercultural tem por obrigação não adotar um sistema de inclusão para a exclusão. A educação intercultural deve ser um sistema decolonial, coteórico, de diálogo, de composição e parceria.

Eu entendo a coteorização como um modo muito especial de pensar a educação, de pensar a construção de conhecimentos de forma articulada. No curso de Educação Intercultural do Núcleo Takinahakỹ, a coteorização ocorre a partir dos Projetos Extraescolares, das Ações Saberes Indígenas e dos Estágios. Esses são os três contextos possíveis para a coteorização. Nos Projetos Extraescolares, o primeiro plano de articulação dos saberes é a decolonialidade. Quando os saberes de cada povo são articulados para a retomada de espaços epistêmicos, para a retomada de saberes ancestrais, recriam-se novos saberes. O segundo plano dos Projetos Extraescolares é a articulação intercultural. Tanto no plano da articulação intercultural quanto intracultural surgem novos saberes, coteóricos, porque os saberes já não estão mais em seu campo milenar, esses saberes são fruto de uma reflexão a respeito de como eles podem integrar e contribuir com práticas pedagógicas, na composição das matrizes curriculares, no modo de construir um projeto político-pedagógico. Nós falamos tanto de processos próprios de conhecimento, mas devemos nos perguntar como esses processos vão para a escola. Esses saberes vão para a escola no modo como os indígenas pensam e constroem pedagogias e metodologias de acordo com suas experiências interculturais. Nesse momento, começa a haver a coteorização. O Projeto Extraescolar, além da retomada de saberes, o que por si só já é um processo decolonial, favorece a articulação intercultural no campo pedagógico.

O esforço da coteorização na formação de professores indígenas é bem diferente do esforço da coteorização colocado pelos autores decoloniais. A decolonização é sentida no corpo, na vida, na história e no fazer do presente. A retomada de saberes vem acompanhada das lembranças da colonização, mas também da alegria da atualização cultural. Os Karajá de Itxalá não faziam há mais de 40 anos o hetohokỹ, um dos seus principais rituais. Em 2019, eles conseguiram fazer o hetohokỹ por meio das pesquisas dos seus Projetos Extraescolares. 
O Estágio é outro contexto de coteorização. Quando, por exemplo, ao relatar seu estágio, um indígena me diz que primeiro fez sua aula prática, eu entendo que a aula prática sempre ocorre no campo do concreto, do fazer, da interação. Todos participam. Uns colocando aquele fazer à disposição de todos os aprendizes, e os aprendizes experimentando. Esse saber da aula prática é tecido pela oralidade e também pela observação, pela matéria-prima disponível, pelo evento cultural. Depois do processo da aula prática, é que vai acontecer a aula teórica, que é a aula da sala de aula, da escrita. A escrita não é o barro que eu manuseio para produzir conhecimento, ela está mais para o campo do abstrato.

A Ação Saberes Indígenas na Escola é um outro componente importante para a coteorização. Nela, as atividades são sempre desenvolvidas nas aldeias, e não nas universidades, e os pesquisadores indígenas têm outra temporalidade para organização de seus saberes.

A coteorização, no meu entendimento, não é uma teoria composta somente pelo Ocidente. É uma teoria composta por conhecimentos produzidos em outros modos. Como os próprios indígenas dizem, esses outros modos de conhecimento também se atualizam. Todos esses ingredientes, como a atualização cultural, a aula prática, a aula teórica, fazem parte de um campo coteórico. Eu a entendo de várias formas, tanto para a intraculturalidade quanto como uma contribuição para a vivência intercultural, que extrapola a questão indígena. É a descoberta de outros fazeres, de outros sentidos de fazer a educação. Qualquer conhecimento, com exceção do segredo e do sagrado, pode vir para a escola, porque não é uma escola ocidental. É uma escola que tem por base a coteorização, que é um outro jeito de fazer, que, por sua vez, tem por base a educação intercultural, que vai possibilitar a criação de novas práticas pedagógicas.

Para finalizar, gostaria de dizer que, desde o início do curso, os docentes estão construindo com os estudantes bases de articulação interepistêmicas, a partir de referenciais inauguradores, tais como pedagogia da retomada, prolongar conhecimentos, articular saberes, relembrar saberes, frequentar a língua materna, atualização cultural, bilinguismo epistêmico, documentação de saberes pelo fazer cultural, juntar conhecimento, descobrir conhecimento. Todos esses conceitos surgiram na articulação dos conhecimentos produzidos nos Projetos Extraescolares, nos Estágios, na Ação Saberes Indígenas na Escola e até mesmo 
na sala de aula. Todos esses conceitos dialogam com a Pedagogia do Oprimido, da indignação, da libertação de Paulo Freire; com a Desobediência Epistêmica de Catherine Walsh e Walter Mignolo; com a Ecologia de Saberes, de Boaventura Sousa Santos, demonstrando que a coteorização é um processo contínuo e que o importante disso é que todos se sentirão autores e protagonistas de seu processo de formação e da sua docência.

As matrizes curriculares dos projetos político-pedagógicos já produzidos e dos que estão em produção devem se iluminar por essas orientações epistêmicas. Todas elas se situam no mesmo construto de inspiração e de comprometimento com as lutas indígenas e, consequentemente, com as lutas anticoloniais. A coteorização é uma luta anticolonial, por isso ela é emergente e necessária. Ela é um movimento contínuo e que atende às demandas da decolonização dos saberes indígenas, das escolas indígenas e da criação de novos conhecimentos na educação intercultural.

\section{Sobre a autora:}

Lilian Abram dos Santos: Mestre em Linguística. Doutora em Linguística Aplicada. Docente da área de Linguagens do Núcleo Takinahakỹ de Formação Superior Indígena, da Universidade Federal de Goiás (UFG). E-mail: Iiliabram@gmail.com, Orcid: http://orcid.org/0000-0001-8444-9283

Recebido em 27 de fevereiro de 2020.

Aprovado para publicação em 9 de junho de 2020. 


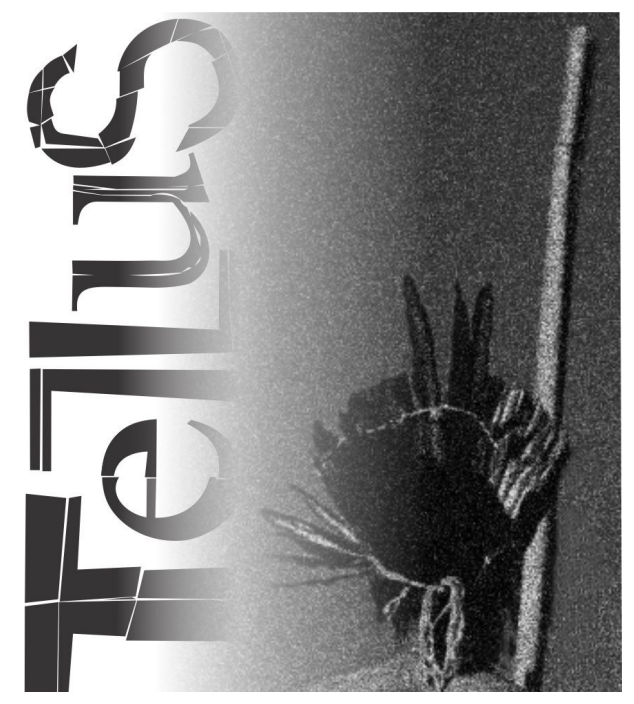

\section{escritos indígenas}




\title{
Uma breve história de retomada: a comunidade Lago da Praia e conflitos territoriais
}

\author{
A brief history of retaking: the Lago da Praia community \\ and territorial conflicts
}

Eriki Aleixo de Melo ${ }^{1}$

DOI: http://dx.doi.org/10.20435/tellus.v0i42.677

Ali era lugar de caçar, era lugar de pescar. Ali é lugar do nosso bisavô, pai, irmão, tio, era o papai; [...] quando papai morava por aqui, era lugar de caçar para lá. Tio Conrado. Todo mundo. No Lago da Praia. Pescar no Santa Rita até na beira do rio Uraricoera. Era lugar de pescar por ali. Joãozinho morava por ali onde era Caimbezal, caçava veado. Então por isso que foi para ganhar aquele pra isso, pra caçar, pra gente caçar. (Assis Aleixo Angelo - Wapichana).

Era uma coisa assim, parece que era um sonho [risos]. (Geovânia Angelo Aleixo - Wapichana).

E é muito impossível dizer assim voltar para lá, como naquela época, né, aquela época não volta mais. Se for, vem outros. Porque a gente não teve apoio, segurança dos governantes, eles falavam uma coisa, falavam outra coisa, mas não podiam fazer nada por nós porque eles estavam, eles eram contra nós. (Gercina Angelo da Silva - Wapichana).

Resumo: Em abril de 2004, deu-se o início da comunidade indígena Lago da Praia, a partir de mobilizações étnicas dos Wapichana e Macuxi da terra indígena Serra da Moça. Sua criação esteve amplamente relacionada ao contexto conflituoso local, no qual a relação entre indígenas, fazendeiros e demais agentes foi historicamente marcada pela violência e a usurpação de seus territórios. Nesse sentido, as tensões sociais foram se agravando no decorrer dos anos, principalmente devido à conjuntura política regional, relacionada à luta pela demarcação da terra indígena Raposa/Serra do Sol e as "condicionantes" impostas pelo Supremo Tribunal Federal. Em 2009, os indígenas passaram a vivenciar diversos eventos críticos e a ser coagidos para que saíssem da comunidade, ocasionando a expulsão dos indígenas de suas casas. Em 2010, o ministro do STF Gilmar Mendes fundamentou uma

1 Universidade Federal do Amazonas (Ufam), Manaus, Amazonas, Brasil. 
ação cautelar, favorecendo o Governo do Estado de Roraima e afirmando que a referida terra indígena não poderia ser ampliada. Este artigo trata desta retomada de terra, da construção da comunidade Lago da Praia e da expulsão dos Wapichana e Macuxi.

Palavras-chave: mobilização étnica; Lago da Praia; retomada; conflitos territoriais.

\begin{abstract}
In April 2004, the Lago da Praia indigenous community started, based on ethnic mobilizations of the Wapichana and Macuxi of the Serra da Moça indigenous land. Its creation was largely related to the local conflictual context, in which the relationship between indigenous people, farmers, and other agents has historically been marked by violence and the usurpation of their territories. In this sense, social tensions have worsened over the years, mainly due to the regional political situation, related to the struggle for the demarcation of the Raposa/Serra do Sol indigenous land and the "conditions" imposed by the Brazilian Supreme Court. In 2009, the indigenous people began to experience several critical events and to be coerced to leave the community, causing the expulsion of the indigenous people from their homes. In 2010, the Supreme Court Justice Gilmar Mendes founded a Cautionary Action, favoring the Government of the State of Roraima and affirming that the referred indigenous land could not be expanded. This article deals with this land retaking, the construction of the Lago da Praia community, and the expulsion of the Wapichana and Macuxi.
\end{abstract}

Keywords: ethnic mobilization; Lago da Praia; land retakings; territorial conflicts.

\title{
1 ISTO NÃO É UMA AUTOBIOGRAFIA - À GUISA DE INTRODUÇÃO
}

Eu gostaria de iniciar este escrito me apresentado brevemente, apenas para situar de onde e o que estou falando. Não é minha intenção construir um texto autobiográfico, mas contar uma parte da história do meu povo na luta pela terra que ocorreu entre os anos de 2004, quando se iniciou uma retomada, até o ano de 2009, quando os parentes indígenas foram expulsos de suas casas na comunidade Lago da Praia. E, devido a minha participação nesta retomada, parte destes escritos são fragmentos da minha turva memória. Turva porque naquela época, com 11 anos de idade, estava cursando a quarta série do ensino fundamental na Escola Estadual Indígena José Aleixo Ângelo e não existia nenhuma pretensão de refletir criticamente sobre essas vivências.

Através deste escrito, pretendo ir um pouco além do que Castro Faria definiu como depoimento, já que "o depoimento [...] permite que a pessoa que fala 
se transfigure em testemunha. Depõe sobre acontecimentos, oferece registros" (CASTRO FARIA, 1993, p. 228). Não é somente isso. Para além de testemunhar parte dos acontecimentos ocorridos durante a retomada, meu esforço para tratar dessas memórias tampouco seria possível se eu não estivesse me valendo também da memória dos parentes que vivenciaram comigo essa luta e que, na época, tinham mais idade do que eu e viveram com maior intensidade os conflitos que se passaram. Esses parentes aqui mencionados foram os que estiveram na linha de frente no processo da retomada. São as denominadas lideranças tradicionais das nossas comunidades.

Esclareço ainda que o que for mencionado ou apresentado, tais como datas, falas, croquis de mapas e publicações de cunho oficiais, são dados levantados a partir de extensa pesquisa de campo realizada no âmbito do Projeto Nova Cartografia Social da Amazônia (PNCSA), entre os anos de 2017 e 2019, para construção de minha dissertação de Mestrado em Antropologia Social no Programa de Pós-Graduação da Ufam. Por isso, não se trata apenas de um memorialismo, até porque no meu caso, como diria novamente Castro Faria, seria "bastante pobre", mas trata-se de um esforço reflexivo sobre esses dados de campo, que muitas das vezes colocaram até dúvidas em minhas memórias e conhecimentos apriorísticos. Em consonância com a crítica à ilusão autobiográfica de Bourdieu (2002) e Castro Faria (1993), não pretendo sacrificar a reflexividade da minha pesquisa de campo ao gênero autobiográfico (ALMEIDA, 2018), mas sim entrelaçar minha memória com a memória dos que aqui contribuíram e a etnografia.

Destaco que trago como fontes os documentos que tramitaram em diversos órgãos. São ofícios, atas de reuniões, memorandos, cartas públicas, assinaturas e croquis que tratam da comunidade Lago da Praia, os quais me foram disponibilizados pela Assessora Jurídica do Conselho Indígena de Roraima (CIR), Joênia Wapichana, no ano de 2016. A maior parte dessa documentação foi utilizada relacionando as narrativas obtidas através de entrevistas com alguns moradores da referida comunidade. Foram 7 (sete) entrevistados no total, sendo 4 (quatro) mulheres e 3 (homens), todos indígenas Macuxi e Wapichana, que moraram no Lago da Praia e que, no período da entrevista, isto é, 2016, já estavam morando em suas antigas comunidades. E, como mencionei, eles estiveram na linha de frente dessa batalha. 
O meu nome é Eriki Aleixo. Na língua wapichana, como meu professor Maxi'i (Andarilho) me chamou, meu nome é Abaxiiz, que significa "orvalho", aqueles pingos de águas que amanhecem nas folhas das árvores. Pertenço ao povo Wapichana, sou morador da comunidade Serra do Truarú, que faz parte da terra indígena Serra da Moça (etnorregião Murupú). Esta terra indígena está localizada a uma distância de $60 \mathrm{~km}$ do centro urbano de Boa Vista, capital do estado de Roraima (Figura 3). Além da comunidade Serra do Truarú, fazem parte desta referida terra indígena as comunidades Morcego, Serra da Moça e, até no ano de 2009, também a comunidade Lago da Praia.

O agrupamento de determinadas terras indígenas caracteriza uma etnorregião. Essas etnorregiões são unidades que reúnem terras indígenas que compartilham elementos culturais, relacionam-se entre si territorialmente e possuem articulações políticas em comum. Desta forma, a terra indígena Serra da Moça, junto da terra indígena Anzol e terra indígena Truarú, constituem a etnorregião Murupú.

Figura 1 - Divisão territorial da Etnorregião Murupú

\section{Etnorregião Murupú}
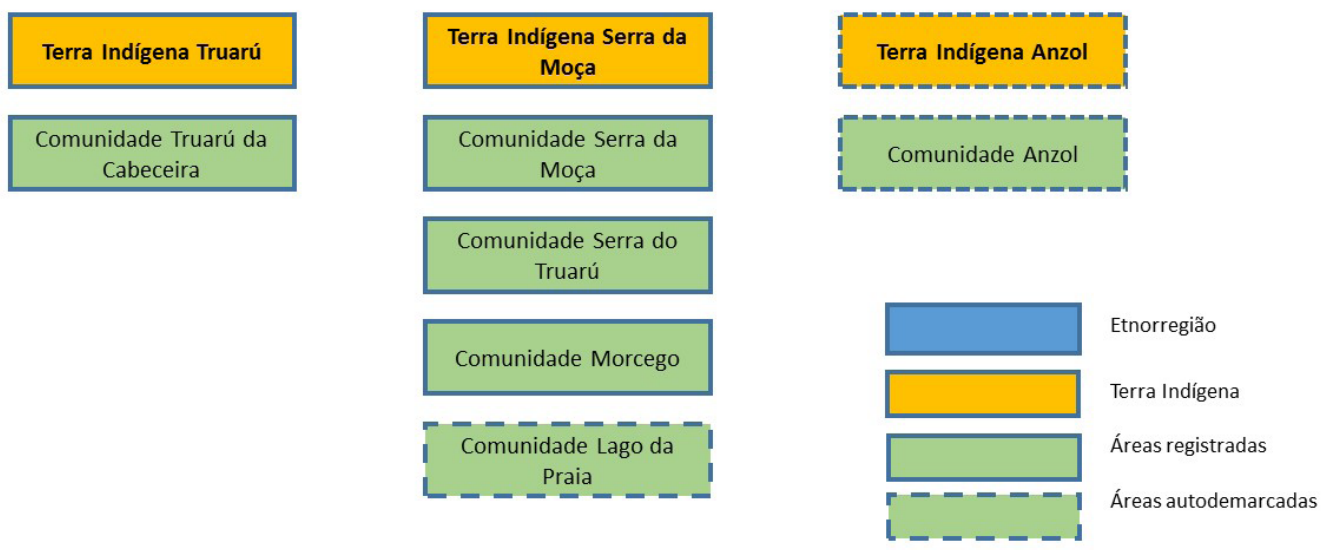

Fonte: Elaborado pelo autor, 2020.

Truarú, vem de Truaruary, que significa Cobra Grande. Dizem que essa cobra veio do rio Uraricoera por debaixo da terra e foi até um certo ponto, onde o relevo 
se tornou mais alto e a terra mais dura para escavar. Então ela voltou e permaneceu até os dias de hoje embaixo da terra, formando a serra do Truarú. Na verdade, a serra é a própria cobra. O lugar por onde ela passou acabou virando um igarapé, que também leva o seu nome. Outros dizem que essa Cobra Grande tinha sete cabeças e que cada cabeça virou um igarapé que deságua no igarapé maior. Já outros contam uma versão menos conhecida, que diz que Truarú era apenas um andarilho que vivia rodeando o "pé" da serra. Embora existam diferentes versões, o certo é que o espírito da Cobra, sempre que acordava, pegava as sombras dos mais fracos, principalmente das crianças e dos doentes que acabavam morrendo. Era necessário que os pajés fizessem rezas para ela voltar a dormir.

Ainda que eu diga que sou morador da comunidade Serra do Truarú, já faz alguns anos que saí da minha comunidade para continuar meus estudos. Em 2012, após concluir o ensino médio na Escola Estadual Indígena Adolfo Ramiro Levi, na comunidade Serra da Moça, fui cursar graduação em História na Universidade Federal de Roraima. No final do curso, em 2016, fiz da retomada do Lago da Praia a minha pesquisa para o trabalho de conclusão. No ano de 2017, ingressei em um Mestrado em Antropologia Social na Universidade Federal do Amazonas, onde aprofundei minha pesquisa sobre o mesmo caso. O contato com diferentes abordagens, bem como pessoas, tais como colegas de laboratório e professores, marcou profundamente minha formação. Por isso, mesmo que este texto não se aprofunde em discussões teóricas, é importante mencionar que ele se localiza nos estudos sobre processos de territorialização e conflitos sociais, bem como nos estudos que se debruçam sobre a ação dos povos indígenas na construção de suas territorialidades e suas autodemarcações.

Posso dizer sou parte de uma geração de indígenas que colheu os frutos de lutas históricas, com acesso à educação superior e que saiu das comunidades em busca de ferramentas que viessem a contribuir na melhoria dos nossos povos, a fim de conquistar espaços estratégicos para que novos projetos indígenas possam ser construídos. Assim, temos incluído em nossas reflexões a nossa própria vivência e agenda dos movimentos indígenas. Atualmente, estou cursando o doutorado no mesmo Programa de Pós-Graduação.

Através dessas utupa siki, "peles de imagens", como diria o Xamã Davi Kopenawa ou karichi, que quer dizer "caderno" ou "livro" na nossa língua wapichana, eu aproveito para contar um pouco da história de uma retomada de 
partes dos nossos territórios que, por diversos motivos, seja devido à usurpação de terras pelos fazendeiros, seja pela negligência dos estudos de identificação, acabaram ficando fora da demarcação.

Então, o que tenho para contar é sobre essa vivência nas mobilizações que ocorreram desde quando iniciamos os preparativos para construir o barracão que viria a ser o Centro Comunitário do Lago da Praia, passando pela ocupação das famílias que efetivamente morariam formando seus núcleos familiares, pelos tempos de quando íamos pescar e caçar livremente no rio Uraricoera e nos lagos da comunidade indígena, de quando íamos colher "murici" na beira do igarapé Muxinga e, também, do início das tensões, quando soubemos de notícias sobre os parentes que estavam sendo atacados pelos invasores, até o "fim" da comunidade, em 2009, quando a comunidade Serra do Truarú comemorava o "Dia dos Pais" no mês de agosto e os últimos indígenas tiveram que fugir do Lago da Praia porque tiveram suas casas incendiadas.

Antes de iniciar falando da comunidade Lago da Praia, é necessário retornar na história para compreendermos como o território da terra indígena Serra da Moça foi configurado a partir da interação entre os indígenas e agentes externos, tais como o Estado, como também fazendeiros e posseiros de terras, os denominados setores anti-indígenas, que historicamente foram usurpando seus territórios no atual estado de Roraima.

Essa interação a qual me refiro é evidenciada em diferentes situações históricas (OLIVEIRA FILHO, 2015), como durante o século XVII, período este marcado fortemente pelo extrativismo e aldeamentos na região do Rio Branco. Esta situação é estudada por Farage (1986), que discute a disputa territorial entre portugueses e holandeses, que utilizaram os povos indígenas da região para consolidação das fronteiras, especialmente os portugueses, através dos aldeamentos. Além disso, os aldeamentos serviam para tornar esses indígenas em servos da Coroa e, desta forma, serem incorporados à sociedade "civilizada".

Outra situação que podemos incluir como uma das que marcaram a região é a expansão da pecuária como forma de ocupação territorial. A implantação da pecuária na região do rio Branco acelerou o processo de perdas territoriais dos 
povos indígenas, como afirmam Farage e Santili (1992). Esse é um período (século XVIII e início do século XIX) marcado fortemente por esse projeto, além, é claro, pela grilagem de terras atrelada à sua regulamentação através de leis criadas a partir do advento da República em 1889.

A pecuária tinha o objetivo de manter o projeto colonial de ocupação e consolidar as fronteiras territoriais. Os primeiros rebanhos de gado bovino foram introduzidos nos campos gerais em 1787, com a criação das fazendas do Rei ou fazendas Nacionais: São Bento, São José e São Marcos; com "esse projeto, como o dos aldeamentos, também teve como objetivo consolidar as fronteiras ao norte e reafirmar de forma mais intensiva a presença portuguesa na região" (VIEIRA, 2003 , p. 35). Repetto (2008) fala na criação de diversas categorias para legitimar esta prática: fazendas, retiros de gados, missões religiosas, escolas, internatos, que, além de absorver a mão de obra indígena, contribuía para que esses povos tivesses suas terras roubadas.

A entrada do garimpo na região veio somar-se à pecuária enquanto prática desorganizada pela ótica estatal e contribuir para que os povos indígenas perdessem mais terras. Santilli (2001) afirma que esse novo fator também vem formar uma conjunção de características de interesses, por parte da incipiente sociedade regional sobre o território dos indígenas Macuxi, principalmente nos rios Cotingo, Quinô e Maú, afluentes do rio Tacutu, o que leva a um novo movimento migratório de colonos. Além dos territórios dos Macuxi, atinge também os Ingarikó, ao norte do estado de Roraima. Santilli (2001, p. 109) afirma ainda que tal prática causou um efeito devastador, contaminando rios e peixes com mercúrio e óleo diesel, além de propagar doenças como malária e leishmaniose.

Pesquisas recentes mostram que, entre as décadas de 1970 e 1990, quando ocorreram os estudos de identificação, demarcação e homologação de grande parte das terras indígenas em Roraima, esses foram marcados por graves erros, principalmente no que se refere à exclusão de partes importantes de territórios indígenas. Conforme o relatório de identificação da terra indígena Serra da Moça e confirmado na fala dos indígenas que presenciaram sua demarcação, era comumente falado que uma parte da terra seria contemplada para "garantir" e, logo após a homologação, a comunidade deveria entrar com um pedido de ampliação para que as terras indígenas consideradas insuficientes fossem revistas, conforme documento abaixo (Figura 2). Há de se levar em conta que esses estudos de 
identificação se tornavam bastante complexos devido às invasões que as áreas indígenas haviam sofrido por particulares, o que dificultava ainda mais a ampliação dos seus limites.

Figura 2 - Documento referente às revisões das terras indígenas demarcadas, 22 de julho de 1991

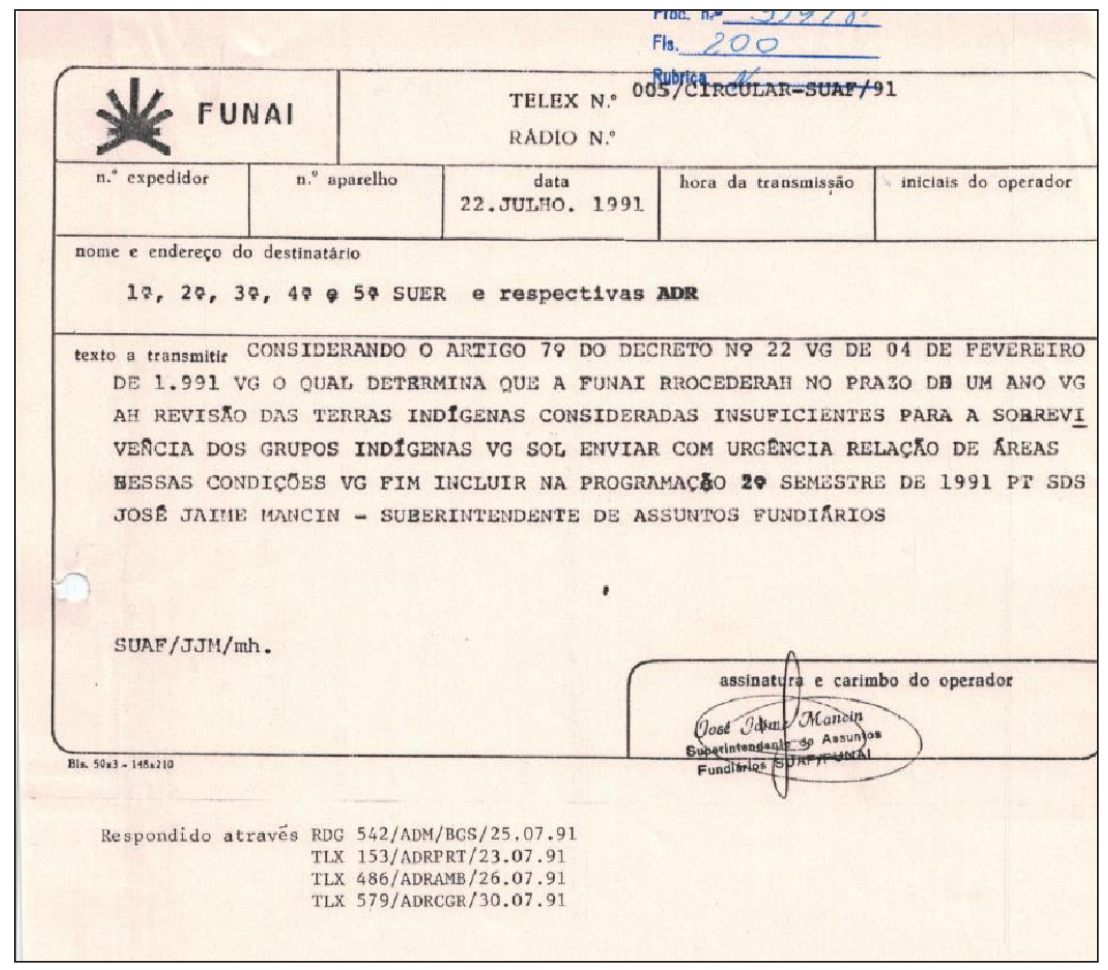

Fonte: Processo 28870.000919/1981 - 68 - Identificação da área indígena Serra da Moça.

É neste contexto que a terra indígena Serra da Moça se situa. Tais fatores desencadearam mobilizações de retomadas, tomando como elementos essas referências e experiências. Essas mobilizações são resultados de anos de uma relação violenta que os indígenas vêm sofrendo cotidianamente, seja por meio das restrições impostas, por não poderem acessar aos rios, lagos e matas, seja ainda por meio da relação de trabalhos com os fazendeiros que Ihes exploravam economicamente economicamente (ALEIXO WAPICHANA, 2020, no prelo). 
A comunidade Lago da Praia, que surgiu dessas mobilizações que reivindicavam a ampliação de seus territórios desde sua demarcação, no ano de 1991, esteve localizada ao norte da terra indígena Serra da Moça, entre o Igarapé Truarú e o Rio Uraricoera.

Figura 3 - Localização da Terra Indígena Serra da Moça como indicação da comunidade Lago da Praia em relação à Terra Indígena Raposa/Serra do Sol

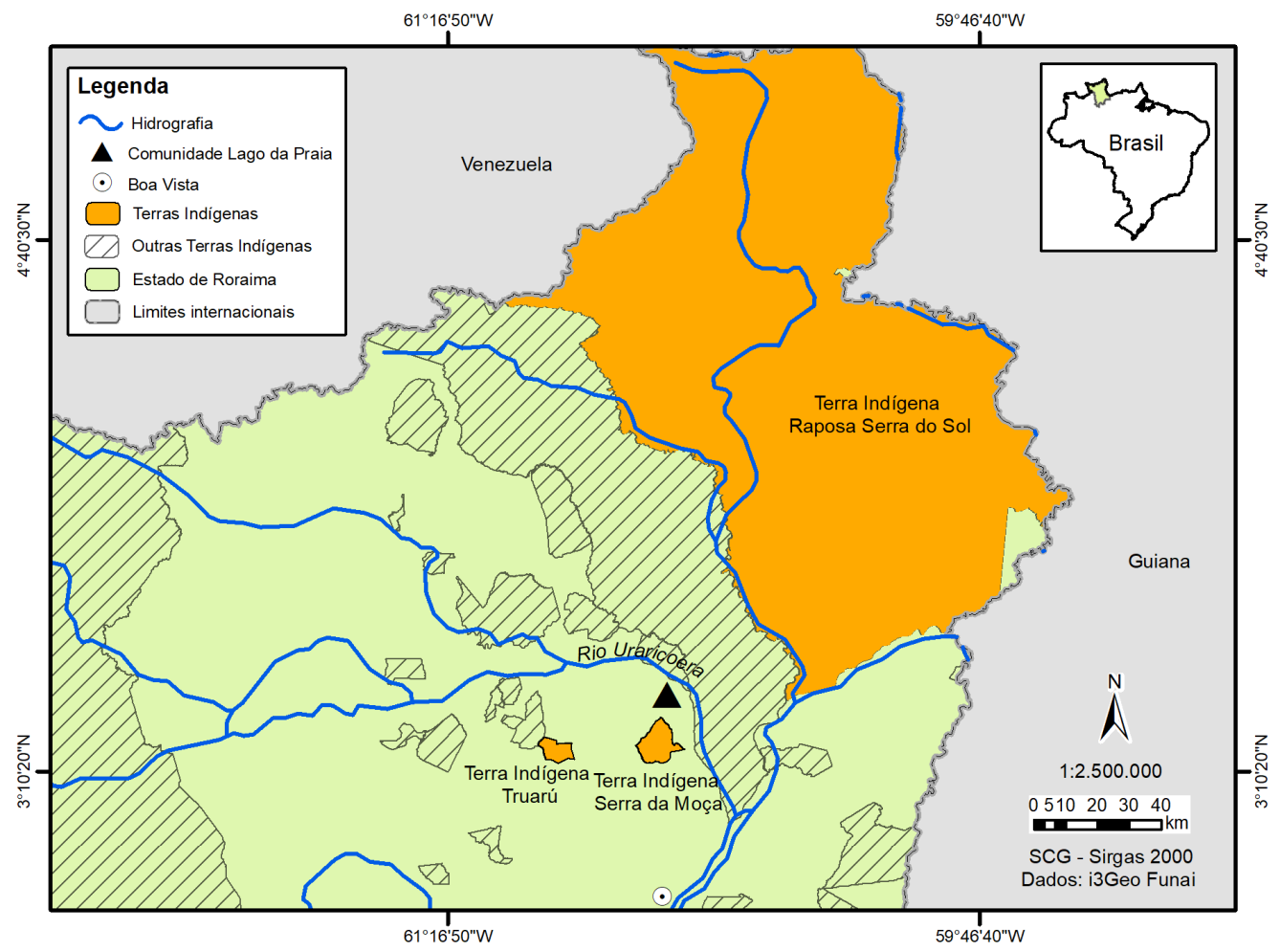

Fonte: Elaborado por Mônica Côrtez, 2020.

Contudo foi apenas no ano de 2004 que as lideranças, junto de suas comunidades, resolveram ocupar permanentemente o referido território, já que anteriormente a área funcionava como uma extensão da terra indígena utilizada para exploração de recursos naturais, tais como colheita de frutas, caça e pesca.

Sob a promessa de que a referida terra indígena seria ampliada posteriormente quando se garantisse uma pequena porção, que naquele momento 
delimitava apenas os lugares onde as famílias moravam, os Tuxauas (lideranças indígenas) não reclamaram, naquele momento, a inclusão dos territórios nos estudos de identificação.

Devido à ameaça de perda dessa extensão territorial decorrente do acirramento da luta referente à terra indígena Raposa/Serra do Sol nos anos 2000, os indígenas da terra indígena Serra da Moça resolveram então criar uma nova comunidade como forma de ocupar suas terras tradicionais, realizando, portanto, diversas mobilizações.

As negociações para a ampliação dessa terra indígena já estavam encaminhadas junto à Fundação Nacional do Índio (Funai), Conselho Indígena de Roraima (CIR), Instituto Nacional de Colonização e Reforma Agrária (Incra) e indígenas, desde o começo das tratativas. No entanto o processo foi interrompido pelo ministro do Supremo Gilmar Mendes, que fundamentou uma Ação Cautelar a favor do Governo do Estado de Roraima. O governo do estado de Roraima, no ano de 2009, era representado por José de Anchieta Junior (PSDB-RR), que entrou com uma ação no Ministério Público contra esses sujeitos envolvidos nas negociações (Funai, Incra, CIR e indígenas). O principal fundamento da Ação Cautelar referia-se à "condicionante" de número 17, que traz o seguinte texto: "É vedada a ampliação da terra indígena já demarcada" 2 .

Esse caso se tornou emblemático para o Movimento Indígena do Estado de Roraima, especialmente para o CIR, que é a organização da qual a comunidade faz parte e que acompanhou as negociações através do coordenador-geral Jaci José de Souza (Macuxi) e da assessora jurídica Joênia Batista de Carvalho (Wapichana). A posição de destaque ocorreu por ser um dos casos em que terras indígenas tiveram seu processo de ampliação ou demarcação interrompido devido a essas "condicionantes".

\section{PREPARANDO PARA OCUPAR: MÚSICA, DANÇA E TRABALHO}

A ideia de se ampliar a terra indígena Serra da Moça veio de lideranças que vivenciaram diversas experiências de luta no movimento indígena que fora

\footnotetext{
2 Tal condicionante refere-se às 19 salvaguardas impostas pelo Supremo Tribunal Federal para que ocorresse a homologação da terra indígena Raposa/Serra do Sol no ano de 2005.
} 
conjugada ainda com a opressão decorrente da relação de trabalho entre indígenas e fazendeiros.

No entanto apenas a experiência das lideranças não era suficiente para realizar a retomada das terras, era necessário também mobilizar os demais indígenas da comunidade, de forma que eles pudessem apoiar as lideranças e aderir suas ideias. As experiências internas, isto é, aquelas vividas pelo restante da comunidade cotidianamente, são também responsáveis por mobilizar e criar uma consciência crítica em relação à retomada territorial.

A combinação dessas experiências é feita em diversos momentos. Um deles são as reuniões e assembleias. E foi assim que numa reunião planejou-se toda a ocupação para a criação da comunidade Lago da Praia. Aqui recorro às palavras do tio Assis, que foi uma das lideranças que estiveram à frente da luta para descrever este momento:

Tio Assis: Tivemos reunião, que eu me lembro é assim, né: fizemos reunião pra ir pra lá e procurar as pessoas que iam, né. Aí apareceu essas pessoas e levamos carne. E lá também já estava o Banana, que era genro do Chicão, pra nos acolher lá. E de lá nós fomos trabalhar no Lago da Praia e dai estávamos lá com ele. Mas tivemos reunião pra ir pra lá. Depois que estávamos lá, começou a chegar Morcego, e daí tomaram conta já.

O que tio Assis conta é que, nas reuniões, foi planejado como seria feita essa ocupação. Acredito que foi numa semana anterior à semana que se comemoraria o dia 19 de abril, que no caso é o festejado o "Dia do Índio". Os Tuxauas decidiram utilizar essa data emblemática para não apenas ir ao lugar construir o barracão, mas também aproveitar o momento para comemorar a data com festas, comida e bebidas tradicionais.

Como é de costume, todos os anos, fazer desta data um evento em que participaria a escola da comunidade Serra do Truarú, os professores e alunos ficariam responsáveis por planejar diversas atividades de cantos, danças e brincadeiras que seriam apresentadas neste evento. E foi em uma reunião na semana anterior que foi decidido que a escola não funcionaria para as atividades regulares, mas ficaria responsável por planejar as atividades a serem apresentadas na nova comunidade.

Na semana de planejamento, duas professoras ficaram responsáveis por organizar as atividades com os alunos: Francinéia Pereira Lima e Elisangela da 
Silva Angelo. As duas eram professoras da própria comunidade Serra do Truarú e, por isso, tinham uma maior proximidade da comunidade, algo que não era tão comum com os professores que vinham de outros lugares.

Após serem delegadas para prepararem as atividades, as professoras decidiram que os alunos passariam a semana ensaiando a dança de duas músicas. Essas músicas faziam parte do repertório apresentado nas assembleias do movimento indígena e suas letras tratavam do cotidiano das comunidades indígenas, isto é, falavam de caça, de pesca, de dança, da música e da comida. Uma das músicas de que me recordo é de autoria de um compositor indígena chamado Celestino, Wapichana da comunidade Pium, Etnorregião Tabaio:

De manhã cedo pego minha darruana, arco, flecha zarabatana vou pro riacho pescar. Pegando peixe, faço a boa damurida, com pimenta malagueta, venho aqui saborear.

Na panela de barro, a damurida, no barro no balde o caxiri, peixe assado na brasa e o gosto do Assaí. É assim que vivem, os índios de norte a sul. Tem vinho de bacaba e buriti, que delícia de beiju.

Na semana de preparação dos alunos para o evento, as professoras orientaram que todos que fossem participar das atividades levassem seus trajes de dança, como saias de palhas e cocares. Muitos de nós fomos em grupos nos buritizais em busca de palha de buriti para fazer nossos trajes. Alguns até levaram para escola para fazer junto aos professores e outros alunos. Outros levaram para suas casas, onde seus pais ou avós eram quem confeccionariam os trajes dos seus filhos e netos.

Foi uma semana muito animada, porque as aulas convencionais foram suspensas e estávamos nos preparando para algo que, no pensamento dos alunos, seria grandioso; primeiro porque, como o lugar onde seria construído o barracão era distante da Serra do Truarú, muitos de nós nunca tínhamos ido até lá, apenas os homens mais velhos que conheciam porque iam caçar e pescar por aquelas bandas. Para grande parte dos nós alunos, que tinham entre 10 e 14 anos de idade, seria um lugar novo que iríamos conhecer. Tínhamos todo um imaginário de que fosse um lugar que pertencia apenas às histórias contadas pelos mais velhos, que era farto de muitas caças, como capivaras, jacarés, veados e tatus, e muitos peixes que só existiam nos lagos de lá, já que nos rios e igarapés da Serra do Truarú a presença de peixes era um tanto escassa. Parecia que lá era o lugar a ser conquistado, ao menos para as crianças, pois, para os adultos, era apenas um retorno. 
No decorrer das preparações, foi orientado pelos Tuxauas que os alunos levassem rede de dormir e corda para amarrar as redes, pois passaríamos bastante tempo por lá. Também era para levar o "kit maloca", como é chamado o conjunto de prato, colher e farinha no movimento indígena, o básico para participar de qualquer evento.

A ida dos alunos e professores estava marcada para a manhã do dia 18 de abril de 2004, pois chegaríamos ainda pela parte da manhã, passaríamos o dia todo trabalhando no barracão e, no dia seguinte, dia 19, comemoraríamos o "Dia Índio". Algumas pessoas mais velhas, isto é, pais e mães de famílias, foram antes, pois precisaria tirar os materiais necessários para construção do barracão, como madeira e palha, além, também, de capinar o local onde seria construído o barracão. Os homens foram também para preparar a alimentação para nos subsidiar durante todas as atividades e, além de matarem um gado bovino da comunidade, também aproveitariam para caçar e pescar nos locais próximos. Desta forma, não faltaria carne até o fim das atividades.

Após a semana de preparação, já no dia em que seria marcado para todos irmos, nós nos reunimos no centro comunitário, junto às professoras que ficariam responsáveis pelos alunos que iriam sem o acompanhamento de seus pais, e de lá pegaríamos o trator da comunidade e seguiríamos para onde já estavam os que tinham ido antes. Eles estariam nos aguardando com todos os materiais para a construção do barracão.

É importante ressaltar que o lugar onde se pretendia construir a nova comunidade já tinha alguns indígenas que lá moravam e que eram parentes de indígenas da comunidade Serra do Truarú, como o senhor Banana. No entanto eles não tinham nenhuma relação política com a comunidade no sentido de pertencimento, não participavam da vida comunitária indígena e levavam uma vida mais parecida com a de agricultores ou camponeses. Quando as lideranças comunicaram que ocupariam a região onde essa família morava, foram eles que recepcionaram e foi na casa deles que ficou funcionando a cozinha que forneceria alimentos para o pessoal da Serra do Truarú.

O trator que nos levaria era de um modelo muito antigo que quase não funcionava, mas tinha uma carroça com capacidade de levar alguns alunos e alunas que não tinham transporte para irem sozinhos. Outros também foram de 
motocicleta ou bicicleta nos acompanhando devagar, já que o trator não passava de $30 \mathrm{~km} / \mathrm{h}$. Cada aluno levava consigo também uma mochila enorme, onde havia mudas de roupas, redes, prato, colher, farinha e nossos trajes para apresentação no Dia do Índio.

Na manhã do dia 18, saímos do centro da comunidade rumo ao lugar que seria formado uma nova comunidade. Atravessamos o igarapé Truarú e seguimos para fora dos limites oficiais da terra indígena. Embora mais tarde chegassem indígenas da comunidade Serra da Moça e do Morcego, neste primeiro momento, participaram apenas indígenas da Serra do Truarú, que foram os que deram o pontapé inicial na mobilização.

À medida que nos distanciávamos da Serra do Truarú, a paisagem começava a mudar. Parecia ser realmente uma paisagem mais preservada, com maior densidade de buritizais e no lavrado com mais árvores, embora todos soubessem que pouco tempo atrás havia pessoas morando ali.

Por volta de duas ou três horas de viagem, chegamos à casa do Banana e, quando chegamos, já estava sendo preparado o almoço. O local onde Banana morava ficava próximo de umas das fazendas que estavam abandonadas. Na verdade, aquela região tinha diversos resquícios de fazendas, como grandes currais, casas de alvenarias e cercas. Esse primeiro local onde chegamos era conhecido como "Alagadiça", nome da antiga fazenda que havia se instalado, e foi numa casa de alvenaria que estava abandonada que nos acomodamos e deixamos nossas mochilas e nossas redes ateadas.

Após nos instalarmos, seguimos para o local onde estava acontecendo o trabalho, que era próximo de um lago. Era um lugar mais afastado de onde estava localizada a antiga fazenda. O lago que ficava próximo de onde estava sendo construído o barracão se chamava lago da Praia, isso porque ele tinha uma parte onde havia um amontoado de areia, que parecia realmente uma praia. E, mais tarde, esse lago foi utilizado para nomear a comunidade.

Quando chegamos onde estavam acontecendo as atividades de construção, já tinha muita gente trabalhando, cada pessoa executava um trabalho diferente. Os mais experientes em construções de casas montavam o sustento, como colocando as madeiras nos devidos lugares e no teto que seria coberto de palha. Os demais aproveitaram que o trator havia chegado para buscar os fechos de 
palha nos buritizais. Alguns carregam os fechos de palha na cabeça. As crianças ficam auxiliando os mais novos, como trazendo as madeiras menos pesadas para serem utilizadas. E, ainda, haviam ficado pessoas onde funcionava a cozinha para preparar o alimento, entre homens e mulheres.

O restante da manhã foi assim: entre trabalho e conversas. E nessas conversas começaram a discutir qual seria o nome da comunidade. Muitos sugeriram os nomes mais diferentes, tomando como referência os lagos e igarapés das proximidades: Lago Grande, Lago do Panelão, Lago do Porco, entre outros. Alguns sugeriram colocar o nome da comunidade como aquele lugar já era conhecido, isto é, o nome das antigas fazendas: Alagadiça e Patativa, mas as lideranças acabaram entrando num acordo de que a comunidade não deveria ter nenhum dos nomes das fazendas dos não indígenas. O mais certo seria nomear como aquela área era conhecida antes das fazendas, como Santa Rita, Caimbezal Grosso ou outro nome citado pelos antigos moradores para referenciar suas antigas moradas. No entanto acabou sendo escolhido um nome novo: Lago da Praia, porque era o lago mais próximo de onde seria o centro comunitário.

Ainda nessas discussões, começaram a ser contadas as mais diversas histórias do porquê daquele lago ser chamado de lago da Praia. Umas das versões que foram contadas, ao menos a de que me lembro, era a seguinte:

Antigamente existia uma praia muito grande, onde os pescadores ficavam sentados quando iam até o lago pescar. O lago era muito grande, escuro e farto de diversos tipos de peixe, além de muitas caças nos seus arredores, como capivaras e jacarés.

Dizem que uma vez, quando um homem estava sentado nas areias da praia, segurando sua linha de pesca, esperando pegar algo, de repente sentiu a praia se mexendo e se deslocando para lado oposto. E, quando olhou para baixo, na direção em que a praia estava indo, avistou a cabeça de um tracajá. E assim ele se deu conta de que a praia, na verdade, era o casco do tracajá coberto de areia. (Lembranças do autor).

Esta foi a história que eu me lembro de ter ouvido, embora outras tenham sido contadas, que diziam que o nome do lago era apenas por ser um amontoado de areia que as pessoas chamavam de praia e onde as pessoas se sentavam para jogar suas linhas de pesca. Não havia nada relacionado a ser um casco de tracajá nem de qualquer outro animal. Era apenas um lago com praia. 
No decorrer das atividades para construir o novo barracão da comunidade, contavam-se diversas histórias, piadas, muitos jovens aproveitavam para aprender com os mais "experientes" a construir uma casa. Outros faziam atividades que exigiam menos esforços, como levar a palha para os que estavam cobrindo o teto do barracão, que era o meu caso.

Nisso tudo, as atividades do dia 18 foram concluídas e voltamos para o local onde funcionava a cozinha, para jantar e acompanhar a reunião das lideranças, pois, no dia seguinte, no dia do evento do "Dia do Índio", estava marcado também para receberem algumas instituições que participariam e acompanhariam a ocupação, como o Incra, Ibama e a imprensa local, instituições essas que participaram de todo o processo de negociação posteriormente.

Como não conseguimos terminar de construir o barracão no dia 18, por diversos motivos, entre eles o fato de que a palha não havia secado ao ponto de serem utilizadas para cobertura do barracão, pois, se usássemos naquele dia, a palha estragaria com menos tempo, esperamos até o dia seguinte para dar procedimento às atividades. Tínhamos que acordar cedo na manhã seguinte, porque, além de ajudarmos na construção, ainda tínhamos que apresentar nossa dança e música para a comunidade.

E assim acordamos no dia seguinte e, após tomarmos café, tomamos banho e seguimos novamente para finalizar o barracão. Entre brincadeiras, histórias e piadas, terminamos de cobrir o barracão apenas ao meio-dia. E, pela parte da tarde, aconteceria a reunião com instituições.

Por isso, como não conseguimos terminar nosso barracão a tempo, os Tuxauas decidiram que os alunos não mais realizariam a apresentação de canto e dança, pois não daria mais tempo. A tia Gercina, que acompanhou esses momentos iniciais, conta como ocorreu:

Tia Gercina: Ah, foi, nós chegamos lá em 2004, nós fomos, eu não sei se foi esse mês aí de abril. Eu sei que nós fomos comemorar o Dia do Índio lá [risos]. Nós fomos comemorar lá, chegamos lá, fomos fazer o primeiro barraco, aí parece que era o Incra, né, o Incra tava lá, aí diz que nós não podíamos fazer. Só que nós não apresentamos nosso trabalho, a escola não apresentou mais. A mãe dela era aluna (apontando para sua neta de 3 ou 4 anos que estava ouvindo atentamente a entrevista com sua vó. A mãe a quem ela se refere era a Cássia, que era minha colega de turma na escola), nós fomos acompanhar também. Aí não deixaram nós fazer... 
Como não tivemos que apresentar mais, apenas voltamos para o alojamento e esperamos a parte da tarde para a reunião com as instituições. Elas chegaram por volta das 14 horas, quando todo mundo já estava debaixo do barracão, falando sobre os primeiros passos que seriam dados para a criação da comunidade.

Quando chegaram, apresentaram-se para a comunidade, falaram da situação de que aquelas terras eram devolutas e que estavam em fase de estudo para reforma agrária. E, como tia Gercina apontou acima, negaram completamente que aquelas terras deveriam ser destinadas para ampliação de terras indígenas. O Incra, na pessoa do senhor Lurenes Cruz Nascimento, havia encaminhado um ofício ao Ibama, no qual alertava sobre essa ocupação dos indígenas uma semana antes, no dia 13 de abril de 2004, e, num linguajar preconceituoso, acusou-nos de estar cometendo crimes ambientais, afirmando que os indígenas eram aculturados e conheciam as leis ambientais:

Of. INCRA/SR-25/G/RR/N. 115, de 13/04/2004

Nilva Baraúna - gerente executivo do Ibama

Comunicamos a vossa senhoria que índios da Maloca Serra da Moça estão invadindo a área da antiga Fazenda Bamerindus e matando animais silvestres como capivara, cutia e outros.

Como existe o projeto de assentamento do INCRA na referida área, solicitamos providências do IBAMA, considerando-se que os índios da Serra da Moça são aculturados e conhecem a proibição de caça e animais silvestres. $\mathrm{Na}$ oportunidade reitero a vossa senhoria voto de considerações e amizade.

Lurenes Cruz do Nascimento - Superintendente Regional do INCRA. (Dossiê Terra Indígena Serra da Moça - Lago da Praia/CIR).

Este foi um dos principais questionamentos que foi discutido pelos Tuxauas na reunião. Durante a reunião, a imprensa local também estava presente, mas os Tuxauas negaram que fosse gravada qualquer imagem, por motivos de segurança e para preservar a vida das pessoas que estavam presentes.

Por volta das 16 horas, a reunião foi encerrada, os representantes das instituições acabaram indo embora e passamos mais uma noite por lá. Na manhã seguinte, tomamos café, e quem tinha que retornar para Serra do Truarú, retornou, e quem tinha ido para morar, acabou ficando por lá na nova comunidade que tinha acabado de ser criada. E a partir daí outros indígenas das outras comunidades da terra indígena Serra da Moça começaram a chegar para construir suas moradias. 
No dia 6 de maio de 2004, o CIR encaminhou à Funai um ofício das comunidades da terra indígena Serra da Moça que havia sido enviado à Procuradoria da República de Roraima, no qual apresentam uma defesa ou esclarecimento sobre o que estava ocorrendo. Nesse ofício, inicia-se falando que decidiram ocupar a área, pois ela já estava em reinvindicação da ampliação desde anos atrás, e que a base para essa ocupação era a própria Constituição Federal, que Ihes assegurava o direito originário às terras tradicionalmente ocupadas. Ainda, informava-se que havia ocorrido uma reunião do dia 20 de outubro de 2003, na comunidade Serra da Moça, com essa pauta, e que estavam presentes representantes do CIR, Incra, Funai e Associação dos Povos Indígenas de Roraima (Apirr), aos quais as lideranças contaram as dificuldades pelas quais os povos estavam passando desde que a área foi demarcada, em 1991, além do fato de que foram deixados de fora igarapés, rios, matas.

Nesse documento, dizem também que foi garantido, numa reunião anterior à ocupação, pelo Incra (senhor Lurenes), que uma parte da antiga fazenda Bamerindus seria para as comunidades e a outra para assentar 18.000 desempregados, assim como, na semana seguinte à reunião, seria realizada uma visita para que fossem definidos os limites do que seria a comunidade.

Contam ainda na carta que o encontro nunca veio a ocorrer como combinado e, depois de esperarem muito tempo, perceberam que estava ocorrendo o assentamento e que a promessa do Incra não se cumpriria. Decidiram então, por conta própria, isto é, que não estavam sendo instigados por ninguém ou qualquer entidade, ocupar as terras que na verdade já eram deles, "pois aqui os nossos povos conviviam e usufruíam dessa terra a muito e muito anos antes mesmo de existir esses órgãos como: INCRA, FUNAI". Logo após, no documento, fazem referência à firma de JG de Araujo, dizendo que:

[...] foi nesse período que os antepassados foram expulsos, mas que deixaram para trás marcas como taperas, cemitérios e utensílios indígenas, e que isto provam que não estão invadindo e sim que estamos ocupando o que já era nosso. Apesar das pressões, ameaças e calunias que estão usando contra o nosso povo iremos permanecer no local e não vamos sair, é uma decisão nossa, lutaremos pelo que é nosso, se é pra morrer, preferimos morrer lutando pelos nossos direitos, que está assegurado na Constituição Federal. (Dossiê Terra Indígena Serra da Moça - Lago da Praia/CIR). 
Após isso, fazem referência à denúncia que o Incra fez ao Ibama e dizem que a acusação de matanças não tem provas e que já aqui é relatado que o Incra se nega a ter assumido o compromisso com as comunidades, compromisso que havia sido feito com representantes de várias instituições e que agora o Incra estava ameaçando colocá-los na Justiça para obrigá-los a sair.

Então, é relatado que no dia 17 de abril de 2007 três moradores estavam pescando quando foram surpreendidos no entardecer por alguém que eles não reconheceram, e que esta pessoa atirou numa capivara e foi embora, deixando-a baleada. É relatado ainda um conflito com um senhor que se dizia funcionário do Incra com uma família indígena que já morava há cerca de 20 anos no local, que era a família do senhor Banana, e dizem que era esse senhor não indígena que comercializava peixes e prendia tartarugas dentro de sua casa.

A carta é finalizada dizendo: "Que sejam tomadas providências cabíveis o mais rápido possível antes que aconteça algo mais grave com o nosso povo: se isto vier acontecer as autoridades responsáveis serão culpados".

\section{A CRIAÇÃO DE UMA NOVA COMUNIDADE, EFETIVAÇÃO DA MORADIA}

No primeiro momento, conforme o ofício encaminhado no dia 30 de abril de 2004 ao CIR, as lideranças informaram que, para construir uma nova comunidade, iriam 10 famílias para construir 10 casas, um barracão, 1 posto de saúde e 1 escola às margens do rio Uraricoera. E, conforme dito, foi isso que ocorreu no decorrer da construção da comunidade.

Primeiro, foram morar apenas famílias que se mudaram da Serra do Truarú, entre elas a família da tia Gercina, junto ao Tuxaua Leôncio Lourenço, seu irmão José Lourenço, Geovânia Angelo, Orlando Silva e dona Lourdes. Juntaram-se à comunidade também a família do senhor Banana, que era casado com a filha do Chicão, Anete, indígena da Serra do Truarú - e, como já mencionei, eles já moravam naquele lugar.

Conforme Geovânia, a decisão de sair de sua comunidade para ir a outra era principalmente para se ter facilidade de acessar os recursos, pois na Serra do Truarú se tinha muita dificuldade para caçar, pescar e criar, ou seja, pela oportunidade de ter uma vida melhor: 
Geovânia: É, por aqui estava fácil, está difícil; a gente vive aqui porque é nossa comunidade, nós não queremos sair daqui, eu principalmente. Aí, como tivemos oportunidade de ir aonde tinha mais espaço pra criar, pra criação, criar os filhos, nós vimos que era melhor, a terra, a água, mas não deu certo, né. Nós voltemos pra cá de novo e voltemos nossa vida normal de novo, e agora, até agora esses tempos, nós não temos mais roças; não tem nem como, assim, pra fazer farinha; não tem, a gente não plantamos mais, e é com essa seca também, ai pronto.

Quando se iniciou a comunidade, foram chegando outras famílias das outras comunidades, Morcego e Serra da Moça, e, conforme foi chegando, a efetivação de suas moradias aconteceram em concordância com toda a comunidade, obedecendo aos critérios específicos de suas territorialidades, ou seja, os indígenas dessa comunidade passaram a escolher os lugares para construírem suas casas em ambientes que eles consideravam bons, estratégicos para morar, criar, plantar e se locomover.

Por exemplo, a fala da Geovânia demonstra como ocorreram essas escolhas dos lugares, tendo como principal critério de seleção do lugar a proximidade do igarapé Truarú, em um lugar onde se localizava uma antiga fazenda chamada Patativa:

Geovânia: Então, nós escolhemos o lugar, próximo, quase próximo do Truarú. Nós fomos, moremos, a gente morava longe do "Centro". O centro era ali na Alagadissa, o centro que a gente fizemos a reunião, e aí a nós escolhemos o lugar [que] seria bom. Se fosse lá onde o seu Banana morava ou era aqui no Alagadissa. Como ficou distante de onde ficava da nossa casa que era fazenda a mesma distância da fazenda do Banana, a gente fiquemos lá no Alagadissa. O centro, concordemos que o centro seria lá, que aí o pessoal chegava no mesmo horário, de lá como daqui.

Observemos também que o lugar deve ser estratégico, tanto por ser próximo de uma fonte de água, como também um lugar considerado bom para criação de animais, como galinha e suas plantações, e por isso a distância do centro comunitário é levada em consideração, porque assim suas criações não iriam até o centro fazer sujeiras.

Já tia Gercina conta que a escolha do lugar onde construiu sua moradia foi também por estar próximo da rede de água, onde seria mais fácil cavar um poço. Além disso, era porque o lugar não apresentava tantas elevações, era "plainado", ou seja, era mais fácil para locomoção das pessoas: 


\section{Eriki: E o lugar onde vocês fizeram a casa, porque vocês escolheram aquele lugar?}

Tia Gercina: Aquele lugar lá porque lá era rede de água. Naquele local onde nós chegamos, a água era bem baixa, o poço que saiu ficou bem rasinho. Porque para lá era mais alto. Não, nós vamos fazer, nós vamos fazer, isso aqui só para nós começar, mas nós não vamos morar aqui não, nós vamos morar mais pra lá assim, que tem um lugar assim bem plainado lá [...].

Dona Lenice, que era esposa do finado Jairo, que na época era uma liderança, tinha sua casa construída próximo ao centro comunitário, onde também seu sogro e sua sogra já haviam escolhido para morar.

\section{Eriki: E o lugar que vocês escolheram pra morar lá, como que foi...?}

Dona Lenice: Não sei, porque o lugar que a gente escolheu, a dona Carminha já tinha essa casa. Aí, como nós ficamos nessa casa dela que ela escolheu lá para o outro lugar já que era casa dela, foi lá perto dessa fazenda. Porque só lá que tinha um poço, mas aí, depois, cavamos o poço da escola, nós carregava água de lá, depois que a gente pagou o menino pra cavar um poço lá pra nós. Água, dava água boa também lá. Que eu me lembro.

A proximidade do centro comunitário também é pensada por ser estratégica para se construir a casa de uma Liderança, pois assim ficaria mais fácil para Tuxaua ser encontrado para os problemas que pudessem vir a ocorrer na comunidade. Sua casa acaba se tornando um ponto de referência para as instituições de fora. Podemos identificar também que neste local, em específico na casa da dona Lenice, moravam duas lideranças, seu sogro, Jaime, que era Tuxaua do Lago da Praia, e seu esposo. Além disto, pode-se pensar que, como o lugar escolhido para construção da casa era onde sua sogra morava, a dona Carminha, percebe-se que ali estava se concentrando um núcleo familiar.

O centro comunitário foi criado com base nas comunidades das quais as famílias vinham: além das casas das famílias, uma comunidade tem que ter alguns elementos essenciais: uma escola, para suprir a necessidade dos filhos, um posto de saúde e uma casa de fazenda.

Desta forma, o centro comunitário acabou mudando de lugar, já que no início o barracão que foi construído em 2004, próximo ao Lago da Praia, acabou ficando de fora no decorrer das negociações com o Incra, o que falarei mais adiante. 
Por isso, foi escolhido um outro lugar para ser construído o centro comunitário, que era próximo de outra antiga fazenda e próximo ao rio Uraricoera. E, no decorrer do processo de consolidação da comunidade, foram construídos a escola e o posto de saúde e, consequentemente, esses tornaram-se pontos de referências para a comunidade, que os utiliza para construções futuras, como campo de futebol, espaços para os eventos comemorativos, igrejas etc.

Se o nome da comunidade foi escolhido no momento da ocupação e um dos critérios para a escolha era que fosse um nome de algum lugar com referências indígenas, o mesmo não ocorreu com a divisão territorial da comunidade, ou seja, os lugares de referências onde as famílias vieram a morar passaram a ser identificados pelos nomes das antigas fazendas. Assim como na Serra do Truarú, em que determinados núcleos familiares criaram suas territorialidades a partir de uma divisão territorial interna, o mesmo ocorreu no Lago da Praia, como falado pela Geovânia:

\section{Eriki: Por que ficou dividido com esses nomes?}

Geovânia: Porque esses nomes, esses lugares é onde tinha fazenda; era o nome dos antigos fazendeiros. Ficou tipo bairro, assim. Ficou lá Alagadissa, que era uma fazenda lá também; ai lá no Patativa era outra família, tinha outra família que era seu Orlando.

A comunidade ressignificou os nomes das fazendas, uma vez que, no início da comunidade, havia ocorrido uma resistência das lideranças para que não se utilizassem os nomes dos "brancos", e agora os nomes das antigas fazendas, Patativa, Alagadiça, foram incorporados na dinâmica da divisão territorial, tornando-se referências para as famílias do Lago da Praia. Esses resquícios das antigas fazendas, como as casas de alvenarias, os currais e toda uma estrutura completa de uma fazenda de gado bovino, fora também utilizada para criação da fazenda comunitária. Gecivaldo, esposo da Geovânia, foi um dos vaqueiros comunitários, e por isso eles foram morar em uma dessas antigas fazendas para tomar conta do gado comunitário.

De 2004 até 2009, a comunidade desenvolveu-se em um ritmo acelerado, tanto que se tornou, em termos de comunidade indígena, uma das maiores produtoras de gado bovino do estado de Roraima, chegando a ter 597 cabeças de gado. Geovânia e tia Gercina contam como viam esse aumento do gado. 
Tia Gercina: Pois é, essa ideia que teve partiu pra lá, que tem mais terra pra gado, né, também, também pra criar gado. E foi muito bom né, os gados.

Eriki: E vocês levaram os gados?

Tia Gercina: Levamos o gado da comunidade, e aumentou nesses cinco anos, nesses cinco anos aumentou mesmo, bastante, tava chegando uns 600 "reis" [...].

Como Geovânia tinha sido uma das pessoas que tomou conta do gado junto ao seu marido Gercivaldo, pôde acompanhar de perto esse crescimento. O gado havia sido levado da Serra do Truarú e Serra da Moça para o Lago da Praia. Esses gados pertenciam ao projeto "Uma vaca para o índio", que era um projeto implantado pela Igreja Católica nas comunidades indígenas na década de 1980. O projeto tinha como objetivo fazer com que as comunidades criassem esses rebanhos bovinos coletivamente. Foi um projeto importante para assegurar os direitos territoriais dos povos indígenas de Roraima. De acordo com a antropóloga e membro do Conselho Indigenista Missionário (Cimi) Gilmara Fernandes Ribeiro (2018, p. 94):

O projeto Uma vaca para o índio, favoreceu uma melhor qualificação, formação e capacitação dos indígenas para lidarem com seu próprio rebanho. Assim os indígenas têm autonomia para criar seus rebanhos. Com isso também, concebem o gado, deixando de ser uma prática do branco, para uma nova identificação, índios criadores o que lhes possibilitou desenvolver uma forma de criação buscando sua autonomia e principalmente, para que pudessem negar todas as formas de opressão que viveram no passado através das fazendas.

E não foi diferente da comunidade Lago da Praia. O rebanho aumentou de forma acelerada, tanto que era para o gado passar apenas dois anos sob o cuidado do vaqueiro do Lago da Praia, mas, como estava aumentando, ficou por mais anos, até quando tiveram que sair de lá.

Geovânia: Aí passado alguns tempos, aí escolheram Gecivaldo como vaqueiro. Ele passou dois anos cuidando dos gados da comunidade. Aí eles trouxeram de lá, porque eles estavam entrando lá pro assentamento, os gados estão no Banana. Colocaram pra perto do rio que lá tinha mais capim pra eles. Capim, água, bastante água. Então a comunidade se reuniu de novo e colocaram. 


\section{Eriki: e aumentou muito mesmo.}

Geovânia: aumentou, bastante, porque na verdade eram cinquenta "reis", né, por comunidade. Eu acho que são cinquenta "reis". Eu sei que aumentou bastante. Aumento bastante mesmo, chegando a quase duzentos.

\section{Eriki: E essas "reis" vieram de onde?}

Geovânia: Do projeto que eles dão "uma vaca pro índio", não tem? Pois é. Esse projeto é que era daqui da Serra da Moça, pra Serra da Moça passar pra lá. Aí era pra passar só um ano. Como estava produzindo bastante, deixaram passar mais dois anos, porque tava muita produção, e se eles ficassem um ano, a gente já ficaria com a metade dos gados, porque nasceu muito mesmo. Porque lá tinha os capins, os capins são bons e eles são daqueles pra gado mesmo, "ticuia". Eu não me lembro bem o nome; na beira do rio, tinha só esse capim, não tinha um capim "nativo" assim não.

Além do aumento do rebanho bovino, a agricultura também foi uma das principais atividades que prosperam entre as famílias do Lago da Praia. Produziram diversos tipos de frutas, mangueira, maracujá. Tudo que eles plantavam ou faziam dava certo, como criação de galinha e porco.

Geovânia: [...] E dava muito leite, muito leite das vacas, cavalos também, aumentaram também; assim a produção desses animais assim era bom; galinha também, "meu", você tinha que ver.... eu criei quase cento e pouca cabeça de galinha lá. Muitas galinhas eu criei; porque a terra, eu acho que a terra é boa pra tudo assim; pra plantação, pra melancia, pra qualquer coisa. Nós plantávamos melancia, é... melão, maxixe, mandioca, macaxeira, nós plantemos banana. Lá no sítio nós plantemos caju, maracujá. Maracujá deu que só lá; Maracujá. Não sei se tu se lembras.

Dona Carminha, uma senhora Macuxi da comunidade Morcego, esposa do Tuxaua Jaime e mãe do Tuxaua Jairo, foi umas das moradoras do Lago da Praia. Ela conta como era sua vida no Lago da Praia, cheia de fartura, diferente de como era depois que ela tinha voltado para comunidade Morcego:

Dona Carminha: Ainda hoje eu estava falando que o menino disse ali, o filho do Ricardo: "Papai, quando nós morávamos no Lago da Praia, sobrava dinheiro, por quê?" Ninguém comprava peixe, ninguém não comprava capivara, ninguém compra o tatu, a gente matava, comia, pescava, comia. Lá tinha dinheiro, agora aqui: a gente compra galeto, a gente compra o chambaril, não sobra nada, ele disse, sabe por quê? Porque a gente pescava. A gente não comprava mesmo, mas aqui a gente não tem onde pescar, aqui é tudo 
cercado aí, pra gente pescar lá no rio, tem que pedir, aí, se não pedi eles dizem que a gente tá roubando.

Durante este tempo no Lago da Praia, a comunidade prosperou bastante, como narra Geovânia, falando de como todos viveram e como todos eram participativos na construção de algo que viria a beneficiar a todos, como escola, posto de saúde: "era uma coisa assim, parece que era um sonho [risos]".

E conforme a comunidade foi crescendo, foi construída uma escola que funcionava como uma sala anexa à escola da comunidade Serra da Moça, já que o governo não poderia criar uma escola por decreto devido à comunidade não ter números de alunos suficiente e pelo fato de a terra ainda não ser homologada. Então, os professores que trabalhavam no Lago da Praia eram contratados pela escola da Serra da Moça. A comunidade do Lago da Praia se reuniu para construir um barracão de palha que funcionaria como uma escola.

Geovânia: Nós fomos, ajudemos na escola também. Todo mundo ajudou a "bater" tijolos para levantar. Nós carregávamos, as mulheres e as crianças carregavam tijolos para a escola. Lá para o posto de saúde eu não ajudei muito mais, porque eu estava quase saindo. Eu não ajudei a construir. $O$ posto de saúde não. Mas a escola assim e casa de apoio eu ajudei a fazer. A gente fez um poço. Os homens caíam dentro e as mulheres puxavam assim. Os homens só para cavar e as mulheres só para puxar barro. As mulheres que não tão na cozinha estavam trabalhando. Mas maioria que cozinhava era dona Lenice e dona Carminha e tia Gercina. Elas sempre ficavam na cozinha. Agora os mais novos sempre estavam no trabalho mesmo, trabaIhavam assim.

Chegaram também a construir um posto de saúde e uma casa de apoio para abrigar os professores que iam trabalhar na escola da comunidade. E, com muito trabalho coletivo, lutas diárias e muita alegria por estarem voltando às suas terras, a comunidade foi sendo construída.

Tia Gercina: três anos assim tranquilo, como a gente ia morar mesmo nós formamos a escola. A gente já tinha formado a escola feita de palha, de barro, parede de barro, com tudo dentro. Eles começaram, dentre três anos nós vivemos bem. A gente estava pensando em nunca sair de lá porque vivíamos muito bem. Lá tinha muito peixe por causa do lago e do rio. Não era que nem aqui. De vez em quando mata uma "reis". Mas era difícil a gente matar por causa da caça, do peixe, a gente pegava só para comer também. 
A gente não caça ou pescava para vender; lá tinha tudo: tinha, jabuti esse aí a gente nem comia porque eu nunca gostei de comer jabuti, mas tinha jabuti demais; jacaré também eu nunca gostei de comer, mas tinha bastante. Quando nós vivemos lá o pessoal da prefeitura levaram o "meio ambiente" e incentivou para a gente não acabar com as coisas, a natureza, com as matas, então a gente nunca mexia, nunca mexia nada. Estava tão bem. Ninguém danificou nada.

\section{CONVIVÊNCIA COM OS ASSENTADOS}

Embora saibamos que, historicamente, a relação entre indígenas e não indígenas é marcada por relações assimétricas, nas quais os primeiros sempre foram alvo da violência física e simbólica, pode-se dizer que, no início da comunidade Lago da Praia, existiu uma relação de certa forma pacífica com os assentados ${ }^{3}$ que foram retirados da terra indígena Raposa/Serra do Sol. Como eles chegaram no ano de 2005, logo após a Raposa/Serra do Sol ser homologada, Lago da Praia já tinha um ano de existência. Por isso, quando os assentados chegaram, foram buscar ajuda dos indígenas para se estabelecerem, construírem suas casas; quando precisavam de água, iam tirar nos poços da comunidade. E isso nunca foi negado pelos indígenas.

Antes de os assentados chegarem para ocupar parte da terra que estava sendo reivindicada para ampliação, ocorreu uma reunião no dia 18 de agosto de 2004, na qual estiveram presentes representantes da Funai, Incra, Ibama, CIR, Associação dos Assentados e trabalhadores rurais de Roraima. Esta reunião tinha como objetivo de acordo o ofício encaminhado ao então presidente do Incra, Dr. Holf Hackbart, pelas lideranças do Lago da Praia, que dizia o seguinte:

[...] objetivo desta reunião foi para fechar o acordo entre os indígenas e produtores rurais na delimitação das terras prometidas pelo superintendente do INCRA aos povos indígena da Comunidade Serra da Moça, Serra do Truarú e Morcego. Depois de várias propostas, foi fechado o acordo na presença de todos os participantes da seguinte forma: 1 o ponto seria na boca do Igarapé muxinga com Igarapé Truarú, acompanhando o limite natural até o 2 o ponto; depois, cortaria em uma linha seca até Cabeceira do Igarapé

3 Utilizarei esta categoria para me referir aos ocupantes por parte do Incra. Esta categoria aparece sendo utilizada pelos indígenas em seus documentos, inserida em contexto de disputas e ameaças, mas também vai aparecer em outros documentos da associação dos próprios assentados para se autorreferirem. 
Carraspano, deixando três lagos para os assentados e três lagos para os povos indígenas; do 3 o ponto, acompanharia novamente o limite natural até o 4 은 ponto e, novamente, cortaria em linha seca, deixando fora a margem do rio Uraricoera desmatada para o plantio, até o ponto do Igarapé Truarú, e acompanharia o Igarapé até o 1 ㅇp ponto, fechando assim o limite. Foi também concordado que os assentados utilizariam a estrada que dá acesso à área de plantio à margem do rio, enquanto a outra estrada fosse recuperada. Todo o trabalho foi feito conforme o acordo. Informamos também que esse acordo entre os assentados e lideranças indígenas foi feito pacificamente em ambas as partes para no futuro não haver desentendimento entre os povos indígenas e os produtores.

Como podemos ver, indígenas e assentados viveriam dividindo as fronteiras territoriais. Devido à proximidade, ao longo do tempo, passaram também a conviver cotidianamente, porque os assentados começaram a adentrar a comunidade; nos fins de semana, iam às praias dos rios que estavam localizadas dentro da comunidade, além de frequentarem a escola indígena.

Dona Carminha conta como era a relação com um dos assentados, chamado Fábio, na qual este indivíduo frequentava cotidianamente sua casa:

Dona Carminha: Esse Fábio aprendeu fazer damorida comigo para ele comer, comia junto com a gente e ainda foi fazer essa coisa para nós. Por isso que diz, ser amigo, depois mais tarde, vem, ficava com raiva. Ficou com raiva de nós. Ninguém ficou com raiva de ninguém, mas eles que ficaram assim, botaram na cabeça deles, né. Era para plantar arroz ali, mas até hoje, nunca nem vi se plantaram arroz.

Esta fala nos revela duas coisas: a primeira é que, da parte dos indígenas, eles sempre estiveram disponíveis para ajudar os assentados, uma vez que, nas reuniões anteriores, ficou acordado que cada um ficaria com uma parte da terra, tanto indígenas quanto assentados teriam um lugar para morar, portanto, não havia motivos para iniciarem uma briga posteriormente. No entanto dona Carminha descreve que, "depois mais tarde", isto, já em 2008, iniciou-se uma discordância, motivada por influências de empresários plantadores de arroz. Os empresários que são citados eram os que já estavam envolvidos no conflito da terra indígena Raposa/Serra do Sol e que, quando houve a homologação, passaram a influenciar os assentados para que iniciassem uma briga com os indígenas do Lago da Praia, de forma que eles também pudessem tomar suas terras. 
Uma das formas que se mantinha essas relações, entre indígenas e assentados, era através dos eventos promovidos pela escola, já que os assentados não tinham uma escola rural, e, como só existia a escola do Lago da Praia, os filhos dos indígenas e dos assentados estudavam juntos. E, através disso, eles participavam dos eventos e até da vida política da comunidade:

Dona Carminha: Nós pescávamos, quando eu fazia, eu me lembro das "pongós" que eu puxava no igarapezinho, no lago, perto do seu Leôncio. Nós pegávamos era muito, com caniço. Agora aqui ninguém vê pongó.

Seu Jaime: Aqui não tem nem água, "vali" peixe.

Dona Carminha: E é tudo longe aqui. Lá era tão perto. A gente ia lá rapidinho, você pegava o almoço, fazia pesqueiro né, aí pegava.

\section{Eriki: Vocês faziam muita festa lá, caxiri, damurida?}

Dona Carminha: Eu achei engraçado, foi bonito, que eu me lembro, foi nos "Dias dos Índios" que nós fizemos. Foi Gercivaldo que matou um veado. Nesse dia fizemos só damorida e foi só veado mesmo, peixe era com o pessoal que vieram, do assentamento.

\section{Eriki: Vocês convidavam ainda?}

Dona Carminha: Convidavam, ora se eu tô dizendo, vinham, comiam, comiam junto com a gente, ninguém ficava encrencando, quando eles passavam, aí, a gente convidavam. Inventaram essas festinhas de festa junina, aí brincavam, depois se zangaram, era porque queriam tomar mesmo. Pensavam que 0 Incra ia deixar eles plantar, mas não plantaram.

Como os filhos dos assentados também estudavam na escola do Lago da Praia, os pais também participavam dos eventos promovidos na comunidade. Eles iam partilhar das comidas e bebidas que eram levadas pelos pais dos alunos, além de participar de todas as atividades esportivas, festas e danças.

\section{NEGOCIAÇÃO: DIMINUIÇÃO DA COMUNIDADE LAGO DA PRAIA}

A princípio, a área que estava sendo pleiteada pelos indígenas da Serra da Moça era de uma extensão de 11 mil hectares, a qual correspondia a uma extensão contínua da terra indígena. Todos os lagos e igarapés estavam incluídos nessa nova extensão da terra. Essa configuração territorial era algo que vinha sendo discutido no movimento indígena motivado pela disputa da terra indígena Raposa/Serra 
do Sol, no qual se lutava para demarcar as terras indígenas em áreas contínuas, em vez de áreas em ilhas. Por isso, a extensão da terra reivindicada era junto à terra indígena já existente.

No entanto, após a reunião do dia 18 de agosto de 2004, conforme ofício apresentado anteriormente, houve um acordo em que os indígenas abririam mão de parte da terra para que fosse destinada à reforma agrária e aos "desintrusados da Raposa/Serra do Sol". Desta forma, foram divididos os recursos naturais, como lagos, igarapés, matas e buritizais. A extensão da terra pleiteada foi reduzida para bem menos do que era reivindicado. No croqui elaborado pelos indígenas, a área em vermelho indica o que estava sendo pleiteado após as negociações, correspondendo agora a apenas 7 mil hectares. A área em verde corresponde à área já demarcada.

Figura 4 - croqui elaborado para identificar a área da comunidade Lago da Praia

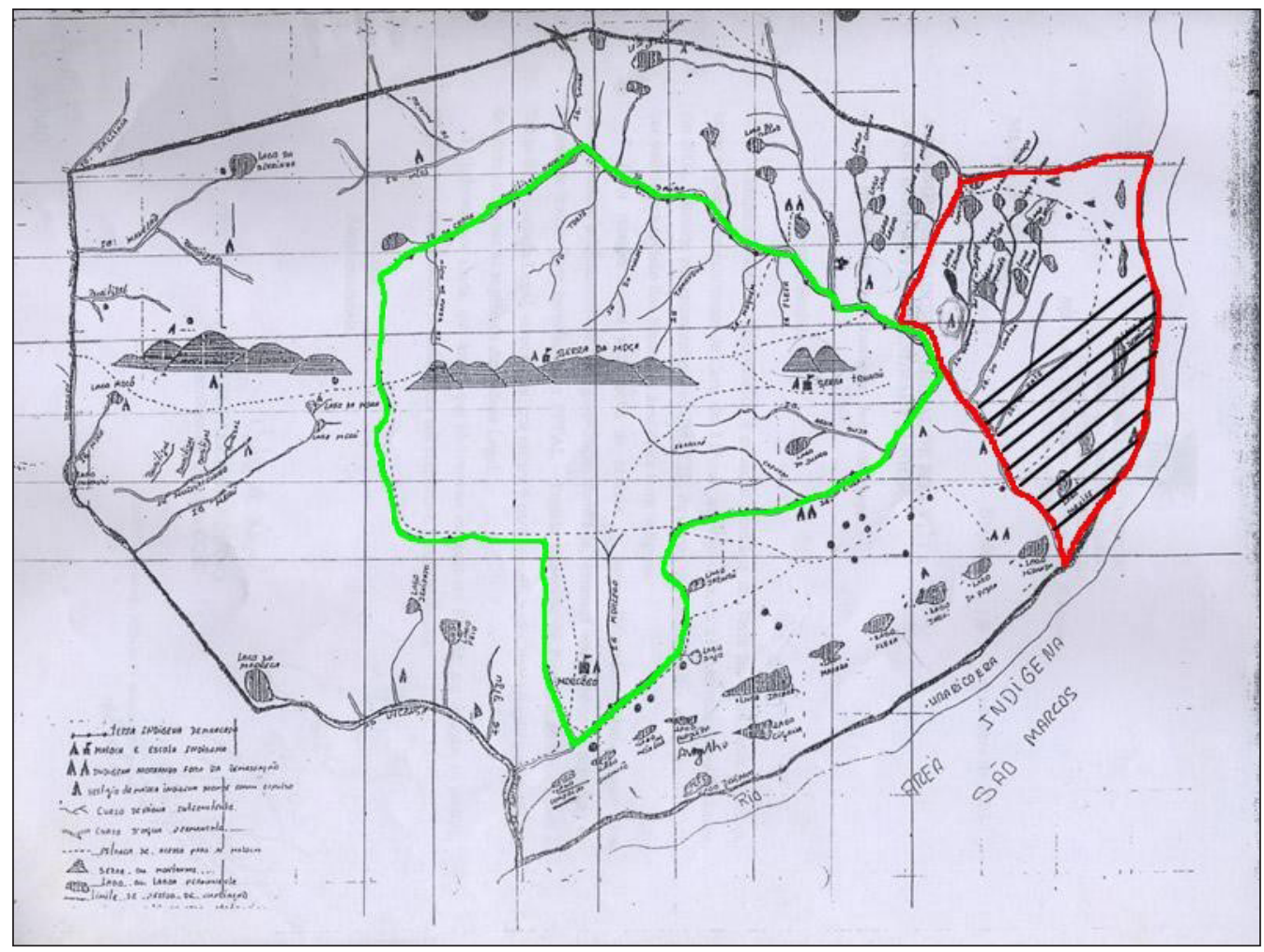

Fonte: Dossiê Terra Indígena Serra da Moça - Lago da Praia/CIR, modificado pelo autor. 
O croqui a seguir, elaborado já conforme as negociações, corresponde à área em hachura do croqui anterior.

Figura 5 - croqui de mapa identificando a comunidade Lago da Praia após negociações com assentados

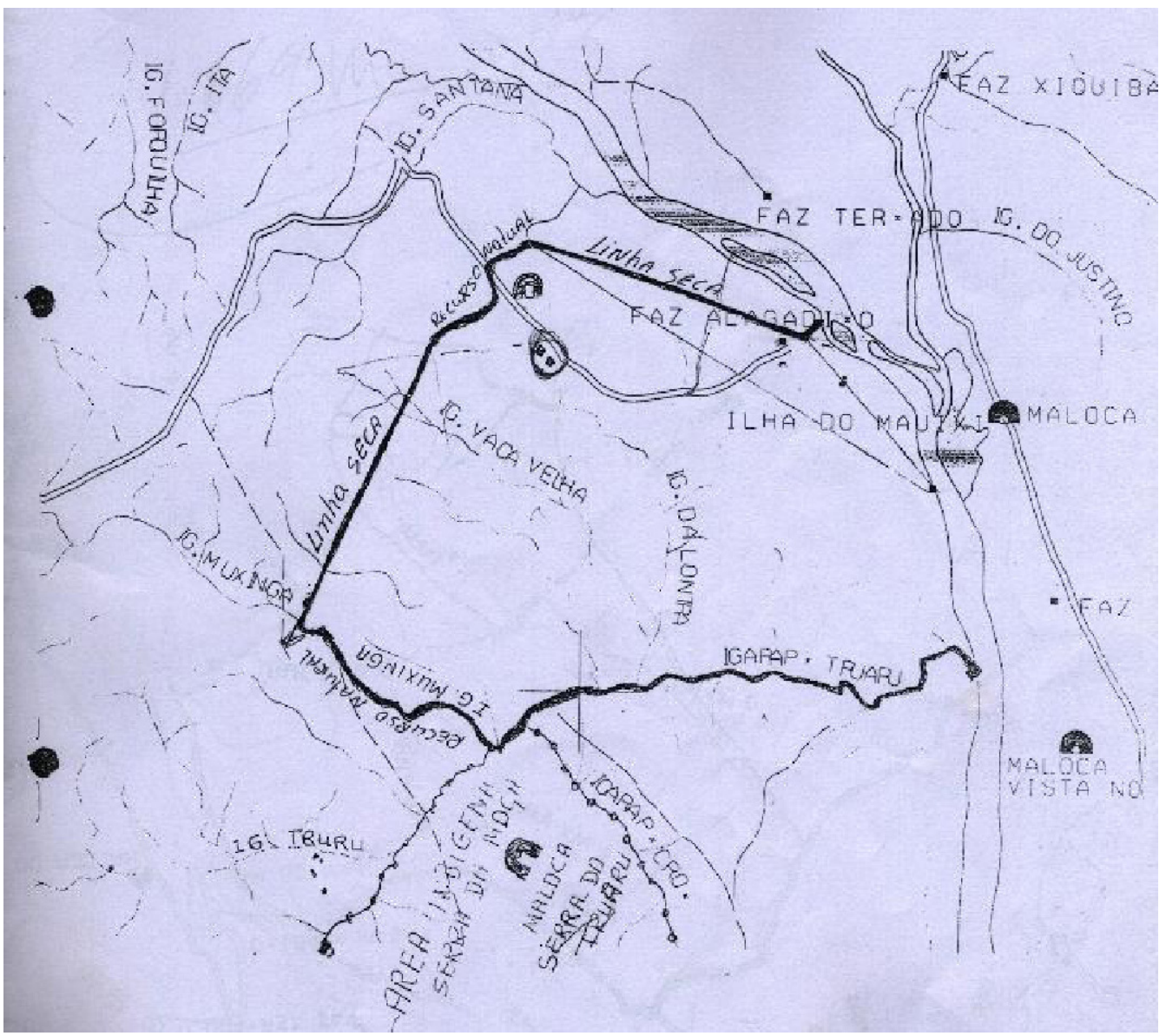

Fonte: Dossiê Terra Indígena Serra da Moça- Lago da Praia/CIR, modificado pelo autor.

Mais uma vez, recorro à fala da tia Gercina, que conta como ocorreram as negociações, quando, na época, seu esposo Leôncio era Tuxaua.

Tia Gercina: Quando o Leôncio, nós estávamos esperando essa terra, mas ela era de 11 mil hectares, aí eles diminuíram pra 7. No final, já pra nós, quando foi para decidir pra de sair, ela era só com 3.3 mil hectares apenas. 
Já não sei nem onde era. Talvez bem perto da beira do rio. Só com 3 hectares quando nós saímos; diminuíram. O governador decidiu dar "eliminar [liminar]" pra nós, pra nossa escola não ser reconhecida mais, aí pronto, foi quando acabou, não podia porque a terra não era regularizada.

Não tive acesso ao mapa que indica quando a comunidade se desfez, no entanto, de acordo com o relato acima, a terra que, a princípio, era de $11 \mathrm{mil}$ hectares, após o acordo com os assentados passou a ser de 7 mil (Figura 4 e Figura 5). Após o início do conflito, as famílias indígenas que moravam mais afastadas do centro comunitário mudaram-se mais para perto, deixando, assim, mais áreas desocupadas. A terra passou a ser apenas de 3 mil hectares e era assim que a terra estava quando a comunidade foi desfeita. Neste processo de negociação, até o lago da Praia que tinha dado nome para a comunidade acabou ficando de fora.

Antes de a comunidade se desfazer, o Incra tentou solucionar o conflito entre indígenas e assentados. O senhor Lurenes, superintendente regional do Incra Roraima, durante as negociações, fez a seguinte proposta ao Tuxaua Jaime: já que o conflito estava perdurando por muito tempo e se agravando cada vez mais e sem nenhuma previsão de haver demarcação, a terra seria dividida entre as famílias indígenas como se fossem loteamentos. Cada família teria um lote individual e, assim, resolveria a situação com maior agilidade, evitando-se conflitos entre indígenas e assentados. No entanto esta proposta foi negada pelo Tuxaua, dizendo que esse modelo de divisão territorial adotado pelo governo não correspondia à organização social indígena:

Tuxaua Jaime: Aí disse que ia fazer loteamento para nós, assim: "Olha Tuxaua nós estamos querendo fazer um acordo, fazer loteamento, como área indígena, mas fazendo cada um ter o seu lote, porque não vai ter muito problema; você pega o seu lote, aí já é seu, outro também pega". Então eu falei para ele: olha, digo: "Não! Eu não aceito dessa maneira porque não vai dar certo". "Por que que não vai dar certo? Por que o senhor diz isso, Tuxaua, que não vai dar certo?"; "Não vai dar certo porque eu sei que não vai dar certo, porque eu estou vendo o pessoal do assentamento que o senhor assentara: hoje tem casa que é terreno abandonado e outros acabaram vendendo, porque não pode, né". Não pode vender e estão vendendo, só pega o lugar, depois vende para outro. E nós indígenas não somos assim. Nós, como indígenas, nós moramos num lugar, a gente mora um perto do outro, mas aí ninguém empata ninguém fazer roça, ninguém empata ninguém de tirar palha, ninguém empata ninguém de tirar madeira, ninguém empata o pescar, nem 
caçar, do jeito que o senhor quer fazer para nós. Não vai dar certo, porque o parente vai pegar uma parte da mata, vamos dizer assim, vai pegar e aquela área é dele, e o outro pega a parte do lago, o outro pega a parte do buritizal, e aí? Quando, se for demarcado, se demarcar cada um com seu lote, não vai dar certo porque o parente mesmo vai procurar confusão; ele vai dizer: "não esse aqui é meu, esse aqui eu ganhei e ninguém pode tirar não"; só se ele autorizar a gente pode tirar, se não, ninguém pode. Mesmo coisa no lugar de mato, se ele for entrar para trabalhar: "não, esse aqui é meu, você não pode botar a roça. Esse lago aí está no meu terreno, ninguém pode pescar não". Então é assim, então, o que a gente está querendo, eu falei para ele, é um lugar, um terreno pra todo mundo tá junto, trabalhando junto, caçando junto, pescando. Aonde tem seu buritizal, todo mundo tira, faz seu barraco, que onde vai caçar, pesca, pega o peixe, caça, tudo aí, ele não vai ter problema nenhum, e se dividir assim como você está pensando não vai dar certo. Ai ele pensou e disse assim: "Não, Tuxaua, o senhor tá certo, mas a gente estava querendo fazer isso pra ver se acabasse essa confusão pra não ter mais. Ai levava lá no Incra, a gente fazia toda papelada, vinha, né, mas não, eu digo não, se quiser fazer, deixa livre, do jeito que tá, não precisa fazer do jeito que o senhor tá dizendo, porque depois tem parente que não vai, ele não vai aceitar isso aí, né, tem parente que entende, ele vai entender, mas tem parente que não vai entender desse jeito [...].

Ao fim, não se fizeram eficazes as negociações envolvendo indígenas, assentados, Funai, Incra e organizações representativas desses sujeitos envolvidos. Os acordos de divisão territoriais acabaram não sendo respeitados por parte do Incra, resultando em um conflito iniciado em 2008, no qual foi marcado por violência física e simbólica, ameaças e casas queimadas, como veremos a seguir.

\section{O CONFLITO}

Conforme demostrado nos documentos e nas falas aqui apresentadas, a negociação apontada anteriormente já resolvia a disputa territorial entre indígenas e assentados, na qual 7 mil hectares estavam destinados à ampliação da terra indígena Serra da Moça, enquanto outra parte seria para o Incra proceder com a elaboração de projeto destinado aos assentados, denominado Projeto Nova Amazônia - Truarú.

No entanto, neste meio tempo, como já foi narrado, iniciou-se um conflito no qual os assentados passaram a ameaçar os indígenas do Lago da Praia, queimando suas casas, suas plantações, roças, o posto de saúde e a escola da comunidade, que os assentados também utilizavam. 
Seu Jaime: Nós moramos cinco anos lá dentro. E saímos rapidinho assim. Quando fez cinco anos que a gente chegou, começaram a invadir e começaram a botar para a gente sair. Não foi porque a gente queria sair de lá, foi por causa deles, que botaram, que faziam a bagunça deles. De noite ou de dia, ficavam correndo para lá e pra cá, tudo armado de terçado. A gente não podia fazer nada, não íamos brigar com eles, até que começaram a queimar casa. Começou primeiro pelo colégio, depois queimaram o posto, onde a Luzia trabalhava, era Luzia que era enfermeira. Queimaram. Tinha rádio fonia que tinham colocado para, queimaram tudo. Aí vieram começaram a queimar a casa do Jairo lá. Aí vieram descendo, descendo, queimando, quebrando.

Conforme memorando da Funai, assinado pelo administrador da regional de Roraima, encaminhado à sua Diretoria de Assuntos Fundiários, todo esse conflito foi resultado de uma decisão da direção local do Incra que resolveu proceder com o loteamento da terra, não mais como já tinha sido acordado.

É importante ressaltar que, embora tivesse ocorrido o acordo, alguns desses assentados já haviam passado por uma experiência de disputa com indígenas da Raposa/Serra do Sol, levando os assentados a adotarem uma postura mais agressiva contra os indígenas do Lago da Praia. Como os indígenas do Lago da Praia não tinham uma experiência de conflito mais intensa na qual poderia se disputar com mais equilíbrio, esta vivência acabou sendo um tanto traumática.

Muitos desses assentados adentravam na área da comunidade fazendo barulho com suas motos, assustando as mulheres e crianças quando seus esposos saíam para caçar ou pescar.

Tia Gercina: Na hora que a gente ia comer, parece que eles faziam para a gente não comer, para a gente não ir pescar, parece que era fraco, né, quando a gente estava sentando para comer, aí vem aquelas motos, carros, fazendo barulho e era buzinando e era a moto era aquela, aqueles carros, motos. Como é que chama? Aqueles "torbal" né, aquela descarga "torbal", não sei quantas motos, mas fazia era medo, sei lá, aí passava até fome a gente não come a mesma não; Aí também lá no Zé, né, passava no Zé e ia até lá em casa, lá fazer aquela volta assim e voltava de novo ficava até na beira do rio no Cláudio e voltava de novo aquela armação. Aí chegava lá e dizia "E aí vocês não vão não? Tem caminhão aí está pronto, se vocês quiserem levar suas coisas o caminhão está pronto" desse jeito; ai "ei pode ficar lá não entra não, nossa casa era cercada, né. Não entra não, pelo amor de Deus" a gente dizia, né, "não entra não, porque nós não estávamos incomodando, vocês não, vocês não essa essas vocês estão só outras essas mulheres aí porque 
eu era lá em casa com as filhas do Zé, né, e a Jacira com as filhas dela, né. E às vezes um Zé com Leôncio ficavam por aí andando, só encontrava a gente. Aí estava fazendo medo mesmo, estavam fazendo medo mesmo; aí o Zé, "rapaz, eu não sei não eu não sei não, mano, mas eu vou matar uma peste desses", ele disse né; "Eu vou matar uma peste desse, eu custo me zangar. Se eu soubesse que essas, que essas pestes, esses bando corresse daqui, se fosse correr daqui eu não tinha vindo".

A partir de então, os assentados começaram a pressionar os indígenas para que eles deixassem suas casas e voltassem para as outras comunidades. Muitos acabaram por sair de suas casas à noite para evitar qualquer tipo de confronto. Estavam fugindo de suas próprias casas, deixando para trás seus bens: roupas, panelas, suas plantações e até os documentos.

Tio Assis: É por causa do, já era do Bamerindus, né, essa área do Bamerindus, que o Bixara usou isso aí tudinho, ai disse "rapaz, esse aqui é nosso", ainda não está, aí tomaram essa decisão. Tomaram não, primeiro que tomaram a decisão de ganhar aquele, porque ainda é tempo isso. Por isso foram para ver se ganhava sabe. Mas enquanto isso, como é que diz, mas já era sim do Bamerindus, sabe, porque uma casa bem aqui no Santa Rita, no Muxinga, do outro lado, tinha uma casa, tinha um caminho que ia direto para a casa lá do Bixara, vaqueiro. Ai lá estava seu Orlando, Marcelo, sabe, ficava lá, né. Então nós vamos ganhar tudinho esse aí, fizemos como fosse para ganhar isso aí. Mas não teve jeito, perdimos tudo. Mas foram tarde já, né, não era pra... Mas foi bom mesmo do tuxaua primeiro, mas não, era para a gente ficar logo lá, antes da demarcação. Aí Lago da Praia acabou.

Em agosto de 2009, só restava a família do Tuxaua Leôncio na comunidade Lago da Praia. As outras já tinham fugido de canoa pelo rio Uraricoera ou de bicicleta, atravessando as plantações de Acácias. Alguns indígenas da comunidade Morcego e Serra do Truarú tinham ido até a comunidade Lago da Praia para tentar ajudar os parentes a permanecerem em suas casas, mas não foi o suficiente. No dia 9 de agosto, enquanto ocorria o evento em comemoração ao "Dia dos Pais" na Serra do Truarú, foi recebida a notícia de que os últimos indígenas que haviam permanecido no Lago da Praia tinham sido pegos pelos assentados a mando de algum empresário plantador de arroz e que eles só seriam liberados se os indígenas fossem embora e deixasse a terra. Assim, após muita tensão, por volta das 18 horas, os indígenas chegaram a pé no centro comunitário da Serra do Truarú, anunciando que a comunidade Lago da Praia tinha acabado. 
Em 18 de janeiro de 2010, o estado de Roraima, na época representado pelo governador José de Anchieta Junior, que veio a falecer em 2018, logo após ter perdido as eleições ocorridas dois meses antes, mostrava-se contrário à ampliação da Terra indígena Serra da Moça, até porque a demarcação da terra indígena Raposa/Serra do Sol tinha representado uma derrota para os interesses da elite do estado de Roraima e o pensamento daquele período era de que não se poderia ser destinado nenhum centímetro a mais para os povos indígenas.

A ação movida pelo estado tinha como embasamento as 19 "condicionantes" impostas pelo STF quando demarcou a terra indígena Raposa Serra do Sol, reforçando a "condicionante" 17, que veda qualquer ampliação de terras indígenas já demarcada.

Ainda nesta ação, é afirmado que o Incra, mesmo responsável por promover a reforma agrária e que deveria executar o Projeto de Assentamento Rural Nova Amazônia/Truarú, teria admitido a "invasão" de indígenas na área. O governador Anchieta finalizava dizendo que a reforma agrária não contemplava os indígenas, isto é, conforme havia sido proposto ao Tuxaua Jaime, devido à demora da demarcação, seriam loteadas terras para as famílias do Lago da Praia, mas essas terras não deveriam ser destinadas às famílias indígenas.

Logo após a ação do governo, 10 dias para ser exato, o ministro Gilmar Mendes assinou uma Ação Cautelar no dia 29 de janeiro de 2010, em que afirma que não competia ao estado de Roraima "decidir quais são os possíveis participantes dos assentamentos patrocinados pelo Governo Federal" e que "a condição de indígenas não os torna, como quer o autor, aprioristicamente inelegíveis a tais políticas públicas".

A Ação Cautelar assinada pelo ministro Gilmar Mendes, mostrando a "agilidade" do sistema judiciário brasileiro, é descrita aparentemente apenas a partir de informações disponibilizada pelo governador Anchieta e pela mídia local, tendo sido decidido o seguinte em relação à situação:

Ante o exposto, defiro o pedido de medida liminar tão-somente para garantir a manutenção dos assentamentos já realizados na referida área (Assentamento Nova Amazônia), vedando-se o acesso de novos grupos indígenas ao local. Determino, ainda, que a União e a Funai se abstenham de praticar quaisquer atos no sentido de reconhecer a referida área como terra indígena. (MEDIDA CAUTELAR EM AÇÃO CAUTELAR 2.541, Roraima).

A decisão, embora fosse apenas uma liminar, teve um resultado que causou um desânimo muito grande nos indígenas do Lago da Praia, pois, após saírem de 
suas casas, expulsos, esperaram poder retornar logo após a decisão do STF. No entanto a decisão de Gilmar Mendes decidindo por manter apenas o assentamento, mesmo que temporário, acabou impedindo o retorno ao Lago da Praia.

\section{CAMINHOS A SEREM SEGUIDOS: O SONHO NÃO ACABOU}

As discussões acerca do conjunto de "condicionantes" referentes ao caso da Terra Indígena Raposa/Serra do Sol, apresentadas pelo STF, especificamente pelo ministro Carlos Alberto Menezes Direito, como condições para sua demarcação, representaram uma afronta aos direitos dos povos indígenas e demais Comunidades e Povos Tradicionais, não considerando, portanto, que essas terras foram alvo de invasões e usurpações por parte de fazendeiros, posseiros, entre outros antagonistas dos povos indígenas.

Além de representarem um insulto a diversos instrumentos jurídicos, como a própria Constituição Federal, desconsideraram um dos instrumentos de luta mais importantes desses povos, a Convenção 169 da Organização Internacional do Trabalho (OIT), quando o ministro anteriormente citado, em seus pronunciamentos, admitiu as instalações de bases, unidades e postos militares, a atuação das Forças Armadas e da Polícia Federal e a instalação de equipamentos públicos e construções, inclusive de estradas, na terra indígena, sem a necessidade de consulta às comunidades que ali vivem (ALMEIDA; DOURADO, 2013).

Embora o ministro Gilmar Mendes tenha se valido de tais "condicionantes" para fundamentar sua Ação Cautelar e acabar com a comunidade Lago da Praia no ano de 2010, somente em 2012, é que o maior golpe contra o direito à consulta e autodeterminação dos povos e comunidades tradicionais foi feito pelo Poder Executivo. A Advocacia-Geral da União (AGU) publicou a Portaria n. 303, em junho de 2012, sob pretexto de dispor sobre as salvaguardas institucionais a terras indígenas. Esta Portaria nada mais foi do que uma forma de tornar regra geral tais "condicionantes", fazendo com que fosse submetidos todos os procedimentos de demarcação de terras indígenas, sejam aqueles que estavam em andamento, sejam aqueles já finalizados, representando, portanto, para a comunidade Lago da Praia, o enfraquecimento do sonho de ter suas terras de volta, mesmo que tais "condicionantes" representem uma afronta direta aos direitos humanos (ALMEIDA; DOURADO, 2013) e uma compreensão atrasada dos estudos antropológicos sobre as dinâmicas de transformações dos territórios tradicionalmente ocupados. 
Embora enfraquecido, retomar a comunidade Lago da Praia nunca foi um sonho deixado de ser lembrado pelos que tinham saído de lá e pelo restante das comunidades da terra indígena Serra da Moça. Em março de 2018, quase 10 anos depois da expulsão, na semana do Acampamento Terra Livre (ATL), as lideranças da Serra da Moça, junto ao CIR e sua assessoria jurídica, na época Joênia Wapichana, levaram como uma das pautas do Movimento Indígena do estado de Roraima, ainda, a ampliação da terra indígena Serra da Moça.

No entanto, no dia 28 de setembro do mesmo ano, o ministro Gilmar Mendes assinou uma nova Ação Cautelar, mais uma vez impedindo que fosse ampliada a terra indígena. E ainda, na Ação Cautelar, que na anterior dizia que não competiria a esta Corte decidir os rumos de uma área que estava sob "posse" da União, agora ele dizia o seguinte:

Desse modo, tem o Estado de Roraima legitimidade e interesse de agir nesta demanda, visando participar de processo de demarcação de reserva indígena, ainda que inserida em área de propriedade da União, bem ainda discutir judicialmente eventual ampliação daquela. (SUPREMO TRIBUNAL FEDERAL STF - AÇÃO CÍVEL ORIGINÁRIA: ACO 0001274-61.2010.1.00.0000 RR RORAIMA 0001274-61.2010.1.00.0000).

Vale lembrar que a atual gestão governamental do estado de Roraima pertence ao Partido Social Liberal (PSL), que teve como integrante o presidente do Brasil, o qual já realizou diversas declarações contra os direitos dos Povos Indígenas e demais comunidades tracionais.

Parece que fica cada dia mais impossível retornar à comunidade Lago da Praia e recuperar o que um dia foram as terras dos indígenas da Serra da Moça. De todos os lados, parece não haver apoio para que ocorra a ampliação. Tanto o governo estadual quanto os demais órgãos que deveriam defender os direitos dos povos indígenas parecem fazer pouco caso, tanto que, até os dias de hoje, nunca foi feito nenhum estudo que demostre a real realidade destas comunidades.

Tia Gercina: E é muito impossivel dizer assim voltar para lá, como naquela época, né, aquela época não volta mais. Se for, vem outros. Porque a gente não teve apoio, segurança dos governantes, eles falavam uma coisa, falavam outra coisa, mas não podiam fazer nada por nós porque eles estavam, eles eram contra nós.

A fala da tia Gercina demonstra que, embora tenha essa vontade de retornar para o Lago da Praia, a falta de apoio e de segurança é desanimadora. O 
sentimento que surge em suas falas o tempo todo revela, ao mesmo tempo, que esta parte de sua história está marcada para sempre na sua vida de liderança. E, como ela afirma, "eles eram contra nós": "eles" são desde os políticos locais às autoridades da Justiça brasileira, que não buscam realmente se esforçar para entender a realidade dos povos indígenas.

Estes escritos são um pouco da história.

\section{REFERÊNCIAS}

ALEIXO WAPICHANA, Eriki. Sociogênese da mobilização étnica ocorrida na comunidade Serra do Truarú (Terra Indígena Serra da Moça, etnoregião Murupú, Boa Vista-RR). Horizontes Antropologicos, v. 26, n. 58, 2020. [no prelo].

ALMEIDA, Alfredo Wagner Berno; DOURADO, Sheilla Borges. Apresentação In: ALMEIDA, Alfredo Wagner Berno et al. Consulta e participação prévia: a crítica à metáfora da teia de aranha. Manaus: UEA Edições; PPGSA/PPGAS/Ufam, 2013.

CASTRO FARIA, Luiz de. A Antropologia no Brasil. Depoimento sem Compromissos de um Militante em Recesso. Anuário Antropológico, Brasil, n.7, v.1, p. 228-50, 1983.

FARAGE, Nádia; SANTILLI, Paulo. Estado de Sítio: territorialidade e identidade no vale do Rio Branco: In: CUNHA, Manuela Carneiro (Org.). História dos índios no Brasil. São Paulo: Fapesp, Companhia das Letras; Secretaria Municipal de Cultura, 1992.

FARAGE, Nádia. As muralhas do Sertão- os povos indígenas no rio Branco e a Colonização. 1986. Dissertação (Mestrado em Antropologia Social) - Universidade de São Paulo, São Paulo, SP, 1986.

OLIVEIRA FILHO, João Pacheco. Regime tutelar e faccionalismo - política e religião em uma reserva Ticuna. Manaus: UEA Edições, 2015.

REPETTO, Maxim. Movimentos indígenas e conflitos territoriais no estado de Roraima. Boa Vista: Editora da UFRR, 2008.

RIBEIRO, Gilmara Fernandes. Criadores de gado: experiência dos Macuxi com o gado bovino. Dissertação (Mestrado em Antropologia) - Departamento de Antropologia, Universidade Federal de Roraima, Boa Vista, RR, 2018.

SANTILLI, Paulo. Pemongon Patá - território Macuxi: rotas de conflito. Petrópolis: Vozes, 2001. 
VIEIRA, Jaci Guilherme. Missionários, fazendeiros e índios em Roraima: a disputa pela terra - 1777 a 1980. 2003. Tese (Doutorado em História) - Universidade Federal de Pernambuco, 2003.

\section{Documentos consultados}

PROCESSO N. 28870.000919/1981 - 68 - Identificação da área indígena Serra da Moça.

PROCESSO N. 28870.002054.1989-21 - Homologação da TI Serra da Moça.

Dossiê Terra Indígena Serra da Moça- Lago da Praia/CIR.

MEDIDA CAUTELAR EM AÇÃO CAUTELAR 2.541 RORAIMA. Disponível em: https://www. conjur.com.br/dl/decisao-gilmar-mendes-invasao-indigena.pdf. Acesso em: jul. 2019.

SUPREMO TRIBUNAL FEDERAL (STF). AÇÃO CÍVEL ORIGINÁRIA: ACO 0001274 61.2010.1.00.0000 RR- RORAIMA 0001274-61.2010.1.00.0000. Disponível em: https:// stf.jusbrasil.com.br/jurisprudencia/782985515/acao-civel-originaria-aco-1522-rrroraima-0001274-6120101000000. Acesso em: jul. 2019.

\section{Entrevistas}

Entrevista com dona Carminha e Tuxaua Jaime, Macuxi, moradores da Comunidade Morcego. Morcego, região Murupú, Município de Boa Vista, RR, em abril de 2016.

Entrevista com Francisco de Assis Aleixo Angelo, Wapichana, morador da Comunidade Serra do Truarú. Serra do Truarú, região Murupú, Município de Boa Vista, RR, em abril de 2016.

Entrevista com Geovânia Angelo Aleixo, Wapichana, moradora da Comunidade Serra do Truarú. Serra do Truarú, região Murupú, Município de Boa Vista, RR, em abril de 2016.

Entrevista com Gercina Angelo da Silva, Wapichana, moradora da Comunidade Serra do Truaru. Serra do Truarú, Etnorregião Murupú, Município de Boa Vista, RR, em abril de 2016.

Entrevista com Gercina Angelo da Silva, Wapichana, moradora da Comunidade Serra do Truarú. Serra do Truarú, Etnorregião Murupú, Município de Boa Vista, RR, em setembro de 2018.

Entrevista com Lenice Nagelo da Silva, Wapichana, moradora da Comunidade Morcego, Etnorregião Murupú, Município de Boa Vista, RR, em abril de 2016. 
Entrevista com Leôncio Lourenço da Silva, Wapichana, morador da Comunidade Serra do Truarú. Serra do Truarú, Etnorregião Murupú, Município de Boa Vista, RR, em setembro de 2018.

\section{Sobre o autor:}

Eriki Aleixo de Melo: Indígena Wapichana, morador da comunidade Serra do Truarú. Doutorando e mestre em Antropologia Social pela Universidade Federal do Amazonas (PPGAS/Ufam). Graduado em História pela Universidade Federal de Roraima (UFRR). Pesquisador do Projeto Nova Cartografia Social da Amazônia (PNCSA). Membro da Articulação Brasileira de Indígenas Antropologes (ABIA). E-mail: eriki.aleixo@hotmail.com, Orcid: http://orcid.org/0000-0002-2658-3027

Recebido em: 9 de janeiro de 2020.

Aprovado para publicação em 22 de maio de 2020. 


\title{
A diversidade sexual entre povos indígenas do Brasil Sexual diversity among Brazil's indigenous people
}

Eriki Paiva ${ }^{1}$

DOI: http://dx.doi.org/10.20435/tellus.v19i39.598

\begin{abstract}
Resumo: Este trabalho contribui com as discussões de sexualidade entre os povos indígenas. O método de pesquisa se deu por meio de entrevista com indígenas - Boe Bororo, Pankararu e Pataxó -, através de um questionário semiestruturado, com perguntas abertas para livre exposição e resposta do entrevistado. Os relatos foram gravados para uso exclusivo na construção da escrita das reflexões apresentadas neste trabalho.
\end{abstract}

Palavras-chave: sexualidade indígena; Pankararu; Pataxó; Boe Bororo.

\section{INTRODUÇÃO}

Meu nome é Eriki Miller Lima Luiz Paiva, pertenço ao povo Terena, nascido e residente na Terra Indígena Taunay-Ipegue. Sou formado em Ciências Biológicas pela Universidade Federal de Mato Grosso do Sul (UFMS), campus do município de Aquidauana, e estudante atualmente do curso de Direito pela mesma instituição, na cidade de Campo Grande.

Durante esses anos na academia, tenho me interessado pela área da pesquisa, sempre tentando obter através da escrita o reconhecimento aos nossos saberes indígenas, que, pela lógica popular, muitas vezes não são tidos como saberes científicos. Busco trabalhar temáticas dentro de nossa cosmovisão, com a autonomia de quem passou de objeto de estudo para produtor do conhecimento. Em minhas produções, objetivo provocar nos leitores reflexões que possam descoIonizar as mentes e quebrar o racismo que se manifesta por meio de estereótipos, ignorâncias e "pré-conceitos".

Acerca do assunto sexualidade e gênero existem inúmeras lacunas a serem preenchidas no tocante às populações indígenas do Brasil. Em muitas etnias indígenas, por exemplo, a cidadania das diversas formas e manifestações sexuais 
ainda é raramente debatida e é indubitavelmente errôneo atribuir aos próprios indígenas a causa desse assunto atrair tabus, em se tratando de sociedades que até pouco tempo não possuíam a informação sobre essas segregações e denominações que os não indígenas dão aos grupos de pessoas com comportamentos sexuais tidos como "diferentes". Na própria historiografia indígena se ocultavam as questões que abordassem a sexualidade. Para os pesquisadores da época, era mais relevante considerar os aspectos culturais dos povos indígenas, um processo em que o indígena foi desconsiderado como sujeito histórico e como protagonista em suas relações, fazendo com que a história indígena ficasse "restrita ao campo laboral e religioso e negligenciando, sobretudo, a sexualidade" (GOMES; NOVAIS, 2010, p. 46 ).

A sociedade trata as pluralidades sexuais de forma polêmica e, dentro disso, as diversidades sexuais entre os povos indígenas como um assunto novo. Entre os próprios indígenas, muitas vezes, há a crença de que esses "novos hábitos" são frutos do contato e convívio com povos externos, de outras culturas. Porém, no Tratado Descritivo do Brasil, datado de 1587, algumas práticas sexuais diferentes dos padrões considerados normais pelos portugueses já eram relatadas entre os povos que tradicionalmente ocupavam o território brasileiro.

Segundo relatou Sousa (1587, p. 308):

São os tupinambás tão luxuriosos que não há pecado de luxúria que não cometam; os quais sendo de muito pouca idade têm conta com mulheres, e bem mulheres; porque as velhas, já desestimadas dos que são homens, granjeiam estes meninos, fazendo-lhes mimos e regalos, e ensinam-lhes a fazer o que eles não sabem, e não os deixam de dia, nem de noite. É esse gentio tão luxurioso que poucas vezes têm respeito às irmãs e tias, e porque este pecado é contra seus costumes, dormem com elas pelos matos, e alguns com suas próprias filhas; e não se contentam com uma mulher, mas têm muitas, como já fica dito pelo que morrem muitos de esfalfados. E em conversação não sabem falar senão nestas sujidades, que cometem cada hora; os quais são tão amigos da carne que se não contentam, para seguirem seus apetites, com o membro genital como a natureza formou; mas há muitos que Ihes costumam por o pelo de um bicho tão peçonhento, que Iho faz logo inchar, com o que têm grandes dores, mais de seis meses, que se Ihe vão gastando espaço de tempo; com o que se Ihes faz o seu cano tão disforme de grosso, que os não podem as mulheres esperar, nem sofrer; e não contentes estes selvagens de andarem tão encarniçados neste pecado, 
naturalmente cometido, são muito afeiçoados ao pecado nefando, entre os quais se não têm por afronta; e o que se serve de macho, se tem por valente, e contam esta bestialidade por proeza; e nas suas aldeias pelo sertão há alguns que têm tenda pública a quantos os querem como mulheres públicas.

De maneira geral, a sexualidade indígena tem ganhado notoriedade dentro do movimento indígena, fato que se mostra através do espaço intitulado "LGBTQI+ Indígenas: Tire seu preconceito do meu caminho, irei passar com meu cocar", que promoveu debate da temática durante o Acampamento Terra Livre 2020 (ATL Virtual). Isso prova que muitas lideranças e comunidades indígenas estão prontas para debater sobre o assunto, corroborando que a discriminação e o preconceito são mazelas deixadas pela colonização, cicatrizes de crenças as quais esses povos são historicamente obrigados a seguir. Na realidade não indígena, a sexualidade é algo que tem aguçado a curiosidade e começou a ganhar espaço entre os historiadores, filósofos, antropólogos e demais pesquisadores do comportamento humano.

Este estudo objetiva contribuir com os debates acerca da sexualidade indígena e suas vertentes, além de viabilizar a nós, jovens indígenas, a oportunidade de falarmos por nós próprios, demonstrando nossa autonomia e protagonismo.

\section{METODOLOGIA}

Três jovens indígenas, homens cisgêneros, que se relacionam afetivamente e sexualmente com pessoas do mesmo sexo, foram entrevistados por meio de um questionário semiestruturado. As etnias dos participantes foram Pankararu, Bororo e Pataxó. De maneira informal, o pesquisador iniciou o diálogo via redes sociais; após conversa prévia, eles aceitaram comentar sobre suas vidas pessoais e íntimas e colaborar com a seguinte pesquisa. Os diálogos foram arquivados em formato de áudio, com as opiniões, vivências e perspectivas dos participantes, os quais propiciaram a discussão trazida pelo presente trabalho.

\section{DISCUSSÃO}

As diversidades sexuais, para muitos indígenas, são ainda confusas, devido aos reflexos deixados pela catequização e colonização. A doutrinação religiosa é 
um dos entraves que dificulta a quebra do tabu criado em torno desse assunto para esses grupos. Diante das práticas consideradas "pecado" pelo cristianismo, as de cunho sexual são as mais condenadas pelos adeptos dessa religião. O julgamento desses religiosos tem ultrapassado os limites físicos das igrejas, e seus fiéis, muitas vezes, têm acatado e reproduzido isso na sociedade. Existe muito fortemente entre os indígenas que se descobrem atraídos por pessoas do mesmo sexo, segundo os participantes, o medo de ser forçado a deixar cargos de liderança na comunidade, de não ser bem-aceito nos rituais sagrados da aldeia ou até mesmo de causar problemas de saúde nos avós e membros mais velhos da família. Há também, entre a juventude indígena, uma hierarquia de respeito com a comunidade, a percepção sobre o dever de obter respaldo das lideranças até mesmo em aspectos pessoais de suas vidas. Para os entrevistados, os jovens indígenas que se libertam desses parâmetros cristãos arcaicos tendem a buscar conhecer e valorizar mais os rituais e crenças religiosas tradicionais de seu povo, se comparados aos demais. Algo citado pelos entrevistados é quanto à falta de representatividade e aplicabilidade das definições do "movimento LGBT" entre indígenas. Esse processo de definição/denominação deve ser uma construção de "dentro pra fora", não de "fora para dentro", para ser espaço de afirmação da autonomia e protagonismo indígena e revitalização cultural: "é um processo que deve ultrapassar qualquer sigla que queiram impor". Unanimemente, entre os entrevistados, apresenta-se a crença de que o preconceito foi "herdado" do não indígena, e que os povos indígenas, num todo, não são originalmente preconceituosos. "Não sofro preconceito pelo meu povo, sofro pelas mazelas da colonização, sofro pelos ditos cristãos e sua alienação", conclui um dos participantes.

\section{CONSIDERAÇÕES FINAIS}

A academia tem possibilitado ao jovem indígena uma oportunidade de se encontrar e se sentir menos solitário no processo de autodescobrimento, enquanto pessoa e sociedade. A diversidade sexual ainda é um grande tabu entre os povos tradicionais, os quais, muitas vezes, são deixados à margem e ignorados dentro dos próprios movimentos ditos de diversidade no Brasil.

Os indígenas que se descobrem atraídos por pessoas do mesmo sexo vêm se destacando no enfrentamento das forças opressoras que tentam os diminuir, 
vitimar, agredir e "engolir" as suas pautas relacionadas à cidadania. Nos espaços que têm ocupado, lutam insistentemente pelos seus direitos, que, muitas vezes, são os mais simples e já foram há muito tempo garantidos às demais pessoas. $\mathrm{O}$ tema necessita de mais pesquisas entre os diversos povos indígenas do Brasil, para auxiliar no combate às manifestações de ódio e preconceito, além de possibilitar que o assunto seja mais debatido.

\section{REFERÊNCIAS}

GOMES, Aguinaldo Rodrigues; NOVAIS, Sandra Nara da Silva. Práticas sexuais e homossexualidade entre os indígenas brasileiros. Caderno Espaço Feminino, Uberlândia, MG, v. 26, n. 2, jul./dez. 2013. Disponível em http://www.seer.ufu.br/index.php/neguem/ article/download/24666/13726/0. Acesso em: 15 maio 2020.

SOUSA, Gabriel Soares. Tratado descritivo do Brasil em 1587. Rio de Janeiro: Typographia Universal de Laemmert, 1851. Disponível em: http://www.dominiopublico.gov.br/ pesquisa/DetalheObraForm.do?select_action=\&co_obra=38095. Acesso em: 15 maio 2020.

\section{Sobre o autor:}

Eriki Paiva: Graduando em Direito na Universidade Federal de Mato Grosso do Sul (UFMS), na cidade de Campo Grande; e graduado em Ciências Biológicas pela UFMS, campus do município de Aquidauana.E-mail: eriki_miller@hotmail.com, Orcid: http://orcid.org/0000-0001-6130-2609

Recebido em 17 de dezembro de 2019.

Aprovado em 10 de junho de 2020. 
